

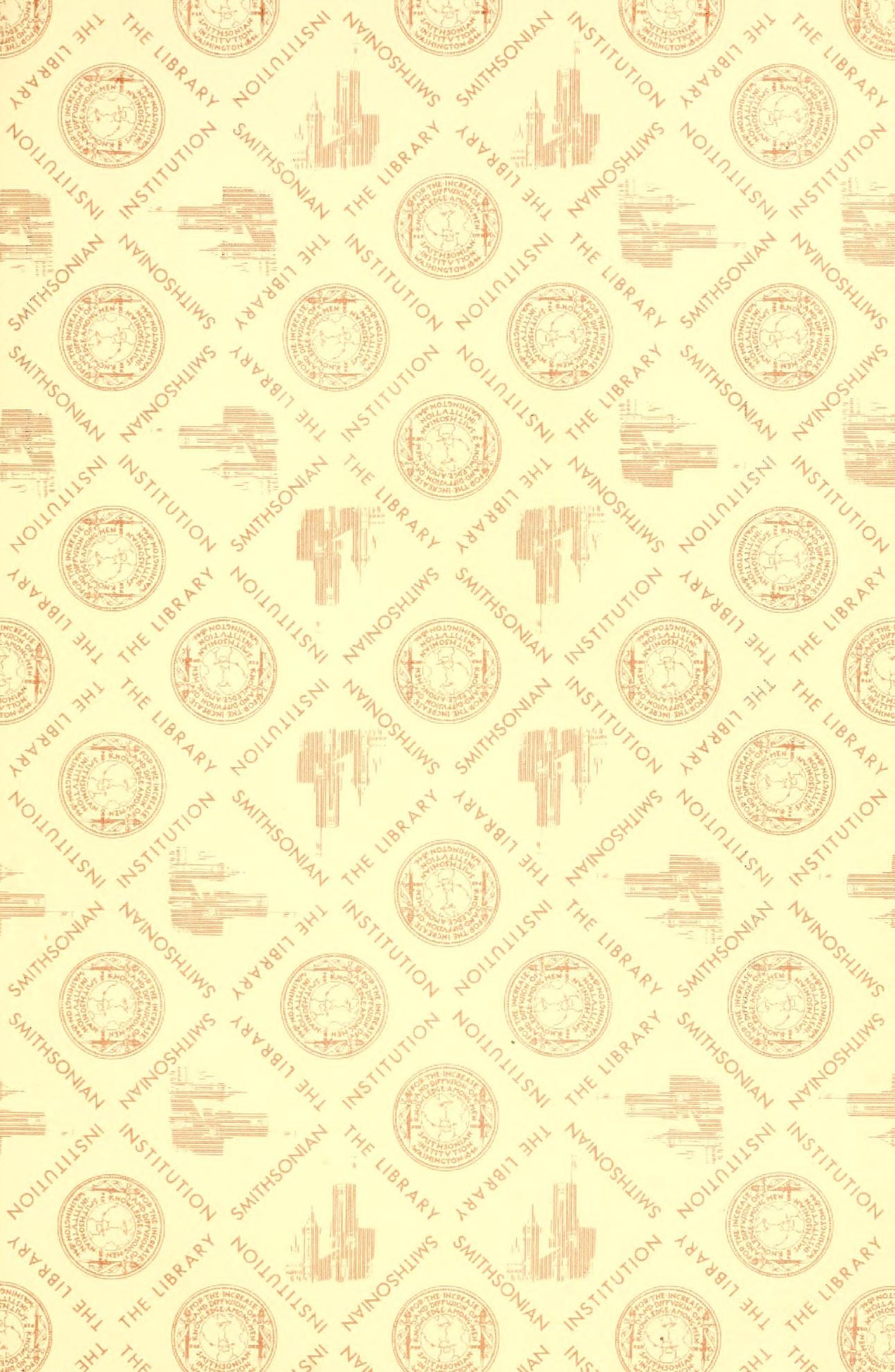






$$
x^{2}+x^{2}
$$

I 


\title{
SECOND REPORT
}

\author{
OF THE
}

State Zoologist

INCLUDING A

SMITHSONIAN

SYNOPSIS AUG 211989

OF THE

\section{LBRARIES}

ENTOMOSTRACA

OF

\section{MINNESOTA}

ZOOLOGICAL SERIES II

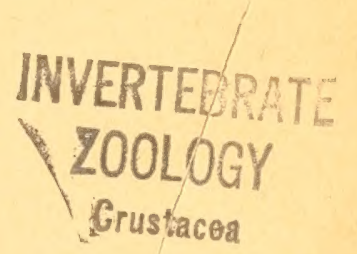


ST. PAUL MINN.::

THE PIONEER PRESS COMPANY 1895 


\section{CONTENTS}

Title

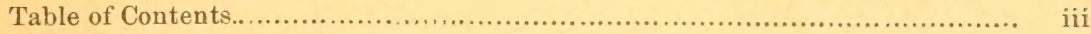

Corrigenda........................................................................ vi

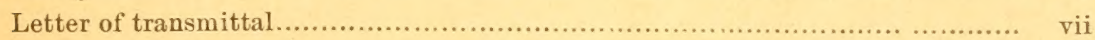

Board of Regents .............................................................. viii

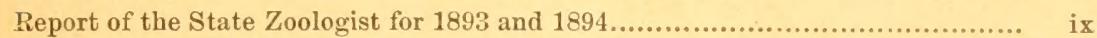

Synopsis of the Entomostraca of Minnesota....................................... 1

Editorial note.................................................................. 3

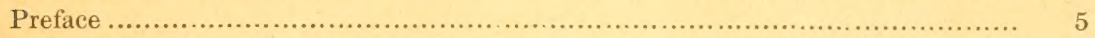

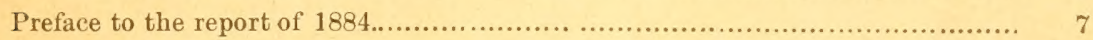

Bibliography.................................................................. 9

Order COPEPODA - Part I.................................................. 39

Family Calanidae.......................................................... 46

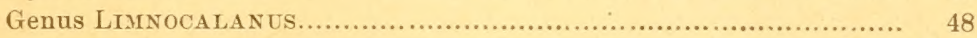

" Eurytemora ................................................... 49

"، PSEUDO-DIAPTOMUS .............................................. 53

"، Diaptomus........................................................ 54

" ВROTEAS ......................................................... 80

"

" EPISCHURA....................................................... 81

" Osphranticum................................................... 85

Family Cyclopidze...................................................... 87

Genus Crclops........................................................ 88

Family Harpacticidae............................................... 124

Sub-family Canthocamptinae........................................ 125

Genus Danthocamptus.............................................. 125

"، ATTHEYELLA .................................................... 136

" MaRSHIA...................................................... 136

Order CL I DOCERA - Part II......................................... 141

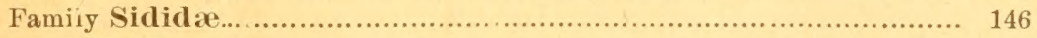

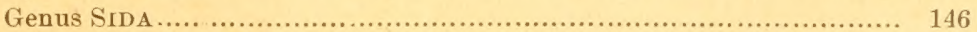

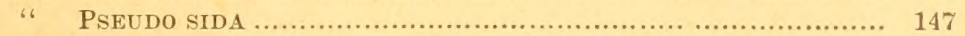

"

، DAPHNELLA...................................................... 148

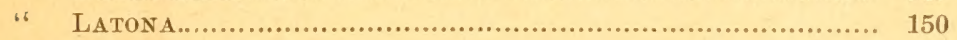

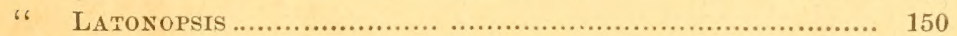

Family Holopedidae .................................................. 151

Genus HoLOPEDIUM .............................................. 15] 
Family Daphnidae................................................... 152

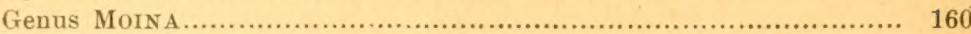

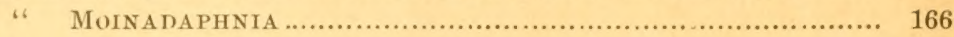

" CERIODAPHNIA ................................................ 167

" SCAPHOLEBERIS.................................................. 174

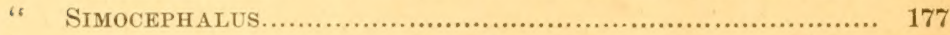

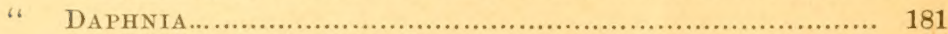

Family Bosminidae ................................................... 206

Genus Bosmina........................................................... 206

Family Lyncodaphnidxe............................................ 209

Genus MACROTHRIX ..................................................... 211

، LATHONURA.......................................................... 215

" Streblocerus ................................................... 216

" DREPANOTHRIX............................................... 217

" ACANTHOLEBERIS.................................................. 218

"، OFRYOXUS......................................................... 218

، ILYOCRYPTUS.................................................. 220

Family Lynceidae....................................................... 224

Sub-family Eurycercinæe.............................................. 225

Genus Eurycercus .................................................. 226

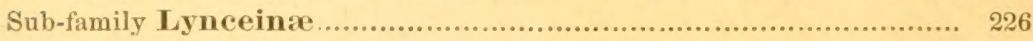

Genus CAMPtocercus................................................... 227

Sub-genus Acroperus................................................... 227

CAMptocerdus........................................... $\quad 228$

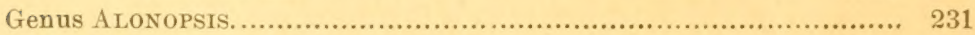

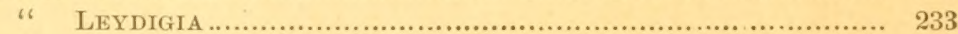

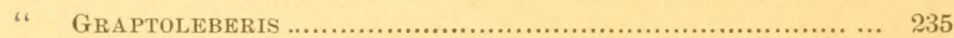

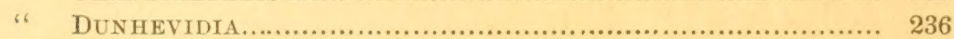

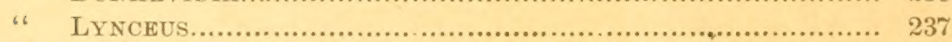

Sub-genus ALONA........................................................ 238

Section A, ALONA .................................................. 238

Section B. AlONELLA ................................................. 249

Sub-genus Pleuroxus .................................................... 253

Section A, Pleuroxus (verus) ........................................ 253

Section B, LePtorhy NCHUS. .......................................... 260

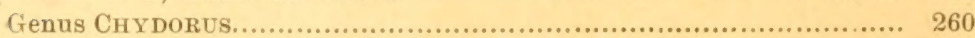

" ANCHISTROPUS .................................................... 264

" Monospilus .................................................... 264

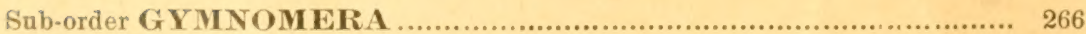

Family Polyphemidae ..................................................... 266

Genus Poly phemus .................................................... 266

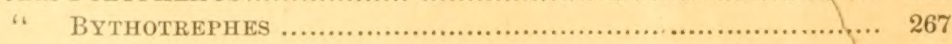

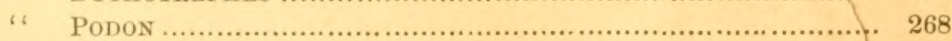

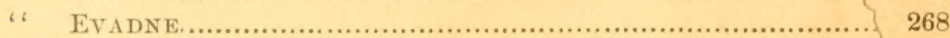

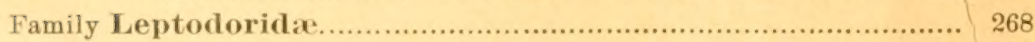

Genus LePtodoRA...................................................... 268

Appendix to Part II.-Notes on the Cladocera of the southeastern part of the

United States 


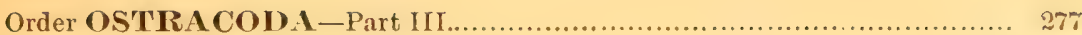

Preface ...................................................................... $\quad 279$

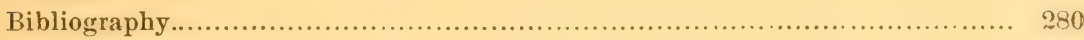

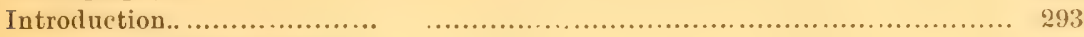

Family Cypridid:r ............................................... 294

Genus Notodromas................................................. 295

" CANDONA ...................................................... 298

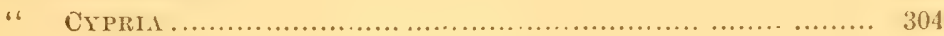

" CrClOCYPRIS ................................................... 310

“ CrPRIDOHSIS...................................................... 312

“ ERPETOCYPRIS................................................... 315

" CYPRIS ........................................................ 319

" CYPRINOTI'S................................................. 329

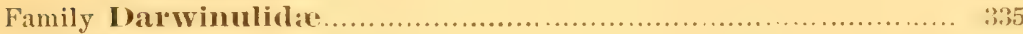

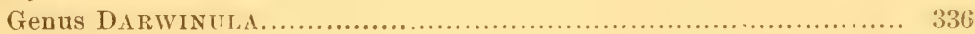

Plates and explanations..................................................... 339

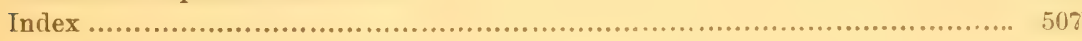




\section{CORRIGENDA.}

P'int.

56. In the "key," thirteenth line from top, read tyrrelli for tyrelli.

73. Seventline from top, read Herrick for He rick.

95. Second line from bottom, read americamus for Americanus.

101. Lmber Coclops pulehellus, supply Plates XXVI, Figs. 4, 5; XXVIII, Figs. 5-8.

105. Middle of page, read $\mathrm{m}$. q. fuscus for $\mathrm{m}$. g. fuscus.

114. Tirelfth line from top, read Cyclopina gracilis for Cyclopsina gracilis.

120. Fourteenth line from top, read lascivus for lascious.

124. Fourth line from bottom, read Copepoda for Copepodx.

126. Second line from top, read Cladocera for Cladocera.

1:29. The last the parre numbers of the "key," aud the last within the brackets, should read respectively 132, 134, 134, 135.

146. Third line from top, read Sididie for Sidide.

148. Third line from bottom, read Sida brachyura for Sida brauchyura.

150. Transfer the plate reference under Latona to Latona setifera.

174. Under Ceriodaphnia cornuta, supply Plate LXVI, Figs. 4, 5.

175. Middle of page, read Rhypophilus for Ripophilus.

195. Eighth line from bottom, read $D$. kalbergensis for $D$. kahlbergensis.

203. Middle of page, read cederstrœmii for cœderstrœmii.

205. Thirteenth line from bottom, read D. schafferi for D. scxhfieri.

210. Near middle of page, read Macrothrix (?) pauper for Macrothrix (?) pauper.

218. liead Icantholeberis curvirostris for Ancantholeberis curvirostris.

231. Eleventh line from bottom, read Alona elongata for Alono elongata.

255. Star Pleuroxus stramineus.

258. Under Pleuroxus procurvus, add LXV, Figs. 6, 7.

260. Under Leptorhynchus falcatus, supply Plate LXII, Fig. 17.

266. Under Polyphemus pedieulus, read LIX for LXIX.

27:2. lical Daphuia longiremis for Daphnia lomgiremus.

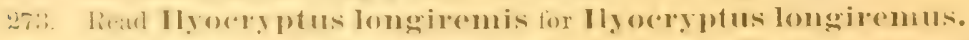

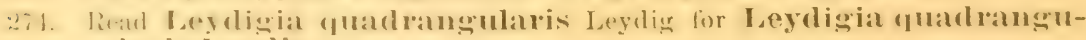
laris leydig.

274. Read Dunluevirlia setiger for Dunhevidia Setiger.

293. Fourth line from top, read adductor for abductor.

301. Read Caudona peircei for Caudona Peircei.

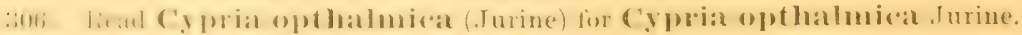

321. Tenth line from top, read Cypris gibberula for Cypris qibberala.

Unexplained remain, Plates XXV, Fig. 15; LVII, Fig. 9; LXI, Fig. 5a; LXV, Fig. 9, and a few unnumbered figures.

A number of the plate references were supplied from the explanations of plates. A few species are noticed only in the index and the plates.

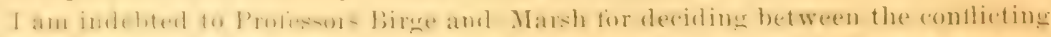
pellines on mum - in the mann-ript that were not ohesered until the index was prepared in most cases from the fiual forms.

I embrace this opportunity to acknowledge the courtesy and good wature of the

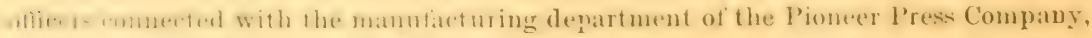
partieularly of Mr. George R. Norrissey.

H. F. N. 


\title{
LETTER OF 'TRANSMTTTAL.
}

\author{
The University of Minnesota, \\ Minneapolis, Minn., \\ November $30,1894$.
}

To the President of the Board of Regents of the University of Minnesote.

SrR: I have the honor herewith to submit to the honorable Board of Regents my second report as zoologist of the Geological and Natural History Survey of Minnesota, together with a report on the Entomostraca of Minnesota by Mr. C. L. Herrick, a graduate of the University and professor of Biology at Denison University. The report on one group of the Entomostraca, that of the Ostracoda. Was written by C. H. 'Turner, professor of Natural Science at Clark University, Atlanta, Ga. These gentlemen have given their services to the survey without charge, having asked for aud received barely enough to cover their expenses.

Very respectfully, your obedient servant,

HENRY F. NACHTRIEB, State Zoologist. 


\title{
BOARD OF REGENTS
}

\author{
OF THE
}

\section{UNIVERSITY OF MINNESOTA.}

The Hon. John S. Pillsibury, President Minueapolis.

The Hon. Greenleaf Clark, M. A .St. Paul.

The Hov. Cushmin K. Davis, M. A St. Paul.

The Hox. Stephen Mahoney, MI. A ... Minneapolis.

The Hon. WILAhM Liggett. . Benson.

The Hon. Ozora P. Stearns. Dulnth.

The Hon. Joei, P. Heativole, Northfield.

The Hon. SIDNEY M. OWEN... Minneapolis.

The Hon. William H. Yaie. .Winona.

\section{EX-OFFICIO.}

Cyrus Northrop, LL. D., Corresponding Secretary Minneapolis. The President of the University.

The HoN. KNUTK NELSON.... Alexandria.

The Governor of the State.

The Hon. W. W. Pendergast, M. A Hutchinson. The State Superintendeut of Public Instruction. 


\section{REPORT}

OF THE

\section{STATE ZOOLOGIST}

FOR 1893 AND 1894.

Shortly after the distribution of $m y$ first report a kindly criticism of the brief reference to the early history of the survey was received from a gentleman who formerly was a resident of Miuuesota and took an active interest in the work of the survey. In accordance with the assurance given to the critic I take this opportunity of correcting, so far as possible, the feature which to him seems unjust.

The statement taken exception to is the last sentence of the secoud paragraph of the "General Introduction," reading as follows: "For many years the Natural History Survey existel ouly in the wisely formulated law, for which excellent and comprehensire law we owe thanks to Dr. Wm. IV. Folwell, who was president of the University at that time."

It is contended that the credit for the survey law is almost entirely due to the Honorable John S. I'ilsburf, and "that the truths of history require that those who know the facts should demand that credit be given where credit is due." It is particularly stated that the Honorable A. J. Ldgerton, now U. S. District Judge at sioux Falls, South Dakota, while Inailroad Commissioner of Mimnesota, discovered there was a balance of a glant of land to the state, called the "Salt Land (rrant," and suggested to the Honorable John s. I'illshury, then a senator from Henmepin connty, that this so called salt land onght to be set aside for the survey fund. The suggestion was taken mp and after considerable hard work the end was gained in "An act to aid the geological and natural history survey of the state," alplyored March 10, 1873.

To this I reply: 1. There is no conflict between the bit of history given by the critic and my statement, which alluded only to the original draft of the law creating the survey. 2. My statement was based 
"1pon the fmblisher history of the survey. 'To this I have never found nor heard of any recorded objection.

() f that who have workes for the interests of the survey the Thonorahl. Juhn $\rightarrow$. Jillshury muguestionably has been the most persistent and uncelich. Lint with no thought of an historical review the reference fo rven such hright lights diel not oceur to me. No one can dexire to ser honor given where honor is due more than wyself, and I trust that. if the puhlished history is wrong and unjust, those who know the facts will publish them.

The disbursement of the funds available during the past two years I shall mot tahulate hele, as the accountant of the University will give full consideration of that in his report.

During thr past year the Survey lost by fire its boats and oars and a few minor pieces of apparatus that were stored in the "Coisenm." The invoice of the survey property will indicate more specifically the condition of the apparatus.

The firld work has been carried on as much as the meagre funds would allow. Special attrintion nas been given to the fishes, the birds and some of the invertebrates.

Doring Jume. July and August of 1833, a party of four University students ( Iugust Bothe, George D. Head. Frank Manson and Clarence T. Whitman) collected material and data in the Ginll lake region. The principal lakes investigated are the following: Giull, Round,

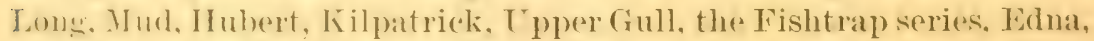
the 'ullen series, Mayo, Sibley, Lone, Twin, Pelican, Malf YLon, Little and lige (iladstone. Sylvan, Edward, Bass and Mission. The principal stramin in this rescion wrere also more or less thoroughly investigated.

Doring the same time another party of four University students

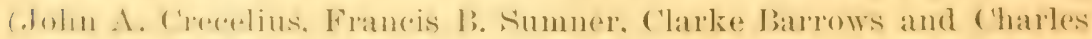

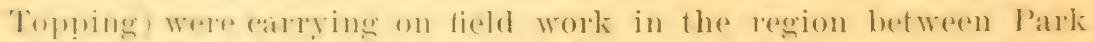
Rapiels and the headwaters of the Mississippi. The prineipal lakes here visitel atre: Fishlook, the lilbow series. fire of the crow Wing series, Itasea, Lik, Bemidji, Cass and Kitihi.

'The matreral rollecetod hy these parties is stored in P'illsbury IIall.

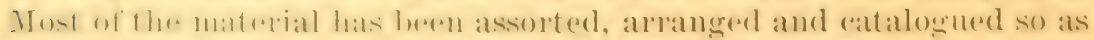
fo makre it reatily areessihle for study. The fishes of the sereral eol-

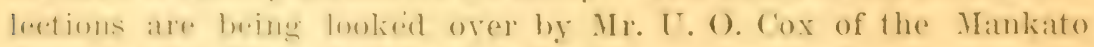

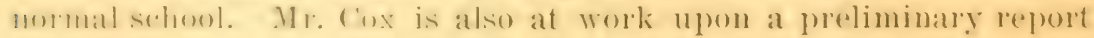

*The llistory of (ieological Surreys of Minnesota, by N. II. Winchell. 1859. 13ulletin No. 1 of the Geologrical and Natural History Survey of Minnesota, page 6 .

Final heport of the Geological and Natural History Survey of Minnesota, 1S84. Vol. I, page 106.

See also the footnote on pare 29 of President Folwell's Inaugural Address, delirered Dec. 22, 1869, and printed immediately after. 
on the fishes of the State. This report we hope to have ready for the printer before next spriug. It will be issued as one of the bulletins of the Survey.

The ornithologist, Dr. Thomas S. Roberts of Mimeapolis, marle a trip of ten days into the southwestern part of the state during the latter part of $\mathbf{M a y}, \mathbf{1 8 9 3}$, and one of ten days into the Lake Vermillion region during June, 1894. IBoth trips were very profitable, and dem. onstrated conclusively that nothing but a visit of the ornithologist to the rarions important sections of the State at the proper seasons can gain for the Survey the information and material required as a basis for a reliable and satisfactory final report.

The wisdom of prosecuting the ornithological work with a view to a final illustrated report is fully vindicated by the great interest taken in the "Notes on the Birds of Minnesota," published with my furst report, and by the numerous infuiries as to when the final report on the Birds of Minnesota is to appear.

The edition of Dr. Hatch's "Notes" is already exhausterl. The demand for this publication has been gratifyingly great, particularly in the State, where, I am glad to say, the great majority of the books have found interested owners.

The distribution fund for this report was insulficient, and the last three hundred or more applicauts were obliged to pay the trausportation charges. The willinguess with which these charges were paid has convinced me that all persons really interested in such reports will gladly pay the transportation charces on them. In view of the facts I. would suggest that hereafter provision be made to pay transportation charges on only those ropies of thr reports and bulletins sent to our "exchanges" and to citizens of Minnesota.

Duriug the past summer MIr. (. I. Herrick, a graduate of the University and Professor of Biology in Ienison T niversity, with the assistance of Professor C. II. 'Thurner' of Sunth Atlanta. Georgia, completed a report on the Copernoda, cladocera and ()stracoda of the state and tendered it to the Survery loublication. The demand for Mr. Herrick's report on the Crustacea of Minnesota, publisherl in the Twelfth Annual Report of the state (ieologist, and the many important and interesting problems (omnected with this group of animals ares a sufficient reason for publishing a revisim of the renort for 1881. The report will also be of special value to our teachers of zoology.

A few purchases have luen made for the museum during the past two years. Of these may be mentioned a young bull moose, two deer, one wolt, one black woodrhuck, and several smaller mammals. T)ring the same time the museum has been enriched by valuable donations, of which the following are worthy of sperial mention: 
From Dr. W. S. Ftrode, Lewistown, IIl., a collection of land and freshwater shells representing about fifty species.

From Jathan Butler, Baruesville, Minn., the bones of a large moose.

From Mr. Ienjamin LadIere. Hickory, Aitkin ('ounty, a fiw mammalian skulls and skins.

From Irr. I). I). Stone, Isunsing, X. Y., a collection of eleven sets of hird eggs containing forty-two eggr, of which fire sets are accompanied with the nests and three sets with the skins of the frumle birds.

From Mr. I) enis (iale, Gold Hill, Boulder county, colorado, fortythree sets of bird eggs containing one hundred aud ninety-seven eggs, of which twenty-two sets are accompanied with the nests. Also the skins of eight birds and three small mammals.

From IIr. James IJobson, Ann Irbor, IIshigan, thirty four momnted skulss, nearly all of them the skulls of different speriest of biras.

From Mr. A. 1). Brown, Pipestone, Minn, three bird skins of special value to us.

From Dr. ('. I. C'ooke, Vew líchland, Mimn., about one humbred bird skins, the majority of which are from Minnesota.

From Mr. Franklin Bunner, Minneapolis, his eutire collection of hirel skins, exges amel nests. This collection contains about six hundreol and fifty skins and represents about two hundred and litty species.

From ln. Thomas s. Roberts, Mimneapolis, his entire collection of hird skins, eggess and nests. This eollection contains eight hundred and fifty skins and represents about three humbled spereies.

In the lioberts and bennee rollections the foiversity has the most

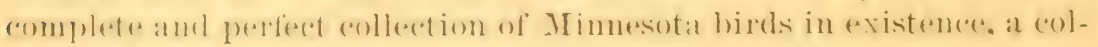
lection that makes the ornitholugical room of the ntmost importances to the student of the ornithology of the Northrest.

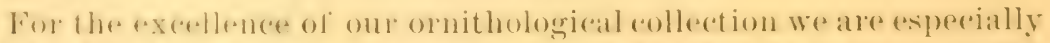

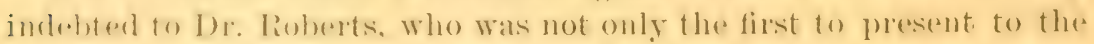
Iniversity so valuable a collection as his own but was also iustru-

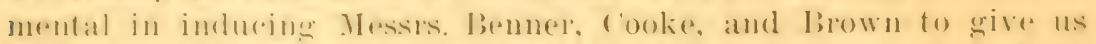
their valuahle (eolleetions. Ho. Roberts has also given math of his

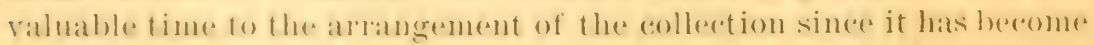
the prepert! of the foirersity. In the tedions wark of relabeling

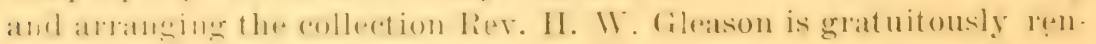
dering indispensable assistance.

In the field work Mr. Thomas Miller of Ineron lake has gratuitmaly rendereel gereat servier to the ornithologist. Several amatemr 
ornithologists residing in different parts of the State have very generously offered me their assistance in the prosecution of the ornithological work, and it will be a pleasure to properly credit all such assistance in the final report.

All acquisitions are properly recorded in the accession record of the museum, the record containing the accession number, the original number aud all known data relating to each specimen, whether purchased, collected or donated.

The ornithological material is recorded in a special record. A card catalogue of all this material is now being prepared, and when completed will make the material readily accessible. Other collectious, such as the collection of fishes and insects, will be similarly recorded and catalogued.

It would be unpardonable not to call attention to the cramper condition of the zoological museum at this time. Some of the valuable collections noted above were presented rather reluctantly on account of the insecurity and insufficiency of the cuarters. The insufficient protection against fire and the lack of room for proper display of specimens have diverted from us some most valuable material that is now the property of musenms in the Fast. Collectors, and particularly specialists, will continue sending their best and rarest specimens to other museums just as loug as we do not offer a safe and adequate depository.

A zoological museum in good yuarters and properly taken care of soon acquires material of great general interest and incalculable scientific value, - material that costs more in both time and money to collect and prepare than any other, aud that often can not be duplicated at any price. It ought, therefore, be housed in the safest possible building.

The zoological musemm in Pillshury Hall has, without any special effort on the part of the curator, already acquired an amount of material that simply cannot be properly displayed or arranged in the present quarters. Hundreds of fine specimens are crowded into cupboards, drawers and boxes. In this condition the zoological museum must be unsatisfactory to the visitor's and discouraging to those in charge of it and desirous of building it up. Moreover, our opportunity to get representatives of those animals which are rapidly disappearing from the State is slipping by.

If the museum is ever to offer a true survey of what the amimal kingdom of the State is and was, adequate aud safe quarters must be provided very soon.

Very respectfully, your obedient servant, Henry F. Nachtrieb. 



\section{SYNOPSIS}

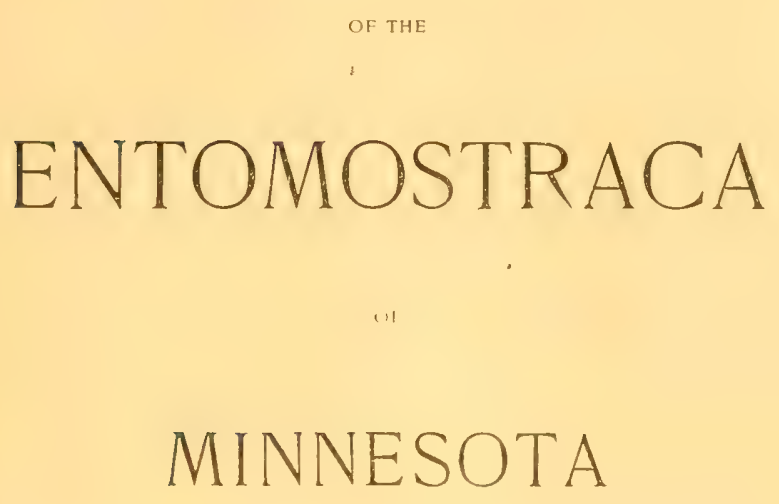

WITH DESCRIPTIONS OF RELATED SPECIES COMPRISING ALL KNOWN FORMS FROM THE UNITED STATES

INCLUDED IN THE ORDERS

COPEPODA CLADOCERA OSTRACODA

By C. L. HERRICK and C. H. TURNER 



\section{EDITORIAL NOTE.}

Early in the spring of $189+$ the state geologist, X. H. Winchell, referred to me a letter from Professor C. L. Herrick containing two propositions, viz.: (1) That the Survey accept and publish the present revision of the report of 1884 ; ( 2 ) that the anthor be permitted to make such use of the old report as he saw fit and publish the revision independently of the Survey. After haring been assured that the errors of the 1584 report had been corrected and the report had been bettered in other respects, it was decided, for reasons that seemed sufficient, to accept the first offer, though the revision had been begun and practically finished without the knowledge of any one connected with the Survey. The maunscript was received during the last week of October, 1894 .

The editorial work as well as the proofieading all fell to the zoologist of the Survey. The author's serious illness and his great distance from the University marle it impracticable to put any of this work upon him. The work was at times very disheartening, but I did my best, and trust that at least most of the errors and shortcomings of the manuseript have been eliminated.

In justice to the author the following matters deserve special mention:

The anthor"s title, "Synopsis of the Microcrustacea," etc., was changed for reasons found principally in the primary destination of the report and in the usage of some of our best and most generally used text-books of zoology.

For making reference only hy author and dite the editor is wholly responsible. The date is always an important and often a very essen. tial part of a publication, and for that reasou alone is far superior to a reference by a purely artificial number. The superiority of an abbreviated reference to a full or more or less mutilated citation is so obvious that it needs no vindication.

In the bibliography the editor has supplied the number of pages, number of plates and similir data of detail from 'Taschenberg's Bibliothece Zoologina, Znologischer Inseiger, Zoologiseher Juhrestericht. and the cutalogue of scientific l'upers compiled by the Royal society of London. Where these data are wanting the citation could not be found in these publications or could not be identified beyond a doubt. In comparatively few cases could these data be obtained from original sources. More or less gross discrepancies between the manuscript and the publications noted above were very numerous as to date, title 
etc. Is a rule, these could be satistactorily cleared. Whenever there was any doubt as to which was correct in part or as a whole, both the author's citation and that of the editor's source were given, the latter parentLetically. Several references made to Strauss have been referred to Straus-I)urckheim, and Sars cited with four different sets of initials it seemed clear was intended for George Ossian Sars. A few citations have been added by the editor from original sources. Those interested will not fail to collect others from the Bibliothecu Znolorier and similar publications. Under the Cladocera the citations had to be given in the original form, because the datagiven in the manuscript aliat make possible a more definite reference. In these cases all but the references to synonyms were cut out.

In accordance with the rules of nomenclature of the German Zoological society. the comma between the specific and author's names has been eliminated and all specific names appear in lower case. So far as possible these rules have heen followed in other respects. The absence of literature, however, made it unsafe for me to touch doubtfiul cases.

Th" "sp. n." of the old report has been replaced by the author's name, Herrick.

The various " keys" have been reduced to a uniform plan, and several of them have heen compiled by bringing the sections together from various parts of the manuseript. To increase the value of these "keys." the page upon which the description of the genus or species begius has been alded and names of authors and other details have been dropped.

The names of families, genera, etc., have been italicized in the general text.

The order and arrangenent of the plates is most unsatisfactory. None of the drawings had been called for by me before they were sent to the engrafer, and hesides the necessity of using so many of the old plates male an orderly and respectable arrangement impossible.

The index is wholly the work of the editor.

Profesinor Turmer's paper practically appears in its origrinal shape. The key to the ('gpridida was changed from the bracket form to the paragraph form for practical reasons only.

I take this opportunity to express my indehtedness to Professor C. Judken Herrick of (ivanville, ()hio, for kindly looking after the fongraving and printing of the plates, and to Mr. W. H. Kussmanl of Cranville for the care he exeresed in the printing of the plates. To the state printing expert. Ir. Creorere ('. Ftevens. I am inclebted for indulgent considerations and a lasting patience.

A PRIL 29, 1895.

HENRY F. NACHTRIEB. 


\section{PREFACE.}

The exhaustion of the edition of 'A Final Report on the Crustacea of Minnesota included in the Orders Cladocera and Copeporla" has led to a demand for republication. It has seemed unfortunate that the imperfections of this work, many of them due to the unsatisfactory state of the European literature, while others were the result of imperfect information aud faulty observation or hasty judguent, should be perpetuated. The original paper grew out of studies made chiefly while the author was an undergradnate at The University of Minnesota and was very fully occupied otherwise, and cireumstances have prevented him from anything but the most casual pursuit of the subject since 1SS4. It might have appeared that the work had served its purpose, but there were many indications of a need for a comprehensive, synoptical survey of this field, and the present paper seemed the only approximation to such a work. A serious illness, which has greatly impeded the progress of the revision at last decided on, has at the same time made it possible by forcibly relieving the author of more pressing duties. It would have been a great satisfaction to him to have given to the subject the thorongh field work and comprehensive bibliographic elaboration it leserves, but strength and opportunity forbid. In default of this it might seem wiser to enumerate only American species, but experience has shown that gengraphical limitations do not prevail to any great extent in most of the families here considered. In such instances. Culuniter for example, the attempt has been made to include all vilid species and a full syuonomy. In the others as full a list is giveu as is now possible, and while this work may not be alone sufficient to enable the specialist to formulate new diagnoses and descriptions, it yet offers much fuller symopsis than yet published and will give a bird'serye view of the taxonomy of the subject.

The most important aspect of the subject, namely, the biological relations of these organisms, has been too generally neglected. In no other group can the problems of parthenogenesis and heterogenesis be so easily and accurately studied. The transparency of the body 
makes it possible to examine vital phenomena directly and watch the eflects of stimuli upon the circulation, ete., in rontime. MIany curious problems, anong them bathymetric distribution and the effects of environment, can be satisfactorily studied in these groups. It is a matter of wonder that greater use is not made of these types in the laboratory courses of our universities. P'robably the chief obstacle has been the lack of suitable means of determining species. This we "udeavor to offer in so fur as may be necessary for this purpose, but purposely abstain from the theoretical questions everywhere pressing on the attention.

This work claims to be a report on the Crustacea of Minnesota, but it was found impracticable to sufficiently describe our forms withont a rapid survey of the whole territory. I am under obligations to Professor ( . Dwight Marsh and to Protessor E. A. Jirge for loan of literature, and to P'rofisisor Charles Turner of Atlanta for many notes incorprorater in this work. My greatest obligation is to my wife, who has collated the bibliography accompanying. This tedious but most useful labor has been wholly performed by her.

For mans incidental aids during the progress of the work I am indebted to my brother, Professor C. Judson Herrick.

The reader is reduested to remember that this is a revision, following to a large extent the mould set in 1834 , and therefore should not be held to the standard of a work wholly prepared in the light of our present knowledge.

The third part of this paper, that dealing with the ostracorla, is wholly prepared by Professor ('. II. Turner, who has been assiduously studying the group for several years, and I beel sure that his contribution will he highly apprediated at the present time, especially as no attempt to monograph the order in America has get been made.

Aliburuerceve. New Mexico, Nov. 1, 1894. 


\section{PREFACE TO THE REPORT OF 18 S ON THE CLADO- CERA AND COPEPODA OF MINNESOTA.}

In presenting what may be denominated a final report of the work done in this state upon the group of ('rustacea best represented and, all things considered, most important, the author must admit that the term "final" refers only to his own opportunities and the limitation of time imposed by circumstances.

While a comparatively large proportion of all the species existing within our limits have been examined during the progress of these investigations, there undoubtedly remain many additional aud curious forms to reward the search of the student. A great variation in the degree of completeness with which the different genera and species have been treated will be observed, due iu part to the circumstances under which they were studied and frequently to the poverty of material. The entomostracean fam is quite different at different seasons, and a complete knowledge of even our local fauna requires a long period of observation. Eveu the dead of winter is a farorable time to study some groups. The late antumu is, perhaps, the most favorable opportunity; for then, in one group, the sexual activities are just at their height and both sexes may be studied. A number of clladocera are restricted to this season. There are a number (how large it is not yet possible to tell) of species in both groups which are to be sought by night, though no phosphorescent species are yet known. Our larger and, especially, deeper lakes have a quite different fanua from the shallow pools and rivers. In general, the flowing waters are poor in Entomostraca. The Cladocera or shelled Entomostraca have here received a large share of attention, and more particularly the Lynceids, which are the most minute of Arthropods. This study has been rewarded with an unexpectedly large number of forms, and a particu. larly large number of species identical with those of Europe aud elsewhere. Professor Birge is the only American writer who has attempted this group, and his valuable work has made us fimiliar with the more striking new species. A few new species are included in our list and several varieties hardly yet known in Europe. 'The 
remarkable Monospilius is among these. 'This animal has but a single larval eye in the middle of its forehead, and wears its old covering over the newly-formed shell till the latter is a curious patchwork mass. The attempt has been male to incorporate a brief description of all American species with those found in Mimmesota, and also to fiame kess for the larger genera, so that the place of a species among its congeners may, at least approximately, be found. The difficulty of fiaming such keys is very great; for few authors have employed the same distinctions in their descriptions, and it is necessary to select points shapply distinctive and conspicuous from the oftun meager remainder after striking off scattering particulars. In somr cases this difficulty has been greatly enhanced by the possibility that some of the species shomld he considered synonyms or varietal forms. The temdency to combine questionable forms thus prodnced it was necessary to officet by what may seem a too great conservatism. Faulty, howerer, as these keys may he, it is hoped that they will serve a good furpose in the extent which they cover. While the limits of this work preclude much more than a systematic outline, opportunity is taken here and there to admit a word on the anatomy or development. fuch allusions must be comsidered simply acoidental, for a complete treatment of these suhperes would reguire large volumes, and the maferial will be lone in gathering. A larger proportion of the rare males of the Cladocerat are here referred to than in any previous work of eppat extent. 'The genus (ycolops, one of the bughears to fireshWater areinologists, is perhaps somewhat summarily treated. The

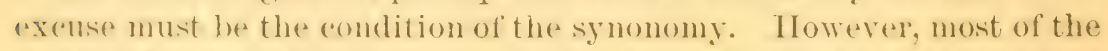
combinations marle were the result of careful stury of latege series from different localities. The sketches illustratiug this paper are photo printed from the writer's own llawings, and, without the elegance of lithographls, serve the purpose of explatining points of struc-

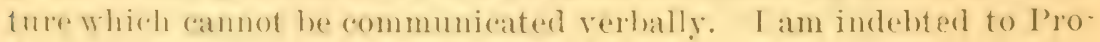

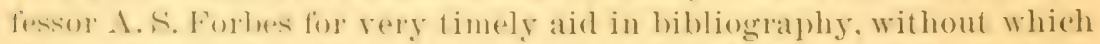
the papere (e)tel not have been completed. To I)r. Lindahl, through

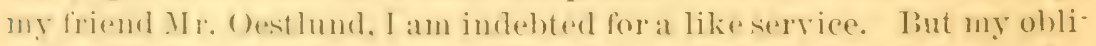

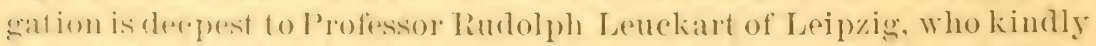
aftureded aceess to almost a complete set of works on Earopean linto.

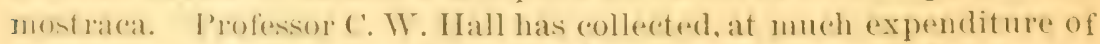
fime and labor, a set of specimens from different parts of the state, which he kindly placed in my hands, thus emabling me to observe the

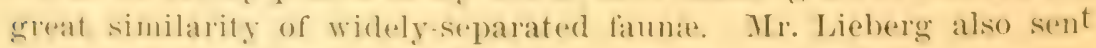
sperimens of loiatomms stagmalis from saline pools in Jakota. 


\section{BIBLIOGRAPHY.}

The present list, chiefly the work of Mrs. C. I. Herrick, cannot hope to prove complete, nor has it been possible to verify references in many cases. The imperfections arising from securing titles at secondhand, however much to be regretted, will not, it is hoped, prevent this catalogue (by far the most complete yet printed) from having a certain value to the working naturalist. [Nee editorial note. Dates later than 1800 are abbreviated.]

\section{Adams, George.}

1746. II icrographia illustrata, or the knowledge of the microscope explained. (4 pl.) London. (Plates in $4^{\circ}$. London 1747. 4th edit. 1771. $8^{\circ} .72 \mathrm{pl}$. )

\section{Allman, G. J.}

'47. Description of a new genus and species of Entomostraca. (Biological Contributions. No. III.)

Ann. and Mag. Nat. Hist. Vol. 20, pp. 1-9 and 47-52.

'48. On the Development of Notodelphys Allm., a new Genus of Entomostraca.

Rep. 17th Meet. Brit. Assoc. Advanc. Sc. in 1817. Notices and Abstracts, p. 74.

\section{Anderson, John.}

'62. On the Anatomy of Sacculina, with a Description of the Species.

Ann. and Mag. Nat. Hist. Ser. 3, Vol. 9, pp. 12-19. (Proc. Roy. Phys. Soc. Edinh. Vol. 2, 1863, pp. 304-314.)

Asper, G.

'80. Beiträge zur Kenntniss der Tief'seefauna der Schweizerseen.

Zool. Anzeiger. Jahrg. 3, No. 51, pp. 130-134 and No. 54, pp. 200-207.

Aurivillius, 0. C.

'79. Balæuophilus unisetus nov. Gen. et Sp. Ett Bidrag till Kännedomen om Harpacticidern ?S Utvecklingshistoria och Systematik. (4 pl., 26 pp.)

Akad. Af handl. Stockholm, Central-Tryck. $8^{\circ}$.

'79' ${ }^{1}$ On a New Genusand Species of Harpacticida. (Balicnophilus unisetus. 4 pl, $16 \mathrm{pp}$.)

Bihang till K. Svenska Vet. Akad. Handl. Vol, 5, No, 18.

\section{Baird, W.}

'34. List of Eutomostraca found in Berwickshire.

Trans. Berwick. Nat. Field Club. Vol. 1.

'37. The Natural History of British Entomostraca.

Mag. Zool. and Bot. Vol. 1, pp. 35-41, 309-333 (3 pl.), 514-526.

'38. Id. Ibid. Vol. 2, pp. 132-114, 400-412.

${ }^{\prime} 38^{1}$. Id. Ann. Nat. Hist. Vol, 1, pp. 245-257.

43. Id. Ann. and Mag. Nat. Hist. Vol. 11, pp. 81.95 (2 pl.) 
'46. Description of some new genera and species of British Entomostraca. (1 pl.) Ibid. Vol. 17, pp. 410-416.

'49. Arrangement of British Entomostraca, with a list of species.

Trans. Berwick. Nat. Field Club. Vol. 2.

'50. The Naiural History of the British Entomostraca. (36 pl. VIII., 364 pp.) Ray Society, London.

59. Description of several species of Entomostracous Crustacea from Jerusalem. ( $2 \mathrm{pl}$.

Ann. and Mag. Nat. Hist. Ser. 3, Vol. 4, pp. 280-283.

Balbiani, G.

69. Ohnerrations relatives ì une Note récente de M. Gerbe, sur lil Constitution et le Développement de l'ouf ovarien des Sacculines.

Compt. Rend. de l'Acad. des Se. Paris. 'T. 68, pp. 615-618.

'69. ${ }^{1}$ Sur la Constitution et le Mode de Formation de l'œuf des Sacculines.

Ibid. T. 69 , pp. 1320-1324.

69. - Sur la Constitution et le Mode de Formation de l'ceuf des Sacrulines. Re. marques concernant une Note récente de M. Ed. van Beneden.

rbid. T. 69, pp. 1376-1379.

\section{Barrois, Th., et R. Moniez.}

'88. Materiaux pour servir à l' étude de la F'aune des eaux douces des Açores. IV. Crustacés. [Copeporles par Barrois; Ostracodes, Cladocerea, Branchiopodes par Moniez.] Lille, $1888.8^{\circ} .20 \mathrm{pp}$.

\section{Beck, Cour.}

'-. On some new Cladocera of tbe English lakes.

Journ. Roy. Mic. Soc. London. Vol. 3.

Beneden, Édouard van.

69. Sur le Mode de Formation de l'ceuf et le Diveloppement embryonnaire des Sacculines.

Compt. Rend. de l'Acad. des Sc. Paris. 'T. 69, pp. 1146-1151.

"70. Recherches sur 1'Embryogénie des Crustacé. III. Déreloppement de l'œuf et de l'Embryon des Sacculines (Sacculina carcini Tbomps.). (1 pl.)

Bull. de 1'Acad. Roy. de Belgique. Ser. 2, 'T. 29, pp. 99-112.

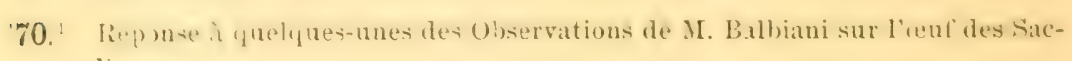
culines.

Compt. Reud. de l'Aead. des Se. Paris. 'T, 70, pp. 197-200.

\section{Beneden, Eduard van, et Emile Bessels.}

'70. Minoire sur la Formation du Bhastoderme chez les Amphiporles, les Lernéens et les Copéporles. (5 pl.)

Mém. cour. et Mém. d. sav, étrang. de Belgique. 'T. 34, p. 59.

Beneden, P. J. van.

'51. Recherches sur quelques Crustacés inférieurs. (5 pl.)

Ann. Sciene. Nat.-Zool. Ser. 3, T. 16, pp. 71-131.

'61. Recherches sur les Crustacés du littoral de Belgique. ( $21 \mathrm{pl}$.)

IÍ́m. de l'Acad. roy. de Belgique. T. 33, p. 174. [Title given by Herrick is: Recherches sur la faune littorale de Belgique, Crustacés. Mem. d. l'Acad. de Bruxelles. Tome 33.] 


\section{Birge, Edward A.}

'78. Notes on Cladocera. (2 pl.)

Trans. Wisconsin Acad. Sciences, Arts and Letters. Vol. 4, pp. 77-112.

'91. List of Crustacea Cladocera from Madison, Wisconsin. (1 pl.)

Ibid. Vol. 8, pp. 379-398.

'- Notes on Crustacea in Chicago water supply, with remarks on the formation of the Carapace. Chicago Med. Journ. and Ex. Vol. 5.

Boeck, Axel.

'59. Trende nye parasitiske Krebsdyr. Forhandlinger.

'65. Oversigt over de ved Norges Kyster iagttagne Copeporler henhorende til Calanidernes, Cyclopidernes og Harpactidernes Familier.

Forhandl. Vidensk. Selsk. Christiania. (Aar 1864.) VII, pp. 226-281.

'68. Om Sildeaat. Tidskrift for Fiskeri I. 1876, and Archiv f. Naturgesch. XXXIV. 1868

'73. Nye Slaegter og Arter af Saltvands-Copepoder.

ForhandI. Vidensk. Selsk. Christiania. (Aar 1872.) XIV, pp. 35-60.

\section{Bourne, G. C.}

'89. Report on the Pelagic Copepoda collected at Plymouth in 1888 89. (2 pl.)

Journ of the Marine Biol. Assoc. of the United Kingdom. New Series, Vol. 1, No. 2, pp. 144-152.

\section{Brady, George Stewardson.}

'64. On the Zoology of the Hylton Dene.

Trans. Tyneside Nat. Hist. Club. Vol. 6.

'67. Reports of Deep sea Dredging on the Coasts of Northumberland and Durham, 1862-64. Pelagic Entomostraca.

Nat. Hist. Trans. Northumb. and Durham (1865). Vol. 1, pp. 29-40.

'68. On the Crustacean Fauna of the Salt Marshes of Northumberland and Durham. ( $2 \mathrm{pl}$.)

Ibid. Vol. 3, pt. 1 (1869), pp. 120-136.

'69. Description of an Eutomostracau inhabiting a Coal Mine. (Canthocamptus cryptorum. (1 pl.)

Quart. Journ. Microse. Sc. New Ser. Vol. 9, pp. 23-24.

'70. Id. Nat. Hist. Trans. Northumb. and Durham. Vol. 3, pt. 1 (1869), pp. 203-205.

'72. A list of the non-parasitic Copeporda of the Northeast coast of England. (5 pl.)

Ibid. Vol. 4, pt. 2, pp. 423-445. Also in: Ann. and Mag. Nat. Hist. Ser. 4, Vol. 10, pp. 1-17. (5 pl.)

'78. Monograph of the free and semi-parasitic Copepora of the British Islands. 3 Vols.

Ray Soc. London.

'80. Copepoda. Exploration of the Faroe Channel by Stafl-Commander Tizard R. N. and John Murray.

Proc. Roy. Soc. Edinb. Vol. 2. 
'83. Report on the Copepoda obtained hy H. MI. S. Challenger during the years $187376 .(55 \mathrm{pl}$.)

Rep. Scientif. Results Voyage Challenger. Zool. Vol. 8, No. 23. 142 pp.

'86. Notes on Entomostraca collected by Mr. A. Haly in Ceylon. (4 pl.)

Journ Jiun. Soc. London. Zool. Vol. 19, No. 114, pp. 293-317.

'88 Description of a new species of Cyclops.

Sixth Annual Rep. Fishery Board of Scotland.

'91. Revision of British species of Freshwater Cyclopida and Calanidx.

Nat. Hist. Trans. Northumb, and Durham and Newcastle. Vol. 11, pt. 1, pp. 68-120. Also separate. London, 1891. $8^{\circ} .55 \mathrm{pp} .14 \mathrm{pl}$.

Brady, G. S., and David Robertson.

'73. Contributious to the study of Entomostraca. VIII. On Marine Copepoda taken in the West of Ireland.

Ann. and Mag. Nat. Hist. Ser. 4, Vol. 12, pp. 126-142.

76. Report on Dredging of the Coast of Durbam and North Forkshire in 187.

Rep, 45th Meet. Brit. Assoc. Advanc. Sc. in 1875, pp. 185-199.

\section{Brandt, J. F.}

'5u. Ueher eine Ahhamlung des Herm Dr. Seh. Fischer, betitelt: Ergänzungen, lierichtigungen und Fortsetzung zur Abhandlung ïber die in der Umgegend von St. Petershurg vorkommenden Crustaceen aus der Ordnung der Branchiopoden und Entomostraken.

Ball. phys. math. de 1'Acad. de St. Petersbg. 'T. 8, pp. 269-271.

Brauer, Friedrich.

'r2. Beiträge zur Kenntuiss der Phyllopoden. (1 pl.)

Sitzungsber. d. kais. Akad. d. Wiss. Wien. Math.-naturwiss. Cl. Bd. 65, Abth. 1, pp. 279-291. Also separate. Wien, 1872. $8^{\circ} .13$ pp.

74. Vindunlige Mittheilungen üher die Entwicklung und Lehensweise des Lepidurus productus Bose.

Ibid Bd. 69, Abth. 1, pp. 130-141.

'77. Beitrïge zur Kenutniss der Phyllopoden. (8 pl.)

Ibid. Bd. 75, Abth. 1, pp. 583-614. Also separate. Wien, 1877. $8^{\circ}$.

\section{Braun, IM.}

84. Phy inaliohe und hologische Totersuchungen im westlichen Theile des finnischen Meerbusens. (1 Karte.)

Arch. f. d. Naturkde. Liv., Ehst-u. Kurlands. Ser. 2, Bd. 20, Lief. 1. Also in Naturforsch. Gesellsch. Dorpat. 1884. $8^{\circ}$. $130 \mathrm{pp}$.

Brebisson, L. Alphonse de.

'25. Citalonue methodigue des Crustacés terrestres, fluviatiles et marius, recueilles dans le départment du Calvados.

Mem. de la Socićté Linnéene du Calvados. 1825. Pp. 251-274.

\section{Buchholz, R.}

'74. Crustaceen (15 pl.) In: Die 2. deutsche Nordpolarfahrt. 2 Bd., 1874, pp. 262.399.

\section{Burgersdyk.}

57. I.mil en Z wetwater-Schanldieren. Herkolts Bomostaflen voor eene Fauna van Neederland. 1. 


\section{(Burgersdijk, L. A. J.)}

'61. Over inlandische soorten van Entomostraca. (Over insekten nit de omstreken van Breda en zoet-water Entomostraca. Tijdschr. v. Enotomol. Deel IV. 1861. Pp. 20-22.)

\section{Cajander, A. H.}

'69. Bidrag till Kännedomen om sydvestra Finnlands Krustaceer.

Notis. Sällsk. pro Fauna et Flora Fennic. Forhandl. Hät 10, pp. 371-376.

\section{Cann, E.}

'83. Les Copépodes lihres marins du Boulonnais.

Bull. Scient. de la France et de la Belgique. Ser. 3, T. 1, Nos. 1-3, pp. 78-106.

\section{Car. Lazar.}

'84. Ein Beitrag zur Copepoden-Fauna des adriatischen Meeres. (1 pl.)

Archiv. f. Naturgesch. Jahrg. 50, Bd. 1, pp. 237-257.

\section{Caruccio, A.}

'85. Zoolngia in Viaggia di circumnavigazione della R. corretta "Caraciolo" vegli Anni 1881-84. Vol. I.

\section{Chambers, V. T.}

'81. Two new species of Entomostraca. ( 2 pl.)

Journ. Cinn. Soc. Nat. Hist. Vol. 4, pp. 47-50.

\section{Chyzer, Corn.}

'57. Budapest viđékén eddig talált hejanczokrol. Magyarhoni természetbarát. II. Füz Nyitra.

'58. Ueher die Crustaceen fauna Ungarns.

Verhandl, der k. k. zool.-bot. Gesellsch. in Wien. VIII, pp. 505-518.

Claus, Carl.

'57. Das fenus Cyclops und seine einbeimische Arten. (3 pl.)

Arcbiv. f. Naturgesch. Jahrg. 23, Bd. 1, pp. 1-40.

'57'. Weitere Mittheilungen üher d. einbeimischen Cyclopiden. (1 pl.)

Ibid. Jahrg. 23, Bd. 1, pp. 205-210.

'58. Beitrïge zur Anat. u. Entw. 1. Cyclopiden. Weigmanns Archiv.

'58'. Zur Anatomie und Entwickelungsgeschichte der Copepoden. (3 pl.)

Arch. f. Naturgesch. Jahrg. 24, Bd. 1, pp. 1-76.

'58'. Ueher den Bau und die Entwickelung einiger parasitischer Crustacen. ( pl.) Cassel, Fischer. $4^{\circ}$. 34 pp.

'59. Ueber das Auge der Sapphirinen und Pontellen. (Illustrations.)

Mïullers Archiv. (Reichert u. Du Bois-Reymond's Archiv. f. Anat. 1859. pp. 269-274.)

'60. Beiträge zur Kenntniss der Entomostraken. 1 Heft. (4 pl.) Marbourg. $4^{\circ} .28 \mathrm{pp}$.

'62. Untersuchungen über die Organisation und Verwandtshaft der Copeporlen. (Im Auszuge zusammengestellt.)

Würzburg. naturwiss. Zeitschr. Bd. 3, pp. 51-103.

'62 ${ }^{1}$. Ueher die morphologischen Beziehunıen der Copepoden zu den verwandten Crustaceengruppen der Malacostraken, Phyllopoden, Cirripedien und Ostracoden.

Ibid. Bd. 3, pp. 159-167. 
'62'. Ueber Erarine mediterranea n. sp. und polyphemoides. $4 \mathrm{Kt}$. (Illust.)

Ibid. Bd. 3, pp. 238-246.

'62 ${ }^{3}$. Leher den Bau und die Entwicklung von Achtheres percarum. (2 pl.)

Zeitschr. f. wiss. Zool. Bd. 11, Heft 3, pp. 287-308.

'63. I)ie freilebenden Copepoden mit besonderer Berïcksichtigung der Fauna Deutschlands, der Nordsee und des Mittelmeeres. (37 pl.)

Leipzig, Engelmann. $4^{\circ}$. X, $230 \mathrm{pp.}$

'65. Zur näheren Kenntniss der Jugendformen von Cypris ovum. (2 pl.) Zeitschr. f. wiss. Zool. Bd. 14, Heft 4, pp. 391-398.

66. Die Copepoden-Fuma von Nizza. Ein Beitrag zur Charakteristık der Formen und deren Abäuderungen im Sinne Darwin's. (5 pl.)

(Supl. Heftl der 'chrift. d. Ges. z. Beförd. d. gesammt. Naturwiss. z. Marhurg. 4․ 34 pp.)

67. Ther den Entwicklungsmodus der Porcellana-Larven im Verchleiche zu den Larven ron Pagurus.

Sitzun rsber. d. Gessell. z. Befürd. d. gesammt. Naturwiss. Marburg. Pp. 12-16.

68. Beitrigre zur Kemutuiss der Ostrucoden. I. Entwicklungscreschichte von Cypris. (2 pl.)

Schriften d. Gesell. z. Beförd. d. gesammt. Naturwiss. zu Marburg. 1872. Bd. 9, pp. 151-166. Also separate: Marburg, Elwert in Comm. 1868. $8^{\circ}$. 16 pp.

'69. Die Cypris-ihnliche Larve (P’uppe) der Cirripedien und ihre Verwandlung in das festsitzende Thier. Ein Beitrag zur Morphologie der Rankenfiissler. ( 2 pl.) Ibid. Bd. 9. Suppl. 5. (4․ 17 pp.)

'72. \%ur Kenntniss des lau's und der Entwicklung rou A pus und Branchipus.

Nachrichten d. Kön. Gesell. Wiss. Göttingen. Pp. 209-225. Also in: Zeitschr. ges. Naturwiss. Bd. 6.

'73. \%ur Kenutuiss des baues und der Entwicklung von Branchipus stagnalis und Apus cancriformis. (8 pl.)

Abhllgn. d. k. Gesell. d. Wiss. Göttingen. Bd. 18, pp. 93-140. Also separate: Göttingen, 1873. $4^{\circ} .44 \mathrm{pp}$.

'75. Die Schalendrüse der Daphnien. (1 pl.)

Zeitschr. f. wiss. Zool. Bd. 25, Heft 2, pp. 165-173.

75'. Vene Beitruge zur kenntuiss parasitischer Coppoden nebst Bemerkunæen iiber das System derselben. (3 pl.)

Ibid. Bd. 25, Heft 4, pp. 327-360. Also separate: Leipzig, 1876. $8^{\circ}$. 31 pp.

"ซ6. \%ur kemutniss der Organisation und des feineren Baues der Daphniden und verwandter Cladoceren. (4 pl.)

Ibid. Br. 27, Heft 3, pp. 362-402.

76'. L'nterwhohmgen zur Erborschung der (ienealogischen (irundlage des Crustaceen-Systems. Ein Beitrag zur Descendenzlehre. (19 pl. \& 25 wd. ets.)

Wien, 1876. Imp. $4^{\circ}$. VIII, $114 \mathrm{pp}$.

77. Zur Kenntniss des Raues und der(Organisation der Polyphemiden. (7 pl.)

Denkschr. d. k. Akad. d. Wiss. Wien. Math.-Naturwiss. Cl. Bd. 37, Abth. 1, pp. 137-160. Also separate: Wien, 1877. 4․ $24 \mathrm{pp}$. 
'78. Anlass und Entstehung seiner eigenen Untersuchungen auf dem DaphnidenGebiete.

Sitzungsber. der k, k. zool.-botan. Gesellsch. in Wien. Bd. 28, pp. 6-16.

'81. Ueber die Gattungen Temora und Temorella ([n. g. ] nehst den zugrehörigen Arten). (2 pl.)

Sitzber. d. k. k. Akad. d. Wiss. Wien. Bd. 83, Abth. 1, pp. 482-493. Also separate.

'81 ${ }^{1}$. Neue Beitrïge zur Kenntniss der Copepoden unter besonderer Berïcksichtigung der Triester Fauna. (3 pl.)

Arbeiten a. d. Zool. Inst. d. Univ. Wien. T. 3, Heft 3, pp. 313-333.

Costa, Achille.

'82. Liapports preliminare e sommario sulle ricerche zoologiche fatte in Sardegna durante la primavera del 1832.

Rendic. Accad. Sc. fis. e mat. Napoli. Vol. 21, pp. 189-201.

'83. Notizie ed osservationi sulla (ieo-Fauna Sarda (Memoria prima. Risultamento di Recerche fatte in Sardegna in Settembre 1881. Napoli, 1882. 4\% pp. 42). Atti aticad. Napoli. Vol. 1. (Atti R. Accad. Sc. fis. e mat. Napoli. Vol. 9, No. 11. Pp. 41.)

Cragin, F. W.

'83. A contribution to the history of the fresh-water copepoda. (4 pl.)

Trans. Kansas Acad. Sc. Vol. 8, pp. 66-81.

Czerniavski, V.

'68. Materialia ad zoographiam ponticam comparatam.

Daday, J. (Eug. von)

'82. Adatok Kolozsvár és környéke Crustacea-fauná-janak ismeretébez. Orvos-természettud. Értesitö. IV. k.

83. Adatok a Szent-Anna és Mohostó fauná-janak ismeretéhez.

Orvos-természettud. Értesitö. V. k.

'83'. Adatok a Retyézat tavai Crustacea-faunájának ismeretéhez.

Termé:zetrajzi füzetek VII. k.

'84. Adatok a dévai vizek faunájának ismeretéhez.

Orvostermeszettud. Értesitö. VI. k.

'84'. Catalogus Crustaceorum fuunie Transylvaniu (, e collectione musei Transylvanici collegit et determinavit).

Orvostermeszuttud. Ertesitö 6. Köt. Kolzsvar. (Ber. Siebenbürg. Mus. Ver. Klausenburg. 1884. 27 pp.)

'85. Uj allatfojok Budapest edlesvizi faunajabol.

Termezetrajzi füzetek. 9. Köt. Budapest.

'85'. Adatok a Balaton to faunajanak ismeretehez.

II. tud. Akad. Term. tud. Eirtesito. Budapest.

'85'. Beiträge zur Kenntniss der Plattensee Fauna.

Math. Naturw. Ber. aus Ungarn. III. Budapest.

'85'. Jelentes oz 1884 ev nyaran Magyarorszag Kulönbözö videkein vegzett crustaceologiai kutatasok eredinenyerol.

M. tod. Akad. Math.-term. tud. Közlemenyek. 20 Kot. 3. 
'85'. Adatok Magyar-es Erdelyorszag nebany edesvizu medenczejenek nyilttı kri fiunajahoz.

Orvos-term tud Ertesito.

85'. Monographia Encopepodorum liberorum in Ifungaria hucusque repertorum.

A. M. tud. Akademia altal a Vitez-alapbol.

88. Crustacea Cladocera fiune hungarice. E. commissione regie societatis hun. garica seientiorum naturalium elaboravit. Cum 4 Tab.

Budapest, 1888. $4^{\circ}$. VIII, 128 pp. (Hungarian with Latin descriptions.)

'91. A magyarorszogi Diaptomus-fajok átnézete.

T'ermesz. Füzet. Vol. 13, Heft 4, pp. 114-143.

Also: Übersicht der Diaptomus-Arten Ungarus. (3 pl.)

Ibid. Revue, pp."177-180.

Dahl, Friedr.

'91. Untersuchungen über die Tierwelt der Unterelbe.

6 Ber. Comm. Unt, D. Míeere Kiel. Jahrg. 17-21, pp. 152-185.

\section{Dana, James D.}

48. Conspectus Crustaceorum, qua in orbis terrorum circumuavigatione, C. Wilkes e classe Reipublicæ Fœderatæe duce, collectorum. 1817-48.

Proceed. Am. Acad. Arts aud Sciences. Vol. 1, pp. 149-155.

'52. Id. Ibid. Vol. 2, pp. 9-61, 201-220.

52-55. Crustacea, In - United States Exploring Expedition, during the years 1838-42, under the Command of Charles Wilkes, U. S. N.

Vol. 13, 2 prts. 185:, '53. 4. 1630 p.. Atlas with 96 plates, large folio, 1855.

'54-'55. On the Geographical Distribution of Crustacea.

Am. Journ. Sc. and Arts. Ser. 2, Vol. 18, pp. 314-326; Vol. 19, pp. 6-15; Vol. 20, pp. 163-178 and 319-361. Also separate: New Haven, 1854. $8^{\circ}$.

56. I lieview of the Clasification of the Crustacea (with reference to certain principles of classification).

Ibid. Ser. 2, Vol. 22, pp. 14-29. Also separate: New Haven, 1856. $8^{\circ}$.

\section{Desmarest, Ans. Gaëtan.}

'25. Considérations gévérales sur la classe des Crustacés, et Description des espèces de ces animaux, qui vivent dans la mer sur les côtes, ou dans les eaux douces de la France. Avec 5 tableaux et $56 \mathrm{pl}$. gavées, fig. noires (de 140 genera). $8^{\circ}$. Paris, Levrault. Also: "Avec les fig. noires et color.

\section{Dohrn, Anton.}

69. ["ntersulumenen üher Bau und Entwickelung der Arthropolen. 3. Die Seldalendrïse und die embryonale Entwickelung der Daphuideu. (1 pl.)

Jen. Zeitschr. d. Naturwiss. Bd. 5, Heft 2, pp. 277-292.

Du Plessis-Gourret, G.

'85. Essai sur la fune profonde des lacs de la Suisse.

(Mem. cor. par la Soc. Helvet. d. Sc. Nat.) (63 pp.) Neue Denkschr. d. allg. Schweiz. Gesellsch. f. d. ges. Naturwiss. Bd. 29, Abth. 2. Also separate: Bâle, 1885. $4^{\circ}$.

\section{Elymann.}

87. Beitrag zur Systematik der europäischen Daphniden.

Ber. Naturforsch. Gesellsch. Freiburg in Breisgau. Bd. 2, pp. 67-148. 


\section{Euren, A.}

'62. Om märkliga Crustaceer af ordningen cladocera, funna i Dalarne.

Ofvers. K. Vètensk. Akad. Förhandl. 18 Arg. 1861. Pp. 115-118.

\section{Ferussac, Daudebart de.}

'06. Mémoire sur deux nouvelles espèces d'Entomostracés et d'Hydrachués. Paris, Ann. Mus. Hist. Nat. VII, pp. 212-218.

\section{Fischer, Seb.}

'49. Abhandlungen ïber eine neue Daphnienart, Daphnia anrita nud ïher die Daphnia laticornis Jurine mit Zeichnungen nach der Natur begleitet. (2 pl.) Bull. Soc. Imp. Nat. Moscou. T. 22, pt. 2, pl. 39-51.

'51. Bemerkungen ïber einige weaiger genau gekaunte Daphnienarten. (1 pl.) Ibid. 'T. 24, pt. 2, pp. 96-108.

'51'. Branchiopoden und Eutomostraceen. In A. Th. v. Middendorffs's Reise in den äussersten Norden und Osten Sibiriens während der Jahre 1843 und 1844. . . . (etc.) Bd. 2, Thl. 1. Wirbellose Thiere: Anuulaten. Echinorlermen. Insecten. Krehse. Mollusken. Parasiten. (By various authors.) $32 \mathrm{pl}$, $516 \mathrm{pp}$.

'51'. Beitrïge zur Kenntniss der in der Umgegreud von St. Petershurg sich findenden Cyclopiden. (2 pl.)

Bull. Soc. Imp. Nat. Moscou, T. 21, pt. 2, pp. 409.438. (See '53.)

'52. Ueber die in (ier Umgebung von St. Petersburg vorkommeuden Crustaceen aus der Ordnung der Brauchiopoden und Entomostraceen. (10 pl.)

Mem. pres. savants Acad. St. Petersbg. T. 6, 1851, pp. 159-198.

'53. (Title and reference as in '512. T. 26, 1853, pt. 1, pp. 74-100.) (2 pl.)

'54. Ergänzungen, Berichtigangen und Fortsetzung zu der Abhandlung ueher die in der Umgebung von St. Petersburg vorkommenden Crustaceen. (3 pl.)

Mem. pres. savants Acad. St. Petersbg. T. 7, pp. 1-14. Also separate: St. Petersburg, $1850.4^{\circ} .14 \mathrm{pp}$.

'54'. Abhandlung über das Genus Cypris und dessen in der Umgehuug ron St. Petersburg und Reval vorkommende Arten. (11 pl.)

Ibid. T. 7, pp. 127-167. Also separate: St. Petersburg, 1851. $4^{\circ} .39$ pp. (11 pl.)

'54:. Abhandlungen ïber einigre neue oder nicht genau gekannte Arten von Daphniden und Lynceiden als Beitrag zur Fauna Russlands. (1 pl.)

Bull. Soc. Imp. Nat. Moscou. T. 27, pt. 1, pp. 423-434.

'60. Beiträge zur Kenntniss der Entomostraceen. (3 pl.)

Abhandlgn. d. k. bayer. Akad. d. Wiss. II. Cl. Bd. 8, Abth. 3, pp. 647-682. Also separate: Mïnchen, 1860. $4^{\circ} .38 \mathrm{pp}$.

\section{Forbes, S. A.}

'76. List of Illinois Crustacea.

Bull. Ill. Mus. Nat. Hist. No. 1, pp. 3-25.

'82. On some Entomostraca of Lake Michigan and adjacent waters. (2 pl.)

Amer. Naturalist. Vol. 16, July, pp. 537-542; Aug., pp. 640-649.

'91. On some Lake Superior Entomostraca. (4 pl.)

Rep. U. S. Com. Fish and Fisheries for 1887. Pp. 701-718. 
'93. A preliminary report on the agnatic invertebrate fauna of the Iellowstone National Park, Wyoming, and of the l'lathead Region of Montanit.

Bull. U. S. Fish Commission for 1891.

\section{Forel, F. A.}

'74. Faune profonde du lac Léman.

Verhandl. d. Schweiz. naturf. Gesellsch. 56. Vers. Schaff hausen. 1873. Pp. $136-153$

'75. Id. (Denxieme Discours.) Ibid. 57. Vers. Chun. 1874. pp. 129-142. Extr. par 1. Fischer in: Journ. d. Zool. T. 3, 1874, pp. 352-354.

'76. Notice sur l'histoire naturelle du lac Léman.

'78. Faunistische Studien in den Süsswasser-Seen der Schweiz.

Zeitsch. f, wiss. Zool. Bd. 30, Suppl. Heft 2, pp. 383-391.

'80. Les faunes lacustres de la région subalpine.

Assoc. franc. pour l' avancem. d. sc. C. R. de la 8. Sess. 1879. Pp. 744-748.

'82. Die pelagische Fauna der Süsswasserseen.

Biol. Centralblatt. Bd. 2, No. 10, pp. 299-305.

'85. La faune profonde de lacs Suisses.

Neue Denkschr. d. allg. Schweiz. Gessllsch. f. d. ges. Naturwiss. Bd. 29, Abb. 2. 231 po. Also separate: Bâle, $1885.4^{\circ}$.

\section{Forest, H. E.}

'79. On the Anatomy of Leptodora hyalina. (2 pl.)

Journ. Roy. Microsc. Soc. Vol. 2, pp. 825.834.

Fric, Anton.

'67. Kory:i zeme ceske Ziva Casopis prirodnicky. XIV. (N. F. II.) Pp. 1; 102; $171 ; 241$.

'72. Ueber d. Fauna d. Böhmerwaldseen.

Sitzber, れ. bühm. Gesellsch. d. Wiss. Jahrg. 18శ1, Juli-Dec. Pp. 3-12.

' $72^{1}$. Die Krustenthiere Boehmens. (100 text-figures.)

Archiv. f. d. naturwiss. Landesdurchforscb. v. Boehmen. Bd. 2, Abth. 4, pp. 201-271.

'73. I'eber die Crustacentama der Witlinganer Teiche und über weitere Lntersuch, d. Böhmerwaldseen.

Sitzungsber. d. k. böhm. Gesellsch. d. Wiss. Prag. Jahrg. 1873, pp. 33-47.

'73'. Zvirêna jezer Sumavskych. Vesmir. II. p. 247.

'74. O zvirene ry bniku trebouskych. Vesmir. III.

\section{Fritsch, Anton.}

66. Ueber das Vorkommen von Apus und Branchipus in Böhmen.

Verhaudl. d. Kais.-Künigl, zoolog.-botan. Gesell, in Wien. XVI, pp. 557-562

\section{Geer, Charles de.}

1778. Memoires pour servir ì l' Histoire des Insectes. 7 vols. Stockholm, 175278. (Crustacea in Vol. VII, pp. 950, pl. 49.)

1783. Ahove under title: Ahbanllungen zur Geschichte der Insekten, aus dem Fravz. übersetzt mit Anmerkungen. Herausgegeben von Joh. Aug. Ephr. Goeze. Nürnberg, 1778-1783. (Vol. VII, 1783.) 
Gegenbaur, C.

58. Mittheilungen ïber die Organisation von Phyllosoma and Sapphirina. (2 pl.)

Müller's Archiv. f. Anat. u. Physiol. 1858, pp. 43-81.

\section{Gerstäcker, A.}

'79. Die Klassen und Ordnungen der Arthropoden wissenschaftlich dargestellt in Wort und Bild.

Broun's Kilassen u. Ord. d. Thier-Reichs. Fünfter Band. Gliederfüssler (Arthropoda). 1866-1879. [Copepoda, pp. 590-806, pl. VII-XV.]

\section{Giesbrecht, W.}

'81. Vorliufige Mittheilung aus einer Arbeit, ïher die freilebenden Copepoden des Kieler Hafens.

Zool. Anz. Jahrg. 4, No. 83 (May 16), pp. 254-258.

'81'. Die freilebenden Copepoden der Kieler Föhrde. (12 pl.)

4 Ber. d. Comm. z. wiss. Unters. d. deutsch. Meere in Kiel. Abth. I, pp. 85-168.

\section{Gissler, Charles F.}

'72. Coutributions to the Fauna of the New York Croton Water. Microscopical Observations during the years 1870-71. New York.

'81. Variations in a Copepod Crustacean. (14 text-figures.)

American Naturalist. Vol. 15, Sept., pp. 689-698.

\section{Goodsir, H. D.}

'45. On several new species of Crustaceans allied to Saphirina. (1 pl.)

Ann. and Mag. Nat. Hist. Vol. 16, pp. 325-327.

\section{Grobben, Carl.}

'79. Die Eutwickelungsgeschichte der Moina rectirostris. Zugleich ein Beitrag zur Kenntniss der Anatomie der Phyllopoden. (7 pl.)

Arbeiten a. d. zoolog. Inst. d. Universitit Wien. T. 2, Heft 2, pp. 203-268. Also separate: Wien, 1879.

'81. Die Entwicklungsgeschicbte von Cetochilus septentrionalis Goodsir. (4 pl. and 2 text-figures.)

Arbeiten a. d. zoolog. Inst. d. Universitit Wien. T. 3, Heft 3, pp. 243-282. Also separate: Wien, 1881.

\section{Grube, A. E.}

'53 Bemerkungen über die Phyllopoden, nebst einer Uebersicht ihrer Gattungen und Arten. (4 pl.)

A rch. f. Naturgesch. Jahrg. 18, Bd. 1, pp. 71-172. Also separate: Berlin, 1853. $8^{\circ} .108 \mathrm{pp}$.

\section{Gruber, A.}

'78. Ueber Zwei Süsswasser-Calaniden. (2 pl.)

Promotionsschrift, Leipzig. $34 \mathrm{pp}$.

\section{Gruber, Aug., und Aug. Weisman.}

'80. Über einige neue oder unvollkommen gekannte Daphniden. (2 pl.)

Ber. üb. d. Verh. d. naturf. Gesellsch. Freiburg i. B. Bd. 7, pp. 50-116.

\section{Gruithuisen, Frz. v. Paula.}

'28. Ueber die Daphnia sima und ihren Blut-Kreislauf. (1 pl.)

Nova Acta Acad. Leop. Carol. Nat. Cur. Tom. 14, pt. 1, pp. 397-406. 


\section{Guerne, Jules de.}

86. Description du Centropages Grimaldii, Copépode nouvean du golfe de Finlande.

Bull. Soc. Zool. France. T. 11, No. 1-3, pp. 276-285.

\section{Guerne, Jules de, et J. Richard.}

'88. Sur la distribution géographique du genre Diaptomus.

Compt. Rend. Acad. Sc. Paris. T. 107, No. 1, pp. 47-50. Translated in Ann. and Mag. Nat. Hist. Ser. 6, Vol, 2, pp. 177-179.

'88'. Diagnoses de deux Diaptomus nouveaux d'Algérie.

Bull. Soc. Zool. France. T. 13, No. 6, pp. 160-162,

'89. Note sur les Entomostracés d'eau douce recueillis par M. Charles labot dans la province de Nordland, Norvège septentrionale.

Ibid. T. 14, No. 1, pp. 27-31.

'89 ${ }^{1}$. Revision des Calanides d'eau douce. ( $5 \mathrm{pl}$.)

Mem. de la Soc. Zool. de France. T. 2, pt. 1, pp. 53-181.

'892. Sur la faune des eaux douces du Grœnland.

Bull. Soc. Entom. Fr. (Compt. Rend. Ac. Se. Paris. T'. 108, No. 12, pp. 630632.)

'91. Sur quelques entomostracés d'eau douce de Madagascar.

Bull. Soc. Zool. France. T. 16, No. 8, pp. 223-224.

92. Sur la faune des eaux douces d'Islande. (Voyage de M. Charles Rabot en Islande-)

Bull. Soc. Entom. Fr. 8 fevrier, 1892. (Ball. Soc. Zool. France. T. 17, No. 3, pp. 75-80.) Also: Compt. Rend. Acad. Sc. Paris. T. 114, No.6, pp. 310-313.

\section{Gunner.}

1765. Skrifter som udi det Kjobenharnske Selskab. (Acta Harniae.)

\section{Haeckle, Ernst.}

'63. Beitråge zur Kenntniss der Corycaeiden. (3 pl.)

Jen. Zeitschr. f. Naturwiss. Bd. 1, 1864, pp. 61-112.

\section{Haldeman, S. S.}

'43. Daphnia abrupta and Cypris seabra n. sp.

Proc. Acad. Nat. Sc. Philad. Vol. 1, p. 184.

' $43^{1}$. Daphnia reticulata n. sp.

Ibid. Vol. 1, p. 196.

Haller, G.

'79. Vorlïufige Diagnosen einiger Peltidien aus Mfessina.

Zool. Anzeiger. Jahrg. 2, No. 25 (7. April), pp. 178-180.

'80. Beschreibung einiger neter Peltidien. ( $2 \mathrm{pl}$.

Archiv, f. Naturgesch. Jahrg. 46, Bd. 1, pp. 55-71.

\section{Hartog, M. M.}

'84. The Morphology of Cyclops and the relations of the Copepoda.

Trans. Linn. Soc. Lond. (2.) '/sol. V. [Abstract in: Zool. Anzeiger. Jahrg. 8, No. 195 (18. Mai, 1885), pp. 301-302.]

Heller, Camil.

70. Untersuchungen iiber die Crustaceen Tirols.

Nat. Med. Berichte. Innsbruck. I, pp, 67-96. 


\section{Hellich, B.}

'74. Ueber die Cladocerenfauna Böhmens. Sitzungsber. d. k. k. böhm. Gesellsch. der Wiss. Prag. Jahrg. 1874, pp. 205-220.

'77. Die Cladoceren Böhmens. (Wood cuts.)

A reh. f. d. naturw. Landesturchforschung v. Böhmen. Bd. 2, Abth. 4, Heft 2, p. 131. Also separate: Prag, 1877. $8^{\circ}$. Pp. IV, 131.

\section{Herrick, C. L.}

'79. Microscopic Entomostraca .(21 pl.)

The Geol. and Nat. Hist. Survey of Mimuesota. The Seventh Annual Report, for the year 1878. (Appendix B.) Pp. 81-123.

'82. Papers on the Crustacea of the Fresh Waters of Minnesota. (11 pl., 7 wd. cts.) (I. Cyclopida of Minnesota, with notes on other Copepoda. II. Notes on some Minnesota Cladocera. III. On Notodromas and Cambarus.)

Ibid. The Tenth Annual Report, for the year 1881. Pp. 219-254.

'83. Heterogenetic derelopment in Diaptomus. (3 pl.)

Amer. Naturalist. Vol. 17, April, pp. 381-399 (2 pl.); May, pp. 499-505. (1 pl.)

'84. A final report on the Crustacea of Minnesota included in the orders Cladocera and Copepoda.

The Geol. and Nat. Hist. Survey of Minnesota. The Twelfth Annual Report, for the year 1883. V. Crustacea, $192 \mathrm{pp} . \quad(30 \mathrm{pl}$.

'87. Contribution to the fauna of the Gulf of Mexico and the South. (List of Fresh-water and Marine Crustacea of Alabama, with descriptions of the New Species and Synoptical Keys for Identification.) (7 pl.)

Mem. Denison Scient. Assoc. Vol. 1, No. 1. 52 pp.

\section{Hesse, Eugène.}

'64. Ohservation sur des Crustacés rares ou nouveaux des côtes de France Troisième article. (Crustacésparasites dans l' intérior des Ascidies. 2 pl.)

Ann. d. Scienc. Nat.-Zool. Ser, 5, T. 1, pp. 333-358.

'68. Mémoire sur les Pranizes et les Ancées et sur les Moyens curieux ì l' Aide desquels certains Crustacés Parasites assurent la Conservation de leur Espèce.

Mém. prés. par divers Savants à l' Inst. Impér. de France. XVIII. (Mém. Savants Etrang. Paris. XVIII, pp. 231-302. Also: Ann. and Mag. Nat. Hist. Vol. 14, 1864, pp. 405-517.)

'79. Description des Crusticéc rares ou nouveaux des Cótes de France décrits et peints sur des Individus vivants. $29^{\mathrm{e}}$ Art. Description de dix nouveaux Crustacés, dont sept appartiennent du Genre Cycnus de Ḱroyer et trois au Genre Kroyeria de Van Beneden, tous décrits et dessinés sur des Individus vivants. (Avee 2 pl.)

Anu. Sc. Nat. Zool. Ser. 6, T. 8, No. 4, Art. 11. 34 pp.

Heyden, C. v.

'62. Meyers Palreontographica. X.

Hoek, P. P. C.

'76. De Vrijlevende Zoetwater-Copepoden der Nederlandsche Fauna. (5 pl.)

Tijdschr. d. Nederland. Dierkund. Vereenig. III. Deel, 1878. 36 pp. 
77. \%ur Entwiokelungugeschichte der Eutomostraken. II. Zur Embryologie der freilebenden Copeporlen. ( 2 pl.)

Niederländ. Arehiv. f. Zool. Bd. 4, Heft 1, pp. 55-74.

Hogan, Rev. A. R.

'62. Ou Daphuia Schafferi.

Rep. 31st Meet. Brit. Assoc. Advane. Se. in 1861. Notes and Abstracts, p. 146.

\section{Hudendorff, A.}

'76. Beitrag zur Kenntuiss der Süsswasser-Cladoceren Russlands. (1 pl.)

Bull. Soc Impér. des Nat. de Moscou. T. 50, pp. 26-61.

\section{Imhof, 0thmar Emil}

'83. Inie pelagische Famna und die Tiefseetama der zwei savoyerseen. Lac du Bourget und Lae d'Annecy.

Zool. Anzeiger. Jahrg. 6, No. 155 (10 Dec.), pp. 655-657.

'84. Weitere Mittheilung uber die pelagische Fauna der sibswasserbecken.

Ibid. Jahrg. 7 , No. 169 (9 Juni), pp. 321-327.

'84'. Rexultate meiner Studien iiber die pelagische Fauna kleinerer und grö̈serer Süsswasserbecken der Schweiz. (1 pl.)

Zeitschr. f. wiss. Zool. Bd. 40, Heft 1, pp. 154-178. Also separate: Inaug. Diss. Züirich.

'85. Faunistische Studieu in achtzehn kleineren und grösseren österreichischen Siisswasserbecken.

Sitzber. d. k. Akad. d. Wiss. in Wien. Math. nat. cl. Bd. 91, Abth. 1, pp. 203226.

'851. Ueber die "blassen Kolben' an den vorderen Antennen der SüsswasserCalaniden.

Zool. Anzeig. Jahrg. 8, No. 197 (15. Juni), pp. 353-356.

'85'. Pelagische Thiere aus Süsswasserbecken in Elsass-Lothringen.

Ibid. No. 211 (14. Dec.), pp. 720-723.

'88. Ueber das Calanidengenus Heterocope.

Zool. Avzeiger. Jahrg. 11, No. 286 (20. Aug.), pp. 447.451.

\section{Joblot, Louis.}

1754-55. (Dhservations d'histoire naturelle, faites avec le microscope, sur un grand nombre d'insectes, et sur les animalcules qui se trouvent dans les liquers préparées, etc. . Avec un graud nombre de figures. 2 Tom. à 2 pts. (Avec. 14, 15, et 24 pl.) $4^{\circ}$. Paris, 1754-55.

\section{Joly, $N$.}

40. Histoire d'un petit ('rustaré (Astemia salina Leach), aupuel ou a fassement attrubue la Coloration en Rouge des Marais salants Méditerranéens, suivie de Recherches sur la Cause rélle de cette Coloration. (3 pl.)

Ann. Sci. Nat.-Zool. 13, pp. 225-290. (Montpelier, 1840. $4^{\circ} .72$ pp.)

'83. Etudes complémentaires sur l'origine et le mote de formation de la glairine ou baregine dans les eitux thermales sulfurenses des Pyrénées.

Memoires de l'Acarlémie des Sc., etc., de Toulouse. 


\section{Joseph, G.}

'82. Systematisches Verzeichnis der in den Tropfstein-Grotten rou Krain einheimisher Arthropoden (nebst Diagnosen der vom Verfasser entdekten und bisher noch nicht beschriebenen Arten.)

Berlin Entomolog. Zeitschr. Bd. 26, Heft 1, pp. 1-50.

Jurinac, A. E.

'87. Prilog fauni zapodne Slavonije. Glasuik hrvatskoga naravoslovoga drzutra. II.

\section{Jurine, Louis.}

'01. Sur le Monocle puce (Daphnia pulex).

Bull. des Sc. par la Soc. philom. de Paris. Tom. 3, An. 9, pp. 33-34.

'20. Histoire des Monocles qui se trouvent aux environs de Genève. Avec $22 \mathrm{pl}$. color. $4^{\circ}$. Genève.

\section{[King, (Capt.) Philip Parker.}

'54-'59. The references availahle assign the title given by Herrick'under R. L. King to P. P. King.]

\section{King, R, L.}

'52-54. On some species of Daphnidx found in New South Wales.

Roy. Soc. Papers Van Diemen's Land. II, 1852-54, pp. 243-253.

'55. On Australian Entomostracans.

Papers aud Proceedings of the Roy. Soc. of Van Diemen's Land. III. (II, 185254, pp. 253-362; III, 1855-59, pp. 56-75. Title and references were found only under "Capt. Philip Parker King.")

\section{Klunzinger.}

64. Einiges zur Anatomie der Daphnien, nebst kurzen Bemerkungen über die Süsswasserfauna der Umgegend Cairo's. (1 pl.)

Zeitschr, f. wiss. Zool. Bd. 14, Heft 2, pp. 165-173.

\section{Koch, C. L.}

'35-'41. Deutschlands Crustaceen, Myriapoden und Arachniden. Ein Beitrag zur deutschen Fauna. Heransgeg. von Herrich-Schäffer. Regensburg. (Nu. merous plates and text figures.)

\section{Koelbel, C.}

'85. Carcinologisches. (3 pl.)

Sitzber. d. k. k. Akad. Wiss. Wien. Bd. 90, Abth. 1, pp. 312-323. Also separate.

\section{Kortchaguine, A. N.}

'73. Über Diaptomus amblyodon. (See Marenzeller.)

Verhand1. Zool. bot. Gesellsch. Wien. Vol, 23.

'87. Faune des environs de Moscou. I. Crustacés.

Bull. de la Soc. des Amis des sc, nat. de Moscon. 52.

\section{Kröer, Henr.}

'45-'49. Karcinologiske Bidrag.

Nat. 'Tidskr. Ny Raekke 2 det Binds 5. Haefte. 14 pl.) (Kröyer naturhist. Tidskr. N. R. Bd. 1, 1845, pp. 283-345 and 453.688; Bd. 2, 1849, pp. 1-211, $366-446,527-609$.) 


\section{Kurz, Wilh.}

'74. Dodekas nener Cladoceren nebst einer kurzen Uebersicht der Cladocerenfauna Böhmens. (3 pl.)

Sitzungsber. d. k. k. Akad. d. Wissenschaft. in Wien. Math.-naturw. Classe. Bd. 68. (Ibid. Bd. 70, Abth. 1, 1875, pp. 7-88. Also separate: Wien, 1876. $8^{\circ} .82 \mathrm{pp}$.

'75. Ueber androgyne Missbildung bei Cladoceren. (1 pl.)

Ibid. Bd. 69, Abth. 1, 1874, pp. 40-46. Also separate: Wien, 1875, $8^{\circ} .7$ pp.

'78. Ueber limicole Cladoceren. (1 pl.)

Zeitæchr. f. wiss. Zool. Bd. 30, Suppl. Heft 2, pp. 392-410.

\section{Lamarck, J. B. P. Ant. de Monnet.}

'15-'22. Histoire naturelle des animaux sons vertèhres, présentant les caractìres généraux et particuliers de ces animaux, leur distribution, leurs classes, leurs familles, leurs grenres et la citation synonymique des principales espèces qu ${ }^{i}$ s'y rapportent. (1 ${ }^{\mathrm{e}}$ édit. 7 vols. $2^{\ominus}$ édit. 11 vols. 1835-45. Paris.)

\section{Landenburger, $\mathbf{R}$.}

'84. Zur Fauna des Mansfelder Sees.

Zool. Anzeiger. Jahrg. 7. No. 168 (26. Mai), pp. :299-302.

\section{Lankester, E. Ray.}

'82. On new British Cladocera discovered by Mr. Conrad Beck in Grasmere Lake, Westmoreland.

Ann. Mag. Nat. Hist. Vol. 9, p. 53.

\section{Latreille, Pierre André.}

'1792-1805. Histoire naturelle, générale et particulic̀re, des crustacés et des Insectes. (Ouvrage faisant suite aux oeuvres de Leclere de Buffon et partie de cours complet d'hist. naturelle redigé par C. S. Sonini. 14 Vols. Avec $374 \mathrm{pl}$. $8^{\circ}$. Paris.)

\section{Leach.}

'19. Entomostraca. Dict. Se. Nat. XIV.

'23. Crustaceology. Edinburgh Encyclopedia.

\section{Ledermüler.}

1763 Mikroskopische (iemuiths-und Augen-Ergitzung. Bestehend in Ein Hundert nach der Vatur gezeichneten u. mit Farben erleuchteten Kpfrtaf., sammt deren Erklïrung. Nürnberg. 1761. (Num, plates,)

\section{Lenz, Heinrich.}

'82. Die wirbellosen Thiere T'ravemünder Bucht.

4. Bericht der Comm. z. wiss. Unters, d. Deutschen Meere. Abth. 1, pp. 169180.

\section{Lereboullet, (Auguste).}

'50. Ohservations sur le eneur et (sur) lat circulation dans (la Limuadia Herrmanni et dans) les Daphnies.

MEm. Soc. Mus. d'hist. nat. Strasbourg. 'T. IV, Livr. 1, pp. 208-210. 


\section{Leuckart, Rudolph.}

'59. Carcinologisches. (2 pl.) Arch. f. Naturgesch. Jahrg. 25, Bd. 1, pp. 232266.

(-Einige Bemerkungeu ïber Sacculina Thomps. (Pachybdella Dies., Peltogaster Rathke). (Fig.) pp. 232-241.

-Ueber die Gesichtswerkzeuge der Copepoden. pp. 247-262.

- Ceber das Vorkommen eines saugnapfartigen Haftapparates bei den Daphuiden und verwandten Krebsen. (Figs.) pp. 262-265.)

\section{Leydig, Franz.}

'50. Ueber Argulus foliaceus. Ein Beitrag zur Anatomie, Histologie und Entwickelungsgeschichte dieses Thieres. (2 pl.)

Zeitschr. f. wiss. Zool. Bd. 2, pp. 323-349.

'51. Ueber Artemia salina und Branchipus stagualis. Beitrag zur auatomischen Kenntniss dieser Thiere. (1 pl)

Ibid. Bd. 3. pp. 280-307.

'59. Bemerkungen üiber den Bau der Cyclopiden. (1 pl.)

Archiv, für Naturgesch. Jahrg. 25, pp. 194-207.

'60. Naturgeschichte der Daphniden (Crustacea Cladocera). Mit 100 Kupfertafeln. 4\%. Pp. IV, 25:. Tübingen.

\section{Liévin.}

'48. Die Branchiopulen der Danziger Gegend. Ein Beitrag zur Fauna der P'rovinz Preussen.

Neueste Schriften der naturf. Gessellsch. in Danzig. Bd, 4, Heft 2.

\section{Lilljeborg, Wilh.}

'53. Om den inom Skaue förekommaude Crustaceer af ordningarne Cladocera, Ostracoda och Copepoda. Also De Crustaceis ex ordinibus tribus: Cladocera, Ostrocoda et Copepoda in Scania occurentibus. (27 pl.)

Akademisk Afhandling. 2 sectiones. Lund, 1853. 8․ Pp. XVI, 222.

'61. Beskrifuing ifver tveune mïrklima Crustaceer af Ordningen Cladocera. ( 2 pl.) Ofvers köngl. Vetensk. Akad. Förhandl. 17. Arg. 1860, pp. 265-271. (Transl. in: Ann. and Mag. Nat. Hist. Ser. 3, Vol. 9, 1862, pp. 132-136.)

'63 Beskrifning ifver tva arter Crustaceer af ordningarna Ostracoda och Copepoda. (2 pl.)

Ibid. 19 Arg. 1862, pp. 391-398.

'76. De under Svenska velenskapliga expeditionen till Spetshergen 1872-73 derstädes samlade Hafs-Entomostraceer.

Ibid. 32 Arg. $1875 . \quad$ No. 4, pp. 3-12.

'87. Contributions to the Natural History of the Commander Islands. No. 9. On the Entomostraca collected by MIr. Leonhard Stejeneger, on Bering Island, 1882-83.

Proceed. U. S. Nat. Mus. Vol. 10, 1887, p. 153.

'88. Description de deux espèces nouvelles de Diaptomus du Nord de l'Europe. Bull. Soc. Zool. France. T. 13, No. 6, pp. 156-158.

\section{Lindstrom, G.}

'55. Bidrag till Kånnedomen om Oestersjöns Invertebrat-Fauna.

Oefversigt K. Vet. Ak. Förhandl. Stockholm. Pp. 49-73. 
Loven, S. L.

'35. Evalne Nordmanni ett hittills okindt Entomostracon. (2 pl.) K. Vet. Akad. Handl. Stockholm. Pp. 1-29. (Also in Arch. f. Naturgesch. 1838, IV, pp. 143-166; and l'Institut IU, 1835, p. 262.

'45. Fyra uya arter af Sötvattens-Crustaceer fråu Södra Afrika. (4 pl.)

Köng. Vet. Akad. Handl. Stockholm. 1845. Pp. 427-441.

'47. Om afrikanska sötvattens Crustaceer.

Öfversigt. K. Vetensk. Akad. Förhandl. Stockholm. 1846. Pp. 57.58.

\section{Lubbock, John.}

'53. Description of a new geuus of Calanidae (Labidocera). (1 pl.)

Ann. and Mag. Nat. Hist. Ser. 2, Vol. 11, pp. 25-29.

'53'. On the Ereshwater Entomostraca of South America. (1 pl.)

Proc. Roy. Soc. of Van Diemensland. (Trans. Entom. Soc. London. New Ser. Vol. 3, 1854, pp. 232-240.)

'54. On some arctic species of Calanidae. (1 pl.)

Ann. and Mag. Nat. Hist. Ser. 2, Vol. 14, pp. 125-129.

'76. On some Entomostraca collected by Ir. Sutherland in the Atlantic Ocean. (11 pl.)

Trans. Entom. Soc. London. N. S. Vol. 4, prt. 1 and 2, pp. 8-37.

'57. An aceount of the two methods of reproduction in Daphuia and of the stracture of the Ephippium. (2 pl.)

Philos. Trans. Pp. 79-100.

'59. Descriptions of eight new species of Eutomostraca found at Weymouth. $(2 \mathrm{pl}$.)

Ann. and Mag. Nat. Hist. Ser. 2, Vol. 20, pp. 401-410.

'60. On some Oceanic Eutomostraca collected by Captain Toynbee. (1 pl.)

Trans. Linn. Soc. London. Vol. 23, pt. 1, pp. 173-191.

63. Notes on some new or little-known species of fresh water entomostraca. (1 pl.)

Ibid. Vol. 24, pt. 2, pp. 197-210.

Lucas, Hippolyte.

49. Exploration scientifique de l'Algćrie pendant les annćes 1s40, 1R41, 1842, publiée par ordre du gouvernement, etc. 16 vols. 1845-58. Animaux articules par Lucas. Livr. 1-33.

Lund, $x$.

'70-'71. Bidrag til Cladocerernes morphologi og systematik. (5 pl.)

Naturhist. Tidsskrift. Raek 3, Bd. 7, pp. 129-174.

Lutz, Adolf.

'78. Beobachtungen über die Cladoceren in der Umgegend von Leipzig.

Sitzungsher, d. naturfor. Gesellsch. Leipzig. Jahrg. 5, pp. 36-41.

'79. Unterstlchungen neber die Cladoceren der Umgebung von Bern.

Iitth. naturfor. Gesellsch. Beru. 1878. Pp. 38-54.

Marcusen, Johann.

'67. Zur Fauna des schwarzen Meeres.

Arehiv. f. Naturgeseh. Jahrg. 33, pp. 357-363. 


\section{Marenzeller, Emil von.}

'73. Ueber Diaptomus amblyodon. n. sp. (Fig.)

Verhandlgn. k. k. zool.-bot. Gesellsch. Wien. Bd. 23, pp. 593-596.

\section{Marsh, C. Dwight.}

'92. On the deep water crustacea of Green Lake.

Trans. Wis. Acad. Sc. Arts and Letters. Vol. 8, 1888-91, pp. 211-213.

'93. On the Cyclopidæ and Calanidæe of Central Wisconsin. (4 pl.)

Ibid. Vol. 9, Part 1, 1892-93, pp. 189-224.

'94. On T'wo New species of Diaptomus. (1 pl.) [Mississippiensis and hirrei.] Ibid. Vol. 10, July, 1894.

\section{Matile, Paul.}

'90. Die Cladoceren der Umgegend von Moskau. (3 pl.)

Ball. Soc. Imp. Nat. Moscou, 1890. I, pp. 104-169.

\section{Metschnikow, E.}

'84. Ueber eine Sprosspilzkrankheit der Daphnien.

Virchow. Arch. f. path. Anatomie. Bd. 96.

\section{Metzger, A.}

'71. Die wirbellosen Meeresthiere der ostfriesischen:Küste. Crustaceen.

Jahresber. d. Nat. Gesellsch. zu Hannover. 20, pp. 22-36.

\section{Milne-Edwards, $\mathrm{H}$.}

'34-'40. Histoire naturelle des Crustacés (comprenant l'anatomie, la plyysiologie ot la classification de ces animaux. Avec $42 \mathrm{pl} .3$ Vols, $8^{\circ}$. Paris, 1834, '37, '40.)

\section{Moebius, Karl.}

'73. Die wirbellosen Thiere der Ostsee. (Expedition zur Untersuchung der Ostsee. 1871.) Faunistische Untersuchungen.

Jahresb. d. Comm. zur Unters. d. deutsch. Meere. 1, 1873, pp. 97-144; 7 bis 11, 1884 , p. 61 bis-70 bis.

'73'. Die auf der Fahrt nach Arendal grefangenen Thiere, Crustacea Ebenda.

Jahresb. d. Comm. zur Unters. d. deutsch. Meere.

75. Copepoda and Cladocera. (In: Expedition zur Untersuchung der Nordsee. 1872. Zoologische Ergebnisse. IX.)

Jahresb. d. Comm. zur wiss. Unters. d. dentsch. Meere. 2 and 3, 1875, pp. 269276.

\section{Moniez, $\mathbf{R}$.}

'87. Liste des Copépodes, Ostracodes, Cladocères, et de quelques autres Crustacés recueillis à Lille en 1886.

Bull. de la Soc. zool. de France, T. 12, pts. 2-6, pp. 508-518.

'87'. Note sur des Ostracodes, Cladocieres et Hydrachuides observés en Normandie, et description de quelques espèces nouvelles.

Bull. de la Soc. d'études sc. de Paris.

'87'. Entomostracés et Hydrachnides recueillis par M. Dollfus. Feuille des jeunes naturalistes.

Moniez, R., et Th. Barrois.

'88. Matériaux pourservir ì l'étude de la Faune des eaux douces des Açores. IV. Crustacés. [Copepodes par Barrois; Ostracodes, Cladocères, Branchiopodes par Moniez.] Lille, 1888. $8^{\circ}$. 20 pp. 
Mueller, P. E.

'68. Danmarks Cladocera. (Med.6 Tab. og 1 Traesnit.)

Naturhist. Tidsskrift. 3. Raek. Bd. 5, 1868-'69, pp. 53-240.

'69. Efterskrift til Danmarks Cladocera. Ibid. Pp. 355-356.

'6 ${ }^{1}$. Bidray til Cladocerernes Forplantnings-historie. (Med 1 Tab).) Naturhistorisk Tidsskr. 3 Raek. Bd. 5, 1868.'69. Pp. 295-354. Also: Forhandl. Skand. Naturforsk. 10 Mode. Christiania. (1868.) 1869. Pp. 530-540.

Müller, 0tto Friedrich.

1775. Entromostraca, seu insecta testacea, qua in arpuis Danis et Norvegis reperit, descripsit et iconibus illustravit. Cum tabb. aen. XXI. 4 maj. Lipsire et Hafnire 1785.

1776. Zoologice Danicte prodromus, seu animalium J)anice et Norvegrie indigenarum characteres, nomina et synonyua imprımis popularium. 8 maj. Hafnia. (274 pp.)

1785. Von dem mopsnasigen Zackenfloh (Daphnia resima).

Schrift. d. Berlin. Gesellsch. Nat. Fr. Bd. 6, pp. 185-192.

1788-1806. \%oologia Danica, seu animalium Danix et Norvegie rariorum ac minus notorum descriptiones et historia; ad formam tabularum denuo edid. frater auctoris. IV Voll. Cum CLX tabb. Fol. Hafnix et Lipsix (1779-84) 1788-1806. (German and Latin text.)

\section{Müller, Wilhelm.}

'80. Beitrag zur Kenntniss der Fortpllauzung und der Geschlechtsverhältnisse der ()atracoden nebst Beschreibung einer neuen Species der Gattung Cypris. (bicolor.)

Zeitschr. f. d. gesam. Naturwiss. Jahrg. 53 (3. F. Bd. 6.), pp. 221-246. Also separate: Inaug. Dissert. Greifswald, $1880,8^{\circ} .28 \mathrm{pp}$.

Nicolet, Hercule.

49. Crustaceos y Aracuidos. In: Claud. Gay's Historia fisica y politica de Chile ........ auspicies del supremo gobierno. Paris, 1814-54. $8^{\circ}$ (Atlas in Fol.) Zoologia. T. III. $547 \mathrm{pp}$.

\section{Nordman, Alexander von.}

'32. \%weites Helt in: Mikrographische Beitrige zur Naturgesehichte der wirbellosen Thiere. 2 Hefte. $20 \mathrm{Kupfrtaf} 4^{\circ}$. Berlin.

64. Vene Beitrige zur Kenntniss parawitischer Copepoden. Erster Beitrag. $(4 \mathrm{pl}$.

Bull. Soc. Imper. des Nat. Moscow. T. 37, P. 2, pp. 461-520.

Nordquist, 0 sc.

86. Birlate till Kannedomen om Crustacefauna i nägra af mellersta Finlands sjöar.

Acta Societatis pro fauna et flora fennica. T. 3, No. 2. 26 pp. Helsiugfors, 1886 .

87. Bidrag till kïnnedomen om Ladoga sjös crustacéfauna.

Meddel. af Soc. pro Fauna et Flora fenuica. Heft 14, pp. 116-138.

88. Die Calaniden Finlands. (Ahlr. aus: Bidrag till Kannedom af Finlands Natur orh Folk. Heft 47.) Helsingfors, Druck d. Finnl. Litter. Ges. 188\%. $8^{\circ}$. $86 \mathrm{pp} .10 \mathrm{pl}$. 


\section{Norman, Rev. Alfred Merle.}

'63. On Acantholeberis Lilljeb., a genus of' Entomostraca new to Great Britain. (1 pl.)

Ann. Mag. Nat. Hist. Ser. 3, Vol. II, pp. 409-415.

'67. Report of the Committee appointerl for the purpose of Exploring the Coast of the Hebrides by means of the Dredge. Part II. On the Crustacea, Echinodermata, Polyzos, Actinozoa, and Hydrozoa.

Rep. 36th Meet. Brit. Assoc. Advanc. Sc. in 1866. Pp. 193-206.

'68. Shetlaud Fiual Dredging Report. Part II. On the Crustacea, Tunicata, Polyzoa, Echinodermata, Actinozoa, Hydrozoa, and Porifera.

Rep. 38th Meet. Brit. Assoc. Advanc. Sc. in 1868. Pp. 247-336, and Addenda, pp. 341, 342.

'76. Crustacea, Tunicata, Polyzoa, Echinorlemata, Actinozoa, Foraminifera, Polycystina, and Spangida. [From the cruise of the Valorus, 1875.]

Roy. Soc. Proc. 25, 1877, pp. 202-215.

'77. Notes on the Oceanic Copepoda. Appendix of Capt. Nares' fortheoming Arctic Voyage.

\section{Norman, A. M., and G. S. Brady.}

'67. A Monograph of the British Entomostraca belonging to the families Bosminidæ, Macrothricidæ and Lynceidæ. (6 pl.)

Trans. Nat. Hist. Soc. Nortbumberland and Durham. Vol. 1, pt. 3, pp. 354-408. Also separate: London, 1867.

\section{Ouchakoff, Nicolas.}

'55. Pontie de Wacarino.

Bull. Soc. Imper. Nat. Moscou. 28, 2, pp. 245-250.

\section{Pavesi, Pietro.}

'77. Intorus all 'esestenza della fauna pelagrica o d'alto lago anche in Italia. Bull. Entomol. IX.

'79. Nuova serie di ricerche della fauna pelagica nei laghi italiani.

Rendiconti Roy. Instituto Lombardo. Ser. 2, Vol. 12. 10 pp.

$1 / 9^{1}$. Ulteriori studi sulla fauna pelagica dei laghi italiani.

Ibid. Ser. 2, Vol. 12, Fasc. 16. 21 pp.

['81. Quarta serie di ricerche e studi sulla fauna pelagica dei laghi Italiani. (Sunto del autore.)

Bull. Soc. Ven. -Trent. 1881, pp. 68-70.]

['83. Altra serie di ricerche e studi sulla fauna pelagica dei laghi italiani. Con 7 Tav.

Atti Soc. Ven.-Trent. Sc. Nat. Vol. 8, Fasc. 2, pp. 340-403. Also separate: Padova, 1883. $8^{\circ}$.]

\section{Perty, M.}

'32. Über den Kreislauf der Daphnien. Isis.

\section{Philippi, A.}

'39. Beobachtungen über Copepoden des Mittelmeeres.

Arch. f. Naturgesch. Nos. 40, 43, 44. 


\section{Plateau, Felix.}

'70. Recherches sur les Crustac'sd'eau douce de Belgique. I. Cienres (iammarus, Linceus et Cypris. (1 pl.) II and III. Genres Daphnia, Bosmina, Polyphemus, Cyelopsina, Canthocamptus et Cyclops. (3 pl.)

Mém. Couron. et Mém. d. sav. étrang. de Belgique. T. 34 (1867-70), 1870, 66 pp., and T. $35,1870.92 \mathrm{pp}$.

\section{Poggenpol, M. J.}

74. List of the Copepoda, Cladocera and Ostracoda of the Environs of Moscow. (9 pp.) (In Russian.)

\section{Poppe, S. A.}

'80. (Ther eine neue Art der Calaniden-Gattung T'emora Baird [aftinis]. 11 ll.) Abhandl. d. Naturwiss. Vereins z. Bremen. Bd. 7, Heft 1, pp. 55-60.

'81. Über einen nenen Harpacticiden (Tachidius littoralis.) (1 pl.)

Ibid. Bd. 7, pp. 149-152.

'84. Bemerkungen zu R. Ladenburger's: "Zur Fauna des Mansfelder Sees" in No. 168 des Zool. Anzeigers.

Zool. Anz. Jahrg. 7, No. 176 (Sept. 15), pp. 499-500.

' $84^{1}$. Cher die von den Herren Dr. Arthur und Aurel Krause im nördlichen Stillen Ocean und Behringsmeer gesammelten freilebenden Copepoden. (5 pl. $)$

Archiv, f. Naturgesch. Jahrg. 50, Bd. 1, pp. 281-304.

'84'. Ein neues Copepoden-(xeuus aus der Jade. [Huntemannia n. g., Jadensis n. sp.]

Abhandl. Naturwiss. Ver. zu Bremen. Bd. 9, Heft 1, pp. 57-58.

'85. Die freilebenden Copepoden des Jadebusens. I. (4 pl.)

Ibid. Bd. 9, Heft 2, pp. 167-206.

'86. Ein neuer Diaptomus [Zacharix] aus dem Hirschberger Thal. (1 pl.) Zeitsch. f. wiss. Zool. Bd. 43, Heft 2, pp. 285-289.

'87. Boachreibung einiger neuer Entomostraken aus norddeutschen Seen. ( 1 pl.) Ibid. Bd. 45, Heft 2 (April 13), pp. 278-281.

'88. Diaguoses de deux espèces nouvelles du genre Diaptomus Westwood. Bull. Soc. Zool. France. 'I'. 13, No. 6, pp. 159-160.

'89. Berichtiquug zu Dr. (). E. Imhol's Aufsat\%. "Fauna der Sii «swasser-hecken" in No. 275 des Zool. Anz. 1888. P. 166.

Zool. Anz. Jahrg. 12, No. 300 (Feb. 18), pp. 99-100.

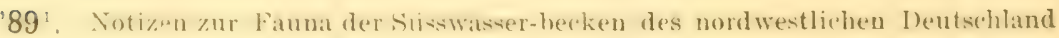
mit besonderer Berücksichtigung der Crustaceen. (1 pl.)

Abhdlinn. Naturwiss. Ver. Bremen. Bd. 10, IIeft 3, pp. 517-551.

91. Ein neur. Diaptouns aus Bracilien. Diaptomus deiterisi nov. sp. (3 text figs.) Zool. Anz. Jahrg. 14, No. 368 (Juli 20), pp. 248-250.

Pouchet, G., et J. Guerne.

'81, 83. [Titles quite similar to those unter l'aves $\times 1$ and ' 43 were given here by the author.]

'85. Sur la faune pelagique de la mer Belgique et du golfe de Fiulaude.

Compt. Rend. Acarl. Sc. Paris. T. 100, No. 83, pp. 919-921. Also: Ann. Mag. Nat. Hist. Ser, 5, Vol, 15, June. Pp. 498.499. 
Pratz, E.

?. Über einige im Grundwasser lebende Tiere. Beitrag zur Kenntniss der unterirdisehen Crustaceen. St. Petersburg.

\section{Prostandrea, Nicolo.}

'33. Su di alcuni nuovi Crostacei di mare di Messina.

Effemer. scient. e lett. per la Sicilia. (Palermo.) Vol. 6, pp. 3-14.

\section{Rathbun, R.}

'82. List of Marine Invertebrata, mainly from the New England Coast, distributed by the United States National Museum. Series II. and III.

Proc. U. S. Nat. Mus. Vol. 4, 1881, pp 298-307.

\section{Redi, $\mathbf{F}$.}

1684. Osservazioni utorno agli animali viventi che si trovano regli animali viventi. Florenz.

1688. Animaletti aquatici. Napoli.

\section{Rehberg, Herm.}

'80.' Zwei neue Crustaceen aus einem Brummen auf Helgoland.

Zool. Avzeiger. Jahrg. 3, No. 58 (Juni 21), pp. 301-303.

'80'. Beitrag zur Kenntniss der freilebenden Süsswasser-Copepoden. (1 pl.)

Abhandlgn. naturwiss. Ver. Bremen. Bd. 6, Heft 3, pp. 533-554.

' $80^{2}$. Weitere Bemerkungen über die freilebenden Süiswasser Copepoden. (I'igs.) Ibid. Bd. 7, pp. 61-67.

\section{Reinhardt.}

'57. Fortegnelse orer Groenlands Krebsdyr. Naturh.

Bidrag til en Beskrivelse af Groenland.

\section{Richard, Jules.}

'87. Sur la faune pélagique de quelques lars d'Auvergne.

Compt. Rend. Acad. Sc. Paris. T. 105, No. 20, pp. 951-953.

'87'. Liste des cladocères et des Copépodes d'eau douce observés en France.

Bull. Soc. Zool. France. T. 12, pts. 3-4, pp. 156-164.

'88. Entomostracés nouveaux ou peu connus.

Ibid. T. 13.

'88 ${ }^{1}$. Cladocères et Copépodes non marins de la fauna de France.

Rev. Scientif. Bourbonnais. Ann. 1, No. 3, pp. 57-70; No. 4, pp. 78-91.

90. Sur les Entomostracés et quelques autres animaux inférieures des lacs de l'Auvergne. (11 figs.)

Rerue des Sciences naturelles appliquées. 1890 . No. 10. 11 pp. Also separate: Paris. $1390.8^{\circ}$.

91. Recherches sur le systìme grlandulaire et sur le systìme nerveux des Copépodes libres d'eau douce, suivie d'une révision des éspèces de ce groupe qui vivent en Fravce. ( 4 pl.)

Ann. Se. Nat. Zool. Ser. 7, T. 12, No. 2, pp. 113-144; Nos. 3-4, pp. 145-256 (4 pl.); Nos. 5-6, pp. 257-270.

'95. Révision des Cladocères. (2 pl.) (Good bibliography.)

Ann. d. Sc. Nat. Zool. Ser. 7, T. 18, pp. 279-389. 


\section{Richiardi, $\mathbf{S}$.}

'75. Sulle Sacculine.

Atti della Soc. Toscana di Scienze Nat. Pisa. Vol. 1, pp. 136-146.

\section{Robin.}

"72. Observations anatomiques et zoologiques sur deux eqpèces de Daphnies. [Daphnia pulex et macropus.] ( 4 pl.)

Journ. l'Anat. et Physiol. Robin et Pouchet. 8. Année, pp. 449-467.

\section{Saccardo, P. Andrea.}

'64. (Cenni storico-naturali intorno agli animaletti) entomostracei viventi nella provincia di Treviso, (colla descrizione di un nuovo genere e coll' indicazione delle poche altre specie di essi trovate nel resto delle provincie Venete. Con 1 tav. $\operatorname{litog}$. Treviso, 1864. $8^{\circ}$.)

\section{Sars, Georg 0ssian.}

'61. On de i Omegnen af Christiania forekommende Cladocerer. (Oversigt af de af ham i Omegnen af Christiania iagttagne Crustacea Cladocera.)

Forhandl. Vidensk. Selsk. Christiania, 1861, pp. 144-167, 250-302.

'63. Oversigt af de indenlandske Ferskvandscopepoder. (2 pl.)

Ibid. (Aar 1862 ) Pp. 212-262.

'64. (Beretning) om en i Sommeren 1863 foretagen zoologisk Reise i Christiania Stift.

Nyt Mag. Naturvid. 13, pp. 225-259.

'64'. Indberetning om en i Pommeren 186:-63 foretagen zoologisk Reise in Christiania og Throndhjems Stifter. (Beretning om en i Sommeren 1त62 foretagen zoologisk reise i Christianias og Trondbjems Stifter.)

Ibid. 12,1863, pp. 193252.

'65. Norges Ferskvandskrebsilyr. Förste Alsnit. Branchiopoda. I. Cladocera Ctenopoda (fam. sididie a. kolopedidx). (4 pl.)

Mel Hs. Maj. Kongens (ruldmedaille Prisbelümiet Afbandling. Christiania. $4^{\circ}$. VIII, $71 \mathrm{pp}$.

74. Om en dimorph Udvikling samt (ienerationsrexel hos Leptodora. (1 pl.)

Forhandl. Vidensk. Selsk. Christiania. (Aar 1873.) 15, pp. 1-15.

'76. Prodromus deseriptionis Crustaceorum.

'85. On some Australian Cladocera raised from dried mud. (8 pl.)

(Forhandl. Vidensk. Selsk. Christiania. No. 8, 46 pp. Alstract in: Journ. Roy. Mic. Soc. 1887, p. 953. Also in: American Naturalist, Vol. 21, Feb., 1887. p. 186.)

\section{Schmankewitsch, Waldimir.}

75. Ther das Verhaltnisuder Artemia salina Milne Edw.zur Artemia Mühlhausenii Milne Edw. und dem Genus Branchipus Schaeft, (1 pl.)

Zeitschr. f. wiss. Zool. Bd. 25, Suppl. Heft 1, pp. 103-116.

77. \%ur Kenntuiss des Einflusses der ïusseren l.ebenshedingungen auf die Or. ganisation der Thiere.

Ibid. Bd. "

Schmarda, L.

'85. Zur Naturgeschichte Aegyptens.

Denkschr. d. k. Akad. d. Wissensch. zu Wien. VII. 


\section{Sch meil, 0}

'91. Beiträge zur Kenntniss der Süsswasser-Copepoden Deutschlands mit besonderer Berücksichtigung der Cyclopiden.

Inuaugural-dissertation. Univ. Leipzig. $8^{\circ}, 40 \mathrm{pp}$. (In: Zeitsch. f. Naturwies. (Halle), Bd. 64, Heft 1-2, pp. 1-40.)

\section{Schmeil, 0tto.}

92. Deutschlauds freilebende Süsswasser-Copepoden. I. Teil: Cyclopidie. (192 pp. 8 pl. and 3 text figs.)

Bibliotheca Zoologica (Leuckart und Chun), Heft 15, I. Teil.

'93. Id. II. Teil: Harpacticida. (102 pp., 8 pl, and 2 text figs.)

Ibid. Heft 15. II. Teil.

\section{Schneider, J. Sparre.}

'84. Undersögelser af dyrelivet i de arktiske fjorde. II. Crustaceer og Pycnogonider indsamlede i Kvanangsfjorden 1881. (5 pl.)

Tromso Mus. Aarshefter. VII. $83 \mathrm{pp}$.

\section{Schoedler, J. Edward.}

'46. Über Acanthocereus rigidus, ein bisher noch unbekauntes Entomostracon aus der Familie der Cladocereu. (2 pl.)

Arch, f. Naturgesch. Jahrg. 12, Bi. 1, pp. 301-374.

58. Carcinologische Beiträge. Die Branchiopoden der Umgegend von Berlin. 1. Beitrag. (1 pl.)

Jahresber. d. Louisenstädtische Realschule zu Berlin. 28 pp.

'62. Die Lynceiden und Polyphemiden der Umgegend Berlins.

Jahresb. d. Dorotheenstädt. Realschule zu Berlin.

'63. Neue Beiträge zur Naturgeschichte der Cladoceren (Crustacea Cladocera) (3 pl.) Berlin. $4^{\circ} .80 \mathrm{pp}$.

'65.' Zur Diagnose einiger Daphniden.

Archiv. f. Naturgesch. Jahrg. 31, Bd. 1. pp. 283-285.

'66. Die Cladoceren des frischen Haffs nehst Bemerkungen üher anderweitig forkommende verwand te Arten. (3 pl.)

Ibid. Jahrg. 32, Bd. 1, pp. 1-56.

'77. Zur Naturgeschichte der Daphuidev. Beiträge zur Kenntuiss der systematischen Angehörigkeit der Daphniden. Berlin, 1877. 4․ $1 \mathrm{pl} .24 \mathrm{pp}$.

Scott, T.

'88. A revised List of the Crustacea of the Firth of Forth.

Sixth Annual Report of the Fishery Board for Scotland.

\section{Shaw, George.}

1791. Description of the Cancer stagnalis of Linnæus.

Trans. Linn. Soc. London. I.

\section{Siebold, Carl Theodor E. von.}

'39. Beitrige zur Naturgeschichte der wirbellosen Thiere. (liber Medusa, Cyclops, Loligo, Gregorina and Xenos.)

Neueste Schr. d. Naturf. Gesell. in Danzig. Bd. 3, Heft 2.

'71. Beiträge zur Parthenogenesis der Arthropodeu. (2 pl.) VI. Uhber die parthenogenetische Fortpflanzung bei Apus und verwandten Crustaceen. Leipzig, 1871. $8^{\circ}$. VIII, $238 \mathrm{pp}$. 
173. Über Parthenogevesis der Artemia salina.

Sitzungsber. d. Königl. Akad. d. Wissensch. zu München. Bd. 3, pp. 168-196.

Smith, F, A.

'61. Sur les Ephippies des Daphnies. (2 pl.)

Nov. Act. Acad. Scient. Upsal. Ser. 3, Vol. 3, pp. 37-50.

\section{Spangenberg, Friedrich}

'75. Zur Kenntniss von Branchipus stagualis. (3 pl.)

Zeitschr. f. wiss. Zool. Bd. 25, Suppl. Heft 1, pp. 1-64.

'76. Über Bau und Entwicklung der Daphniden. Vorläuf. Mittheilung.

Götting. Nachricht. 1876, pp. 517-537.

\section{Stimpson, Wm.}

64. Sruopsis of the Marine Invertebrata collected by the late Arctic Expedition under Dr. I. I. Hayes.

Proc. Acad. Nat. Sc. Philadelphia. 1863. Pp. 133-142.

\section{Straus-Durckheim, Hercule Eugene.}

'19-'20. Mémoire sur les Daphnias, de la classe des Crustacés. (1 pl.)

Mémoires du museum d'hist. nat. 'T. 5 , pp. 380.425; 6, pp. 149-162. (Paris, 1819, '20. 59 pp. Extr. des Annal. du Muséum d'hist. natur. Tom. 5, 6.)

'21. Mémoire sur les Cypris de la classe des Crustacés. (1 pl.)

Ibid 7, pp. 33-61.

\section{Ström, H.}

1765. Beskrivelse over ti norske Iusekter Nr. 9, Tab. IX. Skrifter som udi det Kjobenb. Selsk. (Acta Havniæ.)

\section{Studer, Th.}

78. Beitrïge zur Naturgeschichte wirbelloser 'Thiere von Kerguelensland.

Archiv. f. Naturgesch. Jahrg. 44, pp. 102-121.

\section{Templeton, Rob.}

'36. Descriptions of some undescribed exotic Crustacea. (3 pl.)

Trans. Entom. Soc. London. Vol. 1, pt. 3, pp. 185-198.

37. I)escription of a new Irish Crustacean Animal (Anomalocera pattersonii).

$$
\text { - (1 pl.) }
$$

Ibid. Vol. 2, pt. 1, pp. 34-40.

'38. Id. (Zuea pattersonii). (1 pl.)

Ibir. Vol. 2, pt. 2, pp. 114-120.

\section{Thallwitz, J.}

'90. Entomostraken [aus der Umgegend Dresdens].

V. Jabresber. d. ornith. Beobacht. Stat. Sachsen. Pp. 75-80.

\section{Thomson, George M.}

61. On a new Daphnia.

Trans. New Zealand Inst.

'83. On the New Zealand Copepoda. (7 pl.)

Trans. N. Zealaud. Instit. Vol. 15, pp. 93-116.

'83. (New Zealand Copepoda II.

New Zeal. Journ. Sc. Vol. 1, No. 7, (Jan ), pp. 341-342.) 
'84. On the New Zealand Entomostraca. (1 pl.)

Ibid. Vol. II, 1879 (1878), pp. 251-263.

\section{Thompson, I. C.}

87. On some Copepoda new to Britain (found in Liverpool).

Proceedings of the Liverpool Biological Society, Vol. I.

\section{Thompson, John V.}

'31. Memoir VI. Development of Artemis salinus or Brine Shrimp; demonstrative of its Relationship to Branchipus and the other Crustaceous Phyllopoda, and to those enigmatical Fossils, the apparently eyeless Trilobites with a new Species of Artemis and of Apus.

Zoolog. Journ. V.

\section{Thorell, T.}

'59. Bidrag till Kïnnedomen om Krustaceer, som lerfa i arter af Slægter Ascidia, L. Till K. vet. akad. inlemnad d. 14 September. (Stokholm, Akad. Handl. III., 1859-60.) (In German in Zeitsch. f. d. ges. Naturwiss. Halle. Bd. 15, 1860, pp. 114-144.)

\section{Tilesius, W. G.}

'15. De Cancris kamtschaticis, oniscis, entomostracis et cancellis marinis microscopis noctiluscentibus; (cum appendice de Acaris et Ricinis kamtschaticis.) (4 pl.)

MÉm. de l'Acad. imp. des Sc. de St. Petersbourg. T. 5, pp. 331-405. (4 maj. Petropoli, 1812.)

'14-'19. Üeber das nächtliche Leuchten des Meerwassers.

Ann. d. Wetter. Gesellsch. f. d. ges. Naturkunde. Bd. 3, 1814, pp. 360-372. Fortsetzung. Bd. 4 (Neue Annalen Bd. 1), 1819, pp. 1-10. (2 pl.)

\section{Toth, S.}

'61. A budapesti kandiesfélék. Cladoceerà.

Math. termtud. közlem. Kiadja a m. tud. Akad. I. k.

'61'. Die Rotatorien und Daphnien der Umgebung von Pest-Ofen.

Verhandl. d. k. k. \&ool.-botan. Gesellsch. in Wien. XI. Pp. 183-184.

'62. Pest-Budan 1861 ben talált Daphnidák.

Mathem. term. tud. közlem. Kiadja a m. tud. Akad. II. k.

\section{Trybom, Fil.}

81. Jakttagelser om det lïgre djurlifyet pâ de platser utanfïr Bohusling kust, der sillfiske med drifgarn bedrefs vintern 1880-1881.

Oefvers. Kgl. Vet. A kad. Förhdlg. Stockh. Arg. 38, No. 3, pp. 33-43.

\section{Tivner, C. H.}

'92. Notes upon the Cladocera. Copepoda, Ostracoda and Rotifera of Cincinnati, with descriptions of New Species. (2 pl.)

Bull. Scient. Laboratories of Denison University. Vol. 6, pt. 2. pp. 57-74.

'93. Preliminary Note on the Nervous System of the Genus Cypris.

Journ. Comp. Neurology. Vol. 3, pp. 1-35.

'93'. Additional Notes on the Cladocera and Ostrocoda of Cincinnati. 1. System. atic Portion. 2. Late Larval History of Cypris Herricki. 3. Ilyocryptus spinifer, Herrick, not the same as I. longiremis, Sars. (2 pls.)

Bull. Sc. Labs. Den. Univ. Vol, 8, pt. I, pp. 1-18. 
94. Notes on Americau Ostracoda, with Deseriptions of New Species. (2 pl.) Ibid. Vol. 8, pt. 2, pp. 13-26.

\section{Turner, Wm., and H. S. Wilson.}

'61. On the structure of the Chondracauthus lophii, with Obserrations on its Larral Form.

Trans. Roy. Soc. Edinburgh. XXIII, pp. 67-76.

\section{Uljanin, W. N.}

'74. Cladocera et Copepoda de guelques lacs de la Russie centrale.

'75. Crustacen of Turkestan. Part I. (In Russian.)

'75'. Reise in Turkestan von Al. Fedtschenko. II. Zool. Theil 7. Crustacea. Moscou.

\section{Vauzème, Roussel de.}

'34. Description du Cetochilus australis nouveau „zenre de Crustacé branchiopode. (1 pl.)

Ann. d. Sc. nat. 2 sér. Zoologie I, pp. 330-338.

\section{Vejdovsky, Franz.}

'82. Thierische Organismen der Brunuenwässer von Prag. (8 pl.) Prag. 1882. $4^{\circ} .68 \mathrm{pp}$.

\section{Vernet, $\mathrm{H}$.}

79. (Entomostracés de la faume profonde du lac Léman et description de la Noina bathycola n. sp. Pp. 526-535 of F. A. Forel's) Matériaux pour serrir à l'etude de la faune profonde du lac Léman.

Bull. de la Soc. Vaud. de scienc. natur. Sér. IV,T. 15, No. 80. (1878.)

\section{Vogt, Carl.}

'77. Sur quelyues Copepodes Parasites à Males I'ýgmées hahitant les Poissons. Mem. Inst. Genéva. 13.

'78. L'Adaptation des Crustacés Copépodes au Parasitisme.

Actes de la Soc. Helvétique des Sci. Nat. $60^{\circ}$ Sess. (1877), pp. 121-139.

Vosseler, J.

86. I)ie freilebenden Copepoden Württembergs uud angrenzender Gegenden. (3 pl.)

Jahreshefte des Vereius f. vaterl. Naturkunde in Wiirttemberg. Jahrg. 42, pp. 167-204. Also separate as: Inaug. Diss. (Tübingen.) Stuttgart 1886. $8^{\circ}$.

'89. Die Copepodenfauna der Eifelmaare. (1 pl.)

Arch. f. Naturgesch. Jahrg. 55, Bd. 1, Heft 1, pp. 117-124.

Wagner, Rudolphus.

36. Prolromus II istoriac Cremerationis Hominis atulue Animalium (sistens icones ad illustrandam ovi primitivi, imprimis vesicule grerminative ét germinis in uvario inclusi grenesin atyue structuram, per omues animalium classes mul. tosque indagatam. Accel. tabula dux xri incisæ. Roy. Fol. Lipsix.)

Walter, Alfred.

'88. Transkaspische Binuencrustaceen. I. Entomostraca. (1 pl.)

Zool. Jahrbücher. Abth. f. System. Geog. u. Biol. d. Thiere. Bd. 3, Heft 6, pp. 987-1013. 


\section{Weber, M.}

'76. Ueber die Nahrung der Alausa vulgaris und die Spermatophore von Temora velox Lilljeborg.

Arch. f. Naturgesch. Jahrg. 42.

\section{Weisman, August.}

'74. Ueher Bau und Lebenserscheinungen von Leptodora hyalina Lilljeborg.

Zeitschr. f. wiss. Zool. Bd. 24.

'76. Beiträge zur Naturgeschichte der Daphnoiden. I. Über die Bildung von Wintereiern bei Leptodora hyalina. (3 pl.)

Zeitschr. f. wiss. Zool. Bd. 27, Heft 1, pp. 51-112. Also separate: Leipzigr, 1876. $8^{\circ} .64 \mathrm{pp}$.

'77. Beiträge zur Naturgeschichte der Daphnoiden. II-IV. (5 pl.)

Ibid. Bd. 28, Hefte 1 u. 2. (II. Die Eibildung bei den Daphnoiden. Pp. 95-175. III. Die Abhängigkeit der Embryonalentwicklung vom Fruchtwasser der Mntter. Pp. 176-211. IV. Ueber den Einfluss der Begattung auf die Erzeugung von Wintereiern. Pp. 212-240.)

'78. Id. V. Ueber die Schmuckfarben der Daphnoiden. (1 pl.)

Ibid. Bd. 30, Suppl. Heft 1, pp. 123-164.

'79. Id. VI. Samenbildung and Begattung bei den Daphnoiden. (6 pl.) VII. Die Entstehung der eyclischen Fortpflanzung bei den Daphnoiden.

Ibid. Bd. 33, Heft 1, pp. 55-110; Heft 2, pp. 110-164. Above, I-VII, separate: Leipzig, 1876-79. Pp. XVI, 486. (15 pl.)

Westwood, J, 0.

'36. Cyclops. Partington's Cyclopaedia.

White, Adam.

'55. A collection of documents on Spitzhergen and Greenland. London.

'5\%. A Popular History of British Crustacea comprising a familiar acconnt of their classification and habits. London, 1857. $16^{\circ} .360 \mathrm{pp}$.

\section{Wierzejski, A.}

'81. O Faunie jezior Tatrazaniskich. Pamietnika Tow. Tatrzaniskiege.

'82. Materyjaly do fauny jezior tatrzanskich. (27 pl.)

Spraw. Kornis. fizyjagraf (Akad. umieg.) Krakowie. Vol. 16, pp. 1-24. Also separate: (Polish.) Abstract hy A. Wierzejski in Biol. Centralb. Bd. 2, No. 23, p. 736.

'83. Zarys fauny stawöw tatrzanskich. Pannetnika Tatrzanskiego, VIII, Krakowie.

'87. O. krajowych skorupiakach zrodziny Calanidæ, Nozgrawn (Rozpr.) i Spraw. (1 pl.)

Wydz. mat. przyr. Akad. Umiej. Vol. 16, p. 13.

\section{Zacharias, 0 tto.}

'85. Über die amöboiden Bewegungen der Spermatozoen von Polyphemus pediculus (de Geer). (1 pl.)

Zeitsch. f. wiss. Zool. Bd. 41, Heft 2 (Dec., 1884), pp. 252-258. 
'85'. Studien über die Fauna des Grossen und Kleinen Teiches im Riesengebirge. (1 pl.)

Ibid. Bd. 41, Heft 3 (March, 1885), pp. 481-516.

'87. Zur Kenntuiss der pelagischen und littoralen Fauna norddeutscher.Seen. (1 pl.)

Ibid. Bd. 45, Heft 2 (April, 1887), pp. 255-281.

'89. Bericht über eine zoologische Exkursion an die Kraterseen der Eifel.

Biolog. Centralblatt. Bत. 9, No. 2, pp. 56-64; No. 3, pp. $76-80$; No. 4, pp. $107-$ 113.

\section{Zaddach, E. G.}

'44. Synopseos Crustaceorum Prussicorum prodromus. 4. Regiomonti 1844. $39 \mathrm{pp}$.

'56. Holopedium Gibberum, ein neues Crustaceum aus der Familie der Branchiopoden, beschrieben. ( $2 \mathrm{pl}$.)

Arch. f. Naturgesch. Jahrg. 21, Bd. 1, pp. 159-188.

\section{Zenker, Wilh.}

'51. Physiologische Bemerkungen über die Daphnoiden. (1 pl.)

Mueller's Arch. f. Anat. und Physiol. 1851, pp. 112-121.

(Physiological remarks on the Daphnidx. Q. T. Mic. Sc. Vol. 1, 1853, pp. 273278.)

'54. Anatomisch-Systematische Studien über die Krebsthiere (Crustacea). (6 pl.) Archiv. f. Naturgesch. Jahrı. 20. Also separate: Berlin, 1854. $8^{\circ}$. IV, 115 pp.

54 $4^{1}$. Monographie der Ostracoden. $(6$ pl. $)$

Ibid. Jahrg. 20, Bd. 1, pp. 1-88. 


\section{PART I}

\section{COPEPODA OF MINNESOTA}

BY C. L. HERRICK 



\section{ORDER COPEPODA.}

This extensive order contains minute and predomiuatingly predaceous animals which constitute no inconsiderable part of the fauna of fresh and salt waters. They serve a beneficent purpose both as scavengers and as providing food supply for the fry of fishes and other aquatic animals.

Copepode are never inclosed in a bivalved shell, but ordinarily exhibit a more or less elongated cylindrical form, composed of two obvious subdivisions. There are a few species which, hy the great prolongation and expansion of some of the tergites or dorsal shields, seem to simulate shelled c'mstucea. The anterior part of the body, or cephalothorax, is composed of teu somites which are frequently considerably united or fused. Five of these segments constitute the head and bear respectively the following appendages: first, a pair of several- to many-jointed antennie, which are never primarily sensory in function, although they usually are provided with sense hairs or other like organs; second, a pair of two-branched antennules, which sometimes become almost simple or prehensile; third, a pair of mandibles in the form of masticatory or piercing organs, these being usually provided with a palpus; fourth, a pair of maxille of various form and function; fifth, a pair of maxillipeds which not infrequently subdivide in later life to form what appear to be two distinct pairs.

The five thoracic segments have each a pair of swimming feet consisting typically of a two-jointed base and two similar, three-jointed rami. The symmetry is frequently broken by the retarlation of the development of the inner or outer ramus, while the fifth pair of feet may become rudimentary and in various ways subserve the organs of sex. The five abdominal segments are nearly devoid of appendages and are continued posteriorly by two caudal stylets which hear strong setæ, constituting, in many forms, a tail-fin or spring.

All copepord, even such as are, in later life, parasitic, begin their existence as free-swinning nauplii.

Though the vast majority of genera and species are marine, it would seem that fresh-water c'opepoda make up in the number of individuals what they lack in variety. 
As we are dealing primarily with the fresh-water species, no lengthy description of the group is here necessary.

The earlier history of our knowledge of the animals of this order is given by Baird. According to this authority, the furst to mention any fresh-water species of this group was Stephan Blankatat, * in his

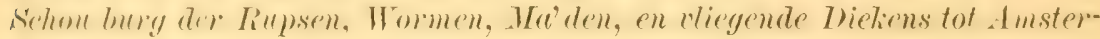
dum. Leenwenhoek adds numerous interesting details, and is accredited by Hoek with being the first to discover the relation between the remarkably diverse stages which occur in the history of the ryclops. Iowerer, it is evident that he had a very incomplete knowledge of the metamorphoses.

I te Geer gives rather characteristic figures of a Cyclops in . Wemoires pour servir a l' Histoire des Insectes, vol. vii, 1778.

Iueller, in his great work on Entomostract, adds new facts, defines species and forms the genus Cyclops.

Ramdohr, in 1S05, gave sundry additions to the knowledge of these animals in his Beiträge zur. Tuturgeschichte einiger Deutschen Honoculusarten. In this work the post embryouic history is quite iully outlined.

Jurine, in his classic work Iristoire des Honocles qui se trouvent anx Environs de Geneve, 1820, crystallized what previous authors as well as his own original experiments had brought to light of the anatomy and biology of these animals.

Ferussac (Memoire sur deux novelles especes d'Entomostraces) redescribes known species.

Gunner, Stroem, and Viviana seem to have had little effect on the knowledge of the group, though they wrote prior to Jurine.

A recent author attempts to revive the names of Jurine, though hitherto it has been thought hazardous to attempt a specific identification.

The (ierman author, C. I. Koch. who only incidentally studied this croup, distinguished more or less perfectly a variety of species which have been reinstated in our literature by Rehberg. Although this proceeling seems quite unjust to the careful authors whose descriptions are recognizable in themselves, the law of priority must probably prevail. Kioch's Meutsrhlonds Krostueen appeared in 1838.

Baird:s British Entomostrued, without greatly extending our knowledgre of this order. put in readable form and made available to English readers what was known, and adderd interesting facts. The distin.

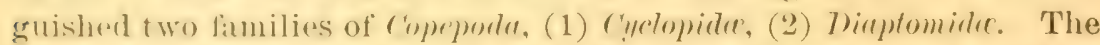

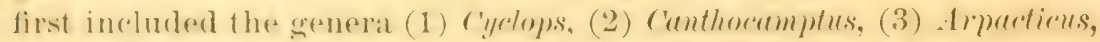
(4) Hltenllu: and the second the genera, (1) Jiaptomus. (2) Temora, (3) Anomlocera.

* Latinized Stephanus Blanchardus. Hoek recognized Cyclops brevicaudatus or C. bicuspilatus as the one described, chlefly through knowledge of the present inhabitants of the locality. 
Fischer, who contributed not a little to our knowledge of the distribution of fresh-water Cladoreru, was the next to describe valid species. He described the species found near Moscom and st. Petersburg, Russia.

The justly famous swedish naturalist, W. Lilljeborg, who has left his mark on so many branches of natural science, has not neglected the microscopic Crustare of his fatherland. Om de inom slatane forere-

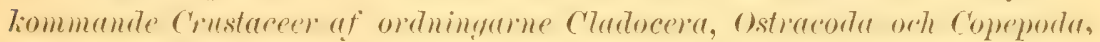
is the somewhat formiclable title of his work, published in 1855 . He recognized the following genera of ('opepoda: Diaptomus, Temora, Dias, Ichtyophorba, Tisbe, Tachidius, Hurpacticus, Canthoctmptus, and Cyctops.s. A species each of IDidptomus and 'cththoc(tmptus is described, and two species of Cyclops. (It would seem from authors' quotations that other species are described in an appendix, but the copy I have seen lacks this.) The author who has done most for micro carcinology in general is Carl Claus of Tienna. His principal works are:

1. Das Genus Cyclops, etc. In Wiegmann's Lrchiv für Vaturgeschichte, 1857.

2. Teitere Mitheilungen ueber Mie einheimischen Cyclopiden. The same, 1857.

3. Die Freilebenden Copepoden, 1863.

The later work especially is indispensable to the student of Copepoda, though in reality it is more important in respect to marine $c o$. pepoda.

In the meantime a work appeared in Norwegian, with Latin deseriptions, from the pen of G. O. Sars. This has been largely overlooked. It is, unfortunately, unaccompanied by plates, but the descriptions bear the stamp of the naturalist.

A little later a secoud brief contribution from this author was pub. lished, but I have not seen it.

Sir John Lubbock in 1863 describes species of fresh-water Copepo$d a$, but the publication seems no longer necessary.

Heller, in Tyrol, Fric, in Bohemia, and Uljanin, in Asia, have studied the Oopepod fauna.

A Russian paper by Poggenpol and Uljanin is quoted as A. Cat

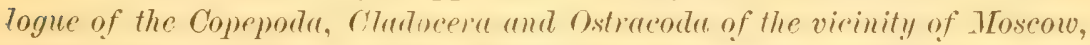
by Rehberg, and as from the Protoliolle der lickis.nuturvo. anthropot. und ethnogr. Ges. in Moskm, but by Cragin, who publishes a translation apparently of the same paper in part, as from the Bulletin of the Friends of Natural History.

Hoek, in the Tijdschrift der Xederlandsche Dierkumdige Tereeniging (Magazine of the Zoological Society of the Nethertands), 1875, and later in German in the Viederläntisches Archiv für Zoologie, gave excellent 
fignrey and descriptions of some species which Claus had too hastily treated.

In $1878 \mathrm{~A}$. Gruber gave descriptions of Two fresh-uater C'alanidu.

In the same year the first volume of Brady's fine British Copepoda appeared. A purely technical work and briefly written, it is yet very comprehensive and in the main reliable. This is a worthy successor of the Ray Society's earliest publication on EntomostracaBaird's great work.

In the sixth volume of the Abhandlungen d. naturwissenschaftlichen Terein zu Bremen, Herman Rehberg gives a systematic review of synonomy, and in the revision unites several species in a manner that the present writer had independently been driven to do. It is probably impossible either to substantiate or positively deny some of this writer's identifications of the species of the older authors.

This paper also contains an ohservation of a hermaphorditic ryclops, which it is interesting to compare with similar anomalies, described by Kurz in Cladocera.

In the seventh volume of the same periodical, Rehberg adds to and modifies some of the views expressed above. In the same number is a description of a new species of Temor by Poppe. (The same species occurs in the semi-saline waters of the Gulf of Mexico, and had wellnigh gone into print under a new name when this was seen.)

In the above review we have noticed only the more important foreign works on the Copepodu and those including fresh-water forms. 1)ana's magnificent Crustarea of the Willies' Exploring Erpedition is not included, because it is essentially restricted to the marine species, the few descriptions of fresh-water species being quite valueless. Among important contributors to the exclusively marine Copepoda, are Boek

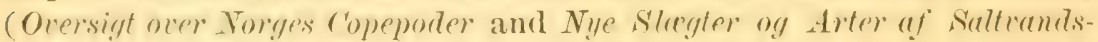
Copepoder), Brady and Robertson, Lubbock and Claus.

The history of the Amtrican literature can be quickly traced.

Say described imperfectly an American species of cyclops in 181 s. Hatdeman describes in volume 7 , of the Proceedings of Philadelphiat Acadeny of Sciencee, p. 331, C'ycropses seteste (which may be C'. serrulutus). Pidering very imperfectly deseribed a new genus of (oppe poder from Lake Ontario in Dekay's Zonlogy of . Tem Yorls. This genus is, most likely, Epischura of Forbes, and, in strictness, ought to rank it. In 1873 appeared A list of Illinuis ('rustucen, by Professor Forbes, in which two spereies of copepode were described which may rank as the first deseriptions, at all adectuately framed, of American members of the order. In the Anmual lieport of the Minnesolu state Crestogist for 1sis, a brief article by $C$. L. Iferrick ontlined, in the light only of the then English literature, the micro-erustacea of Minnesota. No at- 
tempt was made to treat the Copepoda, but two species of Diaptomus are indicated which will prove valid. Occasional papers in the Americen Taturalist and elsewhere follow, till, in July and August of 1882, Professor Forbes added two new genera and several species of Copepoda, constituting by far the most considerable addition to the subject yet produced.

In the Report of the State Creotogist of Mimnesotu for 1S81, C. L. Herrick makes a considerable addition to the knowledge of American Cyclopide, enumerating ten species, of which six seemed new. This writer also describes a new genus and several new species of culamidc, some of which unfortunately are identical with those described by Forbes and published about simultaneously.

In April, 1881, V. T. Chambers gave an account of a species of the Harpaticida, referred by him to Zachidius. The species is especially interesting on account of its novel habitat. Zardhidins (?) fonticolu Cham., is found in saline waters of Big Bone Springs, Ky., and is thus very distant from its marine congeners. It is perhaps doubtful if its gen eric reference cau be sustained, but the species is of great interest. The Diaptomus described by the same author is not recognizable.

Several articles in the Vaturatist bring the bibliography up to May, 1883, when F. WV. Cragin published in the Trans. Kunses Academ! of Science, A Contribution to the IListory of the Fresh-uater copeporta. In this paper ten species of Cyclops are described or mentioned. The author ignored previous American literature and thus adds somewhat to synonomy. The plates are lithographic, and are carefully, if not artistically, prepared. A valuable feature is the translation of the descriptions of Poggenpol's species from the Russian.

These papers, together with the outline presented beyond, it is hoped, will form a basis for future work.

To the above, which is reproduced without change from the first edition, it may be added that there has been a considerable degree of desultory activity in the study of the (ropeporlf in Europe since the appearanee of this work. This has heen especially marked in the case of the Culanidu, and, in particular, in the genus Diuftomus, in which the confusion resulting from confounding many species under one name has been finally removed and the real specific characters differentiated. Among the most important of these japers are the following: De Guerne and Richard: Revision des C'alonides de Eate doure: Brady: Revision of British speries of Fresh-uater Cygatopider and Calanida: Schmeil: Deutschland's Freilebende siassuasser ('oprepoden. American literature since $188 t$ has been but little augmented, the following papers being the only important ones: ILerick: ('ontribution to the Fanna of the Gulf of Meriro and the South, 1857; Forbes: On siome 
Late Superior. Entomostrace, 1591; Marsh: On the Deep-Water Crustacen of Creren Lalie, 1891; Forbes: A Pertiminary Report on the Aquatic Invertebrate Fenna of the Fellowstone National Perli, 1S93; Marsh: On the Cyclopide and Calanide of Central Wisconsin, 1893. (?)

While it is probable that comparatively little remains to be done in the systematic study of North American Copepoda except in the west and in mountainous and brackish statious, yet there are few more attractive fields than that offered by the study of the biological conditious under which these forms appear. The processional appearance of several species in the same pool in the spring, the eflects of staguation on the organization, and the peculiar heterogenesis or polymorphism due to age, are all capable of yielding valuable additions to theoretical biology. While much care and attention are requisite, and considerable collateral information, yet the cladoceran studies of Professor Weismann afford a suitable model and inducement. In a purely systematic paper like the present one no attempt can be made to indicate these lines of work.

\section{FAMILILS OF THE FRESH-WATER COPEPODA.}

I. Calanidx. Body elongate; abdomen more slender and quite distinct from the thorax. Antenuse long, 23-to 25-jointed; in the male that of the right side modified for prehension. First four pairs of feet two-branched, outer branch three-jointed. Fifth feet severaljointed, those of the male prehensile; dissimilar on the two sides. Ovisac single. Habit strongly natatory.

II. Cyclopide. Cephalothorax compact, ovoid; abdomen slender. Antenne usually shorter than the cephalothorax, both geniculate in the male, 8- to 18-jointed. Secoud antenne (antennules) one-branched. Fifth feet rudimentary, a sixth pair sometimes present, especially in the male. Orisacs double, lateral. Habit natatory.

III. Harpacticida. Body eylindrical or flattened; abdomen not sharply distinct. Antenne short, not more than 10-jointed, those of the male both geniculate. Antennules palpate. First pair of swimming feet usually prehensile. Fifth feet foliaceous, somewhat dissinilar between the sexes. Ovisac usually single. Habit ereeping or sub-natatory.

\section{FAMILY CALANIDE.}

This group is pre-eminently marine and contains diverse and gratesul forms, mostly with rery elongated hodies and antemne. Of the six genera here enumerated as more or less habituated to the use of fresh water, two are found as yet only in America and one is confined to Europe. 
Heterocope, namely, is very near Epischura, both being restricted to fresh water. Diaptomus and Osphrenticum are likewise only accidentally found in the seas, though their nearest allies are marine. The geuus Limnoculums is as yet found in America only in the Great Lakes.

In the distribution of genera we here follow Brady, whose definition of the family Calanide, including Culunide and P'ontellide of authors, we quote: "Body elongated; composed of from ten to twelve [obvious] segments. Abdomen nearly cylindrical, much narrower than the cephalothorax and prolonged at the posterior extremity into two more or less cylindrical caudal brauches [stylets]. First segment of thorax often anchylosed with the head; fourth and fifth segments also often coalescent. Head only rarely divided into two segments. Anterior antenna very long and composed of trenty-four or twentyfive joints; that of the right side in the male often modified for grasping [geniculate]. Posterior antenuse large, composed of a basal joint, from which spring usually two branches, the primary branch consisting of two, the secondary of several joints. Mrandibles strongly toothed at the apex, palp (usually) tro-branched. Maxillse strong, and provided with a many-lobed palp. Foot-jaws strongly developed: first pair very broad; the basal joints having on the imner margin wart-like processes, from which spring long eiliated bristles; the distal extremity divided into three short joints which are thickly beset with stroug and loug, ciliated setie; second pair longer and more slender, basal portion forming two long oval joints; apical portion usually four-to six-jointed. First four pairs of feet two-branched, the outer branches always three-jointed. Fifth pair either like the foregoing, or much modified, unilike on the two sides, and in the male forming clasping organs. A heart is present. Eyes either median and stalked or paired (lateral) and sessile; in the latter case being often coalesceut and composed of several lenses. Sexual organs in the female symmetrical, in the male asymmetrical. Ovisac single, borne in front of [below] the abdomen.

The Culanide are distributed over the whole globe, and yet the limitations of range are much more strict than in the other groups. Thus no species of the eastern continent has been positively identified in America, while the majority of the Cyclopide of America are old world species or vicarious forms.

Range of altitude is also limited, and the delicate organization of the calumirter responds to slight changes of the envirohment. The origin of our fresh-water genera from the marine forms in comparatively recent times is on many accounts very probable. The formation of large inland bodies of fresh water was an essential pre- 
requisite, and the limitations of range in themselves point to a more recent origin than the other groups of micro-crustacea; nor is it difficult to trace the connecting links in many cases.

\section{IIEY TO 'THE FRESH-WATER GENERA OF THE CALANIDE.}

I. FIFTH FEET OF THE FEMALE BI-RAMOSE.

a. Inner rami of all the swimming feet three-jointed.

* Inner ramas of the right male fifth foot three-jointed.

+ Outer ramus of the right male fifth foot two jointed. Limnocalanus, 48

it Outer ramus of the right male fifth foot three-jointed.

* Inner ramus of the right male fifth foot reduced.

Osphranticum, 85

b. Inner rami of the first swimming feet two-jointed.

*Boeckella.

c. Inner rami of all the swimming feet two-jointed. Diaptomus, 54

Broteas, 80

II. FIFTH FEET OF THE FEMALE UNI-RAMOSE.

a. All the swimming feet with the inner ramus one-jointed.

* Abdomen symmetrieal, not prehensile in the male.

Heterocope, 80

* Abdomen unsymmetrical, with prehensile appendages in the male.

Epischura, 81

b. First swimming foot with one-jointed inner ramus, the rest twojointed.

Eurytemora, 49

c. Swimming feet with three-jointed inner rami.

* Fifth foot of the male one-branched.

Pseudodiaptomus, 5:

** Fifth foot of the male with one-jointed inner ramus.

*Poppella.

\section{GENUS LIMNOCALANUS Sars. 1863.}

('ephalothorax six-jointed, slender, last segment never divaricate. Abdomen in the female three-or four-jointed (not including stylets), in the male fivejointed. Caudal stylets elongated with five setie. First antemnit 25-jointed, shorter than the body; in the right antenna of the male a geniculate joint between segments 18 and 19 . Second fair of maxillat, strong, eight-jointed, last joint unguieulate. Feet bi-ramose, those of the first four pairs with three-jointed rami. Onter ramus of fifth feet in the female three-jointed, with a claw-like process from the second segment; inner ramus like those of the other fect. 'The onter ramus of the right foot of the male more conspicuously molifiel, apparently two-jointed, with a long apical claw. This groms $\nabla \circ \mathrm{ry}$ closely approaches ('motropuges, which latter is its marine prototype. The gemus is represented by two species, one of which is circumpolar, the other occurring in China farther south.

* Not described by the author. See plates. 
(Species preceded by an asterisk have been reported in America.)

* Limnocalanus macrurus Sars.

Plate I, Figs. 1-4.

Centropages grimaldii, De Guerne '86.

Limnccalanus macrarus var. auctus, Forbes '87; Sars '62; Nordquist '83; De Guerne and Richard '89; Marsh'92.

The subcylindrical three jointed abdomen is longer than the elongate oval six-jointed thorax. The stylets are very long, spiny and ciliated. Antenne hardly reaching the penultimate abdominal segment. The claw of the female fifth foot armed with fine, sharp spines. The claw of the male right fifth foot is thick and bears two spines internally. Color generally hyaline. Length about $2.0 \mathrm{~mm}$.

\section{Limnocalauus sinensis Poppe.}

De Guerne and Richard '89.

This smaller and rather depauperate form from chiua may be recognized by the fact that the claw of the fifth foot of the female has strong and irregular teeth and that of the right fifth foot of the male is slender and flexuous. The abdomen is shorter than the thorax. Length $1.65 \mathrm{~mm}$.

\section{GENUS EURYTEHORA Giesbrecht.}

(Temorella of Claus, Poppe, Nordquist, Herrick.)

Relatively robust; cephalothorax six-jointed; frontal processes present. Abdomen of the male, fire-jointed, of the female, threejointed. Candal stylets slender, often very long relatively; apical setie four, also a similar lateral seta. Antenux 23-or 24-jointed, about as long as the cephalothorax. In the male 20 -jointed with the geniculation between segments 15 and 19. Four pairs of bi-ramose swimming feet, the first pair with a one-jointed inner ramus, the second to fourth pairs with two-jointed inner ramus. Fifth pair of feet in the female simple, similar, penultimate segment produced into a strong hook process; fifth feet of the male uni-ramose, each threejointed, dissimilar, last joint of the right foot unguiform, of the left expanded.

The genus Temora wats founded by Baird, to receive one of the Calcmidre found abundantly on the English coast and since identitied in various places along the shores of the German ocean. Aruch confusion has existed from the first in the nomenclature of this group resulting, in the first place, from the assumption that the type of the genus Temore is identical with Monoculus finmarehicus of Gunner, falsely identified with Cyclops Tongicomis of Mueller, and later from the fact that the male of one species has been wedded by our synon. omy to the female of a distinct though closely allied form. 
Still later it became evident that two sections could readily be distinguished within the genus which have since then been elevated to generic rauk by Claus. Both these groups agree in several characters, such as the following: Head distinct from the thorax, fourth and fith thoracic segments closely united, frequently only the lateral or pleural portions of the latter being evident, abdomen composed of four segments in the male and three in the female, antennse shorter than the body, 24.(or 25 !) jointed, right male antenna geniculate, inner rami of swimming feet, one-or two-jointed, in the female small, in the male prehensile. As restricted by Claus, the genera stand related as shown by the following tabular diagnosis:

\section{Temora.}

Antenve of male 24 jointed, geniculation between joints 18 and 19. Maxillo and maxillipeds rather large.

Finst foot with two-jointed inner ramus.

Fifth feet one-branched, the left in the male three-jointed, dactylate, right two-jointed, unguiculate, in the female apparently two-jointed.

Habit, marine.

Sp. 1. T. longicaudata Lubbock ( $=T$. finmarchica Baird, etc.). Angle of last abdominal segment rounded, left foot of fifth pair in male three-jointed, with a long, immovable process on the first joint, the two remaining forming an apposable clasper, antennx as long as whole body. (North Sea.)

Sp. 2. T. armata Claus. Angle of last abdominal segment produced forward, left foot of fifth pair in the male with the terminal joint expanded into a plate, antenna reaching nearly to end of the abdomen. (Mediterranean.)

Sp. 3. T. dubia Lubbock. (As irlentified by Brady.) Exactly as in T. armat $a^{*}$, save that the antennx are said to be about as long as the cephalothorax. (Pacific and Atlantic Oceans.)
* The agreement is so close, even in minute delaf $\left.\right|_{s}$, that a varietal distinction at the utmost seems demanded. See Claus, Lieber die Gathunhen Temora und Temorella, and Brady, Challenger Copepoda.

\section{Eurytemora.}

Antenræ 24-(25?) jointed, geniculation between joints 18 and 19 . Maxillae and maxillipeds quite short.

First foot with 1.jointed inner ramus.

Fifth feet one-branched, both threejointed, the left with an expanded apex, the right with a strong claw, in the female obviously. three-jointed, the pen= ultimate segment bearing a strong spine.

Habit sub-marine or fluviatile.

Sp. 1. E. velox (Lillg.) Brady (=T. clausii Hoek). Penultimate joint of the fifth foot of female with a single spine externally, caudal stylets four to five times as long as wide and feebly spined. (Scandinavian and North European coasts.)

Sp. 2. E. affinis Poppe. Last segment of thorax produced. Penultimate segment of fifth foot in the female, with two spines externally, caudal stylets six to seven times as long as wida Segmentation of last joints of male antenna more obvious. (Same localities: and rivers Rhine, Elbe, ete.) [See below on T. hirundo.] Poppe very positively declares $T$. clausii to be identical with the T' velox of Lilljeborg, but Claus explains that the male seen hy Lilljeborg was $T$. clausii. As identified by Brady, in England, 1. velox evidently corresponds to $T$. clausii, whic should therefore probably yield priority to the older name.

$E$. affinis occurs very abundantly in rivers and estuaries of, as well as in the Gulf of Mexico.

Sp. 3. E. lacustris Poppe. Last seg. ment of thorax rounded. Penultimate segment of fifth foot of female with two spines. Caudel stylets of female about as long as broad. From fresh-water lakes, Holstein, Sweden, Finland, etc. 
* Eurytemora aflinis Poppe.

Plates I, Figs. 5-10; LX, Figs. 8-15.

Lilljeborg '53 (Temora velox); Poppe '80 (Temora affinis); Claus'81 (Temora aftinis); Giesbrecht ' $81^{1}$ (Eurytemora hirundo).

Form rather robust, about $1.60 \mathrm{~mm}$. long, variously ornamented with colord markings; head separated ly an obvious suture from the thorax, rounded anteriorly, with small forked beak; antenna about as loug as the thorax, 24 -jointed, the twelve basal joints being quite short aud uniform, in the right male antenna geniculated and thickened beyond the twelfth, the geniculation being between the eighteenth and nineteenth, the seventeenth and eighternth segments fumished with comb like or file-like plate against which plays a similar shortrr plate on the nineteenth; the autenuules short, three-jointed ramus with twelve setir, two jointed ramus with about lifteen; jaw with eight acuminate teeth and a small spiur.; maudiblar palp with a two-jointed aud four.jointed ramus, the former with seren terminal and four lat. eral setie; maxilliped very small, six-jointed; first pair of feet with the inner ramus one-the other three-jointed, remaining swimming feet, two- aud three-jointed; fifth foot in the female with three joints (apparently four), the basal bearing a single extrual spine, the second, two external spines and a strong internal process, the terminal joint a long: pectinate seta and a small spine; the fifth fert of the male both fourjointed, the right terminatiug in a long, irregularly excised claw and the left in a fan-shaped expansion with a central spine. The abdomen is five jointed in the male and terminates in two long slender stylets, but sparsely beset with bristles along the inner margin, while in the female the abdomen is three jointed and the shorter stylets are dinsely spinous and bear numerous fiur setir medimly. The second segment of the abdomen in the female is produced into a spiniferous process with small spines on its sides. The candal stylets are about six times as long as wide in the female and nearly eight times in the male, the preceding segment being densils covered with short spines in the former, while in the latter ther' is on either side a cluster of longer stylets. The eggs are carred in a large spherical mass beneath the ablomen as in Oxplurentirum (Potamoichetor). The one-jointed ramus of the first foot bears seven setie. the terminal joint of the other ramus, five setie aud three spines; the second segment of the imer ramus of second and third feet bears six setie, its predecessor three, while the terminal segment of the outer ramus carries five set:e, one long, serrated, apical spine and a short exterual spine; the fourth foot has hut five setre on the apical segment of inner ramus and five setio, a serarted spine and two small spines upon the opposite branch. 
This spereies was first noticed in America by the writer, in an appendix to his paper in the twelfth ammual report of the state geologist of Mimesota. ('areful study of abmudant material since then shows the idrutifiation well-founded, although a few slight differences between this and the north European species can be detected which are by no means so great as the variations in the figures of the several Furopean authors who have described the species. Should it prove that this like other culumidu is dimorphous 'T. clumsii may disappear and the old mane T. relure will then be restored for both forms.

Claus is certainly in error in ealling the fifth pair of feet fourjointed, as shown hy his own figures and especially those of Poppe. Cireat interest attaches to this find, because it seems to indicate that the same morphological species has arisen under similar conditions in isolated stations. Fhould the species be found aloug the Atlantic coast, however, this assumption will be unnecessary.

The curious resemblance, amounting almost to identity, between the Tomond anatu of Clans and Brady's $T$. dubia is likewise instructive, leaving very little doubt of close genetic relationship.

boeck's description of ' $T$. inermis is here tramslated for the sake of

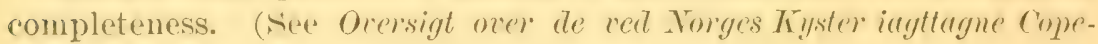
poder; Vidensk.-Selskab. Forhandlinger, 1S64, p. 16.):

Length about $1.50 \mathrm{~mm}$., transparent, colorless, with yellow viscera and a yellow band on the posterior part of the head and another upon the first segment of the abdomen. The body greatly elongated, slender. Ilead divided hy a transverse suture into two parts, likewise the fourth and fifth segments distinctly separated. The fifth segment in the male romeled, in the female accmminated. The first joint of the abelomen in the male. but the middle one of the female, the shortest. The caudal appendages elongate, but shorter upon the abolomen of the male. 'Thr outer seta attached nearer the middle than the end of the cauclal stylets. The anterior antenna of the male is strongly swollen in the middle and is armed with small spiues mpon the eighth to the twelfth joints. Iast foot of the female, two jointed, first segment short: second longer, oval, provided on the onter angle with a spine, on the inner with a longer corved spine-like process, at the apex is a long. straight spine. The fifth legs of the male are theejointerl: seromel joint of left limb shortest, the third expanded at the and: first joint of the right foot long, hut less broad: spines on the immer angle rery small: third segment rather longer and provided at the end with simple teeth.

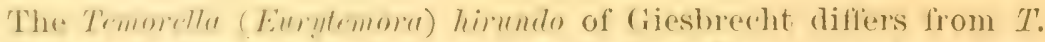
"glinis only in thres very signifirant particulars: dirst, the body is more slender; second. the caudal stylets are considerably longer; third, the 
last segment of the thorax is rounded instead of acute, and bears minute bristles. 'The close agreement of the other parts suggests a local race or variety, but it may be best to retain the uame notwithstanding.

\section{GENUS PSEUDO-DI APTOMUS Herrick.}

Rescmbling Iretridu and Jiuptomus; compactly fiamed; cephalothorax six jointed, last two segments coalescent above; head rounded in frout, beaked; eye small; autenue appearing 2. jointed in both sexes. longer than the thorax: the right male antennit geniculate as in Dinptomus; antennules bi-ramose, both rami rather short, inner one seeming but two or three-jointed; mandible ten toothed: maxillipertes well developerl; fect all bi-ramose save the last, hoth rami threejointed; first leet smaller; fifth feet with inner ramus obsolescent, in the male nearly as in Dinptomns, in the female rather slender, simple, three-jointed; abdomen in the female three jointed, in the male fivejointed; stylets in the female longer; ovisac single; spermatophore pear-shaped, liable to be mistaken for eggs.

* Pseudo-diaptomus pelagicus Herrick.

PLATE I, Figis. 11-17.

Herrick, '84 and '87.

Iiather compact; thorax alike in the sexw, antennu short, seeming 22-jointed; first foot small, both rami three-jointed; fifth feet in the male with but small rudiments of the inuer rami, basal portion heavily armed with short teeth, otherwise almost as in lluptomus; fitth feet of female slender, alike; abdomen in male rery slender, with short stylets armed with five terminal setie and a series of bristles on the inner margins, distal margin of segments of ablomen toothed; a series of spines also ornaments the middle of the first segment below; abdomen of female short and very spiny, first joint thick, second slender, oblong, third joint short; length of ablomen supplemented by that of the elongated stylets, which are spinulous on the edges; ovisac oroid, eggs numerous; opening of operculum vulvie with lateral projectiug lips.

This species is oruamented with irregular markings of brownish color which gives it a strange appearance not observed in any other Copeport. The size is like I'emore velor', which the female resembles a little, a resemblance enhanced by the elongated stylets.

This genus affords an illustration of a "missing link" connecting the fresh-Water genus Dinptomus with its fellows of the sea. In most respects the species closely resembles Jiaptomus, while in others it approaches Diepanopus, and in still others Enchata. The entire reduc- 
tion of the inner branches of the fifth feet in both sexes is especially remarkable in view of the three jointed inner rami of all the other feet. The fifth foot in the male is exceedingly like that of Drepanopus pectimutu: Bratly, while those of the female are on the same numerical plan; in that genus, however, the male antenna is not geniculate and the first foot has the inner ramus one jointed, The genus Eurluta is a somewhat miscellaneous assemblage, with some species resembling l'sendo dinptomus. In some respects (entroproges is likewise similar.

\title{
GENUS DLAPTOMUS Westwood. 1836.
}

\author{
Cyclopsina-Milne-Edwards. \\ Glancert-Koch. \\ Pontie-Ouchakoft:
}

Cephalothorax composed of seveu segments, of which the cephalic two are more or less closely fused to form the head. Abdomen narrow and shorter than the thorax, with three obvious segments in the female and four in the male, the last bearing two short stylets. Each caudal stylet is armed with fire sub equal plumose seta and one smaller internal bristle. Antenne of the first pair long, 25 jointed: in the male geniculate between the eighteenth and nineteenth joint and rariously thickened and armed, the penultimate segment often provided with a curved hook. Second antenne (antennules) twobranched; the exterior branch seven-jointed and bearing apically sereral long set:r, inner ramus shorter and two-jointed. The mandibles armed with about nine acute teeth and provided with a bi-ramose palp. The maxilla of the first pair are very short and armed with closely set setie. The second maxillir, or maxillipeds, are long and directed cephalad, seven jointed. The first pair of swimming feet has a two-jointed inner ramus while ach of the three pairs following has both rami three jointesl. The tifth pair of feet are dissimilar between the sexes and furuish the most important specifie characters. In the female the two feet are alike aud the inmer ramus is reduced or rudimentary, often one jointed. The external ramus develops a strong rlaw from the penultimate joint, while the small apical segment bears une or more small spines. The fifth feet of the male are clissimilar, five jointed. the inner ranti rudimentary, the right limb having a long apical claw on the outer branch.

The species are genclally slender and saraceful, the antennar often foresenting the borly in length. Sume forms are brilliantly colored while most are pellucid. Perhays most of the species are found in open lakes, but a number are restrieted to swampy localities and others are limited to early spring or late fall and stand in such close relations to other species as to strongly suggest a sort of heterogenesis like that we have demonstrated in Cyclops. 
The American literature has been unfortunate in respect to this genus, chiefly because the European species were so imperfectly deseribed that satisfactory differeutiation was impossible. Within the last few years this difficulty has been removed, and the work of De Guerne and Richard has laid the foundation for careful diserimination. It is thought advisable to reproduce the essentials of the descriptions of the known species so that other students may have the means of identifying onr species, only a small part of which are as yet satisfactorily known.

\section{IEEY TO 'IHE OENUS DIAPTOHUS.}

I. Male with a hooked appendage on the last joint of the right antenna. . . . . . . . asiaticus, 56 ; denticornis, 56 .

II. Male with a serrated plate on the antepenult segment of the right antenna. . . serriconis, 56 ; wierzejskii, 57 ; pectinicornis, 57 ; tryboui, 57; hircus, 57.

III. Male with the appendage of the antepenult segment of the antenna prolonged into a curved hook longer than the penultimate segment. eiseni, 58; franciscanus, 58 .

IV. Male with the appendage of the antepenultimate joint of the antenna straight, and as long as or longer than the penultimate joint.

a. The basal joint of the right foot of the fifth pair in the male with

an external accessory process. . . . . . saliuus, 59 ; laticeps, 59 .

b. The hasal joint of the rimht male fifth foot without a process. . minutus, 59 ; ashlandi, 60 ; sicilis, 60 ; baccillifer, 61 ; shoshone, 61 .

$\mathrm{V}$. Male with the appendage of the antepenultimate joint of the antenna shorter than the penultimate joint.

a. The first segment of the abdomen unsymmetrical, with a strong process upon the right side. . Siguicaudatus, 63 ; incongruens, $6: 3$; gibber, 63 .

b. The antepenultimate segment of the antenna of the male with a hyaline appendage along its outer margin.

* Inner ramus of the right fifth foot of the male shorter than the basal segment of the external ramus. . zachariasi, 64 ; leptopus, 64 .

** Inner ramus of the right fifth foot of the male longer than the basal segment of the outer ramus. . . tatricus, 65 ; cocruleus, 65.

c. The antepenultimate segment of the right antenna of the male without a straight lamina.

* The process of tbat segment very short and obtuse. . . . gracilis, 66.

* $\therefore$ The process of the antepenultimate segment of the right male antenna long and pointed.

$t$ Inner ramus of the left fifth foot of the male shorter than or nearly equal to the basal joint of the outer ramus. . orientalis, 66 ; stagnalis, 66 ; albuquerquensis, 67 ; lintoni, 68 .

t† Inner ramus of the left fifth foot longer than the basal joint of the outer ramus.

siciloides, 69 ; novamexicanus, 70 ; sanguineus, 71 ; minnetonka, 71 ; armatus, 72. 
FI. Male with the antepenultimate joint of the right antenna not armed with hook or plate.

a. Internal ramus of the right male fifth foot longer than the basal joint of the outer ramus.

*Internal branch of right fifth foot of the male one-jointed. oregonensis, 72 ;

pallidus, 73; piscinx, 74; laciniatus, 74 .

*: Internal branch of the rimht fith foot of the male two-iointed. . castor, 74 ; glacialis, 75; mirus, 75; sancti-patricii, 75 .

b. Internal ramus of the right fifth foot of the male shorter than the basal joint of the outer ramus.

* This internal ramus greatly expanded.

lilljeborgi, 76.

** Inner ramus of the right fifth foot of the male not enlarged.

† Abdomen asymmetrical. . . roubaui, 76; tyrelli, 76; theeli, 77; lobatus, 77; aflinis, 77 ; amblyodon, 78 ; mississippiensis, 78. (D. birgei, 79.$)$

Diaptomus asiaticus Ujjanin.

PIATE X, FIG. 7.

Uljanin '75; De Guerne and Richard '89.

This seems to be a curious depauperate form found by Tiljanin in the desert of Kisil-Iinm, Sibria. The peculiar form of the fifth feet of the male together with the hook at the extrenity of the right male antrmua serve to distinguish it. Length of female, 1.76 mm.; of antennx, $1.31 \mathrm{~mm}$. Color, red.

Diaptomus denticornis Wierzejski.

PLATE X, Fig. 4.

Sars '63 (castor); Wierzejski '82 and '83 (gracilis), and '87.

This is one of the larese species (3.0 $\mathrm{mm}$. long). It was identified hy Sars with 7). rextor. Although originally foumel in Seanclinavia, it appears to ocent in sultable stations throughout Europe. The an-

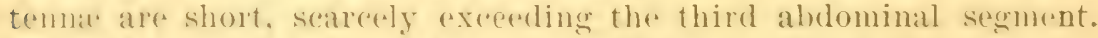
The last segment of the right antemua of the male hooked, the penultimatesesment with a haline plate. The figures illustrate the characters of the fifth feet.

\section{Diaptomus serricornis Lilljeborg.}

Plates ViII, Fig. 14; IX, Fig. 12.

Lilljeborg '88; De Guerne and Richard '89.

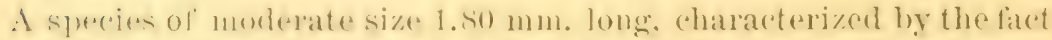
that the antepenultimate of the right male antemna hears a projecting plate fornished distally with coatse teeth. The fifth feet of the male

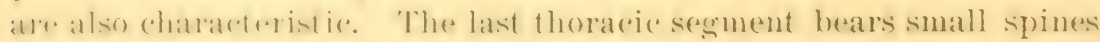
laterally. The (andal stylets about espal in length the two precerling serments (ambinet. The antemna in the female nearly reach the end of the stylets and are said to he 2.j-jointed. The speedes was found in lakes of the Russian tundras. 


\section{Diaptomus wierzejskii Richard.}

Plates ViII, Fig. 4; IX, FIG. 13.

Richard '88; De Guerne and Richard '89.

A rather large species which is obviously very near, if not a variety of $D$. serricornis. The caudal stylets equal the preceding segment. The antennie do not exceed the second abdominal segment and in the male are armed as described above. The internal rami of the fifth feet of the female are one jointed. The species has been encoun tered in Spain and Saxony. Length $2.75 \mathrm{~mm}$.

\section{Diaptomus pectinicornis Wierzejski.}

Plate X, Fig. 3.

Wierzejski '87; De Guerne and Richard '89.

This species cau only be separated with difficulty from the other members of this section. Naking some allowanc for the different positions aud distortions assumed under the microscope some divergence is to be expected. The caudal stylets are a little longer than the preceding segment. Antennac reach to the stylets. The dentate plate ou the antepenultimate segment of the right male antenna has alyont fifteen strong teeth on its distal half. $1.8 \mathrm{~mm}$. long.

\section{* Diaptowus trybomi Lilljeborg.}

Plates VIII, Fig. 17; IX, Fig. 4; X, Fig. 13.

De Guerne and Richard '89.

This is a rery peculiar and easily distinguished speries. It has but a few minute denticulations at the extremits of the appendage of the antepenult segment of the male antenna, hut. in strictness, must fall into the present section. Tiatiner small $(1.5 \mathrm{~mm}$.). The last thoracic segment with a dorsal progection which extends toward the right side. The first abdominal sementent in the lemale also has a large dorsal process. The caudal stylets are short. The antennar almost reach the base of the stylets. The form of the feet mat be gathered from the figures. Oregon.

\section{Diaptomus hircus Brady.}

Plate XXXII, Figs. 6-8.

Braỏy ' 91.

Female. - Seen from above the body is widest in front, thence tapering backwards to the hinder end of the thorax, which is a little wider than the abdomen. The posterior thoracic angles are mucronate but not very strougly produced. The anterior antemnareach backwards as far as the posterior end of the thoras. Inner hranch of 
fifth foot two-jointed, more than half as long as the first joint of the outer branch, its apex clothed with a fringe of minute cilia; second joint of the outer branch ending in a stout, slightly curved claw, which is slightly ciliated on the concave margin; last joint bearing at its apex a lovg, fine y ciliated spine and one much smaller seta.

III.E.-Antepenultimate joint of the right antenna armed with a plow-share shaped process, which is nearly half as loug as the following joint, and has an obsenrely fimbriated free margin. Inner brauch of the fifth foot on the left sidie very small; onter branch sleucler, euding in two suberpual finely pectinated setar; the last joint of the protopodite has a finger-like hyaline appendage on the inwer margin, and there is a similar but smaller organ in the same position on the right foot. Tnmer branch of the right fifth foot very small, pyriform, onejointed, acuminate; terminal claw of the outer branch long, slender, subsigmoid. Length $1.1 \mathrm{~mm}$.

\section{*Diaptomus eiseni Lilljeborg.}

Plate X, Fig. 11.

De Guerne and Richard ' 89.

()ne of the largest species known. First segment of aldomen with lateral spines. ('aulal stylets short, hairy. Antenne short, reaching the lateral processes of the ablomen. Antepenultimate segment of right male antenua with a hooked process reaching beyond the end of the antenua. Inner lamus of the filth foot of female obscurely two. jointed. The fifth feet of the male rely nnequal, inner rami two. jointed: basal joint of the right fout provided with a sping process. Length $4.0 \mathrm{~mm}$ : male $3.5 \mathrm{~mm}$. This form is about the size of $I$. ste!mulis, but seems nuite distinct: it was found at centreville, (al.

\section{* Diaptomus franciscanus Lilljeborg.}

Plate VIII, Figs, 12, 16.

De Guerne and Richard ' 89.

1 sperese of mollepate size (2.3 mm.). Last segment of the thorax obtus. with nimute spines. First segment of abdomen about as long as the pest of the abdomen. spined laterally. Second abdominal segment very short. Camdal stylets short. Intemnar reaching to the stylets. 2.5 jointerl. The homklike process of the antepenultimate joint of the male antennat a lithe longer than the penultimate joint.

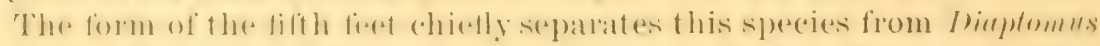

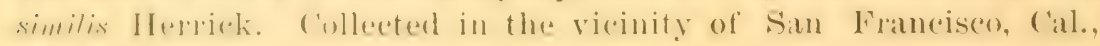
by G. Lisen. 


\section{Diaptomus salinus Daday.}

P'IATE VIII, Fig. 3.

Daday ' $85^{5}$; De Guerne and Richard ' $88^{1}$ (D. blanchardi), and ' 89.

This specifs was found by I taday in Forda, Hungary, and is identified with the form subsequently described by De Guerne and Richard as $I$. blamchurdi. It may be recognized by the sharp spines on the right side of the first and second segments of the abdomen (affording a trausition toward IIrterorepe and Exischura), and also by the peculiar armature of the male fifth feet, which have accessory processes upon the basal joint of the right limb and the second segment of its outer ramus. 'The apical segment of the onter ramus of the fifth feet of the female are unusually well developer. The antepenultimate segment of the male geniculate antenna has a very long straight process, longer than the two following segments. Length of female 2.2 mm. The veryshort antemue and saline habitat further distinguish it.

\section{Diaptomus laticeps, G. O. Sars.}

Sars '63; De Guerne and Richard ' 89.

This species, which is widely distributed in Europe, has the frout considerably dilated. The antenuar are as long as the body. The caudal stylets as long as the two preceting combined. The antepenultimate of the geniculate antenna has a process shorter than the penultimate segment. The male fifth foot has armature similar to $T$. sutinus. Length $1.5 \mathrm{~mm}$.

\section{* Diaptomus minutus Lilljeborg.}

Pl.ITE VIII, Fir. 9.

De Guerne and Richard '89; Marsh '92 and '93.

One of the smallest species of the geums, originally taken in Grexuland, hut wide]y distributed in the northeru regions. Slender, with the greatest width belind the middle. The fourth and fifth thoracic segments fused or more or less distinct in the old, with small mucromate lateral lobes. First senment of the ablomen as long as the remainder, expanded anteriorly and armed with small spines. Fecond and third abdominal sergments partly fused, the second very short. Caudal stylets twice as long as broad. Autenn: 25.jointed, somewhat longer than the stylets. Antepenult segment of male antemna with a long slender process, nearly as long as the two following segments and slightly hooked at the tip. The external ramus of the fifth foot of the female is two-jointed, with a short claw, the immer ramus is small and one jointed. The left fifth foot of the male is much shorter' than the right, and its apieal segment is armed with a spiny parl and 
tro larger spines; the inner ramus is of moderate size. The inner ramus of the outer leg is obsolescent. The accessory spine of the outer ramus is near the middle of its segment. Length $1.0 \mathrm{~mm}$.

Marsh finds this form in Green lake and the Cireat Isakes; it may, therefore, be expected in Lake Superior in Minnesota.

\section{* Diaptomus ashlandi Marsh.}

Plate Vi, Figs. 4-6.

Marsh'93.

"A small pelagice species elosely resembling I). sicilis Forbes. In form it is slender, hardly to be distinguished from $I$ ) sicilis and $I$ ). minufus. The first joint of the abdomen in the female is longer than the remaining part of the abdomen, is dilated at the sides and bears two minute lateral spines. The second and third joints are so closely united that the abdomen appears two jointed. The furcal joints are about twice as long as broad. The antenbar reach just beyond the furea. The right antenna of the male is much swollen anterior to the geniculating joint, and bears on the antepenultimate an appendage slightly exceeding in length the penultimate joint. This appendage may be blunt pointed or slightly enlarged at the extrenity. The fifth feet of the female are rather slender; the onter ramus is twojointed. The third joint is represented by two short spines. The inner ramus is one-jointed, a little longer than the first joint of the outer ramus, armed at the tip with two rather long spines.

"The fiet of the male are slender. The hasal joint of the right foot is about twice as long as that of the left. The first, joint of the onter ramus is a little wider than long. Thr second joint is wider at the immer than the ontere end; the lateral spine is stont, curved, situated near the inner end. The terminal hook is stender and falciform. The imner ramus is slendere, one jointed, and about one-third longer than the first joint of the outer lamus. The left foot extends a little beyond the lirst juint of the outer ramus of the right. The second joint of the onter ramus has three blunt spines upon its aper and is armed with mimute bristles within. The inner ramus is slemder, one-jointed, and reaches about half the length of the serond joint of the outer ramus. Length of female $0.97 \mathrm{~mm}$.; of male $0.89 \mathrm{~mm}$."

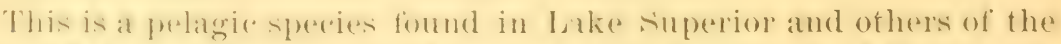
Great Lakes, and consiefuently acedurs upon the shores of Minnesota.

Diaptomus sicilis Forbes.

Prates V, Figs. 1-7; XIIT, Fig. 18.

Herrick '83 and ' 84 ; De Guerne and Richard '89; Forbes '91; Marsh '93.

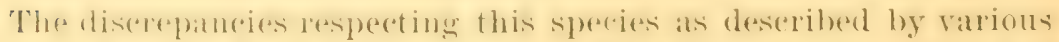
anthors mulst be due to hetrogenenesis. It raries greatly in size and armature of the lieet. The form is slender and grateful and rery like 
D. pallidus, from which it differs in possessing a hook on the right male antemue. The antenus exced the caulal setie and are rery slender; that of the male on the right side bear's a curved plate or hook which in my specimens is decidedly shorter than the following joint, though said to be eyual to it by De Gruerne and Richard. The fifth feet of the female resemble those of mullirlus. The inner rami of the male fifth feet are two jointed in the type, but both Marsh and I find forms with one jointed rami. The terminal claw of the right foot is long and geniculately curved, the accessory spine of the preceding segment is near the distal one-third, the inner ramus is (in our form) quite slender, longer than the basal seghnent of the outer ramus. The terminal joint of the left foot is rounded and ciliated, as well as furnished with two spines. Tength of larger forms $1.4 \mathrm{~mm}$. male considerably less. Our small form is $1.1 \mathrm{~mm}$. Iong and may prove a subspecies, though agreeing with Marsh's figures. Compare also I). siciloiles, the western representative of this small form.

Diaptomus baccillifer Koelbel.

PlATE X, Fig. 2.

Wierzejski '82 (D. gracilis var. $d$ and b); Koelbel '85; Wierzejski '87 (D. montanus); De Guerne and Richard ' 89.

A. small species encountered in high latiturles and altitudes of the old world, Siberia and the 1 lps being the chiei stations, is not well distinguished from its allies. The antenne reach the stylets, and in the male the geniculite antenna has a strong process on the ante. penult joint. The internal rami of the fifth feet are more or less distinctly two-jninted, being very short in the female. The imner ramus of the left foot in the male is fusind with tho preceling segment, and near its base is a spine. The outer ramus of the same foot is forcipate. Length 1.0 to $1.5 \mathrm{~mm}$.

\section{* Diaptomus shoshone Forbes.}

PLATE V FIC 11.

Forbes' 93.

"A very large and robust species. Thorax broadest in front, across the maxille, tapering gradually, with little comvexity to the pusterior third. In the fumale the angle of the last segment is hifir. both projecting points being mintely spiuose at the tip. The first segment of the abdomen is laterally expanded: the expansion of the left side with a mimute spins at the apex behind; that on the right produced at the same point into a small, rounded tubercle, (0.0)3 $11 \mathrm{~m}$. in length, about as broad as long, making this first segment somewhit unsymmetrical." "Fog mass very large, obovate (narrowest for. ward). Right antenna of male robust, the last two joints withont special appendages, antepenultimate with a loug inarticulate process at its onter apex. extending beyoul the tip of the penultimate and to 
the middle of the last segment. The margins of this process are smooth. hut it is broad and emarginate at the tip. The fifth pair of legs of the male resemble the corresponding appendages of $I$ ). stagnalis, but difier notalny in detail. The left ramus of the rigkt leg is borne at the inner terminal angle of the second joint, is longer than the joint following, is armed at the apex with a few small acute spines, and bears upon its outer margin, near the tip, a broad fascicle of delieate hairs. The basal joint of the onter ranus is two thirds the length of the second joint of the peduncle, and withont hairs or spines of any description. The second joint of this ramus is about equal in length to the second joint of the peduncle, and bears at its outer margin. close to the tip, the usual stout seta, which is two thirds as long as the joint to which it is attached. The terminal claw is not regu. larly curved, but is nearly straight for the hasal three-fourths. The leit leg is bi ramose, the inner ramus straight, sleutler, extending about to the riiddle of the second joint of the outer, and armed at its tip. The second joint of this ramus is as long as the first, if measured from the tip of the apical spine. This spine, seen from behind, is stout, conical, rather blunt, and has opposed to it within, projecting from the inner angle of the segment, a stout, curved suta, slightly plumose on its distal hall. Bretween these, but more closely applied to the outer spine, is a hemispherical cushion like elevation, set with small, short spinules. On the hasal half of the inner margin of this terminal segment is also a much larger hemispherical eushion, but with longer and more slender hairs, while the terminal half of the inner mangin of the segment preceding is also moderately inflated and (overed with dericate hairs. The antennar of the female are 25 . joibted, as usual, and reach to the base of the abdomen. The legs of the fifth pair elosely resemble those of stumulis. but have the termiual seta of the inmer ramus much less developerl. This ramus is a little shorter than the basal joint of the onter ramus, and about half its diameter. It bears at its fiptwo stont setar erpualing the ramus itself in length, plumose muler a high power, and has. in arddition at its imner tip and on the margins adjiacent, a patch of delicate hairs and spines. The soremel joint of the outer ramus is as long as the first, if measured from the tipef its terminal claw. The latter is nearly straight, rery slightly recorved. This joint bears a single spone at its outer distal angle, just within which is the rusliment of the third segment of the lamus, which bears two spines similar to the ahove, the imner of which is the longere, the onter itself heing longer than the adjacent spine of the seenul joint. Adultsof both sexesare blood red throughout, except the exy sare of the female. Which is prople." Length of female, in("luling setar. \$. 1 mm, : males somewhat smaller. In various bakes iu Yellowstone Park. 
* Diaptomus signicaudatus Lilljeborg.

Plates VIII, Fig. 13; IX, Fig. 10.

De Guerne and Richard '89.

A small species found at great altitudes in the Sierra Nevada Monntains of California and forming an obvious transition toward Epischur. Form rather robust, rreatest width at the second segment. Last two segments of the thorax confluent, projecting into lateral lobes bearing small teeth. The fourth thoracic segment with a slight dorsal gibbosity. First abdominal segment expanded and spined anteriorly, aud bearing a large retrorse process on the right side posteriorly. Second segment short. Cauclal stylets about half again as long as wide. Antemure 25-jointed, extending little beyond the stylets. Antepenult segment of the right male antemn with a small hook. Fifth foot in the female with one-jointed inner ramus as long as the basal joint of the outer ramus. The terminal segment of the outer ramus is obsolescent. The exterual ramus of the right foot of the male bears a hyaline lamiua on the inner aspect of the basal segment. Second segment more than twice as long as the preceding. Claws simply arcuate. Accessory spine nearer the end than the base of the second segment. Inner ramus wide and acute, shorter than the basal segment of the outer ramus. The left foot has a slender inner ramus, longer than the basal seguent of the outer, whose apical joint is pilose and armed with two spines. I.ength of female $1.5 \mathrm{~mm}$; of male $1.3 \mathrm{~mm}$.

\section{Diaptomus incongruens Poppe.}

Plate VIII, FiG. 6.

Poppe '88; De Guerne and Richard '89.

A Chinese species of moderate size, characterized by the fact that the projecting angles of the last thoracic segment are dissimilar on the two sicles and the possession of a hroad mueronate process on the right side of the first abdominal segment. The antenne extend far beyond the stylets. The antepenult joint of the right male antemu bears a hyaline lamella ending distally in a small hook. The fifth foot of the female has a one jointed inner ramus as long as the basal joint of the onter ramus. The apical joint is distinct aud the claw serrate. The inner ramus of the right foot of the male is one jointed and that of the left foot two jointed. The terminal segment of the outer ramus of the left foot has two spines apically and a ciliated plate within. Length of female $1.4 \mathrm{~mm}$.

\section{Diaptomus gibber Poppe.}

Plate ViII, Fig. 1.

De Guerne and Richard ' 89.

A decidedly unique form from Brazil. The last thoracic segment forms on either side a bi spinose process, the two being dissimilar. The first segment of the abdomen is expanded proximad and bears on 
the right side distally a broad blunt process. Antennie reaching the caudal setie; that of the male on the right side bearing a lamella aud hook on the antepenult segment. Inner rami of fifth feet in the female two jointed, outer ramus three jointed. 'The inner rami of the fifth feet of the male are curiously modified, and we must refer to the figures.

\section{Diaptomus zachariasi Poppe.}

Plate X, Fig. 6.

Poppe '86; De Guerne and Richard '89.

A species closely resembling 7 ). leptopus. and found in silesia. While the last segment of the abdomen is not dilated it is ormamented with two spines. The imner ramus of the fifth feet of the female is twojointed and armed at the apex with three spines, and is somewhat longer than the basal joint of the onter ramus. At the base of the claw of the outer ramus is a strong tooth. The apical segment is distinct and bears two spines. The figures of the male foot are not eutirely satisfactory, but the inner ramus of the right leg is said to be rudimentary, short and two-jointed, while that of the left leg is one jointed but quite long. The apical joint of the left foot is forcipate. The antepenult segment of the male autenna has a hyaline plate which is scarcely hooked dis1ally. Length of female $1.8 \mathrm{~mm}$. Like our I). leptopus this species is brilliantly but variously colored.

Diaptomus leptopus Forbes. 1882.

PIATES II; IX, FIG. 9.

Forbes 's'; Herrick '8.4 (I). longicornis var. leptopus); De Guerne and Richard '89; Marsh' '93.

This species, which is one of the commonest in small lakes in Minmesota, is widely distributed in the Mississippi Villey. While not large it is generally ormamented with brilliant coloration bands, of which the purplish suffusion of the tip of the antennse and abdomen are most constant. Marsh found it of a brownish red color much as 1). sanminems. Wo find it during the smmmer quite pellucid except for the purple markings. The body is stout with the head and last fwo thoracic segments fused. The last thoracic bears on either side one or two small spines. The aldomen is short, the last two segments being lised; the first segment bears a small lateral spine on either side. The female antemner do not extend to the end of the caudal sete and their sprines are short. The right male antenne is strongly geniculate and spined. The antepenultimate segment hears only a rery inconspicunos hyaline lamina but no hook or process as stated by Forbes and by I). (incrne and Richard. The fifth foot of the female is short, with ain inner ramus scaresly shorter than the antepenultimate segment of the outer ramus and bearing at the tip two subequal spines and a cil- 
iated process. We do not find in this species that the claw of the penultimate segment of the outer ramus is denticulate, though in some stages or forms it may be. The apical segment is obsolescent and bears two unequal spines. Ine Guerne and Richard figure an accessury spine at the base of the apical segment. There is occasionally a slight tendeney for the inner ramus to appear obscurely two-jointed. The male feet of the fifth pair are very long. The inner rami are both rather long (longer than the segment of the outer ramus opposite which they stand), one-jointed, and slightly riliated apically. The terminal claw of the right foot is short and shightly curved and denticulate toward the apex interiorly. The preceding segment has a short accessory spine. The segment bearing the two rami has a short spine laterally aud is bristly exteriorly. The terminal segment of the onter ramus bears two spines and a few cilia. while the penultimate segment has a ciliated process inwardly near its apex. Tho armature of the third and fourth feet is similar, the apical segment of the onter ramus bearing an external short spiue, one long spine and two setie at the tip, and three setie internally. Leugth of female 1.5 to $1.7 \mathrm{~mm}$; of male $1.4 \mathrm{~mm}$.

\section{Diaptomus tatricus Wierzejski.}

Plate X, Fig. 8.

Wierzejski '82 (lacinulatus), and '83; De Guerne and Richard '89.

A large, stout form, with anteunie scarcely exceeding the thorax nd the last segment of the latter produced into a large spindle-shaped, protuberauce. The antepeuth joint of the male antenna with a hyaline lamina. Inner ramus of fifth feet of the female short, obscurely tro jointed; those of the male curved. A tooth is found on the middle of the inner aspect of the basal segment of the left foot, and the apical segment of the outer ramus is forcipate. Length $2.1 \mathrm{~mm}$. Color carmine red.

\section{Diaptomus coeruleus Fischer.}

Plate IX, FIs. 7.

S. Fischer ' 53 (Cyclopsina coorulea); Lubbock 't3.3; Poggenpol 'T4; Uljanin 'T.t; De Guerne and Richard '89.

This widely distributed species has been very frequently confounded with $D$. cetstor, than which it is rather smallerand from which it differs in possessing a lamina on the antepenult imate segment of the male antenna. The antemis reach the caudal stylets. The apical segment of the outer ramus of the fifth foot of the female is well developed and its inner spine is almost as long as the claw of the penultimate joint. The inner ramus is two jointed and longer than the basal joint of the onter ramus. The inner rami of the male feet are onejointed. Length $1.8 \mathrm{~mm}$. 


\title{
Diaptomus gracilis Sars.
}

Plate IX, Frg. 1.

Sars '64; (rruber '7\&; Rehberg '8013; Daday ' 455 ; De Guerne and Richard '89.

This very widely distributed species is scarcely over $1.0 \mathrm{~mm}$. long and very slender. The antenue are much longer than the whole body. The stylets are short, and the first segments of the abdomen are armed with strong spines. The inner rami of the fifth feet are onejointed in both sexes, in the female shorter than the basal segment of the outer ramus. The apical joint of the onter ramus is well. developed and bears two spines, one of which is as long as the claw. The inner ramus of the right foot of the male is very long, reaching nearly to the base of the claw. There is a curious, conical, ciliated process from the inner aspect of the onter ramus of the left foot.

\section{Diaptomus orientalis Brady.}

\author{
Plate $\mathrm{X}$, Fig. 5.
}

Brady '86; De Guerne and Richard '89.

There seems to he some doubt whether the various collections from Ceylon and Australia really pertain to the same species.

The last thoracic segment is rounded and armed with short spines, as is the first abdominal. The second ablominal segment is very short. The cauclal stylets are short, with long seta. The antemure reach the stylets. The antepenultimate segment of the male antemna bears a long hook. The terminal segment of the onter rami is clistinct (not so figuled hy Nars), the imner ramus as long as the basal segment of the nuter. Inner rami of male fifth feet very short and one-jointed. Length $1.3 \mathrm{~mm}$.

\section{Diaptomus stagnalis Forbes.}

\section{Plates III; XIII, FIGs. 11, 13.}

Forbes ' -2 ; Herrick' $\$ 2$ (D. gigauteus), and ' $\$ 4$; De Guerne aud lichard ' 89.

This species was lescribed by Profescor Forbes and the writer at almost the same time, but as the former"s description appeared in a prerodical it was more promptly distributed aud deserves priority.

it very larege speceies, resembling 7 . recstor, the place of which it takes in America. Cireatest width in front of the middle. The antemut scarcely extend beyond the thorax. The first segment of the thorax is separated lyy a suture, as is the last, which is greatly prodnexl laterally and hears two spines. The first ablominal segment is much longer than the rest of the abdomen. The candal stylets are very short and hroad, divaricate, and ciliated externally. The caudal sitar are large, short and profusely plumose. The egge sac is large and spherical. In the male the abdomen is slonder and five-jointed. The five joints preceding the hinge of the right male antenna are very 
much thickened. The autepenultimate joint bears a small hook and the last two joints are relatively very small. The antennules are of the usual form, the two-jointed branch being much the shorter. The first feet of both sexes have, as usual, the inner ramus two-jointed. The external spines of the outer ramus are longer in the male. The fifth feet of the female have the inner ramus very long and two jointed, armed apically with two rery long, setose, equal spiues. The apical segment of the outer ramus is distinct and armed with two suberual spines, and is protected by a spine from the preceding joint near its base. The claw is strongly toothed and straight. The right foot of the male is much longer than the left and has a short toothed apical claw. The accessory spine is near the base of the claw. The inner ramus is very small and spatnlate. The preceding segment bears a small spine externally and a lamellate appendage withiu. The inner ramus of the left foot is larger and nearly as long as the basal joint of the outer ramus; it is corrugate internally and bears a short spine apically. Opposite this ramus on the basal segment of the outer are small setre. The apieal segment of the outer ramus bears two enrved spines and numerous setre apically and a hairy plate internally. Length 3.0 to $4.0 \mathrm{~mm}$.

This species has been found in Minnesota, Illinois, Ohio, Kentucky and Alabama.

\section{* Diaptomus albuquerquensis Sp. n.}

Plates VI, Figs. 1-3; VII.

Magnitudine mediocri, Cephalothorax latitudine maxima ad medium sita; seg. mento ultimo femine ad latera extante, utrinque muronibus 2 armati. Segmentum ablominale 1 -mum partem reliquam ablominis, setis exceptis, longitudine superans, utrinque mucrone distincto preditum; segmentum :-dum per brere. Rami furcales segmento antecedente fere ic puantes, intus ciliati. Antenna 1-mi paris extremam furcam attingentes, vel superantes, 25-articulatie. Articulus antepenutimus antenwæ prehensilis maris processu recto vel subanguiformi sat longo preditus. Pes 5-ti paris femina ramo exteriore triarticulato, articulo 3 -tio perspicuo, et aculeo interiore circiter ad medium processus unguiformis articulo :-di porrecto. Processus unguiformis modicis arcuatus, dentibus ad partem melium armatus. Ramus ejus interior extra medium sed non ad finem articuli 1-mi rami exteriores porrectus, biarticulatus, et ad finem ciliatus. Pes dexter 5-ti paris apud marem ramus interior 1-articulatus, per breve, articuli antepenulti rami exterioris longitudinem sequant. Unguis (vel segmentum 3-(1um) per magnum, iu lougitudine pars religuis pedis superans. Processus lateralis segmenti 2 - 1 magnus, al basin intus dentibus minutibus affectus. Pedis sinisteri 5-ti paris apul marem, articulus altimus rami exterioris conicus, iutus lamina ciliatus instructus, ad apicem mucronibus duobus affectus. Segmentum 2-rlum ejus ramus, intus grauulosus. Ramus interior previs, uni articulatus. Animal pleurumque pellucidum, colore albido. Longitud. feminæ 1.4-1.6 mm.

This medium sized species occurs in the water reservoir supplying Albuquerque, New Mexico, together with I). nocumexirums in large numbers. The last segment of the thorax is protuberant and bears 
two strong spines. The first segment of the abdomen is much longer than the "ntire remainder of the abdomen and bears a strong spine on either side anteriorly. The stylets are short and ciliated internally. The antemit reach to the end of the stylets. In the male the ante. penultimate segment bears a straight process directed distad and but slightly ('urved at the tip and shorter than the penultimate segment. The thickened portion of the geniculate autemna is very much modi. fied. The fifth foot of the female has an olscurely two-jointed inner ramus much shorter than the first joint of the outer ramus. The hook of the penultimate segment of the outer ramus is armed with a short series of sharp spines along the middle third of the inner aspect or rather nearer the hase than the apes. There is a small spine at the base of the terminal segment, which is distinct and carries two long but nuepual spines. The final joint or claw of the outer branch of right fifth foot of the male is rery strong and gently curved, being longer than the whole leg. 'The accessory spine is also heary and nearer the end than the base of the second segment, and is minutely dinticulate near its base. 'The inner ramus of the right foot is onejointed, very short, and slightly ciliate at the tip. The left leg reaches to the tip of the inner ramus of the right leg. Its terminal segment is of molerate size and ends in one immoval)le toothed spine and a hristle: along itsinner aspect a ciliated lamina is situated. The preceding segment has a granular area aloug its inner aspect. The inner ramus resembles that of the right leg.

\section{Diaptomus lintoni Forbes.}

Plate V, Fig. 12.

Forbes' 89.

*1 larese recl species occurring commonly with T). shoshome. but. distinguishable from it at a glauce by its different shape, its longer antemme, its smaller si\%n, and by characters derived from the right antemma and filh foot of the male. The thorax is symmetrically elliptical in ontline, hroadest at the midelle. T'ne posterior angles are not produced nor hifir, hut are each armed with a minute spine. The first segment of the ablomen of the female is not especially produced. hut hears at its hroadrst part a minute spine on each side. The abdomen it self is very short, its length (entained ahout thee and one third times in that of thre cephalothorax. The antenna of the female is long and slemder, 25.jojuted. reaching a little beyond the tip of the alolomren. The filth pair of leges in this sey is similar to those of /). shorshome. hut much smaller. The inmer ramus is not jointed. It is longer than the hasal joint of the onter ramus, hears two stout plumose set ie at the tip, somewhat shorter than the ramus itself, and has also at its immer tipa pafch of small spines or fine hairs. The second segment 
of the outer ramus with its terminal claw is two thirds as long again as the precediug segment, the breadth of the latter two thirds its length. The third joint is indicated by a single long, stout seta and one or two smaller ones.

"In the male the geniculate anteuna is relatively rather slender, its last two joints without special appendages, its penultimate with a sleuder transparent apical process, reaching about to the middle of the succeding segment, acute at tip, but urither serrate nor emarginate. Fifh pair of legs in the male usually without internal ramus to the right leg, but this ramus sometimes represented by a small rudiment. The limb is usually slender aud its terminal claw short. The hasal segment of the outer ramus is mearly as long as the adjacent segment of thr pedicel, and the slendr' second segment of this ramus is fully as long. Inong lateral spines borne near the tip of this segment. The terminal elaw is about two thirds as long as the segment, is somewhat abruptly angulated near its hase and slightly recurved at the tip. The inuer ramus of the left leg is very stout and long, reaching ahmost to the tip of the onter lamus, is slightly curved outwards, and has the apex minutely hairy. The basal segment of the outer ramus is thick, two thirds as broad as long, somewhat intlated within, where it extends downwals beyond the articulation with the second segment as a rounded expansion covered with extremely fine hairs. Fecond segment of this ramus longer than first, but only half as wide, braring at its tip, within, a rather small, obliquely projecting cushion covered with eilia, and two stont terminal spines, one short, blunt, straight, and smooth, the other curved and plumose, its length about half of the segment to which it is attached." Length $2.5 \mathrm{~mm}$.

\section{Diaptomus siciloides Lilljeborg.}

Plate VIII. Fig. 10.

De Guerne and Richard '89.

This species approaches $D$. sirili Forbes and $D$. roroli llerrick very elosely, and is said also to resemble 1 . !rurilis Sars. From roroli it may be at once distinguished hy reason of the fact that the third joint of the outer ramus of the filth foot of the female is obsolescent. From the smaller form of $I$. sicilis it is scarcely possible to distinguish it. The spinous armature of the thorax and abdomen seems more marked, and the second segment of the abdomen is shorter in siciloides aud there is an appendage to the inner aspect of the basal joint of the outer ramus of the right leg. Last two segments of thorax confluent, bearing two lateral spines. First abdominal segment longer than the rest of the abilomen, laterally spined. Fecond segment ver. short. Cuudal stylets once and a half as loug as broad. Antenure somewhat exceeding the stylets. The antepenult joint of the right 
male antenna hears a hook of moderate size. Fifth feet of female short, with a short stout claw and with the inner ramus as long as the basil joint of the outer, one-jointed. The apical joint of the outer raunus is obsolescent, bearing small spines. The male feet are almost exactly as in the small form of $I$. sicilis, but have a process on the basal segment of the outer ramus of the right leg. Length $1.3 \mathrm{~mm}$. Lake Tulan, Fresno, Cal.

\title{
* Diaptomus novamexicanus Sp. $\mathrm{n}$.
}

\author{
Plate Vl, Figs. 7-10.
}

Inter minores sui generis, modice rohustus. Cephalothorax latitudine maxima ante medium sita. Segmentum cephalothoracis ultimum lateribus utrinque mucronibus brevibus ornatum. Segmentum aldominale $1 \cdot \mathrm{mum}$ utrinque mucrone brevi instructum. Segmentum 2 -di per breve. Rami fureales segmentum antecedeus longitudive seruantes, setis apicalibus brevibus. Antenda 1-mi paris feminat retıo circiter ad furcam vel interdum ad finem furce porrecte, articulis 25 compositie. Articulus antepenultimus antenne dextre maris lamina, antice in processu unguifore, apicem articuli penultimi vix attingente, productus, armatus. Ramus exterior 5-ti paris apud feminam 3-articulatus, processu ungúiformi articuli secundi arcuato, intus ad finem denticulato; articulus ultimus distinctus, aculeis 2 brevibus ornatus. Ramus interior 1-articulatus, articulus 1-mus rami exterioris vix longitudine fere

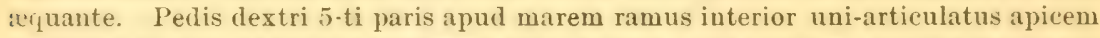
articuli 2-di rami exterioris attingens, apice acutus, pilis obsitus. Unguis terminalis rami exterioris simpliciter arcuatus. Seta accessoria brevis. Pes sinister articulo 2-do rami exterioris oblongovato, versus apicem intus subtilissime aculeato et duos aculeos majores portante, ad basin in lamina ciliata extante. Ramus interior simplex, rersus apicem ciliatus, vero longus et ultra medium articuli 2 -di rami exterioris porrectus. Animal pleurumque pellucidum, interdum ceruleo vel rubro ornato. Long. feminæ 1.1-1.2 $\mathrm{mm}$.

A small species of rather robust form found associated with 7 . allumperquensis in the tank of the city water works of Albuquerque. New Mexico. The greatest width is somewhat in adrance of the midlle. The last cephalothoracic segment is orvamented with small spines only. The first abdominal segment bears on either side a sharp spine. The second segment is quite short. Sț̣lets of moderate length with short setir. Antennie reach the stylets. Antepenult segment with a lamina along its distal aspect terminating in a slightly curved process shorter than the penultimate segment. The segment following the geniculation has a hyaline lamina. The fifth loot of the female laas a single-jointed inner ramus of considerable length armed at the apes with two spines anl small cilia. The claw of the onter ramus is moderatcly curved and armed near the tip with a series of tereth, the terminal joint is distinct and bears two small spines. The inmer rami of the nate fint of the fifth pair are simple and rather long. The terminal claw of the right leg is slightly curved and of molerate length, while the acessory spine is nearer the apex of its 
segment than the base and is weak and short. The outer ramus of the left foot has a cushion of small spines and two small teeth at the apex and a ciliate lamina along its inner aspect. The inner ramus of this leg is nearly as long as the outer.

\section{* Diaptomus sanguineus Forbes.}

Plates V, Figs. 8, 9; XIII, Frg. 12.

Forbes '76; Herrick' 83 and '84; De Guerne and Richard '89; Marsh '93.

A compact species. usually brilliantly colored. Greatest width in front of but near the middle of the cephalothorax. Last segment of thorax laterally produced and armed with two strong spines and produced or "humped" dorsally. First segment of abdomen long, armed with strong lateral spines. Serond segment very short. Caudal stylets rather longer than broad, ciliated, setie short. The antennie reflexed nearly reach the stylets. The right male antenma is strongly geniculate and its antepenultimate segment is armed with a hyaline lamella forming a short hook apically. The right foot of the male is remarkable for the thick segment bearing the two rami, the outer of which is rather long. The terminal claw is rather short and not strongly curved, and seems at times to be crenulately toothed wear the apex. The accessory spine is a little beyond the middle of the second seament of the onter ramus, of which the proximal segment is very small. The inner ramus is short and unarmed (it is incorrectly represented by Forbes as being on the outer aspect), and on the outer aspect is a long spine larger than the ramus. but not jointed, beneath which is an accessory spine or bristle. Thr left foot is very short and compact - "fleshy" is a suggestive word. The inner ramus is short and un. armed, while a strong spine occupies the corresponding position externally. The apical segment bears a stont claw extermally and a smaller opposable spine internally. The species is quite viriable. Individuals from very stagnant water may reach $2.0 \mathrm{~mm}$. while others in clear pools do not exceed $1.7 \mathrm{~mm}$. The mean may be taken as $1.8 \mathrm{~mm}$. The curious fact that there is a succession in rain pools in spring beginuing with $l$ ). stagmalis and passing through several varieties to 1). somyminem. later in the season, has led the writer to suspect an actual transition. Of the heterogenetic character of these forms there is absolute proof as in ('yctops, but much farther study in necessary to clear up the most interesting biological laws involved in the distribution of these species.

Diaptomus minnetonka Herrick.

Plate XIII, Figs. 8-10.

Herrick '84; De Guerne and Richard '89; Marsh '92.

We are inclined to agree with Marsh that this form is but one of the many variations of $D$. sunguinems. Besides being somew bat smaller than $D$. sanguineus the species differs from it in minor details of the 
feet. The inner ranus of the right fifth foot of the male is slender and longer than in somminus: this is also true of the inner ramus of the left foot. The terminal segment of the onter ramns is provided with the same armature as sungmineus and also bears a ciliated plate along its inner aspect. The terminal claw of the right leg is toothed. In the female the inner ramus is more or less distinctly two jointed and the claw of the outer ramus is toothed. Length of male $1.4 \mathrm{~mm}$. Color dark. In the long antennie the species differs from sanmineus, which it resembles in the armature of the last thoracic and first abdominal segment.

\section{* Diaptomus armatus Herrick.}

Herrick '82 and 84; De Guerne and Richard '89.

The form, which was indicated by only a few points, in the hope that it might be subsequently rerecognized, has never again been seen. Tt appears to be allied to sumguineus. The antennic are said to be shorter than the body, the candal stylets narrow, the right male antenna has a hook upon its antepenultimate joint aud is strongly geniculate. But the one feature which may determine the species is the existence of a tooth or spur near the base of the claw of the right fifth foot of the male.

* Diaptomus oregonensis Lilljeborg.

Plates IV, Figs. 7-12; IX, Fig. 3.

De Guerne and Richard '89; Marsh '93.

This spercies has been found only in Lake Minnetonka within the limits of Minnesota, thongh Marsh speaks of it as occurring in Wisconsin rery generally in the smaller lakes. It was first found near Portland, Oregon, by Trybom.

The species is of metium size $(1.5 \mathrm{~mm}$. long) and rather graceful hahit. The antennil extend beyond the caudal stylets and are strongly spined. The last two thoracic segments are confluent, and bear one or two small spines laterally. The first segment of the abdomen is as long as the remainder and mucronate. The caudal stylets are nearly twice as long as wide. The right male antenna is moderat ly modified. its antepenultimate segment being unarmed. The apial sewment of the onter ramus of the fifth pair of leet in the female is obsolescent with two sharp spines. The claw of the penultimate sesuent is short and slightly curverl: the inner rani are one jointed and armed with two lange spines and fine bristles apieally. The fifth fiet of the male are sub)equal, the terminal claw of the right foot being geniculately "urved and rather long. The accessory spine is near the end of the precerling sengment which also bears a small spiue near the middle. The inner ramus of the right foot reaches to the spine just 
mentioned and bears two teeth. The terminal segment of the left foot is expanded and carries two movable spines and a spur; accorling to Richard's drawing the spines are lentate aud there are accessory ciliar pads along the inner aspect of the onter ramus. The inner ramus is longer than the basal segment of the outer ramus and is ciliated apically.

\section{* Diaptomus pallidus He rick.}

Plates IV, Figs. 1-6; V, Fig. 10; XIII, Fig. 17.

Herrick '83 and '84; De Guerne and Richard '89; Marsh '93; Turner '92.

De Guerne and Richard in their monograph quite overlook the original figures and description, for the remarks in Microseopic Entomostrace cannot be regarded as a scientific description. It is not to be woudered at that it is considered insufficiently described. This was to be expected from these anthors, but is more remankable from Marsh, who had the paper of 1853 before him but fails to note the figures and description, which, though poor (being prepared on a railroad journey), are diagnostic in respect to the armature of the fifth feet. The credit of completing the description belongs to Marsh.

A slender species of medium size. Cephalothorax widest near the middle; head partially separated by a suiture: last cephalothoracic segment fused with its predecessor, armed with one or two minute spines on either side. First abdominal segment long as remainder: second segment shorter than the third. stylets twice as long as wide. The antenua are longer than the set: or at last reach besond the end of the stylets. Right male antenna without special armature. 'The terminal segment of the outer rami of the fifth foot of the fenale is obsolescent aud hears two unequal spines. The claw is short and moder. ately curved. The inner ramus is as long as the basal joint of the outer ramus and bears two long curved spines and a few cilia. The fifth feet of the male are nearly efual, neglecting the rlaw of the right. which is of moderate length and geniculately curved. The accestory spine is short and near the apex, while a suall tooth is siluated about at the proximal one third of the inner aspect. 'The immer ramus of the right foot reaches about to this tooth. The armature of the outer ramus of the left foot is peculiar and was not correctly figured by myself or Marsh. Fig. 2 of the plate is a camera deawing of the usual appearance. Fig. 6 is drawn so as to interpret the appearance. There is a movable claw, blunt at the tip and bearing a knob on the immer aspect which fits into the concavity of a basin-shaped projection whose outline is mistaken for a curved claw in most lights. Fig. 6 was taken from a specimen found in Lake Minnetonka. In greneral, the species prefers clear water. Fig. 1 represents a subimago form, with the first set of 
eggs, and is less slender than the adult. The fact that all these species are heterogenentic has been frequently reported by the writer. I.ength 1.2 to $1.3 \mathrm{~mm}$. Anteuna 1.3 to $1.5 \mathrm{~mm}$. Marsh found the species but once, near Marquette.

\section{* Diaptomus piscinae Forbes.}

Plate V, Fig. 13.

Forbes '93.

A species of medium size (1.75 $\mathrm{mm}$. long), having the last thoracic segment not produced but armed with spines. The fifth feet of the female has the apical segment of the outer ramus obsolescent and the long one jointed inner ramus provided with spines half as long as the ramus. The male feet are very like those of $I$ ). leptomms. The outer ramus of the left foot has a quadrate basal joint much wider than the second segment, which bear's a small blunt spine and a long curved seta. The inner ramus is nearly as long as both the segments of the outer, aud terminates in a broadly rounded, or subtruncate, thickly ciliate end. The terminal claw of the onter ramus of the right leg is short, eiliated; the accessory spine being near its base. The immer ramus is longer than the basal joint of the onter, terminating in a blunt ciliated end.

\section{Diaptomus laciniatus Lilljeborg.}

Plates VIII, Fig. 15; X, Fig. 12.

De Guerne and Richard '89.

This alpine and northern form may be at once recognized among its congeners by the fact that the two last thoracic segments are produced on either side into large projections, of which those of the last one are enormons and are armed with two minute spines. The first abulominal segment is as long as the rest of the abdomen. Candal stylets short. The antenne extend beyond the stylets. Inigth without stylets $1.8 \mathrm{~mm}$. to $1.2 \mathrm{~mm}$.

\section{Diaptomus castor (Jurine.)}

P'I.ITE: IX, FIG. 万.

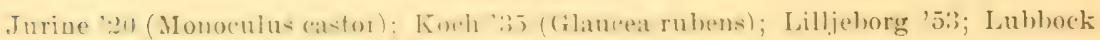
'6j; De Guerne and Richard' 89.

The confurion of several species under this name and loose deseription-of latropean anthor's stood in the way of any difterentiation

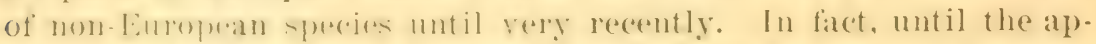

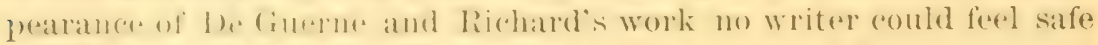
in the attemplto distimgnish speceies in this genus. All references to 1). rester in Imerisat are erroneous. In our own case l). leptopurs has been most often so called. 
A large robust species ( 2.5 to $3.0 \mathrm{~mm}$. long), with the last abdominal segment produced into two long acuminate and mucronate lobes. The first abdominal segment is also produced and spined. The antenne are short, barely reaching the second abdominal segment. The third joint of the outer ramus of the fifth foot is large and furnished with two unequal spines, one being very long. The claw is short and serrate. The inner ramus is two-jointed and armed with one very long and one short spine. The inner ramus of the right foot is twojointed, and of the left, one-jointed in the male.

Two varieties or subspecies are recoguized as separate species, but seem to be due to difference of station simply.

\section{Diaptomus glacialis Lilljeborg.}

Plate IX, Fig. 8.

De Guerne and Richard ' 89.

The last two thoracic lobes are confluent dorsally and are produced into even longer lateral processes than II. corstor. Processes of the rostrum differ from those of $D$. cestor in being elongate, sinuate, and obtuse. The fifth feet of the male differ chiefly in that the inner ramus of the right leg is very indistinctly two-jointed. There is occasionally a rudimentary appendage upon the antepenult segment of the male antenna. $3.0 \mathrm{~mm}$. long. Gilacial waters of Nova Zembla, ete.

\section{Diaptomus mirus Lilljeborg.}

Plate VIII, Fig. 8.

De Guerne and Richard' 89.

A species or variety even larger than $I$. castor $(3.6 \mathrm{~mm}$. long) and differing very little from $D$. gluciulis. The lateral projections from the last thoracic segment (which is distinct) are smaller, and the first abdominal segment is not produced into great lateral processes. The fifth feet are almost identical in the two species. The fifth feet of the males differ only in the proportional development of the parts. The form was found in Siberia hy the Nordenskiöld expedition.

\section{Diaptomus Sancti-patricii Brady.}

Plate XxxiII, Figs. 9-11.

\section{Brady '91.}

Posterior angles of the last thoracie segment very much produced so as to form attenuated spines. Anterior antenne reaching about as far as apex of furca; penultimate joint of the auterior antemna of the male entirely destitute of marginal process. Inner brauch of the fifth pair of feet in the female indistinctly biarticulate, nearly as long as 
the first joint of the outer branch, and bearing three minute apical setie. Last joint of the outer branch smail, the larger apical seta not reaching as far as the extremity of the claw of the penultimate joint. Inner branch of the right foot in the male simple, mueronate at the apex, and reaching beyond the middle of the last joint of the outer liranch; terminal claw of the outer branch strongly falcate, aud delicately ciliated on the inner edge; lateral spine attached near the middle of the last joint, long, slender, and finely ciliated. Fifth foot of the left side (male) terminating in a subcrescenti form hyaline lamiua, the inner elge of which is delicately crenulated. Length of male and female about $1.55 \mathrm{~mm}$.

\section{Diaptomus lilljeborgi De Guerne and Richard.}

Plate IX, Fig. 6.

De Guerne and Richard ' $88^{1}$ and ' 89.

This rather large species (2.0 mm. long) is sufficiently identified by the greatly expanded inner ramus of the right foot. The last thoracic segment is alate and mucronate; the first abdominal being also spined. The antennic are scarcely longer than the thorax, and that of the male as in D. castor. Algiers.

\section{Diaptomus roubaui Richard.}

Plates VIII, Fig. 2; IX, Fig. 11.

Richard '88; De Guerne and Richard '89.

This, which is perhaps the largest species of the genus (5.0 to 6.0 mm.) is recognized by the expansion of the right side of the first abdominal segment to form a rounded spinous protuberance while the third and fourth segments of the male are produced and opposable. The antemnie scarcely excent the thorax. The female fifth feet are like those of $I$ ). (restor. The inner rami of the male feet are onejointeri: that of the right foot being curved and thickened at the apex, that of the left foot indistinctly two jointed and as long as the hasal sergment of the outer ramus, which is narrow and armed with spines intermally. The terminal joint of the onter ramus is swollen and pilose and armed with two thick spines.

* Diaptomus tyrelli Poppe.

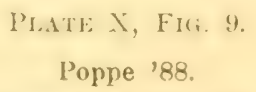

1 spereies from fimmmit lake altitude 5,300 feet, in the Rocky mountains) and ('xutreville. ('al., of moderate size (1.9 mm.) and greatly "xpanderl amel spined thoucte angles. The first ablominal segrment is as long as the remainder and expanded and spined ante- 
riorly. The second segment is transversely wrinkled. Antennir extend to the stylets. Right male antenna with an unarmed antepenult joint. Third joint of outer ramus of fifth feet obsolescent, inner ramus slender aud as long as the basal joint of the onter ramus. The outer ramus of the right male foot with a small hyaline process; accessory spine near the middle of the second joint small. The inner ramus is short and acuminate. Inuer ramus of left foot long, two-jointel, hirsute apically. Outer ramns short.

\section{Diaptomus theeli Lilljeborg.}

Plate VIII, Fig. 11.

De Guerne and Richard '89.

A species rery much like $I$. lnciniutus, except that the last two thoracic segments are not both produced into long projections. as in that species, the last being moderately produced and mucronate. The first abdominal segment is very long (as in the last), and somewhat expanded auteriorly. 'The fifth feet of the female have the terminal segment of the onter ramus distinct and the inner ramus generally (in old forms) two-jointed. There is a small hyaliue lobe from the inner aspect of the peduncle of the right leg in the male. The inner ramus of this leg is curved and acuminate. The inuer ramus of the left leg is shorter than the hasal joint of the onter ramus and acute, with a small spine near the apex. $2.0 \mathrm{~mm}$. long. Collected by the Nordenskiold expedition in Sibera.

Diaptomus lobatus Lilljeborg.

Plate VIII, Fig. \%.

De Guerne and Richard '89.

A species occurring with the last, from which we are unable to find any sufficient reason for separating it. The last two thoracic segments are partly fused, and the last segment projects somewhat more than in $I$. theeli, and there are minor differences in the feet but of rery doubtful value. Size the same. Such differences as exist may be gathered from the figures.

\section{Diaptomus aflinis Uljanin.}

Plate I, Fig. 10.

Uljanin '75; De Guerne and Richard 'є9.

A small form from Turkestan approaching I). denticornis, but lacking the armature of the male antenna. The first abdominal segment is inarmed, while the last thoracic has merely two small spines. Antennie reach the end of the last abdominal segment. The last joint of the 
outer ramus of the fifch feet of the female obsolescent, inner ramus one-jointed, longer than the basal joint of the outer ramus. The figures of the male fent are imperfect, but indicate small one-jointed internal rami on both sides. 1.6 to $1.4 \mathrm{~mm}$. long.

\section{Diaptomus amblyodon Marenzeller.}

Plate IX, Fig. 2.

Marenzeller '73; Kortchaguine '73 and ' 87 ( $(1$. bogdanowi); De Guerne and Richard '89.

A large species rery nearly allied to $D$. gracilis ( 4.0 to $4.5 \mathrm{~mm}$. long). Last segment of the thorax ornamented with two spines. First abdominal segment with a conical process on either side armed with a loug spine. Antenne extending to the end of the thorax. Iast segment of the outer ramus of the fifth foot of the female well developed, inner ramus one jointed, equaling the basal joint of the outer ramus and bearing three setie; the claw strongly toothed. Inner rami of the male fifth foot one-jointed, short, marmed. The basal joint of the outer ramus of the right leg with a small lobe. Apical segment of the left leg densely spiny, with two larger spines.

Wre receive too late to enter the above list in the appropriate plares descriptions of two species of Dimptomus by Professor Marsh ('9t). The description are given verbatim with a reduced reproduction of the figures.

\section{* Diaptomus mississippiensis Marsh.}

Plate XLVII, Figs. 1-3.

6.): mulpratesize. The first two segments of the cephalothorax are neatly explual in lenghth, and together form someshat less than half the rephaththomax. The last sement of the cephalothorax is armed behind with two minute spines.

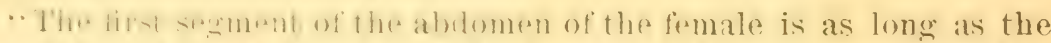
rematmine of the ablumen and the fureat it is dilated laterally and in

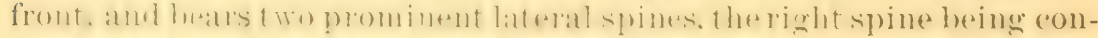

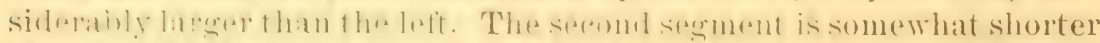

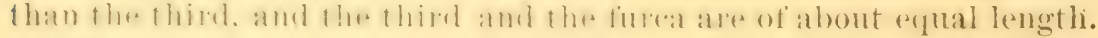

"The antenna reach beyond the furca. The right anteuna of the

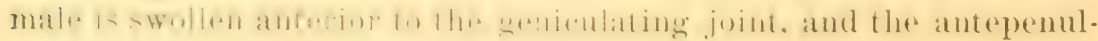
timate joint is without armature.

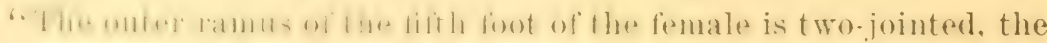

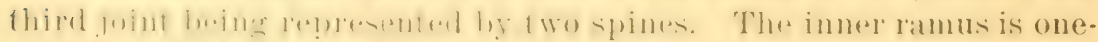
jointerl, a liatle longere than the fir-t joint of the outer ramus, and armed at the tip with minute setio and two rather long spines.

"In the right lith finet of the male the hasial joint is dilated on the inmer margin. The list joint of the onter ramus is slightly broader than long. The second joint is elongated, quadrangular, with the 
lateral spine situated at the distal end. The terminal hook has the symmetry of the curve broken by two rather abrupt angles, and its inner margin is armed with fine serrulations. The inuer ramus is one-jointed, and reaches about half the length of the second joint of the outer ramus.

"The left fifth foot of the male reaches to about the middle of the second joint of the outer ramus of the right. The first joint of the onter ramus is as broad as long. The second joint is armed at tip with two finger-like processes, and both joints are armed within with minute hairs. The inner ramus is one jointed, and nearly equal in length to the outer ramus. Length of female, $1.2 \mathrm{~mm}$.; male, $1.1 \mathrm{~mm}$.

"This species was found in some material kindly furnished to me by Professor E. A. Birge. The collections were male in January and February, 1893, in small lakes and ponds in Mississippi. It was the only Dioptomus in the collections, and was found in nearly all of them. It will be noticed that it bears a somewhat close resemblance to $D$. graciloides Sars."

\section{* Diaptomus birgei Marsh.}

Plate XLVII, Figs. 4-6.

"Of moderate size. The first segment of the cephalothorax is nearly equal in. length to the three following.

"The first segment of the abdomen of the female is as long as the remainder of the abdomen and the furea. It is much dilated in front. The second segment is nearly twice as long as the third, and about equal in length to the furcar. The second and third joints are very closely united.

"The antenne extend to the end of the furca. The right antenna of the male is much swollen anterior to the geniculating joint; the antepenultimate joint is produced on its distal end into a short, blunt process, which makes very nearly a right angle with the longitudinal axis of the joint.

"The outer ramus of the fifth foot of the female is two-jointed, the third joint being represented by two spines. The inner ramus is onejointed. hardly as long as the first joint of the onter ramus, and armed at the tip with miunte setie and two rather long spines.

"The basal joint of the right fifth foot of the male is elongated, trapezoidal in form, it greatest breadth being at its distal extremity. The first joint of the outer ramus is broader than long, armed on its inner margin with a broad, thin expausion of the integument. The second joint is elongate, broader at base; the lateral spine is situated at about the middle of its length, is long and stout, aud armed on its inner margin with fine sermulations. The terminal hook is slightly 
angular and armen with fine serrulations on its inner margin. The innel ramus is one-jointed, efualing in length the first joint of the outer ramus.

".The left fifth foot of the male reaches slightly beyond the first joint of the onter ramus of the right. The basal joint is cuadrangular, considerably shorter than the right hasal joint. The first joint of the outer ramus is about twice as long as broad. The second joint is slightly longer than the first joint; it is expanded at base, where it is armed with fine haiss, and terminates in a finger like process bearing a falciform spine. The inner ramus extends to about one half the length of the second joint. Length of female, $1.5 \mathrm{~mm}$; male, $1.3 \mathrm{~mm}$.

". The material in which this species was found was collected by Profesion l: A. Birge at New Lishon. Wisconsin, and only a few indivilualswere found. I have expected to find it in the collections from other Wisconsin localities; but so far my search has been without suc(exs. It is a clearly mathed species resembling the European $I$ ). gracilis Sars more closely than does any other described American species. The characters of the fifth feet, however, separate it from the European form.

- I have taken the liberty of namiug this species in houor of Profes. sor lirge, to whose kind assistance and encouragement I have been greatly indebted."

\section{GENUS BROTEAS Loven. 1845.}

Thorax five-jointed. First antenne multiarticulate: second pair bi-ramose. Fwimming feret four pairs, bi-ramose, outer ramus threejointed, inmer two jointed; fifth feet dissimilar in the sexes. The third pair of maxillipeds falciform. Abromen of the male six.jointed, in the female two jointerl. The single known species, lis faldefer Loven (Plate X. Fig. 16i). a large slender form (4.0 mm. long), oceurs in salt pans near port Natal.

\section{GENUS HETEROCOPE Sars. 1863.}

rephaluf hurax six-jointerl; last thoracic segunent more or less divari-

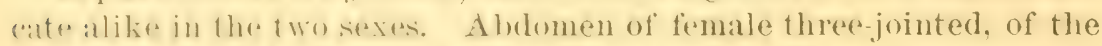

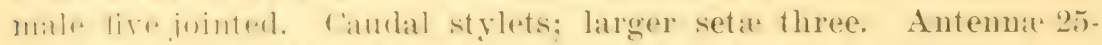
joinfel: in the male right antemnat a genicoulating joint between segment- 1.5 and 19, the six prereding somewhat tumid. Fwimming feet four patis, of which the onter rami three jointed, the inner onejuinted. Fifth tien uf lemale simple, three jointed, those of the male discimilat: the left elediform. Alulomen of the male symmetrical.

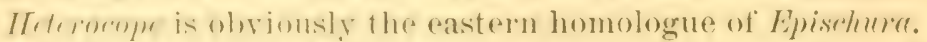

The three spereses of this genus may be tabulated thus, following De Guerne and Richard: 
I. Antenna shorter than the body. Stylets armed at the angle with a short non-eiliated seta. The female has no appendages at the genital orifice. The last segment of fifth foot on the right side of male short.

saliens and boreans

II. Antenna longer than the body. Stylets without the setæ at the angle. Female with eight appendages at the genital orifice.

Last joint of the male right fitth foot long and straight. . appendiculata

Heterocope saliens Lilljeborg. 1862.

Plate I, Fig. 14.

Last segment of the fifth feet of the female short and broad, teeth of its internal aspect distinctly bifid. The prolongation of the inner aspect of the autepenult joint of the left fift foot of the male incurved, not reflexed at its end.

Heterocope borealis Fischer. 1851

PIATE X, Fig. 15.

Last segment of the fifth foot of female long and straight, teeth less distiuctly bifid or trifid. Prolongation of male left foot much curved and reflexed at the end.

Heterocope appendiculata Sars. 1863.

Plate XI, FIG. 3.

Two other species, $I I$. alpimu and $I I$. mmana, have beeu describud by Imhof ('SS). These forms remain imperfectly known and may be simply young of other species.

GENUS EPISCHURA Forbes. 1882.

Related with IIeterorope Sars. The thorax is six-jointed, the last two segments partly united. The abdomen is five-jointed in the male and four-jointed in the female. Intennie 25-jointed, the right male being geniculate. Abdomen of male with preheusile appendages. often more or less distorted. Inner rani of swimming feet one-jointed. Fifth feet one branched, in the mate modified for prehension. Caudal stylets with three long setie. The first mention of an animal of this genus seems to be Pickering's description of sompliphor ragans from deep water in Lake Ontario. It seems almost certain that the species so imperfectly described in llkay's crustacea of New Jork, is none other than a species of Lpischurn, hut I hesitate to substitute for a name accompanied by good descriptions and figures, and one which has already been incorporated to some extent into our literature, one which is founded on a description so imperfect and general that one incidental character alone enables one to guess its applicatiou. The following is Pickering's description: 
"Body small, eye single, near the anterior margin of the shield. Antenuce large, and as long as in the preceding genus (Cyclops), and has the same motions in the water. Abdomen terminating in two styles, each with three setie; last or three last joints. Ovaries none; legs spiny."

What is meant by the "brush" fails to appear, unless the specimens were ormamented with some parasitic plants or animals. The three setie of the caudal stylets and long antenne will place this form in no American genus save Epischura. But even this statement of Pickering may be held doubtful.

\section{Epischura lacustris Forbes.}

Plate XIII, Fig. 15.

Forbes '82; Herrick ' 84 and '87; De Guerne and Richard '89.

"The second segment of the abdomen of the male is twice as long as the first, and produced to the right as a large, elongate, triangular process, somewhat hooked backwards at the tip. The third segment is similarly produced, but rounded and expauded at the tip, which is roughened before and behind.

"From the right side of the fourth segment arises a stout process bearing at its apex a hatchet-shaped plate with seven broad obtuse serratures on its anterior margin. This process is roughened behind, where it is opposed to the concare side of the left ramus of the furca. From the same side of the fifth segment, a short flattened plate, of a spatulate or paddle-like form, extends forward above or beyoud the toothed process just mentioned.

.'The antennie are 25-jointed, and reach to the second segment of the abdomen. There are especially prominent sensory hairs on the first and third joints, borne at the tips of long spines. The antennules are short, the ramus apparently but three-jointed, the short, median joints common in this appendage being only obscurely indicated. The mandihle has hut seven teeth, the first simple and acute, separated from the second by an interval about equal to the second and third, the second to the sisth bifid, the seventh entire and acute. The usual plumose bristle is replaced by a sharp, simple spine.

- The outer ramus of the fourth pair of legs has two teeth at the outer tip of each of the two basal joints. The terminal joint of this ramus is armed as follows: a short simple spine at middle of outer margin and another at the distal outer angle; a single and long terminal seta, strongly and sharply toothed externally and plumose within, and four long plimose setx attached to the inner margin.

-The left leg of the fifth pair in the male, viewed from behind, has the hasal joint very laree. broader than long, with the inner inferior angle produced downwards as a long, stout, curved process or arm as 
long as the two remaining joints. The second joint is trapezoidal, shortest withiu. The thirt joint is about half as wide at base as the first, is straight without, with a sharp, small tooth at its distal third, and bifid at tip. On the imner margin this joint is at first dilated a little, and then deeply excavated to the narrow tip, to receive the lower end of the left leg, the lower two thirds of this margin forming the segment of a circle.

"The right leg is two-jointed, the first joint twice as broad, enlarged at the lower end, forming an auriculate expansion at its inuer inferior angle. The second joint is conical in outline and about two-thirds as long as the first.

"The terminal bristles of the rami are very broad and strong in the female, the onter one especially having an extraordinary siz' aud thickness. There is also at the outer augle of each ramus a short, stout spine, that on the left ramus being inflated like the outer bristle. Length .065 in.

"The legs of the fifth pair in the female are three-jointed and similar, the basal joint short and broad, the second two and one-half times as long as wide. The leg terminates by four diverging teeth, preceded by two others, one on each side.

"Taken in the towing net abundantly in October, 1881, at Graud Traverse bay; also obtaiued rarely by IIr. B. W. Thomas, from the city water of Chicago."

Occurring in Minnesota, probably in Lake Superior.

\section{* Epischura fluviatilis Herrick.}

Plate XIII, Figs. 14, 16.

Herrick '83, '84 and '87; De Guerne and Richard '89.

"similar to the above but smaller ( $0.0+\mathrm{in}$. $)$. The females are very similar, though the fifth feet are more elongate and differently spined. The abdomen is perfectly straight and the three caudal setit are of nearly equal size. The claw is armed with eight teeth, all but the first of which are emarginate. The abdomen of the male is straight, but has a strong process on the left side which hears a movable claw laterally and a small second segment which terminates in two small spines. The fifth foot of the male is peculiar: the iuner ramus (or the left foot) lamelliform, one jointed, with two opposable claws; the right branch is simple and three.jointed, in form like that of the female. Here we have the most marked difference between the two species. Found in Mulberry creek, ('ullman county, Ala. Although a considerable number were examined no oviferous females were found, while the males contained the spermatophores and can hardly be thought immature, and, as it is in the male that the most marked differences appear, the two species seem certainly distinct." 
It is to be regretted that no opportunity has occurred to observe this species since the above was written. It is very probable that mature examples would modify as well as extend the above. It is a bit anusing to find De Guerne concerned over the discrepancy of our locating "baie de Mulberry" in a mountain region-a difficulty which would disappear should he grasp the Eoglish usage of "creek" which he has translated "baie."

\section{Epischura nevadensis Lilljeborg.}

Plate XI, Figs. 1, 6, 8.

De Guerne and Richard's9.

of moderate size. Cephalothorax fire-jointed; last two confluent; last segment not devaricate, rounded. Abdomen three jointed in the female. Caudal stylets shorter than the preceding segment; slightly ciliated internally; caudal seta equal and similar; exterually a short spine. Abdomen of male five jointed, curved to the right, similar to that of $F$. Iarmstris, secoud and third segments nearly equal in leugth, the first shorter: the second segment produced on the right side into a rery large wing.lik" process, denticulate aloug its hinder border ai d (marginate at the tip; third segment with a shorter, smooth and broadly romded process. The fifth segment with a process on both sides. Antenua not reaching the base of the stylets. Antepenult joint of male right antemna not appendaged. Fifth feet of female aniramose, three jointed, more robust than usual. Apical joint with six teeth, of which four are longer. Fifth feet of male uni-ramose, dissimilar. Right foot apparently two jointed, the basal joint thick with a lamedlate and denticulate process at the end, second joint a thick claw. First joint of the left foot a very large hook: thind joint incised intermally, the shallow excavation ciliated, and armed apically with two spines. Length of female $2.0 \mathrm{~mm}$.

Found by A. (i. Eisen in the Sierra Tevala region, Lake Tahoe and Echo lake.

Epischura nevalensis Lilljehorw. Var. Columbia Forbes.

Plate XI, Figs. 4, 10.

Forbes '93.

This alpine form is not only a little larger but the thorax is more distincly jointerl. The antemner of the female reach to the posterior enct of the penulimatr segment of the alulomen. The first segment of the abdome'n is as long as the two following together, and the stylets are as long as the preceding segment. The abdomen is not eurved as in li. lumstris. The three caudal setie are all similar and of equal wisth. There is a stont conieal spine at the onter distal angle and a soft seta at the inner angle of each stylet. 
The fifth legs of the female are broader proportionally than those of tucustris but more slender than those of E. neculensis. The last segment is four times as long as broad aud bears six ( 7 ) teeth, of which four are terminal. The second, third and fifth segments of the male abdomen bear lateral processes extending toward the right. The first three segments are subequal. The lateral process of the second has the form of a stout but thin lamiua projecting to a distance equal to the wilth of the segment; it is acnte at the apex, with the point a little recurved, convex and smooth in frout, and nearly straight behind, except that this edge is irregularly serrate throughout and deeply emarginate where it joins the segment. This blade is strongly curved rentrad like the following. The third segment hears a broad thin lamina which projects out ward, as wide as long, broadly rounded at the end, simple but strengthened beneath by a ridge of chitin. From the fourth segment spring two processes, the rentral being nearly similar to that of neradensis. The dorsal process is a small irregular plate curving forward, inward and downward. Length of female 2.12 to $2.4 \mathrm{~mm}$.

* Epischura nordenskioeldi Lilljeborg.

PLATE II, Fisis. 2, 5, 9.

De Gnerne and Richard ' 89.

This species, from St. Johns, Vewfondlaud, is the largest of the genus (2.9 $\mathrm{mm}$.) and is remarkable for the slender, slightly armed abdomen. Cephalothorax robust, abdomen exceedingly slender, fourjointed in the female, anterior two somewhat fused, third segment longer than the fourth. Caudal stylets twice as long as wide, ciliated internaily; caudal setie similar and equal. Male abdomen five-jointed and slightly flexed toward the right, secoud and third joints equal and half as loug again as the first. The second joint is armed with a rather small, slightly curved, and notehed at the tip. The process of the third joint is very small and acute; that from the last is directed cephalad aud is blunt. Antennar reaching to base of stylets, 25-jointed. Geniculate antenna with the penultimate joint unarmed. Feet of fifth pair in the female uni ramose, three-jointed, nearly as slender as in $E$. Incustris though less so than $E$. fluciulilis, the joints nearly of equal length. The left fifth foot of the male closely resembles that of $E$. columbia; the right differing from the other forms in having an accessory spine near the base of the inner aspect.

GENUS OSPHRANTICUM Forbes. 188:.

(=Potamoichetor, Herrick.)

First reported as Potamoichetor before the Minnesota Academy of Sciences in 1879 , but owing to a disastrous fire, publication was prevented. Priority probably belongs to Eorbes' name, since, although 
first printed in the tenth annual of this survey, the edition was not distributed till after the August issue of the American Naturalist of 1882, containing the description above alluded to. Forbes says this genus has antennil 23 jointed; all the specimens we have gathered from Minnesota to Alabama had 24-jointed antennx. The original description of "Potamoichetor" is appended.

"Cephalothorax six jointed, distal segments evident; abdomen, in the male, fire-jointed, in the female four-jointed; antenna 24 .jointed, the right geniculated as in ('entropages (=Ichthyophorlui(1); first pair of feet with the rami both three-jointed, like the following; feet of the fifth pair, in the female, like the preceding, but with a spine of the joint preceding the terminal one enlarged and divaricated somewhat as in Centropages: in the male, the right with a two-jointed onter ramus, the terminal joint of which is spined and bears near its base a blunt expansion of its inner margin; onter ramus of left foot threejointed, armed with unequal spines; inner branches smaller, similar, three-jointed; the terminal joint bearing curved spines; ovary and testes as in Diuptomus, with which the mouth parts agree in the main; eyes median, confluent."

Ovisac very large, elongate.

Our own experience is that the single species of this genus prefers estuaries of running water. Forbes, however, has taken it from stramps and wayside pools.

* Osphranticum labronectum Forbes.

Plates XII, Figs. 1-8, 13, 14; I.IX, Figs. 7, 8.

Forbes '६.); Herrick ' 82 (Potamoichetor fucosus), '84 and ' 87 ; De Guerne and Richard '89.

"Rather slender, and in size, as well as general appearance, resembling the smaller forms of liuptomus: antenus rather stout, reaching but little beyond the feet. appendaged as in Ifieptomus, in the male strongly geniculated, but somewhat variously so; the six joints prereding the treminal four are thickened; those preceding the joint or hinge are arenate on the distal margins; the secondary antenne are abuut as in I fimplomms: mandibular palp two branched, the onter threejointed, the inner two jointed: the terminal joint of the shorter branch hearing seren selar, of the other four, the proximal joint of the former with three stont spines; the maxilla nearly like llinptomus: the procesies have respectively the following numbers of setar: the hasal plate eight, the small processes at base of posterior branchial appendage one, the appendige itself twelve, terminal portion three groups, first containing nine, the secend three, and the third four or five, the npper of the anterior processes two, and the lower three: fifth feret nearly like the other's in size: the right in the male having the outer 
branch but two-jointed by the coalescence of the two outer to form an arcuate and deformed appendage, armed at the end with three stont equal spines; corresponding branch of left foot three-jointed; the terminal joint bearing three unequal spines, each of the preceding joints only one; inner branches similar, three jointed; terminal joint being short and armed with three short lanceolate set: and three longer ones, two of which are curved so as to be slightly prehensile; fifth foot of female with both rami three jointed; inner ramus much smaller; antepenult segment of the outer ramus exteudiug into a large lanceolate process; ovisac long-ellipsoidal or spherical, reaching nearly to the end of the caudal setre."

Professor Lilljeborg finds this species in Oregon, and as we have collected it in Alabama it may be regarded as ubiquitous in North America in suitable stations.

\section{FAMILY CYCLOPIIE.}

The family contains five genera, viz.: Thorellia, Cyctops, Oithonn, Lophophorus and ('yclopina; passing, by the genera Misophrio and Psendo-cyclops, into the cralanidu or marine ropepoda. The affinities of these little known genera need further study, as they are very inter estiug, the question being still open in how far the cyclopoid forms are altered by adaptation to saliue habitat, if such an adaptation takes place at all.

Cephalothorax ovate and usually much more robust than the abdomen; anterior antenux seldom longer than the cephalothorax, those of male alike on both sides and modified for the purpose of clasping; posterior antenna unbranched (i. e., palpus wanting); palps of mandibles and maxillie usually well developed; foot-jaws mostly less developed than in C'alanidu'; first four pairs of feet as in Calunidur, fifth pair rudimentary, alike in both sexes, and usually one- or two-jointed; ovisacs two.

The circulatory system of this family is partly lacumal and has been thought to be entirely so in the genus ('yclops. Closer observation, however, shows that there is something like an imperfect central organ at the point occupied by the heart of higher copeponta. This was figured in my previous report, Plate V, Fig. 1, but no mention was made of the discovery. It has since been verified. The apparatus referred to is a modification of that described under ('(unthoc(t)m). tus. In the second thoracic segment there is a set of swaying mem. braues which constitute a valvular apparatus, chiefly moved by the action of the stomach.

The following analytical key from Brady will serve to differentiate the genera. 


\section{IIEY TO 'THE FAMILY CYCLOPIDE.}

I. MANDInAR PAJP Olisol.EscENT, a mere tubercle bearing two filaments.

a. Second maxillepeds prehensile.

Thorellia.

b. Second maxillepeds not prehensile.

II. MANDIBLAR PALP TWO-BRANCHED.

a. Secondary branch of palp many-jointed.

Oithona.

b. Secondary branch one-jointed.

$\because$ Fifth pair of feet foliaceous.

** Fifth pair of feet cylindrical, two- or three-jointed.

Lophophorus.

Cyclopina.

All these genera except Cyclops are marine.

\section{GENUS CYCLOPS.}

The sole representative of the genera of the cyclopidc here treated is the best known of the copeporla. Every one is familiar with the "common r'yelopls," but few realize how many are the species included under this name. An attempt is here made to enable the student to recognize the more obvious distinctions upon which the genus is sub. divided and to identify such of the species as seem valid and at the same time recognizable without recondite stady of development. Without attempting a complete elucidation of the synonymy, which is practically an impossibility, a proximate classification of all the species known to me is attempted.

I)IANosis: ('phalothorax robust, oval, hroadest in front, composed, in the fimale, of nine segments. Antenmie short, of less than twenty segments, in the male geniculate on both sides. Antennules one-hrancherl, four-jointed. Mandiblar palp a small two-setose tubercle. First four pairs of feet two branched, all the branches three. jointed. Fifth feet small, one-to three-jointed. In the male a still more rutimutary sixth pair. Ese single but composed of two facets. Ovisac double.

As stated by Prady, the grenus (yrotops is, as regards discrimination of spexeses, one of the most difficult and puzaling of all the copeporle. Chite among the cansesof this difliculty is the polymorphism and hetmogenosis which provail, as well as the great susceptibility to the eflectis of the rntiromment. Living as they do, in pools and streams, molergoing great seasonal and other variation, these forms offer ex("ent innal opportunities lior the study of the plasticity of species.

\section{KEY TO 'THE GENUS CYCLOPS.}

I. Antennic 18-jointed.

II. Antennic 17-jointed.

a. Fifth foot one-jointed.

ater, 89.

b. Fifth foot two-jointed. 
* First joint of the fifth foot broad. . . viridis, 90 ; americanus, 91 ; ingens, 92; vernalis, 92; robustus, 93; parcus, 93; brevispinosus, 95; uniangulatus, $\varepsilon 6$; lenckarti, 96; scourfieldi, 98; oithonoides, 98; dybowskii, 99;

** First joint of the fifth foot longer than wide.

bisetosus, 99 .

† Terminal segment of the fifth foot with one long seta and one short spine. . . . . . . strenuus, 99; lacustris, 10 t.

it Terminal segment of the filth foot with two rather long set:

pulchellus, 101; minnilus, 103; forbesi, 104.

f† Terminal segment of the fifth foot with three sefw. . signatus 105 ;

var. coronatus, 106; var. tenuicornis, 106.

III. Antenna 16-jointed, languidus, 107; modestus, 103; capilliferus, 109;

IV. Antennx 14-jointed.

insignis, 110.

V. Antennis 12-jointed.

a. Fifth foot one-jointed. . . . serrulatus, 111; var. elegaus, 112. macrurus, 113; prasinus, 113; fluviatilis, 114.

b. Fifth foot two-jointed. . . . capillatus, 115; crassicaudis, 115;

varicans, 116 .

VI. Antenne 11-jointerl.

gracilis, 117; diaphanus, 117; aflinis, 117;

bicolor, 118.

VII. Antennæ 10-jointed.

phaleratus, 120.

VIII. Antennæ eight-jointed.

fimbriatus, 121.

IX. Antennæe six-jointed.

requoreus, 122 .

The forms which have been reported with 18 jointed anteunt may not necessarily be representatives of a single species but may be sporadis instances of reduplication in the antennal segments on the part of various 17-jointed forms. (ychops clongutus Claus, the only named species with 18.jointed antennit, is coufdently identified with (' rer. nalis Fischer, by Schmeil, nevertheless ('laus" description is as follows: "Length of body $2.5 \mathrm{~mm}$, elongate, gradually narowed toward the end. The anterior anteune 18 jointed, differing from the 17 -jointed type by the separation of the seventh joint into two: they do not extend far beyond the first segment of the cephalothorax. The fifth abdominal segment is strongly toothed. Rudimentary foot two jointed, with relatively small basal joint and elongate terminal oue, on whose apex is one long and one short seta. The stylets are longer than the two last abdominal segments, with relatively short setie, whose relative size is nearly like those of $C$. cuspidatus."

This species is reported hy ('ragin from near Cambridge, but has been seen by no other observer except the describer.

\section{Cyclops ater Herrick.}

Plates VI, Figs. 11, 12; XII, Figs. 9-12; XXI, Figs. 13-15, 17, 18. Herrick '82, '84, '87: Turner '92.

Cephalothorax very large and broadly oral and usually conspicuously colored. Antenne as long as the cephalothorax (1.2 mm.), 


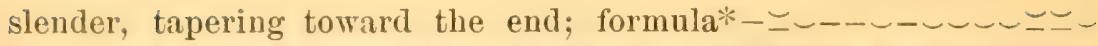
-- ; last three segments not elongate, the last being furnished with an unserrated, hyaline knife-like ridge as in (: temicomis. Antenmules much as in 1 . temirormis. Maxillipedes rather large. Fifth foot one-jointed, armed with three subequal spines. Abdomen very short, especially the last segment. Stylets rather more than twice as long as wide, the three inner setre long and pectinate but none very long, external seta short, lateral seta near the end of the stylet. Fourth foot with the following armature of apical joints:

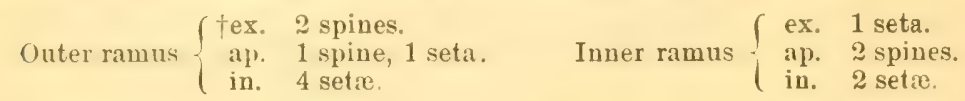

The setir are all short and stout. ('olor deep blue or gray; young with a deep band of color crossing the thorax near the middle. Ovisass pale, rather small. Length $21 \mathrm{~mm}$. This, our most char. acteristic American species, is sparingly but widely distributed, at least, throughout the Mississippi Valley.

Cyclops viridis Jurine. 1820.

$$
\text { Plate XIV. }
$$

Subspecies europacus Herrick.

Var. a. -Koch'35 (C. vulgaris); Fischer'51; Claus '57 and '63 (C. brericornis); Sars'63; I,ubbock '63 (C. hrevicornis); Heller '70 (C. brevicoruis); Fric' $92^{3}$ (C. brevicornis); Uljauin '75; Hoek '76 (C. hrevicornis); Rehberg ' $80^{1}$; Daday ' $85^{5}$; Vosseler' 86 ; Sustaric '88; Thallwitz '90; Lande '90; Schmeil '91; Richard '91; Schmeil '92.

Var. b. -Claus 57 (C. wigas); Sars '63 (C. gigas); Fric '7.21 (C. grigas); Prady '78 (C. gigas); Sostaric (C. viridis var. gigas); Rehberg ' $80^{1}$.

Subspecies americanus Marsb.

Var. a.-Cragin '8:, (C. viridis); Herrick ' 83 (C. parcus) and '84 (C. brevicornis) (passim); Marsh '93 (C. americanus); Turner' 92 (C. viridis).

Var. b. - Herrick' 82 and '83 (C. ingens).

If we accept Rehberg's suggestion that the two European species,

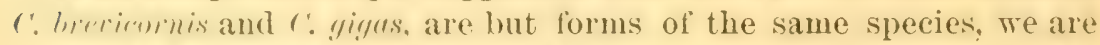
driven to a somewhat anomalous arrangement of the synonomy, though, when so arranged, it expresses a not unusual parallel development of species on the two sides of the Atlantic. As the writer stated in 1S52, the American representatives of this species differ in sereral minor points from the European aud a new name was given. Iater, in deference to liehberg's discovery of greater latitude of varia-

The characters in these formu':ce are used to indicate the relative length of the joints, from base fo tip, as follows: $\smile$, short; $=$, mediun; - , long.

tex. exterior; ap.:=apical; in, =interior aspect. 
tion than once supposed, ( . ingens was united with C. gigas as an unnamed variety of C. viriclis (Herrick'st, p. 145). The preimago stage is similar to that of giges, and this fact made the union seem more legitimate. Still later Marsh, withont recognizing the varietal differences and having only the smaller form before him, erects for it a new species, r. americuns. Of course, if this is to inclucle the whole assemblage representing ('. riritis in America, the name r. ingrus is prior. If not, the later name may be revived for the form corresponding to $C$. gigas of Europe.

To judge from the figures in ('laus' Inc fiemus r'yclops, the European form is subject to a very wide range of variation, for ( $:$ furcifer, afterwards regarded as a simple varietal form of 1 . breciccundutus, has the stylets and antennie greatly elongated. Unfortunately the details of the armature of the feet are not given by Claus or most of the authors following him.

Var. a. *Cyclops americanus Marsh.

Plate XIV.

Subspecies Americanus Marsb.

We quote Marsh's deseription entire:

"Cephalothorax oval, the first segment being about laalf its total length. Antenna 17-jointed, about as long as the first cephalathoracic segment. Abdomen rather slender, the last segment armed on its posterior border with small spines. All the abdominal segments in immature individuals are strongly pectiuate posteriorly. Furea about three times as long as its average breadth, the lateral spine sitnated well towards the end. The first and fourth terminal setie are short, slender and plumose, nearly equal in length. Of the internal setre, the outer is a little more than three-fourths of the length of the inner. The armature of the terminal joints of the swimming feet is as follows:

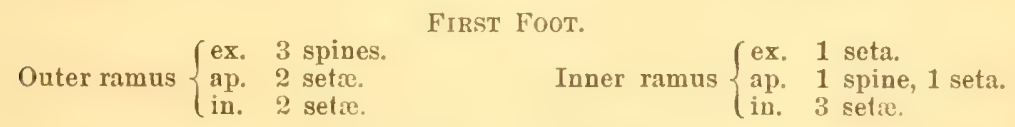

Second ANd Third Feet.

Outer ramus $\left\{\begin{array}{l}\text { ex. } 3 \text { spines. } \\ \text { ap. } 1 \text { spine, } 1 \text { seta. } \\ \text { in. } 3 \text { setre. }\end{array} \quad\right.$ Inner ramus $\left\{\begin{array}{lll}\text { ex. } & 1 \text { seta. } \\ \text { ap. } & 1 \text { spine, } 1 \text { seta } \\ \text { in. } & 3 \text { setre. }\end{array}\right.$

Fourth Foot.

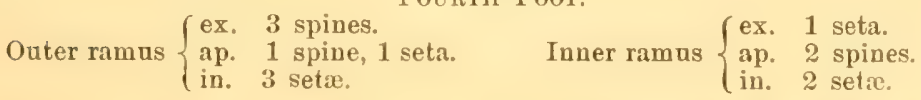

"Fifth foot two-jointed, basal joint very broad, armed with one seta. Terminal joint armed with a seta and a blunt spine. Length $1.2 \mathrm{~mm} . "$ 
The points of difference consist in the fact that the antenns are shorter than European vividis, reaching only to the second instead of to the third thoracic segment, and that the armature of fourth feet are very unlike the figures and descriptions of European authors. Brady is the only author who figures these parts, and these figures are eridently careless, for the anteuna on the same plate have a supernu. merary joint. We have examined a number of specimens of this species from distant parts of the United States, and find, with Marsh, the armature constant or but slightly variable. The proportions of the apical spines of the inner ramus of the fourth foot are the reverse of those given in his figure. The size varies remarkably, passing into the large variety. $1.4 \mathrm{~mm}$. is an an average measurement exclusire of setre.

Var. b. * Cyclops ingens Herrick.

Plate XXV, Figs. 1.8.

This is the largest form yet encountered in America and is rarely seen. It is a simple exaggeration of the last, there being no obvious distinctions except the size. It is occasionally over $4.0 \mathrm{~mm}$. long including the setre or about $3.0 \mathrm{~mm}$. excluding them.

It may be noticed that the males of this group have a well-developed sixth foot. The antenna are strongly modified and amply spined, as shown in the figure. A series of hyaline plates near the joint are well developed.

\section{Cyclops verualis Fischer. (Fide Schmeil.)}

Fischer '5:; Sars '63, C. lucidulus); Claus'63 (C. elongatus); Heller '70 (C. elongatus); Rehberg ' 81$)^{1}$ (C. elongatus and C. lucidulus); Cragin '83 (C. elongatus); Herrick 'R4 (C. clongatus and lueidulus); Daday' $85^{-5}$ (C. Ineidulus); Sostaric '88 (C. lucidulus; Schmeil 'ol (C. elongatus) and'92; Richard '91; Brady'91 (C. elongatus).

We camnot, of conrse, enter the preplexing synonomy which has heen very carefully studied hy schmeil, and we hope that it may now he considered settled. The not quite mexpected discovery that at 17 jointed species may, under certain conditions, becone 1S-jointed rents on the same kind of evidence which schmeil rejects in respect to omr own statements in the case of other species. and offers a certain Jrobability in lavor of the frepuent occurrence of imperfectly mature but oviparous females. which he rejects without making the necesary investigation hy whinh he might easily have convinced himself of its

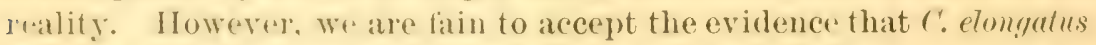
claus is but a "post imagro" of (". lucidulus Sars. Still it is not to be forgotten that otiner spereies may sporadically develop 18 jointed antennar and then night lay chaim to be considered $($ s elongatus. 
Cephalothorax rather long, tapering eandad, fourth and fifth segments somewhat produced. Abdomen more than half as long as thorax, first segment as long as the remainder. Stylets as long as the two preceding segments plus half the next. Median apical setre nearly equal, as are the outer and inner, which are both short. The antennir are shorter than the first thoracic segment, either 17 -jointed or 18 jointed by the subdivision of the seventh joint. Schmeil claims to have found some in which the right antenua is in one condition and the left in another. Fifth foot two jointed, basal segment short, broad, bearing a plumose hair; second joint small, cylindrical, armed with a short spine and a plumose seta. Receptaculum opening transversely narrowly elliptical. Length 1.2 to $1.7 \mathrm{~mm}$.

\section{Cyclops robustus Sars.}

I simply quote the original description:

"Corpus breve et robustum depressiusculum, segmento 1 mo lato et antice rune rotundato, ceteris ad latera sat exstantibus, ultimo quam segmento 1 mo abdominali multo latiore. Rami caudales vix divergentes longitudinem segmentorum antecedentium 2 superantes setis apicalibus fortibus et fere aculeiformibus, iutermediarum interiore quam exteriore multo longiore longitudinem abdominis fere iciuante rersus medium sparsim dein dense ciliata, ceteris duabus brevissimis et fere ejusdem longitudivis. Antenna $1 \mathrm{mi}$ paris 17 articulate, breves et crassic segmento 1 mo corporis breviores. Articulus ultimus rami exterioris pelum natatoriorum latus extus aculeis 3 , intus sotis 4 instructus; seta marginis exterioris articuli ultimi rami interioris in pedibus 2 li -4 ti paris in aculeum fortem conformata; aculeiyue apicales 2 ejusdem articuli in pari 4 to subequales. Pedum 5ti paris articulus ultimus parvus intus aculeo brevissimo et rudimentari armatus. Sacci oviferi ovales ahdomini appressi. Longit. circit. $1 \frac{1}{3} \mathrm{~mm} . "$

\section{Cyclops parcus Herrick.}

Plates XX, Figs. 12-15; XXI, Fig. 22; XXIII, Fig. 8; XXXIV, Figs. 1-S.

Herrick ' 8 ? and '84; Marsh'93.

This species, which is rery near to ('. remulis and r! rividis, has more superficial resemblances to $r$ mulchellus, which it also resembles in the form of the swimming feet, occurs in small and stagnant pools. The antenne are shorter than or about as long as the first thoracic segment, the last two segments of which are acute. The antemules are rather short. Labrum narrow, projecting below into obtuse angles, cutting edge with nin. small teeth. The terminal joint of the larger branch of the maxilliped bears four hairs. The second joint has a moderately large dactyl, the movable finger of which is small and sparsely spiny, the immorable finger is ornamented by an oblicue series of blunt promiuences and a small seta at its base. The armature of the swimming feet is as follows: 
First FeEt.

Outer ramus $\left\{\begin{array}{ll}\text { ex. } & 2 \text { spines. } \\ \text { ap. } & 2 \text { setre. } \\ \text { in. } & 2 \text { setre. }\end{array} \quad\right.$ Inner ramus $\left\{\begin{array}{lll}\text { ex. } & 1 \text { seta. } \\ \text { ap. } & 1 \text { spine, } 1 \text { seta. } \\ \text { in. } & 3 \text { setre. }\end{array}\right.$

SECOND FEET.

Outer ramus $\left\{\begin{array}{l}\text { ex. } 2 \text { spines. } \\ \text { ap. } 1 \text { spine, } 1 \text { seta. } \\ \text { in. } 3 \text { seic. }\end{array} \quad\right.$ Inner ramus $\left\{\begin{array}{lll}\text { ex. } & 1 \text { seta. } \\ \text { ap. } & 1 \text { spine, } 1 \text { seta. } \\ \text { in. } & 3 \text { setre. }\end{array}\right.$

Fourth Feet.

Outer ramus $\left\{\begin{array}{l}\text { ex. } 2 \text { spines. } \\ \text { ap. } 1 \text { spine, } 1 \text { seta. } \\ \text { in. } 3 \text { setr. }\end{array}\right.$ Inner ramus $\begin{cases}\text { ex. } & 1 \text { seta. } \\ \text { ap. } & 2 \text { equal spines. } \\ \text { in. } & 2 \text { setæ. }\end{cases}$

The fifth foot is two-jointed, the basal joint being short, broad, and armed with one seta, while the apical segment is short, fusiform with a long seta and short spine. The foot is very like that of r. riridis, but the basal joint is smaller. The abdomen is rather slender, the first joint being rather longer than the remaining joint exclusive of the stylets. The latter in the average form are rather short and the lateral seta is over one-fifth their length from the apex. The onter apical seta is three-fourths the length of the inner. The inner median setat considerably longer than the outer. In addition to the ordinary form with short stylets there are frequently found others which have the stylets consilerably elongate. Such a form is figured in Plate XXXIII. In this case the stylets are six times as long as wide and equal in length the last two and half of the next abdominal segments. The small lateral spine is more thau a fourth the length from the end, and there is a slight unserrated offset at the basal one-fourth externally. The inner seta is nearly as loug as the stylet, the outer twothirds as long. The inner median seta is three times as long as the stylet, and the onter is but twice as long as the stylet. The antennie in this form are ahout as long as the first segment, which forms nearly half the length of the thorax. The abdomen without the stylets is half the length of the thorax.

The form of the receptaculum is transversely oval, very similar in fact to r. remulis. Infortmately the printer in the preceding edition made the deseription of Plate 24 so read that the figure of this structure was credited to $C$. alolescens.

Length 1.4 to $1.5 \mathrm{~mm}$. The following measurements of the elongate form are given to illustrate the proportions: Length 1.37 mm., thorax 0.8.) mm. first stgment $0.41 \mathrm{~mm}$, abdomen (exclusive of stylets) 0.41 mm., stylets $19.19 \mathrm{~mm}$., antennat $0.45 \mathrm{~mm}$., longest seta $0.50 \mathrm{~mm}$.

It is possible that the elongate form, which is found in association with the type, is to be regarded as a post-imago. There is danger of confusing this form with $\quad$ : brerispinusus Iferrick, and it is not certain that this has not already happened to some extent. 
Cyclops brevispinosus Herrick. 1884.

Plates XXII, Figs. 1-4; XXIV, Figs. 7-12.

This species may be regarded as the pelagic representative of (: purcus. In the original description the following differences wre noted. The form is more slender and the stylets are gratly elongated, the outer caudal seta is reduced to a short ciliate spine, and the fourth foot is differently armed and the receptaculum is somewhat different in form.

Marsh says that one might infer from my statement that the armature of the swimming fort is the same as in r. parcus, but how this could be possible in the face of the plain statement of difference and figure of the fourth foot it is hard to see.

The first segment of the compact thorax is half its entire length and the antennie are rather shorter. The abdomen is rather slender and tapering. The stylets are 4.5 times as long as wide, aud the small lateral seta is more than two-thirds its length from the base. The outer terminal seta is transformed into a very short stout serrate spine, shorter than the inner seta and one-third as long as the stylets. The outer median seta is less than three times as long as the stylet and is naked for more than half its length, when it is suddenly narrowed and very closely pectinate to the end. The inner median seta is almost exactly three times as long as the stylet, and is sparsely pectinate for its middle third and closely so for its apical third.

The armature of the feet is as follows:

\begin{tabular}{|c|c|c|c|c|c|c|}
\hline Outer ramus & $\left\{\begin{array}{l}\text { ex. } \\
\text { ap. } \\
\text { in. }\end{array}\right.$ & $\begin{array}{l}3 \text { spines. } \\
2 \text { setx. } \\
2 \text { setx. }\end{array}$ & First & $\begin{array}{l}\text { Fоoт. } \\
\text { Inner ramus }\end{array}$ & $\left\{\begin{array}{l}\text { ex. } \\
\text { ap. } \\
\text { in. }\end{array}\right.$ & $\begin{array}{l}1 \text { seta. } \\
1 \text { spine, } 1 \text { seta. } \\
3 \text { setre. }\end{array}$ \\
\hline Outer ramus & $\left\{\begin{array}{l}\text { ex. } \\
\text { ap. } \\
\text { in. }\end{array}\right.$ & $\begin{array}{l}3 \text { spines. } \\
1 \text { spine, } \\
3 \text { setre. }\end{array}$ & $\begin{array}{l}\text { SECOND } \\
1 \text { seta. }\end{array}$ & $\begin{array}{l}\text { Foot. } \\
\text { Inner ramus }\end{array}$ & $\left\{\begin{array}{l}\text { ex. } \\
\text { ap. } \\
\text { in. }\end{array}\right.$ & $\begin{array}{l}1 \text { seta. } \\
1 \text { spine, } 1 \text { seta. } \\
3 \text { setre. }\end{array}$ \\
\hline
\end{tabular}

Onter ramus $\left\{\begin{array}{l}\text { Third Foot. } \\ \text { ap. } 3 \text { spines. } \\ \text { in. } 3 \text { spine, } 1 \text { seta. }\end{array} \quad\right.$ Inner ramus $\begin{cases}\text { ex. } & 1 \text { spine. } \\ \text { ap. } & 2 \text { spines. } \\ \text { in. } & 3 \text { setre. }\end{cases}$

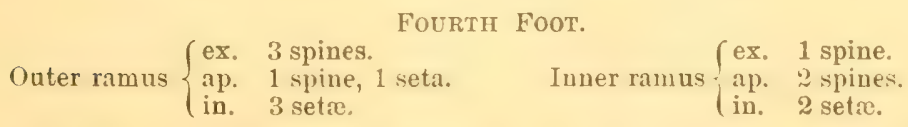

The basal segment of the filth foot is little expanded and bears one seta while the short second joint has an apical seta and a small lateral

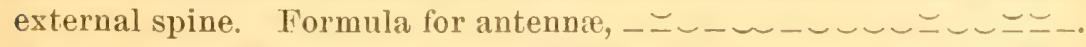
Anteunules rather short. Length $1.0 \mathrm{~mm}$. Marsh suggests that this may be a pelagic form of $('$. rivilis var. Americamus, in which case C. parcus would become a variety of the same species. 


\section{Cyclops uniangulatus Cragin.}

Cragin '88; Herrick' 84.

Cragin was not conversant with the description of $(:$ parcus, with which his description agrees save in one point. It differs from $c$ : prras in having three immer setie on the terminal joint of the onter ramus of the first foot. It would be officious to suggest a possible oversight here, but $(:$ parens has only two in type specimens (though in all this group) the corresponding ramus of the second foot has three setre, so that at present the two must be kept distinct.

\section{Cyclops leuckarti Claus.}

Plates XVI; XVIII, Figs. 1, A-J; XXIV, Figs. 2-6.

Claus '57 and '63; Sars '63; Pogrgenpol '74 (simplex); Uljaniu '75 (tenuicornis); Hoek '78 (leenwenbukii); Herrick' 83 (tenuissimus) aud'81 (simplex and leuckarti); Daday ' 85 (nimplex, pectivatus, and leuckarti); Vosseler' 86 (simplex); Herrick ' $x$ i (simplex); Thallwit\% '90 (simplex); Lande'90 (simplex); Schmeil'91 aud '92; Richard 'y1; Forbes '91 (edax); Brady'91 (scourfieldi); Marsh '92.

-Description of tre FendLE: The form is very slender, an arerage individual measuring between 0.95 and $1.0 \mathrm{~mm}$. exclusive of the caudal setie. The following detailed measurements of a specimen measuring $0.976 \mathrm{~mm}$. Will serve to exhibit the proportions of the parts: First thoracic segment $0.30 \mathrm{~mm}$, second segment $0.08 \mathrm{~mm}$, third segment $0.08 \mathrm{~mm}$, fourth segment $0.056 \mathrm{~mm}$., fifth segment $0.02 \pm \mathrm{mm}$.; first (apparent) abdominal segment $0.16 \mathrm{~mm}$., second segment 0.08 mm. third segment 0.0.45 mm.; caudal stylets 0.085 mm., outer seta $0.08 \mathrm{~mm}$, onter median $10.30 \mathrm{~mm}$., inner median $0.46 \mathrm{~mm}$., inner 0.20 mm. dorsal $0.06 \mathrm{~mm}$; the lateral seta is $0.0: 36 \mathrm{~mm}$. from the end. The antemit reach nearly to the base of the thorax when reflexed, and are yuite strong. They resemble those of $c^{\prime}$ temuiromis in several particolass, hut since it is desimable to distinguish this species with the greatest posibihle accuracy, the following numbers are given to express the rexative length of the several segments, begimning with the first: ${ }_{1} 20,{ }_{2} 5,{ }_{3} 3,{ }_{4} 10,{ }_{5} 7,{ }_{6} 4,{ }_{7} 11,{ }_{8}^{5},{ }_{9}^{5} 5,{ }_{1} 5,{ }_{11} 7,{ }_{12} 7,{ }_{13} 5,{ }_{14} 6,{ }_{15} 10,{ }_{16} 15$, 1: 14. The fourth, eleventh, fourteenth and fiteenth segments bear the lomgest setir. Thr. last two segments are armed with a knife-like

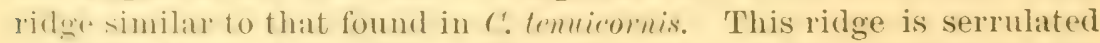
on the last sergment, and near the end is cut by a deep incision so that the twminal fort is like a hook notched upon its convex outer part. Thr antenmules are slender and but moderately spinous, the first three segments buing almost exactly efual $(0.06$ mm.), while the terminal sormont is as long as the basal segment of the antemme $(0.08$ mm.). 'The latmum is armed with thirtedn small teeth. The larger maxilliper is pearled on the posterior margin of its largest segment. The armature of the terminal joints of the feet is as follows: 
First Foot.

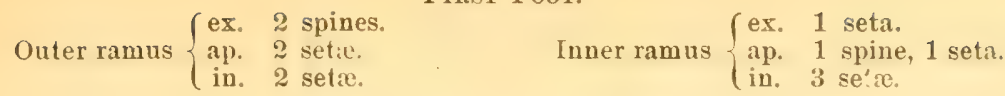

Second and Third Feet.

Outer ramus $\left\{\begin{array}{l}\text { ex. } 2 \text { spines. } \\ \text { ap. } 1 \text { spine, } 1 \text { seta. } \\ \text { in. } 3 \text { setr. }\end{array}\right.$ Inner ramus $\left\{\begin{array}{lll}\text { ex. } & 1 \text { seta. } \\ \text { ap. } & 1 & \text { spine, } 1 \text { seta. } \\ \text { in. } & 3 \text { setæ. }\end{array}\right.$

Fourth Foot.

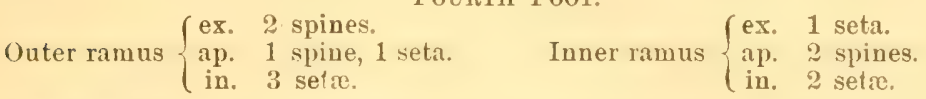

"The fifth foot is two jointed, the basal joint is short and bears a tubercle carrying a seta $0.06 \mathrm{~mm}$. long, the terminal segment is terete and bears a spine $0.10 \mathrm{~mm}$. long apically aud another as long upon the middle of its inner side. The cement gland is of peculiar shape, resembling that of $C$. purms exactly. The last segment of the abdomen is spiny upon the posterior margin above. The color is usually pale, but may be ornamented with bluish suffusions.

"Though elosely allied with the species in America identified with Sars' C. oithmoides there can be no doubt that two forms occur, this one being nearly exactly like the species described by IIoeck as C. leenenholii. The description and drawings are given as a basis upon which to distinguish other allied species. The form from the Southeru States originally called ( temuissimus is probably this species, though possibly distinct."

I have quoted our own original descriptions, correcting misprints in the armature of the feet, which was, however, correctly given in the figures. Schmeil's ligure of the armature of the antennit is fanlty in not representing the teeth upon the lamina although the excision is clearly shown.

The form described in the previous edition as (?. oilhomoides Sars, has not been re examined and I am inclined to believe that it is but a small pelagic form or variety of the typical 1 . leucleterti. (yolops oithonoides is essentially a brackish water form and with its variety lyylinc Rehberg, and o. dybouskiii Schmeil, constitutes a very close group whose members are quite variahle and oceur under such conditions as to lead one to suppose that they coustitute a compound specific group whose members have not yet attained their autonomy.

The original deseription of the American form is appended:

"This most interesting species oceurs under peculiar circumstances. It is perhaps the rarest member of the genus, and seems, beyond a doubt, nocturnal in its habits. It was first found by Sars in saline water, and named, on account of its slender form, from the marine Oithonc. A similar species which, though about half as large, is hardly distiuct, was found by Rehberg near Bremen. Rehberg men- 
tions particularly that it was found oftener at night than during the day. In America a similar species was described fron near Paducah, Ky., under the name 1 . temissimus; but the possibility of identity with the Scaudinavian species seemed excluded by the habitat. A gathering taken at night from one of the lakes near Hinneapolis confained a few specimens of similar characters, and there no longer seems to be a doubt of the identity or very close relation between these forms.

"The antenne are longer than described for (: temuissimus, nearly equalling the thorax. The last joint of the anteune is short, but the tootherl character was not noted. The fifth feet are small, the spines are very long and slender. The margins of the abdominal segments are irregularly toothed. The species will be confused with no other. It is marked with blue in spots. Length 0.5 to $1.0 \mathrm{~mm}$."

\section{Cyclops scourfieldi Brady.}

Brady' 91.

It is very diflicult to determine whether we have in this species a variety of 1 : Renclurti or a distinct species. Brady identifies it with Surs" r. leurlerti, which is regarded as distinet from Claus' (t. leuclarti. Schmeil has decided, after examination of Sars' specimens, that they belong to 1 : leurlietiti Claus, and are the same as $($ '. simplex of other anthors. Under these circumstances there would seem to be no reason for hesitating in referring $($. scourfieldi to $r$. leuclarti were it not that the figure of the fourth foot given by Brady differs in armature from that of Schmeil, and Brady fails to remark the striking armature of the last joint of the antenna. If Schmeil is correct in saying that the pearling or crenulation of the posterior margin of the maxilliped is diagnostic of $\because$ Inuliurti, the matter would be settled at once, for braty clearly ligures it. On the whole, we incline to believe that Brady's ligure incorrectly shows a seta where there should be a spine at the apex of the outer ramus of the fourth foot and that he hasoverlookerl the hyaline plate on the antenna. He says, however, " the character which, so far as I know, distinguishes at once $C$ seourfichdi from all other species is the presence, on the second joint of the posterior maxilliped, of a series of short marginal spines." Length 1.4 mm. It maty be added, that, in a figure of what is considered a variety of 1 '. semerfiedli, the armature of the onter ramus is figured as it ocenus in $r$ : lemelierli, while that of the inner ramus is obviously inaccurate.

\section{Cyclops oithomoides Sars.}

Very slunder, thorax twice as long as wide, abdomen narrow, length (")mparen to that of the thorax as 9:13. Stylets about twice as long as wide. strongly divergent, with short setar: the lateral seta near the 
middle of the outer margin, outer terminal seta short, the onter median seta as long as the innermost, inner median a little longer. Antennse long, slender, reaching the middle of the fourth segment,

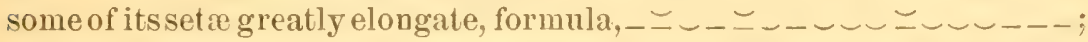
the last two segments have a narrow hyaline membrane which is entire. Armature of fourth feet as follows:

$$
\text { Outer ramus }\left\{\begin{array}{l}
\text { ex. } 2 \text { spines. } \\
\text { ap. } 1 \text { spine, } 1 \text { seta. } \\
\text { in. } 3 \text { setre. }
\end{array}\right.
$$

Fifth foot with short, broad basal joint and an oval elongate apical segment bearing two setie. The receptaculum is elongate, with two curved proximal branches. Length $0.87 \mathrm{~mm}$.

Cyctops dybureslii Laude, which seems hardly a good variety of $c$. oithonoides, is said to differ from it in the following major points: The antennce are shorter and more stout, minute differences occur in the chitin plates which unite the base of the third pair of feet and the lamella of the fifth foot. In fact the differences are less than may be found in any of our species when collected in different stations.

\section{Cyclops bisetosus Rehberg.}

Piate XIIII, Figs. 9-11.

Sars '62 (bicuspidatus); Rehlery '80; Forbes ' 82 (insectus); Herrick '84 (insectus); Schmeil '92.

Cephalothorax depressed, first segment of moderate size, angles of segments rounded. Abdomen long, its length to that of the thorax as $26: 39$. First segment enlarged, as long as the following. Stylets long, lateral seta near the end, small teeth externally and the basal one-fourth, inner and outer terminal sete small, median setie rather loug, the louger as long as the abdomen, the shorter two thirds as long. Antenne 17 jointed, little longer than the first thoracic segment. Fifth foot resembling that of $($. cemmlis, with a small but broad basal joint with a long lateral seta, apical segment with a long seta and short spine. The swimming feet are armed with three spines externally (C. puldellice has but two). Tuength $1.3 \mathrm{~mm}$. As figured by Schmeil, this species differs strongly from r: birmspridulus and is nearex

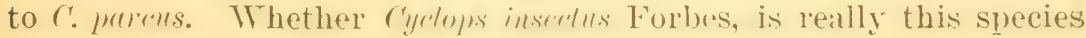
must, in the absence of anthentic specimens, be left open.

\section{Cyclops strenuus Fischer.}

PLATE XXIII, Figs. 12, 13.

Fischer '51; Lilljeborg '53 (quadricornis); Claus '57 and '6:3 (brevicaudatus, and furcifer); Sars '63 (scutifer, abyssorum, aud strenuus); Lubbock '63 (brevicaudatus, and clausii); Fric 'T2 (brevicaudatus); Uljaniu '75 (vicinus, and fedtschenkoi); 
Hoek '78 (brevicandatus); Brady '78 (pulchellus, and strenuus); Herrick '84; Daday' 85 (claudiopolitanus, hungaricus, paradyi, elongatus, and strenuus); Vosseler ' 86 (Iucidulus, bodamicus, and strenuus); Sostaric ' 88 (quadricornis); Thallwitz '90 (lucidulus); Laude '90 (vicinus, and strenuns); Richard '91; Brady '91 (abyssorum, vicinus, and strenuus); Schneil '91 and '92.

This species is said to be one of the most abundant on the continent of Europe and assumes a great variety of forms whose relations are far from clearly understood.

The cephalothorax is large, and the fourth and fifth segments project laterally. 'The ahdomen is five-eighths as long and tapers distally. The stylets are slender, divaricate, longitudinally ridged above and ahout as long as the last three segments of the abdomen. The tro median setie are relatively short, the imner apical being as long as the stylet and twice as long as the inner apical or more. Lateral seta small, not far from the end. The antenua reflexed scarcely reach the base of the third segment. The fifth foot is two jointed, the basal segment being small, nearly cuadrangular and armed with a short ciliate seta. The apical segment is longer, with one long apical seta and a lateral spine. Length 1.5 to $2.5 \mathrm{~mm}$. Schmeil observed a specimen $3.2 \mathrm{~mm}$. long. Schmeil unfortunately places no reliance on the armature of the feet, which, as Marsh also has shown, are of great importance and are fairly constant, and his figures and descriptions help but little in solving the perplexities of this multiform species. In this we are at present the less interested in that the species has not as yet been recognized in America.

Brady gives greater detail and fails to offer valid reasons for sepa-

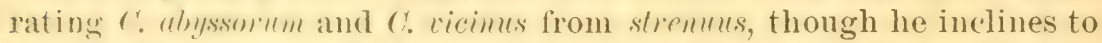
believe $(t$. abyssomm a deep sea variety of $c$. ricimus $=($. pulchellus of his monograph.

The formulie for the feet in abyssorun are as follows:

Finst Foot.

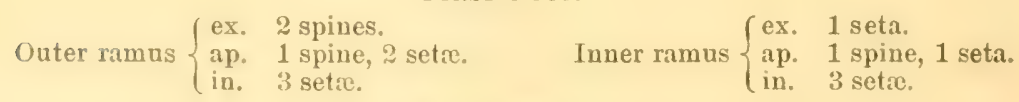

THIRD Fоот.

Juter ramuis $\left\{\begin{array}{l}\text { ex. } 2 \text { spines. } \\ \text { ap. } 1 \text { spine, } 1 \text { seta. } \\ \text { in. } 4 \text { setr. }\end{array}\right.$

Fourth Foot.

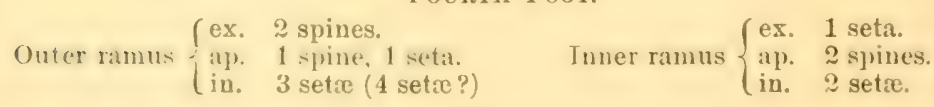

The only difference of importance between the two species seems to be the shorter antenne of $C$. vicimus. 


\section{Cyclops lacustris Sars.}

Cephalothorax sub-ovate, truncate in front. Abdomen of equal width throughout; caudal stylets longer than the last two segments of the abdomen; terminal setc of moderate size, inner three times as long as the outer, internal pair nearly erpul. Antemne as loug as the first two joints of the body. The inner ramus of the fourth foot has the exterior spine very small. Second joint of fifth foot small and external spine minute. Length 1.5 mm. It is suggested by schmeil that this species, with $(!$ scutifer and $r$. abysomm, should be regarded as synonyms for $($. stremmu. T Tpon this matter I can offer no opinion, nor does the brief description repeated above help the matter much.

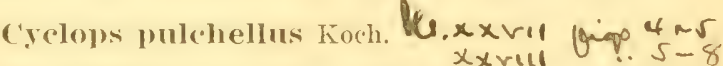

Koch '41; Sars' 57; Claus '57 and '63 (hicuspidatus); Heller '70 (bicuspidatus); Fric

'72 (biesupidatus); Hoek'78 (bicuspidatus); Rehberg' $80^{1}$, and $80^{2}$, (helgolandicus);

Vejdlorsky '8:2; Herrick '83 (pectiuatus); Forbes' '82 (thomasi); Daday' 85 (entzii, and pulchellus); Vosseler '86; Sostaric ' $8 x$; Thallwitz '90; Laude '90); Schmeil '91 and 92 (bicuspidatus); Richard '91 (bicuspidatus); Brady '91 (bicuspidatus, and thomasi); Forbes '91 and '93 (thomasi); Marsh'93.

Schmeil aud Marsh agree in regarding C. thomasi of America as identical with ( $:$ cusphidutus, and in this we are inclined to concur in spite of certain differences in variable characters.

Instead of the original description of Forles, we reproduce that given in the Report on the Invertebrate Finna of the Ielloustone I'ur\%. It is to be noticed that Forbes regarled, in his earlier report, certain spines as apical (in his description of the feet) which may be more logically described as lateral.

A long and slender species, with 17 jointed autemne, oval cephalo. thorax, somewhat closely articulated, slender aldomen, very long and slender cautal rami, and two developed set:e to each ramus, the longer of which is about twice as long as the shorter.

The cephalothorax is midest near the middle, its greatest wilth a little more than half its length. Posterior angles not prominent or produced, except those of the last segment, which are slightly produced ontwards. Sides of the first segment subparallel, rounding slightly toward the front, the segment itself twice as long as the other segments combined; the second sugment shorter than the third, but longer than the fourth; the fifth reduced to a narrow linear band, as seen from ahove, the extremities of which project a little beyoud the lateral outline. Abdomen with furca, a little shorter than the cephalothorax, its greatest width one-fourth of its length, including furca. First segment in the female as long as all the others together, broadest in front, its lateral outlines emarginate behind the anterior angles. Posterior margin of last segment serrate beneath and at sides; 
those of other abdominal segments smooth. Furca as long as the last three segments, the width of the rami about one-seventh of their length. The inner of the two longer setie as long as the entire abdomen, the outer of the two half that length. The outermost of the terminal setie two-thirds the length of the inner, i. e, about onefouth the length of the caudal ramus. Rami slightly curved outwards, with one large spine and a few small ones a little beyond the midlle of the outer surface, and a vertical comb of small spines at one-fourth the distance from the proximal end.

Antennit of the female moderately robust, reaching about to the middle of the third segment, without accessory structures or appendages, the three terminal segments gradually increasing in length, the antepenult two-fifths of the last. The two segments preceding the former, taken together, shorter than the last segment and about equaling the penultimate.

The armature of the swimming feet is as follows:

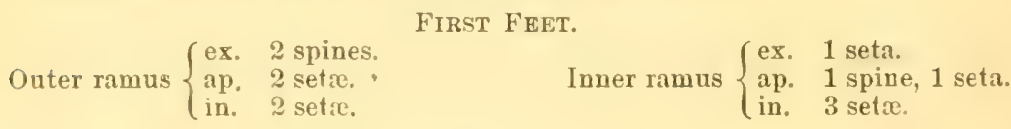

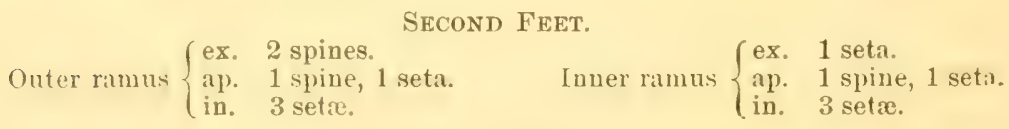

THIRD FeE'T.

Outer ramus $\left\{\begin{array}{l}\text { ex. } 2 \text { spines. } \\ \text { ap. } 1 \text { spine, } 1 \text { seta. } \\ \text { in. } 3 \text { setce. }\end{array} \quad\right.$ Inner ramus $\left\{\begin{array}{l}\text { ex. } 1 \text { seta. } \\ \text { ap. } 1 \text { spine, } 1 \text { seta. } \\ \text { in. } 3 \text { setce. }\end{array}\right.$

Fourti Feet.

Outer ramus $\left\{\begin{array}{l}\text { ex. } 2 \text { spines. } \\ \text { ap. } 1 \text { spine, } 1 \text { seta. } \\ \text { in. } 3 \text { setre. }\end{array}\right.$ Inner ramus $\left\{\begin{array}{l}\text { ex. } 1 \text { seta. } \\ \text { ap. } 2 \text { spines. } \\ \text { in. } 2 \text { setr. }\end{array}\right.$

Fifth pair of leags of two segments, the basal segment about as long as hroat, with a strong plumose spine from the onter angle, the terminal segment eylindriend, twice as long as hroal, with two terminal setit, the guter of which is as long as the seta of the preceding secoment, the inner at little more than hatl the length. Total length, without

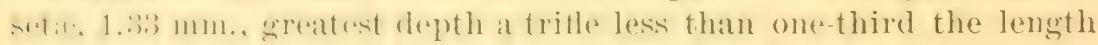
of the cephalothorax. Yellowstone lake, Great Lakes, etc.

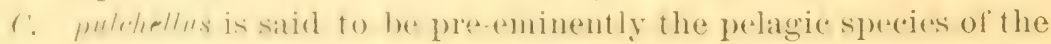
Great Lakes.

*yelops pulchellus var. navus Herrick.

Herrick'82 (C. navus), and '84 (C. pulchellus var. navus); Marsh '93 (C. navus).

This form or variety inhabits shallow pools and is latger than t $^{\text {. }}$ pulchellus. It also has much shorter stylets and differently proportioned antennir, rete. Leength $1.5 \mathrm{~mm}$., thorax $0.9 \mathrm{~mm}$., abdomen 0.6 
mm., stylets $0.14 \mathrm{~mm}$., last two abdominal segments $0.16 \mathrm{~mm}$., antemme $0.7 \mathrm{~mm}$, first segment of body $0.5 \mathrm{~mm}$. The basal segment of the antenne is long and ormamented with several transrerse series of spines; the last two segments are equal aud longer than the preceding. The armature of the first and fourth fect is identical with $C$. thomersi, as is the form of the fomale openings and the fifth fect. The form of the first feet, caudal stylets and other details were correctly figured on Plate $\mathrm{V}$ of the Cyclopide of Minnesota.

specimens of Cyclops muldhellus (thomasi) ware obtainul from a cistern which is supplied solely by raiu-water. The eggs must have been introduced in ice which hat been placed in the cistern at least a jear previously. The cistern is entirely dark, so that these animals must have been deprived of light for many gen "rations. The general color was, of course, very white; the eye spots wer" pale, but present with some pigment aud the lenses. To noticeable alteration in form had resulted.

\section{Cyclops minnilus Forbes.}

Forbes '93.

A small slender speeirs with 17 jointed antenme, with narrow and loosely articulated cephalothorax and salient thoracic angles, sleuder abdomen, long narrow furea, and but two well-dereloped caulal set:e for each ramus. The antemut rach to the posterior margin of the second distinct segment, and are of very nearly the length of the abdomen (excluding the caudal set:e). The greatest width of the thorax is contained two and one thind times in its length, and the furca is very nearly half the length of the remainder of the abdomen. The diameter of a ramus is about one seventh its length.

The rudimentary inner caudal seta is a trible longer than the outer, and about a third the length of the ramus; the longest seta as long as abdomen and furca; the next in length less than hall the longest. The armature of the legs is as follows:

FIRST FEET.

Onter ramus $\left\{\begin{array}{l}\text { ex. } 1 \text { seta. } \\ \text { ap. } 1 \text { spine } 2 \text { setil. } \\ \text { in. } 2 \text { setc. }\end{array}\right.$ Inner ramus $\left\{\begin{array}{l}\text { ex. } 1 \text { seta. } \\ \text { ap. } 1 \text { spine, } 1 \text { seta. } \\ \text { in. } 3 \text { setc. }\end{array}\right.$ SECOND Feet.

Outer ramus $\left\{\begin{array}{l}\text { ex. } 2 \text { spines. } \\ \text { ap. } 1 \text { spine, } 1 \text { seta. } \\ \text { in. } 3 \text { setr. }\end{array}\right.$ Inner ramus $\left\{\begin{array}{l}\text { ex. } 1 \text { seta. } \\ \text { ap. } 1 \text { spine, } 1 \text { seta. } \\ \text { in. } 3 \text { setre. }\end{array}\right.$

Third Feet.

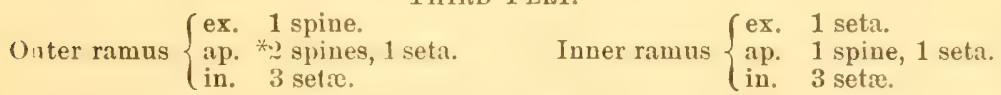

Fourth Feet.

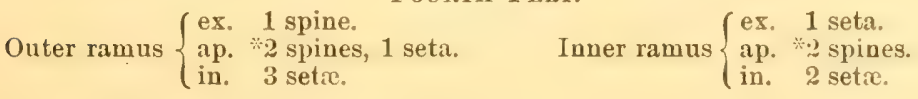

* In each case one spine $t$ wice as long as the other. 
Rudimentary legs of fifth pair distinctly articulated, basal article with a long seta at its outer distal angle, and second article with two setie at its blunt tip, the outer the longer. From Duck lake.

Neither figures nor measurements are given, and the form of the fifth foot is left to conjecture. In this difficult section of the genus it is very hard to place species even when all the details are clearly before us. The original description is reproduced with only verbal alteration for the sake of brevity.

\section{* Cyclops forbesi Herrick.}

Forbes '93 (serratus* ${ }^{*}$ ).

A very long, narrow, loosely articulated species with strikingly salient thoracic angles. (exphalothorax broulest far forward and lobed in front, between the 17 jointed antemna. Abdomen long and slender, with very long and narrow camblal rami, and but two devel. oped setir to each ramus. The first segment is but little longer than wide (eight to seven), is broadest across the middle, and excavate in front at the base of each antenna, leaving a thick, median, projecting lohe. The second segment is nearly a fourth as long as the first, and but little narrower, broadest across its posterior angles, which, though blunt, are so strongly salient that the lateral margins are decidedly simmate. The third segment is as long as the second, but narrower, and with its sides more nearly parallel. The fourth and fifth segments are progressively shorter and uarower, the latter being trapezoidal, as seen from abore, and separated from the first abdominal segment by a deep acute emargination.

The abdominal segments are as long as the cephalothoracic segments two to five taken together, and the furca is as long as the last three segments. The first segment of the abdomen is broalest in front, where its width is nearly as great as its length. The second is as broad as long, the third and fourth equal, the fifth a little shorter, the last with a row of fine spinules around the base of the rami. The wilth of each lamus is contained nearly eight times in its length. Inesiles the lateral spine, situated a little before the posterior third of the rannus. there is a cluster of two or three minute spines at its anterior fimth. The outer and inmer terminal setir are reeluced to short suberual spines about twice as long as the ramus is wide. The other setir are sember, plumose, the immer nearly twiee as long as the outer. The anternit alle rather stout and short, 17 -jointed, reaching to the end of the serend sexment. They are without special structures or appentages. [This probably means armed as usual, but without knife ridges or spurs.] Armature of the legs as follows:

* This name is preoccupied by C. serratus Pratz. 1866. 
First Feet.

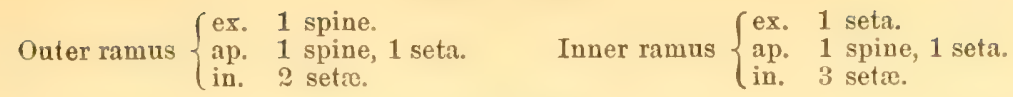

SECuND FEeT.

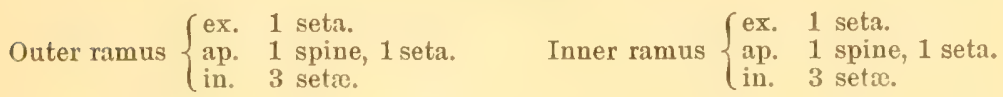

Third FeEt.

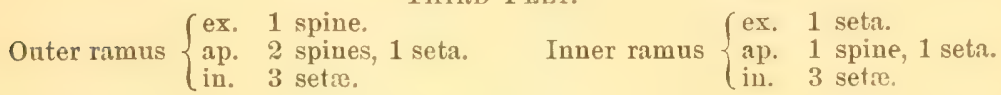

Fourth Feet.

Outer ramus $\left\{\begin{array}{l}\text { ex. } 1 \text { spine. } \\ \text { ap. } 2 \text { spines, } 1 \text { seta. } \\ \text { in. } 3 \text { setre. }\end{array}\right.$ Inner ramus $\left\{\begin{array}{l}\text { ex. } 1 \text { seta. } \\ \text { ap. } 2 \text { spines. } \\ \text { in. } 2 \text { setr. }\end{array}\right.$

The fifth feet are two-jointer, the hasal joint broad, quadrate, with a seta at its onter angle; the second cylindrical, with one long and one short seta at tip. Length, without setæe, $1.34 \mathrm{~mm}$.

\section{*Cyclops signatus Koch.}

Plates XX, Figs. 8-11, 21; XXI, Fig. 16.

Jurine '20 (monoculus quadricornis albidus and $\mathrm{m}$. g. fuscus); Koch ' $\$ 1$ (signatus, and annulicornis); Baird '50 (quadricornis var. b and var. c); Claus '57 and '63 (coronatus and tenuicoruis); Sars '63 (anuulicornis, tenuicornis, aud signatus); Lubbock '63 (coronatus, and tenuicoruis); Fric ' $\% 2$ (coronatus, and tenuicornis); Poggenpol '74 (clausii); Uljanin '75; Hoek '78 (coronatus, and signatus) Brady '78 (tenuicornis, aud siguatus); Cragin ' 83 (tenuicornis, and C. siguatus faseiacornis); Herrick '82 and '84 (tenuicornis); Daday' 85 (tenuicornis, and signatus); Vosseler '86 (tenuicornis, and signatus); Forbes ' 87 (gyrinus); Sostaric '88 (fuscus); Thallwitz '90; Lande '90; Schmeil '91 (allidus); Brady '91 ; Richard '91 (fuscus, annulicornis, and tenuicornis); Schmeil '92 (fuscus, and albidus); Marsh '92; Turner '92 (tenuicornis).

Of the identity of the two varieties which have so long been recosnized as distinct species ( ${ }^{\prime}$. temnicomis and $r$. commatus) the writer has little doubt. The development history has been traced sufficiently to settle this point. This combination was first made by the writer, and not by Brady, as Marsh implies. Cephalothorax large and hroad, considerably longer than the aldomen. First thoracic segment large, more than half as long as the whole thorax. Abdomen rather short, cylindrical. Stylets short and not tapering, shorter than the precoling ablominal segment. Seta very plumose, three of them long, the lougest being about as long as the abiomen, the innermost being nearly half as long and the outermost apical seta short. In the male the first thoracic is much longer and the abdomen relatively shorter. Antenne long and the terminal joints attenuated, the last three being armed by hyaline plates. Fourth foot with the following armature: 


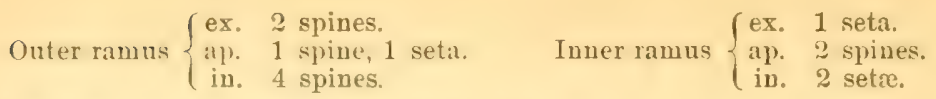

The spines are serrulate and the setir very plumose. Fifth foot two-jointed, hasal joint longer than wide, with a series of small teeth and a long seta, apical joint with three plumose setie. Color bluish or banded, the antennic especially banded on the fifth to sixth and twelfth to fourteenth joints.

\section{Crclops siguatus var. coronatus.}

Plate XV, Figs. 1-4.

First segment of thorax long, its length to that of the entire thorax about as $1: 1.50$. Last segment of antenne with the proximal portion of its hyaline plate coarsely serrate. Caudal stylets short, ciliated interually, length to width as $1.25: 1$. Second segment of antenumles short. Inner apical seta of stylets one-third longer. Color marked.

\section{* Cyclops signatus var. tenuicornis. \\ Plates XV, Figs. 5-7; XX, Figs. 1-7; XXXIII, Figs. 1, 2.}

Finst segment of thorax shorter, its length to that of the entire thorax as $1: 1.9$. List segment of antenna with unserrated lamella. Caudal stylets longer. length to width as 2.1:1, inner aspect not riliated. (Juter apical seta half as long as inner. Fecond segment of antenumles longer. Color variable but always bauded or splotehed. It is also generally true that the ovisacs in the present variets are more strongly divaricate than in the variety coronatus.

sehmeil alio finds differences in the form of the receptaculum and sexual elements.

(T)er against the above differences must be set the close agreement in the armature of the feet and the fact that the late stages of coromotus remain to be deseribed while it is always associated with e trmeirmenis, generally in gereater number's. The greater hairiness and stronger serrations of $1:$ amomulus are characters suggestive of advanced age, as has beron observed in other species. C. tenuiromis is frequently finund without $1:$ aromalus, but the reverse has not been found true in our experience. Finally attempts at experimental rearing of cormatus from temuicomis have been made, and, while some possible sources of error unfortunately crept in, yet I am morally convinced that the apparent transformation was genuine.

I)r. Schmeil discusses this question at length without adding anything to the evidence. It adduces the differences in structure, though he fails to find anything but such as consist in altered proportions of structures common to both. Ife claims that embryos of 
(. cormutus. are "allgemein bekannt," though adding that Rehbergadmits that the yonng of the two species cannot be distinguished until the last moult, which seems to show that the late larrar of $($ ' commutus are hardly "allgemein bekannt" even in Europe. Finally Schmeil denies the possibility of sexual precosity with the general statement that "Auch mir ist trot\% der grössten Aufmerksamkeit unter deu vielen Tausenden der vou nir beobachteten Copepoden noch nicht ein einziges Hal eine solche Larve mit Eiballen zu Ciesicht gekommen." To this we can only say that such larrit have been frequently seen during the last ten years, though only under certain conditions of time and place. It is hoped to furnish conclusive evidence ou this head suon if it is really needed. We had supposed that such precosity was now a well-recognized fact. It is to be hoped that careful embryologieal and biological studies may be instituted upon the copepredu.

\section{Cylcops languidus Sars.}

Plate XVII, Figs. 10, 11.

Sars '63; Herrick '84; Schmeil'91 and '92; Richard '91.

This species has not yet been encountered in America, and from the extended discussion of shmeil we still think there is considerable probability that this form is an illustration of retarded derelopment of some 17-jointed species, perhaps C. bicuspidatus.

Cephalothorax attenuated anteriorly and posteriorly, narrow. Abdomen sleuder. Stylets exceeding in length the two preceding segments. Lateral seta at two-thirds the length from the base, two median setie long, two lateral apieal setie very short, the outer a serrate spine.

Antenute slightly longer than the first segment, with short seta. 16-jointed by the more or less complete fusion of the third and fourth segments. First feet with both rami two-jointed, formula:

$$
\text { Outer ramus }\left\{\begin{array} { l } 
{ \text { ex. } 3 \text { spines. } } \\
{ \text { ap. } 2 \text { setre. } } \\
{ \text { in. } 3 \text { setre. } }
\end{array} \quad \text { Inner ramus } \left\{\begin{array}{l}
\text { ex. } 1 \text { seta. } \\
\text { ap. } 1 \text { spine, } 1 \text { seta. } \\
\text { in. } 3 \text { setre. }
\end{array}\right.\right.
$$

Second foot with a three-jointed outer and two-jointed inner ramus. Formula as follows:

$$
\text { Outer ramus }\left\{\begin{array} { l } 
{ \text { ex. } 2 \text { spines. } } \\
{ \text { ap. } 1 \text { spine, } 1 \text { seta. } } \\
{ \text { in. } 3 \text { setre. } }
\end{array} \quad \text { Inner ramus } \left\{\begin{array}{l}
\text { ex. } 1 \text { seta. } \\
\text { ap. } 1 \text { spine, } 1 \text { seta. } \\
\text { in. } 4 \text { setr. }
\end{array}\right.\right.
$$

NoTk.-The following measurements will serve to illustrate the usual proportions of variety tenuicornis: Total length, including stylets, $1.4 \mathrm{~mm}$, first segment of thorax $0.5 \mathrm{~mm}$., whole thorax 0.85 mm., abdomen $0.52 \mathrm{~mm}$. , stylets $0.10 \mathrm{~mm}$., antenuæ $0.85 \mathrm{~mm}$, last joint of antenne $0.05 \mathrm{~mm}$., longest caudal seta $0.55 \mathrm{~mm}$., inner set a $0.30 \mathrm{~mm}$.

The corresponding measurements of $C$. curonatus are the following: Total length $1.66 \mathrm{~mm}$, first segment $0.67 \mathrm{~mm}$., entire thorax $1.12 \mathrm{~mm}$., sbdomen $0.54 \mathrm{~mm}$., stylets $0.07 \mathrm{~mm}$., longest seta 0.6 mm., inner seta $0.3 \mathrm{~mm}$., antennæ $0.95 \mathrm{~mm}$. 
As rery strong evidence of our observation of the occurrence of sexual adults with larval characters may be noted a statement of Schmeil himself, who nevertheless seems to be so given to his theory as to be quite unable to see its bearing. He says: "Nicht unerwähnt soll bleiben, dass zwischen den exemplaren dieser art, welche den Tümpeln des Brockengipfels entstammten, sich eine A nzah] Männchen vorlanden, bei welchen simtliche Aeste der Schwimmfüsse aus je drei Segmenten bestanden. Dieser Fall ist desshalb besonders interessant, weil hier ein Fortschreiten nach Vervollkommmung im Kürperbau eines Tieres direct zu konstantiren ist." The writer is obliged to confess that he cannot understand why it is not more natural to regard the two-jointed condition (which is common to all larrie) as a retarded or atavistic state, from which the species tends to escape toward the norm under farorable condition, than to postulate an exceptional specific norm (which in this case is confessedly unstable), and assume that from some cause, utterly unknown to us, the form tends to "proceed to a greater completeness in structure." The "greater completion" or realizing of its ideal--."Vervollkommnung" -implies that it is incomplete or has failed to attain its specific possibilities, unless, indeed, the generic characters have for Schmeil a sort of metaphysical cogency or power over its members apart from its heredity. The same considerations apply to the antenne. The fifth feet are as in 1 . bicuspidutus. The form of the receptaculum is much relied on to differentiate this form, but is admitted to vary within wide limits. Length 0.86 to $1.1 \mathrm{~mm}$. MLotions slow.

* Cyclops modestus Herrick.

Plate XXI, Figs. 1-5.

Herrick' 83 and '84; Marsh '92.

This small spereies, $1.0 \mathrm{~mm}$. long, was first recognized in cullman comint 5 . Ala, but oceurs also in our lakes. 'The color varies, but very characteristic is the peeuliar shining or glateous surface of the strongly arched thoracic shield and the evenly curved segments of the ahdomen. The antennir reach but little beyond the rery long first segment: they are usually 16 jointed, but I have notes of a similar form in which the antemnit are 17 -jointed. The leet are all three-jointed and armed as follows:
Outer ranu $\left\{\begin{array}{l}\text { ex. } 3 \text { spines. Fir } \\ \text { ap. } 1 \text { spine, } 1 \text { seta. } \\ \text { in. } 3 \text { setre. }\end{array}\right.$
Inner ramus $\left\{\begin{array}{l}\text { ex. } 1 \text { seta. } \\ \text { ap. } 2 \text { spines, } 1 \text { seta. } \\ \text { in. } 2 \text { setx. }\end{array}\right.$
()uter ramus (ex. 3 spines.
(a). 1 spine, 1 seta.
in. 4 setre.
Inner ramus $\left\{\begin{array}{l}\text { ex. } 1 \text { seta. } \\ \text { ap. } 2 \text { spines. } \\ \text { in. } 1 \text { spine, }\end{array}\right.$
SECOND Foot. 
THIRD FOOT.

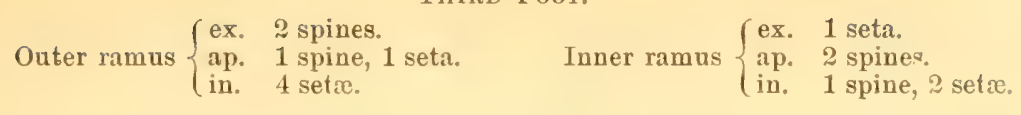
Fourth Foot.

Outer ramus $\left\{\begin{array}{l}\text { ex. } 2 \text { spines. } \\ \text { ap. } 1 \text { spine, } 1 \text { seta. } \\ i n .4 \text { setæ. }\end{array}\right.$ Inner ramus $\begin{cases}\text { ex. } & 1 \text { seta. } \\ \text { ap. } & 2 \text { spines. } \\ i n . & 2 \text { seta. }\end{cases}$

The fifth foot is obsenrely three.jointed, the second joint bearing a short spine and the terminal joint two spines of varying length. The caudal stylets are once and a half as long as the last segment, and are peculiarly excavated for more than the caudal one third, beginning at the point where the lateral spine is situated. The outer apical seta is short, the median setie are rather short while the inner seta is nearly as long as the onter median. All these setio are pectinate. The receptaculum seminis is elongate oval. The antenna of the male is divisible into five regions, the third heing formed by the thickening and union of four or more segments. Color violet or purplish red.

* Cyclops capilliferus Forbes.

Plates VI, Fig. 13; XXVIII, Figs. 1-4.

Forbes '93.

This is a symmetrical, compact cyctops, with the cephalothorax closely articulated, widest in the middle, and the sides regularly conrex, with the abdomen narrow and slender, with three well dereloped caudal setre, and 16 jointed autemne bearing several very long setie.

The abdomen, with caudal furca, is contained a little less than twice in the cephalothorax, and the brealth of the latter is just half its length. First segment very long, five times the length of the second; second and third equal; the fourth very short, on the median line semicircularly excavate behind. The abdominal segments in the female diminish regularly in length from first to last. The caudal rami are twice the length of the last segment aud one fourth as broad as long. The lateral seta is placed a trifte beyond the middle of the ramus; the onter terminal seta is a short, naked spine; the other three well developed and plumose. The inner and outer of these are of nearly equal length, the latter a little longer, the middle one much the longest one of the group. Antenna moderate, reaching about to the middle of the second segment of the cephalothorax. Sixteenjointed in all adult females, and further especially distinguished by the presence of very long flexible sete upon the first, third, tenth and fourteenth segments. Terminal setu likewise very long. The seta borne by the first segment extends to the twelfth; that of the third reaches to the fourteenth; that upon the tenth segment extends to the 
tip of the antenua, and that upon the fourteenth far beyond it. The first segment is as long as the two following, and rery nearly twice as long as wide. The second is very short, its length one fourth its width, and the length and width of the third are equal Of the three terminal segments the penultimate is longest, being twice as long as broal: the antepenult two thirds the length of the following: the last is about as wide as long. The armature of the legs is as follows:

First Feet.

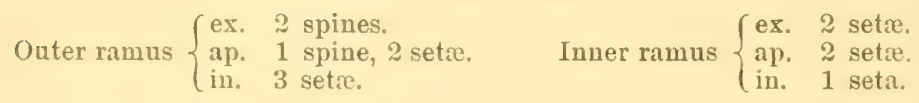

SECOND FEET.

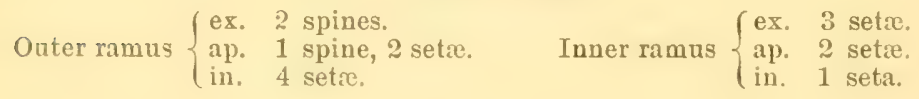

THIRd FeET.

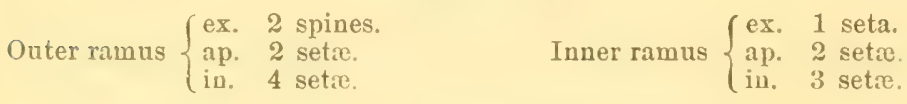

Fourth Feet.

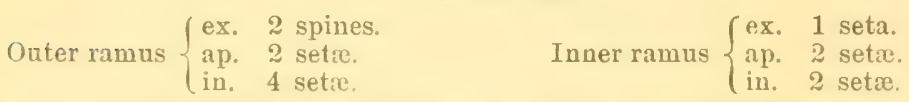

The fifth feet are two jointed, the terminal joint with one long and one short seta at tip): the basal joint with one long seta without. I.ngth without setat 1.2 nm. Grebe lake, Iellowstone Park.

\section{* Cyclops insignis Claus.}

Plates XXII, Figs. 11-14; XXIII, Figs. 6, 7.

Claus '57 and '63; Sars '63; Fric '72; Braly '6r (lubhockii) and '78 and '91; Rehberg '80; Herrick '84; Richard '91; Schmeil '91 and '92.

Schmeil has douldfully identified ('. Inblowdii Brady with the brack-

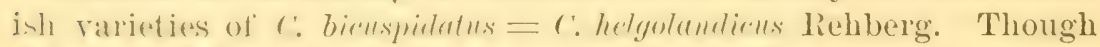
the names are griven in the synomomy above, it is with the understancling that they at least constitute a distinct variety.

The typical form has an alliptical cephalothorax, the first segment being more than half as long as the remainder. The abdomen is relatively short and its first segment greatly expanded. The stylets are rerg long. fully half as long as the rest of the abdomen, and are longiturlinally ridged as in $r$. strenums. The lateral apical seter are short, white the median ones are long and more nearly equal than usual. Antenne 14-jointed, not much longer than the first segment of thorax, similar to $C$ strenum.s. Fifth foot exactly as in $1:$ stremuns. Length 2.5 to $5.0 \mathrm{~mm}$. 
In the previous edition it was suggested that this is but an atavistic

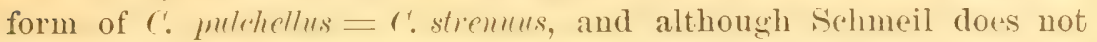
accept this suggestion, he adds strong probability to it by noticing that the eighth joint of the antenne show indications of subdivision and have the armature reyuisite to correspond with $r$. stremus after such division. Against the suggestion he urges, (1) that this form is not simply found in scattered individuals but in large groups; (2) that there seems no sufficient reason for such suppression; (3) that the animal is often very large, and we should therefore expect it to attain its full development. To these it must be replied (1) that it is rery common for copeporls of a given stage to be associated almost to the exclusion of others, thus the net will sometimes bring in from a given locality almost solely half grown Jiontomi where on a previous risit adults preponderated; (2) that we kuow too little of the biology of these animals to plead our ignorance as a reason for rejecting what is anatomically probable; (3) rapid increase in size (unusually rank nutrition) may be just a condition for retardation of development, as it often is in other groups of crustacea. Questions of this nature demand careful and continuous observation and experiment, and should not be arbitrarily closed by a priori arguments.

Respecting C. Inblurlii Brady, whether it should be considered an ataristic form of $(\vdots$ strenums or of $r$. hirmspidalus is difficult to say. Its brackish habitat speaks strongly in favor of its not being a distinct or permanent species. The short first thoracic segment and antenub incline me to ally it to the latter species. Specimens sent me by Mr. E. A. Congdon of Columbia c 'ollege. from Long Island, seemed identical with C. lubluorlii Brady, and if this form eamnot be brought into relation to a 17 .jointed species. Brady's earlier name should be revived. It must be observed, howerer, that the American specimens Were within direct influence of the sea.

\section{* Cyclops serrulatus Fischer.}

Plates XV, Figs. 8-11; XIX, 2-5; XXVI, Fig. 10; XXIX, Figs, 17-19.

Fischer '51; Lilljeborg '53; Claus '5t and '6:3; Sars '63; Lubbork '6:3; Heller '70; Fric '72; Hoek ' 78 ; Brady '78 (serrulatus var. Inontanus, and serrulatus); Uljanin '75; Herrick'82, and '84 (serrulatus var. elegans, and serrulatus); Rehberg' 80 (agilis); Cragrin '8:3 (pectinifer); Daday ' -5 ' (agilis); Sostaric 'ro (agilis); Thallwitz '90 (agilis); Lande '90 (agilis); Richard '91; Schmeil '91 and '92; Marsh. '92; Turner' 92.

The commonest and most abundant species of the Eastern States.

Cephalothorax oval, compact. Abdomen slender and ahout threefourths as long as the thorax, cylindrical, suddenly enlarged hefore its union with the thorax. Antenuc slender, reaching nearly to the 
cephalic margin of the last thoracic segment, tending to assume during life the form of a rude $Z$, the proximal four joints forming the base; the last three joints are slender and elongate and are each armed with a hyaline plate. Antennules small, reaching about the sixth joint of the antenne?. Jars small, with large teeth. Caudal stylets over four times as long as wide, nearly as long as the last two abdominal segments, serrate down the outer margin. Outer apical seta changed to a very strong and serrate spine, inner seta weak, onter median seta over two-thirds as long as the inner. Formula for the armature of the feet as follows:
FIRST FEET.
Outer ramus $\begin{cases}\text { ex. } & 3 \text { spines. } \\ \text { ap. } & 2 \text { set:e. } \\ \text { in. } & 3 \text { setre. }\end{cases}$

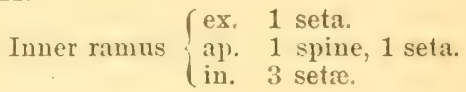
Shcond AND Third FeEt.
Outer ramus $\left\{\begin{array}{l}\text { ex. } 3 \text { spines. } \\ a p .1 \text { spine, } 1 \text { seta. } \\ \text { in. } 4 \text { setro. }\end{array}\right.$ Inner ramus $\left\{\begin{array}{l}\text { ex. } 1 \text { spine. } \\ \text { ap. } 1 \text { spine, } 1 \text { seta. } \\ \text { in. } 3 \text { seto. }\end{array}\right.$

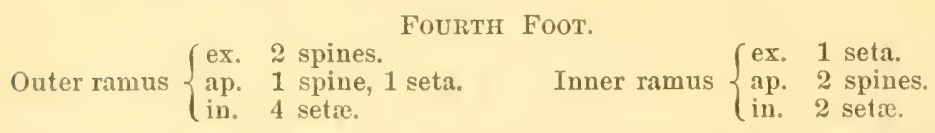

The spines of the feet are strongly serrate and the setie fully pectinate. The fifth foot is one-jointed, having one very strong serrated spine, an apical seta and a longer inner seta. The adjacent margins of the fifth segment are serrate. Lgg sacs oval, as long as the abdomen, divaricate. Lggs few, dark. Length inclusive of stylets 1.5 mun. thorax $0.62 \mathrm{~mm}$., first segment $0.32 \mathrm{~mm}$., abdomen $0.42 \mathrm{~mm}$., stylets 1.11 mm., longest seta $5.0 \mathrm{~mm}$, antennar $0.5 \mathrm{~mm}$. Color rather opayue. A pelagic form or variety has been distinguished, but it must not be confused with var. montanus of Brady.

\section{* Cyclops serrulatus var. elegans Herrick.}

I)istingnished from the type by the greater size, and the elongation of antemnir and caudal stylets. We will first of all give the measurements which afford a criterion for judging of the form and proportions.

Total length $1.34 \mathrm{~mm}$, thorax $0.76 \mathrm{~mm}$, abdomen $(0.40 \mathrm{~mm}$., stylets 1). Is mun. greatest width $0.12 \mathrm{~mm}$., inner median caludal seta 0.60 mm., onter median seta $0.36 \mathrm{~mm}$. innere setal $0.08 \mathrm{~mm}$. The first segment of the thorax is long proportionally $(0.40 \mathrm{~mm}$. ). The antenter are very long, reateding beyond the base of the third segment (0.68 mm.). The regr-sats are rongate-oral, being more slender even than in typi(al Castulutus; in the animal measured they were $0.50 \mathrm{~mm}$. long by $0.19 \mathrm{~mm}$. wide. The caudal stylets are slightly longer than the last two segments of the abdomen. The antennules are very short, and 
each joint has its series of fine teeth. The fre'e lower margins of the thorax are ornamented with series of prominences, while the last segment is extended into a blunt angle bearing long teeth. The last segment of the abdomen is spiny-margined and is ormamented with a double row of spines at the anus. The armature of the stylets as well as that of the feet is identical with that in typical C. serrulutus. The last two joints of the antenu: measure $0.1 \mathrm{~mm}$. each, while the two previous measure unitedly $0.12 \mathrm{~mm}$. 'The color is not oparue as in the smaller form usually. Prauly's var. montemus has shorter stylets than the type, but se'ms nearest the small dark form found in peaty waters in America. (yyrops pectinife. Cragin has no distinctive points, it being typical $C$. serrulatus.

Marsh also fiuds this varicty rarely elsewhere than in pelagic localities, and only in occasional association with the type. Schmeil notes discrepancies in the original measurements of the two forms, and is led to doubt their distinctuess. It can only be replied that the distiuctions insisted on do actually (xist, and are very apparent wheu the forms are before one, and are sufficiently obvious from the measure. ments given above.

\section{Cyclops macrurus Sars.}

Sars '63; Uljanin '74 (alajeusis); Brady '78; Rehberg '80; Sostaric '80; Herrick '84; Vosseler '89; Lande '90; Richard '91; Schmeil '91 and '92.

This form is so close to $r$. semulutus as to suggest the question whether it is more than a rell-marked variety. From that species it differs in the shorter antemna which are hardly longer than the first segment, the slender, smooth ablomen, and the greatly elongated stylets, which lack the lateral line of teeth. The feet and the proportional length of the joints of the antenna are as in sermlutus. The species occurs in Scandinavia and Germany, but rarely.

Cyclops prasinus Fischer.

Jurine '20; Fischer '60; Vernet '71 (lougicornis); Vosseler '86 (pentagonus); Richard 's7 (pentagonus var. vichyensis) and'91 (pentagouus); '́chmeil '91 (pentagonus) and' 92.

Cephalothorax hroad. attentated behind. Ablomen slender, nearly cylindrical. Stylets one and one-half as long as last abdominal segment. Lateral seta a little distad of the middle. Onter apical seta forming a strong spine and about as long as the inner slender seta. Longest seta four times the length of the stylet, shorter median seta three-fourths as long. Antenna reaching the end of third thoracic segment, proportions and armature as in r! sermulutus. Fiftl foot one-jointed, closely resembling that of (:. sermlutus, but the exterual seta is delicate and not a strong, heavy spine. Ova few, appressed. Length 0.8 to $0.9 \mathrm{~mm}$. Color green. 
Cyclops fluviatilis Herrick.

Plates XXVI, Figs. 1-8; XXX, Fig. 1.

Herrick '52, '84 amd '87; Cragin '\$3 (magnoctarus); Braly '91 (maguoctarus); 'Turner '92; Marsh '93.

This small species, lirst describud in America, has been encountered by liady in Great Britain, though he chooses to make the comparison to calmidn of the original description a reason for adopting a sulseguent name. It is one of the most abundant forms in many of our lakes and their outlets. In its smaller age form it is barely visi. ble to the "ye. while the larger and particularly the highly colored contition is conspicnous especially by reason of its rapicl motions. In appearance it reminds one of Cyclopsina gracitis.

The borly is slender, the cephalothorax being elongate, oval, with its first segment very long. In a specimen measuring $0.57 \mathrm{~mm}$. to the end of the stylets, the following proportions were noted: First segment of thorax $0.22 \mathrm{~mm}$., secoud and third segments each 0.056 , fourth 0.032 , total length of abdomen 0.17 , stylets 0.032 , longest seta 0.128 , outer median $0.10 \mathrm{~mm}$. The antenne are nearly as long as the whole thorax, and are remarkable for the elongation of the serenth to ninth segments. There are elongated setieupon the first and fourth segments. The last joint of the antenuse is slightly curved and carried at an angle to its predecessor during life, giving it the appearance of being hinged. It has also the rudiment of a kuife ridge. The antennules are slunder and alongate. The labrum has about twelre small teeth. The maxillat have the usual form. The fert are peculiar in the rxceedingly long seta. The armature of the apical segments is as follows:

First Foot.

\begin{tabular}{|c|c|c|c|c|}
\hline Outer ramus & $\left\{\begin{array}{l}\text { ex. } \\
\text { ap. } \\
\text { in. }\end{array}\right.$ & $\begin{array}{l}3 \text { spines. } \\
2 \text { setre. } \\
3 \text { setre. }\end{array}$ & Inner ramus & $\left\{\begin{array}{l}\text { ex. } \\
\text { ap. } \\
\text { in. }\end{array}\right.$ \\
\hline Outer ramus & $\left\{\begin{array}{l}\text { ap. } \\
\text { in. }\end{array}\right.$ & $\begin{array}{l}\quad \text { SECOND ANI } \\
3 \text { spines. } \\
1 \text { spine, } 1 \text { seta. } \\
4 \text { setr. }\end{array}$ & $\begin{array}{l}\text { ThitRD FFet. } \\
\text { Inner ramus }\end{array}$ & $\left\{\begin{array}{l}\text { ex. } \\
\text { ap. } \\
\text { in. }\end{array}\right.$ \\
\hline
\end{tabular}

FourtI Foot.

Outer ramus $\left\{\begin{array}{l}\text { ex. } 2 \text { spines. } \\ \text { ap. } 1 \text { spine, } 1 \text { seta. } \\ \text { in. } 4 \text { setre. }\end{array}\right.$

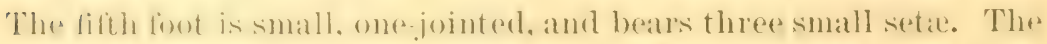
alolomon is slombre, thomgh rather short. The stylets are three times as lome as broand. The onter of the truminal setae is a short spine,

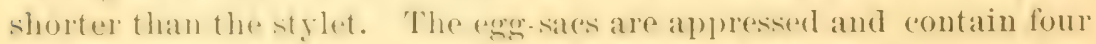
or five ova in the list state amd a few more in the aclult. The two 
dimorphic states are very distiuct and seem, in part at least, to bo governed by habitat. The colors are frequently brilliant, varying from deep indigo to greenish brown. 'The coloring matter is some. what irregularly distributed but is most persistent butween the bases of the leet, in the last segment of the abdomen and in the last joints of the antenna.

The full-grown female measures ahout 0.70 mm., the males heing more slender. Oviferous lemales often have the fourth pair of feet. with two-jointed rami. American anthors find the species pelasic, and Brady, though he found it in ditches immediately connected with large sheets of water.

Marsh notes that there is a resemblance between this species and C. pentugumus Vosseler.

\section{Cyclops capillatus Sars.}

"Cephalothorax sub.ovate; anteriorly uniformly rounded; segments projectiug somewhat laterally, the last being scarcely wider than the first abdominal segment. Abdomen attenuated posteriorly; caudal rami almost as long as the last three abolominal segmeuts, hardly divergent; the external and internal apical setie short aud nearly equal, the interior of the median sete as long as the ablomen, lateral seta about in the midale of the stylet. Intennie of the first pair robust, slightly exceeding the first segment of the body when reHexed, with the twelve joints densely covered with long aud divergent hairs. 'The last joint of the outer rami of' swimming feet are elongated and armed externally with three spines, internally with four setar; the interior apical spine of the interior rami of the fourth pair of feet longer than the exterior. Feet of the fifth pair large, with a large and thick basal segment and a small oval second joint bearing one long seta and a short spine. Orisaes small, narow and divergent. Eye very small. Length nearly $2.0 \mathrm{~mm}$."'

Very close to $C$. viridis in many points. Found only in Scandinavia.

\section{Cyclops crassicaudis Sars.}

Cephalothorax elongate-ovate; segments produced laterally, especially the last. which extends into a somewhat procurved process. Abdomen short and thick, first serment somewhat excavated: caudal rami equaling the last two segments of the ablomen. External apical seta longer than the introual, both short; median seta long. Antenne of the first pair 12-jointed, scarcely longer than the first segment. Swimming feet short and thick, spines and setit short; the interior apical spine of the last joint of the inner ramus of the fourth 
foot almost twice as long as the exterior spine. Terminal joint of the fifth foot small, amed with a spine and a seta; seta of the hasal segment short. Orisacs oral, somewhat divergent. Length $0.75 \mathrm{~mm}$.

Found only in Scandinavia.

\section{* Cyclops varicans Sars.}

Plates XIX, Figs. 12 AND 13; XXX, Figs. 2-8.

Sars '63; Uljanin '75 (orientalis); Lande '90; Schmeil '91 and 92.

Thu Imerican form which approaches nearest to this species differs liom it apparently in proportions. Unhappily we have only gathered the species once ant our information depends on the camera drawings taken at that time. Rather slender, especially the abdomen which is nearly as long as the cephalothorax. First abdominal segmrnt vers long, as long as the rest of the ablourn. Stylets over twice as long as wide, lateral spine one third from the apex, onter lateral spine shorter than inner seta, median setre rather long, onter two-thirels as long as inmer, inuer three-fourths as long as ahdomen. Antemnic shorter than the first thoracic segment, 12 -jointed, formula

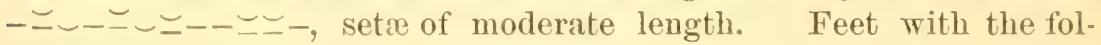
lowing formula:

\section{First Feet.}

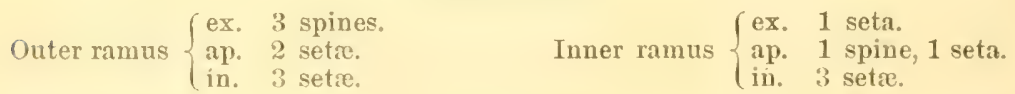

FoURTH Foot.

Outer ramus $\left\{\begin{array}{l}\text { ex. } 3 \text { spines. } \\ \text { ap. } 1 \text { spine, } 1 \text { seta. } \\ \text { in. } 4 \text { setre. }\end{array}\right.$

Respeseting the fondth foot it is plain that the last joint is homologmento two fused segments, and that the separation might take place at the next moult.

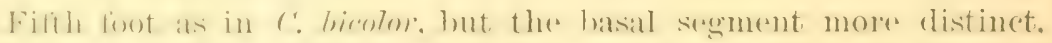

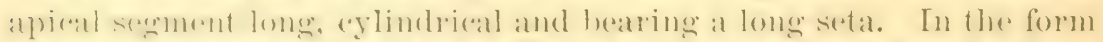

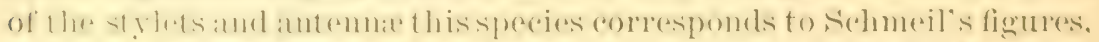

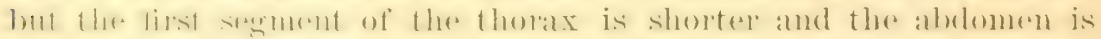

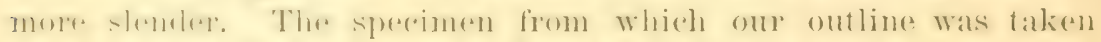

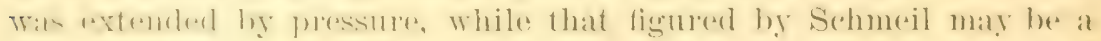

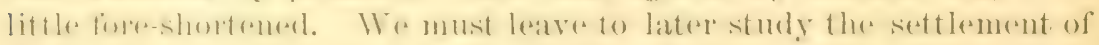
the purstions. as also that of the relation between this and the mext.

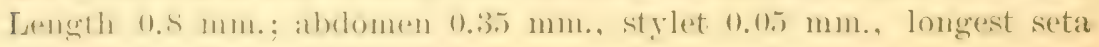
$0.28 \mathrm{~mm}$. , antennie 0.23 . 
Cyclops gracilis Lilljeborg.

Plate XIX, Figs. 10, 11.

Lilljeborg '53; Schmeil '91 (diaphanus), and '92.

Apparently this is a clistinct species, chameterized by the slender form, especially of the abdomen, which is to the thorax as 5:7, divergent eylindrical stylets, short sete and form of the fifth foot and receptaculum. The antenve are slender, reaching the caudal border of the fouth segment, and are of the form of the 12.jointerl species; formula - - - ニ-ニニニ. Fifth foot with a broad basal segment and a erliudrieal terminal one, which bears a short spine and a loug seta. Eggs few. Feet all two jointerl. schmeil speaks of the fifth foot as one-jointed, but the fact that the basal segment is immovably soldered to the body should not prevent us from recoguizing its existence. This species has been found only in sweden, I'oland and Germany.

\section{Cyclops diaphanus Fischer.}

Plate XIX, Figs. 6-9.

Fischer '5:3; Claus '63 (minutus); Heller '6:' (minutus); Daday '855 (f'riraldszkyi); Sostaric '88; Schmeil '92.

The above synowomy is derived from schmeil's monograph, which can hardly be considered very authoritative since its author never saw the species and offers only comparative data to discriminate this species from the last. Abdomen broader than 1 ' lrimolor, stylets as long as the two preceding segments. lateral seta nearer the base than the encl. The lateral apieal setere short. equal, median setie as "2: 3 . Antenue 11 -jointed, short, only reaching the second segment. Swimming feet with two-jointed rami. Fifih foot with a short spine and long seta at the end of the cylindrical apical joint.

* Cyclops aflinis Sars

PLATE XXX, Figs. 9.11.

Sars '63; Uljanin '75; Brady '78; Rehberg '80 (pygmæus); Daday '855' (pygmaus, and affinis); Herrick '84; Vosseler '86; Lande '90; Richard '91; Brady '91; Schmeil'91 and '92.

Schmoil makes the statement that "Irarrick regands ('. mlinis ats

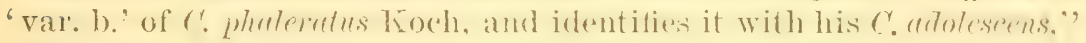
overlooking the platin statenent that "it is imposible to suflicientiy identify it [the American form] with any of the abore." and the finct that Sars" description was appended in a separate rubric. Sohmeil devotes considerable time to the relations of ('. adolesens and is not unmaturally provoked by the incomsistencies in the two references, which are explained, however, hy two provoking typographical errors 
which were both beyond the writer"s control. The first was the displacement of a line in the tabulated list of species in the Alabama erustacea, by means of which the figure of $r$. pheterotus was referred fo 1 . fimlwiulus and the error then repeated in the making up of the deseription of plates; sreond, in the Final Report, ['late 24, in Fig. 15 the printer has set $C$. adolexens one line too soon, making the figure of the receptaculum of $r$. purens refer to the former species. Tipon this point schmeil remarks, "Schon hierans ergiebt sich * * * mit welcher sorgfalt Herrick die Zeichnung angefertigt hat:"' We beg that author to transfer his irritation to the typo, and believe that the drawing in question is substantially correct: As to the position of C. adolescens, more beyond.

The original description of Cyclops affinis Sars is here repeated, and it justifies the doubt which, in the absence of authentic specimens or figures, was felt respecting its position.

"Antecedenti [C. phalerato] simillimus. Corpus autem minus robustnm colore cwruleo vel potius glauco sat siturato insigne. Segmentum ultimum thoracicum ad marginem posteriorem extrosum pilis vel spinulis subtilissimis pectenatim exornatum. Rami caudales yuam in C. phalerato aliquanto longiores, setarum apicalium interna yuam externa multo breviore, intermediarum interiore altera fere triplo longiore longitudinemque ablominis superante, in medio aculeata dein vero subtile ciliata. A utenne 1-mi paris segmento 1-mo corporis multo breviores, tenues, articulis 11 compositie. Pedes 5-ti paris distincti, uniarticulati, setis 3, quarum interior ceteris multo major et ciliata, instructi. Sacci oviferi parvi abdomini appressi. Longit. circit. 3 mm."

From $(:$ phaleralus, which it closely resembles, it differs, according to Sohmeil, in its more slencler form, short stylets with single oblique series of spines, peculiar shape of the filth foot and the method of motion and also especially in the number and relative length of the antennal joints and the form of this organ in the male.

The formula for the length of the antennal joints in 1 . aflinis is $-\simeq \smile-\simeq \smile \simeq---\ldots$, while that of $C \cdot$ phaleratus is

The fith foot is one-jointed, and this joint is quadrate with three spines apically. The stylets are twice as long as broad and are orna. mented by an ohlique line of small spines. The receptaculum is smilar in form to that of et pholenentus. The motion is a ereeping or slow swimming near the surface. Length $0.85 \mathrm{~mm}$.

\section{* Cyclops bicolor Sars.}

\section{PLATES IVIII, Figs. 3-3e; XXI, Fig. 12.}

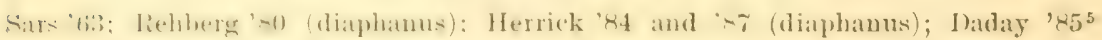
(diaphanus); Lande '88 (diaphanus); Richard '91 (diaphanus); Schmeil '91; Marsh '92.

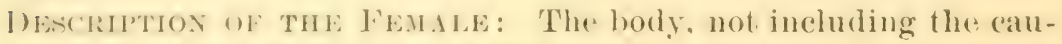
dal setar. metstures fom 0.6.j $100.80 \mathrm{~mm}$. 'The following are measure¿Very curiously in Schmeil's reference to figures, 1). 157, C. fimbrialus is referred to as $C$. afinis, Fig. S, Plate VII. 
ments of a rather small specimen: First segment of cephalothorax 0.24 , second segment 0.066 , third segment 0.06 , fourth segment 0.036 ; $\mathrm{mm}$; the remainder of the body to the stylets measures $0.24 \mathrm{~mm}$., while the stylets themselves are $0.024 \mathrm{~mm}$. long and bear a lateral spine about one-third their length from the apex. The longest seta is $0.2+\mathrm{mm}$. loug, the outer median seta being about $0.19 \mathrm{~mm}$. The body is comparatively rather sleucler and tapering, with an unusually long first thoracic segment. (Measurements of a large specimen of this species may serve to indicate the observed fluctuation in size: Leugth $0.81 \mathrm{~mm}$., thorax 0.50), ablomen 0.31, stylets 0.06 , longest seta 0.40, onter median seta $0.36 \mathrm{~mm}$.) The antenne are considerably shorter than the first thoracic segment, being about $0.19 \mathrm{~mm}$. long, the serenth and eighth joints about equal and the longest of the eleven segments. The first joint is very large. The antennir in a state of rest assume a curved position. The antenuules are small, the terminal segment measuring (in the animal tirst ahove referred to) $0.032 \mathrm{~mm}$. The labrum has six similar teeth, which are bordered on either side by a larger one. The longest joint of the outer maxilliped measures $0.06 \mathrm{~mm}$. All the feet are usually two-jointed in both rami. The outer ramus of the first pair of feet has the terminal joint armed externally with three stont spines, terminally with two setie, and internally with thee seta. The second and third pairs of feet are alike in their spinous armature, the onter side of the terminal segment bearing three spines, the end a very large toothed spine and a seta, and the inside four setie. The fourth foot has two spines on the ontside of the terminal joint, a heavy spine aud a seta terminally, and four setie within, while the terminal joint of the inner ramus bears extermally one spine, apically two spines, and internally three setre. The fifth foot consists of a fleshy basal segment, more or less coalescent with the last thoracic segment and bearing a curved spine externally, and a terete terminal segment $1.012 \mathrm{~mm}$. long, which has an apical seta four times its own length. The abdomen is slender and its last segment bears a series of spines dorsally on the caudal margin. The eggsacs are appressed and contain eight to twenty rather large ovat. The color is bronzy and opaque.

Although Marsh says his "specimens agree very well with the deseriptions of Sars and Schmeil, the only marked difference being in the length of the caudal setur." we find several points of divergence which may make it necensary to create a new rarinty or species. The stylets are much shorter in the American form and the setie are longer. The external apical seta is a well formed spine. The form of the basal segment of the fifth foot is more as in '. rericuns, there being a decided protuberance to receive the second joint. The receptacu 
lum is also more elongate, but this is subject to considerable variation.

'The armature of the feet, structure of antenne and most diagnostic points agrese so fully that I hesitate to separate the two forms. In the description of $(:$ dinphumus given in the first edition some of the statements apply to $t^{\prime}$. reriecens or an allied form. The form of the receptaculum figured on Plate R, Fig. 12, of that report may be compared with that of P'ate VII, Fig. 3", Crustacea of Alabama, to illustrate the rauge of variation.

\section{* Cyelops phaleratus Koch.}

Plates XVII, Figs. 1-7; XVIII, Figs. 2-2 d; XIX Fig. 1; XXI, Figs. 6-10.

Koch '35; Fischer '51 (cauthocarpoides); Lilljeborg '53 (canthocarpoides); Claus '57 and '63 (canthocarpoides); Lubl)ock '63 (cauthocarpoides); Sars '63; Fric '72 (canthocarpoides); Pogrgeupol '74 (lascious); C'ljanin '75; Brady '78 and '91; Herrick '8. (adolescens), aud ' 44 and 'č; Cragin ' $\rightarrow 3$ (perarmatus); Daday '85'5 ; Richard '91; Schmeil '91 and '92; Turner'92; Marsh '93.

IBody sub-(cylindrical, thorax little enlarged for the genus, abdomen large and eylindrieal. The transition from thorax to abdomen is less sharply marked than uswal. ('ephalothorax oval, first segment longer than the remainder. Abdomen shorter than thorax, stylets short and profusely spinons. An oblique row of spines passes across the stylet some distance hehind the lateral spine, which is very short, and other rows of spines or teeth may ornament the inuer aspect or may be aherent. The whole inner aspect is also ciliate. The outer apical seta is a ciliate or toothed spine and the inner is shorter and weaker. The outer metian setat is nearly as long an the abdomen and is spatsely sththed with sharp teeth. The inmer median setat is about hatf as long and similarly ormamented. The antenna is usmally 10 jointed hut frefunently is 11 jointed. (b) and is much shorter than the first thoracie

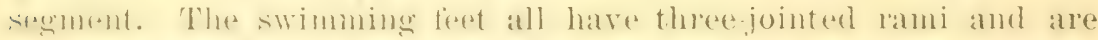
strongly armed with relesely set short teeth. The armature of the terminal joints of the fourth foot is as follows:

Outer ramus $\left\{\begin{array}{ll}\text { ex. } & 2 \text { spines. } \\ \text { ap. } & 1 \text { spine, } 1 \text { seta. } \\ \text { in. } 4 & 4 \text { setce. }\end{array}\right.$ Inver ramus $\left\{\begin{array}{lll}\text { ex. } & 1 \text { seta. } \\ \text { ap. } & 2 & \text { spines. } \\ i n . & 2 & \text { seta. }\end{array}\right.$

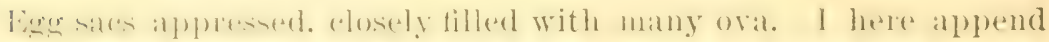

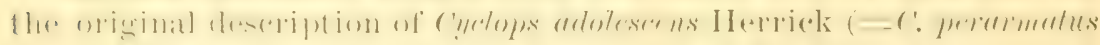

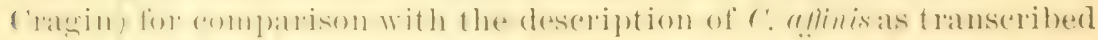
hwom, as it contains other data: "Whorax oval. hroat, acute ante-

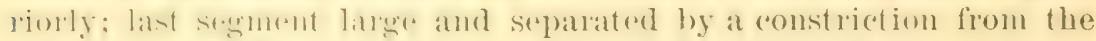
anterior ones. The heat is heakerl below; lisst thorarejesegment large

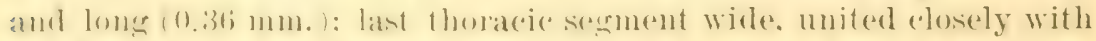
the lims alulominal segment. armed with series of teeth. Abrlomen 
short, especially the last segment, with is toothed behind: stylets very short. The anteunix are much shorter than the first segment, 11 jointed. The maxillipeds are very small. All the feet are armed with a row of very large teeth or lanceolate spines down one side: fifth foot one-jointed, with three spines, the onter being smooth, the others spiny; egg-sacs raviable, narrow, appressed; eggs larege, color usually dark. The animal moves like ('anthoc(m) tus, and is able to progress out of water better than other species. 'The following measurements will give an idea of the proportions: Length 1.26 :mm., thorax 0.76 mm., abdomen $0.44 \mathrm{~mm}$., stylets $0.06 \mathrm{~mm}$., longest seta $0.34 \mathrm{~mm}$., antennæ $0.25 \mathrm{~mm}$., width of thorax $0.44 \mathrm{~mm}$."

Ieasurements of another specimen are as follows: Isength $1.1 \mathrm{~mm}$, thorax 0.65 , first segment 0.33 , abdomen (0.45. longest seta 0.6 .

The male is more slender $(0.93 \mathrm{~mm}$. long) and the longest caudal seta greatly exceels in length the whole ablomen. The antenue are strongly modified.

\section{* Cyclops fimbriatus Fischer.}

Plates XVII, Figs. 8, 9; XXI, Fig. 11; XXV, Figs. 9-14.

Herrick '82 (crassicornis), aud ' 84 aud ' 87 ; Turner' '92; Marsh '93. [The manuseript gave not the slightest hint as to date or reference in the following, given in the order of the manuseript:] Mueller (crassicornis); Fischer; Sars ('rasicicornis); Heller (gredleri); Fric (patuper); Uljanin (crassicornis); Brady (crassicornis, and fimbriatus); Rehberg (popnei, and fimbriatus); Daday (fimbriatus, and margoi); Vosseler; Schmeil; Richard.

A small species $(0.8$ to $0.9 \mathrm{~mm}$.). Thorax oval, not greatly expanded, angles of segments rather prominent. First thoraros segment forming about half the lensth of the cephalothorix. Ablomen rather long and thick, trete, ahout as long as the thorax. Last two ablominal segments ammed with a low of spines at the caudal margin. Caudal stylets twice as long as the last abdominal segment.

A series of small teeth in a longitulinal series gencrally ormaments the stylet. Lateral spine small. The outer apieal spinestrong. the two median setre long, spinonsly armed, inner two-thirds as long as the outer. Inner apical seta weak and short, pectinate. Antemnac shorter

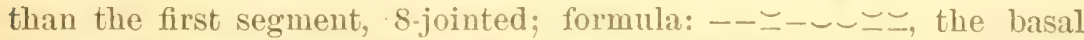
joint with a small semiciremalu series of fiue hristles. Antemules short, apical segment short with but two strong setie and several smaller ones. Feet armed with spines aud histles. Formulie for fourth foot as follows:

$$
\text { Outer ramus }\left\{\begin{array}{l}
\text { ex. } 2 \text { spines. } \\
\text { ap. } 1 \text { spine, } 1 \text { seta. } \\
\text { in. } 4 \text { setæ. }
\end{array}\right.
$$

IBy a curious mistake in this paper on p. 14, the reference to Plate VII, Fig. 2, is placed opposite C. finbriatus and not, as it should be. opposite C. phaleratus. This wistake was then reproduced in the description of plates, p. 56 . 
Fifth foot small, one-jointrel, with three spines, of which the inner is large and serrate. Total length $0.8 \mathrm{~mm}$., thorax $0.42 \mathrm{~mm}$., abdomen 0.3s mm. stylet $0.09 \mathrm{~mm}$, antemna 0.15 $11 \mathrm{~m}$. Egg.sacs appressed, with few ova.

\section{Cyclops aequoreus Fischer.}

PLATE XXIII, Fig. 5.

Lilljeborg '53 (magniceps); Fischer '60; Brady '68, '78 and '91.

Body emporsed, attemuated caudad. Antemmar shorter than first segment, stout, six jointed, fourth and sixth segments longest. Fifth feet with a small hasal joint and a triangular lamina bearing on the distal margin three spines and a seta, lateral margins ciliate. Abdomen slenter, first segment very long, last very short. Stylets less than twice as long as wide. Longest seta as long as the abdomen. First foot with the formula

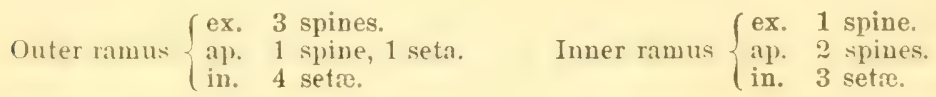

Length $0.85 \mathrm{~mm}$.

This species lives in salt marshes and brackish pools, and is interesting for its leparture from the generic type in several particulars.

Three species of ('ignlops wore found by E. Pratz in 186 in in the hydrant water of Munich and described as new.

The first of these. 1 . correns, is hlind and colorless and has 11 jointed antennie.

The serond species, (! subtermmes, is doubtfully identitied by Schmeil with $C$. bicuspidatus.

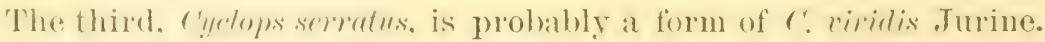

Two hlind speceses of rymops have been deseribed by (i. Joseph ('š): (: hyalimus and $($ : anophthalmus. hut the deseriptions are not accessible to me.

\section{IIETEROGENAST INI) PREIMAGO FERTIITT IX CYCLOPS.}

The present writer's views and statements in respecet to the reation of sexual and anatominal maturity and the influenee of the environ-

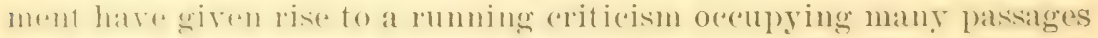
throughout the recent monograph of Schmeil, '92.

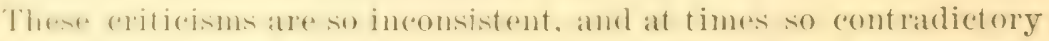
of the allther"sown ohservations and statements, that it is hopeless to attempt to answer them, especoially as his notions respecting varietal and speritice redations serem strangely obsemes. If a plain statement of the position of the present writer will remove any obsemity he ferels bound to offer it. 
First - As a matter of frepuent observation and beyond all doubt, it frequently happens that a young female (yolops becomes oviparous before the moult, when it acyuires its full adult complement of serements in the antenne and fieet. Sinch animals are ohviously larval and exhibit this fact in their small size. pale color, small number of eggs, imperfect development of serrations, spines, etc. Schmeil himself has observed males in this stage with spermatophores and had before him a figure in my Final Report. (I'late Q, 5), reprinted from the tenth annual report, in which this matter is plainly stated, of young grarid females of $C$. semulutus - a species not likely to be mistaken-with less than twalve joints in the antennie and two-jointed rami of the swimming feet. After admitting that "kein Grund vorlisgt, an der Richtigkeit der Herrick'schen Angabe zu zweifeln," he says "Herrick figures, as a matter of fact, not a young form but a completely developer animal, in which, to be sure, in certain segments of the antenuio the normal subdirision has not taken place." I Ie adds (entirely misconceiving my position as to heterogeny : " Irass hier nicht an einem. Fall vou Pädogonieoler gar Heterogenie zu denken ist, ist sellnstverständlich.' Had he consulted the original paper Schmeil would have seen that the failure to develop a full complement of antennal joints is but one of the symptoms of the larval state manifested by this specimen. Horeover, such forms are found among vast numbers of adults and larvie in the midst of the most prolific seasous and in suitable situations. We claim that the next moult would have hrought to this very animal its normal adult structure. Nor is this an isolated case. Let Sehmeil could iu all consistencr be forced to erect a varity for such forms. In glaring inconsefuence, we find, on p. 101, fichmeil says of c. rousii Heller: "()bgleich ich der Insicht bin, dass wir es hier wohl kaum mit einer selbstindigen Art, somdern nur mit einer .Tugendform einer anderen (des ('. rivilix) zu thum haben," etc.

Second - As a second and entirely distinct point, though confused with the former by Schmeil, it is helieved that many of our species, especially such as live in pools which undergo great changes with the season by reason of eraporation, intrusion of water plants or animal forms serving as food, etc., may, after reaching full maturity and bearing more than one generation of exgs, undergo comsiderable changes, or that, under these changed conditions, what is usually the uitimate condition becomes a transitory one. This dhange may show itself not only in increased size but in enormons enlargement of the setar. For example, I have seen (': ingens with the pectinating hairs on the setie elongated till they became long hairs. All the spines and plates and serrations are exaggerated, while the relative proportions are altered.

In the case of $(!$ riritis this is especially liable to occur, because of its stagnaut stations. The color changes with the rest and the change 
may be moticed in the same pool during the progress of the seasons. In these cases, according to our nomenclature, the modified form is a post imago, and if young born from the ordinary female enter this state and produce young in turn which never reach that state, we have a "ase of what was termed "heterogenesis" in the old general sense; i. e., two rycles of development occur in the same species. Tow, as these cycles are dependent on environment, the process may be termet padogony if the term is taken in the sense indicated. What to do with such cases is puzzling to taxonomy. It is obvious that they are quite different from the sporadic appearance of sexually functional larve, for here we have a stage which does not necessarily belong in the history of the species, and is, as it were, superiuduced. The objection raised by Schmeil against making varieties of them-i. e., that you cannot fix an arbitrary size limit - would militate against almost all geographical varieties equally. In fact, however, the changes following the last moult are usually evident enough to produce no trouble. In the case of 'yclops simulus we are coufronted by a question of fact. This is undoubtedly the most conspicuous instaner, if an instance at all, of the change referred to. If the actual rearing of $r$. simmtus var. inometus should prove that (C. signetus var. temuiromis does not belong in its cycle then the two forms must be separated and this particular instance of patogony disappears. We think it possible, however, to prove the contrary. Most remarkable of the many curious statements mate by Schmeil on this point is the following: "Herrick even in his later work is not in position to demonstrate among the known species a single sexually mature larva. The is mot in the position to hring a prof of a single one of his assertions. Also nome of the of her investigiater's has observed this, according to I Lerridek, common phemomenon." Ilaving orerlooked my earlier payer he is surprised at the fatume to asain revert to it. But, after his own admissions, how he can deny the evidence of sexually mature larve is unintelligible.

\section{FAMUL IIARPACTICHDE.}

Pumerieally the laregest of the tamilies of the (ome pute. this geromp) comatus forelominatingly marine and mosty mimte animals. fres-

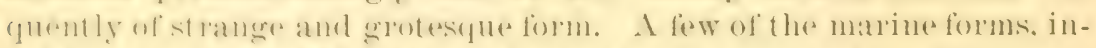

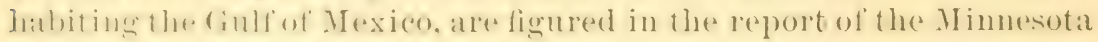

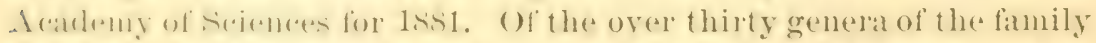
less than a half lozen ale not exclusively marine and of these most are

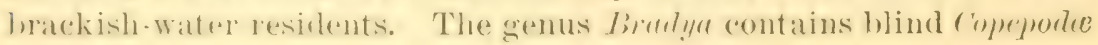
living in slime.

The name was propeseel by loana. hut was dropped in the final Jeport. Again levived hy ('laus, it is now in use by the best authors. 
The generai form and structure elosely resembles that of the 'yclopidic. The following characters are the more important ones in distingmishing the family from the other families of the order:

Body flattened or subcylindrical. Abdomen usually not much smaller than the thorax, from which it is not separated by a sudden constriction; antenne rather short, 4- to 10-jointed; mandibles strongly toothed. palpate; maxille well developed, palpate; first pair of maxillipeds with strong teeth at the eud, second pair usually forming a claw. The first pair of lect are often turned forward or prehensile; fifth pair one- or two jointed, serving as egg supports in the fenale.

Iost species live among sub-aquatic vegetation.

\section{THE SUB-FAIILY GANTHOCAHPTINE,}

To which our sole genus belongs, is further distinguished from the other sub-families of Iformutictle by the fact that the secoud maxilliped has a prehensile hook. The feet of the first pair are not clawed, lut have the inuer branch elongated, and the palp of the mandible is one-branched.

\section{GENUS CANTHOCAMP'TUS Westwood.}

These little animals may be secured in considerable numbers by gathering a supply of water from among weeds in shallow ponds and permitting the debris to settle in a spot where light only touches the jar from one side, when the (inthor(tm)ti congregate on the exposed side.

contheremptus is an elongated animal, with the hody diviled rather olscurely into two portions, of which the first, or anterior portion, is largest. This part of the borly has fire semments, each of which has at least one pair of appendages. The first, consisting of the head proper with one of the somites of the hody or thorax, as is discovered by observing that a pair of legs is attached to it, is the largest segment of the body.

As seen from above, it is triangular and extends in front into a short, stout beak or snout, like the rostrum of a ray fish. Ahore the heak, in the centre of the foreherd, is the eye. consisting of pigment and two lenses, showing that we really have to do with two eyes confluent on the median line. This is the simplest form of a compound eye. The same methorl of componnding the eyes is exhibited in a more complicated manner by Inophin and other "ldedocere. ()n wither sicle of the beak springs an antenna with six to nine joints of unerual size. The first three joints are profusely covered with hairs. The fourth joint is more slender than the preceding, and terminates in a process below, which bears besides a long hair a peculiar blunt 
bristle that serves some unknown purpose-probably heing sensory in function like the similar hairs on the antenne of some rhuloreme. The next joint is shorter than the rest, while the remaining three are spined at delinite points. The antemue of the male are courously altered, or ereniculate, on hoth sides, as in ('yclops. The three basal jointsale shortened, while more or fewer of the following ones are coalescent. followed by a hinge joint and two elongated semoments.

The second antenna or antemmles are two-jointed. and the basal joint has a two-jointed hrouch or palp; the terminal joint is covered with spines: at the end are longer and curved spines, jointed in the middle.

The mandible is a flattened plate with digitate teeth at the end. on ont side of which springs a two jointed palp, and from the other a blunt process. The maxilla is somewhat like it, but has rudiments of other elements.

The first pair of fect have two three-jointed rami. The outer ramus is shorter and with the longer branch is directed forward. The fourth foot has the inner branch two-jointed. The inner hranch of the third foot of the male is peculiarly morlified to form a prehrmsile organ, as it is this foot which fastens the spermatophore to the female. The fifth feet are composed of two flat plates.

The second division of the body, the ablomen, consists of five serments, of which, howerer, the first two are united in the female. The last serement of the abdomen beas two stylets, which are sometimes considered as together constituting an additional segment. Farde of these stylets has, with several small spines, two elongated caudal setite one of which is usually as long or longer than the entire abdomen. The stylets are usually ensiderably longer than wide. but the proportions vary somewhat in different species.

Viscorat: The hody eavity is traversed by the alimentary camal, which is a strajght tule with no lateral carea of hlind sales. as in some

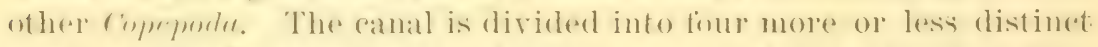

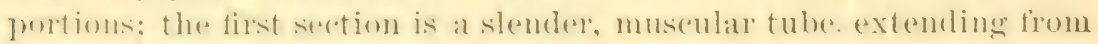

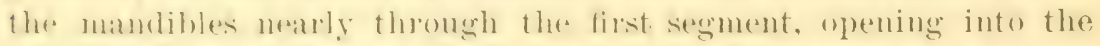
somareh profure. which is a muscolar and grlandular sare or tuhe filling 1he greatle pat of the tholax: at the begimning of the ablomen, the

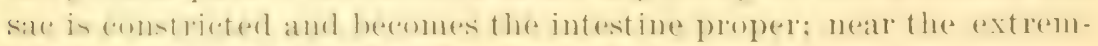

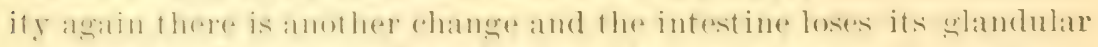

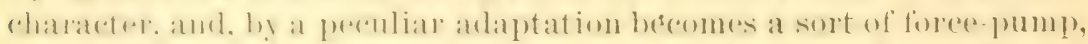

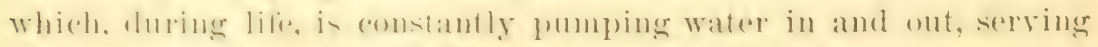
as a means of respiration. This anal respiration is quite ammmon amome afuatio animals in this as well ats other orders. 'This latter

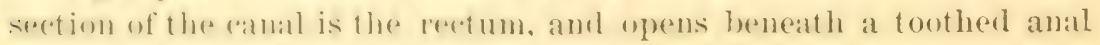


plate, above and between the stylets. No special divarications or cucat are atpended to the digestive tract, and the only other organ which is at all considered to belong to the alimentary system, is what is known as the "shell-gland," present in most erustacae. hut till recently thought to be absent in Gomfhoramplus. It is a coiled tuhe found in the lower part of the first segment of the thorax. It is imposible to find this organ in ('unthocamptus, in every case, it being rery obscure; and its oflice is uncertain, though it is supposed, perhaps with little reason, to be hepatic in function.

There is no functional beart in this animal, lut its place is taken by a peculiar apparatus, hitherto undescribed; this consists of a tube, surrounding the posterior portion of the alimentary canal. This sac around a sac is open in front, and serves by a double mechanism the oftice of a pulsating heart, though in a very imperfect manner.

There are no true biematic or lymph corpuscles in this animal; so far, at least, none have been discovered. The place of these hlood corpuscles is taken by globules of yellowish or red color of the most diverse size. These nutritive globules, or fat globules, as they have been called, are undoubtedly reservoirs of nutriment in a shape convenient for the animal's use, and equally certainly are derived from the contents of the intestine. In those ropepoda which have a functional heart, it is open anteriorly into a general body. cavity in the same way as in this animal. That a portion of the vascular system should surround the alimentary camal is no unexampled thing, for in Dryhnia a large sinus embraces a portion of the canal. The same provision as this described in cunthocomptus occurs in the rycompida. The nutritive globules are often very large, and are frequently extremely abundant, especially in females soon to hecome gravid. Three-hundredths mm. is not a large measurement for the diameter of such drops.

The nervous system is very hard to trace, consisting of a large pear shaped ganglion just below the eye, from which extend commissures around the asophagus, commecting them with the rentral ganglia lying between the bases of the feet. The senses are not apparently well developed, for, excepting the ('yes, we cannot locate with certainty the orans of any sense. 'There are, howerer', two spots which are evidently devoted to special sense: first, the processes on the fourth joint of the antemne, which may he simply the seats of tactile seuse, or may have nerves suitable for pereeiving chemical stimuli; second, the area on the forehead bordered by a raised line and covered with little pits, each with a small bristle. The character of this organ can be hut conjectured; it may be homologized with the frontal nerrons organs of the cladocera. 
The sexual organs are quite extensively developed, and periodically olscure the remaining viscera. In the male the simple testis is situated in the seend segment, and the single vas deferens, after numerous windings through nearly the entire length of the bony, opens at the base of the limst ablominal segment under a spined plate. A part of the ras deterens is ol a glandular character and secretes an elongate tuhe. the spermatophore, which serves to contain the spermatozoids, and is fastemed ly the male at the opening of the median pore of the f'male: (1) contact with the water thistuhe, which is at tirst soft, contracts and presses the contents into the openiug of the female organs. So lomg is the vas deferems that as many as three spermatophores are sometimes secu in the borly at ouce. The spermatozoids are rery small. The geniculated male antemue are used in grasping the setie on the tail of the female, and the curiously morlified inuer branch of the third foot of the male may assist in fistening the spermatophore mpon her body. The ovaly ocenpies the same position as the testes, and the two ducts are coiled in the body from end to end, openiug in the median pore behind the fifth pair of feet. When the eggs are ready to be latid, they are forced out, carrying with them a film of the secretion of the lower, glandular portion of the ducts, which is of a collolion-like consistency, and which forms the inclosing sac. The young become fully developed sexually before they asisume their final form, and it is not musul to find ova bearing females which are not only much smaller than the parent, but with considerable differences in the various organs.

This solt of heterogenesis is not uncommon among lower crustacea, for the youme mate differ much from the mother till after they have themselves produced young.

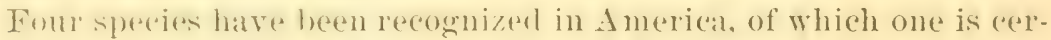
taimly idention with a widely distributed Emopean form, and a sec

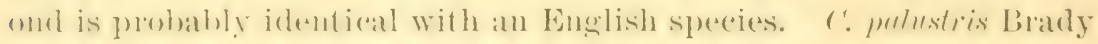

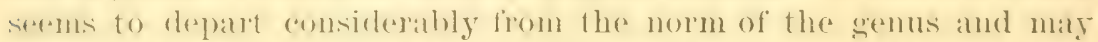

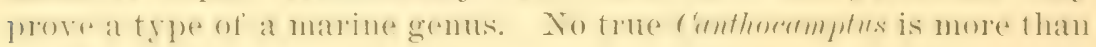
accidentally marine.

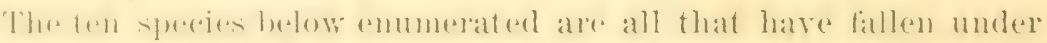

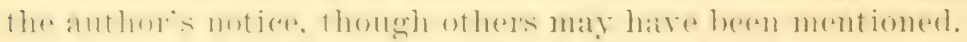

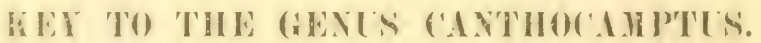

I. Inner ramus of the fourth foot two-jointed.

a. Inner ramus of the first foot two-jointed.

* $1.0 \mathrm{~mm}$. long; hasal joint of flith foot small.

** $0.5 \mathrm{~mm}$. long; hasal joint of fifth foot long.

brevipes, 130

b. Inner ramus of the first foot three-jointer.

* Inner ramus of the second foot two jointed. 
+ Antenva thick.

crassus, $130^{\circ}$

it Antennie slender. . . trispinosus, 130; and northumbricus, 130

** Inner ramus of the second foot three-jointed.

+ Stylets rather long.

it Stylets short, oval.

II. Inner ramus of the fourth foot three-jointed.

๘. Male antenua normal.

b. Male antenua reduced, hooked at the end.

illonimutes, $131-\widehat{\delta}_{2}$ mer

hibernicus, 133

palustris, 133

[Not noted in the key are: tenuicaudis, 129; northumbricus var. americanus, 130; borcherdingii, 134; minnesotensis, 134.]

Canthocamptus elegantulus, C. mareoticus and C. hovidus are uncertain, probably referred to the wrong geuss. $C$. stromii Baird (=Dactylopus stromii), C. rostratus Claus (三 Stenhelia ima). C. virescens, C. linerris, and ('. roseus of Dana, are maxine Ilorpueticide of uncertain affinities. ('. mimutus of ('laus is not sufficiently described, but appears to be the earlier condition of $r$ ' mimutus Mueller ( $C$. staphynatis Jurine).

\section{Canthocamptus gracilis Sars.}

Is elongated linear, with the abdominal segment smooth. Caudal stylets long and slender; external caudal setil about our-fourth the inner. All the fert with two-jointed inner rami; onter branch of fourth foot longer than the others, inflexerl; basal process of fifth foot slightly expanded. Length $1.0 \mathrm{~mm}$.

\section{(*Canthocamptus tenuicaudis Herrick.)}

Plate XXIX, Figs. 15 and 16.

At Decatur, Ala., Was foumd a species of Combocomptus which is different from any American species, and seems in many points nearest the alove, but, unfortmately, only a hasty sketch could be made at the time, and the notes are insuffieient to define it. The form is not remarkably slender; the first and second abluminal segments are very larar. The caudal stylets ares slender and elongated, the inner seta heing very long and rurvel, while the outer is quite short. The anal plate is coverenl with hairs only. The antenne are normal, of moderate length, and the lifth foot has but a narrow process at the base.

If this form be worthy a distinctive name, it may be called chuthocomptus tenuicaudis.

¥Distinguished from the following by the presence of only three spines on the process of the basal joint of the fifth foot. 


\section{Canthocamptus brevipes Sars.}

This small form is almost certaiuly the young stage of some other species; yet I transcribe the description:

"Corporis forma et marnitudine C. pygmier non dissimilis. Sermenta abdominalia vero postice magis attenuata seriebusque aculeorum destituta. Rami caudales elougati duplo Iongiores yuam latiores, setis apicalibus brevisculis parumpue divergentihus, exteriore dimidiam longitudinem interioris nonattingente. Operculum anate ahsque dentibus. Antenui 1-mi paris breves, articulis ultimis duobus in unum conJluentibus articulum. Pedes natitorii brevissimi, ramo exteriore intus setis destituto, interiore biarticulato in perlibus 1-mi paris longritudinem exterioris xuuante, in stcuentibus multo hreviore. Pedum 5-ti paris articulus basalis intus in processum foliformem, sat magnum et angustatum, articulum ultimum elongato-ovatum aluguanto superantem, exit. Color albidus. Longit. parum supra $\frac{1}{2} \mathrm{~mm} . "$

\section{Canthocamptus crassus Sars.}

Robust; segments margined with peetinate bristles. Caudal stylets oval, contortad, coustricted at the base. Antennit thick, densely coverrd with long setie. Fifth leet with long setir: basal process rather small. All the feet excepting the first, with biarticulate inmer rami. Length $0.75 \mathrm{~mm}$.

\section{Canthocamptus trispinosus Brady.}

\section{Plate L, Fig. 6.}

This species with the last and next has all the feet save the first with biaticulate inner rami. Very near the next, from which it dilfers in the form of the tifth foot of the female, which has the basal process smaller, bearing only three spines, while the next has six, the second joint being longer and narrow. The male is unkmown. Not jet identified in America.

\section{Canthocamptus northumbricus Brady.}

PLATE XXIX, FIGS. 20-22.

liody robust: antemmat long as first segment, nine-jointed; maneli. bula jall minnte. In the male the immer branch of the thind foot is three-jointed and dactylate, as in $C$. minutus.

Canthouanptus morthumbricus liady. Var, americanus Herrick.

PLATES XXIX, FIGS. 6-14; XXXIII, FIGS. 3-5.

()me of (n) most rommon surecies is rery near the English form: so neats, ju litct, that I lislike to remove it from it. A lew points of divergence, however, may be mentioned.

The form ame proportions are much like those of $($ ' mimntus. The hearl is large and rouls in a prominent bent heak. The antenuar are 
rather loug and slender and have a well-marked flagellum. (brady figmres no tlagellum.) The palp of the antennule is as in (t. mimutus. The mandibular palp is small. The first pair of leet normal, rathor small; all the other swimming feet with two jointerl iuner rami, save in thr ease of the male third foot. The filth fert are exactly as figured by Brady, save that there is a prominence or tooth of the basal segment near the point of attachment of the terminal joint which is puite long. The sensory area of the heal is oval and pointed. The male antemna has a long llagellum, not, as figured by Brady, a rery short one. The egg-sac is very large, oblong. The animal seems to fall short of the size of the English species, though measuring upwarks of $0.65 \mathrm{~mm}$. Our form is very well distinguished trom any other spocies. It is found in Lake Minnetonka, Lake ('alhoun, and elsewhere.

Canthocamptus minutus Mueller.

Plates XlviI, Figs. 7-21; L, Figs. 7, 8.

Monoculus staphylinus-Jurine.

Canthocamptus minutus-Lilljeborg, Baird, Sars, Uljanin, Brady, Herrick.

Canthocamptus staphylinus-Claus, Fric.

Canthocamptus minutus var. occidentalis-Herrick.

A well-known species which has been frepuently described and seems quite circumpolar in its distribution.

First mentioned from Anerica in a paper by the writer in 1878 A pretty full description will also be found in the author's Types of Animul fife. A very abundant speeies, frecuent in muddy pools, but somewhat variable in abundance. It may frepuently le found in great numbers in winter.

[The following description, compiled from Types of Animal Life, is inserted here for the convenience of those who are likely to use this report as a manual. H. F. N.]

Length about $1.0 \mathrm{~mm}$. Antennie a little longer than the first seg. ment of the body; first three joints profusely rovered with hairs; fourth joint more slender than the preceding and terminating in a process below, which bears, besicles a long hair, a peculiar blunt bristle; fifth joint shorter thau the rest; the remaining three joints are spined at definite points. The antenn: of the male are geniculate; the three basal joints are short while the three following joints are coalescent. and are followed by a hinge joint of two elongated segments.

The antenumles are two-jointed; the basal joint bears a two-jointed palp; the terminal joint is covered with spines; at the end there are three longer and curved spines, jointed in the middle, and the upper furnished with three small spines at the curve. 
The mandible is a flatteued toothed plate, bearing a two-jointed palp on one side and a blunt process on the other.

The first maxilliped is short and bears claws and spines. The second maxilliped is simple, three-jointed, and has a claw at the end.

The first pair of feet are biramose, each ramus being three jointed; the outer ramus is shorter than the immer. The immer ramus of the fourth foot is two-jointed. In the male the imner ramus of the third foot is modified into a sort of grasping organ. The fifth feet are composed of two llat joints, larger in the female than in the male.

'The first abdominal segment of the male carries a pair of threespined proceses. The last abdominal segment bears two stylets, each terminated by two long setie, one being longer than the abdomen and longer in the male than in the female.

\section{Canthocamptus illinoisensis Forbes.}

Plate XXIX, Figs. 1-5.

This robust and pretty species was first taken near Dimmeapolis by IIr. A. IT. Jomes, a student of the University, who lound it in a peaty ditch. Forbes' description is appended.

* Length 1.0 mm. Head and first segment united; five abdominal segmentis in male, four in female. The suture between the first and second segments is not wholly obliterated above in the female.

"Last abrlominal segment is de(x)ly and acutely emarginate. Branches of lureat as wide as long, immer bristle plumose, a little longrer than ahdomen; onter plumose only on outer sille, about half the length of the immer. The second to fith abdominal segments have each a row of spinules along ventral portion of posterior.

$\therefore$ Irale with antrerior antenne composed of seven joints, the fourth joint very short. The front outer angle of the third is produced, the blunt process bearing three long bristles surrounding a slender olfactory (ouh) which is as long as the three following joints. The penultimate joint hears a strong spine or slender appressed process at the midele of its posterior margin. The fire outre joints constitute the crasping orean. The posterior antemne bear five long hristles at tip, three of which are mate prehemsile hy the ocemrence of from eight to fwelve slont articulat ions in the midelle of the hatr, allowing it to be hent forwarl. At the hase of these articulations on the onter bristle are two short spinules. 'Two nearly lougitulinal rows of tive or six strous, short spines atch appeal on the under surfice of the outer juint of thre antemule. 'The secondary flagellum, borne as usual on the midrle of the basal joint, is mot articulated. and bears four long bristles, two terminal and two on distal hall of inner side. The out. line of the mandible is exactly like that lignered by claus, but it bears 
about ten teeth, the upper thick and blunt, the immer sharp, slemin' and longer. Several are notched at tip. The lower augle bears a lougsimplobristle. Mandibular palpus two-jointed, second joint with three long terminal hairs aud a shorter spine attached at basal third of anterior margin, jointed at base and clirected towards tip, like a dactyl. The maxilla and maxillary palpus are searcely to he distin. guished from those of $C$. staphylinus.

"The fist maxillipeds are three-lobed, the onter lobe const ituting a loug. strong claw. The second and third are abont one-third as long as the first, and bear each one strong simple spine and one weak branched hair. The inner lobe is widest, about two-thirds as wide as long. The dactyl of the posterior maxilliped is spinous on its inner edge, and the same edge of the hand is ciliate and bears a short, stout, sparingly plumose bristle at its base, just beyond the tip of the closed dactyl. The width of this joint (the second) is nearly half its length.

" Basal joint of inner ramus of first pair of legs nearly or quite as long as onter ramus, the second wider but only half as long as the third, and obliquely truncate. Inuer ramus of third jair of legs in male is three jointed [the onter two-jointed] chelate. The finger is ovate, truncate, terminating in two long plumose hairs. The dactyl is linear, curved at base, and twice as loug as finger. The inner ramus of the fourth pair of legs is ahout half as long as outer, twojointed, basal joint short, termiual joiut about as long as middle joint of outer ramus. The fifth pair of legs is best developed in the female. In the male the length is not over one-thind the width. The basial portion bears three plumose hairs on its very broadly rounded anterior margiu, of which the innermost is longest. The outer plate is nearly orbicular and bears five spines on its terminal margin, of which the second from the internal angle is the longest. Cienital plater. found in male at posterior border of first abdominal segment, beneath, are short, slightly expanded internally, with internal angles romulecl, and extermally bear three subequal hristles, jointed at hase, the immer largest and strongest and semi plumose. 'The antemue of the female are eight jointed, extending barkward to the first free segment. The basal joint of the fifth pair of legs is subelliptical in ontline, with the basal half produced externally into a hroud, triaugular process which bears the second joint on its posterion margin. The free and of the basal joint bears six large plumose bristles, of which the inner is longest. The greatest width of the joint is nearly equal to its greatest length. The secoud or outer joint is ovate, subtruncate, spined on each margin, and bears four plumose bristles at tip and one at the middle of its outer margin. Its length is about twice its breadth."

* Evidently a misprint, for it is the inner ramus which is chelate. 


\title{
Canthocamptus hibernicus Brady.
}

\author{
Plate L, Figs. $3,4$.
}

A small species differing from all others save the next in having a three-jointed inner ramus of the fourth foot.

- Interior antennit of the female slender, eight-jointed; about as long as the lirst borly segment, and much like that of 1 ' mimutus. Inmer loranch of the secoud anteuna very small, one-jointed. Postrion foot jaw having a broal hand armed with a long apical claw. Inner manch of the first pair of leet scarcely twice as long as the outer; first joint longer than the entire onter branch, and nearly twice as long as the 1 mited second and third joints, both of which are extremely smitl. Inner branches of the second, third and fourth pairs shorter than the onter. and three-jointol, the first joint being very small. Inner segment uf the basal joint of the fifth pair of feet in the female elongated, fringed, bearing two long and three short apical setat; second or onter joint suloovate, finely fringed internally; externally bearing six long marginal setae. In the male the limb is smaller. the basal joint short, hroad and having six short setie of enual length; second joint nearly like that of the femalr. Caudal segments somewhat longer than broarl: immer seta about twice as long as the outer: anal opereulum denticulate. Length 0.65 mm." Not found in America.

\section{Canthocamptus palustris Brady.}

\author{
PLATE L, Fig. 5.
}

A hrackish-water species about $0.9 \mathrm{~mm}$. long, found in a mumber of places in the British Isles. The species presents several anomalies.

The antemin of the female are eight-jointed; those of the male robust, the last joint torming a hook. The first four pairs of feet have hoth hanches thres-jointed: the difth pair in the female are twojointrel, with a short and broat hasal joint, the second joint being sul)orate. hearing five long apical setar: in the male the filth pair is

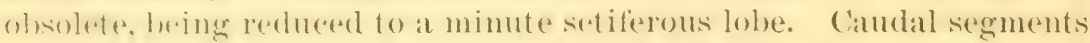
shert. bearing two principal setate the onter half as long as the inner.

\section{Canthocamptus borcherdingii Poppe.}

$$
\text { Poppe' } 89 .
$$

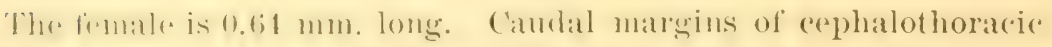
serentents montmed. hut in the midelle of each segment a tramsverse lime of spimmles. Ablominal segments spined beneath. Amal opereu-

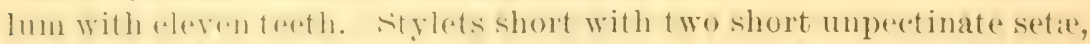
the immer half as longas the houly while the outer is one-fourth. Anformat (eight-jointed, shorter than the litst segenent. Mandiblar palp 
short, one-jointed, armed with three short sete. The branches of the first foot are equal, the outer three, the inner two-jointed. The joints of the latter are equal and spined laterad. The first segment bears on the mesal aspect a short seta, the second a short seta, and at the end a long seta and stout spiue. The apical segment of the outer ramus bears a spine and at the apex a spine twice as long as the lateral one, a curved seta and a straight seta. The inner rami of the secoud to fourth feet are two jointed. The fifth feet are exactly like Brady's Attheyellucryptorum, which l'oppe thinks may have arisen by degenerative modification of this species.

The fifth feet of the male are two-jointed; the inner portion of the first segment is less developed than in the female and hears two short pectinate bristles. The oval apical secment has six setie. The two inner ones are short and pectinate, the next is long, the next is shorter and finally two simple setie. The inner ramus of the third leg of the male is three-jointed and is longer than the second joint of the onter. The first joint is very short with a small seta internally, the second segment is twice as long with a stont, curved pectinate seta, the apical segment is unspined but bears a long pectinate seta. Length of male $0.544 \mathrm{~mm}$. Occurriug in various fresh-water lakes of northern Germany.

\section{* Canthocamptus minuesotensis Herrick.}

Prate XXil, Figs. 1-6.

Since the manuscript of this genus was finished, a small species has been found which seems undoubtedly distinct from any of the above. A siugle pair were taken in a gathering from Bassett's ereek containing $\because$ minutus in abundance. Unfortunately the characters of the swimming feet are not certainly known, but they were apparently all three jointed save the last. The antennie are very short and thick, eight-jointed, with a long flagellum; the antennules are of the usual form, and the mouth parts rather large. The first pair of fieet have the two rami of nearly equal length. 'The form is moderately elongate. The candal stylets are very short, quadrate in outline and woll armed with spines. The fifth foot of the female has four long and two short spines on the inner lamina, and the terminal joint has five unerual spines. In the male the fifth foot has two spines on the lamina and six on the second joint, one being a small bristle. The male antenna is of peculiar form. 'The teeth of the anal plate are large and emarginate (see Fig. 4). 
The swimming feet are all armed with very strong spines, aside from the usual puota of spines at the end of each joint. Iength 0.65 inm.

\section{GENUS ATTHEYELLA Brady.}

This renus, the diagnostic characters of which have been above indicated, contains three nominal species. It is quite difficult to say What differ(nees exist between Sars' ('muthocomptus mygmons and Atheyella sprimsor. Brady did not seem to recognize the fact that his diagnosis included that species. The thind species is the blind 1. cmptomm of liraty, which it is interesting to compare with the blind Bradyc limicote of the coast of the Gulf of Mexico.

\section{GENUS MARSHIA Gen. nov.}

Allied with Athryellu. Inner branch of first foot three-jointed, scarcely elongated, barely subprehensile. Secoud and third feet with otter ramus two-jointed, short. Fourth foot with minute one-jointed outer ramus and three jointed maser ranus. Fifth feet one-jointed. Antennie six-jointed, the fourth joint with a slender lyyaline process longer than the end of the antemna. Second antenna without obvious palpus, prehensile. Mandihlar palp simple? First foot-jaw with an minciliate papillose palpus. Second foot-jaw with a long uncinate special joint. Antemue of the male strongly modified. Habit, fresh or brackish waters.

\section{* Marshia albuquerquensis sp. n.}

Plates XXXI; XXXII, Figs. 1.5.

Lody with ten olwious segments, with the aspect of conthoramp/us. Antrmat short, six jointed. The proximal joints enlarged and spinous: second aliso tumid, with three or more cilia: third joint longer: fourth with a lones seta and still longer flagellum: filth joint rery short; apical joint clomgate bearing about ten setar. Antemumles short, prehrosile. with four geniculate setae apically and several short spines, (sperially a transwerse series of sharp teeth on the dorsal aspect. Jaws with vix sharp teeth. Interior maxillipeds with a minute unisroture latle and three processes hearing curved spines. Posterion

Notw-C: frontinalis Iebberg. This anthor seems to have parted with his usual acumen in the remarks upon this species. After describing a Canthocamplus ivith the inner ramus of the first foot "reichlich doppelt so lang wie die beiden Grundglieder des Aussenaste," he draws a moral on the mutability of genera from the fact that Brady founded the genus Atheyelin "auf grund der Eingliede des innenastes am fierten Fusspaare und einer derartigen Bildung des ersten Fusses, wie er bei $C$. frontinalis beschrieben ist." Brady says (Bril. Copepoda, p. 58): "Inner branch of first pair of feet scarcely at all elongated, and eitber two- or three-jointed," etc. The distinctive characters being the one- or twoointed second and third feet and the one-jointed inner ramus of the fourth foot, it is doubtful if $C$. rontinalis is rually new. 
maxillipeds with a long claw longer than the preceding joint. First foot with the outer ramus nearly as long as the inner, tro-jointed, bearing at the apex three pectinate setie. The basal joint bears a pectinate seta externally and a spine internally. The inner aspects of all the joints of both rami are spinous, the outer setose. The outer ramus of the second foot is two-jointed and has one pectinate seta apically, one spine internally and one spine externally, while the corresponding segment of the third foot has two pectinate sete apically and one internal seta and two external spines. The fourth foot has a minute one.jointed onter ramus bearing one long pectinate seta and a short external spine. The fifth foot seems to consist of one piece, armed as follows: Externally a conical projection near the base with a long simple seta, outer apical lobe (三 the homologue of second joint) with five setre, the second and fourth of which are longer and pectinate; the inner apical lobe bears six (or five) setie, all but the imnermost being pectinate. The two lobes are separated by a simple incision, aud repeated examination showed no indication of any segmentation in either sex. The abdomen is very slender, and, like the thorax, its segments are all ornamented candad with a series of spines or teeth. Stylet two and a half times as long as wide, with one or two small spines externally one third the length from the base and one longer spine near the middle of the inner margin, which is eiliate. The two median apical setie are fused at the base and the inner is three times as long as the outer, which is twice as long as the stylet. 'The inuer apical seta is short, the outer obsolescent.

In the male the antenna is reduerd to a thick tumid member with the third aud fourth segments greatly enlarged. The apical segment is furnished with three hook-like claws. Flagellum slender, of uni. form diameter. Fifth foot has on the onter apical lobe fone sete and a small spinule, and on the inner three non-pectinate setre. Candal stylet greatly elongate, over four times as long as wide and nearly twice as long as the preceding segment.

\section{Marshia brevicaudata $\mathrm{sp} . \mathrm{n}$.}

Plate XXXII, Figs. 6-13.

The second species of this genus at present known may be described comparatively. Similar to $\%$. allumprynensis in most respects, but differing in a few points so fir as known. The camblal stylets are short, about twice as long as broad, the longest seta heing seren times the length of the stylet. while the onter median seta is twice and a half as long as the stylet. These setir are not fused at the base. In the male the difference between the species is greater. The proportions of the stylet being the same as in the female, but the longest seta is 
nine times as long as the stylet. The fifth foot of the female nearly as in the previous species, but the proportions of the setie differ. The fifth feet of the male are like those of .I. allmquerquensis. The antenua of the male seem to be different. In .M. alburnerquensis the apical segment is larerer and the lagellum is long and of uniform width, while in the present species the flagellum is short and clavate. The swimming feet seem sinilar. Length of male $0.56 \mathrm{~mm}$., length of first segment $0.15 \mathrm{~mm}$., length of stylet $0.01 \mathrm{~mm}$., length of longest seta 0.28 $\mathrm{mm}$. to $0.34 \mathrm{~mm}$.

The stylets in the female of .I. alluquerpuensis measure $0.072 \mathrm{~mm}$. in the female and over 0.08 in the male, the longest seta being 0.37 and 0.42 respectively.

It must remain for larger experience to determine the value of these distinctions, which rest on comparatively few individuals in the case of M. brevicautata. 


\section{PART II}

CLADOCERA OF MINNESO'TA BY C. L. HERRICK 
. 


\section{ORDER CLADOCLRA.}

This very extensive group contains a variety of types, but there are sufficiently evident connectlng links uniting the extremes of structure. The frymnomern which, following the usual custom, we include here, stand distinct from the other groups, yet have sufticiently evident cladoceran affivities. It is very unfortunate for utio. logical speculation that this the only truly marine group should stand thus isolated from its fellows. According to the notions at present prevailing, the Phyllopods stand nearest the primitive type of crustacea. There are unmistakable hints at an "arly origin for that group, and not less evident are certain analogies with both cludoceren and Copepoda.

There has. how rer, recently been made an attempt to derive the Phyllopods from an original cladoceran stem with, as we think, somewhat unsatisfactory results. I)o we not rather see in both groups two like phases which may be looked upon as incidental and comparatively trivial? The shelled and the shell-less phases appear in both. The most closely shelled Phyllopor is mmistakably nearer Bronchipus even than any of the clutectre. It would seem that the brief and imperfect embryonic nauplius condition of the latter sufficiently indicated their later origin. Again, no fanciful analogy can unite the ostrucode with the Lynucirle. We know of no recent diseoveries casting discredit on the remark of Balfour: "The independent origin of the Ostracoda from the main crustacean stem seems probable."

Professor Packard says:*

"We imagine that when a permanent body of fresh water became established, as, for example, in perhaps early silurian times, the marine forms carried into it in the egg-condition, possibly by birds [sic?] or hy high winds, hatched joung, which, under favorable conditions, changed into sidn, Moinn and Imphnir-like forms. The r'molocere are, then, probably the more generalized forms, from which the I'hyllopods. at this time, and probalbly ever since l levonian times, pur excellence a fresh-water assemblage of forms, took their origin. Whatever affuity there may be between the shelled I'lyplopmis and the

\footnotetext{
Terr.

*A Monograph of the Pliyllopod Crustacé," etc., XIIth Annual Rep. U. S. Geol. and Geog. Surv.
} 
Chuduren, it would sem that the evidence is conclusive that the latter (rroup) is not the direct continuation of the line of development inau. gurated by an ostracole ancestor. As shown beyoud, thr present centre of the group seems near .Moinc. with indications of a divergence from this lather generalized type, especially of degradation and heteronomy on the side of the Lynceids.

It seems at the present time that more might be accomplished for atiology by a careful study of such groups as the present, in which are a variety of closely allied forms, than by the attempt to join widely s'parated gromps. When we shall have seized upou the latest edries and mapperl their direction, it may become possible to combine thr indications in such a way that liues of divergence thus traced accurately through some small part of their course may be produced backward to their intersection. This, then, is our present duty-the accurate mapping of minute districts and the careful noting of any moving straws competent to indicate movements in the vast complex of vitalized nature. We conceive the rladocero to have had a comparatively recent origin, and to express the culmination and retrogade development of a plan of structure first differentiated after the appearance of clear bodies of fresh water. All the species save a very few are confiued to inland waters. Aceepting the above mentioned theory, the Sidille will oceupy the first place as departing least from the type from which the whole group sprang, while it is comnected by the genus In aphnella with the Daphnille. The Inophnide, begimning with Moina, find their ultinate development in some monstrous forms of the genus Iraphnia. but pass into the Lymeodaphnithe by way of Marothrix. The links uniting all these minor groups are very obvious.

Our own ideas of the relationships among the culyptomerous cludocere are expressed in the accompanying table. This table is to be consid. ered a projection of a portion of a genealogical tree, seen from below, in which the genus. Moinc forms the arbitrarily chosen fixed point. The hetwy dotted line is imagined as directed downward vertically. That hranch rising toward the top of the page is growing obliguely upward. The Drphnide are reperesented as expanding upon the same

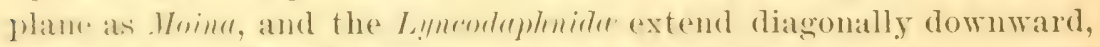
yroducing the L.ynre id branch. The lossminide spring from the stem at a lower point.

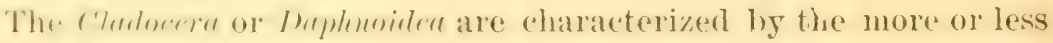
leat-like fere and the lamina of thin chitine which incloses the greater

NOTK.-To adant the diagram to the theory that the Lynceidec are the progenitors of Cladocera, it is only necessary to revolve the imaginary line to the right, ill it coincides with the axis of that family. The question mark may be understood to indicate that the source of the pivotal group, Moina, is uncertain. The author must confess that his inclination is toward a belief that the line culminating in the Daphnibo diverged from a group of organisms resembling Phyllopoda, wore definitely, resembling Jimnetes. There is a very remarkable resemblance between the larva of Limnetes and Bosmina. The lateral spines of the former are, as will be shown, true homologues of the antensules of Bosmina. The later origin of the Phyllopoda in their present form may be well admitted. 


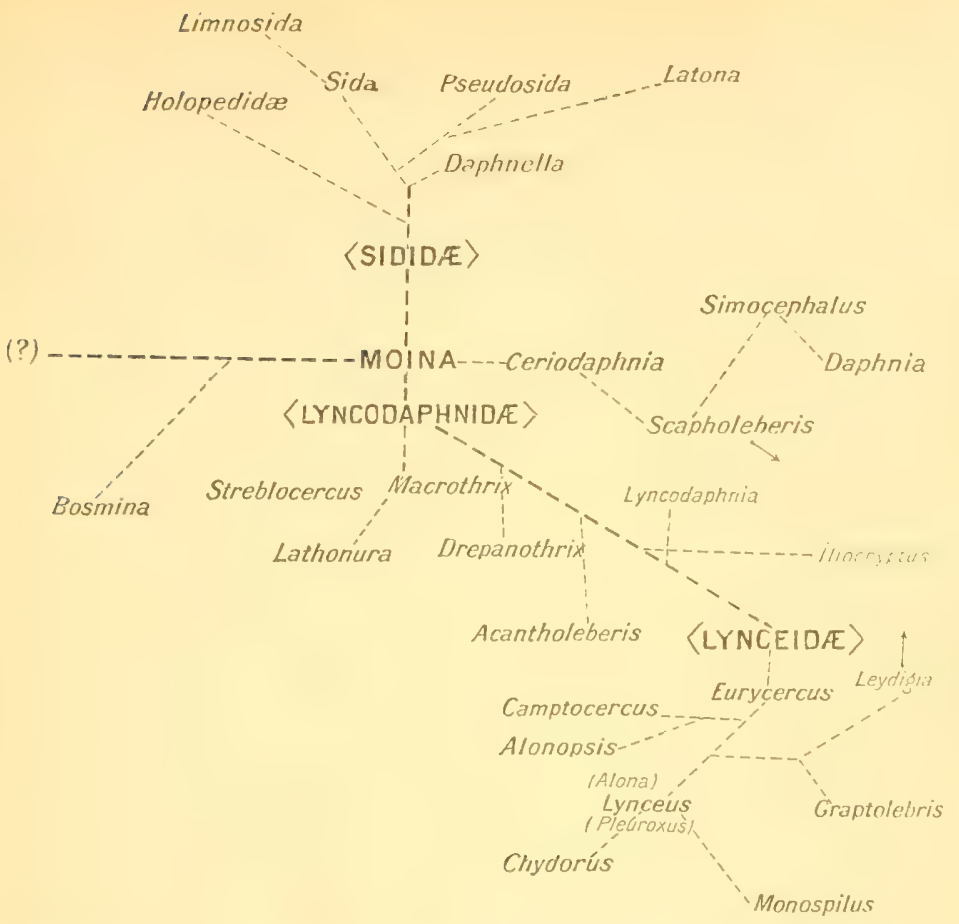

part of the hody, or at least forms a sac for the protection of the eggs. This so called shell springs as a fold from the maxillary segment, and is the most conspicuous and variously formed, while really least im. portant, of the structural peculiarities.

All Cludwerm begin life with a single median eye, but some lose it during later life. In one case it remains the only visual organ.

The outre covering is in most cases changed by frequent moults. The period of the moult is one of the most precarions in the lif history of the animal.

Although figures and brief descriptions of animals belonging to this group are to be found in the works of Swammerdam, Lenwen. hork, Trembley and others of the older authors, Tfueller* was the first to produce a systmatic work upon these in common with other minute fresh-mater crustacea. Ite may be callecl the father of the study of micro-erustacea. Jurine, $t$ an "minent swiss naturalist, was the next to contribute important discoveries relating to these inter esting animals, though Ramdohr had given anatomical details of sev-

* Entomostraca, seu Insecta testacea, quxe in aquis Danixe et Norvegixe repsrit descripsit, etc. Otto Friedrich Miiller, 1785 .

+Monoc, qui se trouvent aux Envir, de Geneve. 
eral species. (iruithuisen, a little later, gives further details of Inephnin simn (simorephulus). The work of Milne Edwards gives a resume of what was known regarding these animals in that period. Soon afterwards the work of Baird beame the beginning of a new era. and the study of the minute crustacea sprang into importance at once. The scandiranian peninsula being the birthplace of the science, - it is proper that the most exhaustive work on the group should be performed there.

The most important of the later writers are Leydig, Schoedler, Fischer, Lilljeborg, I’. E. Mueller, Sar's, Weismamn, Claus and Kinrz.

The complete bibliography of the subject up to MLueller's time is found in Baird's British Entomostrun: the greater part of the later bihliography is to be found in I'. F. Mneller's Imomurl's Cladocera. A fix only of the more important works are here mentioned, the complete list elsewhere given making repetition unnecessary.

Lillyt bory, W., Ie Crustaceis ex ordinibus tribus, (or) Om de inom skime forekommande Crustaceer af ordningarna Cladocere, Ostracoda och Copepoda.

This valuable work is particularly good on the clactorere, but is unfortunately without Latin deseriptions; so that the Swedish text is a hindrance to its usefulness. It is chiefly of historic value now. Large 8vo. Lind, 1855.

Leydig, Fr., Naturgeschichte der Daphniden.

The most magnificent work published on this group.

Surs, G. O., Om Crustacea Cladocera, iagttagne i Omegnen af Christiania, 1862.

This valuable work is dificult of access, printed on thin paper and without illustrations. A second paper by the same author in 1863 is mentioned, but I have never seen it.

Schoedler, J. E., Neue Beiträge zur Naturgeschicte der Cladoceren, 1863.

One of the most important works on the Lynceide.

Sars, G. O., Norges Ferskvands'rebsdyr Cladocera etenopoda, 1865.

The best work on the Sidide, ete.

Mucller, $P$. E., Danmark's Cladocera.

One of the most useful hooks on the subject. Eepeecially good on Lynceide and Bosminide.

Grobben, C., '/ur Eutwicklungsgeschichte d. MIoina rectirostris, 1789.

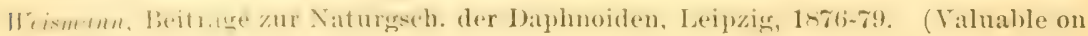
the physiology.)

The American litrature may be catalogued in a few lines. The firs descriptions and figures with which I am familiar are those in the liepunt of the l'nited stentes Fish rommision, 1Si\%, wheres. I. Smith 


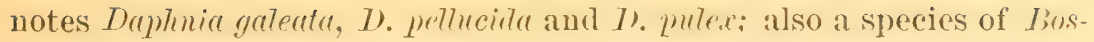
mina, Eurycercus lamellatus and Leptodora hyatina.

A. E. Birge was the first to systematically study Clutucere in America, and his Votes on Cladocera furnished a basis upon which to build. A few notes were published by the writer a little later.

A few additional notes and descriptions of new speries were published in the Eldewerth Anmul Report of the Minnesota Geological and Natural History Survey.

Professor Birge published other notes in the Medicul fournal and Excminer of Chicago, which I have not seen.

Professor Forbes of Tormal, Ill., in an article in the Americun Nuturalist, July, 1582, adds a number of facts and one new species.

In addition to the above, a figure of sidu nas printed in one of Ifuycten's survey lieports, and some account of the cluducere of Lake Michigan was given hy B. W. Thomas, I believe, in one of the official reports of the Chicago Water Commission.

Since the publication of the first edition several papers by Profes. sor Birge, Professor Turuer and the writer seem to be the only ones requiring notice.

\section{KEI TO 'THE ORIER (LAIOOCERA.}

I. Body enclosed in a bivalve shell. Mandibles truncate below. Maxillæ distinct, spiny. Thoracic ganglia discrete. (Sub-order Calyptomera.)

a. Six pairs of feet, similar, foliaceous, all distinctly branchiate.

(Tribe Ctenopoda.)

* Swimming antennæ with two unequal rami, intestine simple. Family Sididae, 146

** Swimming antennæ simple, elongate cylindrical (in the male prehensile); intestine with two lateral dilations.

Family ILolopedidie, 151

b. Five (or six) pairs of feet, the anterior pair more or less prehensile and destitute of branchix. (Tribe Anomopoda.)

* Rami of antenne three- and four-jointed; five pairs of feet, the last with a curved appendage guarding the branchial sac; antennules of the female short, one-jointed.

Family Daphnidac, 152

**: Six pairs of feet; antennules elongated, many jointed.

Family Bosminidae, 206

\%举 Antennules of female elongated, but one-jointed; intestine simple or convolute. . . . Family Lyncodaphnidae, 209

养** Antennæ with both rami three-jointed; intestine convolute, with abdominal but no anterior coeca. Family Lyuceirae, 224

II. Body witbout or nearly destitute of a bivalve shell; feet not branchiate, spiny; anterior thoracic gauglia in one mass. (Sub-orier Gymnomera.)

a. Abdomen curved, terminating in two long stylets.

b. Abdomen straight, ending in short claws.

Family Polyphemid:e, 266 Family Leptodorid: , $: 68$ 


\section{CLASSIFICATION OF THE CLADOCLRA. SUB-ORDER I.-CALTPTOMERA (membrane-clothed).}

Trime I.- Сtenopoda. Families: Sidide, Holopedidr.

Trine II.-A vomorona. Families: Daphnidx, Bosminide, Lyncodaphnidre, Lymecirle.

\section{SLB-ORIER II.-GYMYOMERI (lestitute of covering).}

Families: Polyphemidx, Leptodoridx.

\section{FAMILY SIDIDE.}

Ireal separated from the body by a depression, without prominent fornices (or spreading shields) over the base of the antenne. First pair of antenne, or antenmules, as we shall uniformly call them, onefointed, usually rather small in the female, but extending into a very strong flagellum in the male. Antenua long, biramose, with unerual hranches. Mimdihles truncate at the end. Maxillat armed with large spines. The form is usually elongate, and the abdomen often extends beyont the elge of the shell hehiud. The male openings are usually in the end of long appendages which depend from the base of the postabdomen. This interesting family is represented in America so far hy four species, one of which constitutes a new genus. Others will indoubtedly be found upon a careful study of the fauma of the Great lakes. Most of the species prefer the clearer and colder water of large lakes. The processes of development, as traced hy the writer, vary very little from the method exhibited by Mona. The ephippial comdition, however, is not found in these animals which are less sub)ject to destructive influences of the climate. They do, however, pro-

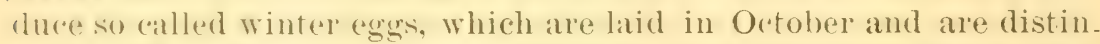
gnuished from the smmmer eggs, which hatch in the hrood cavity. by a hown (o)lor and the presence of fatty spheres. These egges are pro-

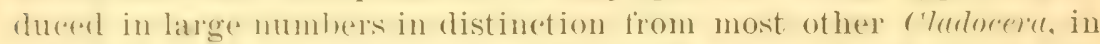
which the winter eags are very few. These exgrs are permitted to settle to the bottom and there develop at the proper time. virla reys. fullime is often fommd in immense numbers in large lakes which contain abmulant plant growth. The size, and especially the reproduction activity is very dependent on the enriromment, and hence littlesucassis obtamed in preservation in apuaria. Fome of the grenera are nocturnal and should he sought at the surface on quiet evenings.

\section{GLNUS SII)A Straus.}

budy romeate, hyaline. Head small, quatrate. Forniresabsent. Intemmules of female smatl, truncate: of male. with a long flagellum. sereond antennte with the rami two-and there-jointed. Male with the 
sexual openings just behind the last pair of feet. It is the upper or louger brauch of the antenna which in Sida is three-jointed, while the reverse is the case in the next genus. The only species, according to P. E. Mrueller, is the ubiquitous

\title{
* Sida erystallina.
}

\author{
Plates XXXV, Figs. 13-15; XXXVII, Figs. 1, 2.
}

P. E. Mueller (Daphne crystallina); Latreille (Daphuia crystallina); Straus; MilneEdwards '34-40; Gmelin, Manuel, Fabricius (Monoculus crystallinus); De Geer 1778 (Monoculus elongatus); Lievin '48; Baird '50; Lilljeborg '53; Fischer; Schoedler'58 and '63; Leydig'60; Sars '65 (elongata, aud crystallina; P. E. Mueller '68; Kurz '74; Birge '78; Herrick '79, '82 and '84; Lutz '79; Weismann; Grobben'79.

The S. elonguta of Sars is distinguished by the smaller head and its concave lower margiu and more elongate shell. The terminal joint of the longer ramus has one less seta than S. crystullina, while the postabdomen has more numerous spines. We incline to believe it a valid variety at least.

\section{GENUS PSEUD0-SIDA Herrick.}

Similar to Sida. Antenuules of the female with a long flagellum, like that of the male of sida, sensory setie lateral. Body elougate, head short, extending into a sharp beak. The post-abdomen is armed with groups of sharp spines or bristles. MIost characteristic, however, is the fact that the antennary joint, which in Sida is two-jointed, in this species is tri-articulate, and the two-jointed ramus has a great number of setæ (16 to 17 ).

\section{*Pseudo-sida tridenta Herrick.}

Plates XXXVI, Figs. 2-6; L, Fig. 9.

Herrick'84 (bidentata. By oversight the number of caudal teeth was misstated and the name made to correspond.) and ' 87.

Head very short, acute below, the beak bearing in the female a pair of rather large antenuules which are armed with a pectinate process three times the length of the antennule, and a cluster of about five sensory setæ. The antenne are as long as in Sida and well armed. The basal joint of the two jointed branch bears seven setr, the secoud ten setre of which two are apical; three-jointed ramus with very short basal segment, second four times as long as wide and armed at the end with two setæ and a spine; third segment very small, with three setre and a minute spine. The maxilla is two-jointed, the terminal joint bearing nine jointed spines or short setre. The first foot of the adult 
female is biramose, the outex ramus being large, its terminal joint bearing seven pectinate processes; the precediug segment has two procesese on the outside, while the short basal joint has a very lajge process, the outside of the base of the limb, with three similar processes, inntel ramus with five set:e on the third and four each upon the secomd third, imere marein of hase of limb produced to form a multisetose hamehial fin. L'ost abdomen rather small, its tem minal claws short and anmed with thees hasal spines and a seriesof spinules along the inside, post-abromen also ormamented with about twelve chusters of teeth along the ponterior matrain and alkout the base of the chas. The exgestalk is long and ahout theer out of evely four egegs produced parthenogenetically servesasnourishment for the fouth, the (ephiplual females (i. e.e the late females which produce pegess coated to resist (o)let or trouth) are smaller than the ordinas examples and produce two very large ova.

The shell is ornamented along the ventral margius with short spines and along the free caudal matrin with minnte hails. In most respects this sueceses is like vill, which it resembles in size. In the form of the female antennat it is like Latom, which it also somewhat resembles in the number of joints of the antenne and the numerous setie they bear. Tit is eertainly an interesting transition form. Found only in swamps bordering Inole Bas, Ala., hut whether in brackish or fresh water my notes do not inform me. Sidn regstallina lives far out in the bay, and Daphnella is found in pools along shore.

\title{
GENUS LIMNOSIDA Sars.
}

\author{
Plate XXXV, Figs. 9, 10.
}

Irad crested: rye in a conical prominence. Shell elongated, producoel above in an acute angle. Antenmules small, trumcate in the female; in the male of enomous size: antemut very long. I'ost abdomen smooth; terminal claw spiny.

The one species, L. firntose sars, is not yet known in Americat

\section{GENUS DAPHNELLA Baird.}

Neither beak nor fornices present. Antemules of female small, trumate: those of male long, llagellate. Antenua with two and threejointed lami. Male with a hook on the first foot, and large copulatory orgaus attached to the base of the post-abdomen.

\section{* Daphuclla brachyura Lievin.}

PLATE XXVI. Figs. 11-16.

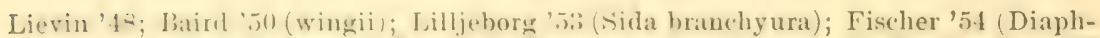
anosoma brandtianum): Sars '(6i) (I)aphnella hrandtiana); P. E. Mueller '68 Daphnella brachyura); Pavesi '79 (Silla brachyura); Herrick '82; Birge '78. 
The species of lluphnella found about Minneapolis, occasionally abundant, seems not to differ in any important character from linopean types of $I$. Inachynu, althongh I formerly regarded it as distinct (D. winchelli, Microseopic Entom., Addenda).

Head less than one-half the body (ahout 0.27 mm., while the hody is $0.6 \mathrm{~mm}$. long); eje ahout one fout th heart; antenna when refleserl extend a little beyond two thinds the length of the body. Marle, 1). $i$ mm. long; antenute rellexed, reaching bate of shell; anterior antemia extremely long: copulating organs reaching nearly to end of chaws. Haring earefully compared our specemens with the deseriptions and fignres given by loirge for his $/$. arpinese, the evidences seems to indicate not only that they are identical, hut both are really l). bucdeynem. The distinctive characters of $I$. enpinder are a greater indentation hetween head and boty, absence of candial teeth, greater length of male appendages, and the opening of the vasa de ferent ia below the "instep" of these appendages.

The absence of teeth upon the post abdomen is of even generic inportance according to sars, who gires it in his synopsis of genera as typical for Inephollu. In our specimens the claws are at least pectinate if not serrate, while the appendages of the male reach generally nearly to the middle of the claws. The relative length of these appendages and the antennæ of the male is variable.

\section{Daphnella braudtiana Fischer.}

Plate XXXVII, Figs. 3-6.

Head as long as half the body, antemne when rellexed reaching beyond the posterior margin of the valyes. Length $0.5 \mathrm{~mm}$. (If the validity of this species we can form no conclusion. It is usually considered a variety or phase of the above.

\section{Daphnella excisa Sars.}

Sars '85 (Diaphanosoma excisum).

Similar to $D$. brachyura. Head olotusely truncate cephalad, without distiuct siuus beneath the eye, dorsal margin slightly arched. Carapace ohlong, truncate posteriorly with the dorsal angle nearly a right angle, valves inflected in the middle and wide open posteriorly, having a well marked angular emargination at the junction of the ventral and caudal margins. Iye large. Antenne, when reflexed, not reaching the caudal margin of shell. Length $1.30 \mathrm{~mm}$. The head occupies about one-third the entire length. The apical claws are armed with three teeth. 


\section{GENUS LATONA Straus.}

Plate XXXV, Fig. 8.

Body elongate, broad; head large and square, appendaged below with triangular lamina; fornices present. Antennules rather large. The larger ramus of the antenne is two jointed and has an expanded process at the base. The lower posterior angle of the shell has a peculiar diverging set of setie. The shell is often ornamented with numerous flecks of bright color. There is a copulatory apparatus in the male.

\section{* Latona setifera Mueller,}

Is the only species, and is not yet recognized in Minuesota, but was found by Professor Birge in Lake Michigan.

P'rofessor Birge mentions "one peculiarity not mentioued by any European writer. There is a thick coat of short hairs on the head, hody and antenna. 'These hairs are $0.02 \mathrm{~mm}$. or less in length, are close set and give the outline a velvoty appearance when seen by transmitted light. It lives in clear water among weeds."

\section{GENUS LATONOPSIS Sars. 1888.}

Allied to Latona. Impression between head and thorax slight or absent. Labrum devoid of plate like expausion. Antennule with a long, plumose, straight or curved flagellum, articulated to the basal part. Antema with simple rami, the superior ramus bi-articulate, the inferior tri-articulate, as in Duphnella. Heart concave dorsally, truncate anteriorly, the aorta arising on the ventral side. Shell gland with three long branches. Male with simple copulatory organ, and hook on first leg. Antennule long, slightly curred, armed with fine treth, resembling in general the antemnule of sida but having a median projection near the base.

\section{* Latonopsis occidentalis Birge.}

Plate XXXVIII.

Birge ' 91 .

Anterior outline of head forming a nearly straight line from the antemules to the eye, where it passes by an abrupt curve into the nearly straight continuous margin of the shell, which, howerer, becomes convex in old females. The ventral margin is continued into the labrum and lacks the leaf-like appendages of Latona. Small hilobed fornices are present. 'The ventral margin of the shell is evenly rounded. passing without marked projection into the straight (atulal margin. The edge of the shell is fringed with long plumose 
setre, of which three at the lower caudal angle are enlarged and divergent. Surface of shell smooth. Antennules composed of a nearly cylindrical basal part and a much longer, curved, tapering, hairy flagellum. Sensory setæ about eight at the posterior side of the distal end of the base. Antenux with massive basal portion bearing a dorsal bi-articulate and a veutral tri-articulate ramus. The basal joint of the former has four to five setie and a spine, and the apical joint seren setie and a spine, while the second joint of the latter has one seta and a spine, the apical four setie. The post-abdomen is short, fleshy, obtusely conical, and armed with nine supra-aual denticles. The terminal claws are strongly curved and have two secondary teeth. The antennules of the male resemble those of Duphnellin, and form near their bases is a ciliated appendage. The copulatory organs resemble those of Latom, and the first leg has a strong hook. This species was found by Birge in a small lake in Wiseonsin.

The remaining species of the genus $L_{\text {. }}$ anstralis Sars is exceedingly close, but the fornices are said to be absent and the antemnules are shorter than the anterior margin of the head. We have encountered this interesting species at Albuquerque, New Mexico, and are inclined to believe it southern in range, only sporadic in the north.

\section{FAMILY HOLOPEDIDE.}

Body inclosed in a hyaline, gelatinons envelope. Head small, depressed. Antennules short, immorable, alike in both sexes. Antennx uni-ramose in the female, in the male a small rudiment of a second ramus present. Munth parts not covered by the shell. There are six pairs of lammellate swimming feet. Yo external copulatory organ.

\section{GENUS HOLOPEDIUII Zaddach.}

The characters are those of the family.

* Holopedium gibberum Zaddach.

Plate XXYV, FIG. 11.

Zaddach '56; Sars '62 and '65; Mueller '68; Fric '72; Hellich '77; Forbes '82; Herrick '84; Birge '92.

The small head is depressed and conical, beakless. Tye small, with few lenses. Pigment fleck large, at the base of the antemules, which are short, "ylindrical, slightly expanded in the middle. There are three apical setie at the end of the second joint of the one-branched female anteuns. Shell sculptureless, its lower free margin is toothed caudad. Post-abdomen short, conical, straight, anmed ou either side 
with about ten teeth. The claws are short and curved and have one lyasal spine aud fine tecth. The palp of the male antenma has two setr.

This species has been fomnd near Mradison by Birge and by Forhes in Lake Michigan.

\section{FAMILY DAPHNIDA.}

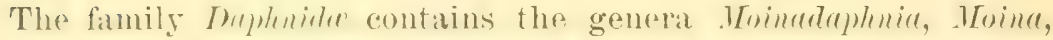

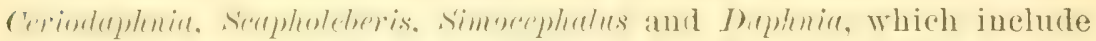
the commonest, as well as some of the largast, chatorera. The genera may be distinguished by the following table:

I. Head rounded, not beaked; antennules long in both sexes, shell not covering the end of the abdomen.

a. Abdomen with process of abdomen to retain ova, Moinadaphnia, 166

b. Abdomen without the process in ordinary females, . . . Moina, 160

II. Head rounded; antenuules rather short; shell inclosing whole body,

Ceriodaphnia, 167

III. Head somewhat beaked below; shell angled below or extending in long spines from lower augle, pigment fleck rouudish, Scapholeberis, 174

IV. Head beaked below; shell rounded below, with a blunt spine above; pigment fleck elongate,

Simocephalus, 177

V. Head beaked below; shell extending in a sharp spine at the upper posterior angle; pigment fleck small,

Daphnia, 181

\section{The Circulatory System of the Daphnidae.}

PlaAte LI.

In the Daphnide, and, indeed, the Cladocera in general, we meet an

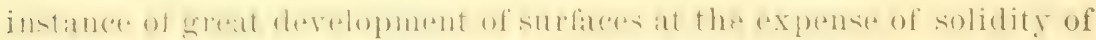

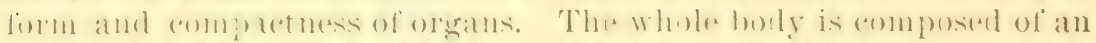

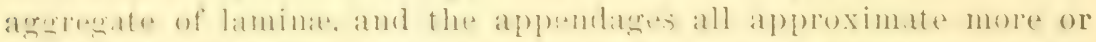

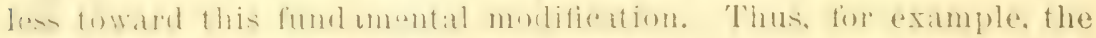

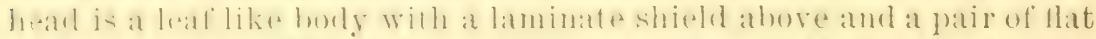

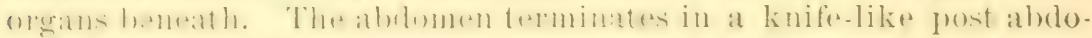

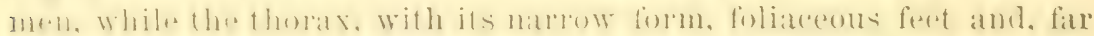
more, the enormous derelopment of the outer wall to inclose, more or less fully, the entire body, is the typical illustration of this fact.

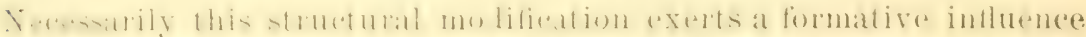

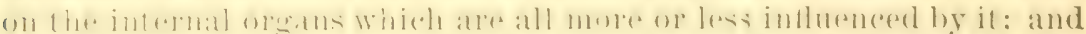

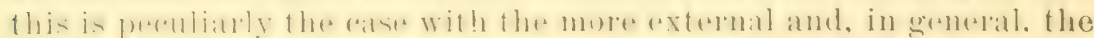

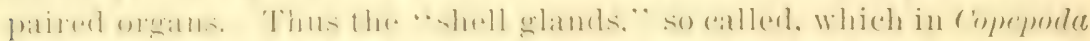

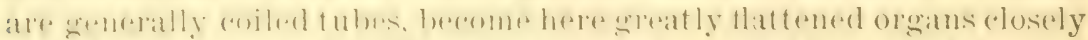

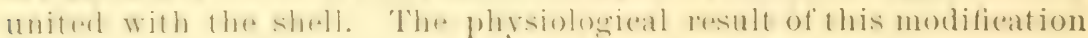
is the sensitifenesto fotheres in the environment, which is universal 
among the Daphnider. The compact. C'mpendu survive the ricissitudes of confinement with comparative immunity, but the fist taint in the water destroys the delicate organism of Imolnnir. The cause for this may be found in the exposure of the most vital and delicate parts of the organism to the influences of the surrounding aqueous medium. In pitticular the circulatory and respiratory systems, which here are mot easily to be distinguished one from the other, constitute a relatively very large area of close contact with the water. It thus liappens that the central organs are influenced in a very short time by whaterer deleterious substances may be disseminated in the water.

Notwithstanding this lack of centralization, the structure of these animals is of a very considerable degree of complexity amr, presenting so many instructive modilications under circumstances so favorable for stuly, has been very thoroughly investigated. The rery trausparency which has male it possible to clear up many yuestionahle points in crustaceology from the lessons leaned in Muphnie has rendered the investigation of cartainsets oforyus extremely diffentt. and among these may be mentioned the circulatory system. The cinemlafion of the nutritive fluid and the genelal farets comnereded with the heart were indeed early understood: but there remain many a detail and some important relations whioh are as yet either imperfectly known or entirely mismurlerstond. The following notes are offered as a (ontribution to the as get incomplete, knowlectge of tie circulatory apparatus.

The observations were confined for the most part to Thphnin selut fieri

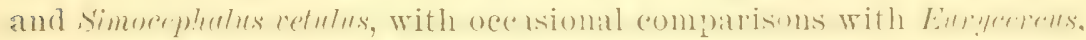
Pleuroxis, Pusithea and others. It is greatly to be desired that the study might the carried to the sididn. in which the larger sizte and superior transparency would douhtess rewad the seareh with several, as get dounteul details. The comentation of the nutritire fluid in the

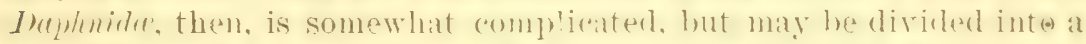
superficial and a deepsytem. It must he remarked that thisclistinction is arbitrary and only usal for its comveniunce. The one extends over the entire inner surface of the "arapace, while the latter is in olose relation with the vegutative organs, and extends into thr hranchial vessels of the feet. Thu mutritive fluid which is nommally colorless and supplied with corpuseles of orsanized nutriment (it sisems dombtful if they should be ralled hlood corpusceles). is eomfined for the most, if not its entire, consse within manhmanoms walls of connective tissue which, howerer, instean of assuming a definite form as "blood ressels." for the most part conform to the contour furnished ly the firmer orgaus. 
This membrane, which is frequently folded upon itself and invests the body walls and the inuer organs, is in some places free, and may be sten as a pulsating, swinging film, or, more frequently, it can only be detected as a swaying line (seen in optical sections), thus giving rise to the misapprehension that one is dealing with a thread, or as moring grains, in which case the film is itself invisible but its presence is indicated by the attached grains of protoplasm. About the heart the freeswaying portions of this membranous layer are so numerous as to render it almost impossible to distinguish the essential from the accidental appearances.

This membrane must serve the most various purposes; aside from the mere retention and direction of the blood currents, it is often transformed into a branchial surface. At definite points it becomes the bearer of the cells which were above mentioned as grains of protoplasm. These are most numerous in young and well fed animals, and in particular in gravid females, while, on the contrary, mature males and females after the escape of the young, are nearly devoid of such bodies. These are most numerous in the angles of the membrane, particularly about the heart, shell glands, ovaries, intestine and the branchial spaces in the feet.

These cells vary in size from that of the blood corpuscles to larger cells with nuclei of comparatively very large size. It would be too. much to say that such cells are developing blood corpuscles; but that they are reservoirs of nutriment which serve to supply the increased demand upon the blood in exigencies of the existence of the animal, cannot be doubted. It is a well-known fact that the number of blood corpuscles, so called, likewise varies, and apparently under the same conditions. It seems altogether probable that the two facts mas be considered as supplementary, i. e., that the same process of depauperating of the blood, which deprives it of its corpuscles in an earlier stage. lays waste those supplies laid up in the cells referred to (whether by their actual separation as blood corpuscles or simply dissolving of the contaned material is of little importance). These cells also are thus parallelized with the "oil globules" of copepondu.

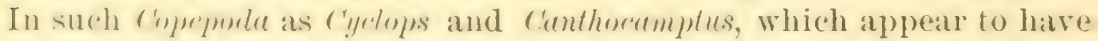
no differentiated heart, there are always present drops of colored fluid, which are most numerous in well-fed and preguant specimeus. These drops ocoupy the same relative position as the blood globules of other finsturen, i. e., they lie within at very thin membrane correspomding to the vascular walls of other animals. This membrame, in general, incests the alimentary canal, as ean be very realily seen in the aldomen, where it incioses a considerable space about the intestine, which is filled with fluid. investing more or less completely the muscles 
and other organs. As there is no rapid circulation of blood, these "oil drops" are comparatively stationary, and yet are moved slowly by the constant contraction of the walls of the alimentary canal, which, in the anterior part, or stomach, are thick and glandular, while in the abdomen they seem to be more fitted for respiratory function.

The above arrangement in (yclops is correlated with its compact habit and thick carapace, and forms a simple starting-point for the study of the circulatory system in arthropods. It seems that the walls of the membranous blood cavity are themselves also, in places, furnished with muscles, so that the fluid is not depeudent entirely on the vermiform or the peristaltic motions of the intestine for its escape from stagnation. If this be correct, we here have an indication of the origin of the central organ of the circulatory system.

But to return to Daphniu, the heart lies in the dorsal region over the intestine, upon which it may be said to ride, as it were, astride, though, as we shall see, it is separated from the intestine by other organs. In Furycerens this is most evident, as here the heart is more obviously bifurcate.

The heart and circulation in Daphniu has been described more or less at leugth by many authors, in particular Claus ('76) aud Gruithuisen (the work of this author I have not seen), while Weismann ('74) describes the heart of Leptodorm, and Claus ('77) that of the Polyphemide. Other authors, except G. O. Sars, who elucidates some points in the circulation of blood in sida, seem to have added little or nothing to our knowledge of this interesting subject.

As already often deseribed, the heart ocenpies a place in a definite space-the pericardial chamber-the sumnit of which is the dorsal shield, which, we believe, should be distinguished from the remainder of the so-called cephalic shield. It is usual to describe the shell of Daphnia as consisting of a bivalve posterior portion or ormostegite, and a simple anterior cephalostegite; but it seems much more proper to consider that portion of the shell which covers the pericardial space and is the point of attachment of the powerfinl muscles of the abdomen and of the membranous walls of the pericardium as a distinct portion of the carapace, as it often evidently appears through the presence of a distinct suture, or, in its absence, through the peculiar seulpture of the shell. Iu such case it might also be proper to distiuguish two regions on the lateral appendages of this dorsal shield, an upper and a lower, separated by the more or less obvious line ex. tending from the union of the lateral lines of the dorsal and cephalic shield in nearly a straight line toward the posterior portion of the shell, and indicating the insertion of the muscles which move the feet and post-abdomen. The lateral walls of the pericardial space are the 
shell walls themselves, and the floor is formed by a membrane suppurted on, and investing in part, the strong muscles which connect the abdomen with the upper anterior part of the dorsal plite. Thus a space is left between the pericardium and the intestine which is occupied hy a special blood sinus leading toward the posterior and lower part of the abdomen. The posterior wall of the space is formed hy a chitinous partition which bounds the hrood space, or its homologur, and is connected by chitinous processes (stutzbalken) with the outer skileton. The anterior, on the other hand, is only bounded by the supporting ligiments of the abdomen above described and membranous partitions. As mally deseribed, the heart lies suspended in the cavity thus definem by slender muscular threads, more or less like those of the heart of 'orether larve and the like: and such seems to be the case at first, but a more careful study shows that this is far from correct. On the contrary, the chief supports of the heart are membranes which, seen in cross section with the attached grains or blood slohules, assume the appearauce of exceedingly slender structureless threats. The action of reagents indicates that these supposed threals are not muscles, but composed of comnective tissue; while by changing the focus the sharpmess of the line is frecuently not altered,

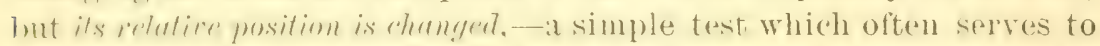
dispel an illusion of this sort. That there are some threads of the (batadere above mentioned is not to be doubted, as in eomection with the valves of the heart; but the proper support of the heart is fonnd in the membranes which invest it in part, and are reflected mpon the walls of the shell and, anteriorly, of the intestine. It is not

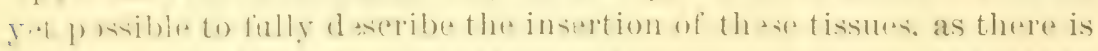
s) barge a number. especially about the anterior opening, where the lir in all direetions and at all angles, and are so transparent that only thrip rertical sentions appear as dark lines. Thus the same membrane

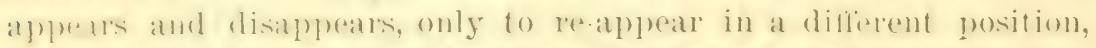
where it might be readily taken for a distinct memblame. In general, howerer. I hope to make no serions apror in the folbowing summary.

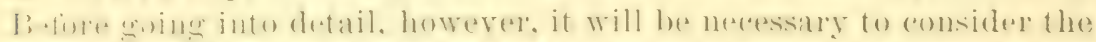

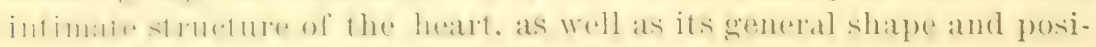
tion. (See I'late LI.)

The general shape is that of an irregular oval with the gereatest

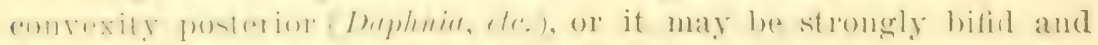

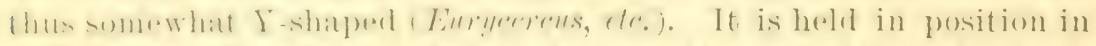
the prericardial cavity hy the membranes above alluded to, to which it is attacherl at definde groints. the principal of which are two slight (-nlengenents on the lower posterior portion. which are in part opjusent to each of her and also to a superior posterior joint of insertion. 
All three of these points are thus held in relation with the shell with which the attached membrane is connected on either side helow and above. The membrane then extends part way along the heart wall towards the anterior and is then reflected to the shell wall. The result of this is that the pericardial space is an angular carity opening in front. It would seem as though the membrane attaching the heart were identical with that lining the eavity itself. The heart proper is obviously composed of series of muscular elements, which are cousidered as simple cells by Chaus, and which in young individuals show very distinct nuclei of comparatively large size. These are arranged like the meridian lines of a globe, uniting above and below, thus forming the most effective apparatus possible for contracting the heart. In the smaller Maphnirle, as stated by Clans, there seems to be

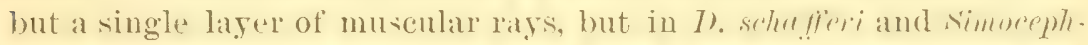
alus. I have repeatedly satisfied myself that some of the longitudinal rays sink below the others and form a series of longitudinal muscles, as stated by earlier writers. These are furnished with a nucleus which is frepuently more or less external, appearing like a spherical appendage. In Leptodorn Wrismann has shown the heart to consist primarily of a membrane of connective tissue, npon which the musenlar fibers or cells sit in somewhat the same position as in /n,phnir. exrept that there is not the same regularity in the arrangement. There are many considerations which would lead us to expect the salne structure in Duphnien, though it is not yet demonstrated: and the strueture of the anterior opening seems to point in the same direction. At any rate there is a close commertion hetreen the muscular and connective parts of the heart. Whe have, them, in the heart of Imphnin a highly developed apparatus for closing it. but apparently none for its opening. This certainly is not accomplished by the few fibers which connect the heart with the shell. the very contratility of which is doubtful. Xay, more, these are insufficient even to hold it in its place in the cavity. Still less can we assume that the heart, from any inherent power, can open itself. This must be explatined by the operation of two factors which are interdependent, i. e.. the elasticity of the supporting membranes and the mexplual pressure of the blood in different parts of the hody. 1. The membranes which support the heart are attached not at right angles. but, on the contrary, in a direcfion more nearly parallel to the walls of the heart, and thus whaterer elasticity they possess is greatly increased: and the diminishing of the size of the heart draws these membrames ont of their position at the expense of their elasticity, which tends to restore them to their original position when the pressure is removed, in the same way a drumhead returns after a hlow to its normal position. This factor is. how- 
ever, only operative so long as the whole system of membranes to which these belong is distended with fluid. If this blood cavity be punctured, the fluid flows out and the heart shrivels. It may continue to beat for some time, but it will be seen that the effort consists simply in a vigorous contraction which is followed by no perceptible enlargement. 2. After the systole the blood of the heart is forced toward the head, whence it is prevented from reentering the pericardial space directly by the valves and the membrane inclosing the arterial blood. The pressure is therefore increased in all parts of the system except the pericardial chamber, where it is greatly diminished. The membrames supporting the heart are thus unusually tense, and the muscular effort having ceased, the walls of the heart are distended, and blood flows in in the direction of the least resistance throngh the two lateral openings or ventral valves of the heart. The contraction of the heart during the systole is not simultaneous in different parts, but begins by the contraction of the posterior part where, being nearly free, the motion is more marked. At the close of the systole the heart is irregularly contracted, the points of attachment above described being more distended than the remaining portions. The anterior of the heart is rendered very difficult to study by the fact that its opening is covered by the muscles of the mandibles and obscured by the many supporting and vibrating membranes alluded to.

It is, however, suspended by two folds of membrane which I have been inclined at times to believe blood-vessels through appearances resulting from the confused currents flowing about them. The upper margin is also attached by a pair of cords directly to the superior part of the shell. The anterior opening or arterial valve is most perplexing, and the following deseription which applies only to Daphnia schufliri must be subject to some doubt. It appears, however, that it has been in a measure misunderstood by previous writers, and namely by ('ams, who compares it with that of leptodora. which, if correctly describer by Weismann, is not at all irlentical in form, but quite comparable with one of the siles or lips of the venous opening. It does not seem to be counected by a thread, as stated for Leplodora, with the aortal bulb, for in reality there is no aortal bulb; the heart simply is connected with the system of mimbranes which more or less inclose the system. The floor of the so-called aortal space is a membrane which separates the outhowing stream from a current which flows toward the abdomen and passes directly under the arterial opening, so that it appears as though there was a stream entering the heart from before as well as at the sides: the arterial opening being nearer the dorsal part of the heart than is naturally expected, and the slight enlargements at the attachment of the supporting membrane 
favoring the impression that there is here a veritable opening. The outflowing blood stream is bounded at first by the membrane above mentioned, which is farther on reflexed onto the shell and intestine so that the streams in the head flowing just under the shell are separated from the deep dorsal stream flowing from the heart.* This main current passes to the region of the eye between the horns of the coen of the alimentary canal, and thence beneath the stomach, and here divides, part becoming external and a deeper part passing under the intestine, thence in front of the heart, flows into the deep sinus which, as before said, passes beneath this organ. Other portions of the returning stream flow around the angle of the union of the head and body and constitute a stream just above the feet in which the current flows vigorously.

Yet other portions flow into the region of the shell gland and are united with blood which here passes through the numerous sinuses deseribed by Claus ('75) as surrounding this organ, and thence flows into the abdomen, uniting with the other two streams. A part also of the current in the head flows into the antennie where it follows a deep course through the basal joint in which the corpuscles may be seen to emerge to the surface from two points where are spaces between the powerful muscles, the first being near the base and the second near the extremity of this joint, and then to return and join the superficial current.

The corpuseles appear to enter the rami very rarely if at all. That part of the superficial stream which reaches the interior of the pericardial chamber passes between the museles of antennæ and jaws, and seems to find its way into the great current beneath the heart, though I have also thought to have seeu it flow directly into the pericardial space as the lateral superficial streams do. That part of the superficial stream which reaches the posterior margin of the shell returns through a canal formed by the walls of the shell and the brood-space, between the "stutzbalken" of which the blood corpuscles can be seen to glide more rapidly than in the free lateral spaces.

Lastly, it only remains to follow the fortume of the strong stream flowing along the neutral surface of the abdomen. The strong current flowing beneath the heart enters a broad sinus which lies over the intestine and extends for over a third of its length, where its walls unite with the surface of the intestine above and thus open downward on either side.

The stream thus directed flows toward the openings of the base of the feet. The structure of the branchix has not yet beeu clearly de-

- In Pasithea rectirostris this septum is easily seen as a swaying membrane, which near the eye is reflexed to the top of the shell. 
scribed. Instead of nearly spherical or oral chambers they are really tubes which connect on one hand with the opening above, and below with the general (avity of the limb, whence the blood returns to the aldonen. The current is rery rapid through these tubes. The blood having been returned to the abdomen, courses in the well-known manner throngh the post ahdomen and flows over the intestine, thence orer the back flowing stream to the posterior lower opening of the pericardial chamber.

The study of the actions of the heart is rendered more diffoult by the latet that in oreler to secure the greatest possible transparency. the living animal must he covered and a little presisure applied, which is frepuently attended with abnomal variations of the circulation. In particular, if the usual exit of the blood he stopped by the cuear of the intestine, as is frequently the case, the operation of the heart mas be reversed, when a vigorous stream may he seen to enter the arterial opening and emerge from the ventricles. This process would be impossible if the anterior valve were as described hy Clans and Weismann: while being really more like the venous valves, it is easily and frefuently permitted. The current of the blood in this case stagnates except near the heart.

The rapility of the pulsations of the heart varies with age and condition of rest or motion.

In $/$. schufieri this variation may range from about $150 \mathrm{per}$ minute to perhaps 250 , 200 being probably a fair average. In a young simorepholus I have observed a heart beat $: 300$ times in a minute. Again, in a specimen of $I$. sdrufferi at rest the heart was beating 170 . but during the spasmolie motion of feet and antenne the pulse rose to over 200.

\section{GENUS MOINA Baird.}

The systematio position of this genus has heen the theme of some discusion, it heing raimed, with good reason, that there are many

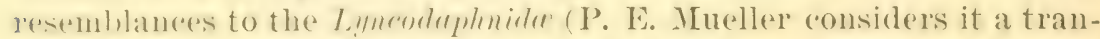

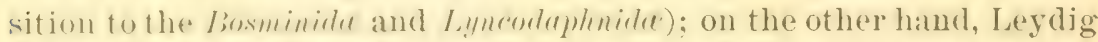
and Ku1\% regard it nore closely allied to the Nislifle, with equally good reason. The long antemir. long narrow antemmles and nuany peculiarities in lorm, ete., suggest the macrothroid crustaceans; the exfented ablomen and expecially the location of the male seminal

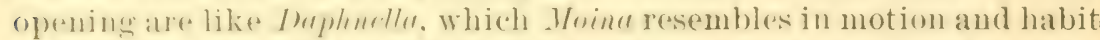
very strikingly. The alsence of the pigment flecek is no more a characteristio of the sidfide than of other groups. After all has been said, the immediate affinities of the gemus are acknowledged to be with the Daphnicte. 
The true place of the gemus, as it appears to the writer, was hinted at by Birge (Ioles on Chadocera). Inomia seems to be the pivotal point of the clatucert, at least of the families above mentioned. Without going into phylogentic speculation, it is suggestive that this genus can and does by preference live in very impure water, and may therefore have had an early origin. From Monum diverges the sten of the

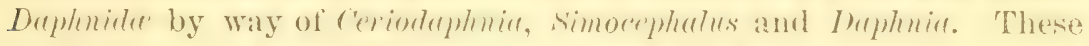
two latter genera are intimately connected hy simompholus dophenides

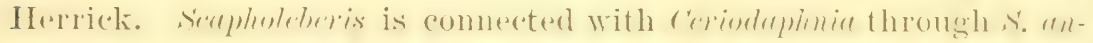

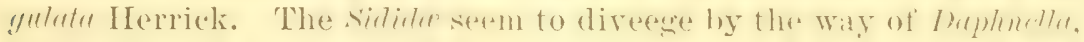

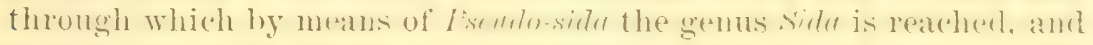
finally Limuside, retone and Ifolopedinem. The relationships of the curious Polyphemide are less evident.

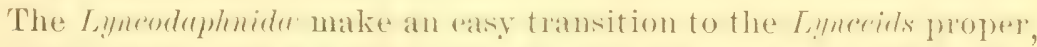
While the Bosminide ale still quite isolated, but are suggested hy .he-

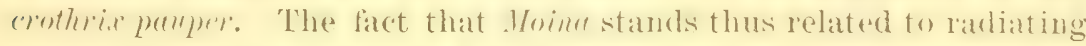
groups is simply suggestive, hut it is suggestive of its possible antiquity and synthetic character.

The three species of this gems stand rery poorly distinguished from one another and their specific validity may be doubted.

The most exhaustive study of the "mbryology of the chedencen was based on Moina (Grobben '79).

The genus is characterized by Weismamn and Gruber ('SO) ahout as follows:

Iead prone; separated by a depression from the thorax; fornices obscure; rostrum none; pigment fleck absent; antennules of the female large, movable, furnished with a sensitive seta near the middle, llagel. liform; antenuules of the male very large, houked at the end. The setre of the antenna are all ciliate; the tri-articulate ramus with fire setie; posterior margin of the valves thicker in the median line; caudal setie very large, about twice in the length of the aumal; anus abore the claws; feet of the first pair of the male with a strong hook.

Weismaun has shown that both summer and winter eggs originate from groups of four cells, one of which only is transformed into the egg, the remaining three serving simply as a supply of nourishment for the egg, which absorbs it directly. Bothe eggs and nutrient cells develop from the epithelium of the termination of the orary. The summer eggs have less jolk than the winter brood, and the yolk is bluish in the summer eggs and deep red in the winter eggs of Mormu redirostris; while in .I. pardorat the summer eggss have yellow and the wiuter set snow-white yolk. There are never more than two winter eggs iu any of the Thunnictie, but there are as many as twenty summer eggs in some cases in Moina. In M. rectirostris only one winter egg is 
produced, which is one of the best distinctions of the species, as this is, perhaps, the only case (Weismann '76-79). The first generation, springing from the winter eggs (impregnated eggs), is composed solely of females which reproduce parthenogenetically; the second brood contains sexual males and females, thus completing the cyclus.

To the ahove, which is reproduced with a few verbal changes from the first edition, it may be added that the interesting genus Moincdinphniu, found in Alahama, makes the transition toward the genus In lookerl that there are several forms of Moina which have the anastomosing strix upon the shell which is characteristic of Simocephetus, while the ephippium has the characteristic hexagonal marking of crimaphniu. The synonomy of the genus is uncertain, and there is no donlht that several authors have confused more than one species under a single name.

The following artificial key may assist in placing the species, but should not be too mechanically relied upon.

\section{IEY TO THE GENUS MOINA.}

I. Shell not sculptured or simply dotted.

A. Spines of the abdomen ferver than nine.

micrura [not described.]

B. Spines of the abdomen nine or more.

a. Claw with a basal series of strong spines externally.

* Ephippium with two eggs, shell reticulate. . Jrachiata, 162

* Ephippium with one egg, shell smooth. . . rectirostris, 163

b. Claw with a basal series of fine hairs externally and a continuous series of the like internally.

fischeri, 165; paradoxa, 164

II. Shell more or less covered by anastomosing strix.

A. Claws smooth. . . . . . . . . . propinqua, 165

B. Claws with teeth. . . . . lilljeborgi [not described in the text.]

[Not noticed in the key: azorica, 165; salina, 166; banffyi, 166]

Moina brachiata Jurine.

Plates XXXIX, Figs. 5-8; XliII, Figs. 1, 2.

Jurine $: 20$ (Monoculus hrachiatus); Straus-Durckheim '19-'20 (Daphnia macrocopus); Zaddach '44 (Datphnia brachiata); Lievin '48 (Daphina brachiata); Baird '50; Leylig '(60) (I)aphnia hrachiata); P. E. Mueller '68; Uljanin '75' ; Kurz, 74; Hellich 'ซf; Schoeller '7\%; l'irge '78 and '91; Herrick '82 and '84; Richard ' 881 ; Lund ' $70 \cdot 71$.

It is guite cortain that the above bihliography includes several instances wheres the name. II. brachiata is applied to other species or to include sereral species. but it serms best to place all in evidence. 
The description given hy Hellich is the most full at our disposal and runs about as follows: Body robust, untransparent greenish in color. The head depressed and broadly and deeply excarated ahove the eye. Lower angle of head with the front strongly arched. Eyes with many lenses; pigment fleck absent. Antennules springiug from the middle of the lower margin of the head, slightly enlarged at the middle, covered with short hairs, with one lateral flagellum, as loug as the head. The antenne redlexed do not attain the posterior margin of the shell and are hairy. Shell margin short spined in front and armed with fine spines to the posterior lower angle. Shell faintly reticulate. Post abdomen large, lateral spines teu to eleven, the first heing bifid. Claws strongly curved. with a series of eight or nine strong teeth at the base and a continuous series inwardly. Length 1.i) to 1.4 mm. Male smaller. head extended. Antemules affixed ne:trer the front, longer than the liead, flexed at the middle, armed at the end with four cleft claws and at the midelle externally with three short bristles. Unfortmuately Ifellich does not deseribe the first foot of the male, though P. E. Mrueller figures it as devoid of the elongate dlagetlum characteristic of $M$. paradoxa.

\section{* Moina rectirostris Jurine.}

Plates XXXIX, Figs. 1-4; XLI, Figs. 2, 5, 8, 10, 11.

Jurine ':O (Monoculus rectirostris); Fischer '1: (I):lphnia rectirostris); Leydig '60

(Daphuia rectirostris); Baird '50; Fric '721 (Daphnia rectirostris); Kurz '74;

Weismann '77; Hellich '77; Schoedler'77; Herrick'84.

From the preceding, which it too closely resembles, this species differs in the fact that the shell has no trace of reticular marking, the ephippium has but a single ova horizontally placed, while .T. Drachiata has two in a vertical position. The post abdomen has twelve to fourteen teeth as against. nine or ten for M. Inquhulu. The free caudal margin of the abdomen is hairy. The shell margins below are armed with distant and shom teeth. Ifollich thinks Kurz ielentified this species with the last. With the ahove this species agrees in the form of the head and antenna and nearly all other characters.

As for the American forms, it is ynite possible that we shall erentwally be enahled to distinguish sevelal valieties of the fruchirtu rectirostris type, but very careful sturly of local and seasomal influences will he necessary to give to such distinctions any value as specifie claracters. That considerable variation does ocenr is beyond question. Tre may recognize two types which do not correspond fully with the two European varieties.

YARETY A - I ength 1.1 to $1.2 \mathrm{~mm}$. head 0.37 mm. depth of head 0.40. IIead slightly angled ahove the eye: antennules short not much 
more than half as long as the height of the head), hairy, straight, spindle shaped, inserted some what behind the middle of the lower margin of the head and not in a special depression, flagellum onethird from base $0.21 \mathrm{~mm}$. long. Jody subject to great variation, but always much willer than the head. Lower shell margins sparsely spined to near the posterior angle. Lbdomen slender, with several teeth in front of the claws. Claws slightly curved with a basal external series of strong teeth and a continuous inner series of fine spines. Lateral abdominal spines twelve or thirteen. Posterior margin ahove the anus slightly hairy. Ephippium with one egg, ephippial female with an abdominal process. Shell with elongate hexagonal markings.

VARIFY B-L'roportions exhibited by the following measurements: Length, $1.1 \mathrm{~mm}$.; leugth of head $0.41 \mathrm{~mm}$, height of head $0.46 \mathrm{~mm}$. The head is strongly depressed, excavated above the eye. Anteunules slender, long, hairy, attached far from the ese at a sharp angle of the inferior margin, flagellum nearer the middle than the preceding. Antenno very hairy. Body less robust than the preceding, ventral margin sparsely hairy to a point some distance from the posterior angle, thence to the upper posterior angle armed with minute closely set spinules or teeth. Abdomen slender, without the numerous small teeth above the claws on the front margin, claws with about ten strong basal teeth and a continuous inner series. Lateral abdominal spines ten or twelve. In neither variety have we seen any other markings than the point-like elevations scattered over the shell except upon the ephippium. Almost the only reliable difference between these varieties serms to be in the form and insertion of the antennules and the outline of the head.

* Moina paradoxa Weismann.

Plates XXXIX, Fig. 9; XL; XLI, Figs. 1, 3, 4, 6, 7, y.

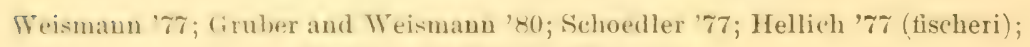
Herrick ' 84 ; Moniez' 88 (azorica).

This speecies may be distinguished from the preceding by the latet that the head is short and not excavated above the eye, the teeth of the ferminal claws are reduced to bristles in two series, the first foot of the male has a long flagellum, longer than the whole member, the male antennule is rery long and flexed at about the middle, and the ephippium contains two winter eggs.

The mature summer female is almost monstrously deformed by the multitude of goung in the hrood sace, which swell that cavity into a great sub-spherical sac extending in all directions beyoud the ordi- 
mary limits of the shell. The ephippial female retains more of the normal proportion, hut the dorsal half of each valve is mostly transformed, by the development of very pronomed reticular markings and thickening, into a two-valved, pod-like case for two perpendicularly disposed winter ova. The male is elongate, with the head much produced formard and remalkably developed antemmules and feet of the first pair. 'The former are sharply flexel near the middle at the insertion of the musche, at which point is one short spine and a slender fligellum. At the end are three curved claws and the sensory filaments. The inner hranch of the tirst foot is, as msual, modified to form a stroug hook, while the outer ramus has a very long curvel flagellum which protrudes beyoud the shell and bears a terminal hook. The antenumle of the female is attachnd nearer the eye than the base of the labrum, but has no prowounced depression; it is nearly cylindrical and but slightly curved, very hairy, and its flagellum is at its basal one-third. The antenna are strong and densely ciliate throughout. The whole ventral margin of the shell is armen with distant setr. The abdomen is rather short, the claws being short and slightly curved and bearing a short series of fine spines externally at the hase and a continuous series of spiuules intermally. The lateral spines are nine to ten and ciliate. The dorsil part of the posterior margin is ornamented with clustered hairs.

Moina fistheri Hellich is undoubtedly the present species, but there seems to be no way to settle the priority of names.

Length $1.03 \mathrm{~mm}$; length of head $0.35 \mathrm{~mm}$, antennule $0.27 \mathrm{~mm}$, height of summer female $1.05 \mathrm{~mm}$, length of male antenma $0.04 \mathrm{~mm}$, length of ephippium $0.6 \mathrm{~mm}$.

It may be noticed in passing that the generic distinction claimed for Moina, based on the absence of the process for occhuding the brood sac, is not absolute, for we have seen in the case of gravid females of.$M$. paratoin a small process, and sins also mentions one in $M$. propindur. This prepares us to find it well leveloped in the next of kin, Woindaphnir. Matile states that this species was first described by Hudendorff ('T6) as Moinc flayellatu, but I am not prepared to investigate the question.

Moina sulina Stephanow was regarded by him as a saline modification or variety of $I$. rectirostris.

The description of Moimu "oride, as given by Moniez, is as follows:

"Chez sette espèce, la tête, dans les devix sexes, est arrondie, sans depression; l'antenue du male est terminće nou par des crochets, mais par des tentacules yui, sous l'influence de l'alcool, prenuent une forme assez irreguliere et dont l'extremites'invagiue en doigt de gant; l'antevue port une soie unique a l'endroit de la coubure. Le fout de la premiere patte du male est enorme, et mesure 5 fois la longuer de 
I'article terminal, mesure a partir de l'extremite de la branchie; chez la femelle cette meme patte est charaterisee par l'uue des soies, yui s'est transformee en un batonnet court et gros, cilie d'une facm particuliere. La conformation des autres pattes, dans les denx sexes, presente egalement des characteres speciaux, difficiles a exposer sans le secours du dessin on sans une longue description. La carapace est marquee de tubercules termines par des poils; les crochets dorsaux sont simples et limitent un large espece qui prend la configuration d'un cour quand la corguille est etalee. Les crochets terminaux du post-abdomen portent au cote interne et vers leur base une plarue dentere, et. ils sont surmontes d'une dent unique; ils n'ont pas de peigne. La femelle porte deux œufs dans son ephippium."

Daday mentions the following speceies, which are added provisionally:

Moina salina Stephanow.

Capite supra oculum impressione iusioni, fornice indistincts; testa corporis fere quadramenlari, marrine auteriore ac inferiore setis perpucis; antemis in mare apice monihus (urratis, majusculis 5); ahdomiue sine processu; ('auda aculeis magnis 10 setosis armata, marnine superiore tuberculis perparvic lateribusque setis minutis, in scries transversales hositis; unguibus caudalihus sine spenarum serie pectiniformi magine anteriore processu dentiformi longe, usque ad medimm setosis. Longit fem., 0.75 to $0.9 \mathrm{~mm}$.; altit, 0.45 to $0.5 \mathrm{~mm}$.

\section{Moina banftyi Daday.}

Testa capitis setis tecta; testa corporis fere quadranıulari, obtuse angulata, parte postica supra duos processus curvatos formanti; antennis primi peris abigue ciliatis, laminis yuadrangulatribus ohtectis; cauda apicem versus attenuata; nuguibus candalibus curratis, setosis. Longit. fem., 0.9 to $15 \mathrm{~mm}$.

\section{GENUS MOINADAPHNIA Herrick. 1857.}

Head stromgly arched ahove, angled in front of the eye, somewhat beaked at the cauclal end of the lower marcin, near which are aftixed the slender antemmules. Tody quadrate, as in 7)(ephire hut merely anched at the dorso-candal angle. P'ost-ahdomen rongate, armed as

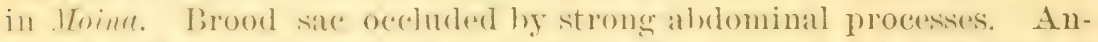
femmat with a lomg mojuinted spine from the apex of the last joint of the fomr jointed ramms, othersise as in Moimu. The first member of

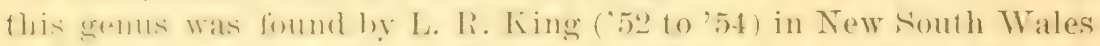

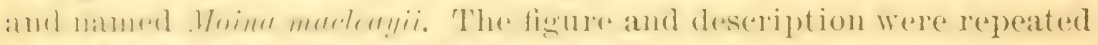

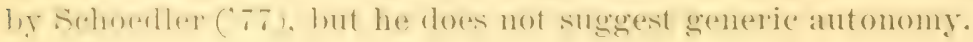

-Noinadaphnia alabamensis Herrick.

PLATE XXXVI, FIGS. 7-10.

Herrick' 87.

As stlectested in the original paper. this species not omly affords a

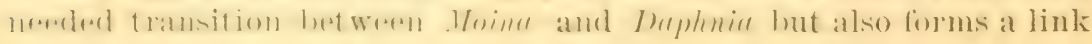


with the fanna of the southern hemisphere. The species is large compared with Mlonia, being $1.68 \mathrm{~mm}$. long. The head is shaped much as in simoceplenlus, being acutely rounded in front of the eye and provided with a distiuct beak, near which the antenne are attached. The eye is large and the fornix evident, as in Imphnia. The antemnules are long and slender, little narrowed apically, armed with a flagellum at the basal third. Antenue slender, segments narrow; apical segment of four-jointed ramms has in addition to the three geniculate setie a very long spine representing the short thorn occupying that place in Moinu, otherwise as in that genus. Boxly quadrangular, somewhat produced above at the posterior angle. Lower margin armed with short spines as in lnuleniu. Abdomen slender, claw slightly curved and armed with a continuous series of small setit. I short spine in front of the claw. Lateral spines as in Ifoinu, twelve or more in number, the first being bificl. Dorsal part of abdomen with a long process for occluding the brood sac, also a blunt tuberosity caudad of it. The general habitus is like Koinu, but in the form of the shell and many details it approaches Inphuir. The description of King's species is not full enough to make specitio comparison possible, but of the generic relationship there can be no question. The most important diaguostic difference - that in the formula of the antennary spines - not lundamental but a mere matter of proportions.

\section{GENUS CERIODAPHNIA Dana.}

The genus rerimathnin is the successor to . Frina, which some species greatly resemble; the post-abdomen, however, is shorter and has a habitus resembling Inphnio; the antennir are smaller and the shell is thick and coarsely reticulated.

Ceriodephnim has the same ganeral mode of life as . Yoinu, living in muddy pools in late summer and bearing numerous broods which often greatly extend the brood cavity. The antennules are shorter but have a similar form; the male antennit: show a transition in the various species from forms adapted for prehension to such as are found in Duphnir. The brood cavity is chosed by two ridges on the abdomen instead of one, as in Moina, or three, as in Daphnia.

The ephippium contains but a single ovun. In general, the form is oral or puadrate, angled but not spined posteriorly: head separated from the body by a deep depression; pigment fleck present: heak absent; antenuules movable, rather short; antenna with the threejointed ramus with five setre; lirst foot of the male with a hook or flagellum. 
The members of this genus are diuger signals from a hygirnic point of view. for they frepuntert water containing decaying matter; as many as 1, 100 were counted in a single quart of such water. The genus is partivalarly preplexing, as the rarieties named seem to be hardly entitled to speceifice rank and are so similar as to require great care to properly distinguish.

The following artifial key, it is helievel, will assist in placing the speximens which may be obtained in America. Thereseems no reason to douht that onr fanna is very similar to that of north linope. (of the twelve species here enumerated at least one third mas be symonyms and others of the remainder are with difieulty distinguished.

\section{KEY 'TO 'THE ('ESUS (ERIOI) A PIISIA.}

I. Head without a "horn."

a. Shell irregularly striate. . . . . . . . . . megops, 168

b. Shell with hexagonal meshes.

* Shell with doubly contoured markings.

$\dagger$ Head broad, short.

pulchella, 169

†† Head narrowed, depressed.

† Antennules normal. . . . . . . . . rotunda, 169

†े Antenuules elongate. . . . . . . alabamensis, 170

*: Shell simply marked.

+ Claws with teeth.

reticulata, 170 ; (lentata, 170

$\dagger \dagger$ Claws without teeth.

† Antenne very long.

punctata, 171

† Antenuse normal or short.

\%. Post-abdomen broad. . laticaudata. 171; consors, 171

\%. Post-abdomen narrow.

Head not angled behind the eye. . quadrangula, 172

III Head abruptly angled behind the eye. . . scitula, 172

*** Shell opening pointed.

setosa, 173

c. Shell recticulate with rectangular meshes. . . . . . . nitida, 173

II. Ifead with a curved "horn." . . . . . . . . . . coruuta, 174

[Not noticed in the key: asperata, 173; minuta, 173; textilis, 173;

rotundata, 173; echinata, 173.]

Ceriodaphuia megops Sars.

PLATE XLI, Fig. 20.

Birge '78 (cristata).

This sperom is mor of the latgest and most reatily distinguished

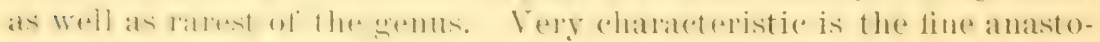

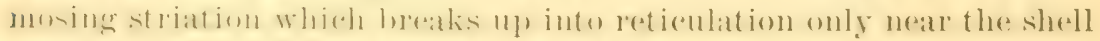

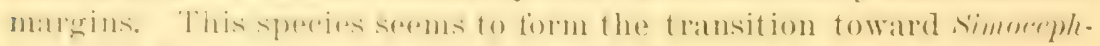

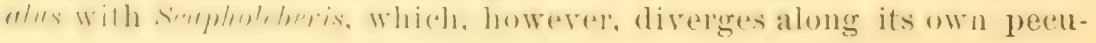


liar track. The length is sometimes $1.0 \mathrm{~mm}$. The head is olscurely angulated in front of the antennules, which are large. The antennules of the male are long and have hooked seta at the end.

The description of 'eriouluphnia reistatu given by Birge would apply in almost every particular to $C$. mremps, though he seemed to overlook the close conformity. The size is much less $(0.7 \mathrm{~mm}$.), and the pustabdomen seems more abruptly truncate: nnoreorer the number of anal spines is less. The erest upou the dorsal margin may le the eflect of prominences such as are described hy P. E. Mneller: at auy sate in riew of the fact that but few specimens were discorered. the suggestion lios near that $r$. cristutu is the young or, at least, a reshesen form of $C$. merops. I'rofessor Birge writes thet he nom unites cristente with C. megops.

Found at Southampton, Mass.

\section{Ceriodaphnia putchella Sars.}

Plate Xli, Figs. 14, 19.

Verg much like C. refirmtertu. hut smaller. Haad large. turgid, and anglex in front of the antennules, firming almost a right angle; fornices moderate: antennules rather large: shell oval, reticulated with donble contour lines; post-abdomen of menlium size. narrowed toward the end, slightly truncate. with about nine spines; terminal claws short, smooth. The flagellum of the male antenne is but slightly hooked, 0.5 to $0.6 \mathrm{~mm}$. long. This species is not certainly identified from America, though a form with smooth claws and small fornices occurs with $C$. dentati in some places.

\section{Ceriodaphnia rotunda Straus.}

Plates Xli, Figs. 12, 23; Xlit, Fig. 1.

Daphnia rotunda-Straus, Baird.

As sair by Kur\%, this species is not easily mistaken; the small head (only paralleled by the followiog), the very evident reticulations and the broad abdomen give it a peculiar hahitus which is mmistakahle.

If ard depressed, small, spiuy bolow, not angulated; fornices prominent, thorned; body rotund, almost spined above; shell doubly retieulate: post-abdomen broad, with seven or eight anal spines: claws large, smooth. The male antenuules are little larger than those of the female. I have not yet seen this species in America. 


\section{Ceriodaphnia alabamensis Herrick.}

PLATE XLII, FIG. 2.

(American Naturalist, May, 1883. Puate V, Figs. 11, 12.)

This species was seen but once and is insufficiently known. The body is elongate, quatrate, the shell reticulated with double contour lines, the head very small and produced downward below the eye, which is very small, the antennules are longer than in any other species, ohviomsly two jointed, with a lateral seta; the antenne are very long: post ablomen long and rather narrow, with the margins nearly parallel, truncate at the end, with over nine anal spines; claws smooth, ahruptly truncate. My drawing represents a daphnia-like set of processes for closing the brood cavity. Length $1.0 \mathrm{~mm}$.

Tuscaloosa, Ala.

* Ceriodaphnia reticulata Jurine.

Plates ILI, Figs. 15, 21; XliI, Fig. 3; XLIII, Fig. 3; Xliv, Figs. 3, 4.

Honoculus reticulatus-Jurine.

Daphnia reticulata-Baird, Leydig.

Ceriodaphnia quadrangula-Schoedler.

Ceriodaphnia fischeri-Leydig, Schoedler, etc.

Ilead long. obscurely angled in front of the antenunles; fornices very prominent: antenumles small; post-ablomen of moderate size, rommled at the end, slightly tapering; about eight long anal teeth; terminal claws with a series of sharp spines at the base. The reticulations are sharp but simple. The flagellum of the male antennule is either straight or moderately curved. Kurz says that some varieties hase the fornices blunt while other's are sharp. I have seen only the blunt form, which is then much like the next.

\section{[* Ceriodaphnia dentata Birge.]}

This form diflers from the above only in having the inside of the chas fringed with minute bristles (sometimes absent), the angle of the hear being more marked and the fornioes lese prominent. It is

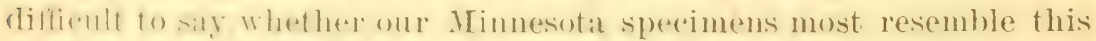
or the typical re relienlater of Europe. Thes seem intermediate, some having furnices with an abrupt angle. It may be instructive to quote

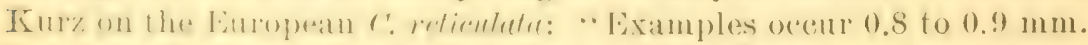
longer oflers on the contrary only 10.5 to 0.6 mm. long and combining with the smaller size some diflerential characters. In the latrger variefy. I found the formix olituse, while in the smaller it extends in a shatp thorn directed upward and out watrd. In this small sub-species 
the secondary teeth of the claws of the post-abdomen seemed to be absent, though in $C$. reticulutu three to five are constantly present." Professor Birge now identifies this species with $C$. reticulutu.

Ceriodaphnia punctata P. E. Mueller.

Plate XII, Fig. 13.

Head depressed, rounded at the end, not angulated, ornamented with minute spines within the hexagoual areas. Fornices slightly prominent, either smonth or spiny: antennules very long: shell rotund, reticulated; post-abdomen of medium size, width nearly uniform, truncate below at an obtuse angle; anal spines large, increasing toward the end; claws smooth. Length 0.7 to $0.9 \mathrm{~mm}$.

Found as yet only in Scandinavia.

* Cexiodaphnia laticaudata P. E. Mueller.

Plate Xli, Fig. 22.

Ceriodaphnia quadrangula-Sars (fide Mueller).

Ceriodaphnia consors-Birge.

Head small, depressed, rounded at the end, not angulated; fornices prominent; shell roundish, or sulh-fludrangular, moderately reticulated, antennules rather large; post-abdomen broad, narrowed from the middle to the end; the nine or ten small anal spines nearly equal; claws large and smootb. In I'. E. MLeller's time males unknown. Length $1.0 \mathrm{~mm}$. Specineus $0.6 \mathrm{~mm}$. long from Minnesota agree in most respects, but the reticulation is rery markerl and irregular and the terminal claws are pectinate. This form coustitutes a transition to the next.

A species related to C. luticumdutu, but only half the size. Was found in Clarke's lake, a small but very deep' pool, containing a fauna like that of the Great Lakes. The appearance is like the small form alluded to under that species, but the clans are smooth, the head is slender and strongly angled behind the eyes, and the antenmules are of rather large size. The fornices are not very prominent. The shell is large-reticulate and the abdomen is large and obliquely truncate, the anal teeth being very large and strongly curred. The ouly individuals seen were ephippial females measuring $0.55 \mathrm{~mm}$. This may be

* Ceriodaphnia consors Birge.

Plates Xlil, Fig. 4; XLIV, Figs. 5, 6.

This differs from C? lutirumbuta in one or two points, being about one-half the size and having fewer caudal teeth. Birge says the abdo- 
men is hroad aud obliquely truncate. The difference between being oblifuely truncate and narrowed at the end in some circumstances disappears, so that really this species seems quite close to laticunduta.

Found in Madison, Wis.

\title{
Ceriodaphnia quadrangula Mueller.
}

\author{
Plate XLI, Figs. 16-18.
}

Daphnia quadrangula-O. F. Mueller.

Daphnia reticulata-Baird.

IFead depressed, rounded at the end, only slightly angled; fornices prominent, antennules large; post-ahdomen narrow, of equal width for the lower half, romded at the end, with about eight small spines; claws smooth, length about $0.6 \mathrm{~mm}$. 'This species resembles a smoothclawed D. reticulata.

* Ceriodaplinia scitula Herrick.

Plates Xli, Figs. 5-8; Xliv, Figs. 1, 2; XLV, Fig. 1.

Gne of the most ahundant species of cerimduphniu in Minnesola is a large form much resembling r. qualdantyulu. The post-abdomen is exactly as in r. reticulutu or C. dentede, which latter it resembles in having a sharp angulation in front of the antennules. The shell is ohlong and heavily marked with minute, regular hexagonal lining; the upper angle is rather sharp. The head is closely appressed, the fornices are prominent and abruptly truncate at the tip, the eye is small, the pigment fleck also small; antennules short. The postabdomen is of moderate size, narrowed toward the end and armed with about ten powerful curved spines; the terminal chw itself is large and rurved, armed only with fine spines extending down the entire inner side. The size is 0.5 to $1.0 \mathrm{~mm}$; color pinkish, oparpue; antemma, especially, often bright pink. Male $0.6 \mathrm{~mm}$; Hagellum of the male antenne long; sensorg filaments lateral, also one anterior, lateral flagellum.

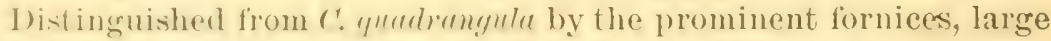
an:al spines, small retioulations, form of head and larger size.

A small variety resembling the ahove very closely is the commonat liom in our larger lakes: the reticulation is commonly larger hut less distinct. the head is depressed and narrowed. with a sinuous "1ppr. outline. The fornices are prominent and the form of the postablement is exactly as in the last. The spines of the post-abdomen are very long and seated on small eminences. The length hardly exrereds $0.55 \mathrm{~mm}$. The claw is densely ciliated, but not spined; these 
smaller forms have but few eggs (two). The goung have a thorn on the angle of the fornices. Plate XIT, fig. 1, represents the ephippial female of this species. There seems no reason to douht that this is only a variety of $r$. scitule. The small form of $r$. retiruluta mentioned by Kurz might be referred here. while the larger form with less prominent fornices is not so different from the American $C$. dentata.

\section{Ceriodaphnia nitida Schoedler.}

\section{Ceriodaphnia quadrangula-Leydig.}

This species seens to be characterizul by the (quadrangular form of the meshes of the shell-markings and the presence of tecth upon the claws. Probably invalid.

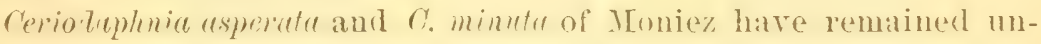
known to me. Cf. Note sur des Ostracodes, Cladoceres, et Hy-

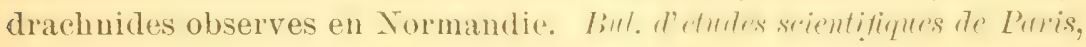
$188 \%$.

Cerioduphnire textilis D.una is not sulliciently fully figured to allow of a suggestion as to its affinities.

Dephenir rotundute siay is very probably a momber of this genus, thongh the deseription is hardly intelligiblu. . Ismly rounded hehind; npper autenne three-branched, a small spine abore at the joints; lower five-bauchel: color white. L'ngth $1.5 \mathrm{smm}$." It is probable that we should read "upper bruch of" antenne with three setie," ete., in which ease we may identify the above with rhymorns or the like.

\section{Ceriodaphnia setosa Matile.}

Matile' '90.

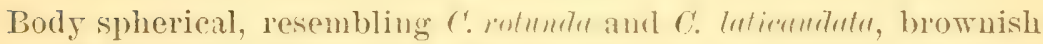
red. Head small, elepressed. Front nuiformly rounded. A deep depression between head and hody. Fornix moderate, spiny. Head and body ornamented with polygonal meshes from every angle of which springs a spine perpendicular to the surface. Autenne very short. Antenuules rather long, lateral seta nearer the base than the tip. Post-abdomen large, gradually narrowed toward the end. Anal tecth seven or eight and nearly wilual. Claw armed with a series of fine cilia. Eye large. Macula small. Length 0.42 to 0.56 mm.; heighth 0.27 to $0.36 \mathrm{~mm}$.

It is probable that this is identical with feriodephnim edhenda Moniez ('s7, 1. 512), but there are minor differencess and the problem must be left open. 


\section{Ceriodaphnia cornuta Sars.}

Sars ' 85.

This interesting species furmishes further evidence of the close relation between revioduphnia and stopholeberis by the possession of a frontal spine or "horn." Head much depressed, with frontal part slightly dilated. A process arises directly cephalad of the eye, another forming a beak. Carapace broadly oval, tumid, with a bifid caudal projection from the upper angle. Whole shell distinctly reticulate with polygonal markings. Antemunles short, fusiform, lateral setal near the middle. 'Two distinct abdominal processes. Aral spines ahout eight. Claw without basal teeth. Jeugth $0.6 \mathrm{~mm}$. The form resembles $C$. quadrangula. The fornices are acute.

\section{GENUS SCAPHOLEBERIS.}

The genus sorpholeberis stands rather closely related to rériorluphnir. from which it is at once distinguished by the angled or spined lower posterior angle of the shell. The head is rather clumsy, and the continuation of the fornices rums toward the apex of the incurved beak, which commonly lies within the valves of the shell. The lower anterior angle has a prominence and there is a basin-shaped area inclosing the base of the antenua part of which lies on the shell and part on the head. This area is more strongly lined or reticulated than the rest of the shell. The lower margin is straight and terminates, in most forms, in a long scythe shaped spine which is directed backward. 'The shell itself is usually indistinctly reticulate or ummarked, and commonly is deep colored. 'The post-abdomen is very like reriorlephnin ol more as in simorephulus; the anal spumes are firw and the older specimens have more than the young; the place at which additional spines are to appear is marked hy prominences. The eye is of mod(1ate size. the pigment fleck rather small and the antemunles short and hidelen by the batk. The antenute are of small size and generally dark colorecl. The "phippium contains hut one enges; the males do not have altered antemmat or feet. The sexual periods tall in early summer and in antmm, areording to Weismann; the males appear but

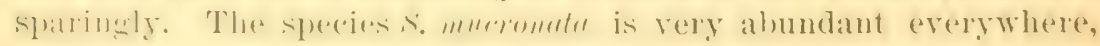
while the others are less frequently seen.

\section{* Scajholeberis mucronata Mueller.}

PLATES XLIII, FIGS. 4-7; XLV, FIG. 5.

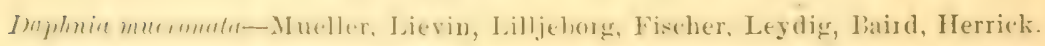

This well-known suecies with rather short spines below is fomnd 
abundantly everywhere. In this country at least it is characterized by a dark color. The head is large, rounded in front of the large eye, serrate below and extending posteriorly into a roundish beak, back of which are the short antennules. The fornices are very short and rounded; a line counects the fornices with the beak hy a sudden deflection downward; it sets off the area which forms a part of the basin of the antenner. A second line springing from just allove the termination of the fornices passes over the eye by a broad curve. The postabdomen is truncate and bears beside the terminal claws four or more spines which rapidly decrease in size. The chats are minutely spined; the spines on the shell are of variahle length, hut do not exceed onefouth the leugth of the remainder of the lower margin. This species ranges over all Europe and eastern United States.

Length 0.6 to $0.8 \mathrm{~mm}$.

Scapholeberis coruuta Schoedler.

Plate XLV, Fig. 6.

Monoculus bispinosus-De Geer.

Daphnia mucronata var. acute rostrata-Baird.

Scapholeberis mucronata var. fronte cornuta-P. E. Mueller.

This species differs from the above only in having a sharp curved horn on the head in front of the eye. 'The use of this appendage can only be conjectured; but it may loe that, like the ('urved beak of Ripophilus, it serves to clear away rubbish in the filth in which these animals frequently live. This form, be it variety or species, is not kuown in America.

\section{* Seapholeberis armata Herrick.}

Plate XLII, Fias. 10, 11.

Scapholeberis mucronata var. armata-Herrick.

A verg beantiful aud unique species. which possesses the extreme development of the peculiarities of the genus. The head is shaped rery much as in the previous species, the fornix is stuarish, the basin for the antenne is small. The npper lines from the fornix meet behind the eye; the form of the shell is as in the above, but the spines upou the lower margin are longer. The seythe-likespine on the lower angles of the valves is extremeny long, falling little short, in extreme cases, of being as long as the entire lower margin, in othersabont onehalf as large. There are the usual lines parallel to the lower edge of the shell. The specimens haring the longest spines were found in fresh water about MLobile, Ala.. Int the species ocents in Minnesota and intermediate points. though sparingly. Probably the earlier plan of regarding this as a variety of $S$. mucronuta is nearer correct. 
* Scapholeberis aurita Fischer.

Daphnia aurita-Fischer.

Scapholeberis nasuta-Birge.

Form much as in the last, head shorter, "prolonged into at rather sharp heak, at whose apex the continuations of the fornices mite. The beak does not project downw ard as in s. mucromulu, but backward, and in its natural position lies between the valves." The usual reticulated and lined areas are present and the balance of the shell is covered with "small pointed projections." "The antennules are much larger than in s. murvomule, though they do not project beyond the rostrum." The pigment fleck is long and large; the post-ablomen is much as in the preceding species; the terminal claws have several fiue teeth. The males have the opening of the vas deferens close behind the terminal claws: mucro short and blunt, length $1.0 \mathrm{~mm}$. This species is very near the next, but differs in several particulars. It forms the transition to the next, which is the extreme of the genus in a direction converse to that pursued by the S. armata.

\section{* Scapholeberis angulata Herrick.}

Plates Xli, Figs. 9, 9a; XLV, Figs. 7, 7a.

Herrick'83.

Form as in the above, but comparatively larger; valves quadrau. gular, anterior margin strongly arched; head short, only slightly concare below the eyes: the beak is as in s. nusutu. but seems to be directed more nearly directly downward than in that species. The antennules are long and resemble those of simocephulus. The pigment fleck is sifuare and rather large; the antenne are of the usual size. The reticulated areas are as in the other speries. The post-abdomen is more as in Imphnir. not sosquarely truncate and with five to seven large teeth: the first foot has one elongated jointed seta; the posterior angle of the shell has no spine, at most there is a somewhat prominent acute angle, the inner shell layer is armed at this point with some elongated teeth as in the corresponding situation in simorephalus. On the whole, there is a similarity to that genus in this as well as in the previous speceies. S. nusutu has a short spine and elongated pigment fleck, the fresent sperefes hats a sipurish but rather large fleck and no spine; the post abdomen has a greater number of spines than any other species. South of 'Tennessee river, in Alabama and Mississippi.

The species of this genus are predominatingly American, four ont five heing fonnd in the Inited states: the fifth, moreover, is more often reagarded a variety of one of the others; in fact, the absence of 
S. cormutu from dmerica is one of the most important supports of the specific independence of the two forms. All the species delight in disporting themselres near the surface in sumy weather.

\section{GENUS SIHOCEPHALUS.}

Although a very well circumscribed group, this genus passes into the next rather directly by means of $x$. macrollwoiles. The commection on the other hand seems to be by the way of sompholeberis, though there is a rather broad separation between even smpholeberis angulute and any known simocephalus. The rularged spines near the angle of the shell and the form of the antennules as well as some other points, show a transition through that species toward the present genus. The general form is ruadrate with the lower posterior margin sinuate; in young specimens the shell is nearly a perfect rectangle. The upper margin is produced more or less at the point of union with the free posterior margin, and the shell is either arched or very abruptly angled above the prominence in old females. The head is produced into a projection at the eje, while the beak proper is between the anterior margins of the valves; the pigment fleck is rather large and variously shaped. The fornices are larger than in Scapholeberis and extend to the front of the head over the eyes; the antennules have a lateral flagellum which is large and lance-shaped. The post-abdomen varies very little in shape; it is truncate and excavated below and very broad. The anal teeth are few, large, curved, pectinate; the claws are straightish and pectinate or spined; the labrum is shaped as in Duphrio; the anterior part of the stomach has the usual coeca.

The members of this genus are among the most abundant and conspicuous of the family and are more persistent during the changing seasons than any other form. S. retulus, the commonest species, stands in the centre of the genus, while two extremes are expressed by the other members of the group.

The winter or sexually produced eggs are lodged in an ephippium or saddle-like modification of the shell, which is finely reticulate; while the shell is msually marked by fiue anastamosing lines which, in some species, show clearly their derivation from a rather fine hexagonal marking.

The sexual periods, when males are produced, occur in atumu and spring. The males have few distinguishing charactoristic's, the form being that of the young female.

Theopening of the vasa deferentia is back of the anus, hence these ducts cross the course of the intestine. They have ejaculatory musclus 
about the lower fart. The smaller species are frequently deeply colored with pink, purple and brown fatty deposits and the markings are more conspicuns than in the American Eurycerens, wach is itself often hrightly spotted with blue or purple. The aspect in the water is betreen that of Eurycercus and Daphia.

The first mention made of any member of this genus in America is

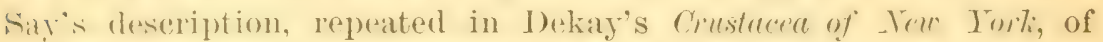
Inphnir angulatu. This description which follows is anite suflicient 10 identify the genus, and indeed to indicate that either s. amerirums or a related form is intended, but it is hardly competent to alter names the significance of which is quite clear.

"Sides striate with numerous parallel minute oblique lines; hind edge of the body with a prominent angle in the midlle. Antennse with four filaments on the upper and five on the lower branch. Color white or red. Letength $0.1 \mathrm{~mm}$. Stagnant water in the forests of the Sonthern states."

* Simocephalus vetulus Mueller.

Plates XLIV, Fig. 7; LII, Figs. 6-9.

Daphnia vetula-Baird, Herrick.

Inphnin simn-Mueller, Latreille, Bosc, Ramdolır, Gruithuisen, Desmarest, Lamarck, M. Edwards, Koch, Gmelin, Manuel, Jurine, Lilljeborg, Leydig.

This (ommonest and one of the largest species is apparently distributed over the northern hemisphere and abounds in all the more shallow lakes. The head is rounded in front and is not angled between the prominenes of the eye and the beak. The body is very large and mot abruptly angled above, the spine of the shell being inconspicuous and high. so that the free posterior edges of the shell lack little of mpllaling the greatest height of the shell. The shell is covered with minute densestriations which spring from the free edges. The pigment Herek is relongated in old spereinens and the upper angle follows 11p beside the suture separating the antemnary basin from the rest of the shell of the hearl. The antemules are ornamented with minute grines. It the lowes angle of the shell are three emred spines which diffor from the preseding filaments. The mumber of exges which are

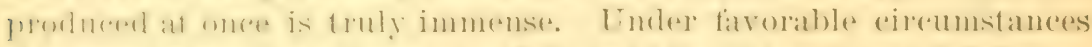

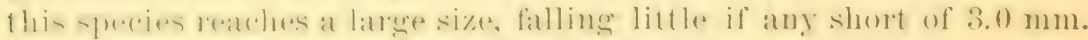

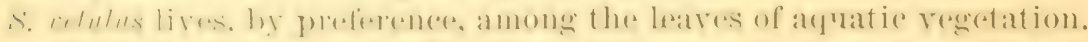
With us this spereies serens to live in the smaller pools as well as in

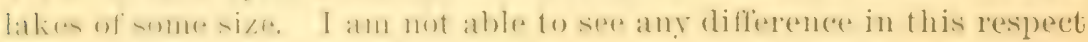
between the various species. 
*Simocephalus serrulatus Koch.

Daphnia serrulata-Koch, Lievin, Fischer, Lilljeborg.

Head narrow, extending anteriorly into a sharp spiny angle in front of the eye. Dorsal line of the shell abruptly angled or curved posteriorly, projecting to form a broad obtuse spine behiud; this spine is serrate with sharp teeth aud lies somewhat above the middle of the height of the animal, so that the free posterior margins of the shell fall much short of reaching the greatest height of the shell. Postabmomen of the usual form, with the claws armed with two series of spines or bristles, the outer being much the larger; anal teeth curved or angled, dentate; pigment fleck triangular or rhomboidal. Length 2.0 to $2.5 \mathrm{~mm}$.

I am not sure that the three following species are more than varieties; the first in particular is very close to the European type.

\section{[* Simocephalus americanus Birge.]}

Plate XlV, Fig. 9.

My own observations of this form made throughont the Mississippi Valley are not in complete accord with the description of Birge, but it seems improbable that there is any mistake in the identification. The very generally distributed form on which this species rests is subject to marked variations within certain limits. This species differs from S. servulutus in the following points. The head, although promineut and spiny near the eye, is not angled between this prominence and the beak; in fact, it is either straight or simply curveri. The pigment fleck is usually rhomboidal and only occasionally oval, triangular or irregular. In other respects the agreement is rather close; the terminal claws have two series of spines, one of which is larger (not, as said by Birge, equal); the outer series is not so much larger as in s. rostratus, but not nearly as inconspicnous as in s. vetulus. The terminal claws are rather evenly curved. This species is frequently colored with pink or brown markings. In old females the back is squarely angled above, forming a pocket for the egges. The size falls short of that of the last speeies. I have found this species from the Gulf of Mexico to Mimmesota. I'rofessor Birge now recognizes this as S. serrulatus.

\section{*Simocephalus rostratus Herrick.}

Herrick'84.

This form is of the size and color of s.t. ctmericums, and approaches nearest to Schoedler's S. cispinosus in general characters. The back is arched above but not abruptly angled; the spine is as in S. conericums but not so low. The free posterior shell margins are somewhat shorter 
than the greatest height of the shell. The head is produced below the eyes in an angle like a right angle, which is not sping. The lower margin of the head is excavated to form a right angle, and in front of the smooth antenumles forms a very prominent beak, beyond which the antemules reach but a short distance. The terminal claws of the post-abdomen are straightish and are more heavily spined than in the preceding: the anal spines are doubly curved or geniculate. The pigment fleck is rhomboid or pentagonal; the antennules are smooth. The abdominal processes differ somewhat from the previous species. in which the serond one is rounded above, for in this it is syuarely truncate. This species was found only in shallow pools at Ocean Springs. Miss., and was very carefully compared with s. muericamus, which is also found there.

\section{Simocephalus exspinosus Koch.}

Heat extending into an obtuse angle at the eye, pigment fleck rhomboidal. Shell without a spine: maximum height of the shell greater than that of the free posterior margin. Caudal claws with an unerpal series of spines; anal spines evenly curved. There is little to distinguish the ahove from this species save the geniculate anal spines and the presence of a blunt spine on the shell.

Tirr. rungener shoedler has the lower outline of the head sinuate instead of angled.

" Simocephalus daphmoides Herrick.

Plate X́LVI, Figs, 5, 6 .

Herrick' 83.

A rurions transition form, found only sonth of the Temmessee river, was described in the American Xaturalist for May, 1Ss:i, under this name. IBy an orersight a comparison made with s. mmericomus apgreated as though made with s. refulus. The general shape is oval; the greatest height of the valves lies mear the middle and not posterior to it as in all the other species. The head is short, depressed, rounded in front: the beak is wanting; the lower margin of the heal is straight. The pigment fleck is small, oval or irregular; the fornices are small and short. The anteunules are smooth.

The postabilomen is narrow, shaped more as in Imolnhin: the terminal claws are straightish and fringed part way with spines; the anal spines are slightly curved. The processes of the abdomen are long, as in lmphuin. The shell is covered by the characteristic striations and extend into a hunt spine. In every detail, almost, there is an approach toward the genus Dophnin, while the general result is suffi- 
ciently llke simocephulus. The lower angle of the shell is not armed with the peculiar curved spines as in all the other species. This species becomes over one-tenth inch long. In such old individuals the spine is nearly midway of the height.

One could wish a tritle (eloser link to somploleberis than that furnished by s. angulutu: but, on the whole, the position of this geuns can not well be called in question. America has four species out of the six known and but one of these certainly identical with the European, though others are probably closely related.

\section{GENUS DAPHNIA.}

Long considered the type of the family, this genus is most frequently seen, or, at least, is more comspicuous than ary other group. It has already been pointed out that the forms here united are the extreme development of a diverging line. vimorephulus is the link connecting it with the typical forms of the family. As might be expected, this genus presents more purzling problems than any of the others. It contains more peculiarities of structure and diversities of habit and derelopment than any other of the genera. ITere the sexual differences are most interesting. The young are hatched with a peudant appendage attached to the npper posterior angle of the shell, which soon becomes the rigid spine characteristic of the younger stages and males of the genus. The females almost immediately atter birth commence the production of eggs by an asexual process. (iroups of epithelial cells containing four each are formed and one of the cells of each group derelops at the expense of the others, forming the egg. Many such eggs are laid simultaneously and deposited in the cavity between the shell and the dorsal part of the animal. The eggs are prevented from escaping by means of three long processes, of which the first is much the larger and curves forward. At stated periods in spring and autumn the males appear; the females of the gentration in which occur the males have a tendeney to produce eggsiof' a different sort charged with a different mission. At the same time the upper portion of the shell (that surrounding the brood carity) becomes finely reticulated and pigment is deposited between its layers. 'This ephippinm, as it is called, in allusion to its sadde-like form, is the case in which the winter egg is to pass the period of cold or drought which is to follow. The method of the formation of the ephippium is obscure and, in spite of the investigations of Lubbock and smitt, cousiderable remains to be learned with reference to this interesting modification of the shell. Some rather careful study has been devoted to this subject by the writer, but it was unfortunately interrupted before completion. The 
most promising method of pursuing the investigation is that of sectioning ephippial females in various stages with the microtome. A preparation of soap was employed with partial success as a medium for embedding.

\section{Development of Daphnia.}

Although the careful researches of Claus and Grobben have added much to our otherwise rather meager knowledge of the development of the Clutocerc, there still remain many interesting points, particularly with reference to the individual species, which merit careful study.

The following observations relate to the single species $D$. schefferi which was available during a short stay in Leipzig.

The winter eggs of 7 ). sethefferi are two in number and are lodged in the well known manner in an ephippium.

The shape of these eggs is sharply ovoid, there being no distinguishable difference between the two ends. The position in the ephippium is not, as might be expected, with the longer diameter parallel to the axis of the body, but the posterior end is slightly elerated. This is undoubtedly due to frequent elevation of the abdomen betreen the valves during the extrusion of the eggs.

The color is dark green and the only protection as the egg leaves the ovary is a thick, tough shell which is at first so soft as to be susceptible to pressure. It is thus reticulated, apparently through the simple pressure of the walls of the ephippium.

The length is $0.43 \mathrm{~mm}$; width $0.33 \mathrm{~mm}$. in the average, though egrgs were occasionally found of an elongated form, measuring 0.48 , $0.31 \mathrm{~mm}$. The contents of the egg consist of spheres of greenish plasma of various sizes and fat or oil drops. These oil globules are not very numerous as compared with those of the summer eggs. and likewise never attain the dominant size seen in the latter. The rarious forms assumed by the plasma balls are perplexing but frequently result from the action of external agents. The clearage stage was not soren, and if actual segmentation takes place, it must be inconspicuons as would he expected from the large quantity of yolk present. The differentiation of the blastoderm ocenrs very early, perhaps in the ovary itself, and the result is a tolerably uniform layer of prismatic rells. The mag now comes to a period of repose after the blastoderm lats produced a second external envelope apparently by simple secretion.

This envelope consists of a fine st ructureless membrane. The egg, nnder ordinary ciremstances, remains dormant during the winter in this most firorahle stage. The reason for which is evidently the fact 
that the differentiation has proceeded to the extent of producing the greatest number of protective layers without materially increasing the complexity, and thus the sensitiveness, of the organism. Lnder favorable circumstances the development proceeds farther and near one pole appears a slight indenture of the surface which grows deeper and seems to form a true invagination. This blastopore, if such it really be, remains for some time, generally till the two "Scheitel" plates appear. These "Scheitelplatte" are formed by a simultaneous thickening and lengthening of the cells of limited areas on opposite sides of the egg, near the opposite pole from that occupied by the blastopore. The "Scheitelplatte" are situated at right angles to a plane perpendicular to the blastopore. The nuclei of the cells of the "Scheitelplatte" are nearly $0.0208 \mathrm{~mm}$. in diameter, while those of the other blastoderm cells are about half that size.

The egg remains a long time in this stage, while the following stages are passed through quite rapidly till the embryo assumes its nauplius form. The remainder of the development agrees, so far as seen, quite fully with that of the summer eggs, to which we will now return.

The summer eggs vary greatly in size and number, but are nearly as large as the winter eggs. The number is sometimes reduced to two or three or rises to as many as fifteen or even more. In color the eggs vary from green to brown. The fresh egg consists, as the winter egg, of two sorts of yolk spheres. The plasma or formative yolk contains colored globules of rather small size, distributed throughout the whole of the mass quite uniformly. The food yolk or oil globules assort themselves in two sizes; first, a few (generally three) very large oil drops, which persist throughout the earlier stages of the embryo; second, smaller globules of appirently the same character, which are quite numerous and form a very considerable part of the contents of the egg. In an egg of about $0.35 \mathrm{~mm}$. in diameter, the largest of the smaller size of oil drops measured $0.029 \mathrm{~mm}$., while the larger three exceeded $0.060 \mathrm{~mm}$. The oil drops are distinguishable by their light refractive power, pellucidity and the intense dark brown or black color assumed when treated with osmic acid. The latter reagent affects the formative yolk but slightly. It will be seen that though the summer egg is nearly as large as the "I buterei" in some cases, yet the relative amount of formative yolk is more diverse than at first appears.

The great similarity between the two sorts of eggs in Implmin schefferi is throughout striking as compared with Iroinu, the only one of the Dephnida the development of which is fully studied. In the summer "ggs I have not been able to see the complete segmentation 
described for Moinu. The following stages are much as described by (rrobben. An invagination occurs and a median swelling appear's on the ventral aspect of the egg.

Labrum and second antemnit bud out and are soon followed by the antemat, mandibles and two pairs of maxille, after which the five pairs of leet soon appear. In an early stage there is present a basal palpus to the secont antemne, a fact not before observed, aud this persists as the small two-bristled wart found on the basal joint of the antenna. It is a conspicuous object in the embryo and is thus a true embryonic organ.

The eyes of the embryo appear as two separate pigmented flecks which approximate and are covered with an oval refractive hody, which later is penetrated by the pigment and divides to form the small lenses. Foon after this the shell grows over the ere as described for toine.

The first indieation of the shell appears as two folds of the maxillary rexion of the back. being thickest laterally. These grow forward and backward to form the cephalic and body shield. At a little later stage there appears a very interesting modification of the shell which stands in elose relation to the growth of the brood sac. A slight protuberance appears on the margin of the shell in the median dorsal line and extends toward the abdomen. It grows much more rapidly than the other parts of the shell and, in a later stage, forms a comparatively enormous tail, which curves under the animal between the shell valves which now extend beyond the body. This "tail" extends well along the ventral margin of the shell and reminds, by its position, of the tail of a frightened dog. The true tail, or post-abdomen. is, in the meanwhile, well developed and is constantly kicking the useless protuberance of the shell upwards. As the animal leaves the

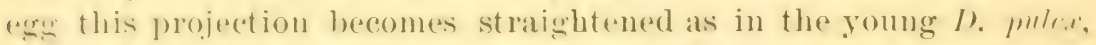
finally beconning the still considerable spine, though it is proportionately matele shorter than in the embryo. The spine becomes shorter with suedescive moults, and the mature form has only a slight rounded knol, in plate of a spine more than half the length of the body.

The use of the long spine in the young lmphen is a matter of intreme Its lingth agrees portty well with that of the hrood carity and it serme pusible that it serves to prevent the shell from bemeling abruptly dewn when it is only partially removed during the monlt and thus hreaking off and so leaving a portion of the clothing of the hooml cavity therein to berome a somere of irritation. This is more

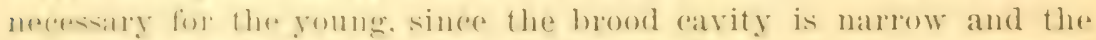
shell weak, so that white the onter shell is remored like a glowe from the fiuger, if eannot be pulled npwated or downward, hut directly 
backwards. It is well known that male Dephnie often have the spine while the females may have none, and here again it is possible that the narrower cavity over the abdomen requires this assistance, while this is not the case with the females.

The shell gland is early formed and the branchial lamellat of the feet appear almost simultaneously with the feet themselves as distinct lobes. The brauchial chamber is not a simple chamber, but is essentially a curved tube, as can be very well seen in the last foot of the adult. This tube doubles upon itself and crosses in the manner of a loop and a constant stream flows rapidly through it.

The nervous system is, at first, paired from beginning to end and first unites anteriorly, the ocular ganglia fuse after the union of the two pigment flecks in the compound "ye, then the cephalic ganglion is formed by the union of the two precesophageal ganglia, and the commissures passing about the asophagus. I have not been able to de. termine if the subrsophageal ganglia become fused. From the anterior ganglia spring the nerves to the antenuic and jaws, which latter are larger in the embryo.

It is greatly to be regretted that no sufficient revision of Inaphria can now be attempted. This is partly due to the very imperfect nature of the descriptions and partly to the scattered literature of the group. We here supply nothing more than a provisional key and syuoptical descriptions. I take pleasure in acknowledging the substantial assistance, in respect to recent literature of the group, received from my friend, Professor IBirge, as also for valuable suggestions respecting Cladocer in general.

\section{KEY TO THE GENUS DAPHNIA.}

I. Pigment spot present.

A. Anal margin of the post-abdomen deeply excavated. . . schaefferi, 187

B. Anal margin slightly if at all sinuous.

$a$. Head very short and regularly curved from the heart to the beak.

psittacea, 187; atkinsonii, 188

b. Head not very short or regularly curved.

* Claws of post-abdomen with a distinct comb of spines.

$\dagger$ A strong toothed process from the dorsal margin of the head at some time of life.

\$ Spine long, straight. . . . . . . . clathrata, 188

+ Spine short, curved. . . . . . . minnelaha, 189

t† No strongly toothed dorsal process at any period in either sex.

I Head with a helmet-like crest.

?. Spine long, springing from the dorsal angle, curved dossill. 
$\{\xi$ Spine moderate, springing from the middle of the caudal margin.

arcuata, 190

+ Head uncrested.

3. Spine short or absent.

|| Abdominal process united at the base. . gibbosa, 191

III Abdominal processes discrete.

i. Spine near the midile of the caudal margin.

- Anal teeth 20 to 22 . . . . . ovata, 191

${ }^{\circ}$ Anal teeth 9 to 10. . . . . . obtusa, 191

if Spine at the dorsal angle. . . . . alpina, 192

23 Spine of considerable length.

|| Spine near the middle of the caudal margin.

- Ventral margin of the bead convex. . hastata, 192

- Ventral margin of head concave.

- Eye distant from the margin of the head.

ornata, 192

- Eye near the margin of the head.

$x$ Abdominal processes united at the base.

schoedleri, 193

x 8 Abdominal processes discrete. brevispiua, 193

|l|| Spine nearer the dorsal angle. . . . . pulex, 193

* Claws of the post-abdomen without a basal comb of teeth.

t Antennal setae thick, first segment longer than the second.

* Spine near the middle of the caudal margin. ventricosa, 195

+ Spine above the middle of the caudal margin. . caudata, 195

t† Antennal setre with the second segment longer than the first.

Head helmeted.

hyaliua, 195

if Head not helmeted.

3. Abdominal processes united.

|| Dorsal margin strongly carinate. . . . . sarsii, 198

||| Dorsal margin slightly or not carinate.

- First abdominal process much the longer.

- A deep depression separating head and body.

paludicola, 198

- A very slight depression separating head and body. longispina, 199; minnesotensis, 199

- Abdominal processes nearly equal.

- Anal claws 12 to 22 . . . . cavifroms, 200

${ }^{\circ}$ Anal clatrs 7 to 23. . . microcephala, 200

?\%? Abdominal processes discrete.

Abdominal processes short, equal. . . . rosea, 200

III First abdominal process twice as long as the second.

- Beak not greatly produced ventrad. . aquilina, 200

- Beak greatly produced ventrad. . . lacustris, 201

Ht Head with a dorsal tootherl erest.

3. Crest just in front of the heart. . . . dentata, 201

?.? Crest over the bases of the antenna. - . dentifera, 202

II. Pigment spot absent.

A. Head not helmeted or but slightly so.

B. Head helmeter. 
a. Eye near the end of the head.

magniceps, 202

$b$. Eye not near the end of the head.

* Abdominal processes free.

kalbergensis, 203

* Abdominal processes united.

cucullata, 203

[Not in the key: Iubia, 196; pennata and curvirostris, 194; thorata,197; hermani, 198; similis, 204; bolivarl, 205; carinata, 205; lumholtzii, 206.]

\section{Daphnia schafferi Baird.}

Plate LI, Figs. 1.5.

Daphnia pennata - Mueller.

Daphnia pulex-Straus, Koch (fide P. E. Mueller).

Daphnia magna-Lilljeborg, Leydig, etc.

The largest species of the genus, is of an elongated oval and ventricose form. The head is short and evenly rounded. The spine is. entirely absent in old females and of only moderate length in the young. The antennules of the male are long and have a very long flagellum. The post-abdomen is narrowed suddenly below the anus so that the spines cousist of two sets; the terminal claws are spiny at the base. The species may be recognized at once by the concarity of the dorsal margin of the post-abdomen. The plate will make any detailed description superfluous. A common species in Enrope, but not yet found in America.

The sole distinction between this species and $D$. magna straus is found in the fact that the intestinal cuca are very long and recurved in $D$. schefferi and short and thickened at the free extremity in $D$. magnu. We fail to discover sufficient reason for separating them.

\section{Daphnia psittacea Baird.}

Baird '50; Schoedler'58; Fric '721 ; Kurz'71; Hellich '77; Ilerrick '81; L'ymann'87; Daday' 88.

IIead short, rounded in front, beak very short. A depression separates the head from the oval, ventricuse hody. Spine long directed dorsad. Eye distant from the margin of the head. Post-ablomen long, narrowed towarl the end, somewhat simuous in the caudal margin. Anal teeth about ten. Claw bipectinate, rather long. Length 1.8 to $1.9 \mathrm{~mm}$.

This species is at once recognized hy the head, which is rery short and evenly curved, or nearly so, from the heart to the heak. The shell is high, oral, with a rather short spine. The fornices are mide and angled behind. The antemmles are longer than in most sprecies; the post-abdomen is very large, but narrows toward the end and has comparatively few anal teeth, which are of mequal size. 'This is one of the largest of the genus. Not yet found in America. 
Imphnin oflkinsonii Baird appears to us but a variety of this species. There is said to be no depression between head and body and the anal teeth diminish dorsad instead of being nearly equal as in 7 ). psittecen. ('onsiderable disagreement exists in the various descriptions. Daday's figures show no grounds for separating the species.

\section{* Daphuia clathrata Forbes.}

Forbes' 93.

"A species of moderatr size, with short, deep head, medium to very Jong posterior spine, minutr pigment fleck, and pectinate tarsal claw. In the immature female there is a prominent angle just above the swimming antenne, like that of $I$. Nontifer. In the adult female the heal, measured vertically across the rostrmm, is twice as deep as its length from the base of the autenne to the middle of the frout. It is sharply keeled rather than crested. very broally rounded. its lower margin very slightly convex or quite straight, and its rostrum well marlecl in the adult. The eye is close to the front, the transparent orbit rearhing to the margin of the head, of medium dimensions, its antero-posterior diameter contained twice in the space between the posterior margin of the hear. The pigment speck is very minute, placed behind the lower half of the eye and nearer the posterior margin of the head. The fornices are not prominent. Beginning midway between the antenna and the eye, they arch broadly above the base of the former, making an obtuse angle a little beyond the antemna, and continuing as a slight carina backwards and downwards for a little distance on the side of the valve.

"The ventral margin of the shell is more broadly arched than the dorsal, the latter being in the immature female nearly straight from the hart backwards. The ralves are conspicuously quadrangularly reticulate. spinose on their lower edges nearly to the beak, and on the "1]pere erlge to the vicinity of the heart. The posterior spine is rery long. straight. slender, spinose to the tip. contained in arerage cases mot more than twice in the length of head and hody without the spine.

"The antennar are rather short, abut half as long as the distance form the pusterior margin of the eye to the base of the posterior spine. The swimming hairs are two jointed, the basal joint the shorter. The dorsal aludominal forocesses arise in immediate comnection, hut are not united at their batse. The anal furrow has abont a dozen texth on wach sirle. and the camblal celaw has a comb of three or four comspicuous feeth at its base lexides a lithle group of smaller ones. Length of ovigeroms female $1.7 \mathrm{~mm}$. to the base of the spine: the greatest depth

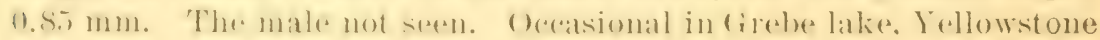
I'ark." 
\% Daphnia minmehaha Herrick.

Plates Xlis, Figs. 1, 2a; L, Figs. 1, 2; LII, Figs. 1-3.

Herrick'84; Birge '91.

This species, which occur's in small pools in autumn (althents of Iimnehaha creek, etc.,) closely corresponds apparently to hars" Thephnia carinatu but differs in numerous points. It, in lact, is more nearly related to $D$. muled thin the group under which that species is placed.

The form is oval, arched ahove, narrowed posteriorly, terminating in a lather short spine which curves lightly uj:wards. In males and joung females the spine springs from the upper angle. but in old females having many summer aggs the spine is nearly median. The heat is depressed, strongly arched and keeled slightly abovit the eye, which orcupies the extreme end of the forehead. 'The keel of the hear extends into a slight augle over the heart and continues lown the back. In young females and in males the slight angle is replaced by a strong knife-like projection which extends into from one to fon sharp teeth, the anterior tooth being directed forwarl. The males, in particular, have this feature emphasized. Ir. longisprinn has a somewhat similar projection, but the more nearly relater forms seem not to show this peculiarity. The beak is slightly curved aul the low'r margin of the head is slightly sinuate. The shell has the usual square reticulations and is usually very transparent hut in peat y waters becomes brownish. The size is small but variable; $1.8 \mathrm{~mm}$. is a common measurement. 'The post-abdomen is narrow, the claws are armed with four or more teeth and a series of lateral bristles. The anal spines are eleven or more in full grown females and decrease only moderately upward. The processes of the abdomen are distinct. The males are smaller and strongly carinated ahove and of the same form as young females. The antennules are rather long, with a short lateral and a long terminal flagellum, which latter is more than twice the length of sensory set:e which are partially lateral. The first foot has a stroug claw and a loug thagellum, while the second foet have a small spiny hook. There is a single abdominal process which is not hairy as in $D . p u l e x$.

The following medsurements may be added: Female-Length $1.44 \mathrm{~mm}$., spine $0.33 \mathrm{~mm}$. head $(1.26 \mathrm{~mm}$. depth of head $10.46 \mathrm{~mm}$.

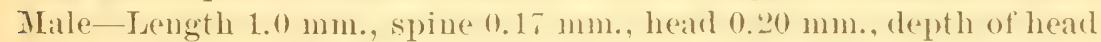
$0.31 \mathrm{~mm}$., length of thagellum of first foot 0.3.5 mm. Ephippial female -Length 1.61 mm., spine 1.20 mm.. head $0.35 \mathrm{~mm}$., de+pth of head $0 . \mathrm{s}$ mm., greatest depth of shell $0.94 \mathrm{~mm}$.

The ephippial females appear in . July in the vicinity of Minnoapolis, and at that time it is rane to find a female with the tootherl crest aleveloped. I). dentifer" Furbes is closely related but has smooth claws. 
* Daphina exilis sp. n.?

\author{
Plate LII, Figs. 4, 5.
}

It is admittedly undesirable to describe a specimen instead of a species, but the form for which the above name is provisionally proposed is so peculiar and its locality so little studied that a description is given based on a single young female. It will be understood that the ovigerous female would differ in the length and position of the spine, siz' of crest and form of the abdominal processes.

A daphnid of moderate size with erested head, long spine and dentate camdal claw. Nearly colorless. Head projecting in the line of the axis of the body, crested from the eye to a point cephalad of the heart, but truncate in front. Ventral outline nearly straight, beak not projecting, antennules very short and applied almost at the end of the beak, which does not lie between the valves. Eye of rather large size. with few erystallines, near the rentral margin. Pigment fleck small, nearer to the caudal margin of the head than to the eye. Circa narrow, strongly curvel. Antenne short and stout, second segment of the setie longer than the basal. Fornix moderate. Valves sub-oval, strongly eurved ventrally, dorsal outline straight from in front of the heart to the spine, which is very long and curved dorsad. In this specimen the spine is longer than the entire valve. There is no dorsal emargination between the head and body Dorsal margin armed with spines beyond the heart, ventral margin spined more than half of the length. Valves marked with the usual quadrangular meshes. Post-ablomen narrowed toward the end. Anal margin sinnate. Anal teeth about eight, nearly equal. Claw short aud moderately (urved. armed with a continuous series of spinules and a comb of fine spines near the base. Length, exclusive of spine, $1.15 \mathrm{~mm}$; length of head $0.38 \mathrm{~mm}$, height of head $0.54 \mathrm{~mm}$., height of shell 0.65 mm. length of spine $0.84 \mathrm{~mm}$. diameter of eye $0.10 \mathrm{~mm}$, length of hase of antemu: $0.26 \mathrm{~mm}$., (raw $0.09 \mathrm{~mm}$. The abdominal processes in this speeimen are not in their mature form. It is not eertain that the dense hatriness of the anal margin above the teeth is an adult character. It would appear that the crest is normally a strongly projerting ("ephatic helmot. but this is but conjectural. Found in weedy pools fed by irrigation eanals at Albuquerque.

\title{
* Daphnia areuata Forbes.
}

Forbes '93.

"Hend hellunded, rounded in fromt, length one-third that of the shell. front andeare, beak produced, extending beyond the sensory hairs of the antemnar. Lye small, about midway between the mandi- 
bles and the front of the head, and about midway between the tip of the beak and the dorsal surface of the head. Pigment speck very small, less than half the diameter of a lense of the eye, and placed midway between the eye and the posterior margin of the head. The latter concave, the beak exteuded backward and applied against the margin of the shell. Swimming antenne reaching the middle of the shell, their hairs moderately robust, the first segment not longer than the secoud. To emargination separating head from body, but the dorsal surface very slightly sinuate there. Abdominal processes all distinct, anterior much the longest. Caudal claw with accessory teeth, about six in number, the three proximal the largest. Anal spines about ten. Posterior spine of the shell given off from the middle of the valves, in the adult female a third to a half as long as the valve. Shell moderately coarsely marked in quadrangular areas, the lower and dorsal margins spinulose from the middle backwards. Length $2.0 \mathrm{~mm}$., depth $1.0 \mathrm{~mm}$. I Ieart Lake, Iellowstone Park."

\section{Daphnia gibbosa Hellich.}

Hellich '74 and '77; Elymann '87.

Body large, very high. Head depressed, ventral margin strongly concave. Eye large, with few crystallines. Antenna long, scaly. An obvious depression separates head and body. Spine short, abore the middle. Abdominal processes united. Anal teeth 17 to 19, diminishing dorsad. Claws with a comb of teeth. Color reddish. Length $2.01 \mathrm{~mm}$.

\section{Daphnia ovata Sars.}

"Caput a latere visum ante oculum fere angulatum, margine inferiore leviter con cavo in rostrum longum apicem versus attenuatum, extremitate tenuissima exeuntespura visum ut in D. pennata cordiforme. Testa cetera a latere visa ovata, margine superiore et inferiore in femina adulta fere xquas arcuatis, postice in medio spinam formans brevissimam vel omnino obsoletam. Processus anteriores duo abdominis disjuncti. Margo posterior postabdominis in medio sinuatus, utrinque aculeis $20-22$ armatus. Color albido-flavescens vel-virescens. Longit. circit $3 \mathrm{~mm}$."

No one besides Sars seems to have seen this species. We suspect it is simply D. schcefferi.

\section{Daphnia obtusa Kurz.}

Lilljeborg '53 (pulex); Kurz'74; Hellich '77; Elymann '87; Daday'88.

Head short, front rounded, ventral margin slightly sinuate, beak short, acute turned caudad. Eye remote from the margin of head. Crest absent. Body oval, margins couvex, spine nearly absent. Post- 
abdomen not ciliate, of moderate size. Anal teeth 10, nearly expal. ('atws bipectinate. Ablominal processes discrete. Jeugth $1.08 \mathrm{~mm}$.

It still seems probable that this is an age form of some species with longer spine.

\section{Daphnia alpina Daday.}

Darlay' 88.

Il ad short, somewhat produced ventrad. front rounded, rentral margin almost straight; beak rather acute, short, extending ventral. Eye large rather remote from the margin of the hearl. No crest. Shell almost round, ventral margin obviously rounded: spine absent or rery short. simply forming an acute angle. Post-abiomen small, laterally setose, bearing 11 to 12 anal spines which are short and curved and slightly diminish in size dorsad. (law with a comb of long teeth and a continuous series of tine spinules. Abdominal processes discrete. Length 1.2 to $1.9 \mathrm{~mm}$, depth 0.9 to $1.15 \mathrm{~mm}$.

The resemblance to $1 \%$. ollusu Kurz is very close, but that species has the sides of the post-ablomen smooth, the ventral margin of the head concave and the spine near the middle of the candal margin of the shell. The shell is longer and more oval in outline. We should wish to be very sure that these are not both old individuals of a spe. cies having the usual spine in younger stages.

\section{Daphnia hastata Sars.}

A latrer species of reddish color, with strongly drepressed head. whose rentral margin is convex. Shell oval, with a long spine. The ahdominal processes are long and approximate. Anal spines 16. Length $3.0 \mathrm{~mm}$. This spereies was inaderpuately described hy sars and probably should be dropped.

\section{Daphuia ornata Daday.}

Daday' $84^{1}$ (serrulata);'88.

If ad not separated hy a degression from the thorax. Ibak rather acutes short, turned rentrat. Fye distant from the margin of the hearl. Shell oval, matrins romded, with a moderate spine directed (audan. Post-abdomens scarcely attenuated apically with eight to ten "urvenl anal spimes, diminishing dorsad; sides setose. Claw with a basal series of spines and a eontinnous series of fine setre. Abdominal

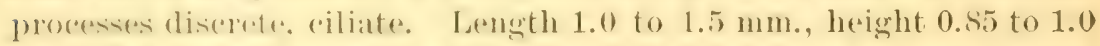
num. The ventral margin of the head in this species is more curved than in 1 . alpinu, and this might well be a younger form of I). obtusu, though the sutil on the sisles of the abdomen are not noted in that spectes. 


\section{Daphnia schoedleri Sars.}

Schoedler'58 (longispina); Sars '61; Hellich '77; Elymann '87; Daday '88.

Head arched in front, rentral margin gently sinuous, beak acute, projecting rentrad. Eye large, near the margiu of the head. Rorly oval, spine long. I'ost-abdomen of moderate size, with 12 [14 to 16] aual teeth. ('law with comb of spines. Ablominal processes discrete but approximate [Daday] or distant from each other [Elymann].

'There is wide disagreement between the various descriptions of this species.

\section{Daphnia brevispina Daday.}

Daday' 88.

Head short, slightly projecting ventrad, front strongly rounded, rentral margin somewhat sintiate. beak short, acute, inclined ven. trad. Fye distant from the frontal margin of the hearl. Shell oval, with a slight depression hetween head and thorax, margins arcuate, with a very short spine. No crest. P'ost-ablomen rather lowg with delicate lateral seta'; amal tecth 1:2, curved, almost equal. ('law with a comb of spines and a contiunous series of finc setir. Alndominal processes discrete, setose. Length 1.2 to $1.5 \mathrm{~mm}$, hejght 0.75 to $1.2 \mathrm{~mm}$.

\section{* Daphnia pulex De Geer.}

De Geer 1778; Hellich '77; Lutz'78 and '79; Elymann '86; Daday '88, Matile '90.

Body large, stout and thick, rather opanue, reddish. Ilead broad, depressed, front protuberant. Ventral margin of head deeply concave. Beak acute, curved backward. Fornix high. Hyesmall, with few lenses. Antennules short, conical, extending but littl beyond the beak. Antenne shori, slenclere, evidentiy marked with s'uta, with long densely peetinate setr. The shell is not separated from the head by a depression in mature temales and is oval in outline. The ventral margin is much more strongly arched than the dorsal. Fipine very short, straight, inclined upwarl and inserted above the middle of the posterior margin. Shell margins with short spines. Surface reticulate in fine quadrangles. ('uca short, clavate, curved dorsad. The abdominal processes approximate; the first twice as long as the secoud; the third small. Post-abdomen long, narrowed toward the end. Its distal end is romoled. Anal teeth 12 to 14 , nearly equal. Claws curved, with two combs of teeth, the higher consisting of six to seven teeth, the lower of three to four. I,ength of female $2.15 \mathrm{~mm}$., height $1.23 \mathrm{~mm}$, spine $0.16 \mathrm{~mm}$. It is at present impossible for the writer to unravel the relations of the numerous varieties and supposed species of the puler group. Probably most of them are simple synonyms. The following American varieties may be mentioned: 
* Daphnia pulex var. denticulata Birge.

The lower margin of the head is said to be less convex [concave?] than Ir. pulce. The abdominal processes are less hairy, there is a continuous series of spinules on the claw and a larger number of anal spines-18 to 20. Daday figures claws such as Birge describes.

* Daphnia pulex var. nasutus Herrick.

Plate XXXV, Figs. 1-4.

This in some respects is more like the type. It has an elongate oval form with spine of variable length arising from above the middle. The impression between head and body is slight. The ventral margin of the head is concave and the beak is curved candad. The terminal claw of the post-abdomen is furnished with two combs of fine teeth. The anal spines are 10 to 14 . The abdominal processes are hairy. Neither this variety nor the above seems to possess the two teeth on the front margin of the claw.

\section{* Daphnia pulex var. pulicaria Forbes.}

This seems to elosely resemble the type. The fact that the antennx are ornamented with spines rather than scales is noticed. The first abdominal process is smooth, as it is also stated to be in the European form by some authors. The male is said to differ more, but comparison of Forbes' figure with that of Elymann reveals nothing of importauce. (Elymann figures spines rather than scales on the base of the antennie of the female.)

\section{[Daphnia pennata Sars.]}

"Antecedenti (D. muler) simillima, caput autem a latere visum latius, rostro breviore, supra visum testa cetera parum angustius fere cordiforme, antice acuminatum. Processus anteriores duo disjuncti. Margo posterior postabdominis in medio sinulo parco et infra hune utrinque aculeis $16-1 \times$ armatus. Color ut in antecedente. Longit 0.2 . $\mathrm{mm} . "$

Although admittedly very close to 1$)$. puler, it is said to differ in the broad depressed head, which is uniformly rounded in front and decoly axravated in front of the beak, which is short and deflected. The post-ablomen has 16 to 18 teeth. The antenmules of the male are almost as long as the head, hearing a lomg pointed llagellum and a short laveral seta.

\section{[Daphnia curvirostris Elymanu.]}

The diflerences relied on to distinguish this species from 7 . pulex seem to 11 s quite inadequate. The head is more depresied and this grives to it a quite different appearance. The male antenmule is thickrneal slightly at the midlle and the llagellum is longer. The hairy abdominal process is absent. 
Daphnia ventricosa Hellich.

Hellich '77; Elymann' 87.

A large pelagic species without the toothed comb of the claw. The head is depressed, small, with rather protuberant front and long beak inclined caudo-ventrad. The short oval shell is deeper than the head, well rounded above and below. Spine long and straight, springing from the middle of the caudal margin. The antenual setie are short and thick aud have the first segment longer than the second. The first abdominal process is twice as long as the second, with which it is united. The post-abdomen narrows toward the end and is hairy laterally. Anal spines 14. Claws with setæ. Length $2.28 \mathrm{~mm}$.

\section{Daplunia caudata Sars.}

Fischer '54 (longispina).

A large species without basal spines upon the claws. II ead somewhat depressed, about one-third as long as the body, ventral margin slightly concave; beak long, inclined caudo-ventrad. Shell oval, with no depression betwern body and head. Spine long, springing from the middle of the caudal margin. Eye near margin of head, with few erystallines. Antennie with short thick setie whose basal segment is longer than the second. Post abdomen narrowed toward the end. Aual spines 9 to 12. Claw with a row of setie on the concave, and two spines on the convex aspect. The two cephalic abdominal processes united. Length 2.3 to $2.67 \mathrm{~mm}$.

This species is said to resemble I'. Tongispinu. It would appear to be closely related to 7 . ventricosu.

\section{* Daphina hyalina Leydig.}

Plates XXII, Figs. 7, 8; XXVII, Fig. 6; XXXV, Fig. 16; XlIX, Figs. 3-5; LIII, Figs. 1-4.

Leydig '60; Sars '64 (galeata); Hellich '74 (gracilis); P. E. Mueller '68 (pellucida); Birge ' 78 (lavis); Herrick '83

The general form and appearance down to the minute details in this species are similar to I). lathlberyrnsis, with which it is almost always associated, except the head which is subject to an astonishing range of variation. A comparison of Figs 1 and 5 of Plate LIII. which were drawn by camera upou the same slide, illustrates the similarity. The body is pellueid. Shell, sub oral, with long, straight, toothed spine as long as the body withont the hearl, and inserted high up. Post-abdomen uarrow with discrete processes, anal teeth about ten, terminal claw finely fringed or smooth. Eye small, either near 13 
the margin and oceasioning a proninence in the ventral outline or retreating from it. Macula nigra small or almost non pigmented. Gastric crecea slender. Antenme weak. The typical form of head is that of Fig. 3. Plate LIII, but the outline may be evenly rounded. The range of rariation is well shown by the various figures. The young have no horn on the head. The spine of the shell is nearly as long as the whole animal in the young. The male of our form is 1.2 mm. long, excluding the spine which measures $0.47 \mathrm{~mm}$. The flagellum is a very little longer than the sensory setie, and there is a very minute lateral flagellum. A peculiarity of this species is the scattered thorny armature of the spine of the shell. There is but little change in the form of head with age. The form of the last feet is peculiar. The ephippium occupies comparatively a small part of the valves and the spine becomes very short and quite smooth. The sexual period occurs in September and October.

\section{(*Daplinia dubia Herrick.)}

Plate Xlix, Figs. 7, 8.

Our D. Aubia may prove distinct. It is nearly related to D. hyalina, but the head is strongly erested all around and the eje is withdrawn, in young as well as old specimens, toward the middle of the head. This pecuilarity is shared in this degree by no other Daphnia. The form is as in I\%. pellucidu, but the spine is more slender and directed upward. The head is shaped much as in $7 \%$. vitrea in the young, but is much less prominent. The older form has a shorter and more slender spine (none wereseen in the ultimate or spineless stage). The head is more evenly rounded, but still well erested. The abdomen is very slender and the anal teeth diminish rapidly in size from below upward. The claws are very short and armed down the whole length with fine bristles. The abdominal processes are well united at the base in old specimens, so that the second seems a small process of the first. The shedl is very transparent and the spine is very long. In a roung sperimen the spine was $1.0 \mathrm{~mm}$., the body $0.7 \mathrm{~mm}$., and the head $0.4 \mathrm{~mm}$. In this specimen the spine was slightly eurved, the head romgate with a slight ridge in front. Another individual harl the spine $1.1 \mathrm{~mm}$. long, while the remainder of the animal was 1.3 $\mathrm{mm}$. This sperimen also had a knife-like hyaline ridge on the erest, which was obliquely truncate in front; it also had numerous summer rmbryos in the brood sac. The spine was perfectly straight and but slightly inclined upward. Older individuals have a romeled erest as figured and no ridge. The spine is relatively somewhat shorter but much more slender. The character's which most clearly distinguish 
this species are the rell crested head, which in young as well as sometimes older specimens has a median hyaline ridge, the with. drawal of the eye from the margin and the very long spine. It resen. bles $I$. galenta in earlier stages. It is very much like $I$. lavis or, in other words, is in the group of II. hyalina. This form has only been found in autumn, September to November, Lake St. Croix and Richfield in Hennepin county.

\section{[*Daphnia thorata Forbes.]}

Forkes' 93.

"This species belongs to the hymlinu group, and may possibly be entitled only to varietal rank. The distinctness and constancy of its characters, however, in collections made by us in Flathead and Swau lakes in western MLontana, and the number of minor points in which it differs from hyalim, as most recently described, lead me to distiuguish it as a specific form.

"It is oval in outline; the loug and slender posterior spine is placed at or a trifle above the middle; the length of the head is about a third that of the valves of the shell excluding the spine, and there is no trace of dorsal emargination between head and body. The head is narrowed toward the base and elongated forward in a way to give ic the outline of a bell jar with a flaring base. Its front is broadly and regularly rounded, its ventral margin usually couspicuously concave and closely like the dorsal, although occasionally the head is straight or convex beneath. The posterior margin is either straight or slightly concave, and the beak stands free from the front margin of the valves, and by its extension downward not only covers the antenne but reaches clearly beyond the tips of the semsory hairs. The eye is of medium size, placed far back of the frout of the head and equidistant from the tip of the beak aud the dorsal junction of the head and boty. The pigment speck is of moderate size, placed directly behind the eye, and much farther from it than from the posterior margin of the head. The anteuna are moderately stout, entirely smooth except for inconspicuous transverse rows of miunte appressed hairs upon both peduncle and rami, and a row of short, tooth-like spinules at the distal end of each segment. The swimming hairs are rather slender, the secoud joint commonly decidedly shorter than the first. Fornices slight, arising above and a little behind the eye and terminating directly behind the antenna, above the bases of which they project but slightly. The lower margin of each valve is set with the usual spinules almost to the beak, and the dorsal margin is similarly armed for a distance in front of the spine about equal to half the length of 
the latter. The valves are marked off by fine lines into large quadrate meshes. The dorsal abdominal processes rise separately, the two anterior, however, in immediate contact at their bases. The first of these is decidedly the longer, but the third process is distinct. although low. The aual setie are two-jointed, the second joint the shorter. The abdomen is regularly narrowed backwards, and the amal gronve is provided with twelve to fifteen teeth on each side, commonly the latter number. The terminal claws are without accessory comb. The intestinal cueca are short, not longer than the diameter of the eye, and extend directly forward. Length 2.0 to $2.5 \mathrm{~mm}$. ; depth half the length, sometimes a little more. Leugth of spine variable, but commonly about equal to the depth of the shell."

As to the specific rank of this form we suspend judgment for the present.

[Daphnia hermani Daday.]

Daday' 88.

Head broad, compressed, front rounded, beak round, projecting ventrat. Eye large. Macula nigra absent. Shell oval, with a long spine. Abdominal processes discrete. Claws withont teeth but ornamented with a continuous series of fine sete. Anal teeth six, diminishing dorsad. Length 0.5 to $0.8 \mathrm{~mm}$.

This we may unesitatingly regard as a form of $I$. hymlime.

\section{Daphuia sarsii Schoedler.}

Sars '60 (carinata); Schoedler '77; Ely mann '87 (carinata).

A large yellowish speeces with a strong dorsal keel. Head uniformly curved, slightly concave behiut the eye, with a long oblique beak. Dorsal and ventral margins curved. Spine short aud curved, springing from near the middle of the caudal margin. The abdominal processes long and united at the base. Claws without teeth. Length $2.5 \mathrm{~mm}$. The very insufticient description may help to place a form not recognized since Sars described it.

When II. rorimulu King is finally placed among its congeners this species will preoceupy Sars' name.

\section{Daphuia paludicola Hellich.}

A larew species of a dirty yellow color. Ifead depressed, front scarcely protuberant, rentral surface slightly concave, beak sharp, short. Antenmules very small. Shell deep, oval, with a short eurved spine springing from the middle of the caudal margin. First abdominial procss much longer than the second, to which it is fused. Post- 
abdomen small. Anal teeth 12 to 14 . Claws with a suries of fine setre. Length $2.18 \mathrm{~mm}$. In the male the lower margin of the head is excavated and the flagellum of the antenunles short and straight.

\section{Daphnia Iongispina Mueller.}

Mueller 1785; Straus-Durekheim '19-':20; Baird '50 (pulex var. longispina); Leydig '60; Sars '61, and '64 (aftiais); Mueller '68; Plateau '70; Lund '70-'71; Kurz'74; Hudendorff '76; Hellich '77; Lutz'78 aud '79; Herrick '84; Elymann '87; Walter '88; Daday' 88 ; Matile '90.

A slender species of modrate size and transparent. Huad not so deep as the body, from which it is not separated by a depression, slightly coucave behind the eye. IBeak long and directed caudo-rentrad. Eye large, near the margin. shell oval; spine long, situated above the middle line and curved upward.

Two largest abdominal processes both directed cephalad and somewhat united. Anal spines 10 to 12. Claws with a series of fine setre and two spines on the convex aspect. I Length 2.0 to $2.5 \mathrm{~mm}$.

Flagellum of the male autennule hardly longer than the sensory set:e. The young have three teeth above as in 1). mimnchan. There is a great deal of diversity of opinion as to the value of this name. Not that there is any doubt of the existence of a widely dstributed form which in general is that intended by Leydig and others, but the variation is so great that the possibility remains that more than one species is included under the one title.

P. E. Mueller recognizes two varieties depending chietly upon the length of the spine.

* Daphnia minnesotensis sp. $\mathrm{n}$.

Pi,Ate L, Figs. 10-12.

Herrick'84 (rosea.)

The later descriptions of $I$. msen leave no doubt that this is a distinct species. The ablominal processes are somerwhat mited at the hase instead of "manifeste discretis." and the first is much longer. In many respects the species is near $/$ ). lomgirpinu. The original description is given: "In form very like I). lomgispinn, this species, which is the only representative of this smooth-clawed. mbleeled group yet found in America, might perhaps be appropriately uniterl with that species.

"Lody oral, moderately rintricose: liead of moderate size, lower" margin nearly straight; eyesitnated in the anterion prominence. The beak is not very prominent. 'The upper outlinc of the head is slightly concare above the eye or rather less convex. The hearl is separated 
from the body by a marked depression. The spine of the shell springs from the upper angle or is quite wanting. The post abclomen is of moderate size, somewhat narrowed toward the end. The claws are smooth, the anal spines nearly equal, straight, about fourteen in number. The abdominal processes are not coalesced or but slightly so. Length $1.50 \mathrm{~mm}$. to $2.0 \mathrm{~mm}$. The species was collected sparingly in a large gathering of $T$. pulex from a small lake in early spring.

"The size and conformation of the abdominal processes are very variable and the long and very slender spine is frequently absent."

The antennules are very short. Males unknown.

\section{Daphnia microcephala Sars.}

I small transparent form, head only half as deep as the shell, slightly concave ventrally and ending in a short blunt beak. Shell elongate oval with a slender somewhat curved spine from the middle of the caudal margin. Abdominal processes nearly equal and united at the base. Anal spines seven. Claws without teeth. Length $0.75 \mathrm{~mm}$.

This is also a species requiring farther study.

\section{Daphmia cavifrons Sars.}

A reddish species with the head separated from the body by a depression, depressed, ventral border excavated, beak large. Shell ventricose with a short spine from near the upper angle. Abdominal processes nearly equal and united at the base. Anal teeth 12. Claw without teeth. Length $1.5 \mathrm{~mm}$.

I am not sure of this and the preceding.

\section{* Daphuia rosea Sars.}

()i moderate size, reddish in color, and resembling l). Iongispinu. Ilatd depressed and not separated by a depression from the thorax, somewhat excavated in the ventral margin, heak blunt. Shell oval, spine long. springing from above the midelle and directed obliguely dorsidl. The two abrominal processes thick, equal, discrete. Anal spines 12 to 14 . Claw without teeth. Length $1.9 \mathrm{~mm}$.

The Ameriean form identified witle this species is more like $J$ ). longispina.

\section{Daphnia aruilina Sars.}

1 spereis of medium size, transparent. Ifead depressed, protuberant at the ere, excavated hehind it the beak lying in the same plane as the froutal projection and strongly corved caudar. Eye large. shell oral, slightly separate from the head. Spine above the middle 
line very slender and short, directed dorsad. Abdominal processes long, approximate, the first twice as long as the second. Anal spines 16 to 17 . Length $1.83 \mathrm{~mm}$.

\section{Dapnia lacustris Sars.}

Very similar to $D$. aquilina and to $D$. rosea. The head is depressed and excavated behind the eye, the beak projecting ventrad below the level of the front. The eye retreats from the front and is large. The shell is oval and the spine is straight, springing from the middle of the caudal margin. The abdominal processes are discrete but approximate. Post-abdomen as in D. Congispina, with 14 to 16 teeth. Length $2.21 \mathrm{~mm}$. This is doubtless to be reckoned among the varities of $D$. Tongispina.

\section{Daphnia dentata Matile.}

\section{Matile'90.}

I translate the description, 1. c. p. 14.

Body transparent. Head low and rounded cephalad; its ventral margin rather short and concave. Apex of beak directed ventrad [nach unten]. Antennal setæe three-jointed, the last segment very short. Head separated from the thorax uniformly in adult animals by a tooth-like projection cephalad. Valves oval, extending into a rather short spine which lies somewhat dorsad of the median, lougitudinal axis. Spine aud the caudal half of ventral margins of the valves spined; dorsal edge without spines. Shell reticulated by regularly crossing lines. First two anal processes approximate aud of equal length. Borders of the anal groove armed on either side with 12 to 14 spines which diminish gradually in size dorsad. Terminal claws without the comb of spines but armed with a continuous series of very fine setie; on the convex side two small spines. Eye large, with many crystallines; macula nigra point-like. Leugth $1.20 \mathrm{~mm}$, height $0.70 \mathrm{~mm}$., height of head $0.25 \mathrm{~mm}$., length of spine $0.11 \mathrm{~mm}$.

The male is smaller. Antennule somewhat curved; at the free end it bears, besides the sensory threads, a flagellum, which is somewhat curved at the end and dark contoured at the base and is at least twice as long at the seusory setat. The lateral seta is situated somewhat separated from the llagellum on the front (cephalic) margin of the antennule. There is the same cervical toothed process seen in the female. Abdominal processes absent. Lengtin of wale $0.7 \mathrm{~s} \mathrm{~mm}$; height $0.42 \mathrm{~mm}$.

It would appear that Forbes 1 . dentifer is the Ameriean representative of this species. It differs in having the cervical process much 
further cephalad, i. e., over the base of the antenne rather immediately in front of the heart. The beak in $I$. dentifra does not turn ventrad but candad.

* Daphnia dentifera Forbes.

Plate LiII, Fig. 9.

Forbes'93.

Broadly oval, long beaked, species with a large eye, posterior spine high and with a prominent angle dorsally between heart and eye in the male and young female. Head broadly rounded, eye near front margin. Fornices short, forming a prominent angle behind the base of the antenne. Lower margin of head concave, beak projecting. Eye large with numerous lenses, its diameter more than half the distance from eye to beak. Pigment fleck immediately behind the eye and nearer it than the posterior margin of the head. Ifead crested, forming above the insertion of the autenne a rectangular process which in the young may bear two or three teeth. This process is seduced to an obtuse angle in the adult female, disappearing in ephippial individuals entirely. spine of shell long and slender, one third or one fourth the length of the shell. Caudal claws smooth, anal spines 13. The two abdominal processes approximate. Length of female $1.8 \mathrm{~mm}$. Male $1.0 \mathrm{~mm}$. Very near if not identical with 1). dentatu Matile. This species differs from l). minnehaha (hiefly in having smooth claws.

\section{Daphnia longiremis Sars.}

I species of moderate size and very hyaline. Head small and rounderl, ventral margin somewhat concave, buak sharp, directed ventrad. Shell oval. spine short, st raight, inclined dorsad. Antenne relat ively longe extending to (audal nargin of shell. Post ablomen similar to that of $/$. Lompisprime. Macula absent. Eye small. Length 1.9) $3 m$. Apparently a pelagie form. We are not certain that it represents an adult.

* Daphnia magniceps Herrick.

The frenliar form figured in the tenth annual report of this survery seem- induhtably new and is distimguished by the peruliar shovel-

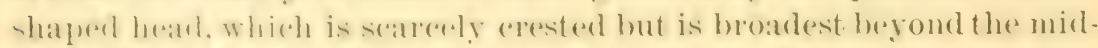
dle. The grime is long, the chaws smooth. the abdominal processes nented and the shell transparent. The eye is near the emel of the romoded hearl and is large: the pigment fleck was apparently absent. Fonnd with louphenir minurhere in a shallow swampy pool in autumn. 
Daphuia cucullata Sars.

\author{
Kurz (vitrea).
}

Tery like the above, but the margin of head is not straight below, is, however, extremely variable and ends in a sharp angle. The eye lies nearly midway between the heart and the end of the head and near the lower margin. The two anterior processes of the abdomen are united for most of their length. Anal teeth five to seven. Chaw ciliate. The flagellum of the male antenna is about as long as the terminal setre.

1). "pirutu Kurz seems to be a large variety lacking the sharp spine of the head. In the main it agrees yuite well. Although the postabdomen is broader than figured by Mueller, the number of teeth corresponds with Sars' description.

Length 0.95 to $1.11 \mathrm{~mm}$.

* Daphnia kalbergensis Schoedler.

Plates XXVII, Figs. 1-3; LIII Figs. 5-8.

Schoedler (coederstromii, and berolinensis); Forbes (retrocurva).

Rather delicate species of moderate size, inhabitants of clear and deep waters. Form oral, with a long nearly straight spine springing from near the middle of the posterior margin. Head very large and produced into an enormous helmet-like crest, which projects ceplon. lad and may be somewhat or greatly curved dorsad. The size of the crest and its form are very variable even iu the same gathering. Eye small, with few leuses, distaut from the ventral margin, macula wanting. Antennce weak. Post-abdomen narrow, with from six to twelve anal teeth; claws weakly ciliated. Abdominal processes discrete.

As above stated, the close association of forms in the same gathering ranging from II. vitren to the extreme of II. retromron seems to forbid their separation, even varictally. The case of $I$. vitren is most open to dunbt. The chief differences serm to lie in the small number (4) of anal tecth and the fusion of the two anal processes. A young specimen from Lake Minnetonka had but four large teeth and two incouspicuous ones and the anal processes were less distinct than in older individuals. All transitions could be found. We agree with Fellich that this, at most, is a depauperate variety of ll. limberyensis. There seems to be absolutely no good reason for separating I). chllerstramii or $I$. retrocurem, as the differences are largely a matter of age and freedom to develop typically.

P. E. Mueller gives the following measurements for II. linllurymsix: Head 0.9 to $1.0 \mathrm{~mm}$., body 1.0 to $1.1 \mathrm{~mm}$, spine 0.7 to $0.75 \mathrm{~mm}$. 
Kurz for his $D$. ritren gives a length of $0.85 \mathrm{~mm}$. plus $0.25 \mathrm{~mm}$., the length of the spine. Judging from his figure, the head would not measure over $0.35 \mathrm{~mm}$.

Forbes says of his 1 . retrocurec that the head is two-thirds as long as the body.

Our specimens measured as follows:

No. $1.1 .6 \mathrm{~mm}$; head somewhat more than half the body and almost exactly like $D$. vitrea in form.

No. 2. Head $0.6 \mathrm{~mm}$., body $0.9 \mathrm{~mm}$., spine $0.5 \mathrm{~mm}$.; about nine anal spines. Head in this case moderately curved upward.

Yo. 3. Head $0.95 \mathrm{~mm}$., body 0.95 or less, spine $0.5 \mathrm{~mm}$.; or the head as long as, or, indeed, considerably longer than, the body and directed upward.

The males have the crest much lower, the spine longer, and the form of antenuules figured by P. E. Mueller. In the older females the beak is elevated above the antennules, as remarked by Forbes, but in smaller individuals there is very little difference between our specimens and Iueller's figures.

The claws of the post-abdomen have, besides the row of fine teeth mentioned by Mueller, a cluster of sharp teeth just at the base.

Found, together with typical I). galeute and the rounded form, in a small deep lake or expansion of a creek not far from Medicine lake, Hennepin county, Minnesota.

We have since found this species at a depth of 80 feet in Lake Minnetonka, and here also in association with $\mathrm{D}$. hyclinu. The range of variation is exceedingly great as indicated by the figures of Plate LIII.

Ilaving given as fall a catalogue of the well known and accessible species as our circumstances now permit, it remains to notice the exjistences of others which are either imperfectly described or the descriptions are out of reach.

\section{Daphnia similis Claus. \\ PLATE XXXV, FIG. 5; LI, FIG. 7.}

The deseription of this species, which was bred in confinement from

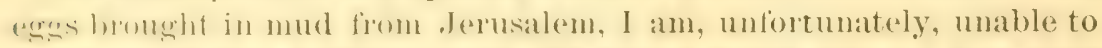
funte. Iulging. however. from the figures which alone I now have

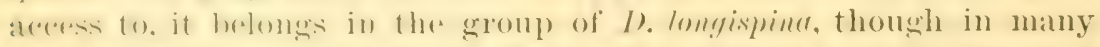
particulats it resembles 1). seducfiri. The form is elongate, the spine short and springing from the upler margin. The antennule of the fimale is rery latge and llagellate, while that of the male is like that of Il. sederfieri. The dlagellum and hook of the first foot of male are rather small. 
W. Schmankewitsch described as new $D$. degeneruta and $D$. rutis, from salt or brackish waters. These he regards as degenerate forms produced by the inferior aeration of dense waters. The author does not appear to recognize the moderu distinctions of genera, so that, not having seen the work, even the generic position cannot be definitely stated. His investigations seem to show that the proximity of salt waters influence the form of the body, or, perhaps, that there is a con. stant interchange between the sub-marine and fresh-water species. Duphniu brevicumdu Chambers is an incorrectly figured and described Simocephalus.

\section{Daphnia bolivari Richard.}

Richard'88.

"Caput a latera visum fere triangulare, latum, margine superiore recto; anteriore cum inferiore lineam usque arl apicem rostri sequaliter ac leviter arcuatam formante; rostro acuto brevi. Testa cetera margine dorsali subrecto inter caput et corpus leviter rinuato, margine ventrali aculeato parum areuato. Spina testre longa aculeis multis ac validis ornata. In capite a latere viso linea circularis patet insignis distinctissime serie duplo aculeorum acutorum instructa, parte superiore modo lavi. Ad apice dorsali et posteriore hugus linese secuitur linea alia eadem structura marginem superiorem test $x$ usque ad apicem caudalis spina. Adest preterea linea alia in medis ntriusque lateris teste, aculeis ornata. Antenna $1 \mathrm{mi}$ paris magna. 2di paris mediocres piliis brevibus sed distinctissimis ornatre. Setre abdominales mediocres, ad apicem ciliis longis deuse obsitc. Oculus mediocris erystallinis pancis perspicuis; macula ocularis rotunda, parva. Longit. fem. spina testie inclusa, $3.35 \mathrm{~mm}$., spine, $0.8 \mathrm{~mm}$."

This Spanish species is not sufficiently described to be allotted to it, place among its congeners. The armature of the abdomen is absolutely essential.

\section{Daphnia carinata King.}

\section{King '52-54.}

This form, though incompletely describer, will be easily recognized when rediscovered. It belongs to the I). scuhfieri group and is said to resemble 1 . similis Claus, beins one of the largest of the greus. The head is armed with a crest but is depressed and uniformly rounded. The shell is oval with a long spine from the upper angle in the young female. Abdominal processes thick. Post-abdomen attenuated. Details of armarure not given. Ephippium with four eggs. 'The eye is somewhat distant from the margin.

Duphniu gravis Schoedler serms to us but an extreme variation of the above as it was regarded by King.

Daphnia kingii Schoedler is a very large species with the head greatly helmeted. 'The outline is nearly circular aud rises above the level of the back. The shell is oval with an pxtremely long spine which is directed obliquely dor aad. 
Duphinu cephululu stohoedler is named from rude drawings by King, which, if they show anything, seem to prove that they represent an abnormality, probably of $I$ ). limgai. The sac like distension of the head is at the expense of the lower part of the head.

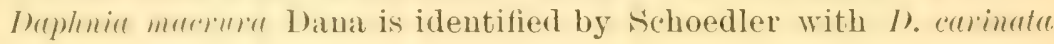
King.

Inohniar lisillinmensis Schoedler=I). vitror Utjanin is apparently I). longivemis Sars.

Implenin menprtii Baird, from India, is quite insufficiently deseribed but belougs to the $D$. schafferi group.

Schouller mentions Inphnia brasiliensis Lubbock and Inuhnia granaria Gay, from Chili.

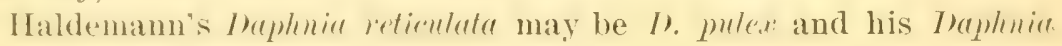
abrupta is Simocephalus.

\section{Daphnia lumholtzii Sars.}

PI.ITE LXVI, Fici. 6.

This spucies from Australia is well characterized by acute depressed frontal spine and the flaring fornices which end in curved spines of consideralile length. The male and ephippial female lack the frontal spine but preserve the long spine springing from the upper angle. 'The antemnules of the malesar.vary long and the flagellum two-jointed and about as long as the antenumle. The claw of the first foot is gruatly developed. The claws have no spines. The aual teeth are 12 or more. Abdominal processes discrete.

\section{FAMILY BOSUIVIDE.}

Simall cladoceral of remarkable form, due to the great elongation and morlifieation of the antemmules, which are seated on a small eonical luak like projection of the rentral aspect of the head and form lome, foimtel. probosis-like appembages corved in varioms ways. The

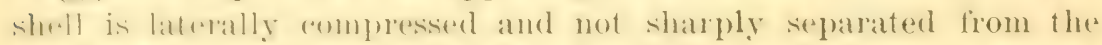

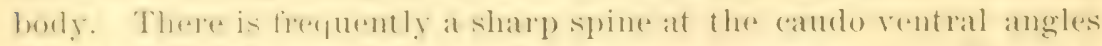
of the shell. 'lbe strfare is reticulate, striate or smooth. Feet, six pairs. The lir-t pair hooked in the male. The antenuat have three amb foml juinted lami amd ale very small. The post-ablomen is trun-

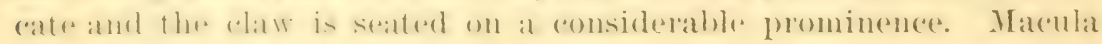
cerebri and cocea absent.

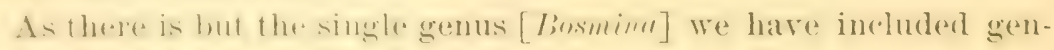
eric charicters. 
These curious animals are often found at great depths in the larger lakes, though they may also oceur in weedy localities. They are poor swimmers and rarely eaught in the net.

\section{* Bosmina cornuta Jurine.}

Plate LXV, Figs. 3-5.

Oval, almost spheroidal. Head high, concave below the eje. Beak long, its flagellum midway between the eye and end of beak. Eye large. Antennules curved like a hook composed of 10 or $11 \mathrm{seg}$. ments. Antenuic as long as the end of the antennules, three-jointed ramus with fire seta, the four-jointed ramus with three setie. Shell high, greatest height in middle of the length. Iack uniformly enrved and forming an obtuse angle, with the straight caudal margin. Spines at the caudo-ventral angle short, turned dorsad. whell hexagonally reticulate. Post abdomen short, truncate aud excavated apically, with two anal spines. Claw finely pectinate. Length 0.4 to $0.54 \mathrm{~mm}$.

\section{* Bosmina longirostris O. F. Müller.}

PI. ITES XLV, FIG: 2; LAIT, FIG. 2).

General form oval, shell highest in the middle. Ifead high, heak short, flagellum arising from near the end of the beak, front protuberant. Antenuie louger than in Is. rormulu, three jointed ramus with five, four.jointed with four seta. spines of shell short and straight. Post-abdomen short, truncate, unarmed. ('laws on a protuberance, pectinate. Length 0.31 to $0.35 \mathrm{~mm}$.

Bosmina longicormis Schoedlex.

Very similar to B. Tongivestris, but the front is not protuberant, the flagellum is midway between eye and end of heak. The spmes of the shell are loug, toothed reutrad and directed obliquely dorsad. Shell unmarked. The finely pectinate claws have at their base several large accessory spines. Length $0.36 \mathrm{~mm}$.

\section{Bosmina brevicornis Hellich.}

A large species with depressed head having a uniformly rounded front. Shell higher than long and coarsely reticulate, spine short and curved. The beak is short and little curved, the flagellum being quite near the eye. The antenumles have seven segments. The postabdomen is large withont anal spines aud the claws are simply pectin. ate. Length $0.55 \mathrm{~mm}$. Hellich says this differs from B. brevirostris P. E. Mueller, which has a protuberant front and long serrate spine and the claws have seven accessory spines. 


\section{Bosmina bohemica Hellich.}

Body large, slender. Ifear high, front uniformly rounded, flagellum nearer the end of beak than the eye. Beak short, rounded. Antennules long and arched, composed of 16 or 17 segments. The triangular spine ahove the sensory filaments large and acute. Shell as long as high, highest in the middle. Spine long, curved dorsad and toothed. Shell irregularly reticulate and longitudinally striate. Post-abdomen large, truncate and excavated. Inferior angle ciliate. Claw protuberance long, unarmed. Claw with six spines at the base. Length $0.6 \mathrm{~mm}$.

Bosmina microps P. E. Mueller.

(b)long, length much greater than height. Front not protuberant. Cando-rentral angle of the shell without the spine, rectangular. Antennules long, nearly straight, flagellum nearly midway between beak and eye. Leugth $0.5 \mathrm{~mm}$. or less. The shell is reticulate and the antennæe are very short.

\section{Bosmina maritima P. E. Mueller.}

Obloug, longer than high, frout moderately protuberant. Shell strongly arched above: spine long, directed obliquely ventrad. Antemules slender, gently curved; flagellum near the beak. Shell smooth. Length $0.5 \mathrm{~mm}$.

Bosmina brevirostris P. E. Mueller.

()hong. length greater than height, front greatly protuberant. Shell arched above, strongly spined. Antennules moderate, straightish but inclined caudad. Flagellum near end of beak, sensory setex remote. Length 0.6 to $0.7 \mathrm{~mm}$. Color reddish.

\section{Bosmina diaphana $P$. E. Mueller.}

(ijbhous, length greater than height, front not protuberant. A slight sinnosity in the dorsal ontline over antenne. Shell very strongly arched without the spine, smooth. Antennules very long, curvel, convergings at the ands. Flagellum near the end of the beak. Length 0.6 to $0.7 \mathrm{~mm}$.

\section{Bosmina lilljeborgii Sars.}

PIATE XLV, FIG. 3.

Tory gibhous dorsally, length and breadth nearly equal, front not protuberant. Inosal outline sinuous over the antemna. Spine absent. Antenmules longer than the body. straight or slightly curved, divergent. Flagellum near end of beak. Iength 0.6 to $0.75 \mathrm{~mm}$. 
Bosmina curvirostris Fischer.

Body rounded, length little greater than height, front somewhat protuberant, dorsal margin strongly arched, antennules short and strongly curverl. Flagellum midway between eje aud end of beak. Seven to eight setre upon the cephalic aspect of antemne. Iength 0.39 to $0.4 \mathrm{~mm}$.

\section{* Bosmina striata Herrick.}

\section{Plate LxV, Fig. 1.}

Herrick' 82.

This form is very imperfectly known, but resembles $B$. bohemire and may be identical, but that is a much larger form. Oblong, slender, greatest height cephalad of middle, front strongly arched. Eye large. Flagellum near the beak. Antennules very long, curved. Shell irregularly marked with anastomosing longitudinal lines prodncing a deformed reticulation. Spine large, curved, but not long. Ventral margin sinuous, ciliated cephalad. Isength $0.25 \mathrm{~mm}$.

\section{* Bosmina atlantaensis Turner.}

This is not adequately described. It, however, affords proof of the existence of a fourth type of Bosmina in America. IB. Iomgirostris, IB. cormute and B. stritte all have the shell marked and peculiarities of structure otherwise. The southern form has a smooth shell, long antennules, depressed spine, sinus between head and body, and flar. gellum nearer to the eye than to the sensory seta. The post-abdomen is broad and the claws toothed. The whole genus requires revision.

Other species which cannot now be placed are the following:

$B$. gibberc and $B$. rotunda Schoedler.

$B$. loevis Leydig, probably the young of tongirostris.

B. londensis Norman and Brady.

B. obtusirostris Sars, probably is B. brevirostris.

B. leeustris and B. nitide Sar's.

B. coregoni Norman and Brady, is B. lilljeborgii.

B. macrorhyncha, a species from the Nile.

\section{FAMILY LYNCODAPHNIDE Sars'61; Herrick's1.}

This is a rather small family with several gevera of minute animals which are abundant only in summer. Many, and indeed most, of the species are amoug the rarer of fresh water crustaceans of this group, and a few are among the rarities which only now and then reward the 
collector. This family undoubtedly is the link connecting the Dophmirle with the Lymerelee, relationships to which are expressed by Mremothrir, on the one haud, and Lyncoduphinin on the other.

The rank of this groul as a family must be, of course, a matter largely of opinion. Sias was the first to adopt this view. sustained by certain curious transition forms leadiug toward lynceidu. Later writers seem never to have found these genera and the group was acrin included with the Inplmide. The writer ('S2). upon the discovery of the L.mmedaphnin was forced to regard this group as of equivalent grade with the above mentioned families and again proposed the family name Lyncodaphnida.

The genus llyoryptus is a little one side the normal course of the family and seems related to the lynceid genus Leydigia.

The waters of the northern I nited States are very rich in members of this family.

The aberrant family liosminida funds its ouly connection with other cludurer, through this group by means of the remarkable MucroIhri., (?) pauper: and here it is only vaguely hinted at in the elongated antemules and angled lower margin of shell, as well as the presence of certain boties near the base of the antemules. It has been alfirmed that none of the L.ymorduphnide have an ephippium, i. e., the saddleshaped thickening of the shell walls to include and protect the winter egess; but I hare discovered it in the case of Macothrir temuirornis liur and presume it may occur exceptionally in others. Kurz says that Ilyury!ntus has no moult proper, but this probably refers only to the dimopean I. somdidus. The American species differs from the generic description given by kurz, and may be different in this respect also.

In this fanily the regularity in the disposition of the setre on the antenna is hoken and the fringing of these hairs serves the purpose of specific distinction. The antennules are always long and frequently differ ronsiderably in the sexes. The pigment fleck is always present ( KIIr is in error in denying its existence in Lathonum). In many forms there is no free posterior margin of the valves, while the lower

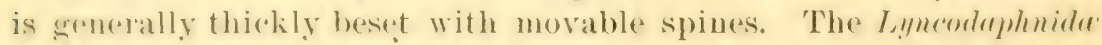
will be distinguished from revioflymbir, which they resemble, by their motion, which is a surectsion of quick hounds. while the hroater

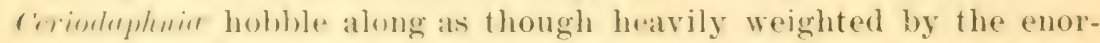
mons mass of exgers with which they are generally laden. The abdomen is uslually shost and the anus is behind the ferminal claws, but in Ily. ornplus the claws are long and spined at the base. In the Aneriean I. spinifer the anal opening is elevated to a point nearly molerneath the stylets, and there is a rudimentary anal rocom as in Lynceids. 
The males have the opening of the rasa deferentia in front of the claw's, which may be absent: the antemules are also modified, being longer and curved. In Luthonum the abdomen is elongated posteriorly till it begins to suggest a transition to Polyphemus.

The known genera and their distribution is as indicated below. Half of the known species are found in Imerica, one-fourth being peculiar to it.

\begin{tabular}{|c|c|c|c|c|c|}
\hline Genera. & $\begin{array}{c}\text { Total } \\
\text { Number of } \\
\text { Species. }\end{array}$ & European. & $\begin{array}{c}\text { Also } \\
\text { Amer.can. }\end{array}$ & $\begin{array}{l}\text { Only in } \\
\text { America. }\end{array}$ & $\begin{array}{c}\text { Total } \\
\text { American. }\end{array}$ \\
\hline Macrothrix ............................ & 4 & 3 & 2 & 1 & 3 \\
\hline Lathonura............................... & 1 & 1 & 1 & & 1 \\
\hline Drepanothrix ......................... & 1 & 1 & & ... & .... \\
\hline Streblocerus ............................. & 1 & 1 & & ..... & ... \\
\hline Acantholeberis........................ & 1 & 1 & & & \\
\hline 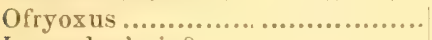 & 1 & 1 & 1 & & 1 \\
\hline Lyncodaphnia?....................... & 1 & & . & 1 & 1 \\
\hline Iigocryptus............................. & 3 & 2 & . & 1 & 1 \\
\hline Totals............................ & 13 & 10 & 4 & 3 & 7 \\
\hline
\end{tabular}

\section{GENUS MACROTHRIX Baird.}

Body oval, pointed behind: head broad; antenne of first pair long, nearly straight, beset with spines, olfactory threads terminal; swimming antennie large and powerful, propelling the animal by bounds; three jointed ramus with a greatly elongated setw which is thormed and jointed: labrum with the basal joint enlarged, resembling that of Iynceids; first foot with a hook in both sexes: last foot with a long process (respiratory body); abelomen short: claws short; eaudal st ylets often with a bush of hairs at tip. The intestine is straight and without creca in front or behind.

The first one to observe a member of this genus, apparently, was

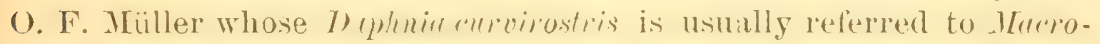
thrix laticornis.

The name Erhinisen was proposed hy Lievin, hut Inemothrid was applied by Bairl in 1843. Four species are known, three of which occur in America, and without douht the fourth will ultimately be found. No males of this genus were known till $157-7$ when the male of Ir. lutirormis was deseribed and figured (Cirube and Weismann'so.) Tearly two years later the male of $1 /$. roser was describerl from 11 in. consin by E. A. Birge. Deseriptions of the male of Tuthonura are also given in both the above mentioned sources. 
* Macrothrix laticornis Jurine.

\author{
Plates LIV, Figis. 9-12; LVI, Figs. 8, 9.
}

Juriue '20); Baird '50; Fischer '52 (I)aphnia curvirostris); Lilljeborg '53; Schoedler

'58; Leydig' 60; Norman and Brady'67; P. E. Mueller '68; Lund '70-'71; Fric '72'1 Kurz' '74; Herrick'81; Birge '91.

This ubifuitons species was first reported in America by Birge thomgh it had been encountered by the writer in several instances. It is recorded at Madison. Wis., Minneapolis, Minn., where it is not rare, and in Albuquerque, New Mexico.

The boly is compactly oval, with a curved or subangular lower margin which is armed with spines which project in three planes, thus producing three series; dorsal margin convexly arched, crenulate or subdentate. Head short, produced rentro-cephalad to form a blunt beak from which the antenmules are suspended. Eye of moderate size; pigment fleck large; puadrate. Aitennules short, greatly expanded at the tip, provided with the usual sensory sete and flagella and a cluster of spines at their bases, also a second cluster upon a special protuberance posteriorly. Tpon the anterior margin are series of bristles and this margin is serrate. The antenne are strong, hairy, and armed as usual in the genus. The feet are sufficiently represented in the figures. The post-abdomen is short, with very small terminal claws, in front of which are several bristles not previonsly noticed; about the anus are several bristles, and a series of short teeth ornaments the dorsal margin. The whole shell is hexagonally reticulate except along the lorson where the slight crest modifies the markings. Jength 1.7 to $6.0 \mathrm{~mm}$. IBirge found this form ouly rarely and then singly. Fric speaks of it as loving the bottom and occurring singly. Wr. have frepuently found it in Minueapolis and abundantly in New Mexico.

As the type of the genus, it appropriately oceupies a conservative fosition, as shown hy broad tip of the antenumles, a feature exhibited by embryos and young of other species.

\title{
Macrothrix nova-mexicana sp. n.
}

PLATE LIX, Figs. 3-5.

Tenta corporis suboblongata, levis, postice non angulata, marginalibus rentralibus : bralis parvat sed manifesta. Intennat fere rectie, ad apicem versus paulum dilatata, posticx ciliate. Antenna 2.di paris ille $M$. rosea similes. Cauda brevis, apice rotumdato, super anum sinuata, ad apicen versus densa ciliata, margine cetero seribus setarum minimarum armato sive inermis. Longit $1.1 \mathrm{~mm}$.

Is compared with M. roser, its nearest ally, this form is not only (onsirloralily lareger (the larest figures being $0.9 \mathrm{~mm}$. in length by 0.6 
$\mathrm{mm}$. high, while the present form measures 1.1 by $0.7 \mathrm{~mm}$.) but the form and several details noticeably differ. The shell, as seen from the side, is nearly quadrangular, reminding of Lathomur, and is not produced into a sharp spiue as in .II. rosece. The head is also shorter aud is not excavated hetween the eye and pigment fleck. The ventral margin of the valves is not obviously sinuous and is spinulus as in $T$. rosed. The anteunules are straight, and not strongly curved, as figured by Kiur, neither are they spiny in frout. At the tip they bear the usual sensory sete and posteriorly a cluster of spines while the posterior margin is ornamented with several clusters of bristles distally. The antenuie seem not to differ materially from those of $M$. roser. The postabdomen is shorter than in $\boldsymbol{u}$. roseu, its terminal claws aresmall, curved, deep colored and unarmed; in the protuberance formed by the auns are closely clustered spines and bristles while the rest of the margin is either unarmed or furnished with a few minute spines. The long stylets are as uswal in the genus. No markings were seen on the shell. Projecting into the brood-cavity are two leaf-like plates which seem to serve an accessory branchial function and contain many blood corpuscles. Details of the feet are wanting. The species has been but once seen, in the clear water of the tank supplying Albuquerque, New Mexico, accompanied by two species of Diaptomus and a Moina.

1I. rosef occurs in the north, often in considerable numbers (Birge '91) and the present species may take its place to the sonthward. It may be admitted that it approaches Luthomu'a more than any other species of the genus.

It is just brought to my notice that Matile deseribes in an appendix to his paper "Die Cladoceren der Ungebung" von Moskan, 1S91," Macrothrir borysthenier, which is so very close to our species that we suspect intimate comparison will prove the two identical. The attennules in Matile's species are shorter and the dorsal margin is less strongly marked. The armature of the post-abdomen is perhaps slightly different but our lescription was drawn from very large iudividuals and considerable variation was observed. I therefore withdraw the name proposed for the present.

\section{Macrothrix hirsuticornis Norman and Brady.}

Norman and Brady '67; Daday '88; Matile '90.

Head separated from the thorax by a depression. Shell roundish, caudal angle obtuse, smooth, ventral margin gently rounded. Antennules dilated toward the end, slightly curved, cephalic margin with five series of small setie. Post-abdomen rounded at the end, having distally seven setre and proximally small teeth. Length $0.55 \mathrm{~mm}$. 
Macrothrix serricaudata Daday.

whell rouncled. puncetate, transparent. obtusely angled caudad. Caudal part of dorsial margin serrate. ventral margin nearly straight, sparsely ciliate cephabal. Antemules long, subcylindrical, attenuate at the end, slightly enved, armed with minute seter. Jost-ablomen rounded at the end, sinuous ahove the anus, serrate with strong teeth. Length 0.9 to $1.0 \mathrm{~mm}$. 'This species is near to our own $M$. pauper'.

* Macrothic rosea Jurine.

PuATES LIV, Figs. 1-3; LVI, Figs. 5-7, 11, 13.

Monoculus roseus-Jurine.

Lynceus roseus-Desmarest.

Daphnia rosea-M. Edwards, Jurrell.

Echinisce rosen-Lievin.

The body is sub oval, terminating behind in an acute angle: the lower margin is less conspicnomsly spined than the last or the following; the antemate are but slightly dilated at the end and nearly straight. 'The longest seta of the antenne is longer than in the last, reaching beyond the tips of the terminal set:; abdomen more slender, sinuate in front, beset with short hairs.

Length $0.6 \mathrm{~mm}$. male $0.3 \mathrm{~mm}$. The male has small relaws on the end of the post-abdomen, and the antennules are curved and elongated.

In a later publication Birge finds small claws on the post abdomen of the male which resemble that of limminu. On the posterior side of the apex of the antenmules of the male is a cluster of five or six long sense hairs peculiar to this species.

\section{* Macrothrix tenuicornis Kurz.}

Plates I.IV, Figs. 5-8; LVI, Figs. 1-3, 12, 20.

(5ee Notes on Cladocera of Minnesota, 1). 245.)

The body is oval, produced posteriorly in a sharp joint; the abdomen is strongly areloel. while the upper ontline of the head is a

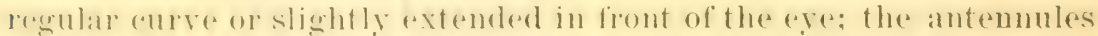
are loms. mealy straight amb a very little narrowed towarel the end, just in front of which is a series of short teeth; there is no lateral spine. lut a strong terminal one in addition to the semsory filaments; the piement spot is larger the "ye small and the lohus opticus well

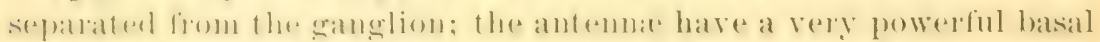

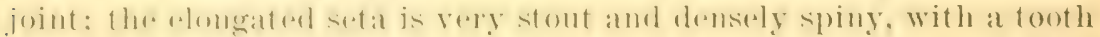

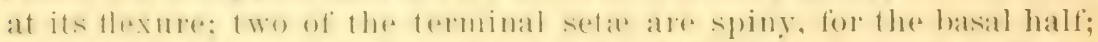

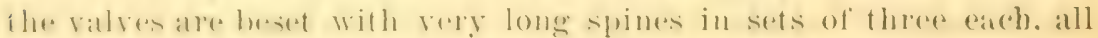

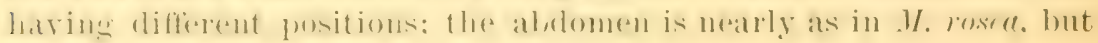


the posterior margin has a series of loug sharp teeth; the mandibles are nearly completely exposed by the arched auterior margin of the valves.

The labrum, in this speeies, is an ord link between that of the Inchlmide and Lymeride. The basal segment is greatly enlarged and is sub-triangular in outline, with a movable lip attached to the inner free face; the $t y p$ ical daphnoid st ructure is preserved, but the enlarged salient angle of the basal portion shows how the transition to the great triangular labrum of Alome, ete. is made. In young specimens the head is proportionately larger, the antemules are broader at the tip, and the dorsal outline is less convex: the marginal spines of the ralves are also proportionally larger, as are the appendages of the first and last pairs of feet. This is one of the largest species of the genus. 0.75 mm. being the length. This is very close to $M$. rosea but seems distinct.

This form is quite commom about Minneapolis, Minn., but is not yet noted elsewhere in America.

\section{* Macrothrix pauper Herrick.}

Plate LVI, Fig. 4.

This species is described from a single specimen from Lake Minnetonka, and I can add nothing to the very meager notice given then. (Herrick'82.)

The body is broad and very narrow, the lower outline is angled and nearly unarmed; the pigment fleck and eye are small and approximated; antenunles very loug and curvel backwarl and outward; abdomen short, eiliate below; claws short, ciliated. This female had a full complement of eggs but the antemine resemble those of a male. This is unusually interesting and should be rediscovered and studied; for there seems to be some affinity between this species and linsmina, and it is probable that it renuires to be distinguished generically from Mecrothrix.

\section{GENUS LA'THONURA Lilljeborg.}

The form is oval; the head is curved more than in Mucrothrix and the shell is more obtuse behind. sinuate below where it is beset with short spines anteriorly; first antenum long, straight: second antemne with five setie on each ramus; only four pairs of feet apparent; abdomen short, prolonged upward to the insertion of the caudal stylet; male similar but smaller. 


\section{* Lathonura rectirostris O. F. Müller.}

PI,ATE LVII.

K orh '35'41 (Pasithea rectirostris); Zaddach'44 (Daphnia brachyura); Lievin '48 (Daphnia brachyura); Fischer'52 (Daphnia mystacina); Lilljeborg '53; Leydig '60 (Pasithea rectirostris); Norman and Brady '67; P. L. Mueller '68; Schoedler '52 (npinosa); Birge '78; Gruber and Weismann '80 (Pasithea rectirostris); Herrick' 82.

The only species of the genus is distributed probably over the entire northern temperate zone. It has been fomm in America at cambrialge, Mass, and in the vicinity of Minneapolis, at both of which places it is very rare.

The form is a rather quadrangular oval, the head being strongly archerl to the beak which is much lather posterior than in Mucrothrix, in this respect resembling the Imphnidu: the eye ocoupies the center of the lower part of the head margin, and is of molerate size; the pigment fleck is near the base of the antenumles and well removed from the ere; the antemnir are straight and long. with a sensory bristle near the hase in frout and two bristles a third from the end; the second antenua are furnished with a powerful basal joint, while each of the main subdivisions of the rami has its bristle, which are neaty eymal: two of the terminal setar are toothed for the basal half and pectinate distally. but the others are feathered throughout: the four jointed lamus has a spine on the second joint and a longer one at the end, and all the joints of both rami are ormamented with triple series of spines; the maxille are three sponed at the end and are in almost constant motion: the first pairs of feet have curious comb-like bunches on some of the seta: the ablomen is very short and terminates in inconspicuous teeth. the pusterior part of the abdomen being ornanented with teeth flatteneal longitudinally so as to look like spones from the side; the last foot is simple but bears a large appendage; the posterior third of the shell is fringed by extremely minute spines, but anteriorly by lanceolate stift spines thattened longitudinally like the spines of the ahdomen: the camdal sotar are seated on a high prominence of the abdomen, and are linged alome their whole length, not merely at the emcl. The fomale is $1.0 \mathrm{~mm}$. lomen, the male 0.5 to $0.6 \mathrm{~mm}$, in which sex the antemmoles have more numerous lateral bristles, the first foot bas a claw and the back is less alevated. The semen bodies are irregularly round with small nuclei.

\section{GENUS S'IREBI,OCERUS Sars.}

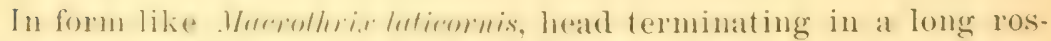
trum bearine the lons. twisted antenumles. Antenumles very large, emred backwarl and outwat. Head not separated by a distinct 
depression from the body, very high, slightly arched above, abruptly curved below with spines upon the margins. The antenuse are large; four-jointed ramus much the longer, with four setie. Labrum with a large process. Post-abdomen much as in . Hocrothrie tulicornis, serrated or notched behiud. Eye near the beak; pigment fleck small, situated below the eye at the base of the antennules.

The shell is hexagonally reticulate, arched above and angled below; ventral margin armed with rigid spines. Claws eiliate. Length 0.31 to $0.4 \mathrm{~mm}$.

Our ILucrothix muper seems a near approach to this geuns; both have a strong spine or claw on the first foot which projects beyond

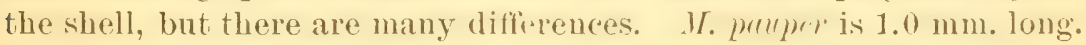
S. serricaudatus Sars (Plate LXVI, Fig. 1) is the only species.

\section{GENUS DREPAYO'THRIX Sars.}

The head separated from the valves by a depression: furnices moderate; rostrum rather arite, distant from the anterior edge of the valves. The form is subrotund; reticulate, with the margins of shell fringed below by loug movable spines: pigment lleck present; swimming antenue with three ciliated set:e on the four jointed ramus, the three-jointed ramus with its basal joint armed with an mujointed, strong, spinous seta and four ciliated setir on the remaining joints. The postabdomeu is broad. Intestine coilent. 'The male has longer antenux and a hook on the first foot.

\section{Drepanothrix dentata Euren.}

Platej XlVi, Fig. 9; LIV, Fig. 4; LVI, Fig. 14.

Acantholeberis dentata-Euren.

Drepanolhrix setigera-Sars.

Drepanothrix hamata-Sars.

* Drepanothrix hamata Norman and Brady.

This animal is only $0.5 \mathrm{~mm}$. in length. The antennules are laterally curved in the middle and ornamented with notches on the margins; the pigment fleck is quadrate and rather large; the post-abdomen is truncate at the end, convex behind and ornamented with a suries of small spines. Shell margins with long spines.

Birge reports this species from Lake Wingra near Marlison, Wisconsin. It seems to be repulled hy light and is a bottom-loving form. Though it swims fairly well, the stiff sete are chiefly used as pushing poles. The species has been taken in Deumark, Scandinaria, England and France as well as America. 


\title{
(ANCS ICANTHOLEBERIS Lilljeborg.
}

Body more or lesis yualrangular, head triangular, acute cephalad, hearing the antenumles at the front. Fornix slightly developed. Ifead scarcely separated loy a depression from the body. Antemmes elongate, expanded apically. The three-jointed branch of the antennate has five setat, the four jointed ramms has thee, all being apical. The seta of the basal joint of the three jointed ramus is elongate. Labrum with an arute process. Foet six pairs. Tutestine with a loop. l'ostahklomen hroad, armed with a series of spines. Margin of the shell with loug spines below.

\section{Ancantholeberis curvirostris O. F. Mïller.}

\author{
Plate Xlvi, Figs. 1-4.
}

O. F. Mïller 17s, (Daphnia (urvirostris); Schoedler '46 (Acantbocercus rigidus); Lievin ? 48 (Acanthocereus rigidus); Lilljeborg '52, and '58 (rigida); Leydig '60 (rigidus); Norman '63; Norman and Brady '67; P. E. Mueller '68; Lund '70-'71; Hellich'77.

This race species has not yet been found in America but may be confidently expected. The aspect is macrothroid, the whole ventral margin being long ciliate. while from near the posterior angle an isc a number of greatly elongated setie. The caudal margins are armed with short spines. The macula is present but rather small. The antemmules are clongate, expanded toward the tip). somewhat curved and armed apjoblly with about eight unequal lanceolate processes and smaller spinules. The post abdomen is hroad, romded distally. 'The claws have two small basal teeth and a series of small setae. 'The posterior margin is armed with a series of small teeth. Length less than $1.5 \mathrm{~mm}$.

\section{GENUS OFRYOXUS Sars.}

\section{Lyncod(ph)nia-Herrick.}

body elomgated, somewhat ructangular as seen from the side, greatest widh and hejuht of shell a litte posterior to the heart: head separated ly a dopresion fiom the boly, trumcate below: antennat and

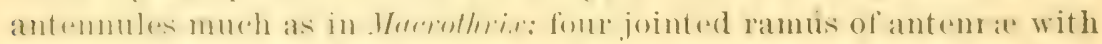
no latelat setar: rye small, pigment fleck present: intestine twice conroluted. respunded posteriorly, with anterior hut no posterior caca, openimg near the “herel” of the post-abdomen: post-abdomen large, triangular: truminal claws lones. rather straight. with two accessory spines at the base.

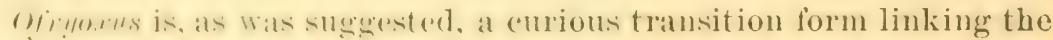
Daphnide with the Lynceide. 
O. grarilis not only has the disc like last foot colored but the swimming antennas are banded with purple as in simmrephatus rostrutus

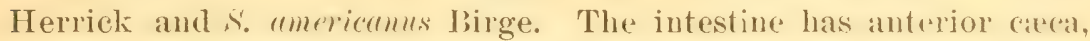

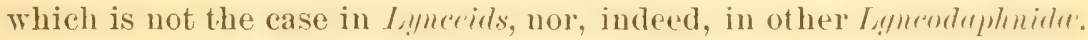

The four-jointed ramus of the antenna approarhes Lyncridu in the absence of a lateral seta, but the other ramus is as in Hurothrir. 'The convolution of the intestine, the form of the postablomen and the situation of the anus are all of a strictly Iruceid type: moreorer, the flattened appendage of the last foot is like that of Euryrerens.

Even in the form of the shell there is a combination of chatracters; the anterior part of the shell has the form peculiar to I, mnemlephnirlu: but posteriorly it again expands and becomes truncate hehind; the form in the adult is not mulike that of some rynceidu, but the young has a long spine posteriorly exactly like the spine of Imphnir. The latter fact is very instructive, for it indicates that the theory proposed (American Naturalist, 1Ss:; p. S15) to explain the origin of this ap pendage is probably the correct one. P'rofessor Lenckart suggested that this spine was a balancing rod intended to keep the proper equipoise over the center of gravity; hut it is difticult to see why these loug-hodied forms, in which the greatrr part of the weight lies "abaft" of the pivotal point-the hase of the antenu-should be thus provided while the shorter forms are not. We conceive that it is an apparatus for effectiug the moult of the inner lining of the brood cavity of long-bodied and tendr.s.shelled animals such as Juphnie and the present genus. The great development of the head in the crested Tophnitu may undoubtedly be explained upon Professor Lenckitht's theory.

\section{* Ofryoxus gracilis Sars.}

Plates Xli, Figs. 12-15; LVIII, Figs. 1-3; LIX, Fig. 2.

Herrick '82 (Lyncodaphnia macrothroides).

Sub-rectangular, greatly elongated, truncate behind, with a slight spine above; head and eye small, fornix moderate, beak truncate: antennules rather long, slight]y curved, tapering a little towarl the end, whence spring three lanceolate spines and several sensory filaments, five stont spines behind, above the middle, and several more slender ones; swimming antenuce very long, terminal setie smooth to the joint; labrum as in Inphniu: mandible attached behind a salient angle of the front margin of the shell; no ahdominal processes; post-abdomen hroad above, triangular; terminal claws pectinate, furnished with one very large toothed accessory spine and a smaller one; the first foot has a hook; the last foot consists of a large oval plate which bears poste- 
riorly the ordinary branchial coil, here shaped like a thumb and forefinger. The young is of a different shape and bears a long spine. The male is known from figures recently published by Birge ('91).

\section{GENUS ILYOCRYPTUS.}

Form empact, short; head short, triangular. with large fornices forming a roof over the head; the posterior margin of shell nearly as long as the inferior; lower angle a broad curve; antenuules two-jointed, basal joint very short, second joint straight, rather long; sete terminal, but one setal near the base; the four-jointed ramus of the antenna with hut three (terminal) seta; six pairs of feet, last pair rudimentary; tail large, as in Lymeorluphniu, anus elevated; intestiue straight, without carca, hut an expansion near the rectum sometimes simulates one; the margin of the shell is hordered with long spines, which may be branched or simply pectinate. There is often, perhaps generally, a failure to entirely rmove the moulted shell; when this occurs the newly-formed shell from eath moult remains under the older ones till the animal seems to be wearing six or more overeoats, and the spaces so formed become filled with algie and filth till the animal is no longer ahle to swin. I'. R. Alueller and Kurz, who seem to have seen only I. somdirlus, agree that Ilyorrymus camnot swim, but poles along in the mul on the bottom by means of antemir and abdomen: our $T$. spinifer, on the other hand, swims freely till loaded up with old clothes and filth.

This genus is also closely allied with the Iynceide.

Ilyocryptus sordidus Licvin.

Plates LV, Figs. 6, 10, 11; LVI, Figs. 15-17.

Acanthocercus sordidus-Lierin, Leydig.

Dorly higher than long; head small, terminating anteriorly in almost a right angle: posterior part of the shell margins covered with hrandhing. thorny spines: antemules cyliudrical: antemne short; fourjointed rani with no lateral seta'; post abdomen large, broad; terminal claws with two spines at the base: anns in the middle of the pesterior margin. Which is rerg hearily armed with spines; a hairy abdominal process is present, according to Kurz.

There are un anterior carca (my statement that P. L. Mueller deserihed - Heh carea was an error: see Notes on Cladoreca of Minnesota, 1) 2lli). Lerngth (). is mm. The talmated romparison beyond makes a full description unnecessary. Jirge reports this species from Wisconsin and it has been encountered in Minnesota. 
* Ilyocryptus spinifer Herrick.

Plates LV, Figs. 1-4; LVI, Figs. 18-19, 21.

Herrick '82, '84, and '87; Turner'93.

The description given in my Final Report, etc., is very brief, and no comparisons were there instituted with the $I$. agilis of Kurz, which is its nearest ally in Europe. The paper by Kurz referred to gives detailed descriptions of the three European species, accompanied by elegant plates. We are able, therefore, to draw up the following distinctive diagnosis of the species, hoping thereby and by weans of the figures to show the relations of the four species at present known. It is almost certain that we have more than one species in America, and the careful description of the known form may make the detection of others easier.

The size varies greatly; a full grown female with eggs in the hrood cavity is nearly $0.90 \mathrm{~mm}$. long and $0.70 \mathrm{high}$, while a smaller female measures $0.65 \mathrm{~mm}$. long hy $0.4 t$ high. The form of the shell is nearest like that of $I$. acutifons, the height being less than in $I$. sommilns, and the angle between the ventral and posterior margins less than in 1 . agilis. The entire length of the post abromen in the large female is $0.56 \mathrm{~mm}$. measurerl to the base of the candal stylets, of which length $0.168 \mathrm{~mm}$. pertains to the claws. The width of the post-abdomeu is but $0.14 \mathrm{~mm}$. Thus it is evident that the proportions of the postabdomen differ greatly from any of the other species, it being very long and narrow. The terminal claws are exactly as in $I$. ugilis, having two small basal spines and a lew sharp serrations near the apex, anteriorly. Near the base of the claw is a cluster of small spiues of two sizes, then begins a series of ahont 16 lateral teeth areraging $0.02 \mathrm{~mm}$. in length and extending to the sides of the anus. Ahove this point the contour of the margin is convex and is ornamented with nine spines twice as long as the preceding. Then follow the prominences which bear the long and simple candal setir. Besides the above mentioned spines there are four spines on either side upon the lower posterior angle of the post-abdomen which are four times as long as those of the previonsly mentioned eontinuous series (i. e., (1.05 mm.). Above, the abdomen is hirsute or thorny as in I. crgilis, and the process for closing the brood sac is similar. It will be seen that the post-abdomen differs in armature as much as in form from other species. From I. sordidus it differs in the following points: The claws are not pectinate behind but are serrate in front, the anal opening is higher and the details of the spines vary; from $T$. antifions it differs in that the claws are not pectinate, neither is there aspine in front of the claws, aud the anus is not terminal; from $I$. agilis it differs in that the shape is different, there are fewer enlarged spines, and the 
shape of the nine spines above the anus is different. The head is convex. resembling $I$. smolidus most nearly, but the antennules are much longer and more slender than in any other known species. They are $0.17 \mathrm{~mm}$. long and about $0.016 \mathrm{~mm}$. wide, while the longest seta is 0.0st mm. long. The antennic are almost exactly as in $I$. somlidus. The labrum has the usual shape, as have the jaws and other appendages. 'The margius of the shell are ormamented with spines simply prectinate or harbed as in $I$. agilis. In $I$. sordidus these spines are variously branched, and in that form alone of the European species, according to kury, is there a failure to perfect the monlt; in our spe. ries, which has simply pectinate set:e, the oid coverings are all but uniformly retained. The spines of the lower posterior margin are from $0.16 \mathrm{~mm}$. to $0.20 \mathrm{~mm}$. long.

such are some of the rhief peculiarities of the species, but, to make the relation between the four species of this little known genus even clearer, if possible, the following comparative table is appended.

The shell moulted periodically

I. agilis.

I. acutifrons.

The shell not moulted but retained...

f I. sordidus.

(I. spinifir.

Antennules not more than eight times as long as broad

I. sordidus.

$\{$ I. agilis.

I. acutifrons.

Antenuules more than eight times as long as broad.

I. spinifer.

Claw of post-abdomen pectinate

fI. sordidus.

1. acutifions.

Claw of post-abdomen not pectinate

$\{$. agilis.

I. spinifer.

A strong spine in front of claw

I. acutifrons.

Fine bristles or none in front of claw.

I. sordidus.

$\{$ I. agilis.

I. spinifer.

Anus opening near the claws.

I. aculifrons.

Anus about midway of the posterior border.

(I. sordidus.

I. agilis.

I. spinifer.

Marginal spines of shell much branched.

I. sordidus.

Marginal spines nowhere much branched ...

I. agilis.

I. acutifrons.

I. spinifer.

Elongated anal spines on either side, four or five, very long....

I. spinifer.

Elongated anal spines more numerous

I. agilis.

I aculifrons.

I. sordidus.

Upper (one to three) spines of the supra-anal series modified and $f$. acutifrons. enlarged 1. ayjilis.

1. serdidus.

Tpper spines like the others.

I. spinifer. 
The above is extracted verbatim from the Alabama Crustacea, which Professor Birge shonld have consulted before saying "none of the specific characters are mentioned or figured" (Birge'91).

Professor Birge is inclined to identify our species with $I$. longiremis Sars, from Australia. Iut if the Madison specimens have antennary setie nearly equaling the total length of the animal, they difler from all individuals of $I$. spmifer yet seen. The armature of the postalndomen is also different, for there are but four elongated elaws at the inferior angle and a series of about 14 anal spines and six longer supraanal teeth. We infer from IBirge's figure that the autennce are different. It would be well that the Madison form should be more carefully described and figured and compared with other American species. Length $0.60 \mathrm{~mm}$., height $0.46 \mathrm{~mm}$., base of antenua $0.19 \mathrm{~mm}$., fourjointed rauns $0.13 \mathrm{~mm}$., post-abdome $10.19 \mathrm{~mm}$., claw $0.125 \mathrm{~mm}$., long post anal spines $0.06 \mathrm{~mm}$., antennule $0.10 \mathrm{~mm}$.

\section{Ilyocryptus acutifrous Sars.}

PLATE LT, Fig. 7.

This species is only mentioned in the appendix to the paper of Sars on the cladocern from the vicinity of Christiania. The following is a condensation of the description.

Head large, acute in front. Shell truncate behind, with shorter sete behind than below. Antennules shorter and thicker than in I. sordidus. Antenuie long and robust. Abdomen with a short, obtuse process. I'ost-abdomen shorter than in I. sortirtus, posterior margin continuous, anus terminal; candal claws straight, very long, with two minute basal spines and a cluster of teeth in front. Pignent fleck almost touching the eye. Iength less than in $T$. sordictus, $0.6 \mathrm{~mm}$.

In this species the moult is perfect. (See table above.)

\section{* Ilyocryptus longiremis Sars.}

Plate LV, Fig. 5.

Sars '88; Birge' 91.

Professor Birge finds this species abundant near Madison. The original description is not now accessible. It appears, however, that the form of the postabdomen is very similar to $I$. syminifer, while its armature is quite different. The seta of the antenne are very long. nearly equaling the length of the hody. There are five to seren super-anal teeth, largest in the middle, an outer row of ahout eight long post anal spiues and an inner row of 11 to 12 post-anal denticles, besides several very small teeth near the terminal claw. There are three or four denticles on each side of the anus. The moult is incomplete as in I. spinifer. 


\section{FAMILY LYNCEIDE.}

This family, which is numerically the largest among the Cludorern, is, in the main, well limited, though there are transitions toward the Lymmoluphnide, which are quite direct. The genera Iyncodaphnin,

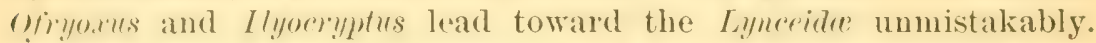
Most of the members of this family are small, comparatively few ex. creding one millimeter in length. The head is covered with an arched shield, which frequently passes with no indentation into the shell of the body. This head covering generally extends forward and downward to form more or less of a sharp angle in front, while in several genera it is simply rounded in front. It, in either case, arches orer the more lleshy lower side of the head from which hang the two short antennules and the labrum, while the strong two-branched antennie spring from well up under its posterior expansion. The rounded sides of this shield, which protect the insertion of the antenne, are called the fornices. Above the insertion of antennules is a dark fleck lying near or on the lower angle of the brain; this is the larval or nauplius eye, which is the first to appear in all these small crustacea. This murulu nigra is not infrequently as linge as the eye itself,; or even larger, and in one genus it is the only visual organ. The antennules are small and bear on the end several sensory filaments as well as a lateral flagellum. The antenuules of the male differ very little from those of the female. The labrum is furnished with a process, which is triangular or semicircular and is usually larger than the terminal portion. The mandibles are as in buphnide but usually shorter. Iaxille are often conspicuous, but the flrst pair of feet serve, by a slight alteration at the base, the same purpose. There is rarely an indication of the sixth pair of feet, and the antenne have both rami three jointed. The terminal part of the boly, or post-abdomen, is usually enlarged, and the anal opening is near its base; the armature is usually considerablet. The form of the post-abdomen is one of the hest reriteria for distinguishing genera and speries-a process often attended with much difficulty.

The shell is of various forms, frequently beatifully seulptured. The number of egrs produced at one time is limited, and the winter egge are very often laid in the brood-cavity with no preparation of the shell previous to it: in other words, the ephippium may be absent. (I) the other hand, sometimes the shell is considerably modified, and generally there is a deposit of dark pigment in the upper part of the shell. The males are very rale and until recently few were known. The dilingence of liurz has added a great many, and we now have a

* The name "Lynceus" is derived from that of the son of Aphareus who was famous for the sharp. nameness of his vision. 
fair idea of the sexual variations. These consist usually in a narrower body and shorter beak, in a strong hook of chitin on the first foot and certain modifications of the post-abdomen. The hook mentioned is simply an enlargement of one of the terminal bristles of the foot, and serves to fasten the animal to the shell of the female. In one American species of Pleurosus we find an approach to this structure in the female-an interesting example of inheritance of sexual peculiarities across the sexes. The alteratious in the form of the post-abdomen consist in a narrowing or exeavation of that organ to permit its introduction into the brood-cavity, and in some forms (rhydorms) this change ean only be understood by observing the form of the shell of the female about to produce winter eggs. In general, as in other Cludecem, males are found only at the period when the females are sexually perfect. The ordinary method of reproduction is by vircinbearing or parthenogenesis. In some cases it would seem, from Treismann's observations, that the sexual method occurs only incidentally. The orifice of the male organs is between, or anterior to, the terminal claws of the post-abdomen (Euryceress alone excepted). The males are usually but not always smaller. Plate LAI gives views of typical Lynceide. Fig. 1 is particularly instructive, for in it the details which can be usually made out in the living object are represented. The following points may be especially noticed. The large size of the pigment fleck, the large antenuules $\left(\Lambda^{1}\right)$, the keel of the labrum ( Lb.), the peculiar modification of the first pair of feet to assist the maxillar (not shown) which are exceedingly small, the largely developed anal gland (A. g.), the form and unscular mechanism of the abdomen, which, however, is better illustrated by Fig. 10 of the same plate. Fig. 1 contains an embryo seen from the side with the partially derel. oped limb. Fig. 3 shows the appearance of a different embryo from below and in an earlierstage. Fig. 2 illustrates the relation of the brain to the eye and the very small optic cauglion. Fig. 9 of Plate LXIII gives details of the fect in another species, and the modifications seen in the male of the same species are sufticiently show in Fig. 1 of the same plate, which also well illustrates the various sculpture of the shell displayed by this group. Figs. 4 and 9 of Plate LXIV show curious modifications of the post-abdomen of the male, and Fig. 7 ex. hibits the structural peculiarity of sexually perfect females which is correlated with it, or, perhaps, we may say, occasions it.

\section{SUB-FAMILY EURYCERCINE.}

A single species constitutes the sub-family, and it will be necessary to point out only those points which are distinetive.

The Eurycercince differ from the true Lynceide and approach the Iyncoduphnide in having the digestive tract not coiled, with two ceca 
in front and the anus at the end of the post-abrlomen. Many eggs are produced at once. The male opening is at the base of the abdomen, as in virlidu. The general halnitus is, however, lynceid. The males appear in autumn or when, by the gradual drying up of the water or other canses, the continued existence of the animals is threatened.

\section{GENUS EURYCERCUS Baird.}

Characters of the sub-family.

Eurycercus lamellatus O. F, Müller.

Plates Xlvi, Figs. 7, 8; LI, Fig. 6; LX, Figs. 5, 6; LXII, Fig. 19.

I.ıne us lomellatus - Mueller, Edwards, Koch, Zaddach, Lievin, Leydig, Zenker. Eurycercus laticaudutus - Fischer, Schoedler.

A gigantic Lymered, reaching the dimension of $3.0 \mathrm{~mm}$. The figure of the male given will sufficiently illustrate the general form. The aldomen is hroad and armed behind with a dense row of saw teeth. The eye is larger than the rather small pigment fleck, and the intestine is hent upon itself but not coiled. The last foot is found in few other L. murevile. Acroperus has the same, and Plemorus unitens also has a rudimentary sixth foot.

\section{SUB-FAMILY LYNCEINE.}

Intestine coiled; amus nut the end of the post-abdomen; opening of vas deferens nealy terminal. There are no anterior ceca but urially a single anal diverticle of the intestine. Rarely or uever more than two embryos produced at once.

\section{IIET TO THE SUB-FAIILI TSNCEINE.}

I. Head or dorsal line keeled or ridged; abdomen long; shell marked with diagonal strixe.

Camptocercus, 227, 228; Acroperus, 227; Alonopsis, 231

II. Usually no keel above, or, if keeled, the post-abdomen is not long. The majority are highly arched dorsally, and have comparatively short postabdomen and pointed beak. The antenna are usually feeble and the notion slow.

A. Post-abdomen nearly round in outline, armed with rery long, stout spines, terminal claw with one minute basal spine or none; greatest height of shell about equal to the posterior margin. . Leydigia, 233

B. l'ost-abdomen more or less triangular, armed with bristles; greatest height of shell moderately exceeding that of the posterior margin; shell marked with hexagonal meshes. 
a. Head nearly horizontal, blunt; post-abdomen prominent in the anal region.

Graptoleberis, 235

7. Head depressed, acute; post-abdomen excised near the anus,

Dunhevidia (=Crepidocercus), 236

C. Post-abdomen more or less quadrangular, armed with one or two rows of small teeth on either side behind; terminal claws with one or two basal spines; height of posterior shell margin usually less than the greatest height of the shell.

Lynce1s, 237

D. Prst-abdomen terete; greatest height of shell little less than that of posterior shell margin; terminal claws very minute.

Phrixura.

E. Greatest height of shell more than double that of the posterior margin.

a. Eye and first foot normal. . . . . . . . Chydorus, 260

b. First foot with a claw which extends beyond shell. Anchist ropus, 264

c. Eye absent, only the pigment spot used for vision. . Monospilus, 264 (Not noticed in the key. . Alona, 238; Alonella, 249; Plenroxus, 253)

SERIES A.--This section is proposed for the old genera Camplorercus, Acroperus, and Alonopsis, which seem to form a natural group though passing into Alona.

\section{GENUS CAIPTOCERCUS (> (amptocerens Baird).}

This easily recognizable genus contains two groups, each with several nominal species, which are distinguished mainly by the width of the post-abdomen. In both the shell is elongated, more or less quadrangular, longitudinally striate, armed behiud with one to four minute teeth. The head and back are keeled and the former strongly arched. The antennules rarely extend beyond the beak and are commonly curved laterally. The eye is proportionately small. The post-abdomen is long and furnished with a lateral row of scales. The terminal claws have a single basal spine and are serrate. There is an ephippium, and the male opening is in front of the terminal claws.

\section{SUB-GENUS ACROPERUS Baird.}

Post-abdomen broad, margins parallel; aual teeth very minute, lateral seales large and usurping their place. Antemuse with eight setse $(309)$. Three species are described, one of which is very abundant in Minnesota.

\section{* Acroperus leucocephalus Koch.}

Plates LXi, Fig. 5; LXiI, Fig. 9.

Lynceus leucocephalus-Koch, Fischer.

Acroperus harpe-Baird.

Acroperus sp.-Herrick.

Acroperus striatus-Jurine, M. Edwards, Lieviu, Lilljeborg, Leydig, etc., seems to helong here, but I am able to add nothing to the elucidation of the puzzle.

Body rounded above, angled behind; head moderately arched and carinated. Lower margin of the shell pectinate, terminating in two 
teeth. The antenuir are long and when reflexed the setie reach nearly to the posterior margin of the shell. The posterior angle is not always as prominent as shown in Fig. 5, Plate LXI.

\section{* Acroperus angustatus Sars.}

Plate LXII, Fig. 10.

This species is distinguished from the former by the head, which is higher and rery strongly arched. The dorsal contour is nearly straight. The antemne are shorter. The form of the post abdomeu of the male is iess different from that of the female than in the above. The length of both species is about $0.7 \mathrm{~mm}$.

The American form figured in Fig. 5 of Plate LXI differs from hoth the above slighty. The head is carinated and incurved almost as in $1:$ angustulux; the antemne fall a little short of reaching the posterior margin of the too low and oblong sheell; there is an obvious depression between the head and the body. However, in the main there is close agreement with r. Ifucompluhlus, to which it has been previously referred. There is always a ruliment of an additional pair of feet.

A. cuvirostris P. E. Mueller, is not known in the female sex. The male has a twisted cantial claw. It is probahly founded on an abnormal individual.

\section{Acroperus alonoides $\mathrm{Hudendorff}$.}

This speceies is only known to me from incidental references in Iratile. The pustabdomen is said to be broader than in either of the above. The claws have only one basal spine. The crest is low and the macula is nearer the end of the beak than the eye.

\section{(Acroperus transylvanicus Daday.)}

"Cariua capitis rotundata; testa corporis dorsali leniter rotundato; postice angulo indistincto; margine ventrali fere recto angulum inermem formanti, cauda apice rotundata incisal; unguibus caudalibus magnis, fere rectis. Longit 0.8 .5 to $0.9 \mathrm{~mm}$."

The ligures do not greatly fill out this hopeless description. The form is short and so is the abdomen, but the armature of the latter has nothing distinctive.

\section{SUB-GENUS CAMPTOCERCUS Baird.}

Although the general form is similar to the last section, the body is msually longede: the post ablomen narrows toward the end; the anal teeth exceed the lateral row; the antemnac have usually but seven setre $\left(\frac{300}{10}\right)$.

The species emmmerated are so cosely related as almost to batte definition. 


\section{IEEY TO TIIE SLB-GEXLS CAMTOCERCES (VERLS).}

I. Beak pointed.

A. Head depressed.

a. Pigment spot larger than the eye.

biserratus, 229

b. Pigment spot smaller than the eye.

B. Head directed forward.

II. Beak truncate below.

macrurus, 229

rectirostris, 230

latirostris, 230

III. Beak cleft below or with a forwand projection.

A. Antenuules shorter than the beak.

lilljeborgii, 230

B. Antenuules longer than the beak.

rotundus, 230

\section{Camptocercus biserratus Schoedler.}

Plate Liit, Fig. 4.

Is very nearly related to the next. from which it is distinguished chiefly by the fact that the pigment fleck is larger than the eje. Schoedler overlooked the fact that in (': marmms there is a lateral line of scales on the abdomen, and relied upon that character to distinguish this form. (Sehoedler says that the pigment fleck in 4 : manmurs is smaller than the "Je, P. L. Mueller says they are nearly equal, while in our specimens they are much smaller or nearly eyual.) If much variability is foumd, fichoedler's species seems to rest on a slender basis. The basal spine of the claw, however, seems to be peculiar in sitting on a distinct prominence.

\section{* Camptocercus macrurus Mueller.}

Plate LXI, Figs. 10, 10a.

Lynceus macrurus - Lilljeborg. Schoedler, P. E. Mueller, Kurz, Birge, Herrick.

This universally distributed species occurs in our larger bodies of water and is not rare, though hardly abundant.

The body is long and nearly rectangular; the head strongly arched and keeled. The keel of the head is extended down the whole dorsal line. The dorsal line is moderately auved, while the shell is but slightly excavated below. The head exteuds into a blunt beak looking downward; the direction of the head is somewhat variable from rertical to an angle of about 30 degrees). The ege is much larger than the pigment fleck; the antemules are shorter than the beak, and have one elongated terminal seta. The post ablomen is rery long and has numerous anal teeth as well as a lateral row of scales. The basal spine of the claws is large and serrate, the claw itself being nearly straight and armed with an increasing series of spines to beyoud the middle. The lateral scales of the post-abdomen are inconspicuous. The shell gland is long. The antennules reach to almost 
the end of the beak, are curved and bear a lateral flagellum. The first foot of the female has a sort of hook (branchial sac?). The labrum is armed with teeth on the posterior face of the triangular process. The intestine is very strongly, almost twice, coiled. The lower margins of the valves are feebly spined for three-fourths their length, and armed with from one to four teeth at the angle. Length $0.8 \mathrm{~mm}$. to $1.0 \mathrm{~mm}$.

\section{Camptocercus rectirostris Schoedler.}

Plate LXII, Figs. 1-3.

Inistinguished from the above, which it closely resembles, by the form of the head, which is less rounded and directed anteriorly. It hardly exceeds half the height of the body. The beak is sharp. I am not sure that Weismann's figures (1. c., Plate XI, Figs. 13 and 14) realiy belong to this species, for the drawing of the post-abdomen does not agree with that of P. E. Mneller fully. Outline copies of the former are given in Plate LXII, Figs. 1 and 2. The male has a hook upon the first foot. Not yet recognized in America.

\section{Camptocercus latirostris Kurz.}

Plate LXiI, Figs. 5-6.

C. lilljebargii, P. E. Mueller (?).

Closely allied to the next, but distinguished by the position of the head, which is a little less depressed, and, especially, by the truncate beak. The dorsal margin is convex and crested; the lower outline is also convex. The claws are toothed more as in C.macrurus than the following. The basal spine springs from the claw itself and not from the post-abdomen as in the next. Length $0.9 \mathrm{~mm}$. to $1.0 \mathrm{~mm}$.

\section{Camptocercus lilljeborgii Schoedler.}

Plate LXII, Figs. 7-8.

Iread depressed, rounded in front; beak divided at the end by the extension of the fornices. The terminal claws are pectinate for their entire length, and the basal spine is seated on the end of the postabdomen. This species, in the main, closely resembles c.mucrurus.

\section{Camptocercus rotundus Herrick.}

The second of the two species found in America is this short, strongly carinated form, which is known from a single gathering. It diflers from all the above species, with which it agrees pretty well in shape, by its more compact form; high dorsal keel (which extends the entire longth of the body): the longantennules, which extend far below the beak; and the somewhat pointed beak. The head is much as in 
the last, but it is not certain that the beak is eleft, although it has a peculiar form (not indicated in the figure) near the end. The length is $0.7 \mathrm{~mm}$. The terminal setie of the antennules are very unequal; but in most points, as in the armature of the post-abdomen, the details resemble $C$. macrumes. [This is probahly but a variety.]

\section{GENUS ALONOPSIS Sars.}

This curious genus includes three species of small Tymueids which exhibit a combination of characters. The form of the beak and head is like that of Plenroxus, which the form and seulpture of the shell otherwise resembles. The back is exteuded more or less in a knifelike ridge above, thus resembling Acroperus, a resemblance heightened by the excarated lower margin. The form of the post-abdomen approaches that of Acroperus, but in that genus it is of about equal width thronghont and in this it rapidly narrows. The internal organs and feet are of the typical lynceid form, while the antenne are as in Pleuroxus.

The type of the genus, $A$ elongutu, is apparently much closer to Acroperus than the two species which have been identified in America.

Shell sub rectangular, high, produced into a ridge above; lower margin convex anteriorly, concave behind; beak rather long; antennules slender; antenna with eight setw; abdomen long, narrowed toward end, incised at the extremity: claw rather large, with median spines and a basal thoru; third foot with a long bristle. Male smaller, withont the carina above; orifice of sexual organs in front of the claw, which is removed from the anterior margin. The young are more elongate and (sometimes) have hexagonal reticulations instead of the usual strong diagonal strix. Motion slow.

\section{Alonopsis elongata Sars.}

Lynceus macrurus-Lievin, Zenker, Leydig.

Alono elongatx-Sars.

Acroperus intermedius-Schoedler.

The shell is wide, the upper margin forming an even curve, manifestly angled behind; rentral margin nearly straight, eiliated throughout, with a single tooth behinc. Fornicess large; head narrow, not cariuate. Post-abdomen compressed, truncate at the end, armed with a series of marginal spines and of lateral scales; caudal claws large, with a single spine at the base and two median spines followed by a series of minute setie.

This form I have never seen, and it seems somewhat doubtful that the following really belongs with it. 
* Alonopsis latissima Kurz.

Plates LXI, Fig. 8; LXIII, Figs, 1 and 9.

body rery high, compressed, with a high dorsal keel or ridge; the npper outline strongly and evenly arched, terminating behind in no angle; lower margin almost angled at the anterior third, rounded behind. fringed with long bristles anteriorly, with short ones posteriorly. Head rery narrow; beak extremely long; fornices small; antennules nearly as long as the beak, straight and narrow; pigment fleck smaller than the eye. The abdomen is long, somewhat narrowed toward the end, where it is deeply cleft; the terminal claw is furnished with a large and small basal spine, while there is an increasing series of spines extending to the middle.

The elongated spine of the thind foot is pectinate and reaches nearly to the posterior margin of the shell. The shell is marked by a few strong stria which are diagonal except anteriorly where are a few parallel to the front margin. The male is small and lacks the crest on the back, while the lower margin is straight; the antennse are longer than the beak and differ somewhat from those of the female. The first foot has a claw. The post-abdomen lacks the anal teeth. Kurz gives the size as $0.5 \mathrm{~mm}$.

The American form varies between $0.45 \mathrm{~mm}$. and $0.55 \mathrm{~mm}$, and stems to have a higher dorsal keel and longer beak. Kurz speaks of but a single accessory spine on the terminal claws; there is, however, a second rery minute spine or cluster of hairs in this as well as the following.

Found in the same gathering with the following near Minneapolis (marshy ofl'set from I3asiett's creek near Oak Lake Addition): *

\section{* Alonopsis latissima var. media Birge.}

Plate LXI, Fig. 9.

I give Birge's description verbatim.

- liostrum prolonged, and shell sharp, somewhat puadrangular in

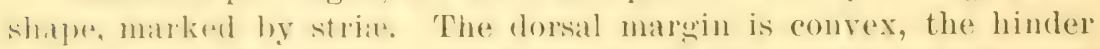
matregin nearly straight. Its lower angle is romoled and without

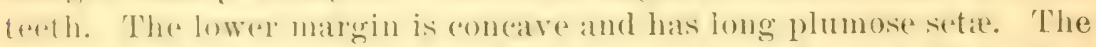

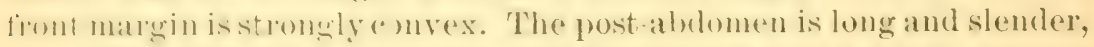

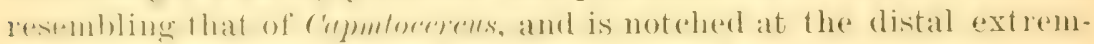
if y: it has two lows of fine teeth and some fime seales ahove them. The terminal rlaws are longe, slender, with a hasal spine, a spine in

Note ro Aloworsis LAtissisa. (See Fig. 1, Plate LxiI.) Since writing the above the males of our American form have been found; they are shaped as the females, with a high dorsal keel; the postabdomen is rounded, with transverse series of small bristles; the claw has a minute median spine, and the porus genitalis is anterior and elevated. 
the middle, and are serrated. 'The anteunules are long and slender, but do not reach to the end of the rostrum. They have each a flagel. lum and sense hairs. The antrunce are small and have eight ( $\left.\frac{30}{3} \frac{n}{1}\right)$ setce and two $\left(\begin{array}{ccc}1 & 0 & 0 \\ 1 & 0 & 0\end{array}\right)$ spines. The labrum resembles that of 1 . lencocephalus, but is slightly prolonged at the apex. The intestiue, cacum and color resemble those of Leroprens. There is a trace of a keel present on the back."

The specimens seen in Minnesota resemble this species very uearly, apparently, but there are some differences. The terminal claw of the post-abdomen has an increasing series of spines to the middle; there seems to be no lateral row of scales besicle the anal teeth; the abdomen is rather broad at the base and narrows towarl the end. The shell is not square behind. The lower margin has a few long hairs anteriorly which are followed by a series of teeth, and in the concave part a somewhat longer set to a point just before the lower curved angle.

The pigment tleck is nearly or quite as large as the eye. The autenmule is shorter than the beak (which is almost as in Pleuroxus hustutus), and has a thagellum about midway; at its base it is narrowed and inserted on a prominence.

The embryo still in the brool-sac has a more elongate form and hexagonal reticulations upon the shell, while the antennules were longer than the very long beak, and the pigment fleck was smaller than the eye. Length of female $0.52 \mathrm{~mm}$. The color is darker, aud the stria more numerous, than in A. latissima.

From a private letter we learn that this form is now regarded as simply a variety.

Series B.-This section includes Leydigia, Graptoleberis, Dunhevidia (=Crepidocercus). Lynceus, Alona, Alonella, Pleuroxus, Phrixuru, Chydorus, Anchistropus, Monospilus.

\section{GENUS LEVDIGLA Kurz.}

In this genus, both the known species of which are found in America, the posterior part of the shell and body is emphasized at the expeuse of the antrior. The curver posterior margin is equal to the greatest height of the shell. The head and anterior part of the body are of the form characteristic of . lomm: indeed, the whole hody is in plan like. Hom, but in the back part the organs are all enlarged. The general form of the body and abdomen reatls llyorymptux: the post abdomen, in particular, is very like that genus. The last two pairs of feet are much enlarged. 'The shell is usually irregularly maked with longitudinal striat; the lower margiu is covered with long spine-like setae. The post-ablomen is armed with several sets of 
long spines and aggregations of bristles and small spines; it is almost round and enormously enlarged. The intestine is coiled and expanded at the end but the anal cecum is rudimentary. The antenna are heavily spined and have eight seta; the labrum is more or less hairy. The male has a strong hook on the first foot, and between the terminal claws of the abdomen is a peculiar intromittent organ.

\section{Leydigia quadrangularis Leydig.}

Plates LIX, Fig. 6; LX, Fig. 4.

Lynceus quadrangularis-Leydig, Fric. Alona leydigii-Schoedler, P. E. Mueller.

The shell is comparable to that of Alonu quadrenguluris, but higher behind; the markings are not very distiuct; shell transparent. The head is very small; the eye smaller than or of abont the size of the pigment tleck. The post-abdomen is very broad, the posterior margin nearly the segment of a circle, armed with numerous very long unequal spines which extend only about half the height, being replaced by short close hairs; the anal openiug is very high; the terminal claws are long, straightish, and have a small thorn near the base.

The males are smaller than the females, and the abdomen is less broad; the antennules are longer than the beak and furnished with a flagellum. The sexual period occurs in september or irregularly. This species has only been encombered once, during September, in Poplar river, Cullman county, Alabama.

\section{* Leydigia acanthocercoides Fischer.}

Lynceus acanthocercoides-Fischer, Leydig.
Eurycercus acanthocercoides-Schoedler.
Alona acanthocercoides-P. E. Mueller.
Leydigia quadrangularis-Herrick.

This speecies, reported in a previous paper, is, as was said, nearest like L. nemulloweremides: and I am now able to verify the very inconspicuous diflepences upon which the two are separated. Our specimens of the L. equedrenguluris have the pigment flecek fully as large as the "ye. Kur\% to the contrary notwithstanding, and the spine of the claw of the postabdomen is present, while in the present species the pigment fleck is much larger and furnished with lenses; the spine of the claw is wanting: the labrum is densely hairy; the abdomen is narrower, and the shell higher. The shell is very obviously striped in the posrrior portion. The anns is higher than in the previous species. In ther respects the two seem alike. 


\section{[Alona balatonica Daday.]}

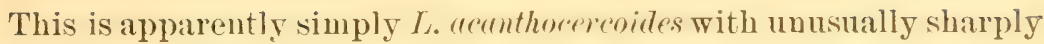
marked shell. The figures are very poor.

\section{Leydigia australis Sars.}

PI.ATE LXVI, Fig. 7.

Very similar to $I_{\text {s. }}$ acunthoremosides. Head comparatively erect, rostral projection not much curved. Body quadrangular, expanded behind and obliquely truncate. Hacula nigra at least three times as large as the eye. Antennules reaching nearly to the end of the beak. Abdomen very large, lamellar. Spines about 20, increasing distad. Length $0.84 \mathrm{~mm}$.

The points most relied on to distinguish the species are the large size of the macula and the absence of teeth from the claws. A very full description with numerous figures is given by Sars.

\section{GENUS GRAPTOLEBERIS Sars.}

A genus having affinities with Honelln. The shell is entirely reticulated, and there is a sort of crest along the back; while, on the other haud, the head is thattened and rounded in front. There can hardly be said to be a beak. Seen from above, the animal resembles some species of Alomellu, but the head is larger proportionally and more horizontal. The lower posterior angle is spined. The antemne have seven setie and are very long, in this respect resembling Crmpitoremens. The dorsal contour is not greatly arched. The postabdomen has short claws and anal bristles, but no teeth.

* Graptoleberis testudinaria Fischer.

Plate LXV, Figs. 8, 11, 12.

Lynceus testudinarius-Leydig, Lilljeborg.

Lynceus reticulatus-Fric.

Alona testudinaria-Schoedler.

Graptoleberis inermis-Birge.

Form trapezoidal; lower margin straight, armed behind with two teeth, thickly beset with long hairs in front; the dorsal margin is not greatly elevater, rounded at the posterior angle, forming a slight "hump" where it unites with the head shield. The head and shell are reticulated with hexagonal or suadrangular markings. The shell gapes below and rises to a sharp ridge above. The antemn have long rami, the antenules being hardly longer than the fornices. The eyo is large; the pigment fleck is small. The post-abdomen is narrowed 
towat the end, rounded in front; the terminal claws are small and have two basal teeth. The dorsal margin of the post-abdomen is covered with tufts of hairs. The winter eggs have noephippium. Length $0.55 \mathrm{~mm}$. to $11.7 \mathrm{~mm}$. The male is smaller and has a lower dorsal keel; the post-abdomen is excavated behind.

The only differences betwren the Minnesota specimens and the typical European form seemed to be the absence of the rery minute spines on the front of the terminal claws. The eye and pigment fleck are of about the proportions figured by Kinrz. Birge's figure of the postabdomen does not agree with his description fully. Our Minnesota specimens have an obvious but not high keel.

\section{* Graptoleberis reticulata Baird.}

Alona reticulata-Baird, P. E. Mueller.

Lynceus reticulatus-Lilljeborg, Leydig. Alona esucirostris-Schoedler.

Shell almost rectangular, reticulate, ventral margin straight, ciliate anteriorly, with two teeth behind. Pigment fleck smaller than the eye. Post-abdomen short, narrowed towards the end, dorsally covered with clusters of spines; caudal claws with a minute tooth at the base. Length $0.4 \mathrm{~mm}$. to $0.5 \mathrm{~mm}$.

The pigment fleck is nearer the end of the beak than the eye, and is smaller than in the previous species, but, on the whole, there is, perhaps, too great similarity.

Professor Birge writes that he unites the two species.

\section{GENUS DUNHEVEDIA King.}

\section{Crepidocercus - Birge.}

The characters of this group place it rather near. flomellu or bet ween that and PMrurorks. Form sub-quatrate with rounded angles; dorsal line uniformly arehed, terminating in a sharp angle behind; lower matrin convex, armed behind with a single spine as in Plemroms meilres, and along the entire length with loose setar. Beak of moderate length, atrute. Post-abdomen deeply incised in the anal region; lower posteriol marein straight, rounded at the apex: vent ral margin straight or roncale: rlaws with a single basal spine and a few teeth. The post abulomen is shoe shapeel and armed with transverse rows of setre.

The antemnat are large, having edght setale and the usual spines. Shell sunoth or retionlate. Fontuded by King to include two species from Australia, I). cresse and D). sodugre. 
* Dunhevedia setiger Birge.

Plate LXiv, Fig. 3.

Length $0.4 \mathrm{~mm}$. to $0.5 \mathrm{~mm}$. Minnesota specimrns measured 0.5 mm. This species is hut rarely encountered, aud is so peculiar as to be easily recognized when seen. Homn intermenlin has a post-abdomen with clusters of bristles, but in Immberidin the post-ablomen is more as in species of Gruptolebris than any other genus. The markings upon the shell are very indistinct. Birge says that the male is similar in form to the female. The first foot has a stout hook. The claws are smooth in both sexes. This species has been found by Daday in Hungary.

\section{GENUS LYNCEUS O. F. Müller.}

The perplexing inter-relations between the thres genera flom, Alonella and Plenroxus give rise to the utmost confusion. No two authors are agreed as to their respective limits, and the points given by Kurz, who has carefully gone over the ground, are obviously insufficient. Although there may be practical benefits to be derived from the continuance of the nomenclature in use for groups which in the general view can be distinguished, the value from a theoretieal standpoint is reduced to a minimum.

The genus Camptormens (inchuding here foroprems, which differs solely in the form of the abdomen, as a sub-genus) passes through

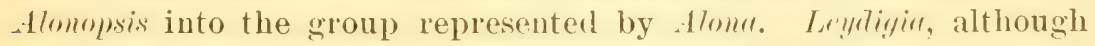
very near such forms as flomu qumdrmmuluris, may be conveniently distinguished as a transition to species like Ilyocryptus.

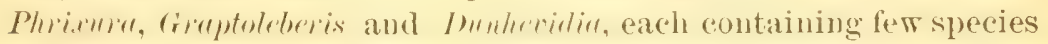
which cau be readily recomnizer, fill a place in the system; lout it is practically impossible to distinguish . Home from I/rumens without instituting the very indefinite genus Alomella to contain a variety of

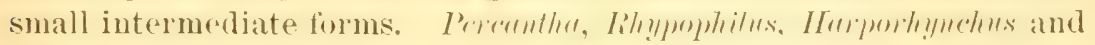

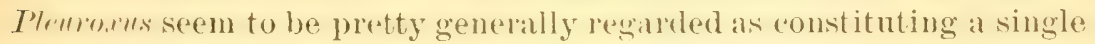
group which may be recognized by the long rostrum, high shell and greater development of the antenna bristlus. Alom, on the other haut, with its hroader fornices, shorter beak, failly developed antenuse, and more rectangular shell, is, perhaps, the pivotal point of the group). According to this view, then, the old name Lymerns is re. vired for the aggregate; and the other names are retained, in part, as titles of largely conventional groups or sub genera, thus: 


\section{GENUS LYNCEUS.}

Sub-Gexus Alon A-Section A, Alona vera. Section B, Alonella.

Sub Gexus Plevroxus-Section A, Pieuraxus rerus. Section B, Leptorlyndhus. ${ }^{3}$

Characters of Pereonthe and Rhypoylilus are combined in the species $P$. mormmus, Birge, so that one must be dropped or new diagnoses formulated. I am not sure that the sitme species is not at first Plourocks rens and ouly later assumes the form known as Rhypophilus. So with Promtlun the amount of serrature of the posterior margin is in part a question of age.

\section{SUB-GENUS ALONA.}

This group contains two sections which resemble each other in form aud, in geueral, in detail; but it is exceedingly difficult to formulate a diagnosis that shall strictly linit it. 'The form is generally sub)quadrangular with rounded corners; the terminal claw is armed with but a single spine at the base; the beak is rather short; and the prevailing marking consists of longitudinal lines.

\section{Section A, Alona (vera) Baird.}

This genus contains a large number of minute animals which are widely distributed.

The authors who have done the most to elucidate this genus are S'choedler, I'. E. MLueller and Kiurz. Birge has contributed most largely, thus lar, to the knowledge of American species, which are, for the most part, identical or very close to the European. No other genus is so difficult among the Lymmilue, for the most minute differences are relied upon to distinguish species. The species of this genus are not greatly altered by the production of the winter eggs. The maies are frefunently but little smaller than the opposite sex, and are recognized by the altered form of the post-abdomen and the presence of a hook on the first hot. 'The form is more perfectly rectangular than in the next section: the shell is only exceptionally reticulated and rely rarely tubereulate, occasionally smooth. The lower angle of the shell is not armed with spines, but is generally rounded. There is only one basal spine mpon the chaw of the post-abdomen, which usually hates a row of scales beside the anal spines. The antenne have wight setar. The chaw of the male post-ablomen is remored firom the lower angle.

Inaty species are known, all of which that seemed recognizably defined have hern includer in the following key, which is believed to

1 Instead of Harporhynchus, a vame preoccupied in zoology.

2 Embryos of P. procurrus have the part which is to be curved forward attenuated before leaving the brood cavity, however. 
more nearly represent our present knowledge of the genus than that of the previous edition. Unfortunately the key must be based on the statements of other authors, and in this genus it is rare to find complete agreement between the published descriptions. The best thing a student can do is to disregard much of the synonomy and make an exhaustive study of a species from a large number of individuals in oue locality and then cautiously extend the range of work to include adjacent stations.

\section{KEY TO THE GENUS ALONA.}

I. Macula cerebri much larger than the eye. . sanguinea, 239 ; moniezi, 240

FII. Macula cerebri about as large as the eye. quadrangularis, 240; (aflinis, 240 oblonga, 240 ;) lepida, $24 \%$. . . . . (See also intermedia, 244)

III. Macula cerebri smaller than the eye.

A. Post-abdomen narrowed toward the end, at least not broadly rounded.

a. A single series of anal spines.

$\div$ Strix oblique to the axis of the shell. . . . . lacustris, 242

** Strix parallel to the axis of the shell.

$\dagger$ Abdomen very long, with long anal spines. (One form of)

tenuicaudis, 242

†† Abdomen not very long. . . . . . . . guttata, 243

b. A lateral as well as an anal series of post-abdominal spines, setre or scales.

* Post-abdomen long and slender. (Usual form of) tenuicaudis, 242 ** Post-abdomen of ordinary form.

$\dagger$ Anal spines two. Row of setre in addition. . dentata, 244

†† Anal spines represented by transverse clusters of bristles.

intermedia, 244

$\dagger \dagger \dagger$ Anal spines large, nearly equal. . . . . pulchra, 245

$\dagger \dagger \dagger$ Lower anal spines larger. . . . . . . porrecta, 246

B. Post-abdomen broadly rounded below.

a. Anal spines in a single series.

stagnalis, 246

b. A double series of anal spines.

* Strix of shell close, fine and oblique. . . . . elegaus, 247

** Strix of shell distant.

† Striæ oblique. . . . . . . . . angulata, 247

††Strixe parallel to the longitudiual ax is of the shell. coronata, 247

(Not noticed in the key. . . . . . . costata, 245; barroisi, 248)

* Alona sanguinea P. E. Mueller.

Plate LXII, Fig. 20.

Body nearly rectangular; ventral margin nearly straight, with short setre; posterior angle rounded, unarmed. Beak short; pigment tleck much larger than the eye. Post-abdomen large, the end truncate, broadened; posterior margin rounded, with a series of spines and a 
lateral row of scales; terminal claw with a small spine. The shell is ornamented with fine, close, longitudinal striations. Length $0.9 \mathrm{~mm}$. flome elemus is rery near to this and should have followed. In August.

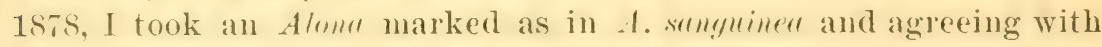
TIneller's description in all points which can be rerified in the drawing. The small size of the eje is remarkable for so large an animal. I have never again seen this species; it seems to he very rare here and in Europe.

Alona moniezi Richard.

Richard' 88.

- Testa antice quam postice latior, striis multis, interdum areis ornata, supine sat arcuata, postice fere truncata, angulo inferiore cotundato, inferce subrecta, ciliis longris, hic obsita. Antennæ $1 \mathrm{mi}$ paris apicem rostri fere attingentes. Articulus ultimus utriustue rami antemarum 2 di paris, set is 5 longis et aculeo forti pucditus. Rami exterioris articulus penultimus Ionga seta instructos. Macula vigra oculo major, inter hunc et apicem rostri in medio sita. I'ost-abdomen breve latitudine fere acpuali, ad angulum posteriorem et inferiosem rotundatum, seriehus (-9-9) aculeorum ( $\{-5$, uorum exterior multo major) fusitormium, preterea aculeis minutis acualilus fisciculatim usque ad processum obtusum positis, armatum. Adest denique series lateralis syuamarum spinis gracilihus ac lowgis compositarum. Cugrues temivalfs sat longi, usque ad apicem viliis minutissimis obsiti, dente basli gracile, et sat magna. Setit abdominales longa. Mas femina majore paulo dicrepans. Postabdomen brevius, latum, spinis unguibusque terminalibus multo breviorihus quam infemina, onatum. Pedes $1 \mathrm{mi}$ paris in hamulo valido curvato ad basin crasso, apicem rersus acuto exeuntes. Longit. fem., 0.5-0.55 mm.; mas., 0.45-05 mm."

Found near Vichy.

Alona quadrangularis Müller.

Plate LXI, Figs. 1, 2.

Alona oblonga-P. E. Mueller.

Alona affinis-Leydig.

Alona sulcata-Schoedler, Hudendorff.

The gromp of forms included muder the above mames is in inextricahle confusion. II thich evidently describes the same species as

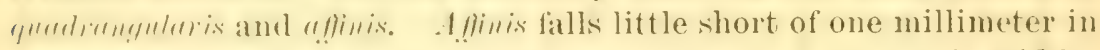

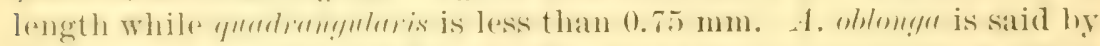
ki1\% to measure 0.s to $0.9 \mathrm{~mm}$. Te, however, did not know A."flmis.

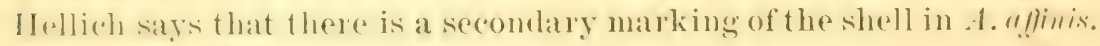

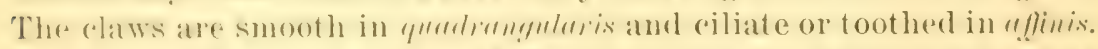
Slatements of rarions allthors differ respecting the relative size of eye and pigment fleck.

The American form, which most relosely approaches mplinis, has the claws clenticulate and the pigment lleck smaller than the eye. In the fienre (Plate I.XIV. Fig. 14) the head is somewhat protruded ly 
pressure, but there is nevertheless greater proportional length than in ordinary specimens of 4 . quediunguluris, and we may have to do with a new species.

Accordingly we quote our original description.

"Form sub-quadrangular; height ahout once and one-half in length; the dorsal outline forming a regular and low curve from end of head to upper posterior margin: lower ontline very slightly sinuate, anterior one not at all; posterior angles rounded: head nearly horizontal; eye of moderate size; pigment lleck considerably smaller; antenumles rather large, with unequal sensory hairs at the end, one spiue just above the end in front and a bunch of minute hairs near the base behind; anteune comparat ively large, basal joint spiny, onter ramus with three sete, two of which have thorns at their midlle, also a terminal spine; inner branch with two of the terminal seta thorned and the upper lateral setic reduced. The postabdomen is very broarl and short, expanded below and rounded at the end; the terminal claws are straightish, denticulate, and the spine at the base is also dentate; there is a series of heary spines on the upper margin of the post-abdomen, accompanied by a series of scales on the side. The shell is unornamented and fringed below with short brist les. Length $0.9 \mathrm{~mm}$, or more. This fiue species is recognized by its smooth shell, the horizontal position of the head, and the form of the post-abdomen: it beIongs among the largest of the genus. Lakes near Minneapolis not rare.

"Birge quotes A. spinifirm from Wisconsin. In all probability that species is the younger stage of the ahove."

The American form, which we identified with Alonc oldongu, was said to differ from $A$. quadrengularis in the following points:

"The greatest height of the shell is anterior to the middle; the lines are less evident, and all confined to the lower part of the shell, while the centre of the valves is maked with very minute stria: the pigment fleck equals the eye, and the post-abdomen is of ahout the same width throughout and hardly as round below. This aud the preceding species have a well-marked keel on the process of the labrum. The size is greater, this being one of the largest and most abundant, as well as one of the most striking species. It, perhaps, should rank as a well-marked and permanent variety of the above. Length 0.9 to $1.0 \mathrm{~mm}$. The abdomen of the male is narrowed at the end and lacks the teeth. Lakes about Minneapolis.

"A small form of 4 . qumdrumpuluris in Lake Calhoun had the eye and pigment fleck equal and the terminal claw smooth.)"

We are satisfied that a wide range of variation must be allowed for. The presence or absence of markings is unreliable. 


\section{* Alona lepida Birge.}

General shape of the genus. Head depressed, rostrum sub acute, nearly reaching the level of the ventral margin of the shell. Talves quadrangular, dorsal margin arched, caudo-dorsal angle obtuse, well marked. Caudal margin oblique, bearing a row of spinules. Caudoventral angle rounded, very slightly emarginate. Veutral margiu with plumose setae. Talves marked by closely-set, conspicuous, lougitudinal strice, alteruately strouger and weaker, occasionally auastomosing, parallel to the dorsal and ventral margins and converging to a reticulated area at the cephalo-ventral portion of the valves. The antennules extend nearly to the end of the beak, are small, spindle shaped. Antenuary setie $\frac{300}{31}$. The terminal setre are of unequal length. All are plumose and without spines. The eighth seta is of moderate length, bi-articulate and plumose. Spines of antenux $\frac{101}{100}$. Eye moderate. Macula about as large as eye, angular, aud somewhat nearer to eye than to apex of rostrum. Post-abdomen enlarged posteriorly, lower angle rounded, hearing 15 to 17 serrate post-aual denticles and about the same number of squamse. Terminal claws smooth. Basal spine rather large. Abdominal setre of ordinary length. Length $0.8 \mathrm{~mm}$.; male $0.6 \mathrm{~mm}$. Obviously this species is near to $A$. elegans.

\section{Alona lacustris Daday.}

Daday' 88.

"Rostro brevi; macula cerebrali oculo minore; labro processu mediali glabro; testa corporis striis longitudinalis dense vestita, linea dorsalı parum arcuata, margine ventrali subrecto, setas postice breviores gerenti, postice angulum obtusum inermem formanti; cauda brevi, apicem versus rotundatum attenuata serie fere marginali aculeorum sensim minorum armata, unguibus caudalibus unidentatis. Longit. fem., 0.4-0.5 mm.; altit. $0.35-0.4 \mathrm{~mm}$."

It is questionable whether this form is sufficiently differentiated from $A$. parvula; it is also very like $A$. guttata $=A$. intermedia.

\section{Alona tenuicaudis Sars.}

Plate LXII, Fig. 11.

Alono camptocercoides-Schoedler.

Form nearly rectangular: rentral margin rounded, with long setae, posterior angle rounded. Jieak short, pigment fleck smaller than the eye. l'ost-abdomen with sides parallel, long, incised below; lower angle armod with ahout six strong teeth, remainder of the series small; a latera] line of scales present; claws with a strong basal spine. The shell is striate with longitudinal lines. Iength $0.5 \mathrm{~mm}$.

()ne: of the most easily recognized species: not identified in America. 
It would appear that the lateral line of scales upon the post-abdomen may be absent. There is often, if not always, a cluster of fine spinules above the spine on the otherwise smooth claw of the postabdomen.

\section{Alona guttata Sars.}

Norman and Brady '67 (Lynceus guttatus); Kurz '74 (parvula and tubereulata); Hellich '77 (anglica, and guttata); Matile '90.

A small species of sub quadrangular lorm. The beak is very short; the eye small, but larger than the minute pigment fleck. The shell is short, with a rounded posterior angle and marked by hexagonal or rectangular meshes running about parallel with the lower margin. The post-abdomen is of moderat size, rounded at the apex, with a series of stout teeth behind: the terminal claw has a minute basal spine. P. E. Mueller, in I Manmark's Cladocera, confused this with A. intermetiu, which he described under this. The postabdomen in that species is larger. less rounded behind, and armed with clusters of spines instead of teeth. The length is about $0.3 \mathrm{~mm}$. in both. In males the hook is small aud the aual spines are absent.

* "Aloun pervelu Kinrz is said to have the body sub quadrangular, arched above; ventral margin straight, rounded behind. Shell marked by longitudinal, feeble and irregular lines. The post-abdomen is narrower toward the end, with eight or more teeth; the row of scales is absent; at the end it is sharply truncate and incised; the claws have short basal spines. Hardly to be distinguished from the next.

* "Alona porvelu var. tuberentute Kurz (Alome tuberculate Kiurz) described by Kurz in 1874, aud more at length by Lutz under a different name (Alonu cerrucosa) in 1878 , appears to be simply a tubereulate variety of the above. Observations upon the American representatives of the two forms indicate a close relationship between them. The shell is covered with rows of tubercles (or depressions?) which vary in number greatly.

"I do not know how to distinguish *Aloma glaciutis Pirge (Plate LXIII, Figs. 2, 3 and $s$ ) certainly from $A$. pumult. It, however, seems to have the lower angle of the post-abdomen less squarely truncate and the incision less obrions. Birge says that the abdomen is rounded. I have found specimens which apparently belong here, with the postabdomen rather sharply angled and deeply incised; there were about fourteen teeth with a row of hairs in front. The form is hardly to be distinguished from another variety which has a shorter post-abdomen, rounded below, and with only about seven or eight teeth and with a smooth shell. This form passes directly into a tuberculate variety, having the post-abdomeu similar but the shell covered with numerous 
rows of tubercles. Sometimes a transition from a lined shell to a tuberculate shell is seen (as in Plate LXIII, Fig. 1t). Aluma tuberculatu Kurz is said to have a truncate and incised post-abdomen with no literal row of hairs. Birge thinks these identical; if so, our form referred to 1. glacialix is identical with A. murvmla. There is also a form fonnd with the above in which no markings are visible and the shell is considerably arched; these were, howerer, nearly all ephippia females or approaching that period.

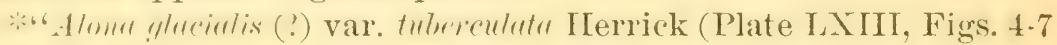
ancl 1.) will, then, be our tuberculated ulonu with a lateral row of scales and a series of fine spines along the anus. Alomu gluriulis (?) var. lucvis Herrick is the smooth form with higher dorsal margin.

"The autemue of the two last have spines at the eud of the rami of the antemne, a circlet of spiues on the ontside of the second joint of the setose ramus, and a spine on the basal joint of the other ramus; two of the set:e at the end of the setose ramus have spines at the angles. The males found among the above small forms have the same characters as val. lovis and the abdomen is rounded at the end; the claw is situated in the middle of the lower margin, in front being the opening of the porms yrnitulis and behind a cluster of hairs; the spines are alosent, hut there is a lateral row of long bristles. A stroner hook is found on the first foot. Length $0.3 \mathrm{~mm} . "$

To the above, which expresised my opinion in 18St, I can only ard that I am more thau ever convinced that all should be united (probably with A. guttatu).

\section{Alona dentata P. E. Mueller.}

Plate LXII, Figs. 12, 13.

Form sub-rectangular, somewhat arched above, obseurely longitudinally striated; lower augle obtuse, margined below with short seta. T'ost-abdomeu small, slender, armel with a lateral line of scales and two strong teeth at the lower angle; claw with a minute basal spine. The form of the post-abdomen is iclentical with Honpringuchus fulvelus Sars, which this species also resembles in having the pigment fleck larerer than the eye, and in general form and the character of the striation. The beak, howerer, is very short. In size I'. I. Mueller says it is among the smallest of the genus.

\section{Alona intermedia Sars.}

Plate LXII, Fig. 15.

Alona guttata-P. E. Mueller.

Form sub-rectangrular, rounded below; beak short; shell marked by longitudinal lines, which may be broken into indistinct rectangular 
meshes. Post-abdomen short and wide, rounded at the end, ormamented by seven or eight clusters of miunte spines behind as well as a lateral row of seales. Length $0.43 \mathrm{~mm}$.

IIellich says the pigment fleck is larger than the eye aucl is farther from the end of the beak than from the eye.

\section{Alona pulchra Hellich.}

Sars '61 (rectangula and lineata); Hellich '74 and '77 (lineata); Matile' 90.

We are influenced by Matile in not recognizing .1. linentu Fischer and substituting Ifellich's name. Alome limerter of Kin'z is said by Matile to be $A$. costute Sars.

IBody small, elongate oval, truncate behind and of a pale color. Greatest height near the middle. The upper margin is rounded, the lower one somewhat sinuate, with sets of moderate length. The beak is short, reaching nearly to the level of the lower margin of the shell; the pigment fleck is one half the size of the eye, to which it is much nearer than to the end of the beak. Post abdomen short, broad and tapering toward the end, truncate, armed with seven to eight large. teeth; short caudal claws with a small basal tooth. Shell marked with distinct lines running horizontally. The ephippial females are recognized by a deep color and the greater elevation of the hack Length 3.8 to $4.00 \mathrm{~mm}$.

I am unable to satisfactorily diflerentiate the species of this group.

\section{* Alona costata Sars.}

PLATE LX, FIG. 3.

Alona lineata-Schoedler, Kurz, P. E. Mueller.

Alona modesta-Herrick.

We need not attempt to unravel the perplexing synonomy. As thus defined the species seems to be common in Europe and America. Shell quadraugular, widest behind the middile. Beak of moderate length. Pigment fleck smaller than the eje aud midway between eye and beak. Antenne with only seven setre. Labrum small. The shell is strongly and coarsely striped parallel to the shell margins. Lower margin straight or concave, armed with rigid setæ. Cxeum long. Post-abdomen rather short, acute and excavated at the distal end. Anal spines nine or ten, equal, with a secondary series of scales. Claws smooth, except for a basal spine. Length 0.55 to $0.65 \mathrm{~mm}$. The claw of the male lacks the basal spine.

The Minnesota representative of this widely distributed species differs in some respects. The lower margin is nearly straight and 
rather sparsely hairy; the beak is blunt, but, on account of the spreading of the extremely wide fornices, does not appear so except under pressure.

The beak reaches nearly to the lower shell margin. The antemnles are nurrow, one or more of the setie being elongated. The dorsal margin is either nearly straight or strongly arched behind; in either case the greatest height of the shell is back of the middle. The pigment tleck is large. The post-abdomen is just as in 1 . costutu, but the lateral row seems to be of spines rather than fringed scales. The shell is marked by rather evident or indistinct lines. The form agrees pretty well with schoedler's figure, except that the posterior shell margin is much higher. The autenne have eight setre, but the last one is very wak. The terminal seta seem sometimes to be spined, as figured by Schoedler, but in some specimens they are perfectly smooth. There is a circlet of spines on the second joint of the setose ramus. There is a hair on the inner aspect of the protuberance of the kabrum. The eje is somewhat nearer the pigment fleck than is the end of the beak.

There seems to be no occasion for separating the American form (Plate LA, Fig. 3), in which the length varies between $0.41 \mathrm{~mm}$. and $0.55 \mathrm{~mm}$. The smaller forms have the back most rounded, while a specimen $0.55 \mathrm{~mm}$. long will appear very like A. quedron!mlaris. Thales are elongate; hook of first foot strong, accompanied by a heary growth of small spines: terminal claw of abdomen with a minute spine.

\section{* Alona porrecta Birge.}

Sub reetangular; ventral line nearly straight; valves marked by longitudinal stria; beak short. Post-abdomen truncate, with about twelve teeth, three or four of which at the end are larger, and a row of hairs ahove the teeth. Male similar. Length $0.34 \mathrm{~mm}$. Distinguishable from the following small species in the armature of the postabdomen.

The lower angle of the post-ablomen is acute. The ciaws are not serrate. hut possess the basal spine. The post-abdomen is said to resemulde that of 1 . Armeremelis in its armature, but not otherwise. This spereies is not enumerated hy Professor Birge in his List of Crustaceat clatdocerat from Madison. Wisconsin [1S?1]. and we are left in doubt whether the species is abandoned or not.

\section{Mlona stagnalis Daday.}

" liostro longraculo, paulum ("urvato, acuminato; macula cerebrali oculo minore; jabro processu mediali flabro; testa corporis longitudinaliter, manifeste striata, linea dorsali rotundata, margine ventrali medio parum arcuato, setas ubiyue me- 
diocres gerenti, postice angulum obtusum, inermem formante; canda brevi, apicem versus rotundatum dilatata, marrine dorsali utrinque serie marginali aculeorum 7-8 sensim minorum et pleurihus minimorum iequalium armata; unguibus caudalibus inermibus dente basali uno. Longit. fem., $0.4-0.48$; alt. $0.18-0.22 \mathrm{~mm}$."

While doubting the integrity of this species we are mable to place it and quote the anthor's description.

\section{Alona elegans Kurz.}

Plate Lxit, Fig. 14.

Form rectangular: back slightly elevated, posterior margin high, lower margin straight. Shell covered with minute striations springing from the region of the attachment of the head shield. Head rather large, pigment fleck smaller than the eye. The antenne have eight setar and a circlet of spines on the second joint of the inner ramus, and a single thorn on its first joint. The postabdomen is short and broad, romided at the end, and is armed with about ten anal teeth and a lateral row of scales. Length $0.4 \mathrm{~mm}$. to $0.5 \mathrm{~mm}$.

\section{* Alona angulata Birge.}

Dorsal margin considerably arched, terminating in a more or less obvious angle at the hinder corner; the hinder edge is convex, as is also the front margin: the ventral margin hears plumose set pointed, extending nearly to level of ventral margin of the ralves. Fornices broad. Shell obvionsly striated diagonaly and less obviously marked by cross lines. Pustahdomen broad. truncate: ahout twelve anal teeth, with a series of seales and hairs back of them. The pigment fleck is much smaller thau the eye. Male smaller; beak shorter'; post-abdomen with a lateral row of hairs: anterior feet hooked; sculpture less distinct. [Birge.] Letngth of female 0.4 mm.; male $0.35 \mathrm{~mm}$.

Whether Professor Birge still continues this species does not appear, but it is dropped from the list of MLadison Cladocera.

\section{Alona coronata Kurz.}

Fellich identities this with his . 1. putchro, but with Matile we re-

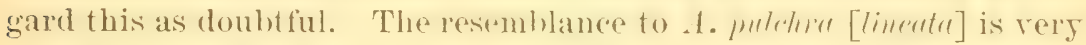
close, the outline being identical. The lower margin is sparsely hairy. The beak is blunt. A half circlet of teeth ormaments the end of the middle segment of the inner ramus of the antemnit. The macula is but little smaller than the eye. The post-abdomen is hroad as in d. eleguns, not narrowed at the end, but broadly rounded. The anal 
spines are represented by clusters of hairs and there is a secondary series of scales. Kurz lays great stress on the fact that the intestine is flexed rather than coiled. Length 0.35 to $0.42 \mathrm{~mm}$. male $0.3 \mathrm{~mm}$. Abdomen only armed with a series of delicate hairs.

\section{Alona barroisi Moniez.}

We quote the description of Alona barroisi Moniez ('S8). This form is very incompletely described from a single specimen. It is said to be very small and finely striate.

"Il est extremement petit, heancoup plus bombe sur le dos qu'aucun autre Alona et la hord inferieur de la carapace est fortement arrondi, rappelant ainsi les Leydigia. Ce hord est muni decourtes soies; l'ocelle est environ moitie plus petit que l'cil, l'appendice labial est large et arrondi sur les trois cotes libres; le post-abdomen est court, son crochet terminal depourvu d'angruillon a la base, les dents laterales en sont courtes et larges et il y a sur les cotes serie de plaques, la carapace est finement striee."

Island of Terceira, Azores. It is doubtful whether it can be recognized.

I venture to add a few memoranda respecting the long list of names which have appeared within this genus and which for various reasons are not included in the above list. Unfortunately the list is incomplete and can only serve at best as a sort of guide to the perplexities of the synonomy.

A. anglice Hellich is A. guttete.

A. actenthocercoides of various authors is $A$. Leydigia.

A. aculeatus is dlonellu exigna.

A. anyusticunduta Hudendorf is Alonopsis lutissima.

A. bulutonice Daday is A. Leydigia.

A. cumptocercoides Schoedler is A. temicuntis.

A. esocirostris Schoedler is Graptoleberis.

A. excise is alonellu.

A. elongatus Sars is Alonopsis.

A. fulcute Sars is Leptorlynchus.

A. grisen is dlonelle.

A. glucialis Birge is a variety of $A$. guttata.

A. inomate Hudendorff is A. coromate.

A. inseulpte is Alonelle excise.

A. leydigia is Leydinge.

A. lineutu Fischer is unrecognizable.

A. latissime is Alonopsis.

A. minut Pogrenpol is insufficiently described.

A. modesta Herrick is $A$. costutu.

A. namus is Alonella pyymen.

A. ovelu Baird is meertain. 
A. pygmeer is Alonella.

A. parvula Kurz is A. guttete.

A. rectumgularis is A. pulchra.

A. rostrata is Alonella.

A. reticulata Bd. is Graptoteberis.

A. striata is Alonella.

A. sulcata is A. quadrangutaris.

A. spinifera Schoedler is the young of some species.

A. socor's O. F. Miuller is uncertain.

A. tuberculata Kurz is A. gutteta.

A. tuberculata Hudendorff is A. coronata.

A. transversa is Alonella pygmea.

A. testudinaria is Graptoleberis.

A. verrucose Lutz is A. guttuta.

\section{Section B, Alonella Sars.}

In this gromp are included small species with a combination of characters, forming the link between. Ifona and Plemorm. An obvious character is the fact that the shell is usually partly marked by oblique strix, which run in two directions: first, a set extending forward aud upward from the lower posterior angle of the valves; second, a set springing from the anterior aud lower angle, rumuing across the others. At the central part where these two series intersect, they each become zigzag; the result is a series of hexagonal marlings, which may extend to the middle of the lower margin.

The beak is short and the fornices broad; the shell is more or less rectangular, but somewhat elevated in the middle above.

There are usnally but seven setie on the antenuir, or the eighth is a minute hair; on the ramus having the lateral set one of the terminal setie is frequently reduced. In many cases the whole shell is marked by minute strice in aldition to the proper markings. hut this is also found in some species of the true Plenmers. Kury gives, as a character of Alonella, the presence of hat a single basal spine to the clat of the post-abdomen; lut I'. F. Murller figures two spines on the clatrs of one of his species (.1. rigmu), and schoedler figures right scta on the an

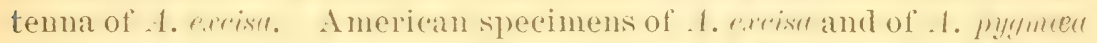
both certainly have a very minute oighth seta. 'There remains, therefore, positively no point which an be relied upon to distinguish

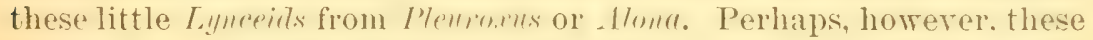
species, as a group, may he recognized by what has alrealy been said. Three species are found in Minnesota. 


\section{KEY 'TO 'THE GENUS ATONELLA.}

I. Rostrum long, bent backwards.

rostrata, 250

II. Rostrum short.

A. Lower posterior angle toothed.

a. Shell more or less reticulate.

* Reticulated areas minutely striate. pulchella, 250; excisa, 251

* Reticulated areas smooth.

† Head depressed.

exigua, 252

†† Head horizontal. . . . . . . . . . grisea, 252

b. Shell marked by lines running diagonally apward and backward.

B. Lower posterior angle smooth, shell longitudinally striate.

pygmaea, 253

striata, 253

\section{Alonella rostrata Koch.}

Lynceus rostratus-Koch, Lilljeborg, Schoedler.

Alona rostrata-P. E. Mueller.

Pleuroxus acutirostris-Birge.

Pleuroxus affinis-Herrick.

Body long, rapidly narrowed behind; dorsal line strongly arched in front toward the depressed head; the lower margin straight, with 0)-3 small teeth at the angle. The fornices are broad, but the beak is sharp; the pigment fleck is but little smaller than the eye, to which it is three times mearer than to the beak. The post-alndomen is long, very much as in $A$. cxeisa, but longer. Length 0.4 to $0.5 \mathrm{~mm}$. Sehoedler says the lower margin is concare and the angle unarmed, a condition not inconsistent with speecific identity, as can be seen in many ot here sperese. The shell seems to be variahly marked, but most conspicuons are the diagonal. curved striale Shoedler compares the

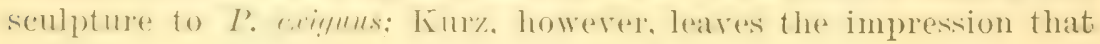
only slight reticulation is present in the female.

The male has the post abdomen narrowed, ornamented with chaters of hairs behind, and the small claws have no hasal spine, while the genital opening is in front of the claws.

Alonella pulchella Herrick.

Plate XIII, Figs. 1.3.

I minute borm reary reently obtained is deseribed under the alnove

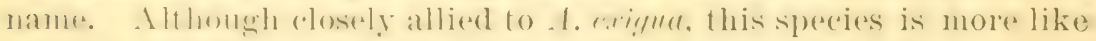

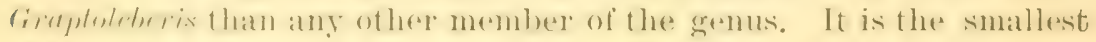

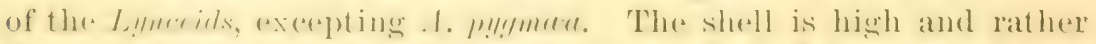
strongly areherl: the prosterion marein is short and armed with four teeth below, which point in different directions as in Gedphtederis. The hearl is short and the antemules long. The pigment fleck is of 
moderate size, but smaller than the eye. The post abdomen is short, rounded below, and armed with sharp and small anal tecth, besides which is an inconspicuous row of minute setie. The claw is rery small, and has a single very minute tooth. The shell is marked by reticulations, which below are regular hexagons but alove pass into elongated meshes, and finally on the beak and head become longitudinal striations. The areas are lined as in .Le cerixe. Thus this species combines the form of abdomen of . L. rigmu with the teeth of craptoleberis and the markings of $A$. excisa.

Length hardly $0.27 \mathrm{~mm}$. Motion active. The specimen figured contained a single large ovum. The head may possibly have been. somewhat protruded by pressure. Halitat, vicinity of Minneapolis.

* Alonella excisa Fischer.

Plates XXII, Fig. 10; LXI, Figs. 6-7; LXIII, Figs. 10, 11.

Lynceus excisus-Fischer.

Pleuroxus excisus-Schoedler.

? Pleuroxus insculptus-Birge.

This species is closely allied to Ilomello crigma; jet that species shows appreciable differences (which can hardly be claimed, perhaps, for Pleurocus insenlptus). The various anthors who have written of this Lynceid have all laid emphasis upon the sculpture of the shell, almost to the exclusion of other points in the description. I'rofesson Birge has found a quite different form, apparently, which has the same peculiar markings: and eren the common flome whtomm has a part of the valves covered by minutestriations. Schoedler"s figure of this species is unrecognizahle: hut, as identified hy hurz, the species seems undoubterly the same that is common in shallow pools in Minnesota, during autumn, and probably also in Massachusetts.

The variations to which this species is subject are considerahle and may account for the marked disagreement in the aceounts of our sifferent authors. Schoedler erives his specimeus a length of 0.20 to 0.25

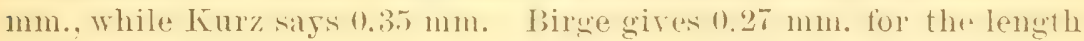

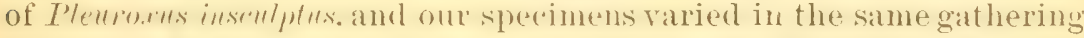
hetween 0.2t mm. and 0.40 mm. Schoedlex figures three tereth at the lower posterior angle: Kurz silys "several (4)": Birge deseribes one or two, and Minnesota specimens show gradual transitions from an inconspicuous augle to three or perhaps four teeth. These teeth are the extensions of some of the strong ridges or crenulations which mark the shell. I'. E. Mneller's figures of the shell and abdomen of I. exigna would apply to our species perfectly, save the absence of minute striations; Kurz's statements with reference to the differences between these two forms seem to agree ouly in part with those of 
Shoedler. I must here express my suspicion that the IMenroxus "rulculus. I'. exiguns and $P$. exrisus all belong under this species. I have seen a small form which lacked the fine striations; and there appeared to mes to he, at times, a slight indication of a second series of hairs upon the post-abdomen.

The form is oblong, truncate behind, variously arched above, but usually with a rather low, evenly curved dorsal contour; the lower shell margin is either nearly straight or convex in front and concave along the posterior third, and is heavily beset with very long pectinate bristles. The head is moderately depressed, with a very broad, blunt and short buak (in some positious this beak seems acute, but it is an optical delusion); the fornices are rery broad, covering the antennules completely; seen from above the head is broad and truncate in front; the eye is larger than the large pigment fleck, which is nearer it than the eud of the beak. The antenme have eight setre, the last of which is minute; the five spined ramus has a strong thorn on the end, and the inner terminal seta is reduced. The post abdomen is rather broad and truncate or somewhat rounded below; its length is very variable, being short in small individuals: its form is subject to concomitant variations. The seren to eleven anal spines extend in a series of minute bristles above the anus. The lower posterior angle of the shell bears one to four terth; the marlinge consists of wary ridges and strice, producing, by the crossing of two sets springing from the two lower angles, a reticulation covering more or less of the entire shell. The head-shield and the spaces between these markings are densely striated. Color yellowish, often opayue. Length 0.24 to $0.40 \mathrm{~mm}$. At times abundant. IBirge alone has seen the males; his deseription agrees with Kury's areonnt of the male of .1. rignu, save that the former speaks of spines, and the latter of thorns, along the post abdomen.

\section{Alonella exigua Lilljeborg.}

Lynceus cxigurs-Lilljeborg, Leydig, Fric.

Plcuroxus cxiguus-Schoedler, P. E. Mueller.

Lynceus amuleatus-Fischer.

Aside from the differenees in the male sex as above indieated, this form is said to have a convex lewer marewin, a rounderl post abdomen. amel the prigment Heere neatre the and of the heak than the eye. The alweneref the line st riation. linally, is the most marked chatrateristice Length 0.30 to $0.33 \mathrm{~mm}$. Not identified in America.

\section{(?) Alonella grisea Fischer.}

This species is included here on the authority of kur. The sheell may or may not be towtheel at the lower cormer, and is partly lined and party reticulate; lut the only character which at all separates this 
species from the abore seems to be the position and form of the head, which is said to be blunt aud nearly horizontal, as in c'cmintorepress rectirostris. Is this a transition to Graptoleberis?

* Alonella pygniea Sars.

Plate LX, Fig. 7.

Pleurowus transversus-Schoedler.

Alonu transversa-P. E. Mueller.

Lynceus namus-Fric.

Alonella pygmaa-Kurz.

The form is rotund, much like species of 'hyrtorts: in the highly arched dorsal outline; the beak is rather short and depressed; the lower outline of the valyes is very convex in front, and barely sinuate behind, where it terminates in a minute spine. The shell is marked, as in no other Lymerid, by lines runuing diagonally backward, and only on the lower part reticulated, if at all.

The post-abdomen is short, broad and rounded below; the claw has a single basal spine. Length 0.20 to $0.28 \mathrm{~mm}$. This is the smallest member of the cladocera. In form it so nearly resembles chydorus that upou first sight the writer took it for a member of that genus. Our one specimen measured $0.25 \mathrm{~mm}$. The shell is marked by plications rather than strix, which arch over the back.

\section{Alonella striata Schoedler.}

This species is said to resemble 4 . mignd in habit and sculpture of shell; the form is quadrangular and not greatly elevated in the middle; the lower margin is nearly straight and fringed with bristles; the posterior angle is rounded and unamed. The antennules with their setie extend beyond the heals: the pigment fleck is smaller than the ege and half way to the beak. The post-ablomen is long and narrowed toward the end: there are sereen or eight anal spines, and two spines on the terminal claw. Length about $0.5 \mathrm{~mm}$.

\section{SUB-GENUS PLEUROXUS.}

\section{Section A, Pleuroxus (verus) Baird.}

This group of Lynceids is most obviously defined by the long heak, formet by the extension of the chitinous eovering of the hear. (There is rarely a beak in the sense of that word as applied in the case of Scapholeberis or Inumnia, but the antemnules are simply attached to low prominences on the under side of a hroad shield-like projection of the sbell.) This beak-like projection is acute and often long and either curved backward or even bent forward. The fornices, or lateral 
projection of the head-shield, are narrow. The form varies much, but is almost always very strongly convex above, and the posterior margin is thus only a fraction of the whole height of the animal. In some American species the body is very much elongate, and these also depart from the characteristic habitus of the genus in having strong longitudinal strice instead of reticulations. The lower posterior shell angle has teeth which, in a few cases, extend across the eutire posterior maroin. The post-abdomen is slender, usually truncate and armed hehind with a single set of sharp teeth on either sidr; the terminal claw has usually two spines and may be serrate.

: The male has a shorter beak, the post-abdomen is more or less modified, and the first foot has a powerful hook. The winter eggs frequently have a true ephippium; and sometimes this structure is like that of chydorus, toward which the round forms of this genus seem to lead. There are upwards of a dozen valid species, several of which are American.

\section{KEY 'TO PLEUROXUS VERUS.}

Beak not curved forward.

A. Shell reticulate. . . . . . hastatus, 254; (?) straminens, 255

B. Shell smooth, except upon the front margin. . . . . . adunctus, 255

C. Shell striped.

a. Shell very long and low.

* With one tooth below. . . . . . . . . . gracilis, 257

Without a tooth; female with a hook upou the first foot. hamatus, 257 b. Shell high.

The whole posterior margin of the shell spined. . . . truncata, 258

** The lower angle of the shell spined.

† Antenux with eight setx; the anterior margin of the valves toothed.

denticulatus, :2.56

† Antenne with seven setc. . . . . . . . . bairdii, 256

Beak procurved (Rhypophilus).

A. Shell reticulate (either strongly or quite faintly). . . . personatus, 259

B. Shell striped.

1". The posterior margin of the shell toothed.

U. ()nly the lower anele of the shell toothed.

(Not noticed in the key.

procurvus, 258

uncinatus, 259

trigonellus, 255)

\section{Plemoxus hastatus Sars.}

PLATE LIII, Fig. 16.

Pleuroxus levis-Sars.

Form someshal oral, dorsal line stromgly curved, posterior margin short. with a twoth berow: head short, heak rery long, straightisli: shell obscurely reticulate. Post-abdomen very long, narrow, 
with small teeth; claw with two basal spines. Color corneons. The sculpture consists of faint reticulations. The ephippium forms a truncation of the upper part of the shell. Length 0.50 to $0.55 \mathrm{~mm}$. The male has a shorter beak; the first foot has a weak hook; and the spermatozoa are spherical.

\section{Pleuroxus stramineus Birge.}

This form is the American representative of the preceding, if not identical with it. Birge mentions minute strice in the meshes. $P$. stremineus is said to be lower than $P$. Thestutus, while its beak is shorter. Undoubted specimens of $P$. denlimlutus exhibit the same differences, an increase in the convexity of the shell accompanying an increase in the length of beak. The form of the abdomen appears nearly identical, if we compare P. E. Mueller's Llate IV, Fig. 1s, with the outline given by Birge at Plate II, Fig. 11. The color in both is deep, especially during the period when the winter egg is forming. The direction of the reticulations is said to differ, but P. E. Mueller's figure does not furnish positive eridence of this. Tength $0.6 \mathrm{~mm}$.

\section{Pleuroxus trigonellus O. F. Müller.}

Lynceus trigonellus-O. F. Müller, Lievin, Lilljeborg, Leydig, Fric. ? Pleuroxus ornatus-Schoedler.

Dorsal line strongly arched; the beak rather long, straightish, pigment fleck smaller than the eye. Shell faintly reticulate, the markings consisting of transparent ridges. Post-abdomen widest in the middle, attenuated slightly toward the end, which is truncate; claw large, with one long and one very small basal spine. The anal margin of the post-abdomen has a series of small spines, and the lower shell-margin is hairy. The post-abdomen of the male is somewhat as in Crepitocercus, and densely hairy; the first foot has a moderate hook.

To judge from Kurz's statements, $P$. ornatus Schoedler is not specifically distinct. Not yet identified in America.

\section{Plenroxus adunctus Jurine.}

Honoculus adunctus-Jurine.

Very like $P$. trigonellus, but with the back more strongly arched. The anterior part of the shell is striped. The beak is shorter than in $P$. trigomellus, but no other permanent differences are discoverable. The temptation to believe this a mere varietal form of $P$. trifmullus is great. Indeed, four species (the two here noted, $P$. buririi and $P$. dentidututus Birge) are very nearly related. The ephippium, where known. is marked by minute punctation and a darker color. 
Pleuroxus bairdii Schoedler.

Pleuroxus trigonellus-Baird.

This form, so far as ean be gathered from Ibaird's brief description and figures, differs from the others in having the shell marked by straight parallel lines runniug diagonally back and upwards, and in lacking one of the terminal bristles on the 5-setose ramus of the antennie. The first is a possible but unusual structure, while the second might result from an overlooking of the very small seta which fills this place in the other forms. Baird himself did not distinguish it from P. trigonellus.

\section{Pleuroxus denticulatus Birge.}

Plates XLV, Fig. 8; LXIII, Figs. 10a, 12, 13.

Resembliug very closely $P$. adunctus, which, however, has a broader post-aldomen than the ordinary $I$ '. denticulutus. The posterior angle of the shell is armed with from one to four (generally three) teeth. The beak is very long.

The character most emphasized by Birge is a series of teeth along the anterior margin of the valves. The same thing is found in $I^{\prime}$. promurns, as I have repeatedly satisfied myself. In certain positions these teeth do not show, or the smaller teeth on the lower margin only appear. $\quad P$. adunctus, as figured by Schoedler, has similar teeth on the lower margin, and very likely has them anteriorly. The edges of the valves are heavily fringed with pectinate setie. The male has a shorter beak and the post-abdomen simply rounded without the peculiar modifications seen in $P$. adunctus.

There seems to be two varieties in Minnesota, both of which have the characteristic irregular striations, which radiate from an irregularly marked or ummarked area in the centre of the shell toward the edges: hoth have the toothed posterior angle and the serrated posterior angle and the serrated anterior margin. Isut the common form is much longer, with the dorsal margin less convex and the beak shorter. The robust form has a largor pigment lleck, while the postabdomen is shorter and more robust, resembling more nearly Schordler's figures of the ablomen of $I$. adunctus. There is another variation or abuormality, in which the lower margin is quite concave. The resemblance to $P$. procurvus is remarkable in some phases.

I have collected this species in Blount springs, Ala., in the st. Croix river, and at various intermediate points, as well as very often in Minnesota. 
*Pleuroxus hamatus Birge.

Pldte LX, Fig. 1.

This species is smaller than those of the preceding group aud forms a trausition to the two next, to be described, in the greater elongation of the shell, which is, however, higher and more strongly arched. The head and beak are much as in I'. denticulutus. The lower margin is concave posterior to the middle and slightly convex at the posterior angle, which is umarmed. The lower margin is hairy. The markings are as in I'. denticulutus, but, in addition, there is a set of horizontal strice all over the shell. 'The post abdomen is widest in the middle and almost exactly as in $I^{\prime}$. dentimulutus. The first foot bears a claw such as ordinarily distinguishes the males.

The only specimens which I have seen were from the Tennessee river, near Waterloo, and near Lecatur, in Mlabama. My notes contain no reference to the minute striations, which could perhaps be hardly seen with the instrument employed. The process of the labrum is long and rather acute, the heak moderate, and the pigment fleck very large. The markings on the anterior of the valves are irregular and are inter-connected by cross lines or auastomoses. Ova two. (The genus Inchistrofms has a hook upon the first foot, but is like Chyclorus.)

\section{* Pleuroxus gracilis Hudendorff.}

Plate LXiV, Figs. 15, 15a.

Pleuroxus unidens-Birge.

An extreme among these elongated species, the length of body falling little short of double the height. The dorsal line is very flat and slightly but evenly arched; the lower margin is evenly convex or nearly straight, covered by long pectinate bristles. The head is short, and the beak is long and sharp; the antenuules are of moderate size, with a lateral seta one-fourth from the end: pigment fleck less thau the eye; antenne rather long, with strong thorus on the terminal joints. The post-abdomen is long, as in I'. Justutus, sides nearly parallel; anal teeth sharp, small and numerous; claws pectinate, with two strong basal spines. The shell is strongly striate with longitudinal strice, which are parallel with the different margius. Birge says that there is a reticulated area. The lower augle is rounded, and anterior to it is a small tooth directed backward. This species is distributed throughout the Mississippi valley. I have notes of it from Swan lake, near Decatur, Ala. It is often rather abundant about Minneapolis, but it is thought by Birge to be absent from the Eastern states. Almost all the specimens I have seen are very dark, often brown, so as to appear to the eye like dark specks as they swim about. The length 
varies from $0.55 \mathrm{~mm}$. to $0.55 \mathrm{~mm}$. About $0.60 \mathrm{~mm}$. is a common size, according to my observation. Birge mentions a rndimentary sixth foot in this species. This organ is found in Eurycercus and other Lynceids, according to Schoedler.

\section{Pleuroxus truncata O. F. Müller.}

Lynerus trunculus-IIïler, Koch, Zaddach, Lievin, Fischer, Lilljeborg, Leydig: Fric. Percuntha truncata-Baird, Schoedler, Kurz.

Pleuroxus truncatus-P. E. Mueller.

Percantha brevirostris-Schoedler.

This species is widely distributed in Enrope, but is replaced in America by the following. The shell is high, the dorsal contour arched: beak rather long and straight; lower margin slightly convex, setose: posterior margin straight, armed with very strong teeth entirely across it: the anterior margin also is dentate, as in the next. The valves are covered with strong strix, springing from the anteriocentral part and radiating toward the free magins. The post-abdomen is of molerate size and in form much as in the next. The ephippium causes a considerable change in form and coloration. In the male the beak is shorter, and the abdomen has finer teeth. The first foot has an extraordinarily large hook. The length is about $0.5 \mathrm{~mm}$. to $0.6 \mathrm{~mm}$. Perrantha brevirostris Schoedler differs in the length of the beak only.

\section{* Pleuroxus procurvus Birge.}

Plate LXI, Figs. 3, 4.

In size and general appearance this most interesting species is similar to the above, and, especially, to $P$. denticulatus. The general form and even the details of structure agree almost to identity with the latter. The structure of the posterior margin is like Pereantha, while the rostrum is bent abruptly upwards as in lihypophitus. In small individuals the length is greater proportionally. The lower margin is slightly convex or nearly straight, and fringed by bristles which are strougly pectinate; the anterior and lower margins are tootherl as in Perecunthe. The shell grand is more as in the Daphnide than most Lymerids. 'The number of posterior teeth is variable. The "phlippoum is as in 7 '. dentirulatus. Jength $0.40 \mathrm{~mm}$. to $0.50 \mathrm{~mm}$. Xul rare. int less common than $l^{\prime}$. denticulutus. The male post-abdomen is like that of $I^{\prime}$. dentienlatus: the rostrum is as in the female.

(1) the species following it may suffice to say that they are corpulent, filth-loving representatives of $I$ '. trigmellus, $I$. arlunctus and $I$. Imirlii, respeetively. whirh have turned up their noses at a superficial existence and huriod themselves in the mire and debris at the bottom of the pools. It might he fanciful to assume that the curved snout is userl for "rooting," hut the fact that these "schmutrpeterchen" l.mments would find a long straight beak in the way is suggestive. 


\section{Pleuroxus personatus Leydig.}

Leydig '60 (Lynceus persouatus); Schoedler '62, '63 (Rhypophilus personatus and glaber); Norman and Brady '67 (Lynceus uncinatus); Müller '68; Fric '72 (Lynceus personatus); Hellich' 77 (personatus and glaber); Herrick '84; Daday '88; Matile '90; Kurz'74 (glaber).

Shell high, oval, smaller caudad. Head small, depressed, with narrow, long, procurved beak. Macula quadrangular, half the size of the eye, to which it is nearer by half than to the end of the beak. The shell is either hexagonally reticulate or smooth. The lower margin is flexed cephalad of the middle aud bears long cilia. The ventro-caudal augle bears two curved spines. The post-abdomen is rather broad, narrowed toward the end. Anal teeth 10-11, very large. Claw serrate, and with two basal spines. There are seven seta and a spine upon the antenne. The anteunules are fusiform. Longth 0.65 to $0.67 \mathrm{~mm}$.

There seems to be no reason to doubt that $P$. gluber is only a condition of $P$. personatus not even worthy of a varietal name.

Pleuroxus (Rhypophilus) uncinatus Baird.

The shell is ridged with lines ruming upward and backward, as in $P$. buirdii; the lower angle of the shell has three teeth, and the beak is more horizontal than in the above. In size and characters this is almost identical with $P$. bairdii, with which it occurs in England.

This completes the list of swine-like members of the genus; these well deserve to be studied from a morphological standpoint.

The following names may be mentioned, though the list of synonyms cannot claim to be exhaustive.

Plenroxus nusutus diay is a poorly described form from Chili, resembling, according to Schoedler, $P$. ornatus = trigonellus.

A species of Percentha (Iyncens armatus Gay) is found in Chili.

P. exigums Lillj. is Alonella.

P. arivens is possibly . Homella pyymea but is said to have two teeth on the ventro caudal angle of the shell which is faintly reticulated as well as striate.

$P$. striatus Hellich is $P$. gracilis Hudendorff.

$P$. striatus Schoedler is Alonella.

$P$. balatonicus Daday is insufficiently described.

$P$. excisus Fischer is Alonella.

$P$. nanus Baird is Alonella pygmeer.

$P$. Teevis Sars is $P$. hastatus.

$P$. ormatus Schoedler is the young of $P$. trigonellus.

$P$. trigonellus Mueller is $P$. bairdii Schoedler. 


\section{$P$. glaber Schoedler is $P$. personatus. \\ P. brevirostris Schoedler is P. truncatus. \\ P. aculeatus Fischer is Alonella exigua. \\ P. convexus Poggenpol is doubtful.}

SEcriox 13. Leptorhynchu: Iterrick. ${ }^{1}$ - The species for which Sars formed the genus Iturpolhynclus is of Alona-like habit, but has a beak which exceeds that of any known Plenrorus in length, being simulated in this respect by the American $P$. acutirostris, which is, however, in other respects more nearly allied to Pleuroxus.

\section{Leptorhynchus dalcatus Sars.}

Harporhynchus falcatus - Sars.

Alona falcata-Sars, P. E. Mueller.

Borly oblong, arched above; ventral margin nearly straight, setose, with a spiue at the posterior angle: beak strougly arved, folded laterally: pigment spot larger than the eje. The post-abdomen is wide, sides nearly parallel, armed with a few strong teeth below and a lateral line of spines; candal claw with a single small basal spine.

\section{GENUS CHYDORUS Leach.}

This genus, if it be really of generic value, contains minute rotund animals which appear in the water like animate pin-heads of small size. Their motion is a rolling, wavering hobble; and they live by preference upon vegetation, or in slime at the bottom of pools. Occasionally they may be seen in sunshiny weather, disporting themselves near the surface in immense numbers. There are two common species, and six more which are more rare or in part not valid.

The sexual period oecurs at two different periods (i. e., May.June and December), but probahly is not confined to any periods. The males, which only rarely are found even in these periods, have the abdomen warrowed or excavated to accommodate it to the peculiar alteration of the brood cavity which takes place in the sexually mature female. The connection takes place by the insertion of the abdomen within this chamber, which is lacilitated hy the reduced size of the abdomen. The modification of the shell of the brood eavity above referred to consists in the thickening of the wall posteriorly, which may or may not result in the deforming of the shell as shown in Plate L.XIV. Fig. 7, taken from Kur\%. This may be termed an ephippium, although it differs somewhat from the modified shell so called in Inphnir. The male element consists of nearly round uncleated cells, and the opening of the vas deferens is anterior to the terminal claws.

1 Harporhynochus is preoccupied in orvithology. 
The members of this genus are among the most minute forms of the family or the entire group. ('oucisely put, the characters are as follows:

Form globose, not obviously truncate behind; head terminating in a sharp, long, curved beak, which lies close upon the anterior margins of the valves; antenne short; eye larger than the pigment fleck; abdomen flattened, excavated in the male; intestiue with no anterior caca, doubly convoluted, with an anal cecum. Threespecies found in Minnesota.

\section{* Chydorus sphaericus Mueller.}

Plate LXIV, Figs. 4, 7, 8, 10.

Lynceus spharicus-O. F. Müller, M. Edwards, Koch, Zaddach, Lieven, Fiseher, Lilljeborg, Leydig, Toth, Zenker, Fric.

Monoculus spharicus-Jurine.

Chydorus muelleri-Leach.

Form nearly spherical, as suen from ahove broally oval; in young specimens truncate hehind; antennules of moderate size, in the male very large, with curved flagellum near the middle of anterior margin; pigment lleck often nearly as large as eye; heak of moderate length, blunt in the male; first foot strongly hooked in the male; post.ablomen short, broad, rounded at the end, armed with eight or nine sharp teeth; shell reticulated with polygonal meshes. Color light, msuotted. Length $0.50 \mathrm{~mm}$.

This species occurs in spring earlier than most forms, and is ranked as the most abundaut of the micro crustacea, being found over the whole circumpolar land-area. The ephippium for the winter egra was observed hy liurz, but the period at which it is formed seems variable.

('. sphericus of a previous report seems to have been the following species, which is more common in Minnesota in the clearer lakes. A small form in our large lakes measures $0.3 \mathrm{~mm}$; it may be distinct.

* Chydorus globosus Baird.

Plates XXI, Fig. 23; LXIV, Figs. 1-3, 9.

Form glohose, very broad: antemules very large with a strong lateral seta on a small elevation; swimming antenuse exceedingly small; the shell gland is well developed; the pigment fleck is much smaller than the eye; beak very loug and incurvel; post-abdomen rather long, more slender than the last, broader near the end which is truncate, bearing abont 20 spines on the margin near which is a lateral series of minute bristles; the terminal claws are straightish, spined along the basal half, and have an accessory spine; the shell is very indistinctly 
reticulated and spotted; color dark; length 0.7 to $0.8 \mathrm{~mm}$.; male 0.55 nmm. The males have the abdomen very narrow for the entire length. This species is considered rare elsewhere, but is not infrequent near Minneapolis during August.

\section{Chydorus ovalis Kurz.}

Plate I,XIV, Fig. 11.

Form oval, nearly twice as long as high; beak long; antennules two-thirds as long as the beak, with one elongated sensory filament above the others; pigment fleck nearly as large as the eye; antenne small; shell margins heavily fringed anteriorly; post-abdomen of mod(rate size, rounded at the end, with about eight teeth near the end; shell smooth. Length $0.4 \mathrm{~mm}$.

This species is rather near (r. spherims, differing in having the shell smooth, antenne shorter and beak longer. This species is not yet known in America. From r. lutus it differs in the single antennulary flagellum and number of anal teeth.

* Chydorus crelatus Schoedler.

Plate LXIV, Fig. 12.

Chydorus adunctus-Schoedler.

This small species is about $0.4 \mathrm{~mm}$. long and resembles the young of $r$. glohosies in form, from which as well as from all known species it is distinguished by the markings of the shell, which consist of series of rounded elevations (or depressions?) arranged parallel to the lower margins of the shell and head. The description is very incomplete, and the only other author who appears to have seen the animal is Kur\%, who atds that the sensory filaments of the antenne are unequal in "height, and that the so-called elevations are really depressions. A form with a few depressions about the edge and characters of this species was once seen in the vicinity of Minneapolis. This is probably a variety of $C$. sphcerious.

Chyclorus nitidus Schoedler.

Plate LXiV, Figs. $5,6$.

Shell smooth and regularly punctate; the head resembles $('$. sperians, but the pigment llerek is much smaller than the eye, to which it is much nearer than to the end of the beak; the post-abdomen is broader near the and, and bears a row of 10 to 12 teeth on either side.

Chydorus latus Sars.

(of molerate size, oval, rounded behind. A slight depression between head and body. Beak long, slender and curved. Macula quad- 
rangular, smaller than the eye and half as far from it as from the beak. The conical autenumles bear two flagella, one near the end, the other near the basal third. Shell longer than high, strongly arched above, surface smooth. Anal teeth 1:3 or 14. Claws short and smooth except for the two basal spines. (Matile says the elaws are slightly ciliate.) Length $0.5 \pm$ to $0.59 \mathrm{~mm}$.

\section{Chydorus piger Sars.}

Sub-rotund, prominent above, sinuate behind; lower and posterior margins rounded, lower margin eiliated. Head movably united to the body: beak long, separated by an indentation from the head shield. The shell is broad, as seen from above. Shell punctate anteriorly and marked below by indistinct oblique stria. Antemules with seven setre and two small thorms on the end of each ramus. Post-abdomen truncate; the terminal claws with a minute tooth at the base, posterior margin sinuated, rounded below and there densely armed with minute teeth. Abdominal setre long aud flexible. Pigment fleck of medium size, much nearer to the eye than to the beak. Length about $0.33 \mathrm{~mm}$.

\section{(?) Chydorus Iatifrous Dana.}

(U. S. Exploring Expedition, Rep. on Crust., Vol. II, p. 1274.)

Very tumid; inside view rotund, head not separate, very shortbeaked; beak slender and close to the body, acute; in upper view animal very broad, truncate anterior!y, the front thereby nearly as broad as the body; behind low, triangular and obtuse. Feejee Islands.

\section{(?) Chydorus albicans Gay.}

From Chili. Is imperfectly described; but it is interesting to note the occurrence of this genus there.

\section{Chydorus punctatus Hellich.}

Tery small, tumid, truncate caudad. Ifead low, with rather short, sharp beak. Macula round, as large as the eye, to which it is nearer than the beak. Antemules tumid at the middle, with lateral seta above the middle. The ventral margin of the shell is very conver, with long pectinate setie. Hexagonal reticulations, each with a central elevation (?) mark the shell. Post-abdomen short, broad. Anal teeth eight or nine, of uniform size. ('law with one basal spine and a row of setre. Length 0.44 to $0.47 \mathrm{~mm}$. The abdomen of the male is curved and deeply excavated apically. Claws short and smooth. Length $0.42 \mathrm{~mm}$. This is probably only a variety of $(?$ sphlecrirus. 


\section{Chydorus letourneuxi Richard.}

Richard' 88.

Testa a latera visa subrotundaia, sulcis curvatis (10-12) e medio exeuntilus, ad margines anticos liberos porrectis, antice mavifestis ut in Pleurorus adunco, omato; testis cetera lavis, margine superiore prominente, postice leviter siuuato, marginalibus posterioribus et inferioribus rotundatis. Valoulorum margines inferiores postice ciliis longis instructi, margines superiores dentati. Rostrum breve et obtusum. Antenne $1 \mathrm{mi}$ paris ad hasin crassie, rostro breviores, setis requalihus. Antenna 2 di paris setis 7 predita. Macula nigra oculo duplo minor, inter oculum et apicem rostri fere in medio sita. Postabdomen apicem versus rotundatum, unguibus terminalibus brevibus levibus ac robustis, aculeis ad hasin 2 , quorum interior altero multo hrevior, armatis; margo superior in medio sinuatus supra medium processum obtusum format et infra hune aculeis minutis dense obsitus. Spinulis mintutissimis sparsim in lateribus post-abdomen instructum. Color comeus. Longit. circit $0.5 \mathrm{~mm}$. Mas ignotus. Algeria and Tunis.

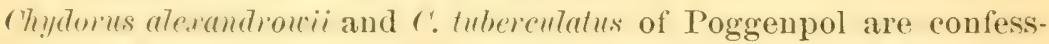
edly imperfectly described. We incline to the belief that there are not more than four good species in this geuns, but extended study of the conditions of variation are necessary.

\section{GENUS ANCHIS'ROPUS Sars, (?)}

Very similar in form to Chydorms: valves gaping below anteriorly; antennules small; process of labrum rounded. Post-abdomen attenuated toward the end, densely covered with fine teeth; terminal claws druticulate. First foot with a powerful claw, protruding beyoud the shell. Eye vory large. Shell indistinctly reticulate. Sars says of his - lurhistropus amargmalus that on cursory inspection it would be taken for the young of rhydorus globosus. He found but few specimrns, about 0.35 mm. long. 'The suggestion is still possible that the young males of some ('hydorix are here mistaken for a new genus. The males of rhydorms globsess were not known till 1878, and their (arly form is still muknown. 'The poumg females have a tolemably strong claw, though it is not much curved. I once found a

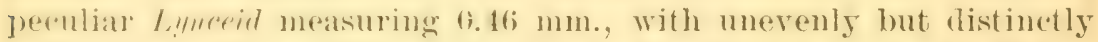
reticulate shell, slender ahdomen, and a strong claw which was drentate. 'There weresereral young (more than two), and the shell in these was more regularly reticulate. All efforts to find a second siecrimell falled, and the one seen was somewhat mutilated: hence I am unable to determine its real position.

\section{GENUS MONOSPIIUS Sars.}

Inad separated hy a depression from the body; shell high, comforesiel. postrior margin somewhat less than the greatest height of the shell. Jost-ablomen broad, ormamented with lateral and posterior 
spines; claws large, with a single basal tooth. The componnd ey" is absent, its place being taken by the pigment fleck, which is the func. tional eye.*

\title{
* Monospilus tenuirostris Fischer.
}

\author{
Plate LXII, Fig. 21, 21a.
}

Fischer '54 (Lynceus tenuirostris); Sars '61; Normau aud Brady '67; Mueller '68; Hellich '77; Herrick' 84 and '87 (dispar).

Shell roundish; ventral margin setose; posterior angle rounded, marked above with numerous impressions. Antennules small; antenne long, with seven setre. Post-abdomen short and broad, bearing a series of spines along the excavated posterior margin, and ormamented on the sides with clusters of bristles. The shell in old individuals is not moulted but remains as in Ilyocryptus, covering the greater part of the new shell. The figure shows an old individual with its successive coverings still clinging to it. Like Ilyornyptus, this auimal passes its life in filth at the bottom of pools and ravely emerges to the light of day. What little visual function there may be is rested in the larval organ.

The specimen from which the drawing was made measured 0.45 mm. The first glance at this rarest of all entomostraca affords proof of its unique character. The strongly arched shell is so compressed as to bear little resemblance to c'hylorus. The dorsal line passes with little angle into the high posterior margin. 'There is a rounded angle below, armed with two teeth-the shortened representatives of the fringing spines of the straight lowel margin. The head is depressed and very short; but the narrow beak is produced to below the margin of the valves. It is rounded so as to resemble, as seen in front, a duck's bill. The fornices are narrow and llare so that the eye is left partly exposed upon the side. The antemules are not long but slender. The labrum has a very large lamella, which is cremulate in front and acute below, the labrum proper being large. The systematic position of this genus is a matter of considerable interest, for it is the only member of the whole order in which the larval eye is the only one

\footnotetext{
* So much interest attaches to this species that we reproduce the latin description of Sars: "Testa in adultibus valvulis composita pluribus, altera alteri inposita, a latere visa lata, latitudine maxima in parte antica sita; margine superiore antice valde prominente, posteriore et inferiore ciliato rotundatis. Caput mobile, perparvum et valde depressum, supine impressione parva sed distincta, a testa cetera disjunctum, deorsum in rostrum rectum et breve apice obtuso exiens. Animal supravisum sat compressum, latitudine maxima capite majore ante medium sita. Pars superior teste et capitis impressionibus numerosis rotundatis notata. Antennce 1 -mi paris minute structura ut in ceteris Lynceidis; 2 -di paris sat longre, ramo altero setas 4 et aculeum unum apicalem altero setas 8 et aculeos duos, quorum alter longus articulo primo ejusdem rami adfixus est, gerunte. Postabdomen breve et latum, apicem versus truncatum; margine posteriore supra obtuse angulato, ad angulum inferiorem rotundatum seriebus ciuabus aculeorum inque lateribus setis vel spinulis brevibus numerosis proditum; ungues terminales ad basin aculeo longo armati. Intestinum, ut in ceteris Lynceidis, in thorace laquem fere duplicem format. Macula nigra unica minima prope basin antennarum 2-di paris; macula infra oculari in ceteris Ly bceidis simillima, in capite conspicitur, qux, quum oculus verus compositus in omnibus ceteris Crustaceis Cladoceris distinctus omnino absit, organum quamquam rudimentare visus habenda est. Animal parum pellucidum, colore fulvescente. Longit. parum supra $1 / 3 \mathrm{~mm}$."
} 
developed, and the first thought would be that this must be a primitive synthetic type; in other words, historically the oldest of clatocera. ("loser study does not warrant the theory. There is much to indicate that, though esisentially lynceid, it stands in close connection with the higher member's of the family and perhaps has more than a superficial resemblanee to such degraded Lymoduphnids as Ilyorryptus. All things considered, however, our diagram stands with this genus as a degraded oflshoot of the more typical stem of Lynceidre.

\section{SUB-ORDER GYINOMERA.}

This gromp is easily recognized by the almost entire absence of the shell. which forms so conspicuous a part in the greater number of the chudorre. Here it serves simply to form a pouch or brood-sac for carrying the eggs and embryos. The feet are nearly terete and prehensile, with but slight indications of branchial appendages.

\section{FAULY POLYPHEMIIE.}

Feet five pairs. Antenne with the rami three- or four jointed.

\section{GENUS POLYPHENUS De Geer.}

If a d very large, separated by a depression from the compact hody; shell covering but a part of the dorsal region. Feet all with an internal dentate and an external lamellate appendage. Caudal seta upon a long process of the post-abdomen.

\section{Polyphemus pediculus Linn.}

\section{Plates LViII, Figs, 4-6; Litix, Fig. 1.}

Mrmm-ulus perlinelus Lindiun, 17 16. Gmelin, Linn. Syst. Nat. Fabricius, Ent. Syst., etc. Sulzer, Insecten. Manuel, Encyclop. Meth.

Mronoculus pediculus ramosus-De Geer, Mem. pour serv. a l'Hist. des. Ins.

Polyphtemus oculus-Mueller, Zool. Dan. Prod. et Entomost. Cuvier, Tab, element. Latreille, Hist. Nat. Crust., ete. Leach, Edin. Encyc.

Polyphemus slagnorum-Leacb, Dict. Sc. Nat. Latreille, Cur. Reg. An. Demarest, Cons. Gen. Crust.

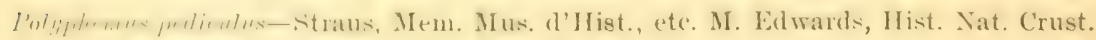
Monoculus polyphemus-Jurine, Hist. Nat. Monoc.

Cephentoculus stagnorum-Lamarek, Hist. An. Vert. Bose, Man, d'Hist. Nat. Crust. Monoculus oculus-Gmelin, Linn. Syst. Nat.

S'culicerus peeliculus-Koch, Deutsch. Crust.

Polyphemus pedieulus-Baird, Brit. Entom.

Polyphemus oculus-Lievin, Branch. d. Danz.

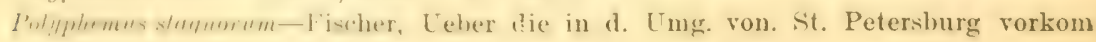
Crust. 
Polyphemus pediculus-Lilljeborg, De Crust. ex ord. trib.

Polyphemus oculus-Leydig, Naturg. d. Daph.

Polyphemus pediculus-Schoedler, Neue Beitr. zur Naturg. d. Cladoceren.

Polyphemus kochii-Schoedler, Neue Beitr. zur Naturg. d. Cladoceren.

Polyphemus oculus-Schoedler, Neue Beitr. zur Naturg. d. Cladoceren.

Polyphemus pediculu:-P. E. Mueller, Danmark's Cladocera. Kurz, Dodekas neuer

Cladoceren. Weismann, Beitr. zur Naturg, der Daphnoiden. Birge, Notes on

Cladocera.

Polyphemus occidentalis-Herrick.

There are two well-marked varieties of this species: one is found commonly in the clear lakes; the other, which I have only once sten, was found in a very shallow weedy marsh. The difference in size is quite remarkable. Our ordinary form measures less than 1.0 mm. The larger form, including the stylets, is $1.6 \mathrm{~mm}$. The ordinary variety, although highly colored, is yet tramsparent, while the large variety is deep red and (quite opatue. The relationship between the two forms is quite like that maintaining between Jlaptomus stafnalis and $D$. sunguineus. Some slight structural differences are observable between the two varieties, as in the form of the antemules, yet quite insignificant when compared with the striking difference in size and coloration.

The feet of this species have not been fully figured hitherto and are accordingly given on I'late LXTX. Some minor differences may be noted between these figures and those given by Lund.

\section{*Polyphemus stagnalis Herrick.}

In order to make the relation clear between these forms, I add. measurements of this species, following each with the corresponding measurement of $P$. peticulux in parenthesis: animals of the same age, as far as possible, being chosen. Head (capsule of eye) $0.3 \mathrm{~mm}$. (0.2 mm.); head and thorax $0.7 \mathrm{~mm}$. (0.45 $\mathrm{mm}$.) ; ahdomen $0.7 \mathrm{~mm}$. (0.56 mm.); caudal stylet $0.36 \mathrm{~mm}$. (0.26 $\mathrm{mm}$.); audal filaments $0.36 \mathrm{~mm}$. (0.3 mm.) Whole levgth of antennie $0.5 t \mathrm{~mm}$. (0.42 mm.); first, second and third joints of the three-jointed ramms $0.08,0.06$ aud 0.10 mm., respectively. The formation of the resting eggs or " damer ei " seems to go on at the same time with the parthenogenetic reproduction.

\section{GENUS BYTHO'TREPHES Leydig.}

Much like Potyphemus, but the external appendage of the feet is rudimentary, and the abdomen extends out into a most enomous spine. The single species is that described by Leydig as I'. Immgimumu, which was found in the stomach of coreyomus artmanni. $P$. cerler. strömii of Schoedler and P. E. Nueller, the latter author now identities 
with the above, and concludes that the supposed differences arose from "l'ctat de macerat ion des exemplaires examines." (Les Clatoceres des

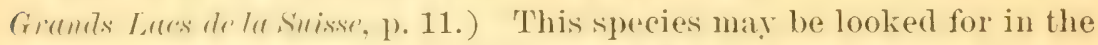
depths of the Great Lakes. (See Plate XXVII, Fig. 10.)

\section{(AENG PODON and GENUS EVADNE.}

These are eompact oval forms confined to the sea. See Claus, Zur Fenutniss des limus der Polyphemiden, Vienna, 1877, for the best aceount of the anatomy.

\section{FAMILY LEPTODORIDE.}

Feet six pairs. Antenne with both rami four-jointed. Body elongated, not curved, shell very much reduced.

\section{* Leptodora hyalina Lilljeborg.}

P'LATE XXXY, FIGs. 6, 7.

The only species, is found rarely in the larger lakes of Europe and America.

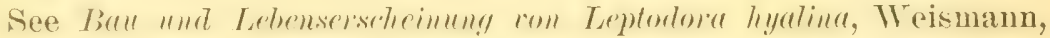

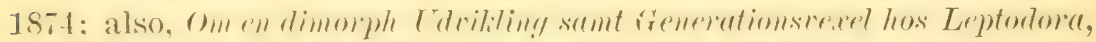

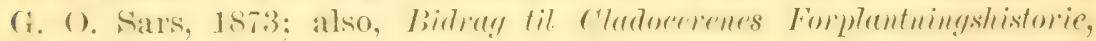
P. E. MIneller.

The work of Sars is particularly valuable, showing that the young produced from the winter eggs pass through a metamorphosis not experiencert by the summer or parthenogenetic brood. I'. I. Aneller Imentions the pathological coudition induced by the plants of the Saprolegnia. 


\section{APPENDIX TO PART II}

\section{NOTES ON THE CLADOCERA}

UF THE

SOUTHEASTERN PAR'T OF TIE UNITED STATES

BY C. H. TURNER 



\section{ORDER CLADOCERA.}

\section{FAMILY SIDIDE.}

GENUS SIDA Straus.

Sida crystallina Müller.

Sida crystallina-C. L. Herrick, Final Report on Minn. Crust., p. 20.

Habitat: Cincinnati, Ohio. Rare. Occurs in deep canal basins.

\section{FAMILY DAPHNIDA.}

GENUS MOINA Baird.

Moina rectirostris Müller.

Mloina rectirostris-C. L. Herrick, Final Report on Minn. Crust., p. 34; Pl. A., Figs. 2, 5, 8, 10, 11.

Length of female $0.94 \mathrm{~mm}$; height $0.63 \mathrm{~mm}$. Habitat: Atlanta, Ga.

Moina paradoxa Weismann.

Moina paradoxa-C. L. Herrick, Final Report on Minn. Crust., p. 34; Pl. A, Figs. 1, 3, 6, 7, 9.

Habitat: Cincinnati, Ohio. During the latter portion of summer this species is very abundant in foul pools.

\section{GENUS CERIODAPHNIA Dana.}

Ceriodaplunia consor's Birge.

Ceriodaphnia consors-E. A. Birge, Notes on Clad., p. 5; Pl. 1, Figs, 3, 4.

Length 0.55 mm.to $0.61 \mathrm{~mm}$; height $0.40 \mathrm{~mm}$. The reticulations on the shell are singly contoured. Habitat: Atlanta, Georgia. Winter and summer.

\section{Ceriodaphuia megops Sars.}

Ceriodaphnia cristata-E. A. Birge, Notes on Clad., p. 6; Pl. II, Figs. 8, 9.

Length $0.61 \mathrm{~mm}$; height $0.50 \mathrm{~mm}$. IIabitat: Kent county. Delaware; Atlanta, Georgia. 


\section{(iENCS SCAPHOLEBERIS Schoedler.}

Scapholeberis mucronata Müller.

Serpholeberis mucrmmetu-C. L. Ferrick, Final lieport Minn. Crust., p. 42; Pl. J, Fig. 5.

Tabitat: Atlanta. Georgia; Cincinnati, Ohio; Lockland, Ohio. Alumdant in shallow grassy ponds and sluggish ereelis.

\section{GENUS SIMOCLPHALUS Schoedler. \\ Simocephalus vetulus Müller.}

Simocephalus vetulus-C. L. Herrick, Final Report Minn. Crust., p. 46.

Habitat: Cincinnati, Ohio; Kent county, Delaware.

\section{Simocephalus serrulatus Koch.}

Simocephalus americanus-E. A. Birge. Notes on Clad., pp. 6-8; Pl. I, Fig. 6.

Lengh $1.7 \mathrm{~mm}$. to $1.9 \mathrm{~mm}$; height $1.4: 3 \mathrm{~mm}$. This species is often covered with vorticellide. IFabitat: Atlanta, Georgia; Barles, Georgia; Cincinnati, Ohio; Kent county, Delaware.

\section{GENUS DAPHNIA Schoedler.}

Daphnia pulex Müller.

Dapnnia pulex-C. L. Herrick, Final Report Minn. Crust., p. 56.

ILabitat: ' 'incinnati, Ohio; ('ovington, Kentucky. 'This species is fond of fonl water and is often associated with Morima puratoxe.

\section{Daphuia longiremus Sars. (?)}

Daphnia longivemus Sars-C. L. Herrick, Final Report Minn. Crust., p. 63.

Iength 1.70 mm. This is a non-erested, hyaline specimen, marked with rectangular meshes and devoid of pigment fleck. It resembles thr. species muler which I have placed it in all respects excepting sir\% I do not consider this alone sufficient to establish a new species. It may, however, be a variety of the above.

\section{FIMIL BOSMINIDE.}

\section{GENUS BOSHINA Baird.}

\section{Bosmina cornuta Jurine.}

Bosmina cormula-E. A. Birge, Notes on Clad., p. 15; Pl. II, Fig. 10.

Ifength 1).2t; mm. Habitat: 'Tusculum, ()hio. Rare. Found: in grassy pools. 
Bosmina atlantaensis Turner.

Bosmina atluntaensis-C. H. Turuer, Notes on the Clad. of Ga., p. 23; Pl. VII, Figs. 12,13 .

Leugth $0.46 \mathrm{~mm}$; height $0.36 \mathrm{~mm}$. Habitat: Atlanta, Georgia. Obtained in the middle of winter from pools that dry up in dry weather.

\section{FAMLY LYNCODAPHNIDA.}

\section{GENUS MACROTHRIX Baird.}

Macrothrix laticornis Jurine,

Marrothric laticomis-C. L. Herrick, Final Repost Minn. Crust., p. 6R; Pl. C, Figs. 8, 9. Length $0.37 \mathrm{~mm}$. to $0.39 \mathrm{~mm}$; height $0.25 \mathrm{~mm}$. Habitat: Atlauta, Georgia.

\section{GENUS ACANTIOLEBERIS Lilljehorg.}

Acantholeberis curvirostris Mïller.

Acantholeberis curvirostris-C. L. Herrick, Final Report Minn. Crust., p. 73.

Leugth 0.97 mn.; height $0.61 \mathrm{~mm}$. Hahitat: Baxley, Creorgia.

\section{GENUS ILYOCRYPTUS.}

\section{Ilyocryptus sordidus Lievin.}

European observers have never found more than a few specimens of this species at any one time. It two different times this summer I have found this species in great numbers in the mud at the bottom of a small pool on the CHark University campus at South Atlanta, Georgia. This pool is a tank about four feet deep, fed by a cool spring. At one end a shallow grassy creek flows outward from it. This creet at its origin is less than a foot deep and has a mud bottom. In this creck, at its source, is where the specimens were obtained. The American specimens tally in all essential respects with the European specimens. Habitat: South Atlanta, Georgia.

\section{Ilyocryptus longiremus Sars.}

Ilyoerylutus longiremus- E. A. Birge, List of Crust. Clad. from Madison, Wis., p. 342; Pl. XIII, Fig. 18.

This species agrees in all essential respects with the species found by Professor Sars in Australia aud by I'rofessor Birge in Wiscousin. Habitat: Baxley, Georgia. It seems to be present in almost all of the pouds near Baxley.

This species is very closely related to Ilyncryptus spinifir. Herrick. At one time I was fully convinced that they were two distiuct species, 
but the more I study this species the more I am led to believe that this and I. spinifer are varieties of one and the same species. If this surmise be true then Professor Herrick's name has precedence.

\section{FAMILY LYNCEIDA. \\ SUB-FAMILY EURYCEREINE. \\ GENUS EURYCERCUS Baird.}

Eurycercus lamellatus O. F. Müller.

Eurycerns lamelletus-C. L. Herrick, Final Report Minu.Crust., p. 80; Pl. H, Figs. 5, 6.

I.ength $1.67 \mathrm{~mm}$; height $1.16 \mathrm{~mm}$. Irabitat: Tient county, Delaware.

\section{SUB-FAMILY LYNCEINA. GENUS CAMP'IOCERCUS Baird.}

Camptocercus macrurus O. F. Müller.

Camptocercus macrurus-E. A. Birge, Notes on Clad., p. 33.

The specimen here tabulated under this genus is smaller than those found by I'rofessor IBirge in Wisconsin and by Professor Herrick in In muesota; but, since they agree with Professor Herrick's description in all other respects. it is thought that this is the right place for it. IIal)itat: Lockland, Ohio. Length $0.63 \mathrm{~mm}$; height $0.42 \mathrm{~mm}$.

GENUS IEYIDIGIA Kurz.

\section{Leydigia quadrangularis Leydig.}

I. yrlighis quadrangularis-C. L. Herrick, Final Report Miun. Crust., p. 88; Pl. H, Fig. 4

Length $1.00 \mathrm{~mm}$.; height $0.5 \mathrm{~mm}$. Ilabitat: (lifton, Ohio: Lockland, Ohio; Atlanta, Georgia.

\section{GENUS DUNHEVIDLA King.}

\section{Dumhevidia Setiger Birge.}

Crepidocercus setiger-E. A. Birge, Notes on Clad., p. 26; PI. I, Fig. 18.

I.rigth 0.13 mm.: height 0.31 mm. Tabitat: ('incinnati, Ohio.

\section{GENUS AIONA Sars.}

Alona quadraugularis Müller.

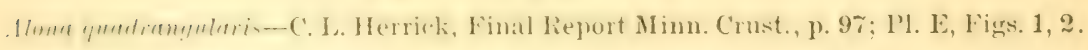

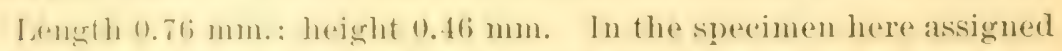
fothe almove named speroes the pigment fleck is as large as the eye and the spine on the terminal chaw of the post-abdomen is pectinate at its base. Habitat: Baxler, Georgia. 


\section{Alona affinis Leydig.}

Alona affinis-C. L. Herrick, Final Report on Minn. Crust., p. 98; Pl. F, Fig. 14.

Length $0.79 \mathrm{~mm}$.; height $0.46 \mathrm{~mm}$. The specimeus here tabulated are smaller than those found by other writers; but since they agree in all essentials with . a flinis they are placed here. In all probability they are immature individuals. Habitat: Tent county, Delaware; Fayetteville, Georgia.

\section{Alona porrecta Birge.}

Alona porrecta-E. A. Birge, Notes on Clad., p. 29; Pl. I, Fig. 16.

Length $0.37 \mathrm{~mm}$. to $0.55 \mathrm{~mm}$. : height $0.22 \mathrm{~mm}$. to $0.24 \mathrm{~mm}$. Habitat: Atlanta, Georgia; Cincinnati, Ohio.

\section{Alona glacialis Birge.}

Alona glacialis-E. A. Birge, Notes on Clad., p. 30.

Habitat: Cincinnati, Ohio. Rare.

\section{Alona intermedia Sars.}

Alona intermedia-C. L. Herrick, Final Report Minn. Crust., p. 101; Pl. I, Fig. 15.

Habitat: Cincinnati, Ohio.

\section{GENUS PLEUROXUS Müler. \\ Pleuroxus acutirostris Birge.}

Pleuroxus acutirostris-E. A. Birge, Notes on Clad., p. 23; PI. II, Fig. 15.

This species seems to be very rare. I hare only encomntered it once. Then it was associated with Plouroms hamatus Birge, which it closely resembles in shape. The specinen resembled in all respects the specimens described by l'rofessor Birge. Habitat: Atlanta, Georgia.

\section{Pleuroxus hamatus Birge.}

Pleuroxus hamatus-E. A. Birge, Notes on Clad., p. 22; P1. II, Figs. 13, 14.

Length $0.46 \mathrm{~mm}$. to $0.52 \mathrm{~mm}$. ; height $0.23 \mathrm{~mm}$. to $0.33 \mathrm{~mm}$. Habitat: Cinciunati, Ohio; Atlanta, Cieorgia. In the northern part of Georgia specimens of this species are more plentiful than those of any other member of this genus.

\section{Pleuroxus denticulatus Birge.}

Pleuroxus denticulatus-E. A. Birge, Notes on Clad., p. 20; P1. I, Fig. 21.

Length $0.57 \mathrm{~mm}$; height $0.43 \mathrm{~mm}$. Mabitat: Cincinnati, ()hio: Kent county, Delaware; Atlanta, Georgia. 


\section{GENUS CHYDORUS Leach. \\ Chydorus spharicus Müller.}

Chydorus spharious-C. L. Herrick, Final Report Minn. Crust, p. 116; Pl. \{F, Figs: $4,7,8,10$.

Length $0.36 \mathrm{~mm}$. to $0.42 \mathrm{~mm}$; height $0.31 \mathrm{~mm}$. to $0.36 \mathrm{~mm}$. Habirat: Ohio, Kentucky. West Virginia, Georgia. This species is very abundant. At Atlanta, Georgia, it can be found any time during the year.

\section{FAIILY POLYPIEMIDE.}

\section{GENUS POLYPHEMUS De Geer.}

Polyphemus pediculus De Geer.

Polyyhemus pediculus-C. L. Herrick, Final Report on Minn. Crust., p. 121; PJ. B ${ }^{1}$, Figs. 4-6.

Habitat: Baxley, Georgia. 


\section{PART III}

\section{FRESH-WATER OSTRACODA OF THE UNI'TED STATES BY C. H. TURNER}





\section{PREFACE.}

Perhaps no other class of animals has been so much neglected by scientists as the American Ostrucodu. With the European Ostracortu it is quite different. In Great Britain, Torway, Germany, Jichemia and along the shores of the Mediterranean Sea able naturalists have devoted many years of their life to the study of the cstrucoda of their respective countries. A perusal of the bibliography given below will show how well they have done the work. In his late monograph (221) Professor Wenzel Vávra devotes several pages to a historical resumé of the work that has been done upon the European Ostracodu. All that has been done upon the recent American (ostracoda can be included in a single paragraph, and a small one at that.

The first scientist to study American dstracode was De Kay (5s). In 1844 he described a few specimens from New York. This was followed in 1852 by an article by Professor D)ana (57). In 1855 Lubbock (123) published a short article on South .I mericun Ostrucode. Text comes a paper by Chambers (41) on Colorudo Crustaced. Between 1879 and 1881 Professor ILerrick $(83,84,85,86)$ published several papers on this subject. His paper on "Alubuma Crusturen" is by far the best article yet published on recent Uniterl States Ostracodu. Professor Moniez (142) has recently added a paper on Lake Titicaca Crustucen. Between 1592 and 1594 the present writer has contributed his mite $(212,213,214,215,216)$ towards furthering the good cause. In 1893 Forbes $\left(67^{\text {a }}\right)$ published a description of a new species.

The fossil Ostrecodu have been studied by Jones (89,92) Brady (29) and Ulrich (217).

In the present communication it is proposed to give complete deseriptions of all known recent United States ()wacoln. In most cases the descriptions are made from dissections made by the writer. When this has not been possible the reseription of some American anthor has been incorporated. In all such eases the deswiption is surrounded by quotation marks and the mame of the author is mentioned.

I here tender my thanks to Mressis. A. B. Whithy and I. D. Hileland, who have so kindly collected for me material which otherwise would have been inaccessible. Mr. Whithy collected in Texas and sonthern Georgia, while .Ir. I Iiletand coliected in Delaware.

I here acknowledge my great indebtedness to Professor C. L. Herrick, not only for the loan of rare literature and for the use of Plates LX, LXII, LXIV, but also for the careful drawings of cymis albuquerquensis and for alcoholic specimens. 


\section{BIBLIOGRAPIIY.}

\section{Baird, W.}

1. Trans. Berw. Nat. Club., Vol. I, 1835.

2. Natural History of the British Entomostraca. (Mag. Zool. and Botany, Vol. II, 1838, p. 132.)

3. Description of some new species and genera of British Entomostraca. (Anu. and Mag. Nat. Hist., Ser. I, Vol. XVII, 1846, p. 410.)

4. Notes on the genus Cypridina, M. Edw. with description of two new species. (Ann. and Mag. Nat. Hist., Ser. I, Vol. I, 1848, p. 21.)

5. Natural History of the British Entomostraca. (Ray Society, 1850.)

6. Description of several new species of Entomostraca. (Proc. Zool. Soc, London, Vol. XVIII, 1850, p. 254.)

7. Monograph of the family Apodide and description of two new species of Cypris. (Proc. Zool. Soc., London, Vol. XX, 1852, p. 1.)

8. Some new species of Cypridina. (Ann. and Mag. Nat. History, Ser. III, Vol. VI, 1860, p. 139; and Proc. Zool. Soc., London, Vol. XXVIII, 1860, p. 200.)

\section{Barrois, Th, and R. Moniez.}

9. Matériaux pour servir à l'étude de la faune des eaux douces des Açores. IV. Crustacés. Lille, 1888. $20 \mathrm{pp}$.

\section{Bosquet, J.}

10. Description des Entomostracés fossiles des terrains tertiares de la France et de la Belgique. Bruxelles, 1850.

\section{Brady, G. S.}

11. Species of Ostracoda new to Britain. (Ann. and Mag. Nat. Hist., Ser. III, Vol. XIII, 1864, p. 59.)

12. Linleseribed Fossil Entomostraca from the Brick-earth of the Nar. (Ann. and Mag. of Nat. Hist., Ser. III, Vol. XVI, 1865.)

13. Rieport on the Ostracoda dredged amongst the Hehrides. (Brit. Assoc. Report, 1866, p. 208.)

14. New and imperfectly known speciess of Marine Ostracoda. (Trans. Zool. Soc., London, Vol. V, 1866, p. 359.)

15. Entomostraca. (Intellectual Observer, 1862, p. 446.)

16. Synojwis of recent british Ostracola. (Intellectual Observer, 186\%. p. 110.)

17. Crustatean Fanna of the falt Marshes of Northumberland and Jurham. (Nat. Hist. Trans. Northumberland and Durham, Vol. III, 1868, p. 1.)

18. Monograph on Recent British Ostracoda. (Trans. Lin. Soc., Vol. XXVI, 1868$, p. 353.$)$

19. Contribution to the study of Entomostracat. (Amn. and Mag. Nat. Hist., Ser. IV, Tol. II, 1868, pp. 30, 178, 220; Vol. III, 1869, p. 45; Vol. IV, 1870, p. 450.)

20. Descriptions of Ostracoda. (Berchom, De Folin, and Perier, Les Fonds de la Mer., Vols. I, II, and IV, 1867-86.)

21. Notes on the Ostracoda. (Nares' Narrative of a Voyage to the Polar Sea, 1875-6, in H. M. S. S. "Alert" and "Discovery," 1878, p. 253.) 
22. Notes;on;Entomostraca taken chiefly in the Northumberland and Durham district. (Nat. Hist. Trans. Northumberland and Durham, Vol. III, 1870, p. 361.)

23. Review of the Cypridinidre of the European Seas. (Proc. Zool. Soc., 1871, p. 289.)

24. Monograph of the Ostracoda of the Antwerp Crag. (Trans. Zool. Soc., Vol. $\mathrm{X}, 1878$, p. 379.)

25. Report Voyage of H. M. S. "Challenger"-Ostracoda, 1880.

26. Notes on Eutomostraca collected by Mr. A. Haly in Ceylon. (Lin. Soc. Journal, Vol. XIX, 1885.)

27. Notes on Freshwater Entomostraca from South Australia. (Proc. Zool. Soc., 1886.)

28. Notes on Entomostraca. (Fifth Ann. Rep. Fishery Board of Scotland, Appendix F, 1887, p. 328.)

Brady, G. S., and Crosskey, W. H.

29. On. Fossil Ostracoda from the Post-tertiary Deposits of Canada and New England. (Geol. Mag., Vol. VIII, 1871.)

\section{Brady, Crosskey, and Robertson.}

30. Monograph of the Post-tertiary Entomostraca of Scotland, and parts of England and Ireland. (Palæontographical Soc., 1874.)

\section{Brady and Norman.}

31. A monograph of the marine and freshwater Ostracoda of the N. Atlantic and of N. W. Europe. Section I, Podocopa. (Trans. R. Dublin Soc., 1889:)

Brady, G. S., and Robertson, D.

32. Notes on a Week's Dredging in the West of Ireland. (Ann, and Mag. Nat. Hist., Ser. IV, Vol. III, 1869, p. 353.)

33. Ostracoda and Foraminifera of Tidal Rivers. (Ann. and Mag. Nat. Hist., Ser. IV, Vol. VI, 1870, p. 1.)

34. On the Distribution of British Ostracoda. (Ann. and Mag. Nat. Hist., Ser. IV, Vol. IX, 1872, p. 48.)

35. Ostracoda taken among the Sicily Islauds, and on the Anatomy of Darrinula stevensoni. (Ann. and Mag. Nat. Hist., Ser. IV, Vol. XIII, 1874, p. 114.).

36. Report on Dredging off the Coasts of Durham and North Yorkshire. (Brit. Ass. Rep., 1875, p. 185.)

\section{Braun, M.}

37. Faunistische Untersuchungen in der Bucht vou Wismar. (Arch. Freunde Naturg. Mecklenburg, 42. Jahrg. 28 pp.)

Brown, Dr. H. G.

38. Die Classen und Ordnungen des Thier-reichs. V. Bd. Arthropoda, I. Hälfte. Crustacea von Dr. A. Gerstæeker, Leipzig und Heidelberg, 1866-1879.

Carrière, Dr. Justus.

39. Die Sehorgane der Thiere vergleichend-anatomisch dargestellt. 1885.

Carus, J. V.

40. Prodromus Faunæ Mediterranex. Arthropoda. 1885.

Chambers, V. T.

41. On some new Eutomostraca of Colorado. (Bull. United States Geological Survey, Vol. III, Art. IX.) 
Chyzer, C.

42. Wher die Crustaceen-Fauna Ungarns. (In: Verhandl. d. k. k. Zoolog.-hotan. Gesellschaft in Wien, p. 505, 1858.)

Chyzer, C., and Toth, Alex.

43. Die Crustaceen der Pest-Ofener Gegend. (Naturfreund Ungarns, 1. Bd., 1857. 5. Heft, p. 84.)

\section{Claus, C.}

44. Ueher die blassen Kolhen und Cylinder an den Antennen der Copepoden und Ostracoden. (Würzburg naturw. Zeitschr., 1. Bd., 1860, Taf. VII, Figs. $1,2,5$.

45. Ueber die Organisation der Cypridinen. (Zeits. f. wiss. Zool., Vol. XV, 1865 , p. 143.)

46. Zur niberen Kenntniss der Jungenformen ron Cypris ovum. (Zeits. f. wiss. Zool., Vol. XV, 1865, p. 391.)

47. Ueber die Geschlechts differenzen von Halocypris. (Zeits. f. wiss. Znol., Vol. XV, 1865.)

48. Beitriige zur Kenntniss der Ostracoden. (Schrift. der Gesells. z. Betörd. d., gesam. Naturwiss. zu Marburg, Bd. IX, 1868, p. 151.)

49. Neue Beobachtungen über Cypridinen. (Zeits. f. wiss. Zool., Bd. XXII. 1873, p. 211.)

50. Die Gattungen und Arten der Halocypriden. 1874.

51. Untersuchungen zur Erforschung der genealogischen Grundlage des Crustaceen-Systems. Wien, 1876.

52. Bemerkungen ïher Marine Ostracodeu aus den Familien der Cypridinen und Halocypriden. (Arbeit. Zool. Inst. Wien und Zool. Stat. Trieste, T. VIII, Heft I, 1888, pp. 149-154. Wien.

53. Wher die Organisation der Cypriden. (Ausz. im Anzeig. kais. Akad. Wiss. Wien. VIII, 1890, pp. 55-60.

Costa, 0. G., and A.

53a. Fauna del Regno di Napoli. Crostacei.

Daday, E.

54. Beitrïge zur Kenntniss der Crustaceen-Fauna der Umgelung ron Klausenburg. (Berichte Klansenbarger medicin.-naturw. Vereins, 1881.)

55. Catalogus Crustaceorum Faunæ Transylvanix, 1884.

Dahl, F。

56. I) Cytheriden der westlichen Ostsee. (\%ool. Jahrbuch, Bd. III, Abth. t. Systematik, 1888.)

Dana, J, D.

57. Crustacea of the United States Exploring Expedition, 1852.

De Kay.

58. Nat. Hist. New York, VI, 1844.

De Saussure, $\mathrm{H}$.

59. Mrimire-uy divers Crustanis nouveaux des Intilles et du Mexique. (Mem. de Soc. de Phipique et d'Histoire Naturelle de Genève, 1858.)

Desmarest, A. G.

60. Consideraţions Générales sur la classe des Crustacés. (Paris, 1825.)

Egger, J. G.

61. Die Ostrawerden der Mioc:in-S(hichten hei Ortenburg. (Stuttgart, 1858.) 


\section{Ferrussac, Daudebert de.}

62. Mémoire sur deux nouvelles Espèces d'Entomostracés et d'Hydrachnes. (Cyclops mülleri et Cypris reniformis). (Ann. et Mus. Hist. Nat., VII, 1806.)

\section{Fischer, $\mathrm{S}$.}

63. Ueber die in der Umgegend von st. Petersburg vorkommenden Crustaceen aus den Ordnungen der Branchiopoden und Entomostraken. (Mém. des Sav. Etrangers, VII, 1847.)

64. Abhaudlung über das Geuus Cypris. (Mém. des Sav. Etrangers, YII, 1851.)

65. Beitrag zur Kenutuiss der Ostracoden. (Abhandl. d. mathemat.-physik. Classe der Königlich-Bayerischen Akad. der Wissenschaft., VII, 1855, pt. 3.)

Fischer, Dr. Paul.

66. Crustaceés Ostracodes Marius des Côtes du Sud-Ouest de la France, 1877.

Folin, Marquis De.

67. Faune lacustre de l'ancien Lac d'Ossegor, 1879.

\section{Forbes. S. A.}

67a. A Preliminary Report on the Aquatic Invertebrate Fauma of the Yellowstone National Park, Wyoming, and of the Flathead Region of Montana. Bull. U. S. Fish Comm. for 1891, p. 207-258, pl. XXXVII-XLII. Published April 29, 1893.

\section{Forel, F. A.}

68. Die pelagrische Fauna der Süsswasserseen. (Biol. Centralblatt, Jahrg. II, 1883.)

Fric, A.

69. Die Krustenthiere Böhmens, 1872.

Fric, A, and Nekut, F.

70. Kor ýs země Ceské. Prag. (Zeits. Živa, v. J., 1867.)

Frenzel, J.

71. Ueher die Mitteldarmdıüse der Crustaceen. (Mittheil. Zuolog. Station. Neapel. V. Bd., 188t, 1. Heft.)

\section{Garbini.}

72. Contrib. all' Anatomia ed alla Istologia delle Cypridina. (Boll. Soc. Entom. Ital., XIX.)

\section{Giard, A.}

73. Le laboratoire de Wimereux en 1888, recherches fauniques. (Bull. Soc. France. Belg., 1 Année, 1888, pp. 492-513.)

\section{Gissler, Chas, F.}

74. Contributions to the Fanna of the New York Croton Water. Microscopic observations during the years 1870-71. (New York, 1872, 23 pp., 5 pl.)

Guerne, J, de.

75. Note sur la faune des Açores. Diagnoses d'un Mollusque, d'un Rotifère et de trois Crustacé nouveaux. (Natưraliste, Paris, 1887, 7 pp.)

76. Compagnes scientifiques du yacht monégasque L'Hirondelle. 3 Année, 1887. Excursions zoologiques dans les îles de Fayal et de San Miguel (Açores). (Paris, 1888, 110 pp., 1 Taf.) 
77. Un Ustracode nouveau pour la faune francaise. La distribution geographique de Crpris bispinosa Lucas. (Revue Biol. 'Nord. France, 4 Année, 1893, No. 12, pp. 518-519.)

\section{Haldeman, C.}

78. Proc. Phil, Acad., 1841 and 1842.

\section{Hallez, Paul.}

79. Drauriges elfactué; dius le Pas-de-Calais pendant les mois d'août et septembre 1838 et 1839. (Revue Biol. Nord. France, Lille, 1 Année, pp. 102-108; 2d Année, pp. 32-40.)

\section{Haupt.}

80. Ueher Cypris im Allgemeinen nebst Beschreibung zweier neuer Arten. (Correspondenzbl. d. zoolog-mineralog. Ver. in Regensburg, 1850.)

\section{Heller, C.}

81. Untersuchangen über die Crustaceen Tirols, 1870.

\section{Hellich, Boh.}

82. O pohlarnim ústroji rodu Cypris. (Oznamovatel I. sjezdu ceských lékǎru a prirodozpytcì, 1880.)

\section{Herrick, C. L.}

83. Microscopic Eutomostraca. (Geol. and Nat. Hist. Survey of Minn., 7 Ann Report, 1879, pp. 81-123; pl. I-XXI.)

84. On New Forms of Copepod and Ostracod Crustacea from the Fresh Waters of the State of Minn. (Ann. Rep. Geol. and N. H. Survey for 1881.)

85. On Yotodromas and Cambarus. (Minn. Geol. and Nat. Hist. Survey, 10th Ann. Rep., 1882, pp. 252-254; 1 fig.)

86. Contribution to the Fauna of the Gulf of Mexico aud the South. List of Fresh Water and Marine Crustacea of Alabama, with Descriptions of the Vew Species and Synoptical Keys for Identification. (Memoirs of Deuison Scientific Ass., Vol. I, 1887, No. 1.):

Imhof, 0. E.

87. Die pelagische Fauna und die Tiefseefauna der zwei swoyerseen: Lac du Bourget und Lae d'Annecy. (Zool. Anz., 6 Jahrg., 1883, pp. 655-657.)

Jeffreys, J. G.

88. Mediteranean Molluska and other Invertehrata. (Ann. and Mag. Nat. Hist., Vol. II, 1863, pp. 393-401, T. 16.)

Jones, T. R.

89. Nonomaph on the Tertury Entomostraca of England. (Palcont. Soc., 1456.)

90. Notes on the Tertiary Entomostran of England. (Ceological Mag., Vol. VII, 1870.)

91. ()n somu. Fonsil ()stracoda from Colorato. (feological Mag., Decade II, Vol. III, 1886.)

92. (ontributions to Canadian Micro-I'alentologr. 5. On Some Ostracoda from Cambro-Silurian, Silurian and Deronian Rocks. (Geol. Nat. Hist. Survey Canada, 1891, pp. 57-100, T. 10-13.)

93. On lihatie and Liasie ()itracodit. (quart. Jour. Geol. Soe., London, Vol, 50, 1894, P. II, pp. 156-168.)

94. ()n some P'alirenice ()straeoda from Westmoreland. ((guart. Jour. Geol. Soc., London, Vol. 50, P. II, 1894, pp. 283-295.) 
Jones, T. R., and Sherborn, C. D.

95. Further Notes on the Tertiary Entomostraca of England. (Geol. Mag., Decade III, Vol. IV, 1887.)

\section{Joseph, Gust.}

96. Erfahrungen im wissenschaftlichen Sammeln und Beobachten der den Krainer Tropfsteingrotten eigenen Arthropoden Berlin. (Separat-abdr. aus der Berliner entomologischen Zeitschrift, Bd. XXV, 1882, Heft II, und Bd. XXVI, Heft I.)

\section{Jourdain, S.}

97. Recherches sur les poils à batonett de l'antenne interne des Crustacés, précédées de quelques remarques sur les poils dit 6lfactifs. (Jour. Anat. Phys., 17 Ann., 1881, pp. 402-418, F. 23 und 24.)

\section{Jurine, L.}

98. Histoire des Monocles, qui se trouvent anx environs de Genève, 1820.

\section{Kertész, K.}

99. Daten zur Ostracoden-Fauna der Umgebung Szeghalom's. (Természetr. Füzetek, Bd. XVI, 1894, Hefts 3 u. 4.)

Kerville, G. de.

100. Les Crustacés de la Normandie, espèces fluviatiles, stagnales e terrestres. Bull. Soc. Amis Sc. N. Rouen, 1888, pp. 133-158.)

King, R. L.

101. On Australian Entomostraca. (Proc. Roy. Soc. Van Diemen's Land, Vol. III, pt. 1, 1855.)

Koch, C. $x$.

102. Deutschlands Crustaceen, Myriopoden und Arachniden, Heft 10, 1837; H. 11,1837 ; H. 12, 1837; H. 21, 1838; H. 36, 1841.)

\section{Kolmodin, L.}

103. Ostracoden silurica Gotlandie cum tab. (In Ofvers. k. vet. Akad., Forhdlgr. Stockholm, 1879, No. 9, pp. 133-139.)

\section{Korschagen, A. N.}

104. Fauna of the neighhorhood of Moscow, Entomostraca-Malacostraca, 1887. 4to (in Russian).

\section{Krause, Aurel.}

105. Die Ostracoden der Silurischen Diluvialgeschiebe. (Berlin, 1891, 24 pp.)

106. Beitrag zur Kenntniss der Ostracoden-Fauna in Silurischen Diluvialgeschieben, mit 5 Taf. (Zeits. d. deutsch. Geol. Ges. 43 Bd., 2 Hft., pp. 488-521.)

107. Neue Ostracoden aus märkischen Silurgeschieben, mit 2 Taf. (Zeits deutsch. Geol. Ges., 44 Bd., 1893, pp. 383-399.)

\section{Lang, Arnold.}

108. Text-book of comparative auatomy, trans. hy Beruard. (London, 1891, p. 290 , etc.)

\section{Ledermüller.}

109. Microscopische Gemuïths- u. Augen-ergïtzungen. I. S. 141, Taf. 43, Fig. d, 1761. 


\section{Lereboullet, A.}

110. Note concernant l'ovaire de Cypris. (L'Institute XVI, nro. 773, 1848, p. 329.)

111. Note sur l'ovaire de Cypris. (Mémoires du Muséum d’hist. nat. de Strassbourg, IV, 1850, p. 211).

Leslie, Geo,, and Herdman, W. A.

112. The Invertebrate Fauna of the Frith of Fourth. (Edinburgh, 1881, pp. 42-52.)

\section{Leydig, F.}

113. Naturgeschichte der Daphniden. (Tübingen, 1860.)

114. Ueler Amphipoden und Isopoden. (Zeits. f. wiss. 7ool., Supp. XXX, 1678, p. 225.)

115. Ueher Verbreitung der Thiere im Rhöngehirge und Mainthal mit Hinhlick auf Eifel und Rheinthal. (Verh. nat. ver. d. preuss. Rheinl. w. Westf., 38 Jahrg., 1881.)

Lienenklaus, E.

116. Ueher die Ostracoden des uordwestdeutschen Tertiars. (Verhilgn. uaturhist. ver. preuss. Rheinl., 49 Jahrg., 1893, 1 Hälfte Korr.-Blatt, pp. 58.59.)

\section{Lievin}

11\%. Die Branchipoden der Danziger Gegend. Ein Beitrag zur Fauna der P'rovinz Preussen. (4 mit 11 'Taf., Danzig, 1848.)

\section{Lilljeborg, W.}

118. De Crustaceis ex ordinibus tribus Cladocera, Ostracoda et Copepoda in Scania occurrentibus, 1853.

119. Deskrifuing ofver tva ürter Crustacea af ordningarna Ostracoda och Copepoda. (Ofvers. af K. Vet. Akad. Forband, 1862, p. 291.)

120. Collections of chitfly Freshwater Crustacea from Swerlen. (International Fisheries Exhibition, Loudon, 1883. Sweden Special Catalogue, p. 140.)

121. De under Svenska veteuskapliga expeditionen till Spetshergen, 18i:-3, derstädes samlade Hafs-Entomostraceen. (Kongl. Vetenskaps.-Akad Förhandl, XXXII., No. IV., p. 3, 1874.)

Linné, C.

122. Systema naturæ, VII vyd,, 1748.

Lubbock, J.

123. ()n the Freshwater Eutomostraca of South America. ('Trans. Eutom. Arice, Vol, III, N. S., pt. IV, 1855.)

124. (n) some Futomostrilea collected by 1)r. Sutherland in the Atlantic Ocean. (Trans. Entom. Soc, Vol. IV, N. S., 1856, pt. II.)

125. () - mue ()eanir Entomostraca collected by Capt. Toynhee. (Trans. Iin. Soc., Vol. XXIII, 1862, p. 173.)

McIntosh, W. C.

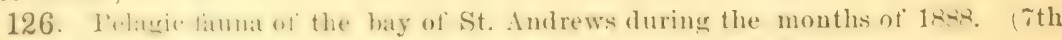
Ann. Rep. Fish. Board of Scotland, pp. 259-310, T. 3-6.)

Malcomson, S. M.

127. Liecent (1-tracoulat of Pellint Lought. (Proc. Belfast Nat. Field Club, 1884-is, p. 259.) 


\section{Martens, Ed.}

128 Ueber einige beim Finkenkrug gesammelte Süsswassercrustaceen. (Sitzungsberichte Ges. Nat. Fr. Berlin, 1881.)

\section{May, Konv.}

129. Veber das Gernchsvermögen der Krebse nebst einer Hypothese über die analy tische Thätigkeit der Riechhärchen. Mit 1 Taf. (Kiel, 1887.)

Marsson, Th.

130. Die Cirripedien u. Ostracoden der weissen Schreibkreide der Insel Rügen. Mit 3 Taf. (Mittheil. naturwiss. Ver, von New. Vorpominern, 12 Jahrg., 1881, pp. 1-50.)

\section{Metschinkoff.}

131. Arb. erst. Vers. russ. Naturf. Abth. d. Anat. und Physiologie, 1868, p. 56.

\section{Milne, Edwards.}

132. Histoire naturelle des Crustacés. Tome III, p. 409, pl. 36, 1840.

\section{Möbius, $\mathbf{K}$.}

133. Systematische Darstellung der Thiere des Plankton, gewonnen in der westlichen Ostsee und auf einer Fahrt von Kiel in dem Atlantischen Ocean bis jenseit der Hebriden. (5 Ber. Komm. Unters. d. Meere, Kiel 12-16. Jahrg. 1887, pp. 109-124, T. 7, 8.)

\section{Moniez, R.}

134. List des Copépodes, ()stracơles, Cladocéres et quelques autres Crustacés recueilles a Lille en 1886. (Bull. Snc. Zool, de France, XII, 1887.)

135. Notes sur des Ostracodes, Cladoceres et Hydrachuides ohservés en Normandie. (Bull. Soc. d'Etudes Scient. de Paris, 1887.)

136. Faune des eaux souterraines de department du Nord et en particulier de la ville de Lille. (Revue Biol. Nord France, Lille, 1 Année, Crustacea, pp. 175-182, 241-257.)

137. Sur la famme de Hable d'Ault. (Rerue Biol. Nord France, Lille, 1st Anuće, pp. 277-280, 346-350.)

138. Les mâles chez des Ostracodes d'eau donce. (Compt. rend. Ac. Sc., Paris, T. 112, No. 13, pp. 669-672, and abs. in Journ. R. Micro. Soc., London, 1891, P. 3, p. 316.)

139. Faune des lacs salés d'Algérie. (Mémoire Soc. Zool. France, T. 4, P. 3-4, pp. 246-257.)

140. Les mîles chez les Ostracodes d'eatu donce. (Revue Biol. Nord. France, 3 Ann., No. 9, 1893, pp. 354-356.)

141. Description d'une nouvelle espèce de Cypris vivant dañ les eaux thermales du Hamman-Meshkontine, 7 figs. (Bull. Soc. Zool. France, T. 18, No. 3, 1893, pp. 141-142.)

142. Quelques Cladocères et sur un Ostracode noureaux du Lac Titicaca, Avec 13 figs. (Revue Biol. Nord. France, 1 Ann., No. 11, 1393, pp. 419-429.)

143. Sur la présence en Asie du Cypris Madarazi, Orley. (Rerue Biol. Nord. France, 4 Ann., 1893, No. 2, p. 80.)

\section{Márzek, Al.}

144. O cysticerkoidech nasich korýšo ù sladknovodnich. (Věstnik král. Ceské spolecnosti nauk., 1890, Tab. V and VI.) 


\section{Müller, Fritz.}

145. Bemerkung über Cypridina. (Jenaische Zeits., V., Heft 2, 1870, p. 255.)

146. Descripcio do Elpidium bromeliarum, crostaceo da familia dos Cytherideos. (Archiv. d. Mus. Nacional. Rio de Janeiro, IV, 1879, p. 27.)

\section{Müller, 0. F.}

147. Fauna insectorum Fridricsdalina, 1764.

148. Zoologix Danicx Prodromus, 1776.

149. Entomostraca, 1785.

\section{Müller, G. W.}

150. Die Spermatogenese der Ostracoden. (Zool. Jahrhüch. Herausgegr. v. Spengel, III. Bd., 1889. Pp. 677-726; 2 pl.)

15l. Ueher Lebenweise und Entwicklungsgeschichte der Ostracorleu. (Matb.w. Nat. Berlin Akad., 1893, Heft V, pp. 239-266.)

\section{Müller, Wm.}

152. Zur nitheren Kenutniss der Cytheriden. (Archiv. tïr Naturgesch., 1884, p. 1.)

153. Beitrag zur Kenntniss der Fortpflanzung und der Geschlechtsverhältnisse der Ostracoden. (Zeitsch. f. d. gesamm. Naturwiss., 1880, p. 21.)

154. Leber die Function der Antennendrüse der Cytheriden. (Zeitseh. f. gesamm. Naturwiss., 1880, p. 213.)

\section{Nordquist, Ose.}

155. Beitrair zur Kenntniss der inneren männlichen Geschlectsorgane der Cypriden.

156. Die pelagische und Tiefsee-Fauna der grósseren finnischen Seen. (7. Anzeiger, 10. Jahrg., 1887, pp. 339-345, 358-362.)

\section{Norman, A. M.}

157. Contrihutions to British Carcinology. (Ann, and Mag. Nat. Hist., Ser. III, Vol. VIII, 1861.)

158. Speries of ()stracoda new to Britain. (Ann. and Mag. Nat. Hist., Ser. III, Vol. IX, 1862.)

159. lieports Deep-Sea Dredgring, Coast of Northumberland and Durham. Crustacea. (Nat. Hist. Trans. Nerthumberland and Durbam, Vol. I, 1865.)

160. liepont of Committee for Fxploring the Coasts of the Hebrides. (British Ass. Report, 1866, p. 198.)

161. Last lieport of Inedging among the Shetland Isles. (lirit. Ass. Report 1868, p. 248.)

162. Report Valorous Expedition. (Proc. Roy. Soc., No. 173, 1876, p. 202.)

163. Notes on the Marine Crustacea Ostracoda of Norway. (Anu. Nat. Hist., (7) Vol. 7, pp. 108-121.)

Orley, S.

164. Leher die Entomostraken-Fanma von Budapest. (Természetrajzi Füzetek $\mathrm{X}, 18 \varepsilon 6$, pp. 7 and 98.$)$

Pavesi, $\mathbf{P}$.

165. Della mie annotorioni zoologiche. IV. Prime linee di uno studio zoologico delle nostre aeque minerali. (Renconditi R. Instituto Lombardo, Vol. 14 1882, pp. 7-11.)

166. Altra serie di ricerche estudi sulla fauna pelagiea di laghi italiani. (Atti. Soc. Veneto-Trent, Padova, Vol. 8, 1883, pp. 340-403, T. 8-14.) 
Peach, B. N.

167. On some new Crustaceans ,from Lower Carboniferons Rocks of Eskdale and Liddesdale. (Trans. Roy. Soc. Edinburgh, Vol. 30, 1882, pp. 73-91, T. 7-10.)

Pelseneer, $\mathbf{P}$.

168. Note sur la présence de caridina desmaresti dans les eaux de la Meuse. (Bull. Mus. H. N. Belg., Tome 4, 1886, pp. 211-222.)

\section{Plateau, F.}

169. Recherches sur les Crustacés d'eau donce de Belgique. (Mem. Couronnés et Mem. des Savants Etrangers, XXXIV, 1868.)

\section{Poggenpol M. J.}

170. List of the Copepoda, Cladocera and Ostracoda of the Environs of Moscow. Russian. (Translation in: Trans. Kansas Acad. of Science, Vol. VIII, 1883.)

\section{Poppe, S. A.}

171. Notizen zur Fauna der Süsswasserbecken des nordwestlichen Dentschland mit besonderer Berïcksichtigung der Crustaceen. (Abh. Nat. Ver. Bremen, 10. Bd., 1888, pp. 295-300.)

\section{Ramdohr, K. A.}

172. Beiträge zur Naturgeschichte einiger deutschen Monoculus-arten, Halle, 1805.

173. Ueber die Gattung Cypris Müll. und drei dersellen gehörige newe Arten. (Mag. d. Gesell. naturforsch. Freunde in Berlin, Jahrg. II, 1808, pp. 8393, Taf. III.)

Rehberg, $\mathrm{H}$.

174. Beitrïge zur: Naturgeschichte viederer Custaceen [Cyclopiclen und Cypriden]. (Abhandlung herausg. vom naturw. Vereine zu Bremen. Bd. IX, 1884.)

Reuss, A. E.

175. Die fossilen Entomostraceen des osterreichischen Tertiarhechens. (Naturwiss. Abhandlungen, III, 1847, p. 41.)

\section{Robertson, D.}

176. Notes on the Ostracoda and Foraminifera of the Firth of Clyde. (Trans. Geol. Soc. Glascow, Vol. V, pt. I, p. 112, 1874.)

17\%. Notes on a Raised Beach at Cumbre. (Trans. Geol. Soc. Glasgow, 1875.)

178. Notes on Cypris lævis and its habit of perforating the leaves of Victoria regia. (Proc. Nat. Soc., Glascow, Vol. II, 1875, p. 7.)

179. Post-tertiary Deposits by Tunnel at ArkJeston near Paisley. (Trans. Geol. Soc., Glascow, 1876, p. 292.)

180. Garnoch Water Post-tertiary Deyosits. (Trans. Geol. Soc., Glascow, 1876 p. 281.)

181. Post-tertiary Deposit at:Misk-Pit and Kilwinning. (Trans. Geol. Soc. Glascow, 1877, p. 297.)

182. Notes on the Fauna and Flora of West Scotland, p. 38, 1876.

183. Ostracoda of Scotlaud. (Append. to Pt. I of Proc. Nat. Hist. Soc., Glascow, IV, 1880.) 
184. Fauna of Scotland, with special reference to Clydesdale and the western districts; Fresh and Brackish Water Ostracoda. Glascow, 1880.

185. Post-tertiary Beds of Garrel Park, Greenock. (Trans. Geol. Soc., Glascow, 1883 , p. 1.)

\section{Rochebrune, A. T.}

186. Onservations sur la Cypris fusca. (Act. Soc. Lin. de Bordeaux, XXIV, 1861, p. 77.)

\section{Saccardo, P. D.}

187. Cenni Storico-naturali intorno agli animaletti Entomostracei, etc. Treviso, 1864.

Sars, G. 0.

188. (Om en i Sommeren 1862 fortagen Zoologisk Reise. Christiania, 1863.

189. Oversigt of Norges marine Ostracoder, 1865.

190. Nye Dybamdscrustaceer fra Lofoten. (Vidensk-Selks. Forhand, 1869, p. 170.)

191 . Undersögelser over Christianiafjordens Dybvandsfauna, 1869.

192. Undersigelser over Hardangerfjordens Fauna. I. Crustacea. (VidenskSelks. Forhand, 1871, p. 278.)

193. I)en Norske Nordhavs-Expedition 1876-187 , Vol, 15, Crustacea II, 1886; $96 \mathrm{pp}$.

194. Nye Bidrag til Kundskaben om Middelhavets Invertehratfauna. IV, Ostracoda Mediterranea. (Archiv. f. Math. og Naturvidenskab, 1887.)

195. On some Freshwater Ustracoda aud Copepoda raised from dried Australian mud. (Christiania Vid. Selsk. forh. f. 1889, No. 8, 79 pp., 8 Taf.)

Sars, Michael.

196. ()m de i Nordge forekommende fossile dyrelivnijgren fra quarticrperiolen. Christiana, 1865 .

\section{Schneider, Rob.}

197. Uther Eisenresorption in thierischen Orgamen und Geweben. (Abh. Akad. Berlin, 1888, 66 pp., 3 Taf.)

\section{Schnur.}

198. Srstematische Aufzillung der Crustaceen, Arachniden und Myriopoden in der Umgebung ron Trier. (Ges. f. nützliche Forschungen zu Trier, 1856.)

Schwarz, 0. G:

199. Teher die sogrenannte Schleimariise der minnlichen Cypriden. (Berichten der Natur. f. Gesells. zu Freiburg, Bd. III, 1888, p. 5.)

Seguenza, G.

200. Le Formazioni Terziarie nella provincia di Regrgio (Calabria), 1 R80.

201. II guaternario di Jizzolo. II. (ili. Ostracodi. (II. Naturalista Siciliamo, Anno III, 1883.)

Sostaric, Dragutin.

202. J'rilou monaranju faune slatknovodnih korepnjaka hrvatske. (Prěst. iz XCII, knjige Rada jugoslavenske akarlemije znanosti i umijetnosti, W. Zagrebu, 1888.)

Speyer, 0 .

203. Die Ostracoden der Casseler Tertiarbildungen. Cassel., 1863. 


\section{Stimpson, W.}

204. Synopsis of the Marine invertebrata of Grand Manan. (Smithsonian Contributions, 1853.)

Straus, H. E.

205. Mémoire sur les Cypris. (Mém. du Museum, Vol, VII, 1821.)

Stuhlman, F.

206. Beitrïge sur anatomie der inneren männlichen Geschlectsorgane und Spermatogenese der Cypriden. (Zeits. f. wiss. Zool., XLIV, 1887, p. 536; and Zoologischen Institut. zu Freiburg, I. B , 1886.)

Terquem, M. $\mathbf{0}$.

207. Les Foraminifères et les Entomostracés-Ostracodes du Pliocène supěrieur de l’lle de Rhodes. (Mém de la Soc. Géol. de France, Sér. III, Vol. I, 1878.)

\section{Terrigi.}

208. Sulla fatuna microscopica del calcare zancleano di Palo. (. Itti. R. Accad. Lincei-Transunti, Vol. 6, 1882, pp. 253-256.)

\section{Thompson, G. M.}

209. New Zealand Entomostraca. (Trans. New Zealaud Institute, Vol. XI, 1878.)

\section{Toth, Alex.}

210. Die in neuester Zeit zu Pest-Ofen gefundenen Schalenkrebse und ibre anatomischen Verbältnisse. (Verhdlgn. d. Zool.-bot. Gesell. Wien, XIII, 1863, p. 47.)

\section{Treviranus (both).}

211. Abhandlung ūber den inneren Bau der ungeflügelten Insecten. (Vermischte Schriften anatomischen und physioloischen Inhalts, 1816.)

Turner, C. H.

212. Notes on the Cladocera, Copepoda, Ostracoda and Rotifera of Cincinnati, with des. of new sp. (Bull. Sci. Lah. of Denison Univ., Vol. VI, pt. II, $1 \varepsilon 92$, pp. $57-74$; pl. I-1I.)

213. Additional Notes on the Cladocera and Ostracoda of Cincinnati, Obio. I Systematic Part, with des. of new species. II Late Larval History of Cypris herricki. (Bull. Sci. Lab. Denison Univ., Vol. VIII, Part 1, 1893, pp. 1-18, pl. I-II.)

214. Preliminary Note on the Nerrous System of the Genus Cypris. (Jour. of Comp. Neurology, Vol. III, 1893, pp. 35-40; pl. III and IV.)

215. Notes on American Ostracoda, with Description of new species. (Bull. Sci. Lab. Den. Univ., 1894, Vol. VIII, Part II, pp. 13-25, pl. VII and VIII.)

216. List of Known American Ostracoda, with description of new species. (Amer. Naturalist, 1894. [?])

\section{Ulrich.}

\section{v. La Valette St. George.}

218. Ueber die Genese der Samenkïrper. Dritte Mittheilung. (Arch. für mikroskop. Anatomie. Bd. X, 1874, p. 497.)

\section{Vávra, V.}

219. Über das Vorkommen einer Sïsзwasser-Cytheride in Böhmen. (Zool. Anz., XIV, Jahrg. No. 357, 1891, p. 77.) 
220. Kritisches Verzeichnis der Ostracoden Bühmens. (Sitzgsber. Kyl. hülım. Ges. d. Wiss., 1891, pp. 159-168.)

\section{Vávra, Wenzel.}

221. Monographie der Ostracoden Böhmens. (Prag, 1891.)

Vernet, $\mathbf{H}$.

222. Acauthopus, un nouveau genre d'Ostracodes. (Forel, Matériaux pour servir a l'étude de la Faune profonde du Lac Leman, IVe Série, 1879, p. 408.)

Vejdorský, F.

223. O. povodu fauny studničé. Slavnostni preclníska ve výrocuím sezení král. (Ceské spol. nauk v Praze dne 3. Června 1880.)

224. 'Thierische Organismen der Brumneuwïsser v. Prag. Mit 8 Tat. 1882.

\section{Wagner, $\mathbf{R}$.}

225. Beitrïge zur Kenntness der Samenflissigkeit der Thiere. (Arch. f. Naturg. von Wiegmann (Troschel). II Jahrg., 1836, I B., p. 369.)

\section{Weismann, A.}

226. Parthenogenese b. d. Ostracoden. (Zool. Anz., Vol. III, 1880, p. 82.)

Weismann, A., and Ischikava, C.

22\%. Ueher die Bildung ler Richtungskörper bei thierischen Eiern. 4 Taf. (Berichte der Naturforsch. Ges. zu Freiburg, Bd. III, 1887.) ’

\section{Wierzejski, A.}

228. Materialen zur Kenntniss der Fauna der Tatraseen. (Ber. physiograph. comm. Acad. Krakau, 1882, 16 Bd., pp. 1-24 (Polish).)

\section{Woodward, H.}

229. A Ciltalogue of the British Fossil Crustacea. British Museum, 1887.

Zacharias, 0 .

230. Die Thierwelt der Eifelmaare. (Biol. Centralbl., 8 Bd., 1-8r, p. 5\%4.)

231. Zur Kenutuiss der Fauna des Süssen und Salzigen Sees bei Halle a|s. (Zeit. f. wiss. Zool., 46 Bd., 1888, pp. 217-232.)

232. Lericht iiber eine zoologische Excursion an die Kraterseen der Eifel. (Biol. Centralblatt, 9 Bd., 1889, pp. 56-64, 76-80, 107-113.)

233. Fannistische Lntersuchungen in den Mataren der Lifel. (Zool. Anz, 11 Jahrg., 1888, pp. 705-706.)

Zaddach, E. G.

234. Synopseos Crustaceorum Prussicorum Prodromus, 1844.

\section{Zenker, W.}

235. De natura sexuali generis Cypridis. (Dissert. inaug. Berolini. c. tat). 1, 1850.)

236. Ceher die (iesthlectsverhiltnisse der Gattung Cypris. (Archiv. für Anatomie u. Physiologie. Herausg. von Dr. J. Müller, pp. 193-202, Taf. V, 1850.)

237. Anatomisch-xystematische studien ïber die lirehsthiere. Herlin, 185t.

239. Ionouraphie der ()stracolent. (Weigmann's Arehiv. f. Naturg., Tome XX, I. Bd., 1854, pp. 1-87, Taf. I-VI.) 


\section{INTRODUCTION.}

The Mstreata form a well defined division of the Entomostraca. Like the Lamellibranchiata the body is always enclosed in a bivalve shell, which is closed by powerful abductor muscles. No doubt the casual observer often mistakes the ()stru(r) fut for miniature mollusks. Tet the resemblance is all on the surface; for, althongh the structure of the enclosed Ostrurodun is quite primitive, yet it is decidedly crustacean.

The body always bears seven pairs of articulated appendages. The first five of these belong to the head; but, in different groups, either or all of the last three of these cephalic appendages may be modified for walking. The last two pairs of members belong to the body and are properly called legs or feet. In some cases, however, (Cypris) the last pair of legs is never used for locomotion. In most cases the abdomen bears a pair of appendages, which usually resemble one-jointed legs. Morphologically they probably are legs which have been arrested in their development.

It is thought that a brief resume of the steps by which the Ostracoles have been assigned to their present taxonomic position may be of interest.

Linneus (or Linné) included all of the lower ('rusturer in his geums Monoculus.

O. Ir. Miiller divided the lower Crustacen into several genera. Col. lectively they were called the "Entomostraca."

Latreille and Cuvier were the first to separate the crustrued from the Insecta. Basing their judgment upon the morphologs of the mouth parts, they divided the lower Crusteree into two artificial

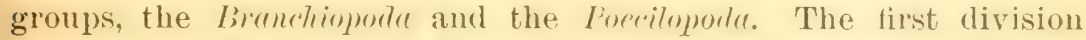

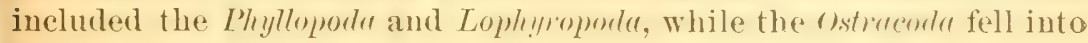
the second division.

Following in the footsteps of Latreille, Milne-Edwards, with the mouth parts for criteria, established an artiticial system of classifica-

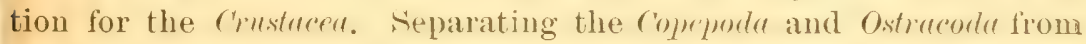
Latreille's Branchiopoda, he united them in the group Intomastrace.

Dana modified slightly Latreille's system.

The first attempt to form a natural system of classification for the lower Crustuen was made by Zenker. He separated the Coprume 
from the ostracode and used the name Entomostrace as a group name for the Siphonostoma and Lernacoda.

Claus used the word Entomostract in a different sense. The PhylTopodu, (s)tracoda, Copepoda and Cirripedia were collectively called the Entomostrace.

Professor (x. O. Sars has divided the Ostracode into the following four sections: 1. Podocopu, 2. Myodocopa, 3. Cladocopa, 4. Platycopa. All of the members of sections '2, 3 and 4 and a portion of those belonging to section 1 are marine.

Brady and Norman have divided the Podocopa into the following families:

Family I. - Oypridida.

Family II.-Bairdiida.

Family III.-Darwinulide.

Family IV.-Cytheride.

Family V.-Paradoxostomatida.

This article treats exclusively of the first and third families.

\section{FAMILY CYPRIDIDE.}

"Shell generally thin and horny; valves equal or but slightly une qual in size, surface usually smooth, or simply punctated; ventral margins more or less sinnated; hinge margins edentulous. Eyes simple, usually confluent, sometimes wanting. Antennules (first antennie) slender, usually seven-jointed, very flexible, usually provided with a number of long hairs forming a dense brush. Antenna (second antenme) pediform, geniculated, four- or five-jointed, clawed at the apex, second joint mostly bearing an apical brush of hairs. Mandibles strong, apex strongly toothed, palp four-jointed, with a setiferous branchial plate at the base. Two pairs of maxilla, the first pair four digitate; its external branch distinctly two jointed, bearing a large setiferous branchial plate; second pair small, composed of a single prehensile lobe and palp, which in the female is generally simple, rarely pediform, is in the male prehensile. Two pairs of feet dissimilar in structure, the anterior pair strong, ambulatory, directed downwards, and having a long curved apical elaw; posterior bent backwards within the shell, and not used for motion. Caudal rami usually well developed, elongated, very mobile, and bearing two or three apical claws. Intestine forming two dilations, of which the anterior is provided with cucal appendages. Geuerative organs large, and of complex structure, and partly extended within the valves; in the male frequently a whorled sac connected with the testis; copula- 
tory organs symmetrical, and of moderatesize." (Brady and Norman.)

It is thought that the following modification of Wenzel Vavra's key will serve to differentiate the genera.

\section{IEY TO THE FAHILY CYPRIDIDE.}

I. The second foot terminates with a cylindrical joint that bears two backwardly directed setæ.

A. The second foot of the female and the male six-jointed. No branchial plate attached to the second maxillx.

Notodromas, 295

B. The second foot of the female five-jointed and of the male six-jointed. The second maxilla bears a branchial plate.

a. The branchial plate is feebly developed in the form of two pectinated bristles.

* The eye is developed.

Candona, 298

** The eye is absent.

*Typhlocypris.

$b$. The branchial plate is developed in the form of three pec-

tinated bristles. . . . . . * Candonopsis.

c. The branchial plate is in the form of six pectinated bristles.

* The palp of the second maxilla is rudimentary. . *Ilyocypris.

** The palp of the second maxilla is normally developed.

$\dagger$ The terminal joint of the second foot is as long as one-third of the fourth joint.

$\dagger$ The terminal joint of the second foot is as long as two-thirds of the fourth joint. . . Cyclocypris, 310

II. The second foot terminates in a beak-shaped joint that bears one backwardly directed claw.

A. Caudal rami are rudimentary.

Cypridopsis, 312

B. Caudal rami are cylindrical with two terminal claws.

* Natatory setæ of the antennæ short.

$\dagger$ These setre not reaching to the tips of the terminal claws.

Erpetocypris, 315

+† These setr not reaching to the base of the terminal claws. *Scottia.

* Natatory setæ of the antennæ long, reaching to or beyond

the tips of the terminal claws.

+ Parthenogenetic.

Cypris, 319

†† Sexual.

$\left({ }^{*}\right.$ Not noticed in the text.)

Cyprinotus, 329

In the above table an attempt has been made to tabulate all known freshwater geuera of the Cypridide. The geuss Stenocymris Sars has been omitted because the data at my disposal do not seem to warrant its separation from the genus Frpectompis Brady and Norman. Of the twelve geuera here mentioned, nine have been found in America.

GENUS NOTODROMAS Lilljeborg. 1853.

In shape the shell of the male is quite different from that of the female.

The antennules are seven jointed. 
In both males and females the antenne are six-jointed. The natatory set: extend to beyond the tips of the terminal claws.

There is no branchial plate on the second maxilla. The palp of this jaw is two-jointed. In the female the distal joint is short and cylindrical. hearing at its apex two short setre: in the male the distal joiut forms a long scythe-shaped appendage.

The serond foot is five jointed, terminating in three setie, two of which are directed backwards.

The two eyes are not confluent.

The abdominal rami are long and slender. Males are numerons. The cylindrical core of Zenker's organ (rerticillate sac) is ornamented with numerous closely set whorls of short stout spines.

Notodromas monacha (O. F. Müller).

Plate LXXif, Fig. $4-4^{\mathrm{h}}$.

178.5.-Cypris monacha O. F. Müller (149), p. 60, Taf. V, Figs 6-8.

1820. - Monoculus monachus, Jurine (93), p. 173, Pl. XVIII, Figs. 13-14.

1837. - Cypris variabilis Koch (102), H. 10, 3.

1837. - " lencomela Koch (102), H. 10, 4.

1837. - " monacha Koch (102), H. 11, 1.

18:37. - " bimuricata Koch (102), H. 11, 2.

1837.- " " nubilosa Koch (102), H. 12, 4.

1814. - " monacha Zaddach (234), p. 31.

1850. - " monacha Baird (2), p. 153; Pl. IV, Figs. 1-11.

1851.- " " monacha Fischer (64), p. 146.

14.53. - Votodromu momachus Lilljeborg (118), p. 95; 'Taf. VIII, Figs. 1-25; Taf. XII, Figs, 13 ; 'Taf. XXYV, Fig. 16.

1854.-Cyprois monacha Zenker (233), p. 80; PI. III, C.

1868. - " monacha Plateau (169), p. 60; Pl. I, Figs. 22-23.

1868. -Notodromes monachus Brady (18), p. 379; Pl. XXIII, Figs. 1-9; PI. XXXVI, Fig. 3.

1870.-Notodromas monachus Heller (81), p. 78.

1872.-Cypris monache Fric (69), p. 228.

1830.-Notodiomas monachus Robertson (184), p. 22.

1882.- " monachus Herrick (85), p. 252.

1885.- " " monachus Nordquist (155), Pls. I, II audi IV.

1837.- " monachus Korschagen (104), p. 24.

1888.-Cyprois monacha Schwarz (199), p. 11.

1889. - Nolodromas monacha Brady \& Norman (31), p. 96.

1891.— " monach Wenzel Vávra (221), pp. 32-39; Figs. 79.

This sumedes does not seem to be as abundant in America as in Europe. I have nevere encountered it. The figures that aceompany this deseription are Professor Herriels's (s6), and the following diag. mosis is due to Professor Brady (18):

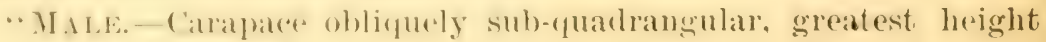
egual fo fwo thimb of the length, situated in the middle. Anterior 
margin broad, rounded at the angles, and expanded into a flattened lamina or flange. Tentral margin straight for about two-thirds of its length, then bending upwards at an obtuse angle. Dorsal margin arched, almost angular in the middle, whence it slopes steeply to the anterior border and with a bold curve towards the posterior extremity, joining the ventral margin at an acute angle. Seen from above, the carapace is ovate, pointed in front, and rounded behind; the greatest breadth in the middle. The ventral surface is bounded by two conspicuous, elevated, arcuate ridges, one at each valve, which together enclose a flattened lozenge-shaperl area. Parallel to the contact margin of each valve rums another straight but much less conspicuous ridge, which towards the front curves out ward, and joins the external ridge at an acute angle, the muion of the two forming a slight elevation, from which a single ridge runs forward, sradually merging in the flattened encircling flange of the anterior border. Seen from the front, the shell is sub-triaugular, the sides convex, but flattened, the dorsum forming a flattened arch; the ventral border perfectly flat, and bounded by the projections of the outermost ventral ridges; the iuner ridges form also conspicnous projectious, which run obliquely mpwards and inwards towards the flattened anterior flange. Lucid spots, about six, oblong and irregularly placed, their long diameters pointing transversely across the valve. Surface of the shell smooth and shiniug, marked by fue impressed lines forming a pattern similar to the imbrications of fish-scales. Color pale greenish or white, transparent, with large and irregularly spread patckes of deep olivegreen or black.

"Ferdale.-Sub-quadrangular. Anterior border flattened, flanged, forming with the ventral margin a well-marked angle; rounded above. Dorsal margin boldly arched, highest at the posterior third, whence it sweeps round with a deep curve to the postero-ventral angle. Tentral margin straight, slightly rising behind, and terminating in a flattened squamous plate, which projects backwards, with the appearance of a spine. The other aspects are similar to those of the male shell, except that the ventral surface of the left valve has at the posterior extremity of its contact margin a flattened squamous plate, which is received into a corresponding depression of the opposite valve."

Professor Brady (is) states that the branchial plate of the mandibvlar palp arises from the lower side of the palp, thus differing con. siderably from other ('ypridide. Professor Yívra (221), however, says that the branchial plate arises from the upper sicle of the mandibular palp.

"The first foot in both sexes terminates in three curred claws, the central one being the strongest and longest. 
"The 'glandular mucosa' [Zenker's organ] consists of a central cylinder, closely beset with radiating filaments, arrauged in 50 to 60 transverse rows, the whole organ being imbedded in a sort of glairy matrix. The two glands are connected each by an efferent duct with the 'bursu copmlatrix', an organ of very complicated structure, and consisting of a much convoluted canal (? vesiculu seminulis), an intromittant. organ or penis, and two hooked appendages. The whole organ is very dense in structure, consisting probably of chitin, deep brown in color, and, with the 'glandulie mucosie,' constitutes a very considerable portion of the male carapace. It should be noted that the "bursu copuletrix,' as well as the testis, $*$ is a double organ, one on each side of the median line. The two burse lie closely in apposition but are not in organic connection except at the upper margin, where they are held together by a ligamentous tissue. Length $\frac{1}{2}$ in. $(1.1 \mathrm{~mm}$.), height $\frac{1}{32}$ in. $(0.78 \mathrm{~mm}$.)." Habitat: Minnesota (Herrick'85).

\section{GENUS CANDONA Baird. 1850.}

This genus, which was founded by Professor Baird (5) has recently been more restricted by Mr. Wenzel Vívra (221). In this connection the genus is used in Vávra's restricted sense.

In the female the autenna is five-jointed. In the male, owing to a division of the fourth joint, the antenna is six jointed. At the division between the fourth and fifth joints of the male antenna two characteristic olfactory hairs are situated. The distal extremity of the third joint is not supplied with a brush of natatory setr. The rudimentary branchial plate of the second maxilla is composed of two, unequal, pectinated setie, which are attached directly to the basal portion of the maxilla. In the female the palp of this maxilla is two-jointed, and terminates with three unequal pectinated bristles. In the male this palp, which is then unjointed, differs in shape from that of the female.

The second foot, which may be either five or six-jointed, terminates with three setie; two unequally long, hackwardly directed, setie and one forwardly directed seta.

The strong post-abdomen (abdominal ramus) bears two terminal (claws. The seta on the caudal border of the ramus is quite remote from the end. At the origin of this ramus the dorsum of the body terminates in a short seta. The eye is small.

Wales are common, larger than the females.

seren circles of chitinous spines are arranged around the central "ylimeler of \%enker"s organ. The copulative organ is not so complex as that of Notodromas.

* Dr. Brady uses testis as a synonym for Zenker's organ. It is now well known that this organ is not the testis. 
The absence of natatory setæ from the antennæ prevents the members of this genus from swimming. They creep along the bottom and frequently burrow in the mud or sand.

\section{Candona fabaeformis (Fischer.)}

Plates LXXV, Figs. 10, 11; LXXVI, Figs. 6, 8.

1851.-Cypris fabxeformis Fischer (64), p. 146; PI. III, Fig. 6-16.

1853. - Candona fabaformis Lilljeborg (118), p. 207.

1870. - " diaphana Brady and Robertson (33), Pl. V, Figs. 1-3.

1889. - " fabæformis Brady and Norman (31), p. 103; PI. IX, Figs. 1-4.

1891. - “ fabeformis Weuzel Vávra (221), pp. 45-48; Figs. 6, 2; Figs. 12, 1-9; Fig. 13.

Length $1.03 \mathrm{~mm}$. Height $0.49 \mathrm{~mm}$. Width $0.38 \mathrm{~mm}$.

The shell is more than twice as long as high and nearly three times as long as wide. The shell being pellucid, the color of the enclosed body shines through the lorica and gives it a greenish yellow tint.

Viewed from the side the shell of the female is sub-reniform; greatest height situated behind the middle; obtusely and evenly rounded in front, obliquely rounded behind. Veutral margin sinuated.

Viewed from above the shell is compressed, tapering equally and suddenly to the two pointed extremities; sides almost parallel. Tear each extremity a process from the left valve overlaps the right. The projection near the caudal extremity is much more pronounced than the other.

The antenna are stout; the smooth terminal claws are slightly curved and are not quite as long as the combined lengths of the last three joints. Natatory setie are absent. For the arrangement of setro consult the figures.

The second foot is six-jointed.

The abdominal rami are strong. In the female they are curved. The terminal claws are stout, curved and pectinate; the shorter claw is a little more than three-fourths as long as the other. The longer claw is about half as long as the entire ramus. Habitat: The only specimens yet found in America were found in a small spring-fed water tauk on Clark University campus, Atlanta, Georgia, Aug. 30, 1894.

Candona acuminata (Fischer.)

Plate LXXI, Fig. 34.

1851.-Cypris acuminata S. Fischer (64), p. 148; Pl. IV, Figs. 12-16.

1854. - " " " Zenker (238), p. 74; Pl. II, D.

1889. " " Brady and Norman (31), p. 104; Pl. IX, Figs. 9-10; PI. X, Figs. 5-6.

1894. - “ " C. H. Turner (215), p. 19; PI. VIII, Fig. 34. 
Length $1.25 \mathrm{~mm}$. Height $0.58 \mathrm{~mm}$. Width $0.46 \mathrm{~mm}$.

The shell is smooth, white, and elongated. It is more than twice as long as high and about three times as wide.

riewed from the sille, the shell is sub-reniform, highest in the middle.

Viewed from above, the shell is sub elliptical with pointed extremities. The widest portion is in the middle. One valve is a trifle longer than the other.

The antemie are stout. The matatory setie are absent and the ter. minal is long and non-pectinated.

The post abdomen (Fig. 34) is curved and slender. The terminal claws are slender and pectinated.

ITabitat: San Antonio River, 'Texas. I have seen only three specimens of this species. They were collected for me by Mr. A. B. Whitby.

\section{Candona crogmani Turner.}

Piates LXXI, Figs. 24-33; LXXXI, Figs. 4-5.

Candona crogmaniana-C. H. Turner (215), p. 20; PI. VIII, Figs. 24-33.

Length of female $1.52 \mathrm{~mm}$. Height $0.76 \mathrm{~mm}$. Width $0.58 \mathrm{~mm}$.

This form is about the size of the elongated variety of Camdona candidu. The two most obvious differences are: 1, the inequivalve shell with pointed extremities; 2 , the second foot is six-jointed.

The shell is very thin. so thin that the ova and spermatozoids are risible through it. It is glossy and is covered with short scattered luairs. These hairs are more numerous aromd the margins than elsewhere. In the living specimen the hody shines through the pellueid shell and gives it a greenish yellow tint. Numerous Torticellidu are usually found attached to the lorica.

Viewerl from the side (Fig. :33), the female is sub-triangular, the caudal third heing the highest portion. The caudal, dorsal and cephalic margins are convex. The ventral margin is slightly sinuate, being concave in the middle.

Virwed from above (Fig. 32), the shell is an elongated ellipse, pointed at hoth ends. One valve is longer than the other and overlaps it at each extremity.

The antennat (Fig. 2.j) is five-pointed in the female. Near the proximal and of the lower margin of the first joint there is one elongaterl filament and one short, mertinated. dasger shaped filament. The terminal alaws are slender, non-pectinated and long-longer than the combined lengeths of the last three joints. The antenna of the male is six jointed. 
The mandibular palp (Fig. 31) is five-jointed. The first joint is large and bears at the distal angle of its inner margin a short daggerlike seta (Fig. 31). The distal half of this seta is pectinate. The mandibular blade is stont.

The spines of the first mandibular process of the first maxillie are non. pectinated.

The first foot (Fig. 29) is loug and slender and is comjosed of five joints. The secoud joint is about as long as the next two joints. The third and fourth joints are of about the same length. The fifth joint is the smallest of all. It is conical and from its distally directed apex arises the terminal claw. The terminal claw is slender and long. It is longer than the combined lengths of the last three joints and the distal portion is flexuose.

The fourth joint of the second foot (Fig. 30) is somewhat obseurely divided into two joints, so that the second foot appears, under a high power, to be composed of six joints. The foot terminates in two long flexuose filaments and one shorter filament.

The post-abdomen (Fig. 2S) is of medium size. The terminal elaws are sleuder, pectinated and curved. The terminal claw is about half as long as the abdominal ramus. The adjacent claw is a little shorter than the terminal claw. The filament in the caudal margin is about one-thicd the length of the ramus from the distal extremity of the post-abdomen.

Habitat: Atlanta, Georgia, December, 1893. Abundant in the shallow ponds near south River. The ponds in which these specimens were found dry up in warm weather.

\section{Candona Peircei sp. n.}

PLATE LXXX.

Length 0.70 to $0.79 \mathrm{~mm}$. Height 0.33 to $0.37 \mathrm{~mm}$. Width 0.22 to $0.31 \mathrm{~mm}$.

The color of the shell is white tinged with yellow. The surface is highly polished and bears a few scattered hairs. The muscle impressions are sulb central and the eye is not visible through the shell. The animal is about half as high as loug, but is not quite so wide as high.

Viewed from the side the shell is sub-reniform. the greatest width being a little caudad of the middle. The two extremities are rounded and are of about the same width. The dorsal margin is feebly convex, in some specimens it is nearly flat. The ventral margin is somewhat sinuous, the middle being slightly concave. In some specimens this margin is almost straight. 
Tiewed from above, the shell is sub-elliptical with pointed extremities. The cephalic extremity is more sharply pointed than the candal. The ides are convex. The hinge-line throughout the greater part of its course is straight, but near the cephalic extremity of the valve there is a slight sinmosity. Yiewed from below the shell has the same general appearance as when viewed from above. The contact line is quite sinuous.

The antenna of the female is five jointed. Near the distal extremity of the inner margin of the second joint there is a long seta, which extends about to the base of the fifth joint. Near the proximal extremity of the inner margin of the third joint there is the usual biarticulate olfactory hair. Near the proximal extremity of the outer margin of the same joint arises a long seta which extends almost to the base of the next joint. From the distal extremity of the inner margin of this joint there arise one long and one short seta. The long seta reaches way beyond the tip of the fifth joint, while the short one does not reach to the extremity of the fourth joint. From the middle of the innex margin of the fourth joint there arise one long and one short seta. The long seta extends to beyond the tip of the terminal joint while the other extends to a little beyond the base of the same joint. From the middle of the outer margin of the fourth joint there arises a short seta which extends to about the base of the next joint. The tip of the fourth joint bears two long and one short claw. The two long claws are stout and are longer than the combined lengths of the last two joints. The short claw is only abont twice as long as the terminal joint. From the tip of the fifth joint there arise one long and one shorter claw. The shorter claw is about two-thirds as long as the other claw. The tip of this joint bears also a biarticulate sensory filament.

The antenna of the male is six-jointed. In structure and appendages the first three joints resemble the corresponding portion of the female antemma. From the distal extremity of the fourth joint arise two peculiar hiarticulate sensory filaments which extend to beyond the tip of the terminal joint. From the distal extremity of the outer margin of this same joint arises a short seta which extends to about the tip of the fifth joint. From the distal extremity of the fifth joint arise two long curved claws and one medium seta. The elaws, which are of erpual length, are longer than the combined lengths of the last three joints. The claws arise from the outer portion, while the seta springs from the inner angle of the margin. The seta is about onelaalf as long as one of the claws. From the distal extremity of the sixth joint there arise one long terminal claw and one biarticulate semsory seta. The claw extends to the tips of the claws that spring from the fifth joint. but the sota extends less than half so far. 
The palp of the mandible is stont, the terminal joint of the same is short. The blade of the female mandible is stonter than that of the male.

The first maxilla bears a large leaf-like branchial appendage.

The second maxilla of the female has the usual generic form, the palp being two-jointed and bearing at its tip three short setse. In the male the palp of the second maxilla is peculiarly modified and the palp of one side is larger than the palp of the other.

The first foot is of the usual type.

The second foot, as is always the case in this genus, bears at its tip two long and one short setre.

The post-abdomen of the female is quite stout and bears at its tip two strong claws. This appendage is strongly curved. One claw is only about two-thirds as long as the other.

The post-abdomen of the male is straighter than that of the female, but its borders are more irregular. The terminal claws are slender and of about the same size.

The verticillate sac of the male bears seven whorls of chitinous spines.

Habitat: Fayette county, Georgia. These specimens were found in the weedy shallows of a large millpond near Faretteville, June $21,1894$.

\section{Candona delawarensis Turner.}

Plate LXXI, Figs. 35-40.

1894.-Candona delawarensis C. H. Turner (215), pp. 21-22; Pl. VIII, Figs. 35-40.

Length $0.95 \mathrm{~mm}$. Height $0.54 \mathrm{~mm}$. Width $0.43 \mathrm{~mm}$.

The color of this form is greenish yellow variegated with blotches of brown.

Viewed from the side (Fig. 39) the shell of the female is sub-reniform, the greatest height being about two-thirds the length of the animal from the cephalic extremity of the shell. The cephalic, dorsal and caudal margius are convex. The ventral margin is undulating, concave in the middle.

Viewed from above (Fig. 37) the shell is an elongate ellipse with its greatest width in the middle. The extremities are pointed. The hinge-line is siumous. Near the cephalic extremity there is a very pronounced sinuosity.

Viewed from below (Fig. 38) the general outline is the same as when viewed from above. The contact line is more sinuous than the hingeline.

Viewed from the end the shell is elliptical. It is widest in the middle and the extremities are rounded. 
The antenne bear no matatory setie on the antepenultimate joint. The terminal claws are non-pectinated and long. They are about as long as the combined lengths of the last three joints. The lower margin of the antrpenultimate joint bears a modified sensory seta. The antenna of the male is six jointed. The mandibular palp of the female is large. The antepenultimate joint bears, in addition to the usual long sensory setie, one short and stout sensory seta which is sub-rectangular in for'm with truncated ends and convex sides. It is about four times as long as wide.

The spines on the first mandibular process. of the first maxilla are not toother.

The post abdomen of the male (Fig. 36) is slender and sub-triangular. The terminal claws are slender and curved.

Habitat: Jones' Creek, Kent County, Delaware. 'The specimens that I have were collected by Mr. L. D. Hileland, March 3, 1894.

\section{GENUS CYPRIA Zenker. 1854.}

This genus, which was founded by Kenker (238), has been revised by Wenzel Vávra (221).

Antennules are seven-jointed.

Antenne in the female are five jointed; in the male they are sixjointed. The distal extremity of the fourth joint bears two olfactory setil. The natatory setie on the third joint are very long, extending way beyond the tip of the terminal claws.

The mandibular palp is much elongated; this is especially true of the terminal joint.

The palp of the first maxilla is strongly developed.

The second maxilla bears a well-developed branclial plate. In the female the palp of this member is unjointed and terminates with three setir. In the male the palp of the second maxilla forms a hooked pre. hensile organ. In that ase the left palp differs somewhat in size and configuration from the right.

The small terminal joint of the second foot, which is about onethird as long as the fourth joint, bears two enually long backwardy directed setre.

The abdominal rami are robust; the camdal seta is situated about mudway the caudal border.

The eye is large. IInscle impressions four.

Males an mumerons. The central cylinder of zenker's orgatn is surdeunded by serten whorls of ehitinous sedie. The upper part of the orean forms a blind dilated sac; the lower forms the fumnel-shaped origin of the vas deferens. The copulative organ is triangular.

The spereses of this genus are all small ovate or reniform creatures. 
Cypria exculpta S. Fischer.

Plates LXX, Figs. 1-8; LXXII, Fig. 3.

1853.-Cypris elegantula Lilljeborg (118), p. 266.

1854.- “ exculpta Fischer (65), p. 18; PI. XIX, Figs. 36-38.

1854. - " punctata Fischer (65), p. 77; Pl. III, Figs. 1.6.

1864. - “ striolata Brady (11), p. 60; Pl. III, Figs. 12-17.

1868.- “ striolata Brady (18), p. 372; Pl. XXIV, Figs. 6-10.

1880._ " gramulata Robertson (184), p. 18.

1887.- " striolata C. L. Herrick (86), p. 29; Pl. IV, Fig 3.

1889.-Cypria exculpta Brady and Norman (31), pp. 68-69; Pl. Xr, Figs. 1-4.

1894. - " exculpta C. H. Turner (215), p. 13; Pl. VII, Figs. 2-8.

1894.- " exculpta C. H. Turner (216), p. -

Length of female $0.5 \pm$ to $0.64 \mathrm{~mm}$. Height 0.33 to $0.43 \mathrm{~mm}$. Width $0.26 \mathrm{~mm}$.

The shell is thin and somewhat trausparent and is covered with a meshwork of sub longitudinal lines (Fig. 5).

Viewed from the side (Fig. 3), the shell is orbicular, highest in the midale, the two extremities being of about equal height. The cephalic, dorsal and caudal margins are convex. The ventral margin is slightly sinuate, being concave in the middle.

Tiewed from above the shell is an elongated, laterally-compressed ellipse. The two extremities are of about the same width and the line of contact is straight.

The natatory sela of the anteuna (Fig. 6) extend far beyond the terminal claws and are much longer than the entire limb. The claws on the tip of each antenna are long and slender. They are longer than the last three joints.

In the male the second maxillx (Fig.8) are dissimilar.

The tip of the second foot (Fig. 2) bears two short ectally projecting setre and two long setie which project backwards as far as the base of the antepenultimate joint.

The post-abdomen (Fig. i) is short, stout and curved. The terminal claw is strong and about half as long as the ramus. About the middle of the caudal margin of each abdominal ramus there is a short filamentous seta.

IIabitat: This species is quite abundant in shallow ponds and slowly flowing shallow creeks.

In America this species has been found at: Atlanta, Georgia (Turner, 215); Burlington, Ohio (Turuer, 215); Alabama (Herrick, 86); Fent County, Delaware (Turner, 215); Fayette County, Georgia (Turner). The specimens from Delaware were collected for me by MIr. L. D. Hileland. 


\section{Cypria opthalmica Jurine.}

Plates LXXV, Figs. 1-3, 7; LXXVI, Figs. 1-3, 5.

1820. - Monoculus opthalmicus Jurine (98), p. 178; PI. XIX, Figs. 16, 17.

1835. - Cypris compressa Baird (I), p. 100; Pl. III, Fig. 16.

1837.- " punctata Koch (102), H. 21, p. 23, Fig. 23.

1837. - " tenera Koch (102), H. 12, p. 3.

1850. - " compressa Baird (5), p. 154; Taf. XIX, Figs. 14, 14a-c.

1851. - " elegantula Fischer (63), p. 161; PI. X, Figs. 12-14.

1853. - " compressa Lilljeborg (118), p. 112; Pl. X, Figs. 16-18.

1854.-Cypria punctata Zenker (238), p. 77; Taf. III, A.

1868. - Cypris compressa Brady (18), p. 372; Pl. XXIV, Figs. 1-5; PI. XXXVI, Fig. 6.

1868. - " ovum Fric u. Nekut (70), p. 48, Fig. 30.

1872. - " ovum Fric (69), p. 213, Fig. 28.

1875. - " rompressa Brady, Crosskey, and Robertson (30), p. 123; Pl. I, Figs. 5, 6.

1879. -? Cypria neglecta Herrick (83), p. 112; Pl. XVII, Fig. 2.

1885.-Cypris punctata Nordquist, (155) p. 150.

1888. - " punctata Schwarz (199), p. 18.

1888. - " compressa Sostaric (202), p. 47.

1889. - Cypria opthalmica Brady and Norman (31), p. 69; Pl. XI, Figs. 5-9.

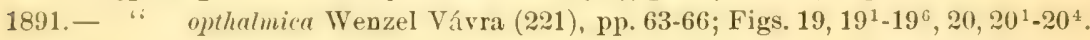

Length 0.55 to $0.58 \mathrm{~mm}$. Height 0.37 to $0.40 \mathrm{~mm}$. Width about $0.30 \mathrm{~mm}$.

The American representative appears to be somewhat wider than the European type.

The translucent shell is covered with irregularly scattered large puncta. Near the two extremities, the shell bears long hairs.

Viewed from the side the shell is reniform, widest back of the middle. Near the two extremities, the dark puncta are often so clustered as to form dark blotches. Caudal, dorsal and cephalic margins convex. Ventral margin is somewhat sinuate.

Viewed from above the shell is ovate, the cephalic end somewhat more narrow and more pointed than the caudal extremity. Hinge line is straight.

Viewed from below the contact line is sinuate.

Viewed from the end the shape is oval, much higher than wide.

For the structure of the female antenna consult Fig. 1.

For the structure of the mandible consult Fig. 5 .

For the structure of the second foot consult Fig. 2.

For the structure of the abdominal ramus consult Fig. 3.

Iabitat: : Minnesota (Herrick, S3); Baxley, Georgia. The specimens from Baxley were collected for me by Mr. A. B. Whitby. The figures were drawn from Baxley specimens. 


\title{
Cypria mons (Chambers).
}

Plate LXXXI, Figs. 6-12.

\author{
?.-Cypris mons Chambers (41), pp. 153-154, Fig. 3. \\ 1887. - " mons C. L. Herrick (86), p. 32.
}

Length $0.70 \mathrm{~mm}$. Height $0.45 \mathrm{~mm}$.

"Ovoid; tumid; highest immediately before the middle. Length $\frac{1}{3 i ;}$ inch; height $\frac{1}{5} ;$. Dorsal margin regularly arched, sloping more rapidly behind the highest point than before it. Extremities rounded; the anterior widest ventral margin very slightly sinuated. Seen from above, ovate, but less tumid than Cypridopsis vidun as figured by Baird aud Brady (Brit. Ent. and Trans. Linn. Soc.). But little or not at all narrowed in front; widest a little behind the middle. Lucid spots seven, near the middle of the valve; the three lower ones in a line and small; one of them very small. Valves white, shining smooth, with numerous almost confluent puncta. The setre of the lower antenna extend beyond the apex of the claws, and the articulate appendage of the third joint has its apex swollen or eularged. Superior antenna with two long and one short seta from the end of the fourth joint; two from the end of the fifth joint; four long ones from the end of the sixth; two long and two short from the end of the seventh (there are also other short setie on the different joints). The last joint of the inferior antenne is small, almost rudimentary, bearing a single large claw. (Indeed, it seems to be bifid, with a claw from each branch.) There are three other claws articulated to the end of the penultimate joint, from which also arise four sete shorter than the claws; two moderately long setie arise from about the middle of the fourth joint above, and three longer ones below; the usual fascicle of five long and one short setie from the third joint, just behind which is a bunch of short cilia and another bunch on the under side. Abdominal ramus straight, slender, with two claws, one under the other. The maudibular palpus, with branchial appendage and two large plumose and one simple setro from the end." (Chambers.)

I have never seen specimens of the above. It is certainly very closely related to Cypria opthulmica (Jurine), yet it seems to be distinct.

Habitat: Pond on Mount Elbert, Colorado; altitude 11,000 feet. (Chambers, 41.)

\section{Cypria inequivalva Turner.}

Plate LXViII, Figs. 1-8.

1893.-Cypria inequivalva C. H. Turner (213), pp. 6-8; Pl. I, Figs. 1-8.

1894.- " inequivalva C. H. Turner (215), p. 14.

1894.- “ inequivalva C. H. Turner (216). 
Length $0.46 \mathrm{~mm}$. to $0.52 \mathrm{~mm}$. Height $0.35 \mathrm{~mm}$. to $0.36 \mathrm{~mm}$. Width $0.26 \mathrm{~mm}$.

Shell inequivalve, one valve overlapping the other in front. Talves glossr, finely pubescent.

In fresh specimens, near the cephalic end of the shell, there is an irregular cross-shaped dorsal dark spot (Figs. $1, \ddot{2}$ ), the arms of which extend latero-rentrad along each valve for abont one-half the height of the valye. Near the caudal extremity of the shell there is another irregular dorsal dark spot. This spot is somewhat fan-shaped, with the expanded portion directed caudad. Occasionally, on the ventral surface, about one third the length of the valve from the cephalic extremity, a small dark spot is seen. In fresh specimens these markings are very pronounced; but in alcoholic specimens, they are usually more or less obscured.

Viewed from the side (Fig. 1) the shell is sub-reniform, higher near the middle. It is about twice as long as high. Dorsal margin, feebly convex; cephalic margin. convex; ventral margin, nearly straight, slightly concave in the middle; caudal margin convex.

Viewed from above (Fig. "2) the shell is sub-elliptical, inecuivalve, one valve overlapping the other in front. Shell widest near the middle. Cephalic extremity ahout as wide as the candal. All margins convex. Hinge-line straight.

Viewed from below (Fig. 3) shell presents the same outline as when riewed from above, but the line of contact of the two valves is sinuated.

Viewed from the end, the shell is oval, widest in the middle, ventral margin about as wide as dorsal.

Antennules typical for the genus.

Antennie of female (Fig. 4) composed of five joints, the joints diminishing in size from the second to the most distal joint. The second joint hearing at about the middle of its ental margin a long seta. The next joint bears at about the middle of its ental margin the usual biarticular sensory hair and at its disto-ental angle a moderately long plumose seta, this seta extends to about the base of the terminal claws. From the base of the penultimate joint arise five very long mon-plumose setie, these setie extending far beyond the tips of the terminal claws. At the middle of its ental border this joint bears a short seta, and opposite this on the ectal border there is a slightly longer setat. From the disto-ental angle of this joint arise two short sevir. From the ectal half of its distal margin arise two long claws; one of these claws extends beyond the tip of the claws springing from the terminal joint. while the other extends nearly to the tip of those claws. At the extremity of the terminal joint there are two large 
claws and two short setr; one of these setæe is located at the disto-ental angle and the other at the disto-ectal angle of the joint. The claws are smooth.

In the male the antenna is six jointed, and the terminal clars are longer and more flexible than in the female.

Mandible resembles that of Cypric exculpte Fischer.

First foot of female (Fig. 5) long and slender, composed of five joints. The most proximal joint large, the broadest of all. The next joint the shortest of all. The antepenultimate joint about as long as the most proximal, but more slender. From the margin of this joint arise two short setre. From the disto-caudal angle of this joint arises a long seta which extends to beyond the base of the termiual claws. From near the disto-cephalic angle of this joint arises a short seta. Along the cephalic margin of the penultimate joint there is a longitudinal row of fine laairs. From the disto-caudal angle of this joint arises a seta of medium length. From the extremity of the terminal joint arises a long claw; this claw is much longer than the joint and appears to be composed of two portions; a short proximal and a long distal portion. From the cephalic margin of the proximal portion arises a short seta.

Second foot of female (Fig. 6) composed of fire joints, the joints diminishing in size from the second to the most distal joint. The most proximal joint bears at about its proximo-eandal angle a long plumose seta which is as long as the joint; and from the distal third of its cephalad margin arises a somewhat shorter seta. From the distal fourth of the cephalic margin of the antepenultimate joint arises a seta. From a correspouding point on the peunltimate joint there also arises a seta. From the extremity of the terminal joint arise two long and two short setie. The two long setre are about as long as the entire limb.

The two shorter setie are but little longer than the terminal joint.

Post-abdomen (Fig. T) is curved, bearing one terminal claw and at its base a short terminal spine. On the convex surface there is a subterminal claw.

Verticillate sac (Fig. 8 ) of male as usual in this genus. It seems to be enclosed by a transparent capsule.

Habitat: This species is abundant among the grass and weeds of mauy shallow ponds. It has been found at the following places: Cincinnati, Ohio (Turner, 213); Atlanta, Georgia (Turner, 215); Fayette County, Georgia (Turner, 216). 


\section{GENUS CYCLOCYPRIS Brady \& Norman. 1889.}

This genus, founded by Brady and Norman (31), has been amended by TVenzel Vávra (221).

Antennules are seven-jointed.

The antennse of the female are five-jointed; of the male, six-jointed. There is no olfactory organ on the fourth joint. Natatory setre are very long, reaching far beyond the tip of the terminal claws. The palp of the mandible and of the first maxilla normally developed.

The second maxilla bears a branchial plate and a palp. In the female this palp is unjointed; in the male it forms a hooked prehensile organ.

The last joint of the second foot is unusually long, being two-thirds as long as the fourth joint.

Males are numerous. Zenker's organ is similar to that of Cypria. The proximal side of its central eylinder is flat. Tas deferens is loug and convoluted. The copulative organ is quadrangular.

The abdominal ramus is rolust, the caudal seta is situated at about one-third the length of the caudal border of the ramus from its distal extremity.

\section{Cyclocypris laevis (O. F. Müller.)}

Plate LXX, Figs. 9-11.

1785.-Cypris lavis Müller (149), p. 52; Pl. III, Figs. 7-9.

1820.-Monoculus ovum Jurine (98), p. 179; Pl. XIX, Figs. 18, 19.

1835.-Cypris minuta Baird (1), pp. 99; Pl. III, Fig. 9.

1837. - " "brunea Koch (102), H. X., Fig. 5.

1837. - " lepidula Koch (102), H. X. 6.

1850. - " minuta Baird (5), p. 155; PI. XVIII, Figs. 7 and 8.

1851. - " pantherina Fischer (64), p. 163; Pl. XI, Figs. 6-8.

1853.- " orum Lilljeborg (118), p. 113; Pl. X, Figs. 13-15.

1868. - “ ovum Bridy (18), p. 373; PI. XXIV, Figs. 31-34, 43-45; Pl. XXXVI, Fig. 8.

1868. - " ovum Claus (48), Pl. I, Figs. 1-5.

1874. - " ovum Brady, Crosskey \& Robertson, (30), p. 125; Pl. I, Figs. 29, 31.

1888. - " orum Schwarz (199), p. 18.

1888. - " ovum Sostaric (202), p. 46.

1889. - Cypria lavis Brady and Norman (31), p. 69.

1891. - " licxis Wenzel Varra (221), pp. 68-71, Figs. 21, 21 $1^{1}-21^{6}$.

1894. - " lavis C. H. Turner (215), pp. 14, 15; Pl. VII, Figs. 9.11.

1894. - " Tevis C. H. Turner (216).

Leugth $0.51 \mathrm{~mm}$. to $0.57 \mathrm{~mm}$. Width about $0.4 \mathrm{~mm}$.

The somewhat translucent shell is hispid and very tumid, being about as broad as it is high.

liewed from above the shell is ovate with rounded extremities. The eye, which is situated near the cephalic extrenity of the animal, is easily seen through the shell. 
The five large setre on the antepenultimate joint of the antennæ extend way beyond the tip of the terminal claws (Fig. 9). The distal extremity of each seta is plumose. According to Professor Brady* in Cypris ovum (Jurine) only two of the natatory setie of each antenna are long. In this respect Cypris ovum (Jurine) differs from the specimen under consideration; but since they are similar in all other features I consider them to be of the same species.

The terminal joint of the mandibular palp is short. 'The terminal claws of this palp extend to the tip of the mandibular teeth.

The slightly curved terminal claw of the first foot is slender and is about as long as the combined lengths of the three distal joints.

The terminal joint of the second foot is about two thirds as long as the fourth joint (Fig. 11). The long, slender, backwardly directed seta upon the distal extremity of this joint is longer than the combined lengths of the three distal joints. This joint bears at its apex two other setr; one, about the same length as the joint is directed backward, the other is very short and is directed forward.

The short post abdomen is about twice as long as its terminal claws. The stout claws are feebly curved.

Habitat: I have seen only three specimens of this species. These Professor L. D. Iileland collected in Jones' Creek, Kent County, Delaware, March 31, 1894.

\section{Cyclocypris modesta (Herrick.)}

Plate LXXII, Figs. 5, $5^{*}, 5 a$, etc.

Cypris modesta C. L. Herrick (86), p. 28; P1. IV, Fig. 5.

This species has never been seen by me. Probably its nearest ally is Cypria inequivalua Turner. The figures as well as the text of this species are taken from Professor Herrick's work (86).

"Shell sub-reniform, greatest height behiud the middle, upper outline somewhat obliquely truncate, especially in the male: color yellowish, scarcely maculate, nearly smooth. Antemie short, with long non-plumose filaments, two from the apical and four from the penultimate segment very long, others half as long: secoud antennie with three toothed claws on the penult segment, one together with three smaller ones, on the apical, anterpenult segment armed only with small bristles, preceding one with six long setie exceecling the claws; first foot slender, apical segment long conical, with a long serrate claw and bristle, other setie short; second foot (in male) with a short terminal segment armed with two very long set:e and one shorter one; caudal stylets very slender, with a terminal claw, a sub-terminal claw some-

* Recent British Ostracoda, $\mathrm{F}, 373$. 
what smaller and a weak pectinate seta one-fifth the length of the stylet from the end; palp of mandible very bristly. The intromittant organ of the male is more simple than those hitherto described, consisting of a broad, flat basal segment on either side, with a coiled ductus ejaculatorius and a funnel-shaped terminal portion cousisting of two opposable llaps. The basal segment is indistinctly two jointed and those of both sides are seated on a common prominence.

"Length of male $1.70 \mathrm{~mm}$., of female $2.16 \mathrm{~mm}$.; height of male 0.84 mm., of temale $1.24 \mathrm{~mm}$. The above measurements are too large, but express the correct proportions. It is one of the smaller species."

Habitat: ? Alabama (Herrick, 86).

\section{GENUS CYPRIDOPSIS Brady. 1868.}

The antennule is seven-jointed.

The antenna is five-jointed. The five natatory setio on the third joint are plumose.

The brauchia of the secoud maxilla consists either of a plate bearing five plumose setie or else of two setie which are inserted directly on the blade.

The second foot is five-jointed and bears, near its extremity, a strong chitinous claw.

The abdominal rami are rudimentary.

The members of this species seem to be exclusively parthenogenetic.

\section{Cypridopsis vidua (O. F. Müller.)}

Plates LXXiI, Figs. 1-1g; LXXV, Figs. 5, 6, 8, 9; LXXVI, Figs. 4, 7. 1785. - Cypris vidua O. F. Mïlller (149), p. 55; Taf. IV, Figs. 7-9. 1820. - Monoculus vidua Jurine (98), p. 175; Pl. XIX, Figs. 5-6.

1837.-Cypris maculata Koch (102), H. 10, 2.

1811. - " strigata Koch (102), H. 36, 19.

1844. - " vidue Zaddach (234), p. 35.

1850. - " vidur Baird (5), p. 152; Pl. XIX, Figs. 10-11.

1850.- " sella Baird (5), p. 158; Pl. XIX, Figs. 5, 5a.

1851.- " vidua Fischer (64), p. 162; Taf. XI, Figs. 1.2.

1853. - " vidua Lilljeborg (118), p. 111.

1854. - " vidu Zenker (238), p. 79.

1868. - Cypridopsis vidue Brady (18), p. 375; PI. XXIV, Figs. 27-36, 46.

1868.-Cypris vidue Claus (48), PI. I, Figs. 6-8.

1868. - "vidua Fric and Nekut (70), p. 48, Fig. 29.

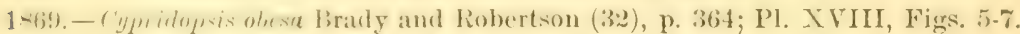

1870. - " oljesc Brady and liobertson (33), p. 15.

1870.-Cypris vidua Heller (81), p. 90.

1872.- " vidua Fric (69), 227.

1-71. - C'ypridopsis oben Brady, Crosskey and Robertson (30), p. 128; PI. I, Figs. 1-4.

1879. - Cypris vidua C. L. Herrick (83), p. 112; Pl. XVII, Fig. 1. 
1887.-Cypridopsis vidua C. L. Herrick (86), p. 33; Pl. IV, Fig. 1.

1883.-Cypris vidua Sostaric (202), p. 46.

1889. - Cypridopsis vidua Brady and Norman (31), p. 89.

1891.- " “ vidua Wenzel Vávra (221), pp. 75-77; Figs. 23, 23¹.234.

1892.- " " vidua C. H. Turner (212), p. 73.

1894. - " vidua C. H. I'urner (215), p. 19.

1894.- ‘ vidua C. H. Turner (216).

Length $0.54 \mathrm{~mm}$. to $0.7 \mathrm{~mm}$. Height $0.3 t \mathrm{~mm}$. Width $0.37 \mathrm{~mm}$. to $0.49 \mathrm{~mm}$.

The color of the tumid shell is yellowish green. The shell is covered with short sparse hairs and is marked with three characteristic dark bands (Pl. LXXY, Figs. 5, S). These bands are confined to the dorsal surface.

Tiewed from the side (PI. LAXY, Fig. 5) the shell is sub-reniform in outline, widest in the middle. Excepting a slight concavity at the middle, the ventral margin is straight. The other margins are strongly convex. Muscle impressions sub central.

Viewed from above (PI. LXXV, Fig. 8) the shell is broadiy orvid, being widest caudad of the middle. The two extremities are rounded, but the cephalic extremity is much more narrow than the other. The sides are strongly convex and the hinge-line is straight.

Viewed from below (Pl. LAXT, Fig. (3) the shell has the same general shape as when viewed from above. The contact line is sinuous and there is a slight depression in the centre.

Viewed from the cephalic end (I'l. LAXV, Fig. 9) the shell is a broad oval, being wider than high. Contact line straight.

The antenna is five-jointed (PI. LXXVI, Fig. 7 ). The terminal joint is small. A projection from the outer angle of the distal extremity of the penultimate joint extends half way the length of the terminal joint. 'Two of the terminal claws are stout and one of them bears, on its iune margin, blunt teeth. The natatory setie extend to a little beyond the tip of the terminal claws and are plumose.

'The mandible is stout. The claws of the mandibular palp extend to the tips of the mandibular terth. The antepenultimate joint of the palp bears a short, pectinated, dagger-shaped seta. As far as my observations go, the penultimate joint does not bear such a seta. The fact that the dagger shaped seta found on the penultimate joint of some Cppridae oceurs on the side renclers its detection quite difficult.

The abdominal rami (PI. TAXYI, Fig. 4) are rudimentary, the long slender terminal claw being longer than the ramus. In addition to the terminal claw there is a shorter and more slender claw.

Habitat: 'This species occurs in all kind of fresh water. I have found it in small tanks, pools, ponds, lakes, creeks and small rivers. It usually occurs in great numbers. 
In America it has been found in the following localities: Eastern United States (Herrick, S6), Georgia (Turner, 215, 216), Ohio (Turner, 212, 213), Texas (Turner 215, 216), Minnesota (Herrick, 83), West Virginia (Turner, 215).

The Texas specimens were collected by Mr. A. B. Whitby.

\section{Cypridopsis newtoni Brady and Robertson.}

Prate LXXII. Fig. 6-6h.

1870. - Cypridopsis (') newtoni Brady and Rohertson (33). p. 14, Pl. VII, Figs. 14-16. 1874. - " nextoni Brady, Crosskey and Robertson (30), p. 129; Pl. II, Figs. 20-21.

1887.- " " Tystrix C. L. Herrick (86), pp. 30, 31; Pl. IV, Fig. 6.

1889. - " (?) newtoni Brady and Norman (31), pp. 90, 91; PI.VIII, Figs. 16, 17. 1891.- " " newtoni Wenzel Varra (221), pp. 77-79; Figs. 24, 241-245.

1894. - " C. H. Turner (216).

Not having met this species, I here give Professor Herrick's description. The figures are his also.

"Length equal to about twice the greatest height which lies just behind the anterior third, anterior outline much higher than the posterior, and evenly rounded, posterior margin acutely angular, lower outline slightly concave, upper margin twice angled; shell covered with long eurved spines; color yellowish, with eight lucid spots. Antennit (first antemme) sleuder, composed of seven segments, of which

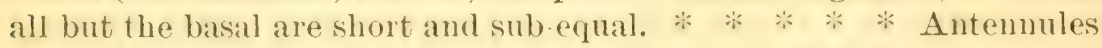
(second antenne) with very short apical segment with two strong unequal claws and a minute seta, penultimate with two equal toothed claws and a number of slender seter, third from end with five long and several short setie, preceding segment large. with three slender setie. First foot five jointed, second joint elongated, third and fourth enual, each with a single short seta, apical segment small, with two seter and a long toothed gently curved claw; last foot moderately slender, termimal joint with a small elaw and two setar at the apex and a lateral spine. Coudal stylets reeluced to minute papillar bearing a slemelere rlaw and a llestoms spine. The mouth parts bear the character's of the genus Cypris.

"In this spredes there is an anreole-like lueid zone about the anterior of the shell and a similar, hut triangular, appendage behind.

"The sperefes may be regarded as forming a transition to cypris proper, as the form if not the size of the stylets is more as in that genus."

Habitat: Minnesota (Herrick, S6). 


\section{GENUS ERPETOCYPRIS Brady and Norman. 1889.}

"General characters of the animal closely approaching those of Cypris; but the setre of the third joint of the lower antenna are short, not nearly reaching the apex of the terminal claws, and are not plumose. The second pair of jaws have branchial plates as in rypris. The power of swimming is lost, and the habits of the animals, which creep along the bottom, are thus very different from those of (yymis." (Brady and Norman).

\section{Erpetocypris minnesotensis (Herrick.)}

Plate Lxxil, Figs, 2-2h.

1887.-Cypris minnesotensis C. L. Herrick (86), p. 28; PI. IV, Fig. 2.

Length $1.60 \mathrm{~mm}$.

This species is elosely related to Erpetorypris fuscintu (O. F. Miüller). In E. fusciuta the caudal margin of the abdominal ramus is smooth, but in 2: minnesotensis it is pectinate. In $E$. fusciutr the length is three times the width, but in E. minnesstensis the length is two and one-half times the width.

The figures and the following description are from Professor Herrick $(86)$.

"From any of the American species it is at once known by the great proportionate length of the valves, which are about two and one-half times as long as broad. Lower margin nearly straight, gently sinuons near the middle, dorsal margin gently curved, highest back of the middle, then gently curved; color light, with two inconspicuous dark transverse bands on either side at about the anterior and posterior thirds; seattered hairs upon prominences are found near the margins. Antenuse (antemunles) slender, seven-jointed, apex with two very loug and one short spine, penult segment with four long setie, antepenult segment with two long plumose set:r above, preceding segment with shorter setir; second antenne with the apical segment very short and armed with one (?) serrate claw and a seta. the preceding with two claws and a lew short seta, antepenult segment with three (four?) shortish setar, not reaching end of claws: mandihle with strong lobed teeth and a large palp; first foot with a large claw; second foot slender, ending in a small hook with a single weak seta; candal stylets rather short and wide, with two strongly serrated claws, the other spines being obsolescent (?); posterior margin serrulated. Lucid spots of the shell seven in number, two being minute. Length of shell $1.6 \mathrm{~mm} . "$

Habitat: Minnesota (Herrick, 86). 


\section{Erpetocypris barbatus (Forbes.)}

Piate LXXVII.

1879. -Candona ornata (?) C. L. Herrick (83), p. 113; Pl. XX, Fig. 1.

1893.-Cyprix bartutus S. 1. Forbes (67a), pp. 214-246; PI. XXXYII, Figs. 2.3; Pl. XXXVIII.

This, which is probably the largest freshwater ostracode, is knowu to me only through the paper of Professor S. A. Forbes. The following (lescription, as well as the figures, is copied from his paper.

“An extremely large, very hairy, oblong Cypris, with rounded ends and dorsal and rentral margins nearly parallel. Length $4.0 \mathrm{~mm}$. Width $1.6 \mathrm{~mm}$. Depth $2.0 \mathrm{~mm}$. A very little deepest at hind end of hinge margin. (Depth across eye 95 per cent of greatest depth.)

"Dorsal margin about straight for a great part of its length, the ventral margin very slightly emarginate or sinuate at its anterior third. The anterior end broadly and smoothly rounded, more obliquely above than below, the posterior somewhat obliquely rounded, the ventral margin being thus nearly half as long again as the dorsal. Seen from above the shape is symmetrical, a slender oval, a little more flattened at the sides behind than before; thickest, consequently, before the middle.

"Color a dirty yellowish brown in alcohol, with a reddish-brown patch on either side above aud behind the middle. Surface of valves opaque, very minutely roughened, and well covered with conspicuous hairs, which give this ("ym) is [Emetocymris] a decidedly hairy appear. ance to the naked eye. Hairs longest before and behiud and length. ening generally towarls the margin, where they project as a fringe, the most prominent part of which is a row of hairs borne on slender conical tubercles within the margin of the valves. The valves are equal and the shell fairly full, but not plump.

"Anterior antenna with the basal segment ohliguely chammeled, partially diviling it into two, the distal part of which hears a single bristle on its superior surfice, and two lone, more slencler ones, springing together from tip of the ventral surface. A short, subpuadrate second sement hears a single seta, about as long as the segment, (1) the dorsil sulface, near the tip. From the distal end of the following sexment spring two long, slightly plumose setie, one dorsal, anr vent ral, the former much the longer. The fourth segment hears at its tip four long setas, two of which arise from the ventral angle and two flom the onter dorsal. The following segment is similarly armed, and the distal axtremities of the sixth and seventh are densely set with lomeg plumosesetio forming a stout lascolele. which extends beyond the end of the antema a distance edual to the length of the antenna itself. 
"The terminal segment of the palp of the first maxilla is a little more than a fourth the length of the basal, the latter with one subterminal bristle withont, and several terminal ones. Tip of last segment with two stout, curved, claw-like setce, and four or five smaller, softer ones. Outer lobe of maxilla proper reaching to tip of first segment of palp, nearly equaling it in diameter, also with two curved claws, shorter but much stonter than those mentioned above, three fourths as long as the lobe itself. Besides these, two smaller setie and three or more sub-terminal ones, two of which are smootb, like the terminal group, one strongly plumose. A single plumose seta also springs from near the base of the concave surface of this lobe. The second and third lobes similarly armed at the tip, but with a larger number of curved setie, all of which are solt. Two of these, on the short inner lobe, are much longer aud stouter than the others, and project directly backwards. The base of this lobe bears two plumose setie about as long as those just mentioned. The length of the inuer lobe is half that of the outer, the middle one being intermediate.

"The second maxilla with about 12 terminal setre, which diminish in length inward, most of them slightly plumose, aud two long sleuder seta, one springing from the middle of the inner margin and the other from the base. Palp thick, slender ovate, twice as long as the masticatory lobe, fringed with a soft silky pile, and bearing three more or less plumose setic at its tip, the middle one of which is the longest. Branchial lobe very small, semicircular, with three fully developed plumose setre nearly as long as the palp, and two much shorter ones, one delicate and smooth, the other stout and plumose.

"The basal segment of the second antenna trigonal, with one moderately long hair beneath, and two of similar length springing together from the inner side of the apex. The second segment subcylindrical, with two hairs diverging from the middle of the outer side of the apex, the under one of which is very short and weak, about as long as the third segment is wide, while its companion reaches about to the tip of that segment. On the inside of the tip of the second segment is another hair, similar to the above, and of abont the same length. The third segment bears, at the union of its basal with its midlle third, on the under side, set beyond a slight tooth-like projection, a jointed olfactory club, whose length is about two thirds the diameter of the segment. Otherwise this segment hears no hairs except at the tip, where, upon its inferior angle, is one long, stout hair, reaching beyoud the tip of the last joint, aud upon its inner surface a fascicle of five plumose hairs, the four longer of which are curved and parallel, while the fifth is short and straight. The third segment is slightly longer than the second and about two-thirds as thick. The fourth segment is three- 
fourths the length of the third and about two-thirds its diameter, slightly enlarged at the middle, where it bears, on the under side, a group of three long hairs, and upon the upper side two shorter ones. At the tip of the segment are a group of three long plumose hairs and a stout, curved, concave, acute claw, nearly three times the length of the last segment, doubly dentate on both edges. At tip of last segment the usually strong, curved bidentate claws, five in number, three of equal length, as long as the two last segments of the antenna, and two others about half that length.

"Maudible with a row of six dark corneous teeth, more or less bifid, the series continued in an irregular eluster of tooth-like spines, and terminating in two highly plumose set:e. The series of teeth with numerous accessory smaller teeth aud spines, and tw o transparent la melle-slender, but as long as the teeth themselves-inserted between the first and second and second and third series, respectively. The lat. ter lamella is recurved and serrate on its concave edge. Basal segment of palp longest, the third next, second and fourth sub-equal in length, the second as broad as the first. The latter bears at its posterior tip three plumose setie of unequal length, in a cluster, and a fourth larger, stouter, decurved articulate one, inserted on the outer side of the tip) of the segment. The second segment has in front a group of three slender seta inserted a little behind the tip; and opposite to them upon a stout tuberosity another group of three long equal setae, to which a fourth stands in the same relation as on the preceding segment. (On the third segment is a group of five seta similar to those on the anterior margin of the segment preceding, and, in addition, a circlet of six, attached around the posterior and imer margin of the (mol of this segment. At the tip of the palp are three curved claws, averaging as long as the two preceding segments together, with some slencler setae intermixed. The so-called branchial appendage is about as lomg as the basal segment of the palp, and bears four stout plumose seta with a small accessory seta in front.

"First leg with basal segunent columuar, clistal portion partially separated, without hair or hristle. Second segment cylindrical, its surfire smooth except for numerous transverse rows of exoredingly fine short setar, present alse on the two sueceeding serments of this

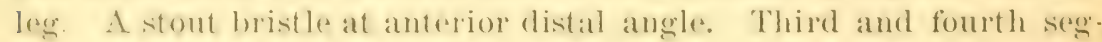

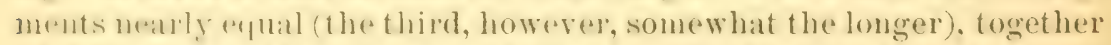
slightly lowerer than the second, the lenesth of each about twice its transverse dianeter. The third with a single apical hair at the anterior angle, and the fourth with hut two, one of which is as long as the segment itself: and the second about half that length. Terminal segment with a very long. slomeler symmetrieally curved, regularly taper- 
ing claw, with two short soft setæ springing from its base. 'The entire claw somewhat longer than the last three segments conjointly.

"Caudal rami long and slender, slightly sinuate, the transverse diameter of each not more than one-twentieth its length; the basal fifth, however, considerably thickened. Rami smooth, except posteriorly, where the margin is closely set with stout, short spines, lengthening toward the distal end of the ramus. Terminal claw slightly curved at the tip, contained two and a half times in the length of its ramus. Subterminal claw nearly two-thirds the length of the terminal, also slightly curved. Claw-like seta almost immediately above the latter, more slender, but two thirds its length. Besides the above, a short slender seta springs from in front of the base of the terminal claw.

"The first and last segments of the second pair of legs sub-equal, each two-thirds the leugth of the second; basal segment straight, its length five times its width, with three sleuder setie, one borne upon the middle of its exterior side, and two near the apex, opposite each other. Second segment slightly curved, with a single slender seta near the apex, on its onter margin. Third segment with two terminal setre, one nearly straight, claw-like, about three-fourths the length of its segment, and the other curved and blunt."

Habitat: Jellowstone River, Yellowstone Park, Wyoming (S. A. Forbes); (?) Minnesota (Herrick).

To my mind Candona ornate Herrick belongs bere. But since the figure given by Professor Herrick is about all I have to base my opinion upon, it is not thought wise to enforce this opinion upon the public.

\section{GENUS CYPRIS O. F. Müller. 1785.}

In both sexes the antenna is five-jointed. The natatory setie on the third extend to the tip of the terminal claws.

The mandibular palp does not extend beyond the tip of the mandibular teeth.

The branchial plate of the first maxilla is large, bearing stiff, plumose setce. The first mandibular process is armed with two biarticulate thorns.

The second maxilla bears a branchial plate.

The second foot resembles that of Cypridopsis.

The abdominal ramus is stout, aud terminates with two more or less stout claws, in front of which occurs a short and behind which a long seta.

Males are unknown; propagation parthenogenetic only. 


\section{Cypris fuscata Jurine.}

Plates LXXI, Figs. 41-46; LXXII, Figs. 7-7p; LXXVI, Fig. 9.

1820.-Cypris fuscata Jurine (98), p. 174; Pl. XIX, Figs. 1-2.

1837.-? " adusta Koch (102), H. II, 3.

1838. - " galbinea Koch (102), H. XXI, 19.

1844.- " fuscata Zaddach (234), p. 32.

1850. - " fusea Baird (5), p. 154; Taf. XIX, Fig. 7.

1850.-Candona hispida Baird (5), p. 161; Taf. XIX, Fig. 4.

1853.-Cypris fuscata Lilljeborg (118), p. 114; PI. X, Figs. 6-9; Pl. XII, Fig. 5.

1868. - " fusca Brady (18), p. 362; Pl. XXIII, Figs. 10-15.

1887.- " "dugesi C. L. Herrick (86), p. 26; P1. IV, Fig. 7.

1888. - " fusca Sostaric (202), p. 47.

1889. - " fuscata Brady and Norman (31), p. 73; Pl. XII, Figs. 3-4.

1891.- " fuscata Wenzel Vavra (221), pp. 98-99, Figs. 33, $33^{1}-33^{3}$.

1894. " " fuscata C. H. Turner (215), pp. 16-17; Pl. VII, Figs. 41-46.

1894. - " fuscata C. H. Turner (216).

Length of the female $1.40 \mathrm{~mm}$. to $1.50 \mathrm{~mm}$. Height $0.9 \mathrm{~mm}$. Width $0.67 \mathrm{~mm}$. to $0.73 \mathrm{~mm}$.

The greatest height of the animal is about two-thirds of the length, while the greatest width is less than the height. The color is greenish brown. 'The shell usually has attached to it furfaceous matter, which Professor IBrady thinks is desyuamating epidermis.

Yiewed from the side the cephalie third of the shell is wider than any other portion. The caudal, dorsal and cephalic borders are convex. The cephalic and caudal margins have a narow hyaline erlge. The valves are not very transparent and are covered with short, scattered hairs. Mruscle impressions near centre of the valve, about sevell.

linved from above the shell is oval, rounded behind and bluntly pointed in front. The greatest height is in the middle.

'The natatory setie of the antenna extend to the tips of the terminal ('laws. The terminal claws are stout, curved and longer than the last two joints. The distal half of the inner margin of each claw is pectinated with a double row of fine teeth.

'The two enlarged spines upon the first mandibular process are toothed. The "xtremity of each spine and the two adjacent teeth are blunt.

The first foot is five-jointed, the third and fourth joints being distinct. The terminal elaw is long and stout, longer than the combined lengths of the last three joints. The second joint is stout and about as long as the combined lengths of the next two joints.

The terminal claw of the second foot (Fig. 43) is about twice as long as the terminal joint. 
The feebly-curved post-abdomen (Fig. 46) is stout and short. The terminal claw is a little more than half as long as the abdominal ramus. The adjacent claw is about three-fourths as long as the terminal claw.

Habitat: Cincinnati, Ohio (Turner, 213); Guanajuata, Mexico (Herrick, 86); Albuquerque, New Mexico.

Cypris virens Jurine.

Plate Lxiv, Figs. 3-3e.

1820. - Monoculus virens Jurine (98), p. 174; PI. XVIII, Figs. 15-16.

1838.-Cypris qibberala Koch (102), H. XXI, 20.

1844. - " virens Zaddach (234), p. 35.

1844.- " pilosa Zaddach (234), p. 36.

1850.- " tristriate Baird (5), p. 152; Taf. XVIII, Figs. 1, 1a-1i, 2-3.

1851.- " ornata S. Fischer (63), p. 157; PI. IX, Figs. 7-10.

1853. - " virens Lilljeborg (118), p. 117; Taf. VIII, Fig. 16; Taf. IX, Figs. 4-5.

1868. - " virens Brady (18), p. 364; PI. XXIII, Figs. 23-32; PI. XXXVI, Fig. 1.

1868. - " pubera Fric and Nekut (70), p. 46, Fig. 26.

1870. - " ventricosa Brady and Robertson (33), p. 12; Pl. IV, Figs. 1-3.

1872.- " " pubera Fric (69), p. 226.

1874. - " virens Brady, Crosskey and Robertson (30), p. 124; Pl, II, Figs. 27-28.

1887.- " Helena Moniez (135), p. 2.

1887.- “ virens C. L. Herrick (86), pp. 24-26; Pl. VI, Fig. 3.

1889. - " virens Brady and Norman (31), p. 77.

1891.- " virens Wenzel Varra (221), pp. 102-104, Fig. 3; Figs. 4, 41, 42 $4^{4}$; Figs. 5, $5^{1} 5^{2}$; Figs. $36,36^{1} \cdot 36^{4}$.

Only once have I enconntered an American form which I supposed was Cypris virens. Then the specimens were accidentally destroyed before accurate drawings were made. Mr. Deming, however (Herrick, 86), claims to have found this species to be quite abundaut at Granville, Onio. The following description is due to Mr. Deming. I have taken the liberty to omit much that is merely generic and to add, in brackets, some specific eharacters.

"Talves sub-reniform, the two euds almost equal, the dorsal side evenly curved, the ventral side sinuated, highest in the middle. The valves are covered with minute hairs. The hinge-line is sinuated and unbroken. The outer part of the shell is slightly lined. The shell as seen on end is oval; seen from above, obloug orate. Lucid spots, about seven in number, are found in about the centre of the valves; these are oblong and irregular in shape, often pointing towards the ventral margin. Isolated spots are found near the dorsal side. The color is olive or yellowish green, with dark brown spots near the dorsal margin and scattered throughout the shell. * * * * * * * *

[The two biarticulate spines on the first maudibular process of the first maxilla are smooth.] 
"The post-abdomen forms two long, movable rami, which are well developed and terminated by two claws of unequal length, and in fine specimens are serrated on their inner edge near the apex. The rami themselves are also serrated." [In European specimens and in specimens tak'n by the present writer to belong to this species the abdominal rami are not serrated.]

Mr. Deming claims to have found the male of cypris virens. I have reason, howerer, for supposing that he has confounded the males of some other species (perhaps $C$. crena) with Cypris virens.

Habitat: Granville, Ohio (Herrick, 86).

\section{Cypris perelegans Herrick.}

PLATE LXXIII.

1887.-Cypris perelegans C. L. Herrick (86), p. 27; Pl. III, Figs. 7-12. 1894.-Cypris perelegans C. H. Turner (216).

Length $3.60 \mathrm{~mm}$. Height $1.72 \mathrm{~mm}$. Width $1.40 \mathrm{~mm}$.

"Carupace of largest size, elongate sub-oblong, sides nearly parallel, upper margin nearly straight, lower outline with two sinuses and two slight convexities, produced to form a slight tooth behind; greatest height at one fourth the length from the posterior, equal to less than half the length; width greatest somewhat in advance of the middle, alout four-tenths the length; color clear, pale yellow, with a well-defined pattern in deep brown, pattern consisting of a sigmoid band crossing the middle of the valves, giving off spurs at each flexure, and sundry other spots, as well as an anterior marginal band; surface shining, minutrly dotted, slightly hairy at margins; lucid spots consisting of two large irregularly pentagonal approximated spots, with three smaller ones grouped below; appendages very similar to $C$. cirens; antenne seven-jointed, slender, basal segment very large, third elongated, four succeeding nearly equal in length, fourth and fifth segments each with two long setit above, sixth with four long and one shorter setix, apiral segment with four very long seta, fifth segment with two setar of moderate length below; antemules (antenna) slender, apical secment with two serrate claws and two slender setir, fourth (antepenult) segment the same, third segment with four long and two shorter setir, second segment with six long pectinate seta reaching to end of terminal claws; labrum with claw-like appendages bearing seven texth, the inner being donble, medianly the labrum appendaged with pertinate plates: the mandibles furnished with six strong teeth, two pectinate setae and several small spines, the palp being well developed; first maxilla with short lobes, the anterior of the one -jointed lobes with four very strong toothed spines; first foot with five segments, the apical one being very small and bearing a single very long 
serrated claw, the third and fourth are equal and much more slender than the second; second foot slender, apical segment with two small claws and one delicate seta, caudal stylets elongated, narrow, serrate behind, with two straight, mnequal serrate claws, lateral spine subterminal." (Herrick, S6.)

Habitat: Mobile, Ala. (Herrick 86.)

\section{Cypris altissinus Chambers.}

Plate LXXix, Figs. 10-13.

18-.-Cypris altissimus Chambers (41), pp. 152-153, Fig. 2.

1887.-Cypris altissimus C. L. Herrick (86), v. 27.

Length $1.26 \mathrm{~mm}$. Height $0.63 \mathrm{~mm}$.

"Valves oblong, slightly subreniform, highest about the middle, rounding regularly before aud behiud; the side view resembling somewhat Baird's figure of C. tristriutu, but less distinctly reniform, perhaps rather resembling in the form of the dorsal margin Cypridopsis viduc; it is, however, much more elongate in proportion to height. Brady's figure of $C$. virens ( $=C$. tristriatu Baird) is a little nearer to this species, but is too distinctly reniform. C. virens also agrees with this species in the number (seven) of the lucid spots, and approaches it in their position on the shell, and in relation to each other, but they differ in shape. In this species, the extremities are more nearly equally rounded than in virens, the dorsal margin being evenly rounded before and behind the middle, and the ventral likewise, both before and behind the slight sinuation in the middle. But the anatomy of the appendages differs more decidedly from that of cirens, as will be seen by a comparison of the following account with Brady's figures. Superior antenne with only twelve instead of fourteen long setw, arranged as follows: There are two short setie (one longer than the other) from the third joint, which has none in Brady's figure; two short and two long ones from the fourth joint, where virens has four long ones; three long ones and one shorter one from the fifth joint, which in virens has four long ones; four long ones from the sixth joint, where tirens has only three, aud three long ones and one short one from the last joint, where virens has three long ones. In the inferior antenne similar differences are found, and in the mandibular palpus even greater ones. The feet of the first pair appear to be identical in the two species, except that this species has a short seta on each of the joints three and four, which are not represented in Mr. Brady's figure. His figure, however, shows one seta more on each of the joints two and three of the feet of the second pair than I find in this species, which likewise is much smaller than $C$. virens, being only one-twentieth of an inch long and one-fortieth high instead of one-fourteenth of an inch long and 
one twenty.fifth high, as in virens. In ventral and dorsal view it also resembles virens. Surface smooth pubescent, with minute punctures. Color bright deep green." (Chambers.)

This species has not been seen by me. It certainly is very closely related to Cypris virens, and may prove to be that species. For the present, howerer, it is thought best to regard it as a distinct species.

Inabitat: P'ond fed by melting snow, Mount Iilbert, Colorado. Altitude, about 12,000 feet. (Chambers, 41.)

\section{Cypris herricki Turner.}

PLATES LXVII, Figs. 1-10; LXVIII, Figs. 40-42; LXIX, FIGS. 32-39.

1892.-Cypris Herricki C. H. Turner (212), pp. 71-73; PI. II, Figs. 1-10.

1893.-Cypris Herricki C. II. Turner (213), pp. 11-15; Pl. I, Figs. 33-39; Pl. II, Figs. 40-42.

Length $3.0 \mathrm{~mm}$. Height $1.70 \mathrm{~mm}$. Width $1.43 \mathrm{~mm}$.

In a lateral view, the shell is sub-triangular, highest near the middle. The ventral margin is straight, excepting at the cephalic extremity, where, after a shallow concave notch, the margin is convex. The remainder of the margin is strongly convex. From the above described ventral notch, a well defined, feebly convex, line passes dorsal to the opposite margin. That portion of the shell which lies cephalad of this line is usually curved laterad. From within the ceplatic and caudal extremities of the valves numerous hairs protrucle.

In a dorsal view, the shell is sub fusiform, being widest caudad of the middle. At their caudad extremity the valves are slightly divaricated, while at their cephalad extremity they are closely approximated. The shell is covered with fine reticulations and minute hairs. In addition to these, it is marked with conspicnous dark green bands. These hands are arranged as follows: One, parallel to and almost adjacent to the mesal border of the shell, extends from the caudo-rentrad angle of the shell dorso-cephalad almost to the cephalad extremity of the valve. There it divides. One portion continues in the same course to the cephalo-ventral extremity of the valve. The other, turning laterad, passes ventrad for a short distance and terminates in a sharp point. At the origin of this line there is a large, convex blotch, which extends ventrad a short distance. Near the centre of the figure several bands fuse in such a manner as to form a hollow, sub-square figure. From the cophalo-dorsal corner of the square a tongue passes ventrocaudad into the symare. Thr length of this tongue and the angles it makes with the sides of the square vary slightly in different individ. mals. Tsually it extends almost to the centre. From this same angle of the shell a hand projects ectad. Alter passing cephalad a short 
distance, this baud forms a convex curve and passes caudo-dorsad almost to the margin of the shell. From the caudo dorsal angle of the square a short band passes dorso caudad and fuses with a broader band which passes caudad, approximately parallel to the dorsal margin of the shell. From this same corner another band passes cando-ventrad almost to the caudal margin of the shell. This band is approximately parallel to the band just described. From the caudo-ventral angle of the square a band passes caudo-rentrad almost to the caudo-ventral extremity of the shell. In the caudal portion of its course this band curves dorsad, otherwise it is approximately parallel to the band last described. From the cephalo-ventral angle of the square, a short band projects ventrad and then broadening, forms a boot-shape band. The short heel of this boot projects eaudad and terminates in a point, the long toe extends cephalad and terminates bluntly. From the same corner of the square, a second band projects cephalad to about the level of the toe of the hoot. There it fuses with a spike shaped hand which extends cephalo-ventrad from near the cephalo-dorsal angle of the square to about the cephalo-ventral extremity of the shell. The head of the spike is at the caudo-dorsal extremity of the band. The two bands fuse near the head.

The number of lueid spots is ahout eight. They are situated in the centre of the valve and ordinarily are inclosed within the square above deseribed.

Viewed from the ventral surface one valve overlaps the other in front. The contact line is sinuous, being laterally convex at the middle.

Viewed from the end the shell is oval in shape, the greatest width being near the dorsal surface.

Antennse slender; the natatory setre on the distal extremity of the third joint reach almost or quite to the tip of the long aud slender terminal claws.

The mandible is stout. Among other setro, the antepenultimate joint of mandibular palp bears a short, pectinated, dagger-shape seta; so does the peuultimate joint.

The two biarticulate claws on the first mandibular process of the first maxilla are smooth. The extremity of that same process bears two setie as long as the biarticulate claws; one, which is curved and smooth, is situated at the outer angle and the other, which is straight and pectinated, is situated about the middle of the extremity.

The terminal claw of the first leg is almost as long as the entire limb. The distal two-thirds is pectinated.

The post-abdomen is long, slender and straight. The distal portion of its outer margin is pectinated. The terminal claws are curved and are a little longer than half the length of the abdominal rami. 
Habitat: Cinciunati, Ohio. Very abundant in a shallow canal basin in Camp Washington. Up to date it has not been found in any other locality.

\section{LATE LARVAL HISTORY OF CYPRIS HERRICKI.}

Plates LXVIII, Figs. 40-42; LXIX, Figs. 33-39.

In this commection it is not intended to discuss the early stages of (ypris Itericlic. These remarks will be confined to what correspouds to the seventh to ninth eedyces of Cypria opthalmica Jurine. Not only that, but the remarks will be restrieted to the external morphology. It is hoped to discuss the internal anatomy in a subsequent paper.

The earliest stage here discussed has been compared to the seventh stage of Cypria opthalmica Jurine, because in that stage the appendages have attained about their permanent form; but it must not be supposed that in this Cypris there are only two subsequent larval stages. These stages are tabulated in the following table:

\begin{tabular}{|c|c|c|c|c|}
\hline Stages. & Length. & Height. & Position of Dorsal Hump, Etc. & Form of Post-abdomen. \\
\hline$A$ & $0.90 \mathrm{~mm}$ & $0.57 \mathrm{~mm}$. & $\begin{array}{l}\text { Some distance in front of middle. } \\
\text { Teeth on caudal margin of shell. }\end{array}$ & $\begin{array}{l}\text { Rudimentary; fewer spines } \\
\text { than in adult; terminal } \\
\text { about as long as or longer } \\
\text { than remainder of the ap. } \\
\text { pendage. }\end{array}$ \\
\hline $\mathrm{B}$ & $\begin{array}{l}1.32 \mathrm{~mm} \\
\text { to } \\
1.35 \mathrm{~mm}\end{array}$ & $\begin{array}{l}0.71 \mathrm{~mm} . \\
10 \\
0.81 \mathrm{~mm} .\end{array}$ & $\begin{array}{l}\text { Approaching middle. } \\
\text { Teeth on shell much larger. }\end{array}$ & $\begin{array}{l}\text { Form normal; number of } \\
\text { spines normal; ratio of the } \\
\text { length of the post-abdomen } \\
\text { greater than in adult. }\end{array}$ \\
\hline $\mathrm{C}$ & $1.98 \mathrm{~mm}$. & $1.20 \mathrm{~mm}$ & $\begin{array}{l}\text { Near tbe middle. } \\
\text { Teeth on shell large. }\end{array}$ & $\begin{array}{l}\text { Ratio of the length of ter- } \\
\text { minal spine to the lel gih of } \\
\text { post-abdomen more yearly } \\
\text { normal than in } B \text {. }\end{array}$ \\
\hline $\mathrm{D}$ & $2.79 \mathrm{~mm}$ & $1.64 \mathrm{~mm}$ & $\begin{array}{l}\text { At middle. } \\
\text { Teeth disappearing. }\end{array}$ & About as in adult. \\
\hline Adult. & $3.00 \mathrm{~mm}$ & & $\begin{array}{l}\text { At middle. } \\
\text { No teeth on shell. }\end{array}$ & \\
\hline
\end{tabular}

In ryprin opthulmica (Jurine) Clans found that by the time the seventh stage was reached, the shell had practically assumed its final form. In the form here described there are pronounced differences betwern the earliest stage here considered and the adult.

In the adult of Cypris Irevidit the dorsal border of the shell is almost uniformly convex and the cephalic border of the shell is about the same height as the caudal. In stage A (Fig. 33), however, the shell is highest near the cephalic extremity, and the cephalic border of the shell is higher than the eaudal. As the animal passes through stages IB to I), the highest point of shell moves gradually towards the middle and the height of the caudal margin of the shell approaches more and more the height of the cephalic margin. 
In the adult Cypris Herricki the caudal margin of the shell is entire. But in stage $A$, the caudal margin of the shell is bordered with minute teeth (Fig. 34). In this stage the teeth are quite small and might easily be overlooked; but in stage B (Fig. 35), these teeth have become very conspicuous. Indeed, they are the characteristic feature of the shell. These teeth are present throughout stages A to D, but in stage $D$ they have beguu to disappear. In the adult stage there is no trace of these teeth.

A careful study of the adult shows that the shell is covered with hairs. These hairs are very conspicuous in stage $A$. The shell of the adult is marked with very conspicuous dark bands.

An effort has been made to discover at what period these bands appear, and to see if they conform to the rules laid down by Professor Eimer. The characteristic bauds on the shell may be present in any stage from $A$ to the adult; and when they are present they do not differ essentially from the markings on the adult. The chief points of difference being variatious in the width of the bands. In all examples of stages Cand D examined, these characteristic markings were found; but in stages $\mathrm{A}$ and $\mathrm{B}$, they were occasionally absent. An examination of Fig. 35 will show that some of these bands are longitudinal while others are oblique.

Professor Eimer has attempted to establish the following rule for the formation of oblique markings on animals.* Oblique markings first appear as longitudinal lines. These lines become resolved into dots, these dots, in turn, rearrange themselves in oblique lines. If these laws were applicable to the markings on Cymis Iterricki, in stages $\mathrm{A}$ and $\mathrm{B}$, where we have some specimens with bands and others without them, we ought to find some transition stages-some stages in which the oblique markings were represented either by parallel lines, or by series of dots. But such is not the case. The shell is either unmarked by bands, or both oblique and lougitudiual bands are present.

As stated above, in stage A the appendages have practically assumed their permanent form. The post-abdomen is a notable exception. This appendage is quite rudimentary; not ouly has it not yet acquired the typical number of setr, but the longest terminal seta is as long as, or longer than, the remainder of the post-abdomen. This great relative length of the terminal seta is due, not to an over-derelopment of the seta, but to an under-development of the body of the post-abdomen. That the post-abdomen appears to be the last appendage to development is rendered more striking by the dispovery of $C$. Claus that the post abdomen appears before the formation of the sec-

\footnotetext{
* G. H. Th. Eimer. Orranic Evolution as the iz ssult of the Inheritanse of Acquired Characters According to the Laws of Organic Growth. Translated by J. T. Cunningham, 1890, P.73.
} 
ond pair of legs. In stage $B$ the post-abdomen has developed the permanent number of setie, but the ratio of the leogth of the terminal seta to the length of the hody of the member is much greater than in the adult. In passing through stages $C$ and $D$, the parts of the postabdomeu gradually assume the proportions of the adult.

Every precaution has been taken to be sure that all the stages above deseribed were stages of one and the same animal. A definite number of each stage was isolated in saucers of water aud a record kept of the number placed in each sancer, and also of the stage of growth exhibited by each set at time of isolation. The water used was collected from a pool which did not contain any Ostracodes which in the least resembled those under consideration. As a further precaution the water was allowed to stand in the laboratory a couple of weeks. The loss in volume was replaced by river water, taken from the eity hydrant. I never have found any ostracode in said river. 'Thus there was no possibility of the water containing the eggs of rypris herridli. The larval stages which were placed in this water were examined from time to time. In every case the specimens derel oped into the adult form.

The morphological differences between the shell of stage B and the shell of stage $A$, and between the shell of stage $B$ and the adult, are certainly as great as the morphological differences between the shells of closely allied species. The morphological differences between stage $A$ and the adult are differences, not only in the shell structure, but also in the structure of the post abdomen. And these differences are as great as those between the genus ('ymris and the genus ('ym)idopsis. These facts show that shell structure of Ostracodes, when taken alone, is of almost no taxonomic value.

These facts also have phylogenetie significance. These various larval stages are resting stages in the development of ('ypris herricki. since it is true that the ontogenetic development of an incividual is a rapid and compact repetition of its phylogenetic history, these larval forms must represent past stages in the evolution of cypris herricti. As has been stated above, stage A corresponds very closely to the genus cypridopsis. The main distinction between the genus rypris and the genus (ypridopsis is the difference in the form of the post-abdomen. In the genus cypridopsis the body of the postabdomen is but slightly developed. while the setar are quite long. In stage $A$, in the larval history of "ypris herridit the post-abdomen is in this rudimentary condition: thus it corresponds very closely to the genus ('ypridop. sis. Not only that, but the unbanded forms of this stage correspond rery closely to cypridopsis hystrie Herrick." Indeed, when this stage

*C. L. Ierrick. Contribution to the Fauna of the Gulf of Mexico and the Soutb. 1837. P.30, Pl. V, Fig. 6 . 
was first encountered, it was supposed to be a Cypridopsis. While working at its anatomy a specimen with the markings characteristic of cypris herricli was discovered. This led to an investigation of the larval history of the crustacean.

These facts give us a very strong hint that the genus Cypris has been evolved directly from the genus Cypridopsis. Should future research show that all members of the genus 'ypris have a ('ypridopsis stage, the discovery would give much weight to the hint. And if, at the same time, the interual structure should prove to be similar, the evidence would be conclusive.

\section{Cypris (?) albuquerquensis sp. n.}

Plate LXXVIII.

Length $0.5 \mathrm{~mm}$. Height $0.28 \mathrm{~mm}$. Width $0.35 \mathrm{~mm}$.

This is a small greenish hirsute shell abont twice as long as high and much wider than high.

Viewed from the side (Fig. 1) it is sub-reniform. The two extremities are rounded, but the cephalic is broader than the caudal. The dorsal margin is convex, the ventral nearly straight.

Viewed from above (Fig. 2) the shell is a broad oval, widest near the middle. The cephalic extremity is a trifle narrower than the caudal. Hingeline straight.

The terminal claws of the antenna are loug, slender and non-pectinate. The natatory setie on the antepenultimate joint do not extend beyond the tip of the terminal claws.

The feet are stout.

For details consult Plate LXXVIII, Figs. 1-7.

This species has not been encountered by the anthor. The description is based on drawings furnished by Professor C. L. I Ierrick.

Habitat: Albuquerque, New Mexico.

The data at my disposial render it impossible for me to rightly classify or characterize the following species: 1 . ayilis I Laldeman (7S), C. discolor Haldeman (7S), C. sculbre Haldeman (7S), (?. simplex Haldeman (78), r. vitreu IIaldeman (6s), (?. hispidı De Kay (58).

\section{GENUS CYPRINOTUS Brady. 1855.}

This genus was first establislied by Professor Brady (26) in 15.5.) to include a peculiar form that had been discovered by Mr. A. Ifaly in Ceylon. Professor Sars (195) in 1859 amended the gents in such a way as to make it include all the sexually propagated forms of the old genus Cypris. In this paper Professor Sars' description has been 
sufficiently modified to include the American forms that propagate sexually. It is presumed that Professor Wenzel Vivra, who objects to the genus Erpefocypris (221), will also object to this one. The species of this group, however, are closely related both anatomically and physiologically, and it is thought that most workers will welcome the division of the old genus Cypris into the several genera here given.

Shell rather thin, compressed, oval or sub-triangular, height exceeding half the length, dorsal margin strongly arched, ventral almost straight. Valves usually unequal, the left valve overlapping the right. The free edges of left valve smooth, cephalic and caudal extremity usually bordered with a hyaliue flange. The free cephalic end of right valve usually armed with tuberculiform teeth. Natatory sete of antenne reach beyond the tip of the terminal claw. Abdominal rami are slender, with smooth or very finely pectinated claws.

Propagation is sexual. Copulative organs are small, with an outer linguiform obtuse plate. The cylindrical core of Zenker's organ bears numerous wreaths of spines.

\section{Cyprinotus incongruens Ramdohr.}

Plate LXVIII, Figs. 9-16.

1808. -Cypris incongruens Ramdohr (173), p. 86; Taf. III, Figs. 1-12, 15, 16, 18-20.

1820.-Monoculus conchaceus Jurine (98), p. 171; PI. XVII, Figs. 7-8.

1820. - " ruber Jurine (98), p. 172; Pl. XVIII, Figs. 3-4.

1820.- “ $\quad$ - aurantiacus Jurine (98), p. 173; Pl. XVIII, Figs. 5-12.

1821.-Cypris fusca Straus (205), p. 59; Taf. I, Figs. 1-16.

1844. - " aurantia Zaddach (234), p. 37.

1844.-?" opthalma Koch (:02), H. 36, p. 17.

1850. - " aurantia Baird (5), p. 159; Taf. XIX, Fig. 13.

1853. - " incongruens Lilljeborg (118), p. 119; Taf. IX, Figs. 6-7; 'Taf. XI, Figs. 1-4; 'Taf. XII, Fig. 6.

1855. - " aurantia S. Fischer (65), p. 650; Pl. I, Figs. 29-31, 60, 61.

1868. - " incongruens Brady (18), p. 73; Pl. XXIIr, Figs. 16-22.

1868.- " fusea Fric and Nekut (70), p. 47, Fig. 28.

1872. - " fusca Fric (69), p. 212, Fig. 26.

1889. - " incongruens Brady aud Norman (31), p. 73; Pl. XII, Figs. 8-9.

1891.- “ incongruens Wenzel Vávra (221), pp. 95-98; Figs. 32, $32^{1}-32^{6}$.

1893.- " incongruens C. H. Turner (213), p. 8; Pl. I, Figs. 9-16; PI. II, Fig3. 17-21.

Length $1.35 \mathrm{~mm}$. Height $0.75 \mathrm{~mm}$.

The shell is equivalve, one valve overlapping the other in front. The shell is yellowish brown in color and is covered with seattered hairs.

Viewed from the side (Fig.9) the shell is sub-reniform, widest near the middle. both extremities rounded and of mearly the same width; the cophalic extremity may be a trifle narrower than the caudal. Ventral margin nearly straight, other margins convex. 
Viewed from above (Fig. 10) the shell is ovoid, pointed in front and rounded behind. The greatest width is caudad of the middle. Hingeline straight.

Viewed from below (Fig. 11) the contact line is straight.

The claws on the antenna (Fig. 13) are toothed. The plumose natatory setre reach to the extremity of the terminal claws.

No dagger-shaped seta visible on either the penultimate or antepenultimate joint of the mandibular palp.

The biarticulate claws on the first mandibular process of the first maxilla toothed.

The claw of the first foot is long, slender, fiuely pectinated and curved.

The abdominal ramus is short, feeble and slightly curved. The terminal claw is long, slender, slightly curved, pectinated near the end. The claw is about two thirds as long as the entire ramus.

I have never encountered any males of this species; but since Wenzel Varra (221) has found males of this species in Bohemia, aud since it is anatomically closely related to the other members of this group, I include it in this genus.

Habitat: Rare. Cincinnati, Ohio (Turner, 213).

Cyprinotus crena Turner.

Pr.ATes LXVII, Figs. 11-13; LXIX, Figs. 22-31.

189.2-Cypris sp. (?) C. H. Turner (212). p. 71; Pl. II, Figs 11-13

1893. - " crenata C. H. Turner (213), p. 9; Pl. II, Figs. 22.32.

Length of female $1.23 \mathrm{~mm}$. Height $0.63 \mathrm{~mm}$. Width $0.60 \mathrm{~mm}$. Length of male $1.14 \mathrm{~mm}$. Height $0.60 \mathrm{~mm}$. Width $0.45 \mathrm{~mm}$.

The shell is equivalve, very thin, the free margins of one valve are bordered with blunt teeth. The ventral margins of both valves bear hairs. Shell reticulated with contorted lines; the reticulations are most distinct on the rephalic portion of valve. Lucid spots about nine, sub-central. Color, various shades of greenish yellow. The caudal half of shell of male appears to be marked with concentric retort shaped lines. Since the shell is very thin this appearance is due to the presence of spermatozoa or spermatophores within the shell.

Viewed from the side (Fig. 22) the shell is sub-reniform, highest about the middle, cephalic and candal extremities about the same width. Caudal, dorsal, and cephalie margins convex; ventral margin nearly straight, slightly convex at the middle.

Viewed from above (Fig. 23) the shell is sub oval, widest behind the middle. Caudal margin rounded, cephalic margin bluntly pointed. Hingeline sinuate. 
Tiewerl from below (Fig. 24) same as when riewed from above. Line of contact of valves sinuate.

Virwerl from end (Fig 25) shell is oral, a little higher than wide.

Antemules (Fig. 25 ) and antenne as usual in genus Cypris.

The mandible (Fig.26) terminates in four large teeth; between each two of these teoth there is a short, slender rod. The mandibular palp consists of four joints. The first joint is very large, about as large as the combined lengths of the other three; it bears about the middle of its dorsal surface a branchial appendage, which in turn bears four long setie: and from the distal fifth of its ventral surface arise two long setie. The antepenultimate joint is very short; from the distal half of its dorsal surface arise two long setse and one short one. The peunltimate joint is long; from its disto dorsal extremity arise three long aucl one short setre; from the disto-ventral angle of the shell arise two short setce. The terminal joint is very narrow and about as short as the antepenultimate joint; at its tip it bears four short claws.

The hiarticulate claws on the first mandibular process of the first maxilla are smooth.

The first foot of the male (Fig. 27) is composed of five joints. The second joint is large. The antepenultimate joint is about as long as the preceding joint. From its disto caudal margin arises a medium sized seta, and from its disto cephalic margin arises a somewhat smaller seta. The terminal joint is about the same size as the penutimate. From its clisto-caudal margin arise a medium size seta and a small spine: from its disto-cephalic margin arises a very short spine. From the distal end of joint arises a long claw; the claw is about as long as the combined lengths of the three distal joints. The claw is composed of a short basal and a long terminal portion. At the distocauclal portion of the basal joint of claw there is a short seta; at the disto-cephalic margin of the same joint there is a somewhat smaller seata. I row of fine hairs extends along the midelle portions of the caudal margin of the terminal joint of the claw.

In the second foot of the male the antepenultimate joint is medium simel. From about the middle of this joint arises a merlian seta, and from the disto-ancial marenin a long seta. The pemmltimate joint is the longent joint: from its disto-cephalio margin arises a median spine. The trominal joint is about as long as the antepenult: from the midclle of its cephalic border arises a short seta; from its tip arises a short seta: from itstip) a more or less corved short colaw and a median seta.

The post almbomen (Fig. 29) of male is curved. At its tip there is a lone claw and a short selat. Entad of this terminal elaw is another long raw: furtherentall arises a short seta. P'ost-abdomen of female is straighter, otherwise the same. 
In the male there is a pair of verticillate sacs (Fig. 30). From the distal extremity of each arises a vas deferens. Length of sac $0.35 \mathrm{~mm}$.; width $0.11 \mathrm{~mm}$. The copulative organ of male consists of distinct halves, each half of which is composed of a large basal and a small terminal portion. The basal portion of each division receives at its proximal end a vas deferens. Length of copulative organ $0.37 \mathrm{~mm}$. ; width $0.11 \mathrm{~mm}$.

Habitat: Small weedy ponds or caual basins. I have not found these very often; but whenever found they were very abundant. On one occasion I found a pool containing millions of males, but not a single female. Specimens of this species have been found at (iucinnati, Ohio. (Turner, 213.)

\section{Cyprinotus burlingtonensis Turner.}

Plate LXX, Fras. 14-23.

1894.-Cypris burlingtonensis C. H. Turner (2:5), pp. 17-19; Pl. VII, Figs. 14-23.

1894. - " burlingtonensis C. H. Turner (216).

Length of the female $1.6 \mathrm{~mm}$. Width $0.59 \mathrm{~mm}$. ILeight $0.93 \mathrm{~mm}$. Length of the male $1.3 \mathrm{~mm}$. Width $0.7 \mathrm{~mm}$. Height $0.7 \mathrm{~mm}$.

The length of the shell is a little less than twice the width and the height is about equal to the width. The shell is very thin and is covered with long hairs (Fig. 15). The shell is also marked with certain dark bands, which are due, in part at least, to the internal organs shining through the translucent shell.

Viewed from the side (Fig. 1i) the shell is sub oval, but the cephalic extremity is wider than the caudal. The dorsal margin is convex, the greatest convexity being nearer the cephalic than the caudal extremity. The cephalic and caudal margins are convex. The ventral margin is nearly straight.

Viewed from above the shell is sub-elliptical, the two extremities being more or less pointed (Fig. 17) and of about equal width. In some specimens the ends are romud. The sides are feebly convex, indeed in some parts they are almost straight and nearly parallel.

Viewed from the end the shell is nearly circular, the sides being very convex.

The antenna consists of five joints (Fig. 20), the fourth joint being very long and slender. The distal joint is narrow, being no wider than the base of the terminal claws. The terminal claws are slender and the distal portion of each is fringed by a longitudiual row of very fine teeth. The natatory setre extend to a short distance beyond the tip of the terminal claws. 
The second joint of the mandibular palp bears, in addition to the usual setre, a short, plumose, dagger-shaped seta (Fig. 18). The terminal claws of the palp are slender and smooth.

The two prominent spines upon the first mandibular process of the first maxilla bear teeth (Fig. 16).

The palp of the second maxilla terminates in three long flexible spines. The middle spine is longer than the whole palp, but the lateral ones are only about two-thirds as loug as the middle one.

The first foot (Fig. 21) is five-jointed, the third aud fourth joints being distinct. The second joint is broad and is as long as the united lengths of the next three joints. The terminal claw is longer than the nnited lengths of the last three joints. The distal third of the cephalic margin of this claw is finely pectinated.

The claw upon the last joint of the second foot (Fig. 23) is curved and is about twice as long as the terminal joint.

The post-abdominal rami (Fig. 19) are slender and straight. The terminal claws are long and sleuder, being about half as long as the ramus. They are straight and one margin of the tip of each is finely pectinated. The lower claw is fully three-fourths as long as the distal one and resembles it in structure.

Habitat: These are found in great numbers in a shallow grassy pool at Burlington, Ohio. They were found in the early part of March, 1893, just after the close of a long and severe winter; indeed, there was a light snow-fall the day before the collection was made. Judging by the lay of the land, I think that the pool dries up in summer.

It Atlanta, ( reorgia, just after some heavy rains in .Tanuary, 1594, large numbers of these active creatures were found in several shallow pools in the South River bottoms. These pools dry up in warm weather. The speeimens remained for about two weeks and then disappeared. Length $1.58 \mathrm{~mm}$.; height $0.94 \mathrm{~mm}$.; width $0.91 \mathrm{~mm}$. Jones Creek, Kent county, Delaware, March 3, 1594, collected by Professor L. I). Hileland. These were immature specimens about $1.4 \mathrm{~mm}$. long.

\section{Cyprinotus grandis Chambers.}

\section{PLATE LIXIX, Figs. 1-9.}

\section{- - Cypris grandis V. 'T. Chambers (41), pp. 151-152, Fig. 1.}

1887.-Cypris grandis C. L. Herrick (86), p. 32.

Length $3.60 \mathrm{~mm}$. Height $2.09 \mathrm{~mm}$. Width $1.39 \mathrm{~mm}$.

"Valve ohlong, slightly sub-reniform, highest behind the middle, sloping thence resularly towarl the anterior end, with a slight bulge on the hingre-malnin just where it rounds off in frout. Greatest thickmess about the middle. In side view somewhat resembling Irady's 
figure of $C$. tessellata (Trans. Linn. Soc., v. 26, Pl. 23, Fig. 39), but this species is longer in proportion to height and has the highest point of the dorsal margin a little farther behind. Ventral margin very slightly emarginate. In dorsal and ventral view somewhat resembling Brady's figure of Macrocypris minne (loc. cit., Pl. 28, Fig. 34). Right [? left] slightly overlapping the left [? right]; surface smooth, with minute punctures and short hairs, but with a group of scattered, large sordid, yellowish punctures about the middle of each valve. Color bluish-white (nearly that of thin milk), though some specimens show a decided pale greenish tinge. Basal joint of superior antenne with two short setse above and one below; second joint with a single short one below; third with two short unequal setre above and one below; fourth with two above like those of the third, and two long ones below; fifth as the fourth; sixth with the two upper setæas in the third and fourth, but with four long ones below; seventh with two long and two shorter setae. Inferior antenne with one moderately long and two short claws, and two seta from the end of the last joint, and with four long claws (one shorter than the other three), and one moderately long seta, and one long one from the end of the penultimate joint, besides four rather long ones above, and two beneath about its middle. Third joint with the nsual single stout seta from its end beneath, and the usual fascicle of five long and one short one above near the end, and the usual articulated process. P'ost-abdomiual ramus similar to that of C. incongruens as figured by Brady (loc. cit., PI. 23, Fig. 20), but longer, having three unequal setre, the terminal one longest. Seminal gland very similar to that of Notodromas monachus (loc. eit., Pl. 37, Fig. 36). Length $\frac{1}{7}$ of an inch; height $\frac{1}{12}$; greatest thickness $\frac{1}{1} 8$. Probably the largest known species of the geuus. It is abundant in the ponds along the upper Arkansas river in the Mount Harvard region, at an altitude of about 8,000 feet. When first taken, my specimens were brownish from adhering mud, but alcoholic specimens have the livid white color above mentioned. The lucid spots are indistinct and difficult to make out; there are about nine, the two anterior obliquely transverse and long, the two posterior small." (V.T. Chambers.)

Habitat: Upper Arkansas river in Mount Harrard region. (V.T. Chambers.)

\section{FAMILY DARWINULIDE.}

"Antenne destitute of swimming setre and of poison gland and duct. Mandible-palp three-jointed; the basal joint large and densely setiferous. Two pairs of jaws, the first bearing a large branchial plate, the second a smaller branchial plate and a pediform palp. Two pairs of feet external to the valves. Post-abdominal lobes sub-conical, small." (Brady and Norman.) 


\section{GENUS DARWINULA Brady and Robertson. 1870.}

"Shtell smooth, thin, and fragile. Carapace oblong, higher behind than in front: lucid spots ten to twelve in number, linear-oblong or wedge-shaped, arranged in a subradiate manner in front of the centre of the valve. Seen from the side, compressed, oblong, sub ovate. Seen from above, orate, acuminate in front, obtusely rounded behind. Valves unequal, the right much larger than the left. Anteunules very short, six-jointed, and stout, strongly armed with short and stont curved setie. Antennic four-jointed, and bearing four or five strong terminal claws; entirely destitute of poison gland or urticating setre, the place of which is occupied by a single curved seta of molerate length. Mandible broad, truncated at the distal extremity, which is provided with six or seven small spiniform teeth: palp three jointed, its basal joint very wide and fringed with several curved seta, bearing also a small lamina, fringed with branchial filaments; second joint loug, slender, and nearly four times as long as broad, slightly curred and dilated at the distal extremity, where it bears one long aud two small setie; terminal joint more slender, about two thirds of the length of the foregoing, aud bearing at the truncate apex about six slender curved spines. First maxilla divided into four short setiferous segments, and bearing a very long oblong palp, which is fringed with about twenty four long branchial filaments, and has also four other long setat at its base. Second maxilla simple, short, and broad, truncate at the apex, and fringed on the distal margin with several slender spine-lilie hairs, bearing also a large, three jointed, pediform palp, and an ovate branchial appendage of moderate size. Two pairs of feet of moderate size, five-jointed; second pair much the longest, and having the last joint armed with one long and two small curved set:e first three joints of nearly equal length; fouth and fifth, respectively, ahout one-half and one third as long as the preceding. Abdomen ('nding in a short conical process. ('opulative organs of the male of (omplex structure, the basal portion of an irregularly shaped plate produced laterally into an aliform process, and on the distal margin into a short, strong hook. Female probably viviparous." (IBraly and Norman, 31.)

\section{Darwinula improvisa $\mathrm{sp} . \mathrm{n}$.}

Plate LXXXI, Figs. 1-3, 13.

Idength of female $0.68 \mathrm{~mm}$. IItight $0.27 \mathrm{~mm}$. Width $0.24 \mathrm{~mm}$. Length of male $0.70 \mathrm{~mm}$. Height $0.23 \mathrm{~mm}$.

The right valve is larger than the left and overlaps it on the ventral sicks. I' the female the height is more than one-third of the 
length and the width is less than the height. In the male the height is about one-third of the length. The color is yellow, with two green blotches, one on each side, in front of the middle. These patches of pigment are on the animal but show conspicuously through the translucent valves. The female carries her young in the enlarged caudal portion of the valves. These are white and show distiuctly throngh the valves.

Viewed from the side the shell is oblong, depressed in front, broadest caudad of the middle. The two extremities are rounded, the cephalic end is narrow, while the caudal one is broad.

Viewed from above the shell is ovate acuminate, widest near the caudal extremity. The cephalic extremity is pointed while the caudal is broad and notched where the two unequal valves meet.

The antenules are stout and appear to be composed of only five joints. In this respect as well as in the arrangement of the setie this member differs from the corresponding member of $I$ ). stewnsoni.

The antenne are stout and are composed of five joints. The long terminal claws are as loug as the combined lengths of the last three joints. The antepenultimate joint bears a conspicuous one jointed appendage which terminates in one long and ont short filament. Here we have another marked difference between this species and $D$. stevensoni.

The mandible bears a three-jointed palp, to the terminal joint of which is appended a lamina bearing several long curved filaments.

The second maxilla bears a leg-like palp. The first foot is stout and five-jointed. The second foot is not bordered by a fringe of hairs. For arrangement of the setæ consult the figures.

The second foot consists of five joints; the termiual claw is longer than that of the first foot. Like the first foot, none of its members are borlered with short hairs. For the arrangement of setie consult the figures.

The abdomen terminates in a pointed process.

IIabitat: The only specimens yet found were collected in a sand bottom reservoir at Atlanta, Georgia, Sept. 1, 1894. This reservoir is about three miles in circumference and is fed by creeks which arise a short distance off at the watershed of the state. 



\section{PLATES}

AND

$$
\text { EXPLANATIONS }
$$





\section{EXPLANATION OF PLATE I.}




\section{Limnocalanus macrurus Sars.}

Firi,

1. Left foot of the fifth pair in the male.

2. Right foot of the same pair.

3. Foot of the fifth pair in the female.

4. Abdomen.

\section{Eurytemora afhinis Poppe.}

5. Female from above.

6. Right antenna.

7. Fifth foot of female.

S. Feet of fifth pair in the male.

9. First foot.

10. One of the swimming feet.

Pseudodiaptomus pelagicus Herrick.

11. Lateral view of female with ovisac and spermatophore.

12. Fifth feet of female.

13. Fifth feet of male.

14. Portion of right male autenna.

15. One of the swimming feet.

16. Abdomen of male.

17. Antenumles.

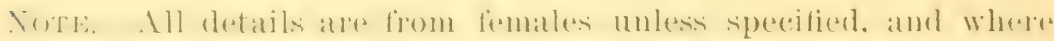

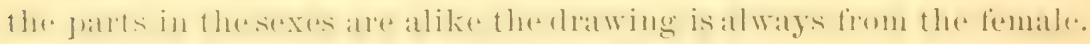


Youd. Survey of Miñ., II, ISes. $11.111 ; 1$.
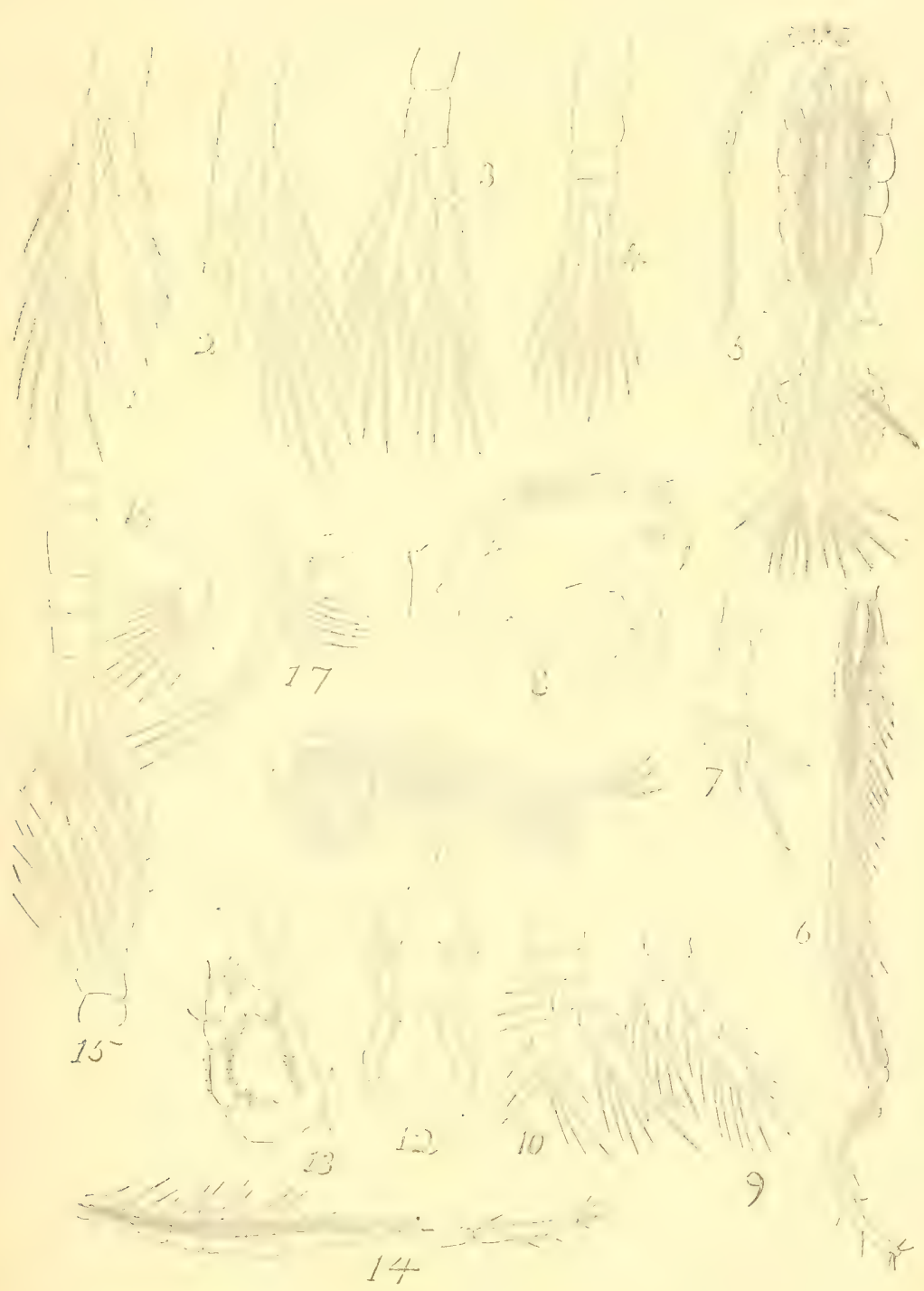

EXPLANATION OF PLATE II. 


\section{Diaptomus leptopus Forbes.}

Fir.

1. Lateral view of female. Shaded portions purple.

2. Dorsal view of the male. To the same scale.

3. Abdomen of the female from above.

4. Fifth foot of the female.

5. Maxilliped.

6. Antennule.

7. Fifth foot of the male.

8. Fourth foot of the female.

9. Right antenna of the male.

10. First foot.

All the figures are from specimens taken near Minneapolis, Minnesota. Mostly camera lucida drawings copied mechanically. 

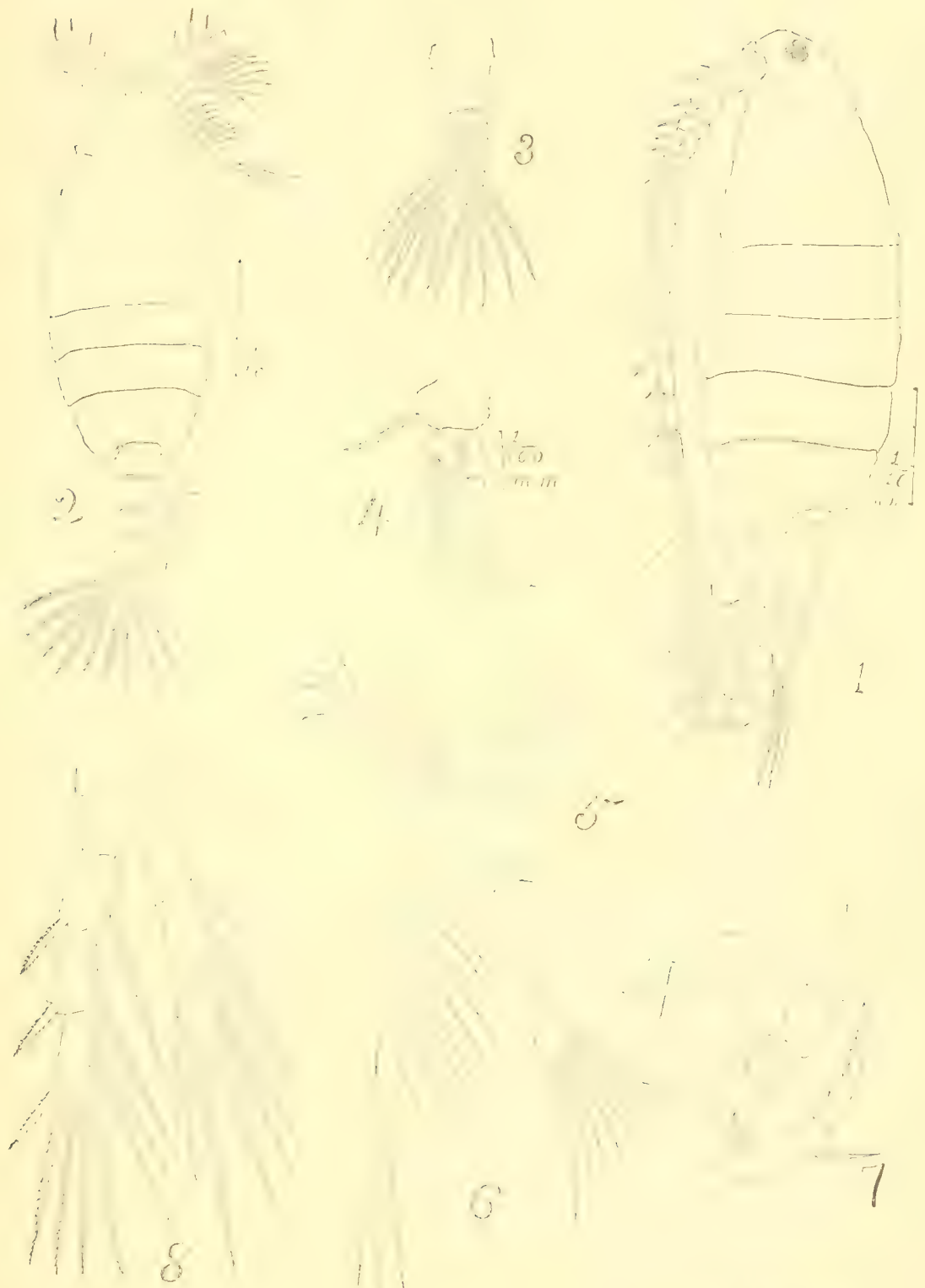

49
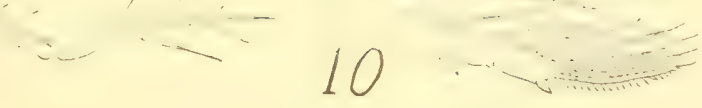

EXPLANATION OF PLATE III. 
Diaptomus stagnalis Forbes.

Fig.

1. Female from above.

2. Male from above.

3. Portion of male right antenna-a variant.

4. Stylet of the female.

5. Fifth foot of the female.

6. Fifth feet of the male.

7. Antennule.

8. Maxilliped.

9. First foot of the male.

10. First foot of the female.

11. 'Third foot of the male.

12. Fourth foot of the male.

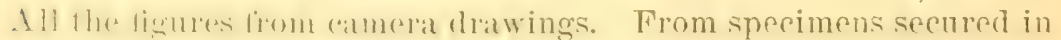
Granville, Ohio, in spring. 
Zool. Survey of Minn., II, I895.

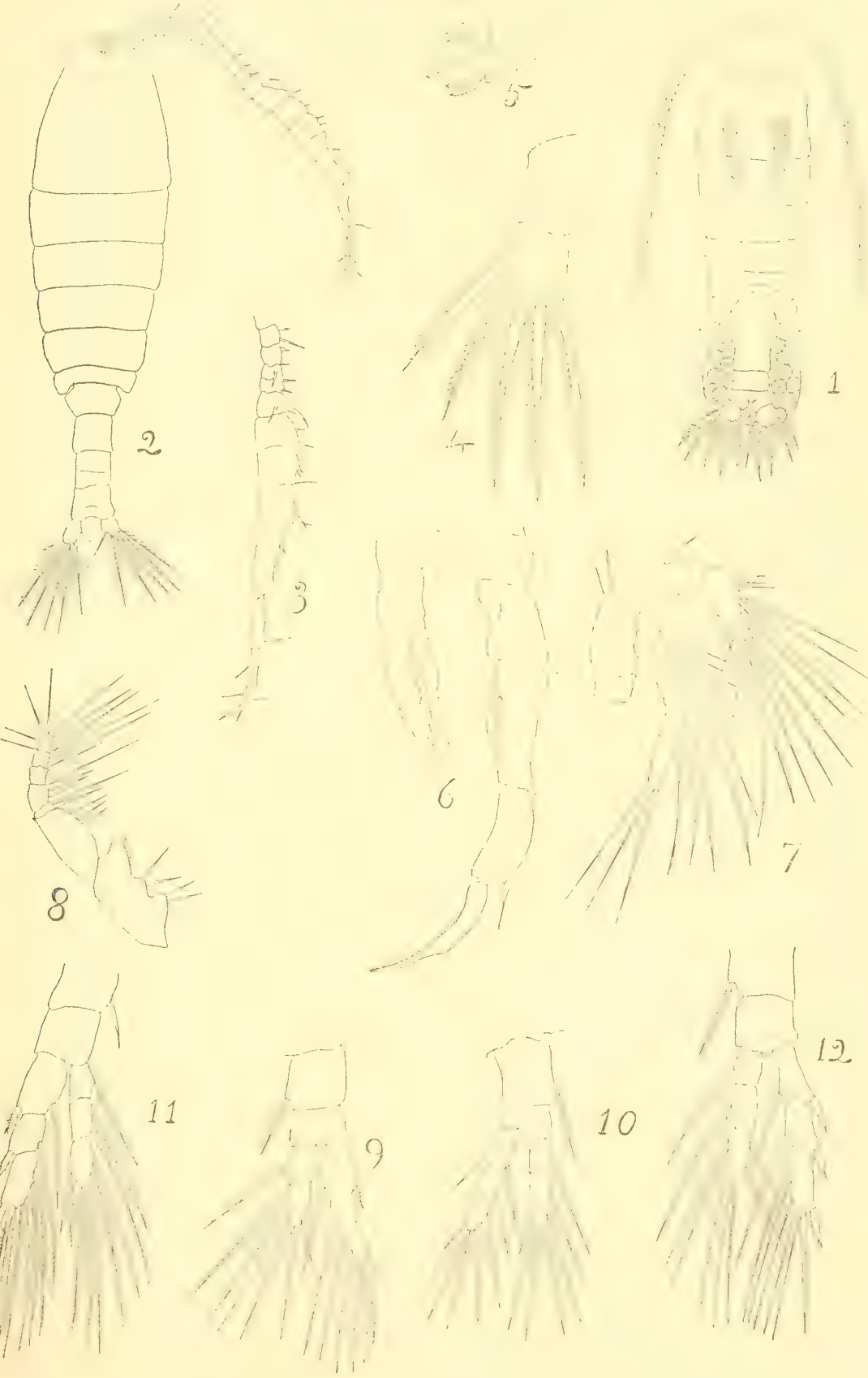



EXPLANATION OF PLATE IV. 


\section{Diaptomus pallidus Herrick.}

FiG.

1. Lateral view of preimago (immature) female.

2. Right antenna of male.

3. Fifth feet of the male as they usually appear.

4. Fifth feet of the female. From Mimmeapolis specimens.

5. Feet of fourth pair.

6. Fifth fert of the male, showing the true nature of the appendages of the left foot. The inner ramus of the left foot is not shown in the figure.

Diaptomus oregonensis Lilljeborg.

7. Right antenna of the male.

s. Fifth feet of the male.

9. Fifth foot of the female.

10. Palpus of the mandible.

11. Left foot of the fifth pair according to Lilljeborg.

12. Fnd of the female antenna.

All but Fig. 11 from specimens from Lake Minnetonka, near Minneapolis, Minnesota. 
ZoOl. Survey of MinN, II, IS95.
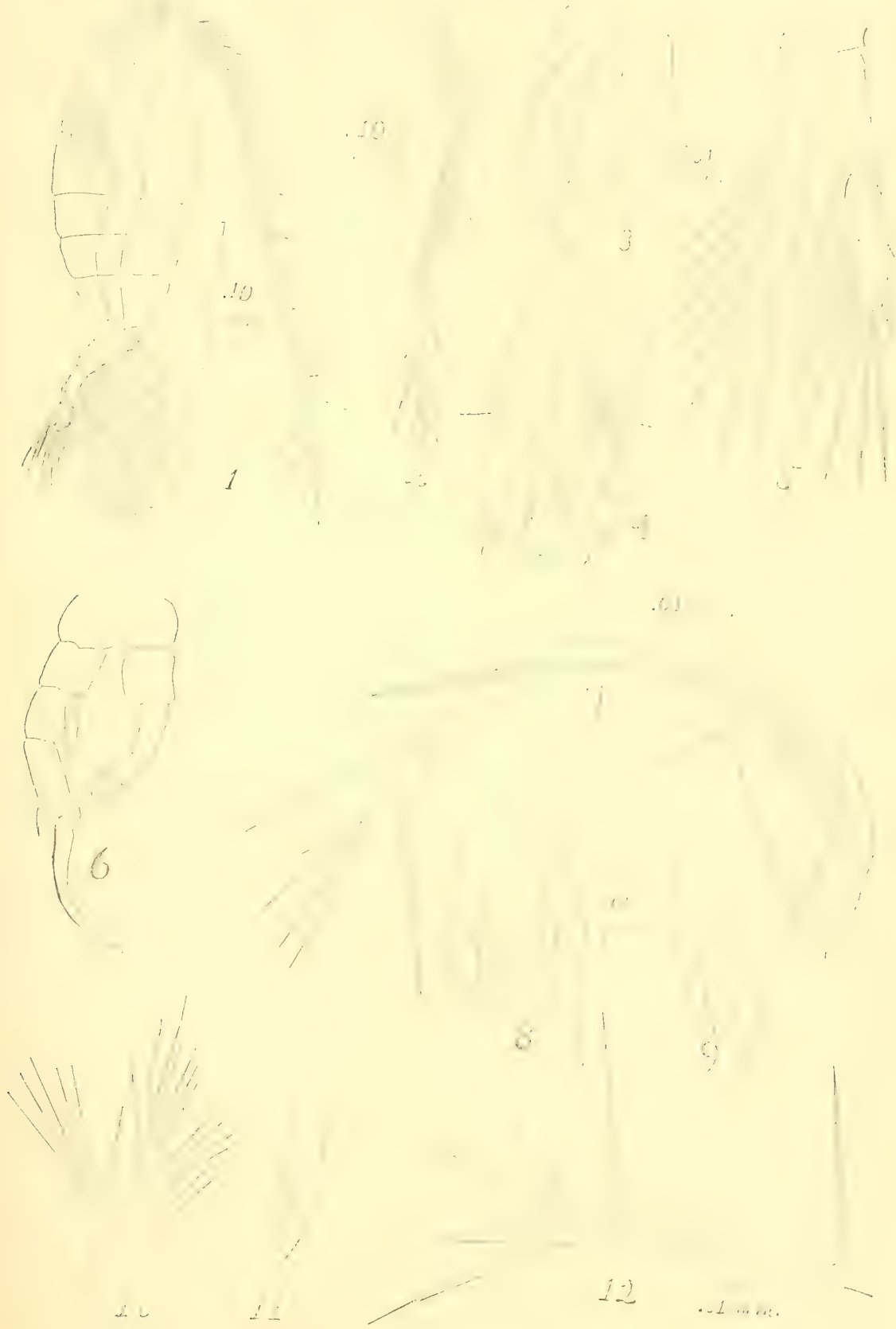

EXPLANATION OF PLATE V. 
Diaptomus sicilis Forbes.

Fif.

1. Dorsal view of the female.

2 . Dorsal view of the male.

$\therefore$ Right antenna of the male.

4. Fifth foot of the female. A series of fine hairs on the inner aspect of the one-jointed ramus is omitted in the figure.

5. Fifth feet of the male.

(i. Antennules.

i. Stylet.

Diaptomus sanguineus Forbes.

s. Fifth foot of the male.

). Male right antenna. From Granville, Ohio,

10. Diaptomus pallidus Herrick. Lateral ontline.

11. $\because \quad$ shoshone Forbes. Fifth feet of male.

1.. $\quad 66 \quad$ lintoni Forbes. 66 6 66

1:i. 66 piscine Forbes. 6 6 6 66 The small hairs at the rend of the one-juinted ramus of the left leg are onitted in the figure. 
ZUOL. SURIEY OF MINN, II, $1 \$ 95$.

PIATE V.
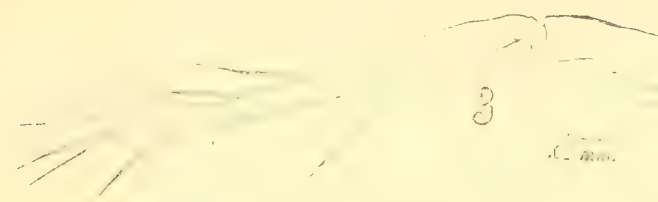<smiles>C1=C[C@@H]2CC[C@H]1C2</smiles>
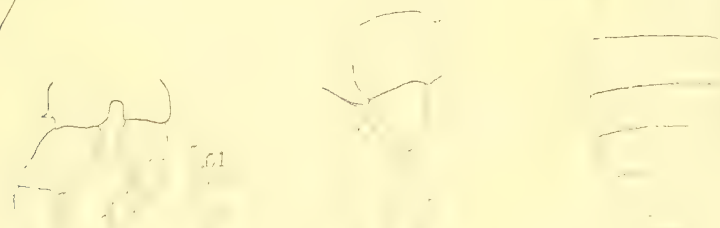

$\pm$
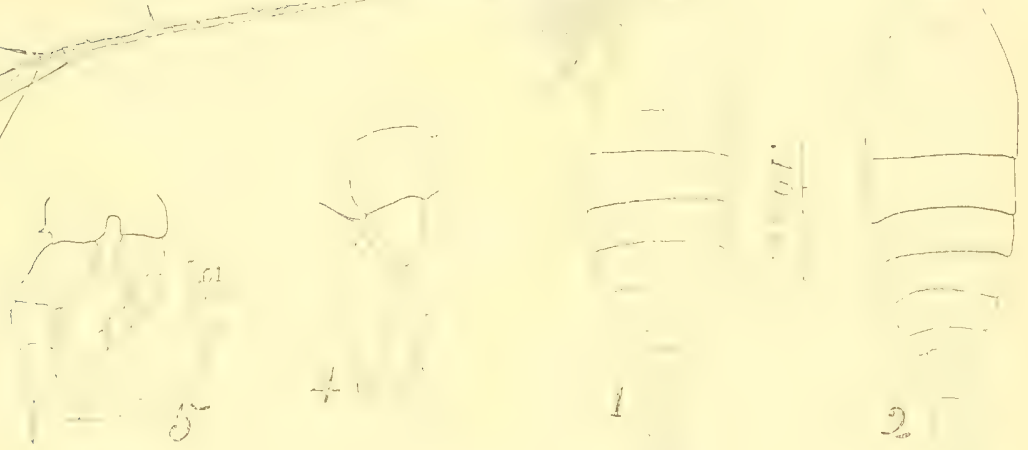

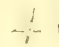

i

2

$\therefore \ldots$

ii

6

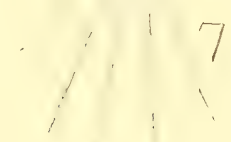

c,

$i$
0
$\vdots$
$\vdots$

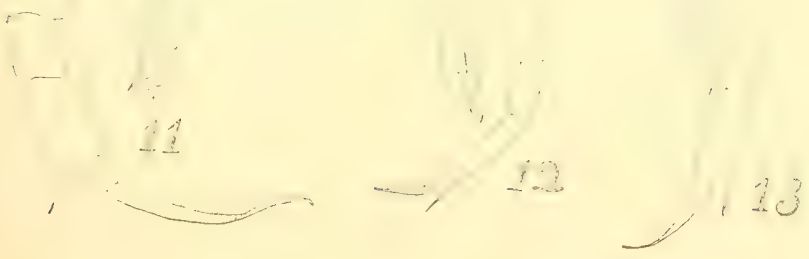

il) 

EXPLANATION OF PLATE VI. 
Diaptomus albuquerquensis Herrick.

Fici. Fifth feet of the male.

2. Extremity of the right antenna of the male.

3 . Fifth foot of the female in one-jointed condition.

\section{Diaptomus ashlandi Marsh.}

4. Extremity of the right antenna of the male.

5. Fifth foot of the female.

(i. Fifth feet of the male.

\section{Diaptomus novamexicanus Herrick.}

7. Female, from above.

s. Portion of the right antenna of the male. The hyaline plate on the antepenult segment is incorrectly represented as depressed in the midale.

9. Fifth foot of the female.

10. Fifth feet of the male.

11. Cyclops ater Herrick. Fifth foot.

12. " " ater Herrick. Fourth foot.

1:3. 6 capilliferus Forbes. Antenna. 
ZOOL. SURYEY Or MINN., II, I 895.
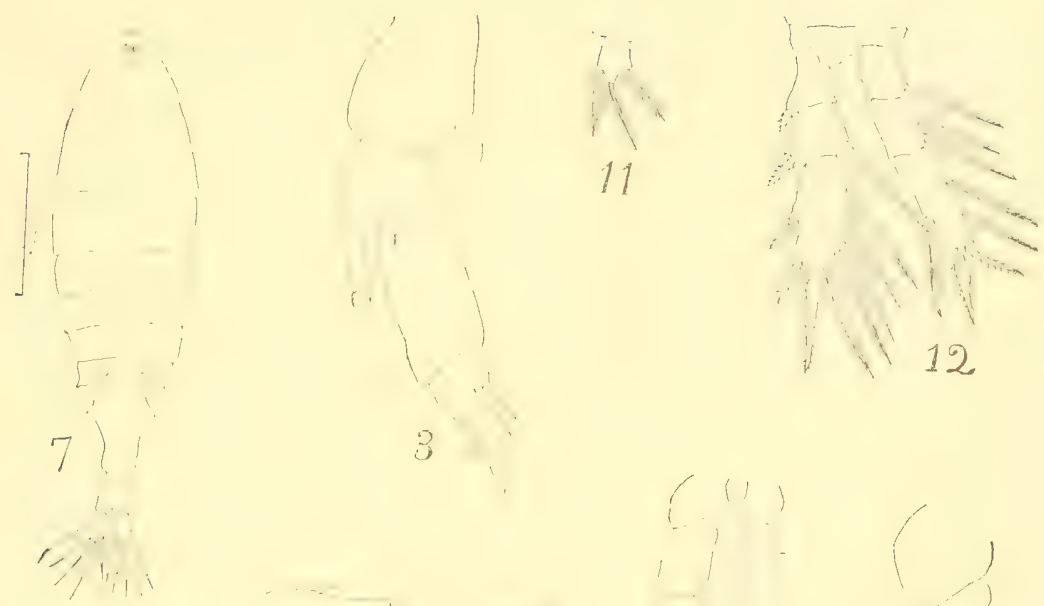

3
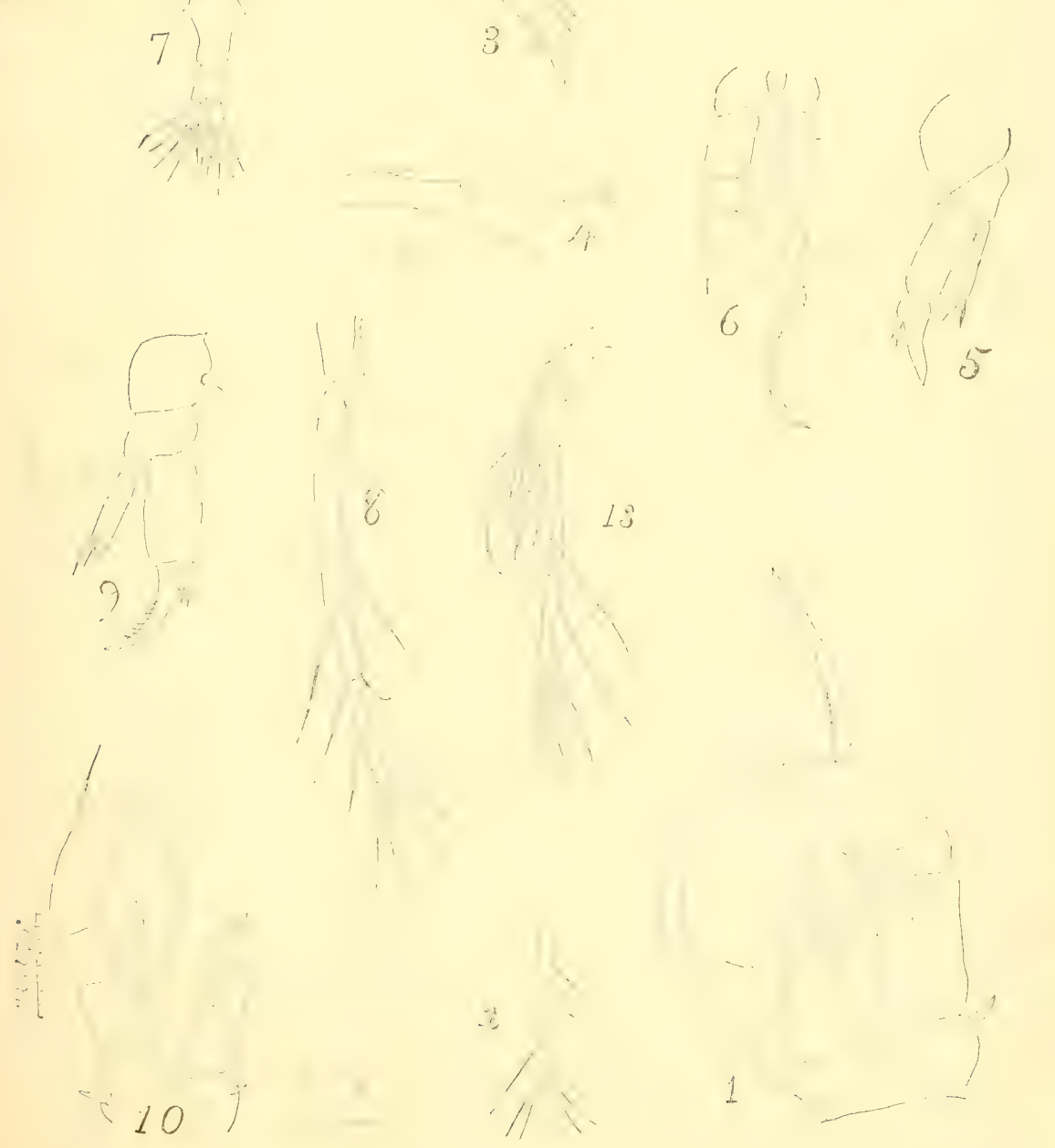

\%

10
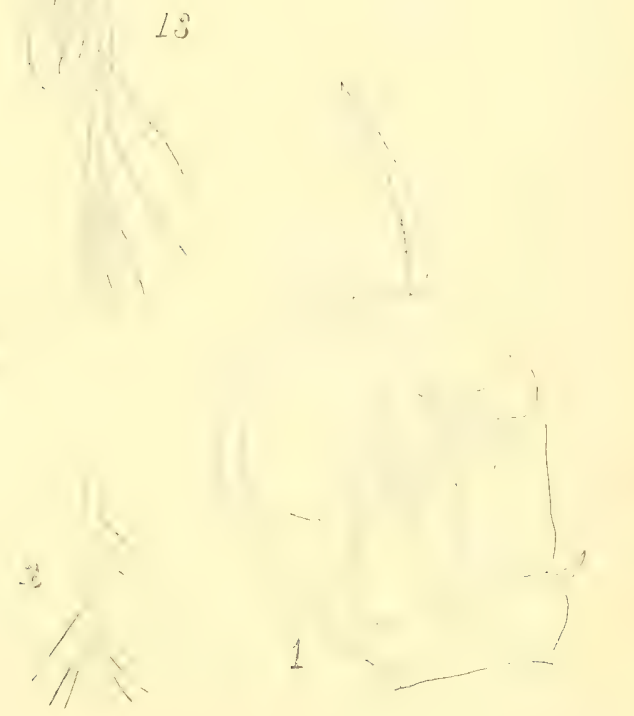

EXPLANATION OF PLATE VII. 
Diaptomus albuguerquensis Herrick.

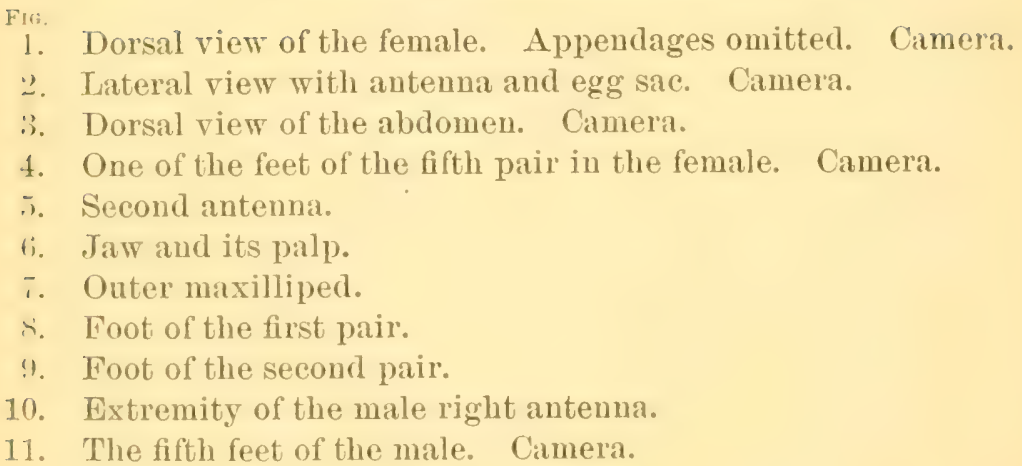


ZOOL. SURVET OF MINN. II, IS95.
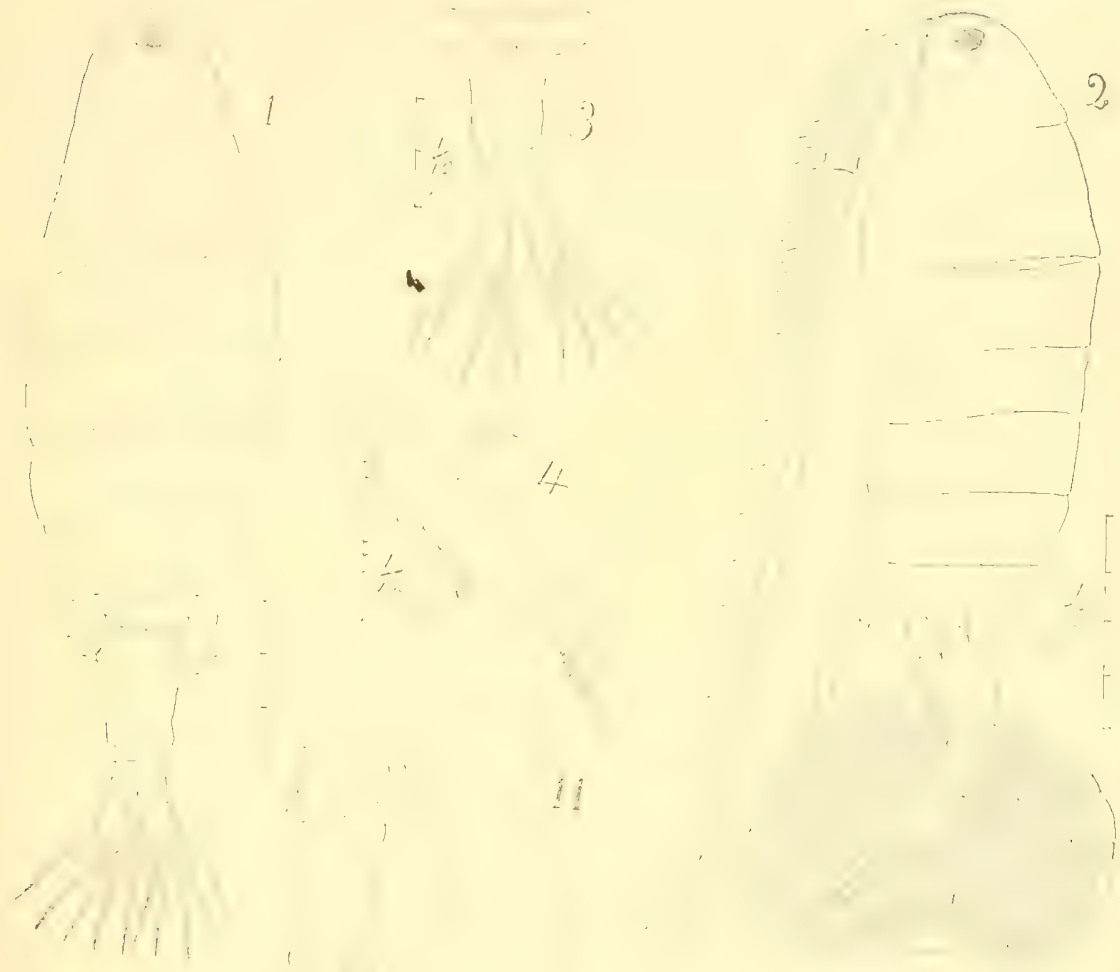

i)

$\therefore \quad \%$

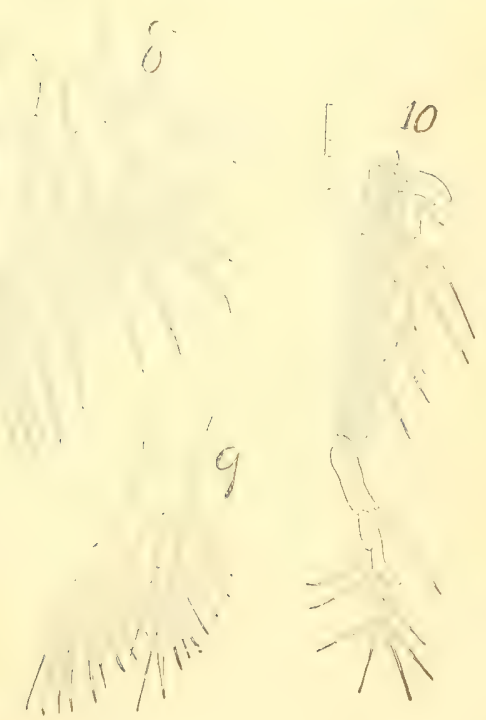

$\therefore-\therefore$ 

EXPLANATION OF PLATE VIII. 


\begin{tabular}{|c|c|c|}
\hline 1. & Diaptomus $g$ & gibber Poppe. Fifth foot of male. \\
\hline 2. & 66 & roubaui Richard. Fifth foot of male. \\
\hline 3. & 6 & Salinus Daday. Fifth foot of male. \\
\hline 4. & " & wierzejskii Richard. Fifth foot of male. \\
\hline 5. & “ & richardi Schmeil. Fifth foot of male. \\
\hline 6. & 6 & incongruens Poppe. Fifth foot of male. \\
\hline 7. & "6 & lobatus Lilljeborg. Fifth foot of male. \\
\hline 8. & 66 & milus Lilljeborg. Fifth foot of male. \\
\hline 9. & “6 & minutus Lilljeborg. Fifth foot of male. \\
\hline 10. & 6 & siciloides Lilljeborg. Fifth foot of male. \\
\hline 11. & "6 & theeli Lilljeborg. Fifth foot of male. \\
\hline 12. & " & firanciscanus Lilljeborg. Fifth foot of male. \\
\hline 13. & “ & signicaudatus Lilljeborg. Fifth foot of male. \\
\hline 14. & "6 & serricornis Lilljeborg. Fifth foot of male. \\
\hline 15. & “ & laciniatus Lilljeborg. Fifth foot of male. \\
\hline 16. & 6 & $\begin{array}{l}\text { franciscanus Lilljeborg. Antepenultimate joint of } \\
\text { right male antenna. }\end{array}$ \\
\hline 17 & $"$ & $\begin{array}{l}\text { trybomi Lilljehorg. Antepenultimate joint of right } \\
\text { male antenna. }\end{array}$ \\
\hline
\end{tabular}



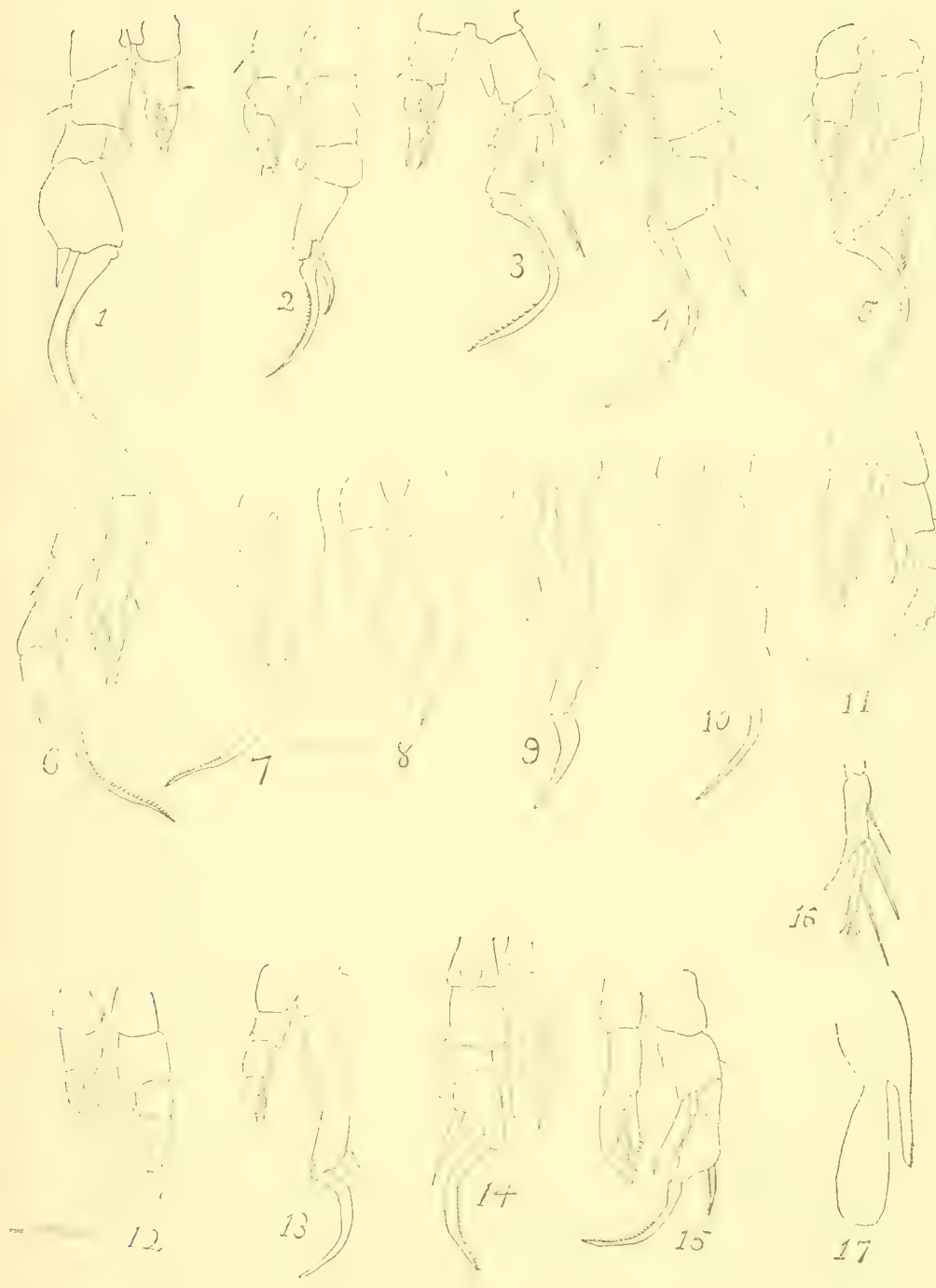



\section{EXPLANATION OF PLATE IX.}


1. Diaptomus gracilis Sars. Fifth foot of male.

2. "6 amblyodon Marenzeller. Fifth foot of male.

3. " " oregonensis Lilljeborg. Fifth foot of male.

4. " $\quad$ trybomi Lilljeborg. Fift foot of male.

5. 6 castor Jurine. Fifth foot of male.

6. " lilljeborgi De Guerne and Richard. Fifth foot of male.

7. " corruleus Fischer. Fifth foot of male.

8. " " glacialis Lilljeborg. Fifth foot of male.

$9 . \quad$ " 6 leptopus Forbes. Fifth foot of male.

10. " signicaudatus Lilljeborg. Abdomen.

11. " roubaui Richard. Abdomen.

12. " serricornis Lilljeborg. Antepenult joint of right male antenna.

13. " wiermejskii Richard. Antepenult joint of right male antenna. 


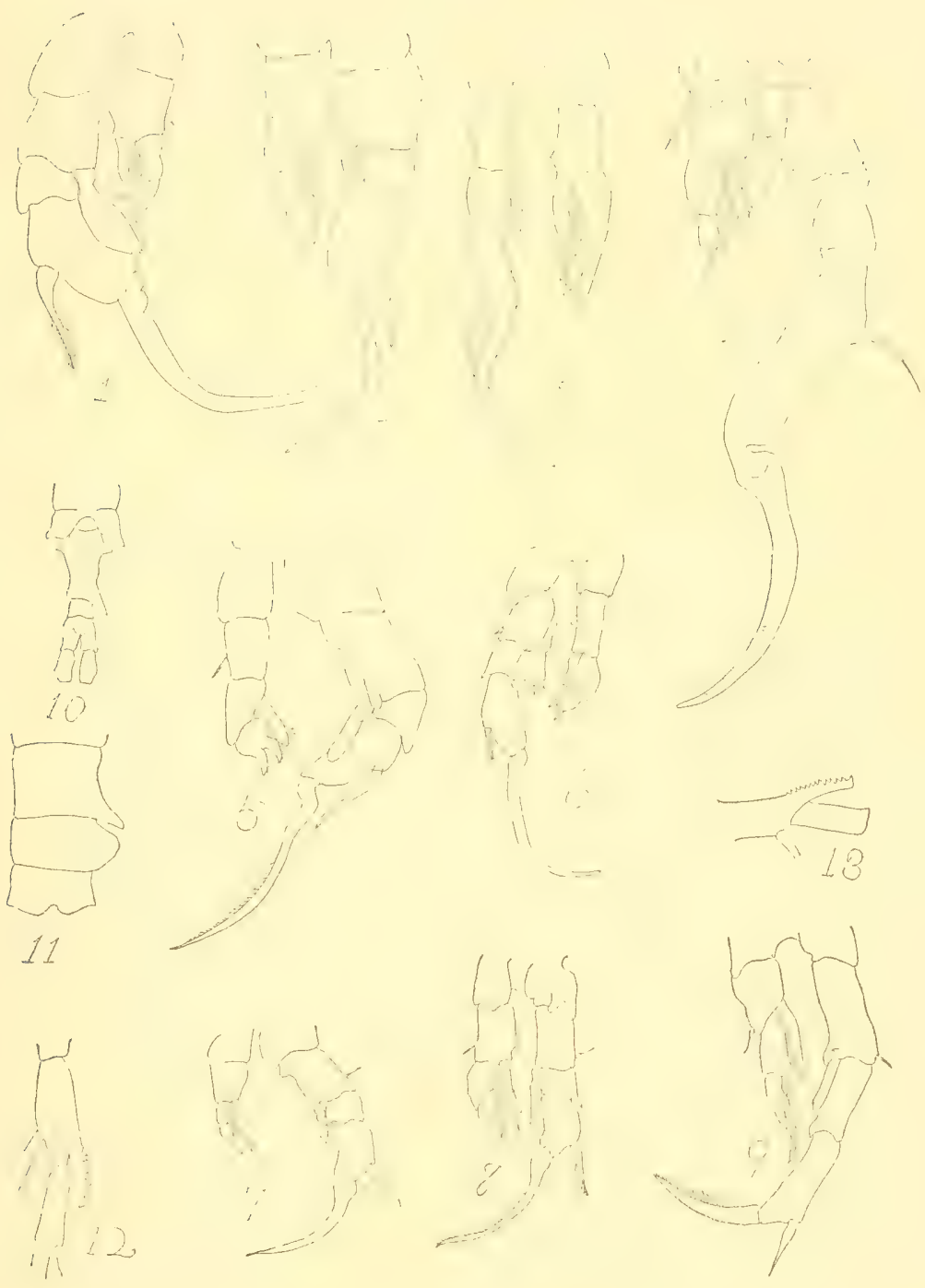



EXPLANATION OF PLATE $\mathrm{X}$. 


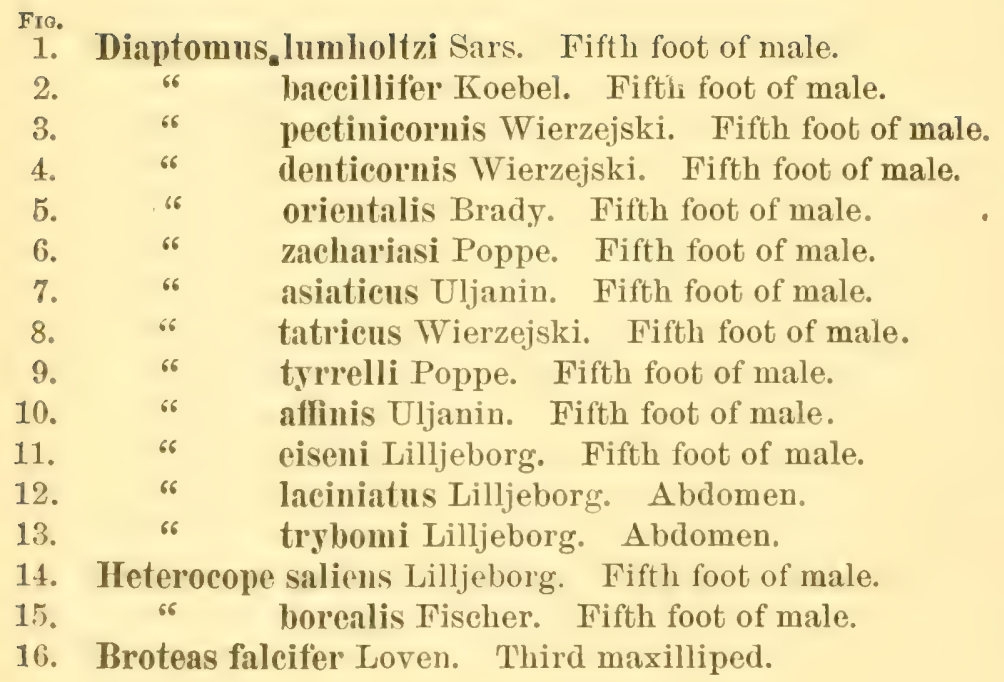



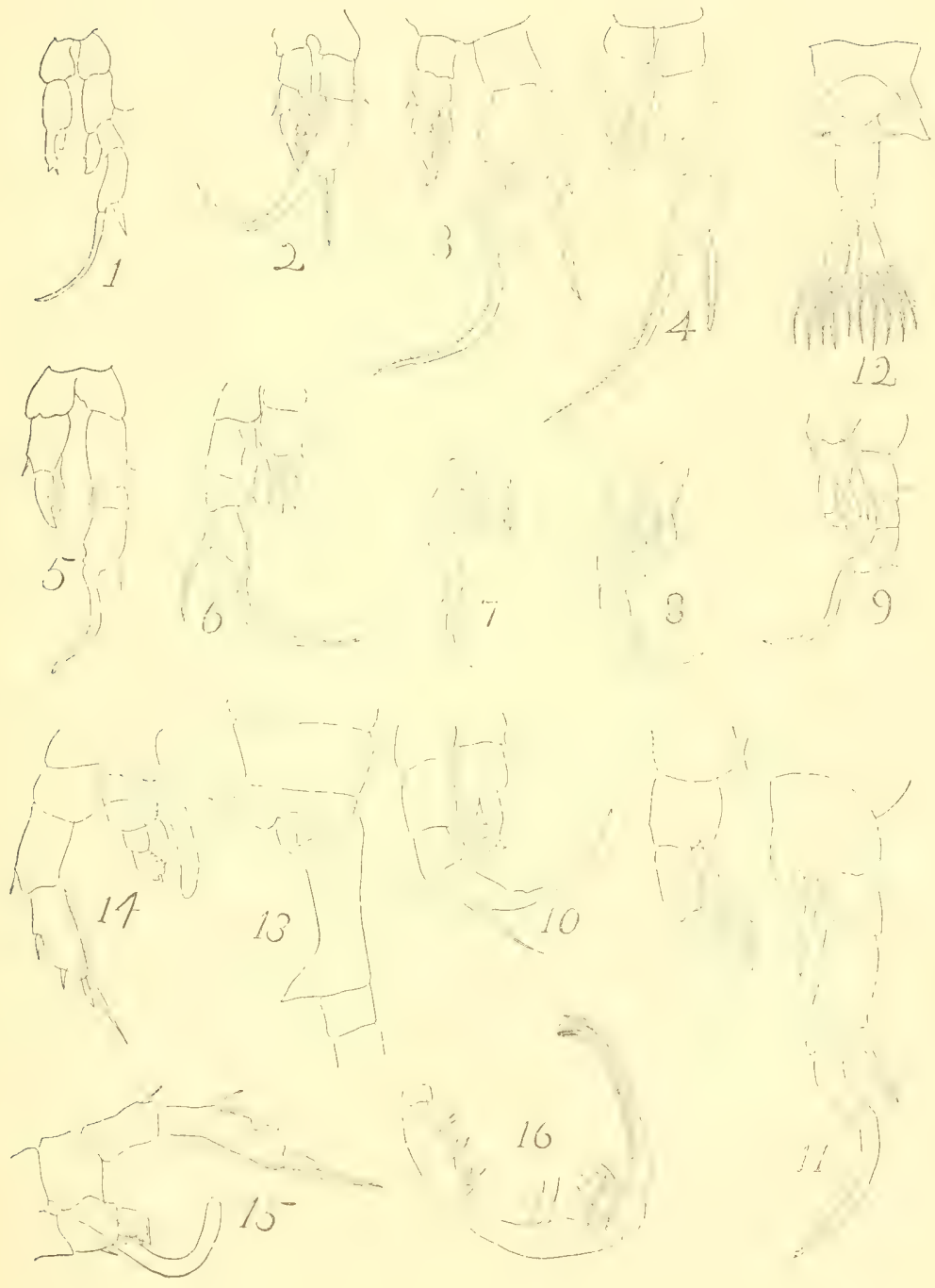

EXPLANATION OF PLATE XI. 


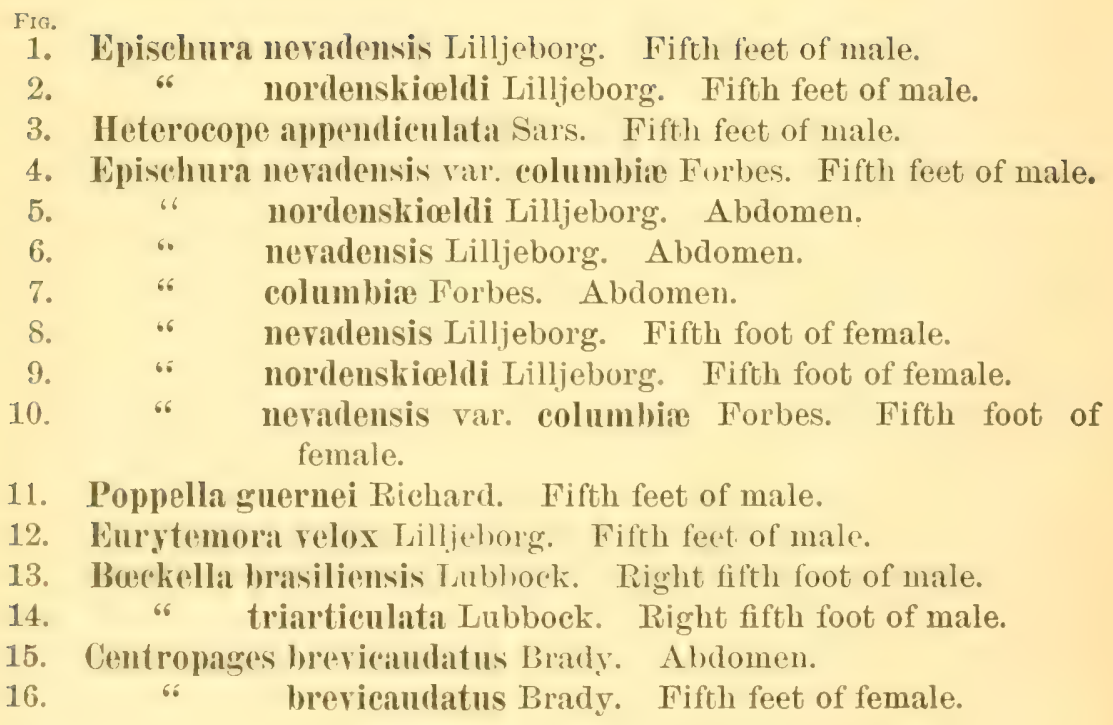



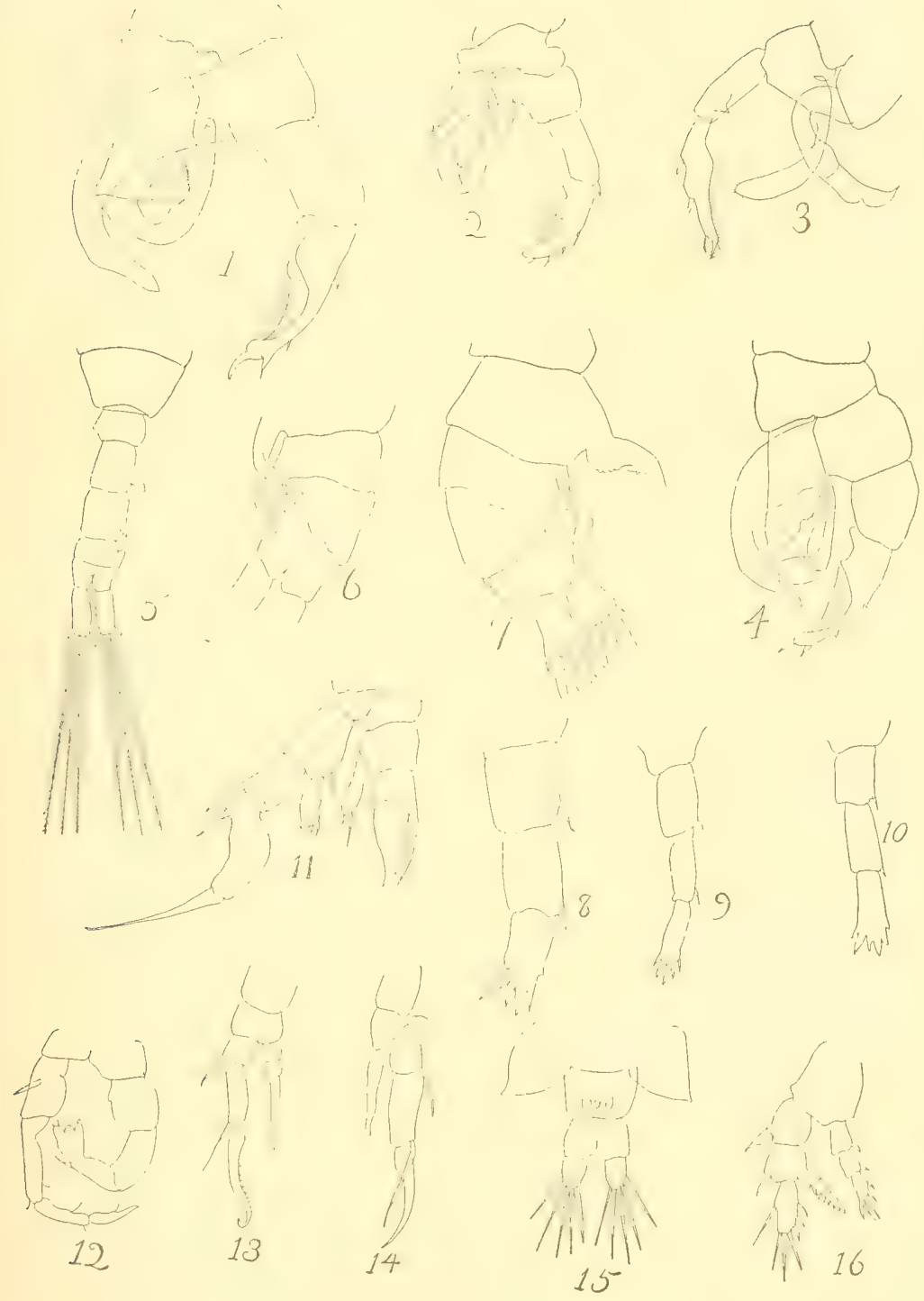

EXPLANATION OF PLATE XII. 


\section{Osphranticum labronectum (Potamoichetor).}

Fra.

1. Male.

2. Antennule.

3. Maxilliped.

4. Fifth feet of the male.

5. Palp of the mandible.

6. Fnd of the abdomen.

7. Feet of the first pair.

8. Eye.

Cyclops ater.

9. Female.

10. Abdomen.

11. Maxilliped.

12. Antenna.

13. Osphranticum labronectum. Maxilla.

14. "6 labronectum. Antenna. 


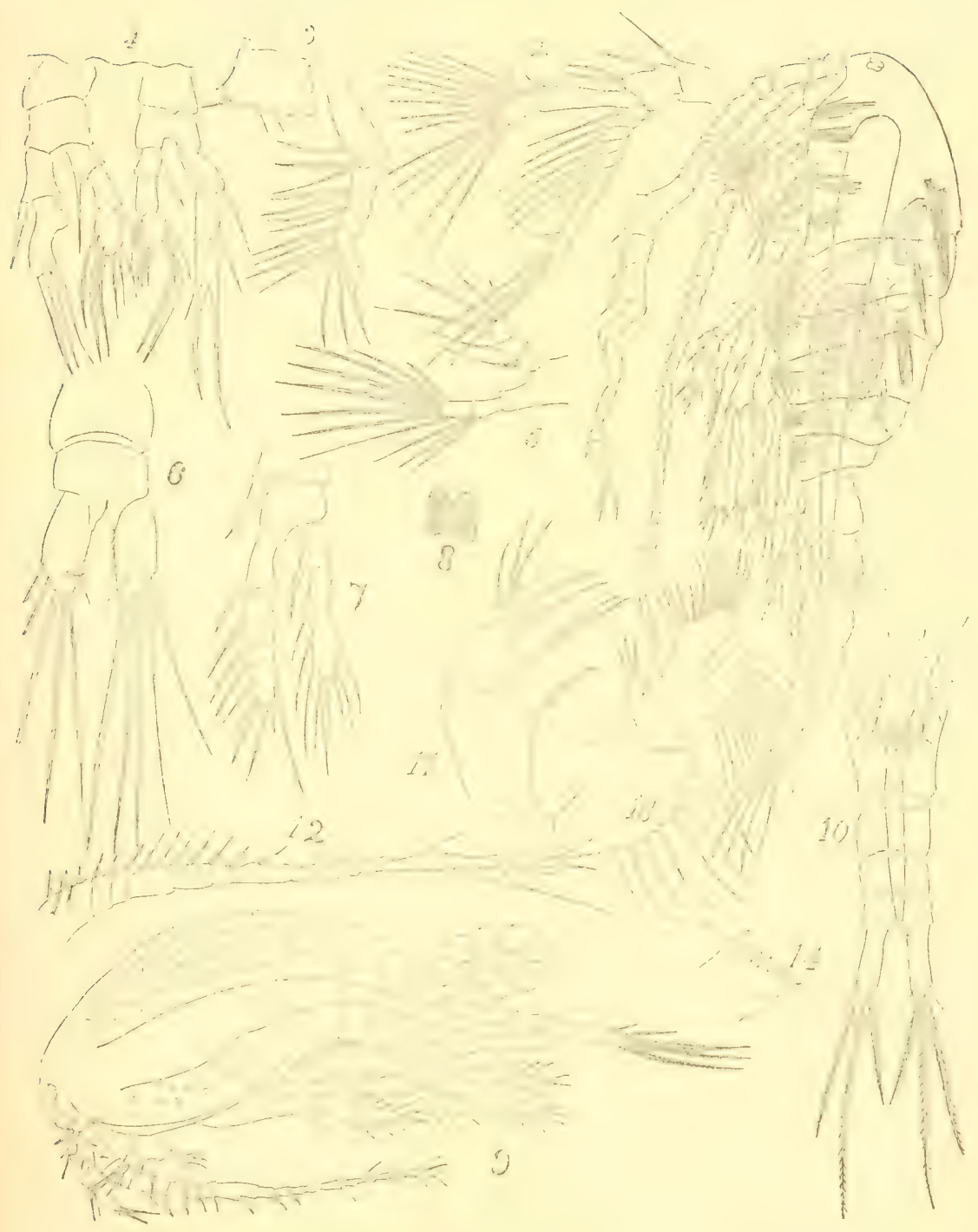



EXPLANATION OF PLATE XIII. 


\section{Alonella pulchella.}

1. Female.

2. Reticulations.

3. Post-abdomen.

4. Alona morlesta. Male.

\section{Diaptomus similis.}

5. Female

5a. Jaw.

6. Fifth foot of the male.

7. Fifth foot of the female.

\section{Diaptomus minnetouka.}

8. Fifth foot of the male.

9. Fifth foot of the female.

10. Abdomen of the female.

11. Diaptomus stagnalis. Margin of the last thoracic segment.

12. " " singuineus. Margin of the last thoracic segment.

13. 66 stagnalis. Fifth foot of the male.

14. Epischura fluviatilis. Abdomen of the male.

15. 66 lacustris. Fifth feet of the male.

16. 6 fluviatilis. Fifth feet of the male.

17. Diaptomus palliclus. Inner ramus of the fifth feet of the male. 18. "6 sicilis. Inner ramus of the fifth feet of the male. 
Zool. Survey of Minn., II, 1895.

PI,TTE XII.

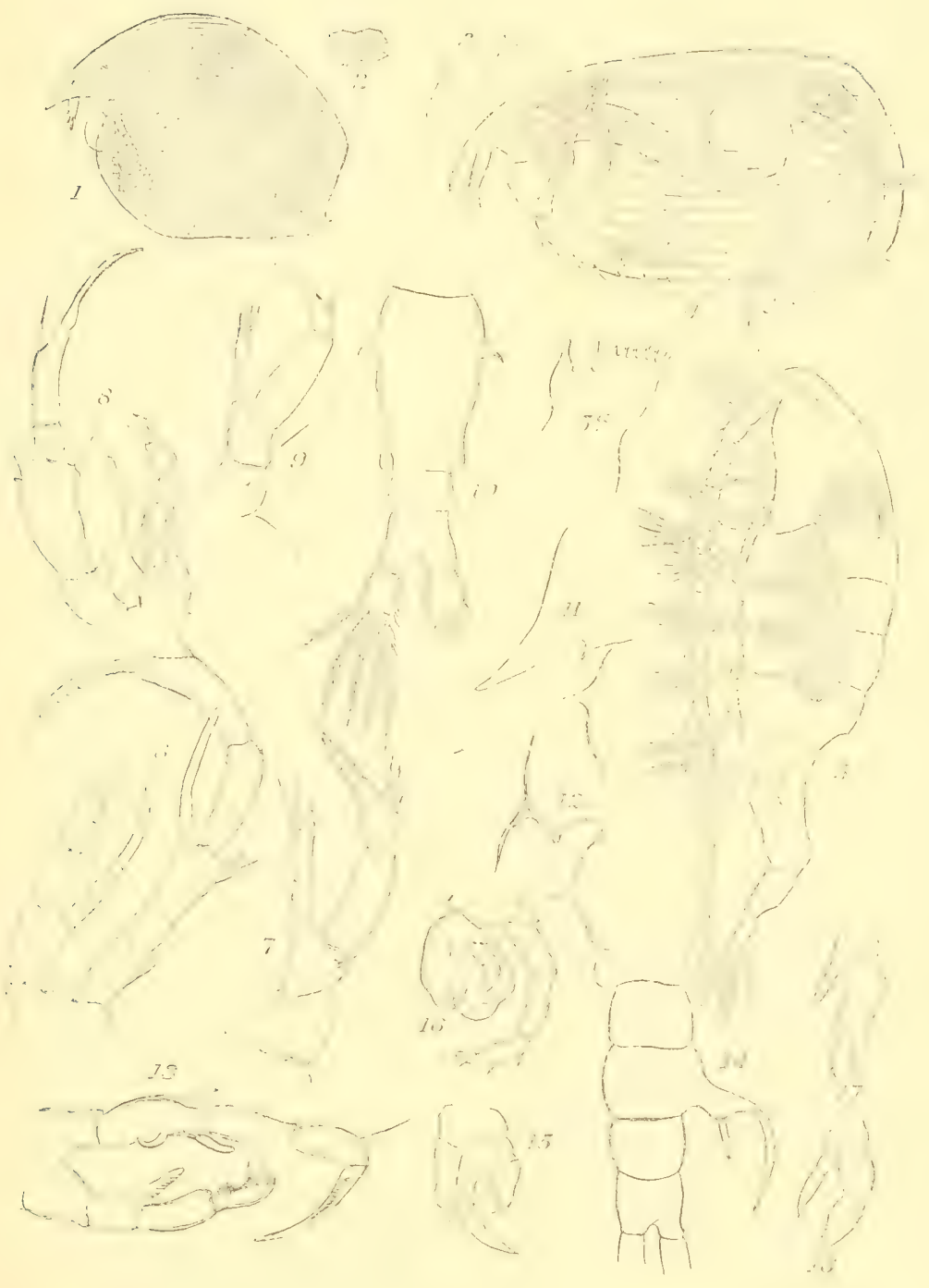



EXPLANATION OF PLATE XIV. 
Cyclops viridis var. americanus Marsh.

Fro. Female from above.

2. Antenna and antennule.

3. Foot of the first pair.

4. Foot of the third pair.

5. Foot of the fourth pair.

6. Caudal stylet.

7. Fifth foot.

8. Sixth foot of the male.

9 . Antenna of the male.

Specimens from Albuquerque, New Mexico. 

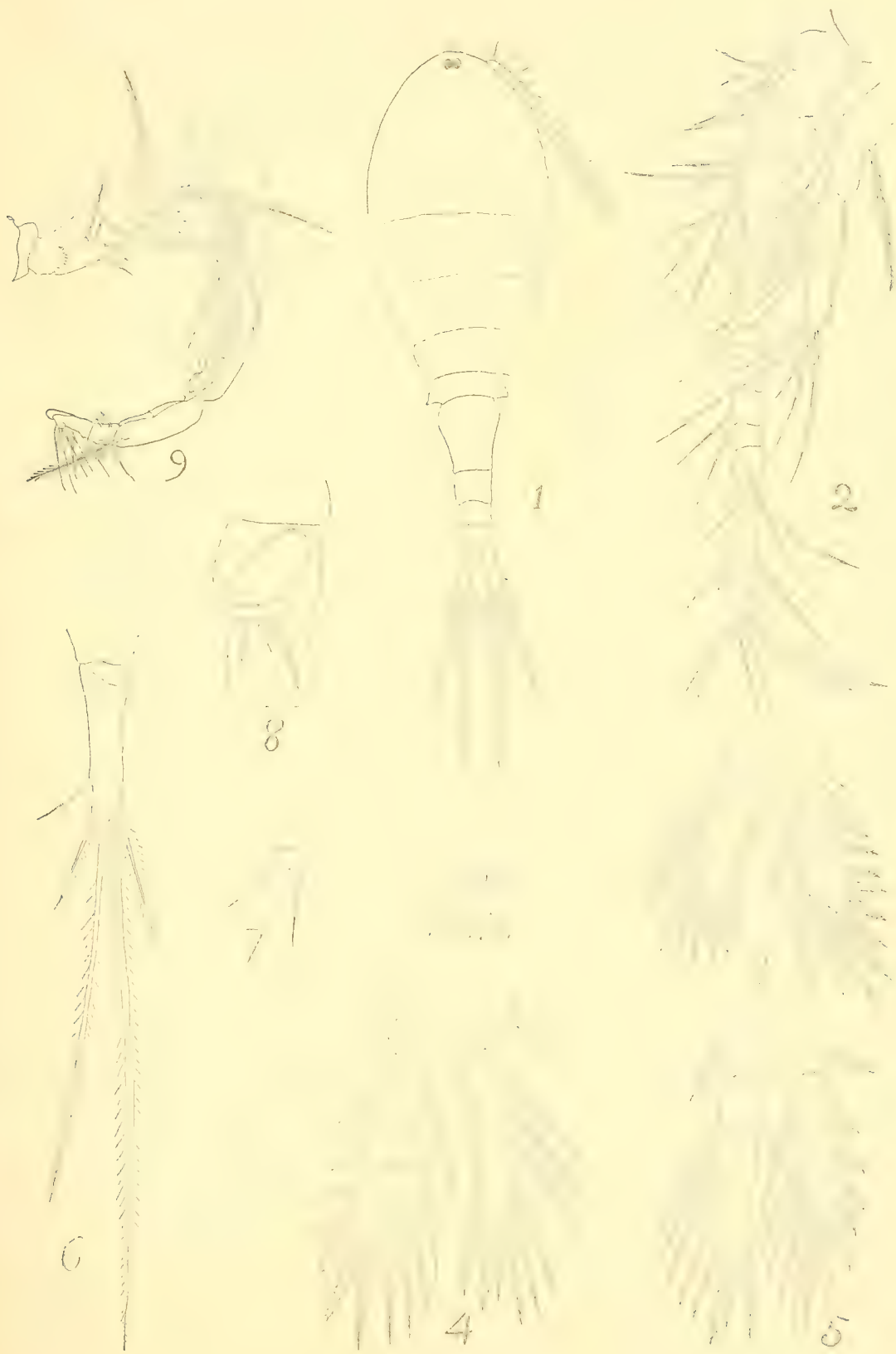

2

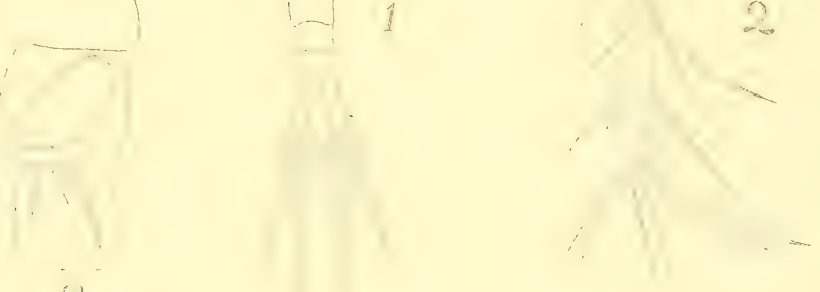

$$
\text { (1) }
$$
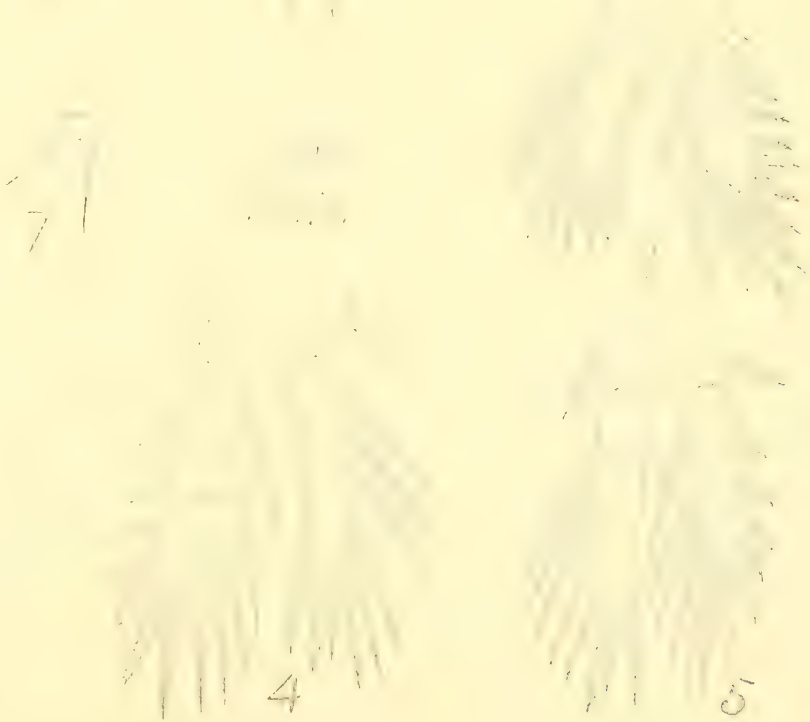

EXPLANATION OF PLATE XV. 
Cyclops signatus var. coronatus.

Fig. Outline from above of a mature female.

2. Outline of a male.

3. Fifth foot.

4. One of the fourth pair of feet.

Cyclops signatus var. tenuicornis.

5. Tip of the antenna of the female.

6. Fifth foot.

7. Stylet of the female.

\section{Cyclops serrulatus.}

8. Foot of the second pair.

9. Foot of the fourth pair.

10. Fifth foot.

11. Stylet of the female. Type. 
ZOOH. SITRVE (2F MINN., II, 1895.

PLATE $\mathrm{XI}$.

-

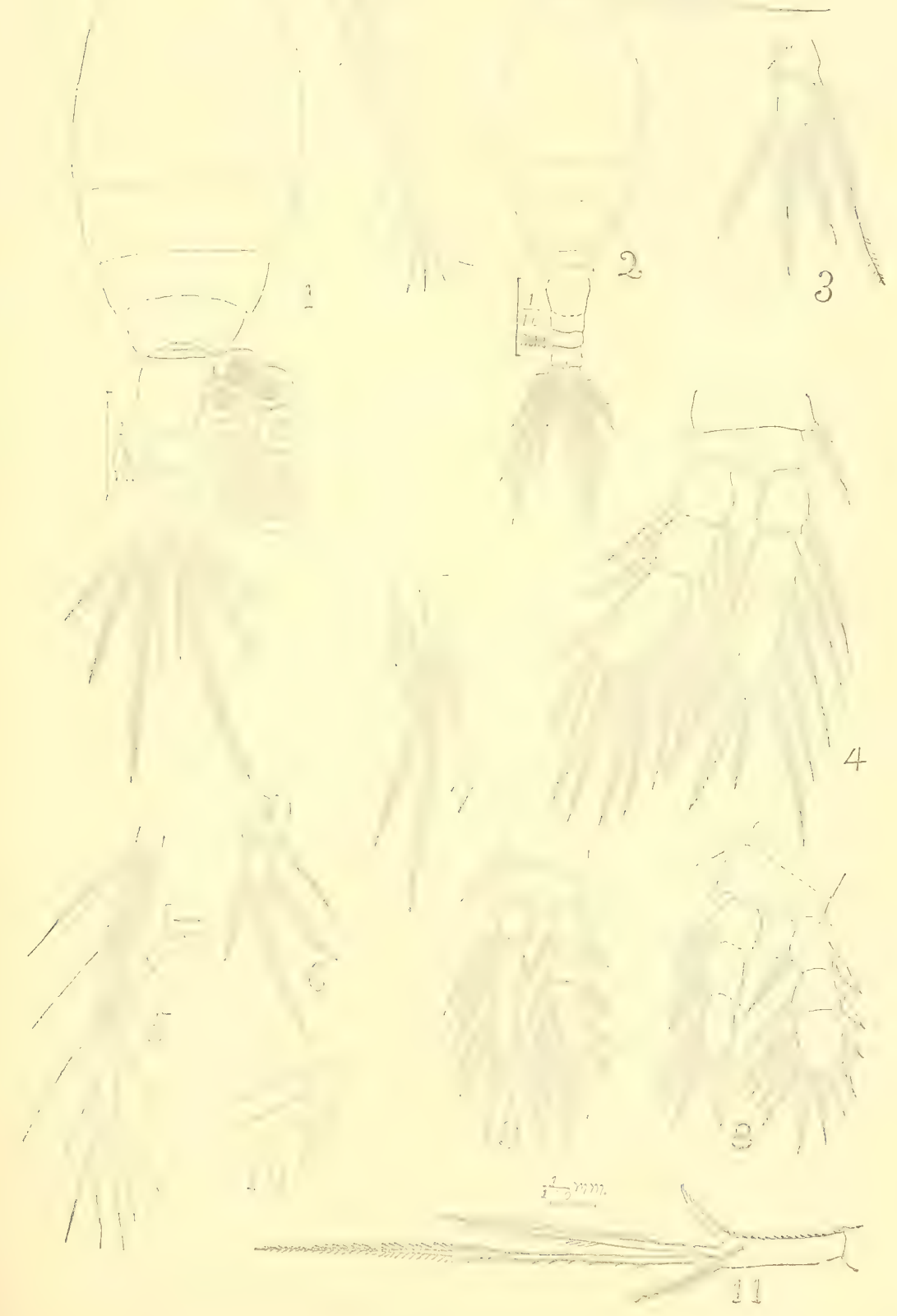



EXPLANATION OF PLATE XVI. 


\title{
Cyclops leuckarti Sars.
}

\author{
1. Camera outline of body seen from above. \\ 2. Antenna. Camera. \\ 3. Caudal stylet. Camera. \\ 4. Terminal segments of antenna to show armature. \\ 5. Fifth foot. Camera. \\ 6. Outer maxilliped. Camera. \\ 7. Inner maxilliped. Camera. \\ 8. Foot of first pair. Camera. \\ ). Foot of second pair. \\ 10. Foot of fourth pair. Camera. \\ 11. Opening of the spermatheca.
}


ZOOt. SURYeY OF MINY. II, IS

I'! 11': i i
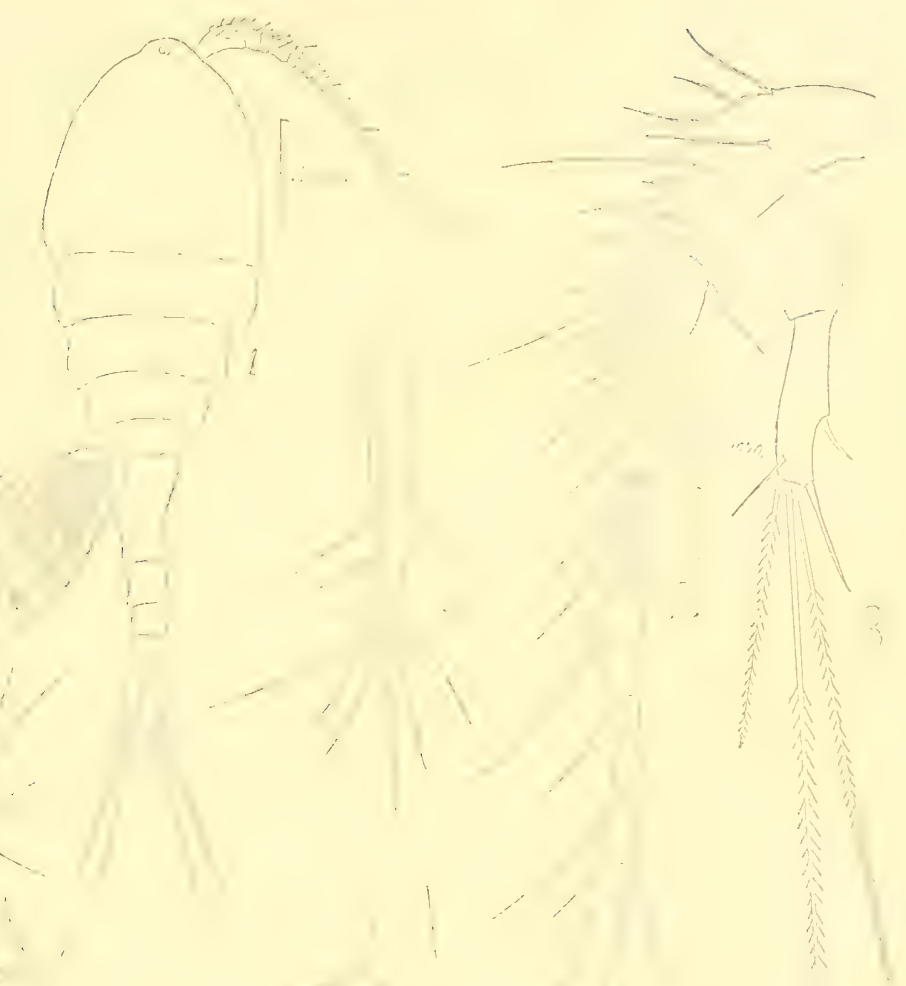

EXPLANATION OF PLATE XVII. 
Cyclops phaleratus.

Fig. Outline of the male from above.

2. Stylet of the male.

3. Fifth and sixth feet of the male.

4. Antenna of the male.

5. Antenna of the female:

6. Fifth foot of the female.

7. Fourth foot.

8. Stylet.

Cyclops fimbriatus.

!. Antenna of the female.

\section{Cyclops languidus.}

10. Antenna of the female.

11. Fifth foot. 
Zool. Sulviey of Mind., II, 1895.

ILATE XTIT

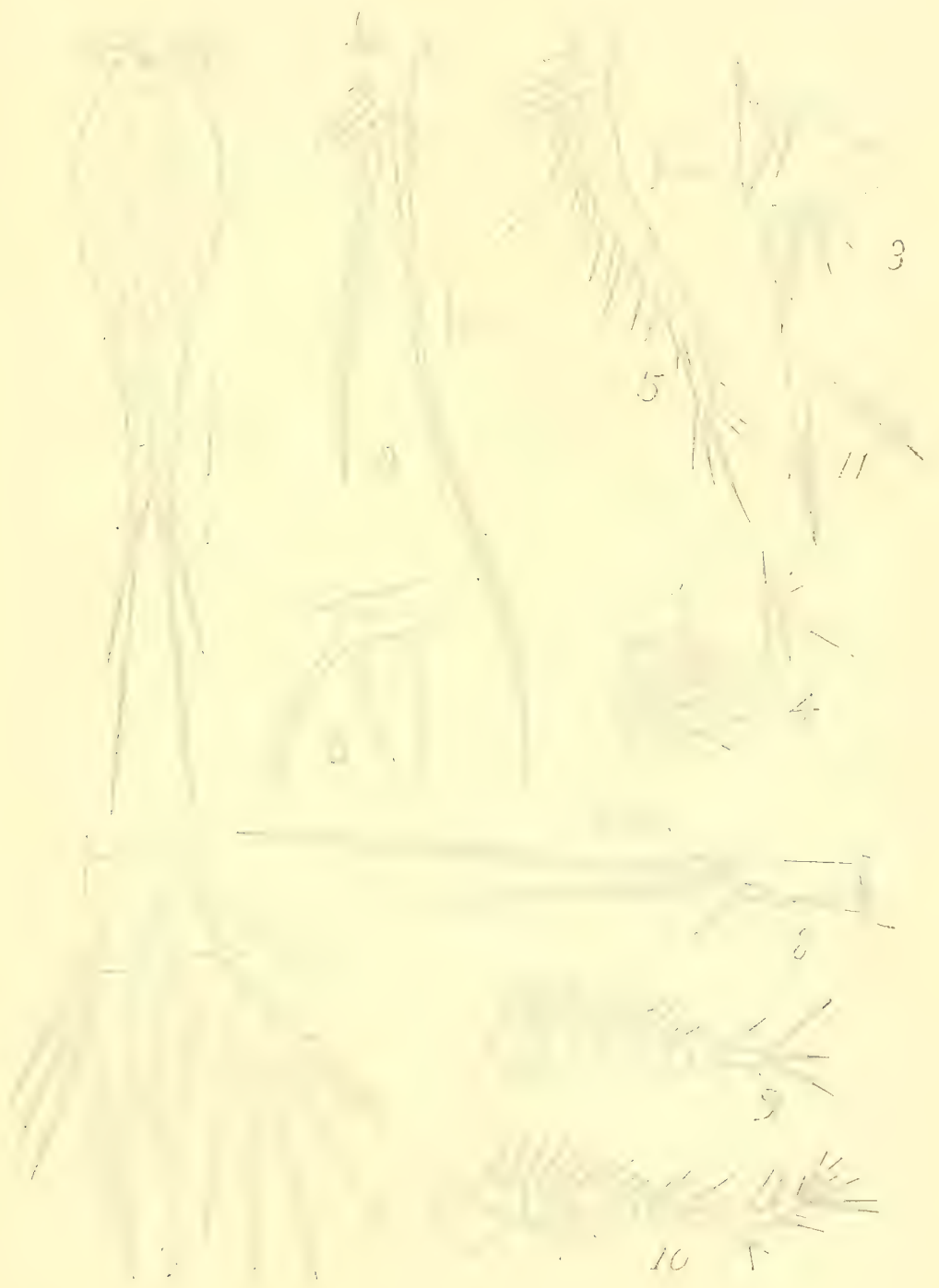



EXPLANATION OF PLATE XVIII. 
Fil.

\section{Cyclops leuckarti.}

1. Slender form.

(1. Abdomen.

b. Labrum.

c. Antenna.

d. Fifth foot.

c. Feet of fourth pair.

i. Feet of second pair.

\%. Feet of first pair.

h. Antennule.

. Maxilliped.

i. Mandible.

Cyclops phaleratus.

2. Ventral view of female.

$2 u$. Part of the abdomen of the male with sixth foot.

2). Antenna.

2ध. Labrum.

2\%. Pair of feet.

\section{Cyclops bicolor.}

3. Lateral view.

3\%. Abdomen.

3\%. Foot of the fourth pair.

3r. Antenna.

37. Labrum.

3e. Receptaculum. 


F1:

1. Cyclops phaleratus. Female.

2. Male.

Cyclops serrulatus.

3. Under surface of abdomen.

4. Last joints of antenna of the female.

5. First foot. The spine of the distal segment of outer ramus is incorrectly shown as curver.

Cyclops diaphanus.

6. Fourth foot.

7. Stylets.

s. Fifth foot.

9. Antenna.

Cyclops gracilis.

11. Abdomen.

11. Fifth foot.

\section{Cyclops varicans.}

12. Stylets.

13. Antenna. 
Zool. Survey of Minn., II, i895.

PI.ATE XIX.

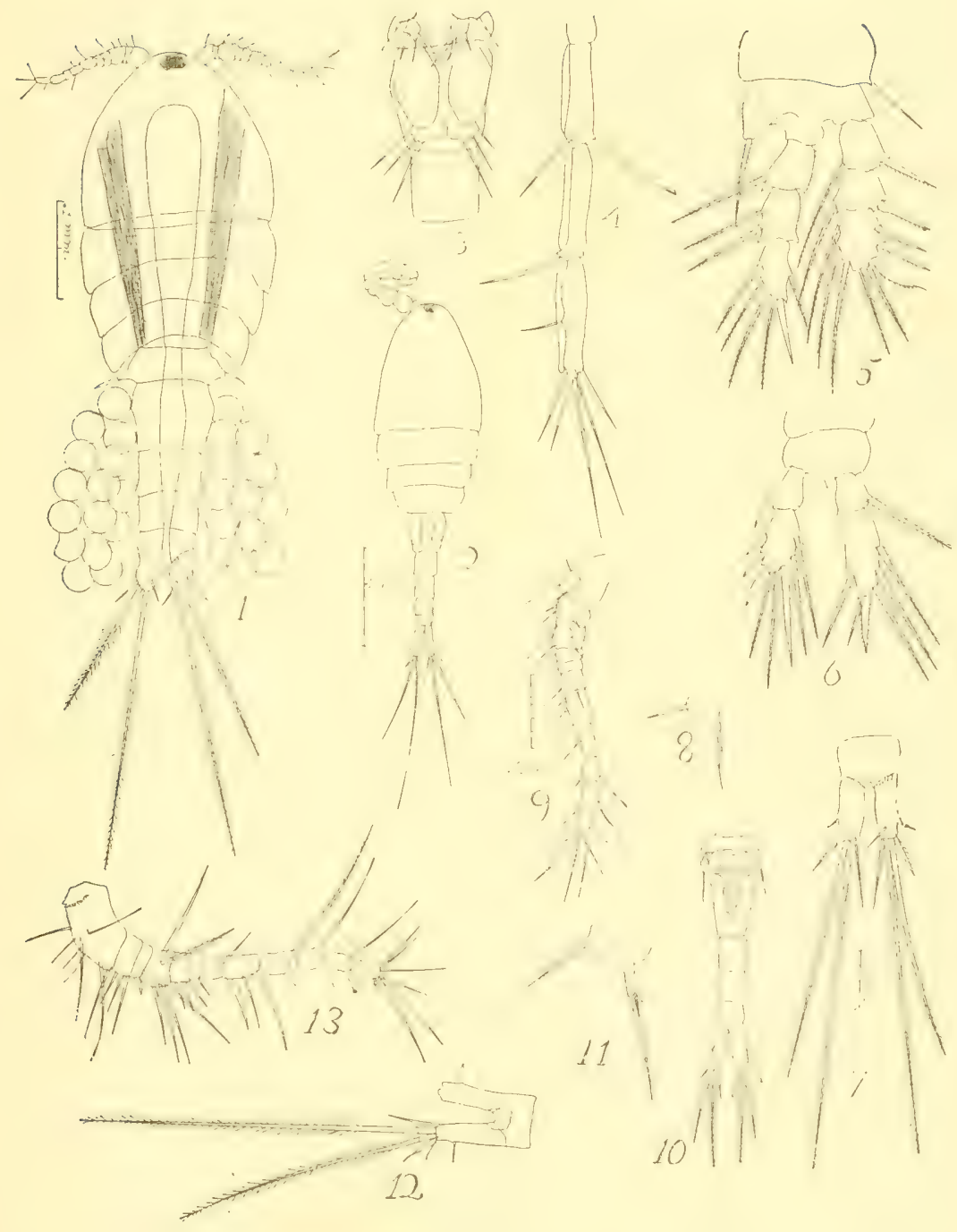



EXPLANATION OF PLATE XX. 
FIG.

Cyclops signatus var, tenuicornis.

1. Female.

2. Mandible.

3. Maxillie.

4. Stylet.

5. Fifth foot.

6. Maxillipedes.

7. Antenna.

Cyclops signatus.

5. Abdomen.

). Antenna.

10. Fifth foot.

11. Mrale antenna.

\section{Cyclops parcus.}

12. Abdomen.

13. Antenna.

14. Fifth foot.

15. Receptaculum seminis.

\section{Cyclops adolescens}

16. Abdomen.

17. lioot.

1.. Antenna of female.

19. Hye.

¿1). Antenna of male.

21. Cyclops siguatus. End of antenua. 


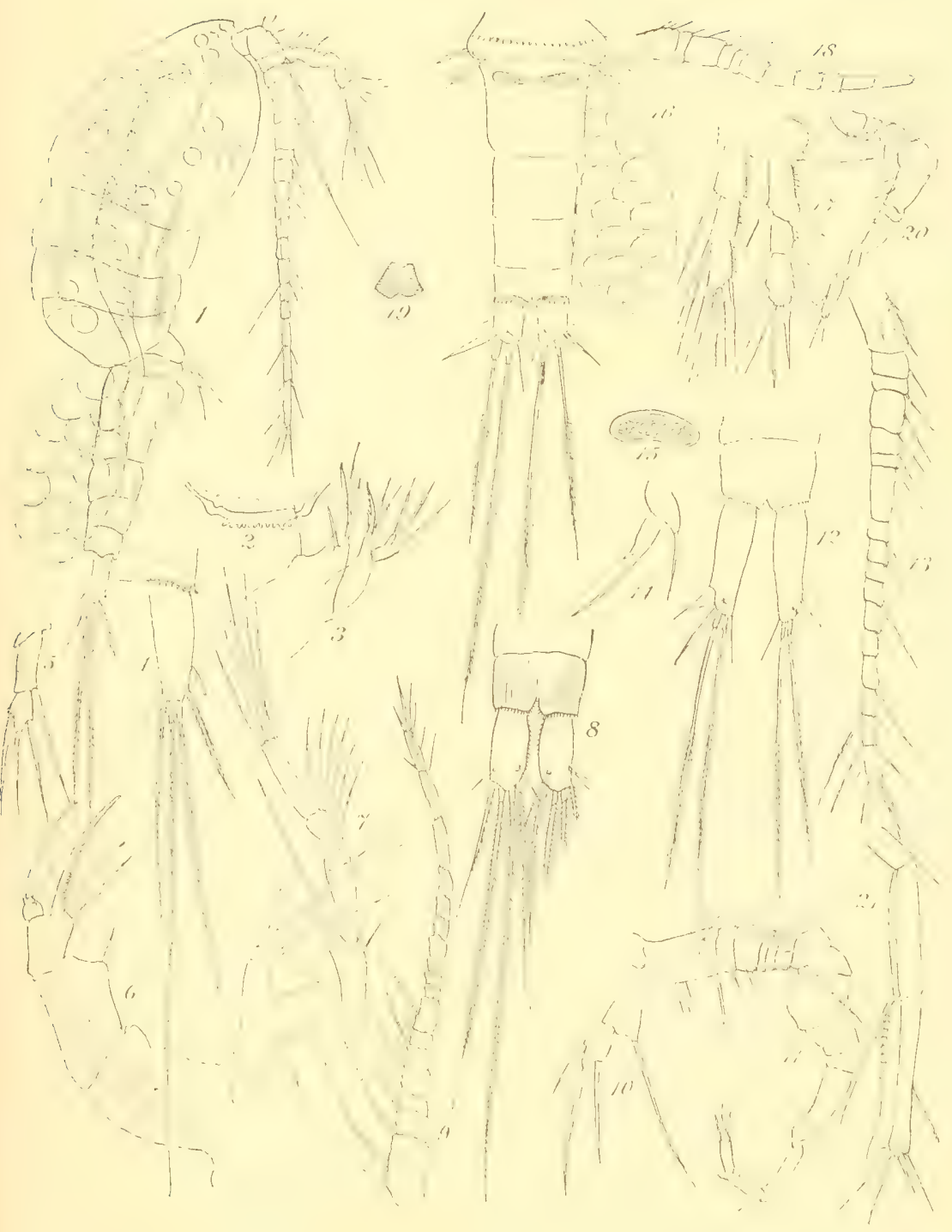



EXPLANATION OF PLATE XXI. 


\section{Cyclops modestus.}

I'T.,

1. Side view.

2. End of the abdomen.

3. Outer ramus of first foot.

4. Outer ramus of second foot.

5. Fifth foot.

\section{Cyclops phaleratus.}

6. Fourth foot.

7. Outer ramus of first foot.

s. Fifth foot.

9. Caudal stylets.

10. Antenna of young, otherwise perfect.

11. Cyclops fimbriatus. End of abdomen.

12. 66 bicolol. Abdomen.

\section{Cyclops ater.}

13. Tnmer ramus of first foot.

14. Outer ramus of first foot.

15. Outer ramus of fourth foot.

16. Cyclops signatus. Fourth foot.

17. 66 ater. Inner ramus of fourth foot.

15. 6 ater. Stylet.

19. 66 sp.? First foot.

20.21. "6 sp.? Terminal segments of fourth foot.

22. 66 parcus. Fifth foot.

23. Chydorus globosus. First foot of male. 


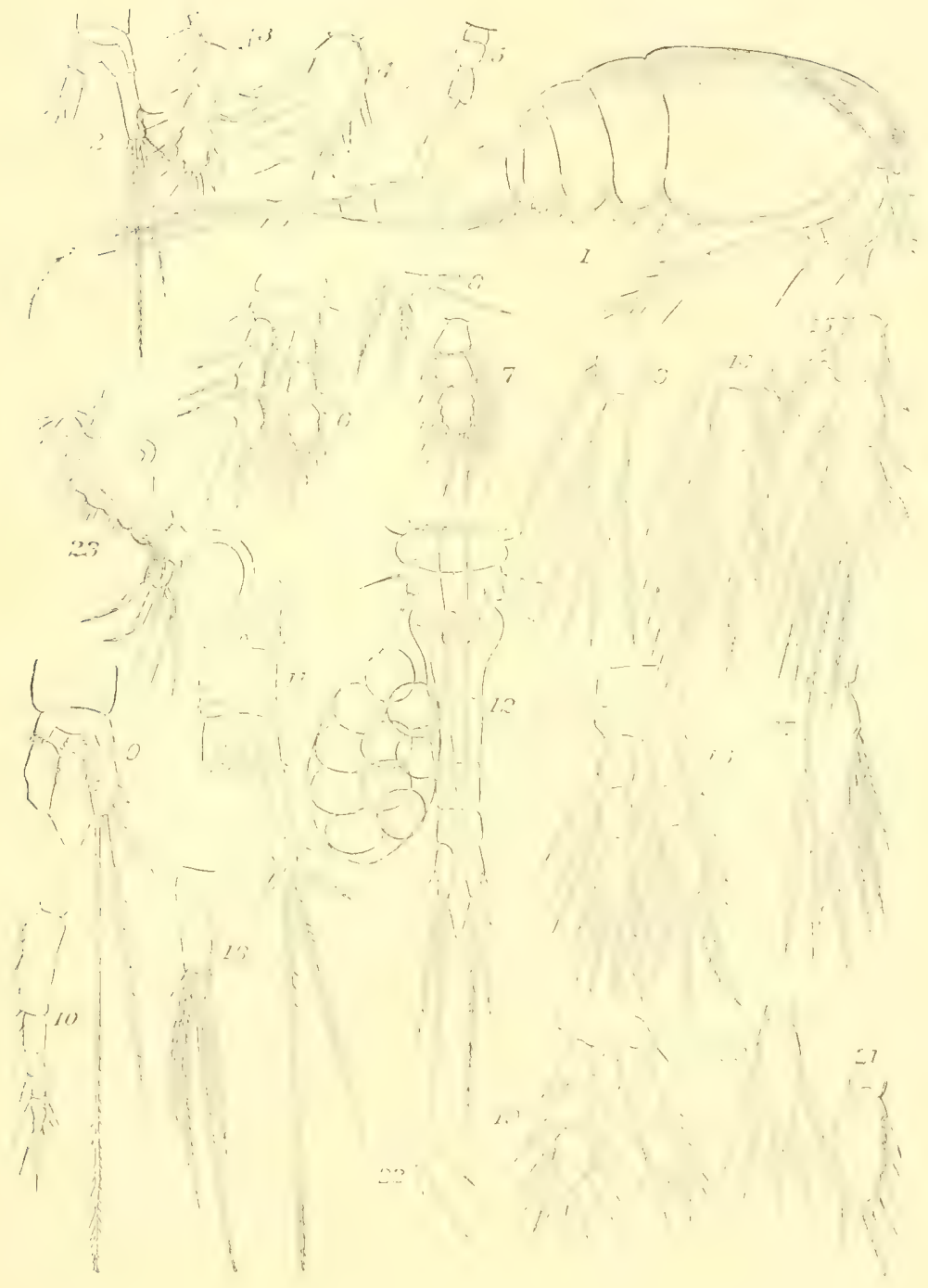



EXPLANATION OF PLATE XXII. 


\section{Canthocamptus minnesotensis.}

Fig.

1. First foot.

2. Stylets.

3. Antenna of female.

4. Fifth foot of female.

5. Fifth foot of male.

6. Antenna of male.

7. Daphnia hyalina (D. galeata). Young.

8. 66 66 66 Male.

9. Camptocercus leucocephalus. Male.

10. Alonella excisa. Male.

Cyclops insignis.

11. Onter ramus of the first foot.

12. Fifth foot.

13. Fourth foot.

14. Sitylut.

15. Worm parasitic in arterial sinus of Daphnia schaefleri. 
Zool. Survey of Minn., II, 1895.

PLATE XXII.

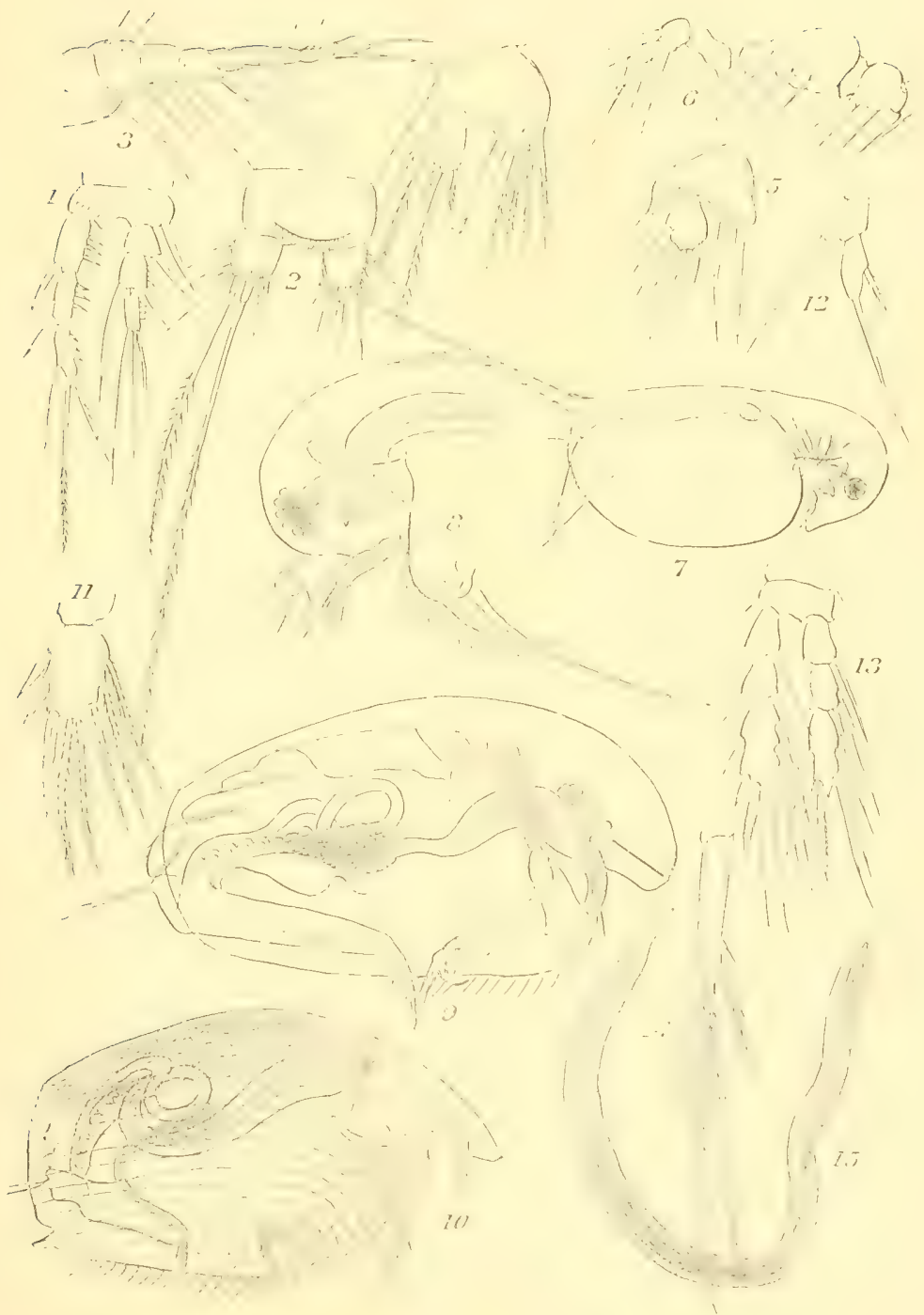



EXPLANATION OF PLATE XXIII 


\section{Cyclops brevispinosus.}

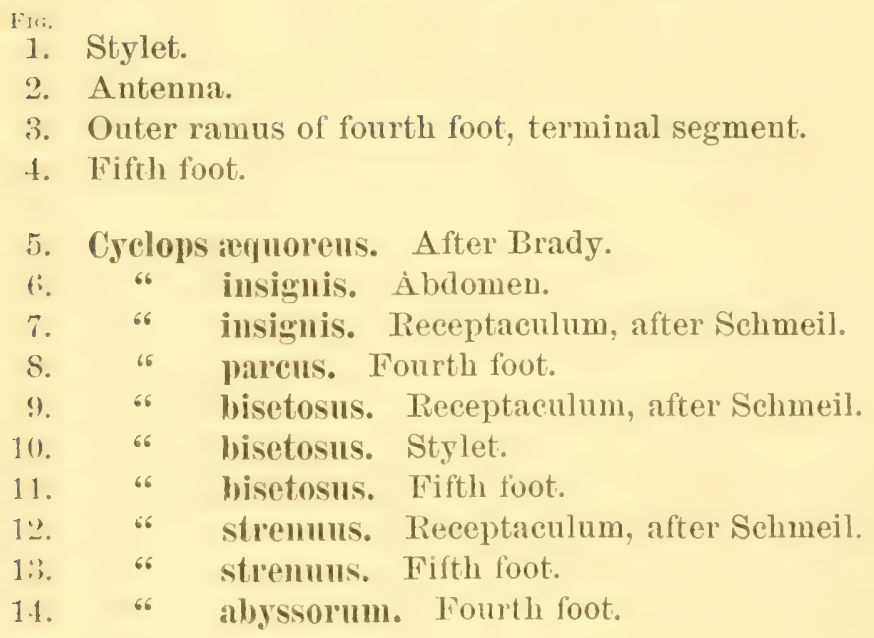



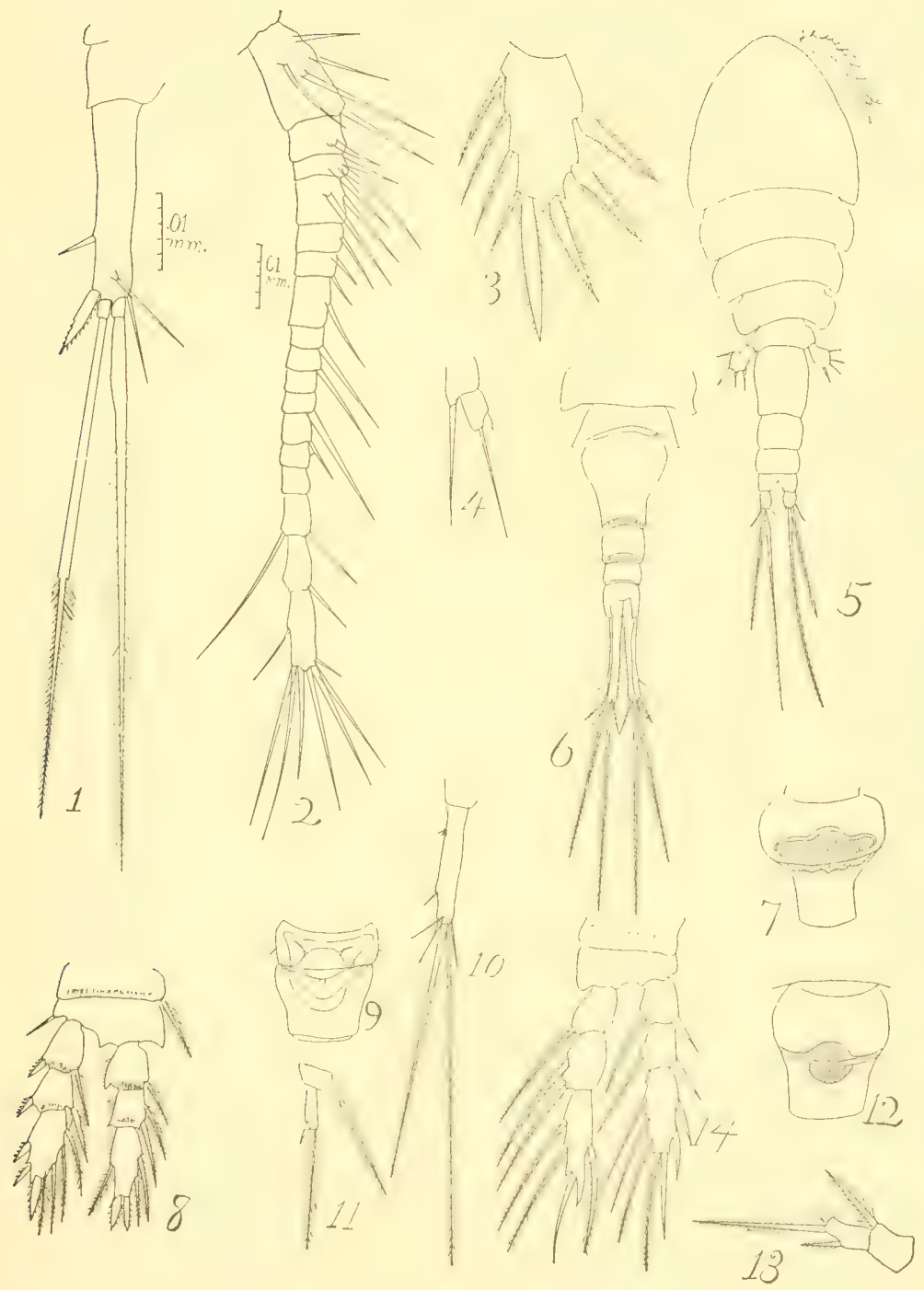

EXPLANATION OF PLATE XXIV. 
1. Ergasilus depressus. Male.

Cyclops leuckarti, deep-water variety, = C. tenuissimus.

2 Stylets.

3. Fifth foot.

4. Antennule.

5. Fourth feet.

(i. Antenna of male.

Cyclops brevispinosus.

7. Stylet.

$\therefore$ Tuner maxilliped.

؛. Swimming foot.

10. Fifth foot.

11. Antennule.

12. Opening of receptaculum.

13. Cyclops sp.? Nauplius. 


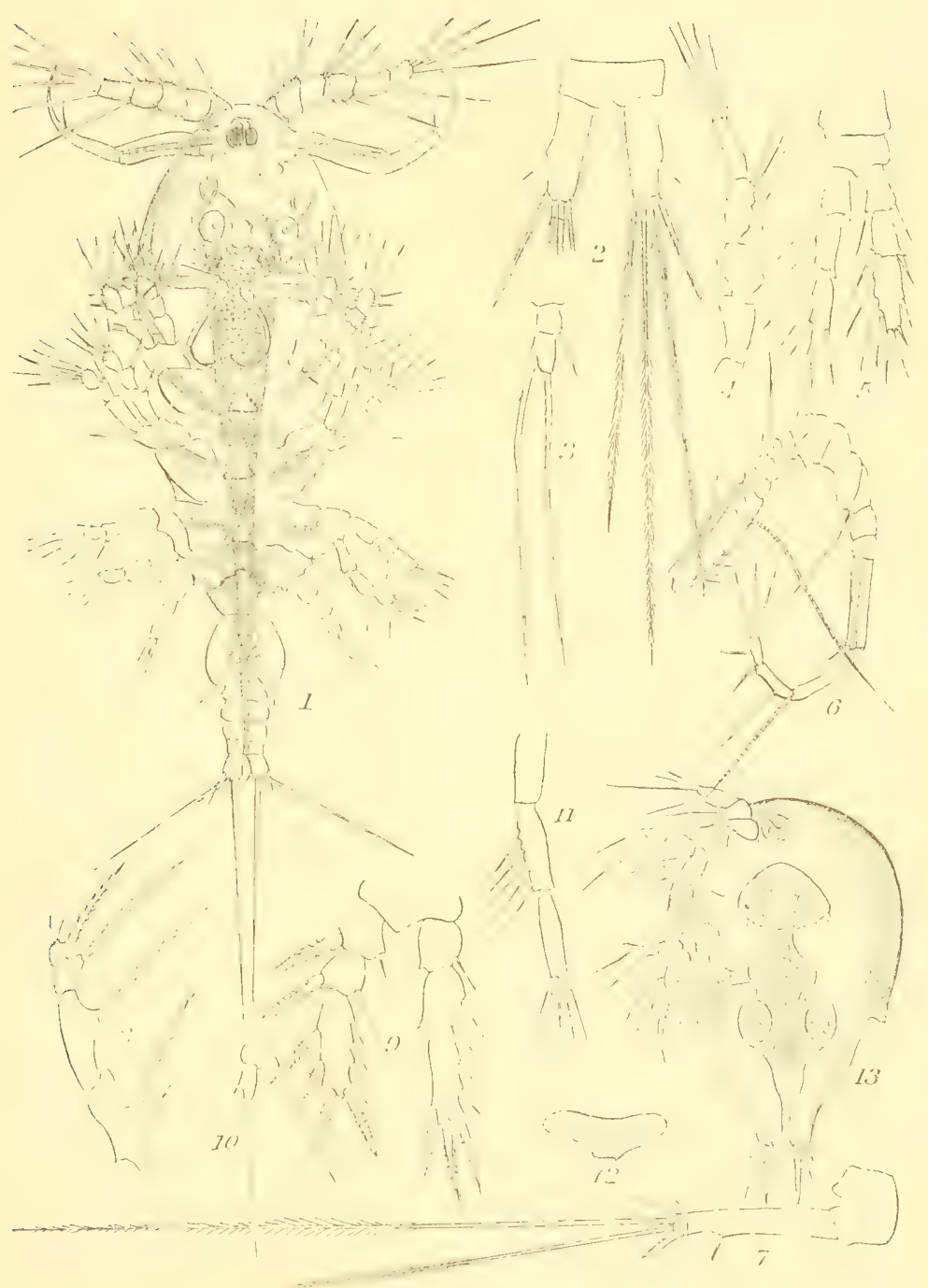



EXPLANATION OF PLATE XXV. 


\section{Cyclops ingens.}

Fir.

1. First segment of abdomen of female.

2. Antenna.

3. Fifth foot.

4. Antenna of young male.

5. Stylets of mature female.

(i. Stylets of young male.

7. Maxilliped.

s. Mandible.

Cyclops fimbriatus.

9. Female from above.

10. Antenna.

11. Terminal portion of abdomen.

12. Female fifth foot.

13. Second antenna.

1.1. Nauplius form. 
ZUOL. SURVE OF MINN., II, 1895.

PLA'IE XXY.
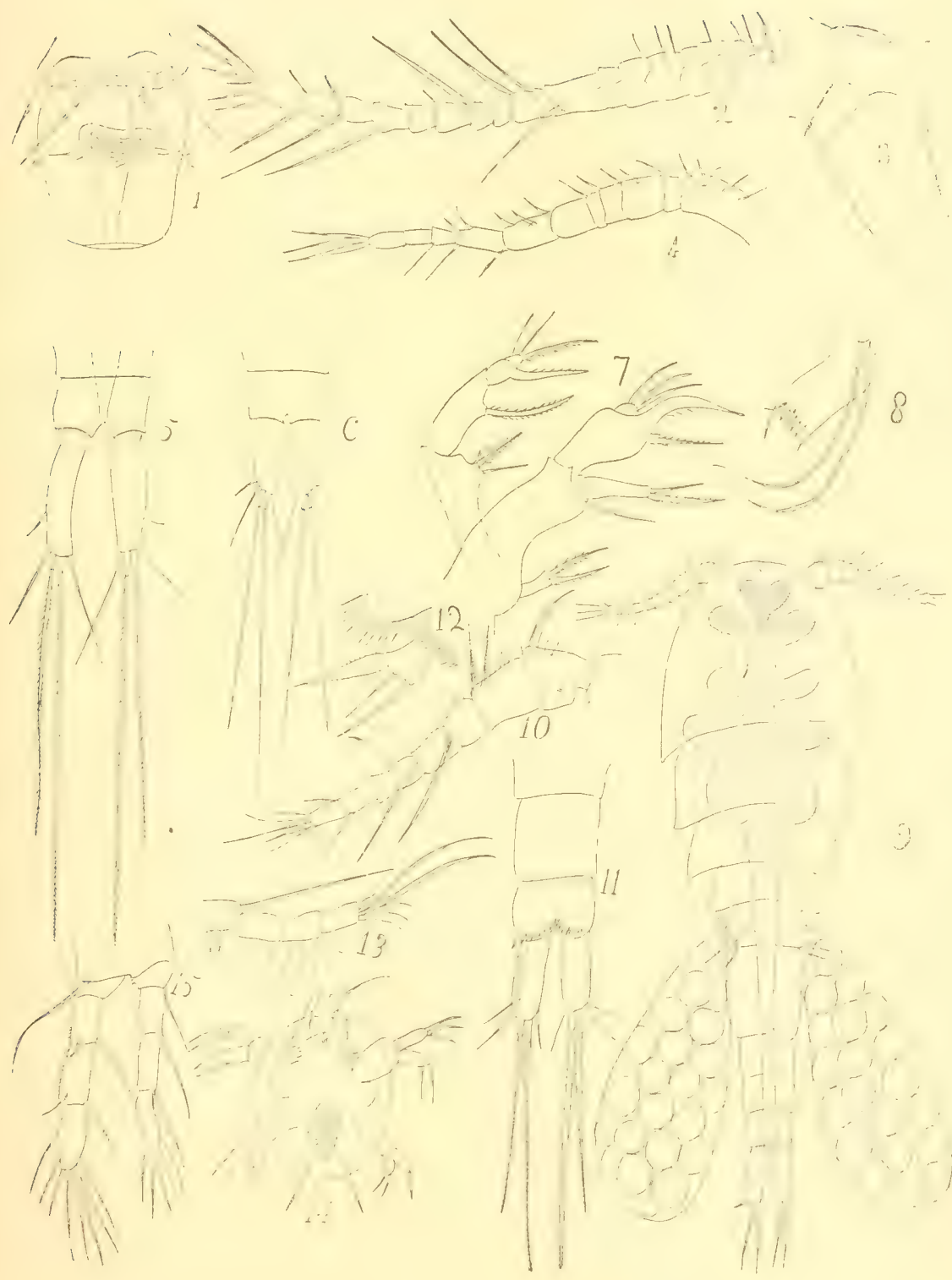

EXPLANATION OF PLATE XXVI. 


\section{Cyclops fluviatilis.}

$F_{I}$.

1. Female from above.

2 Antenna.

:3. Antenna of young.

1. Abdomen of young.

5. Foot of young.

ii. Foot of adult.

7. Fifth foot.

\&, Eye.

?.? (Should have been cut out.)

11. Cyclops serulatus. Young from above.

\section{Daplinella brachyura.}

11. Female. Lateral vien.

12. Male.

1:). Edge of valves.

1. Abdomen of male.

1i). Abromen of female.

16. Antenna of male. 


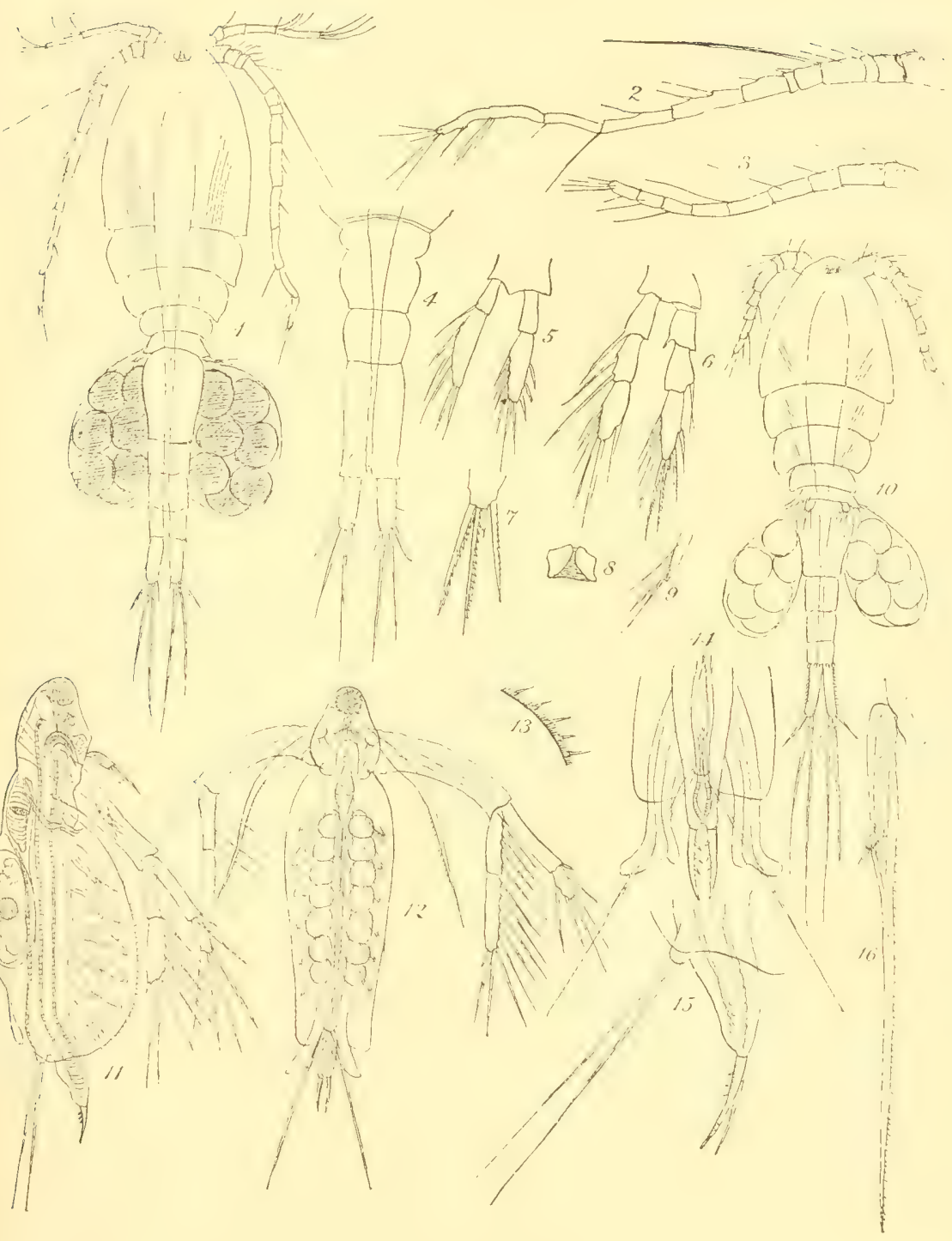



EXPLANATION OF PLATE XXVII. 


\section{Daphnia kalbergensis.}

Fir.

1. Of moderate"size.

2 Antenuule of male.

3. Head of variety.

4. Cyclops pulchellus (thomasi). Fourth foot.

5. "6 pulchellns (thomasi). Onter ramus of first foot.

6. Daphnia hyalina (D. galeata). 'Typical form.

†. Cyclops thomasi. Fifth foot.

s. $\quad 6$ thomasi. Stylet.

9. Crelops (insectus?). Fourth foot.

11. Bythotrephes longimanus. Female.

11. A curious large protozoan; $a$. infundibulum frame work; $b$ : pulsiting vacuole; e. mucleus; d. food and dignated matter; $r$ protective rods; $11 a$. spicules of the infundibulum. 
Zool. Survey of Minn., II, I895.

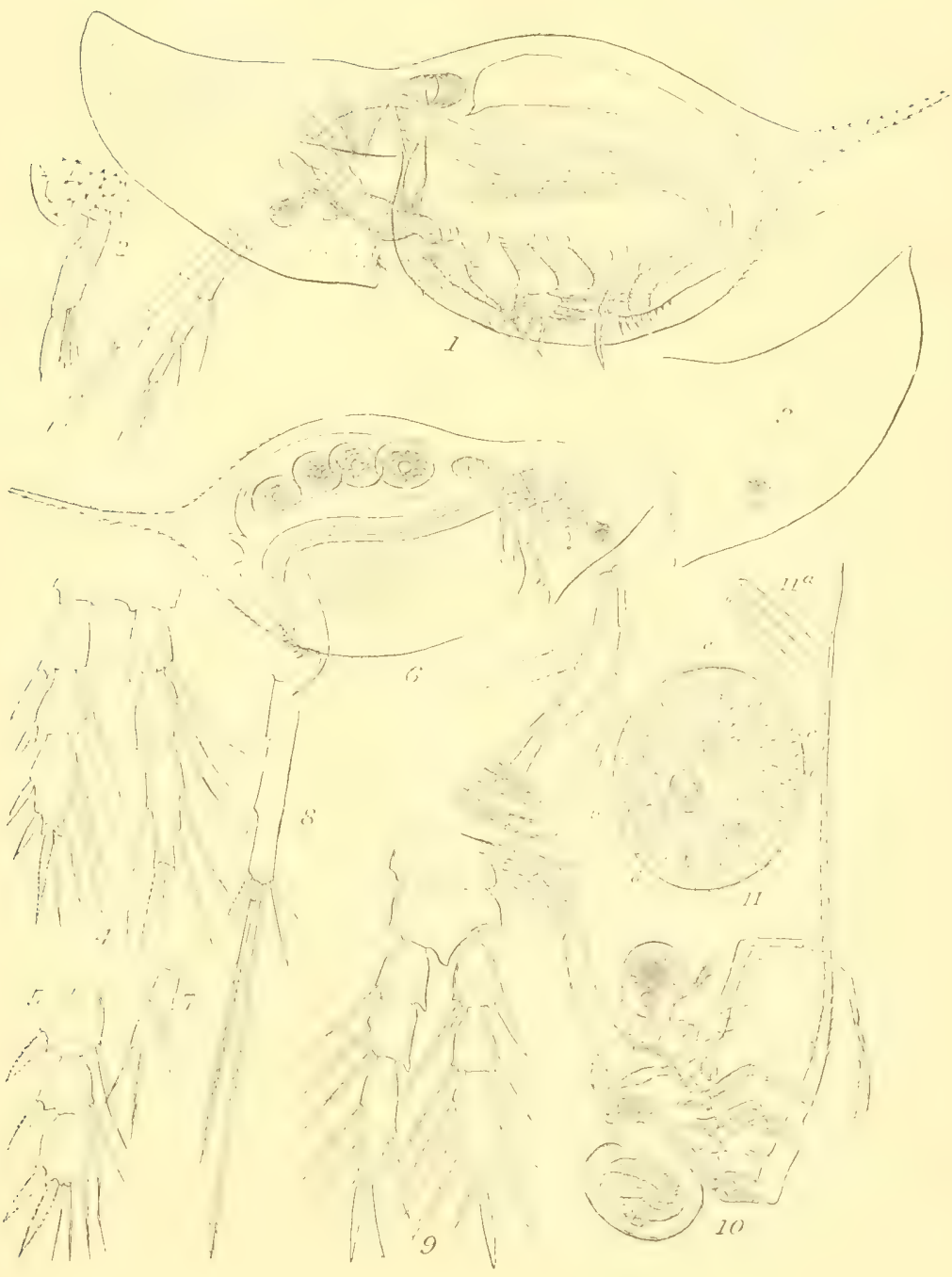



EXPLANATION OF PLATE XXVIII. 
Cyclops capilliferus Forbes.

Fig.

1. Female.

2. Leg of the fourth pair. The terminal spine of the outer ramus is represented too broad.

3. Leg of first pair.

4. Fisth foot.

\section{Cyclops pulchellus ("thomasi").}

5. Leg of first pair.

(i. Leg of second pair.

7. Leg of fourth pair.

s. Fifth foot.

All the figures are copied from Forbes. 
Znol. Survey of Minn., II, i 895 .
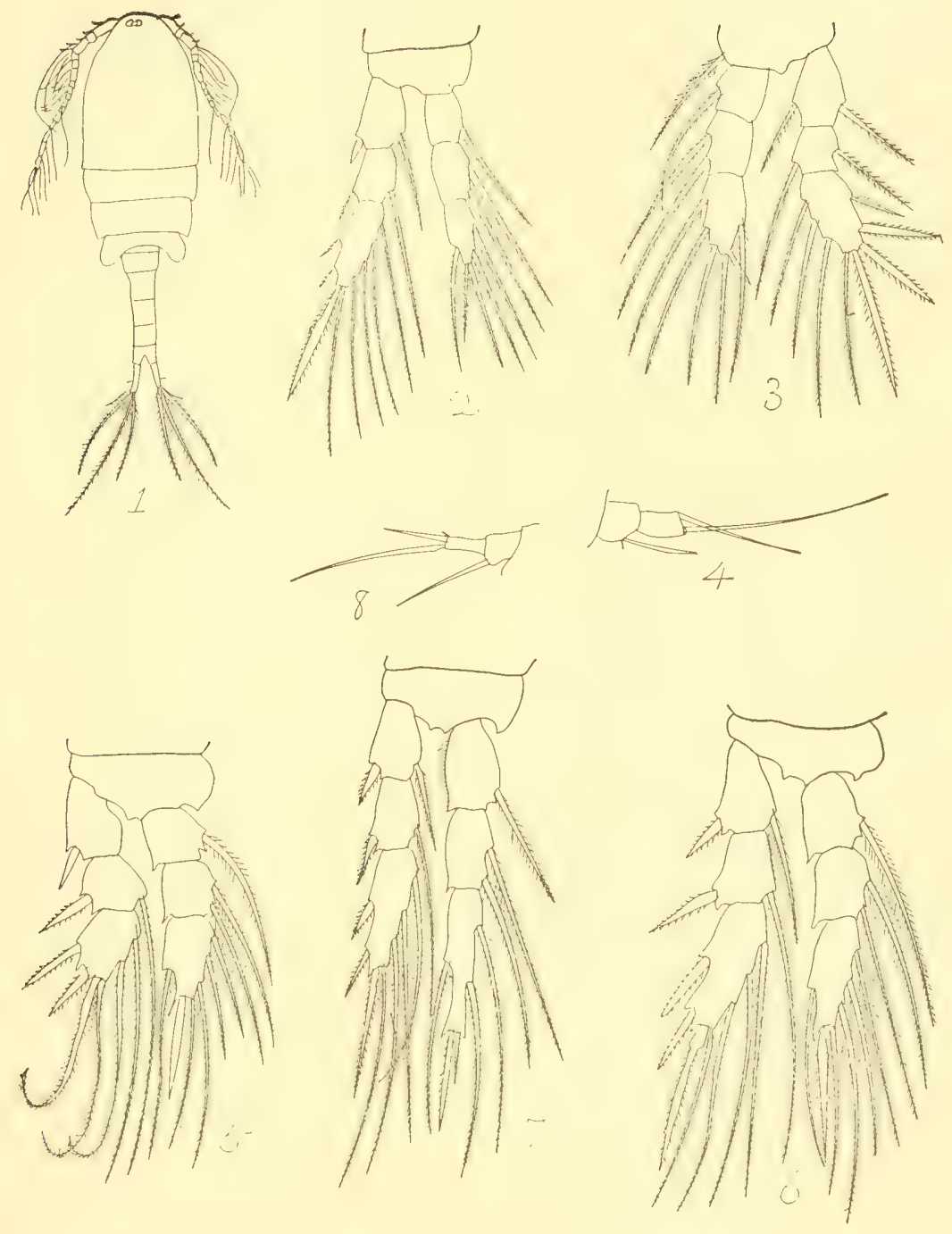

EXPLANATION OF PLATE XXIX. 


\section{Canthocamptus illiuoisensis.}

Fli.

1. Antenna of female.

2. Fifth foot of female.

3. Antennule.

4. First foot.

5. Caudal stylet.

Canthocamptus northumbricus var, americanus.

6. Fifth foot of female.

7. Antenna of female.

8. Maxilliped.

9. Caudal stylet.

10. Antenna of male.

11. First foot.

12. Fourth foot.

13. Fifth foot of male.

i4. Frontal area.

15. Canthocamptus temuicaudis. Stylets.

16. 6 tenuicaudis. Fifth foot of female.

Cyclops serrulatus.

17. Fifth foot.

18. Fourth foot.

19. Onter ramus of first foot.

Canthocamptus northumbricus.

20. Inner ramus of third male foot.

21. Beak.

22. Maxilla. 


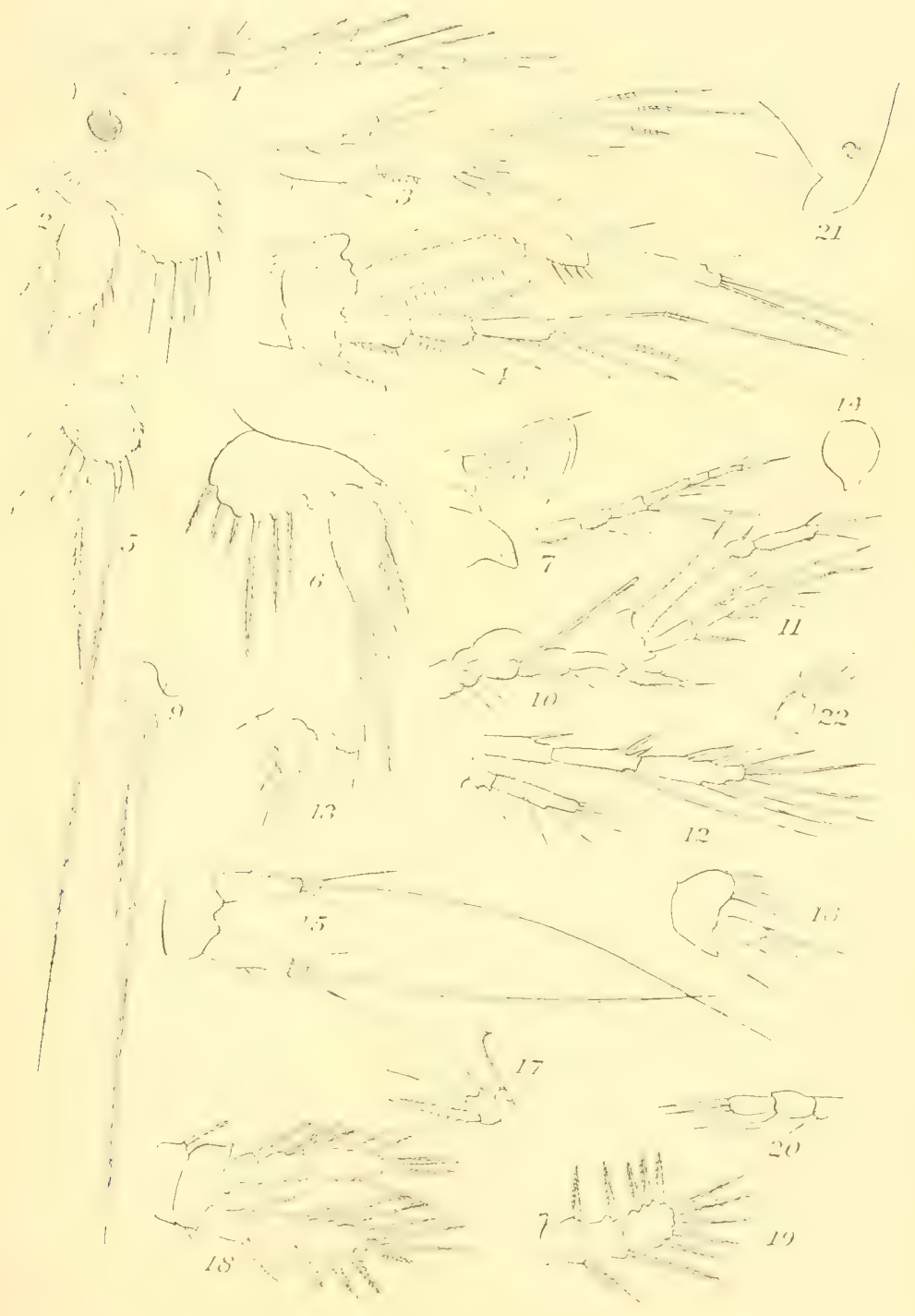



EXPLANATION OF PLATE XXX. 
FIG.

1. Cyclops fluviatilis Herrick. Immature female.

\section{Cyclops varicans Sars.}

2. Female from above.

3. Caudal stylets.

4. Antemna of female.

5. Maxillipedes.

6. Feet of first pair.

7. Feet of fourth pair.

8. Fifth foot.

Cyclops affinis Sars.

9. Caudal stylets, after Schmeil.

10. Receptaculum.

11. Fifth foot. 

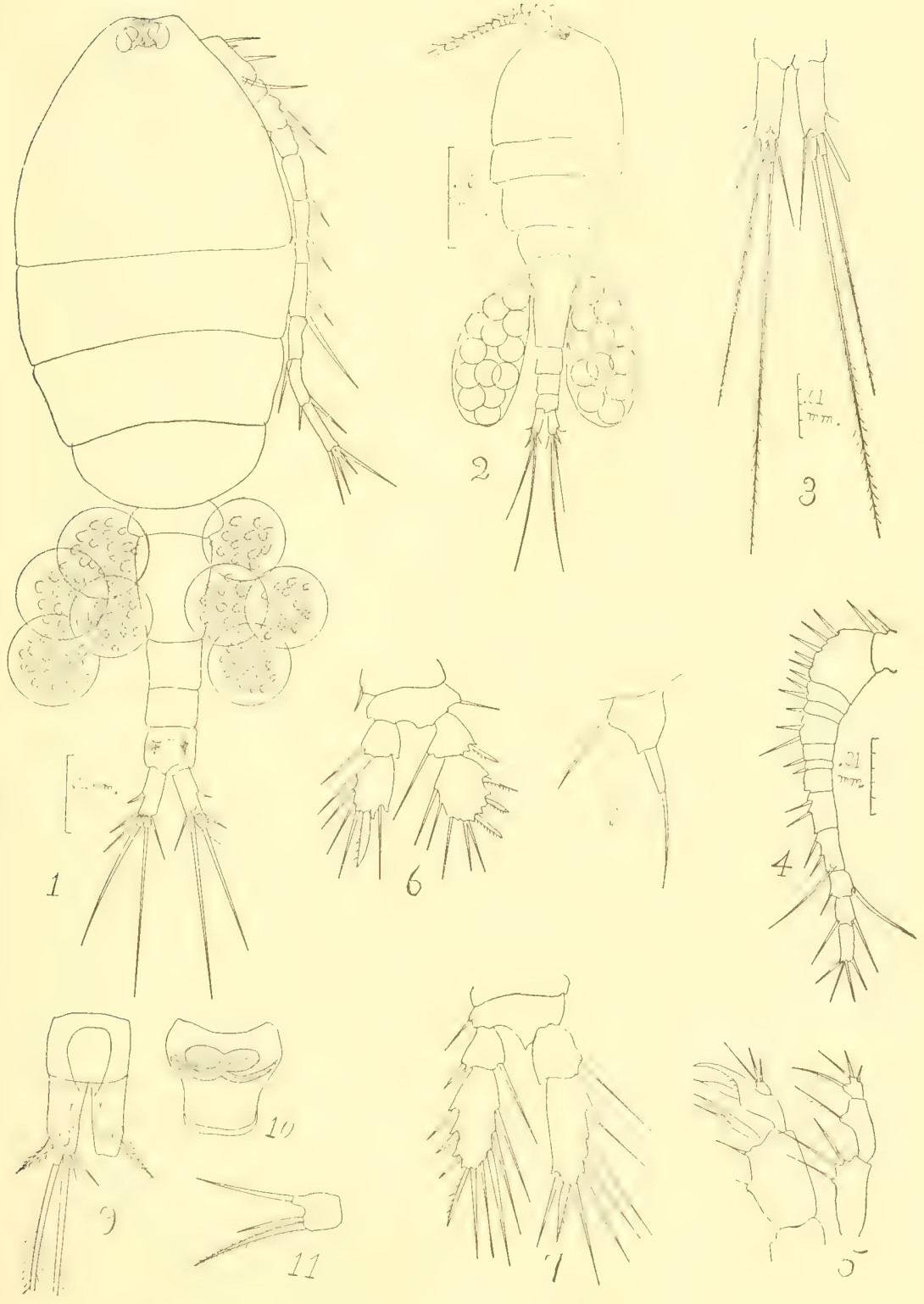

. EXPLANATION OF PLATE XXXi. 
Marshia albuquerquensis Herrick.

Fio.

1. Antenna of female.

2. Antennule.

3. End of mandible.

4. Anterior maxilliped.

5. Posterior maxilliped.

(i. Caudal stylet of female.

7. First foot of female.

S. Outer ramus of second foot.

9. Third foot.

10. Fourth foot.

11. Fifth foot, (a) variety, (b) type.

12. Cumbal stylet of male. The union of the two setie is imperfectly figured. They form a U-shaped symmetrical union. 
Zool. Survey of MinN., II, 1895.
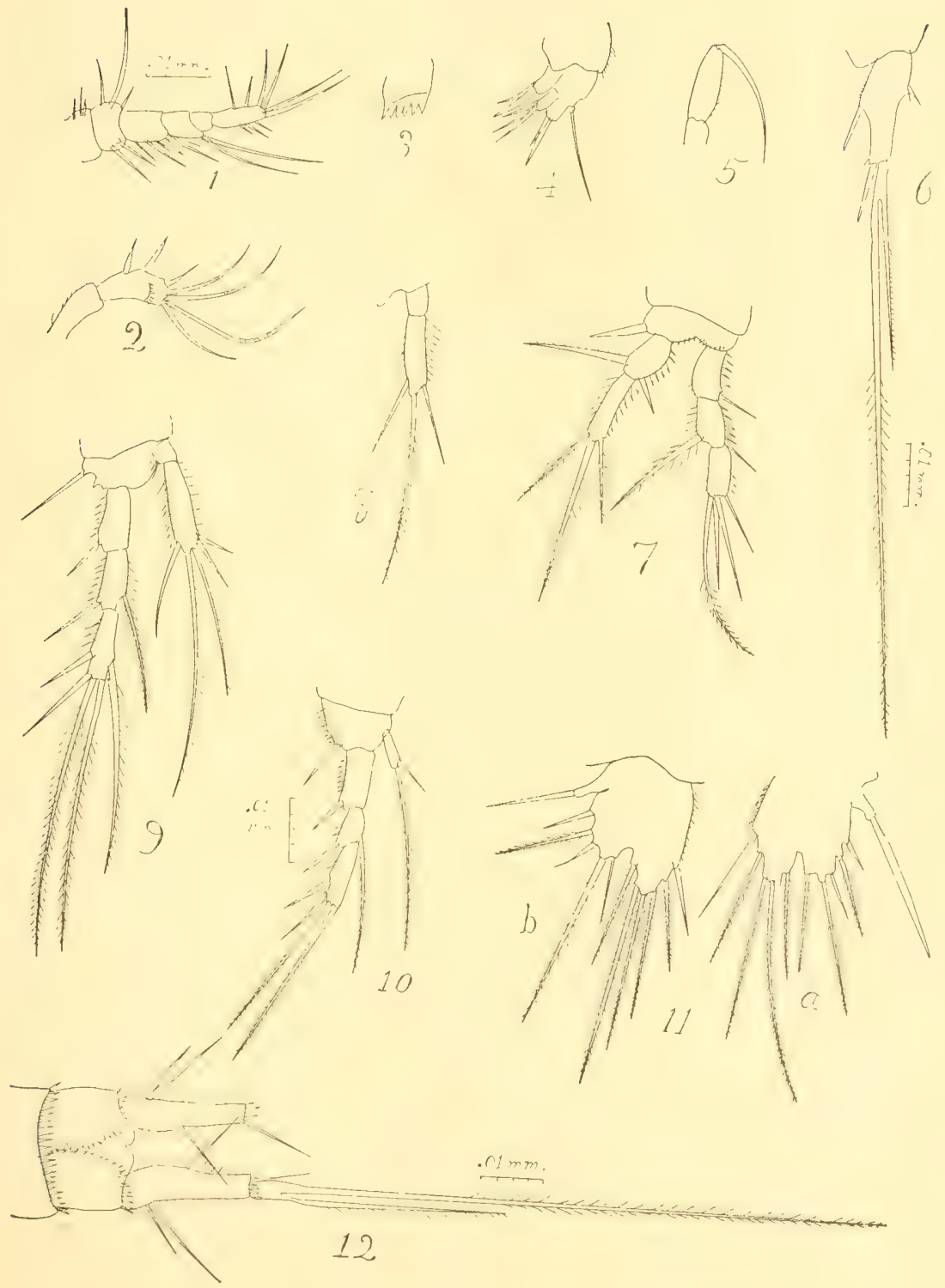

I $1 \mathrm{~mm}$

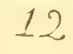



EXPLANATION OF PLATE XXXII. 


\section{Marshia albuquerquensis.}
1. Antenna of male.
2. Antennule.
$\therefore$ Fifth foot of male.
1. Fourth foot of male.
5. First foot of male.

Marshia brevicaudata Herrick.

(i. Mrale.

¡. Caudal stylet of male

s. Fifth foot of male.

9. Fifth foot of female.

10. Antenna of female.

J1. Posterior maxilliped.

1.. Antenna of male.

1:). Second foot. 


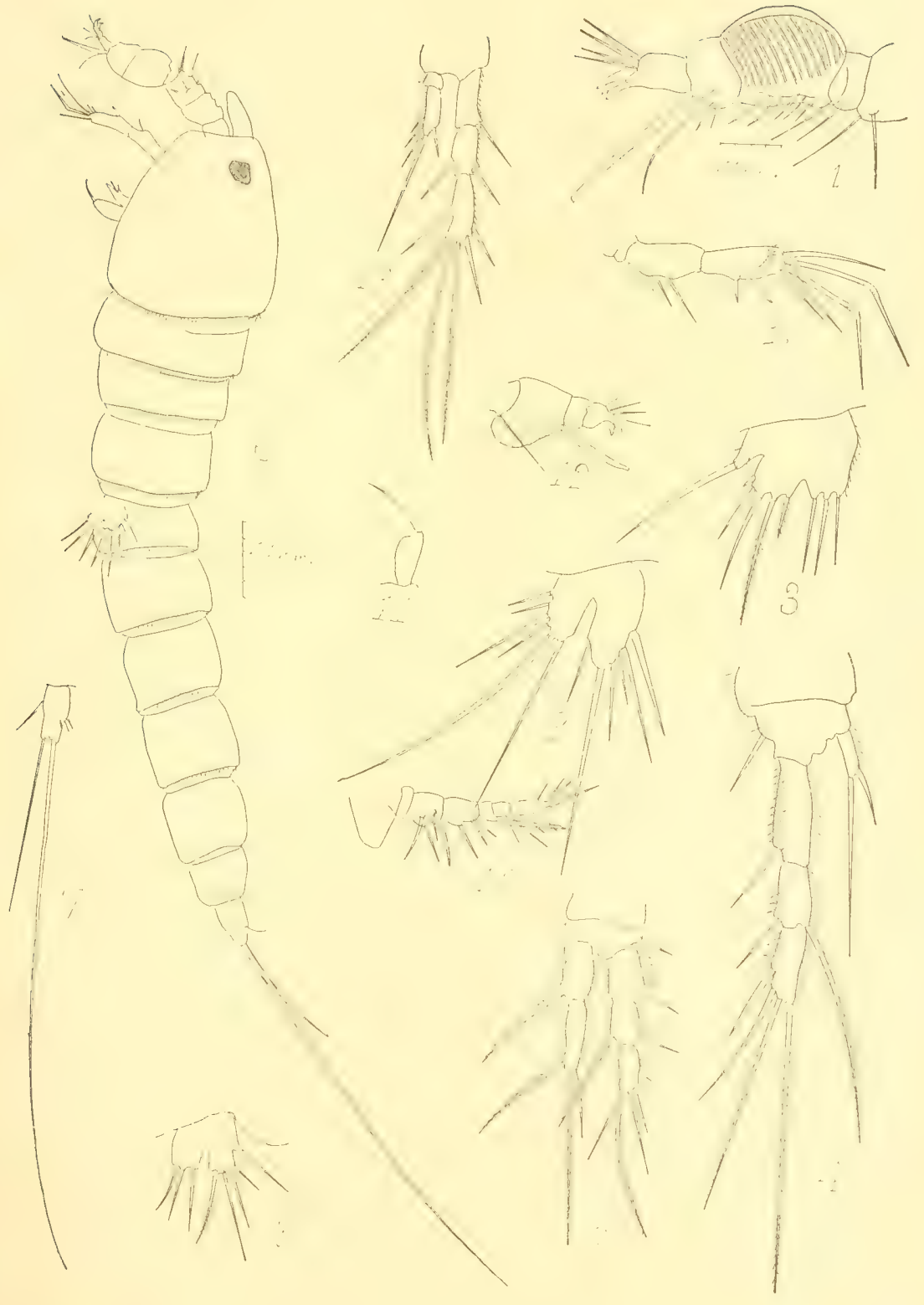



EXPLANATION OF PLATE XXXII. 
Frg,

1. Cyclops signatus var. tenuiconis. Cardal stylet. A case where the inner aspect is ciliate.

2. Fourth foot of same.

Canthocanptus northumbricus var. ansericanus.

3. Caudal stylet.

4. Maxilliped.

5. Fifth foot.

Diaptomus hircus.

i. Tueft fifth foot of male.

7. Right fifth foot of male.

s. Fifth foot of female.

Diaptomus, sancti-patricii.

3. Fifth foot of male.

10. Filth foot of female.

11. Appendages of penultimate joint of right male antenna.

Figs. 6-11 are after Brady. 


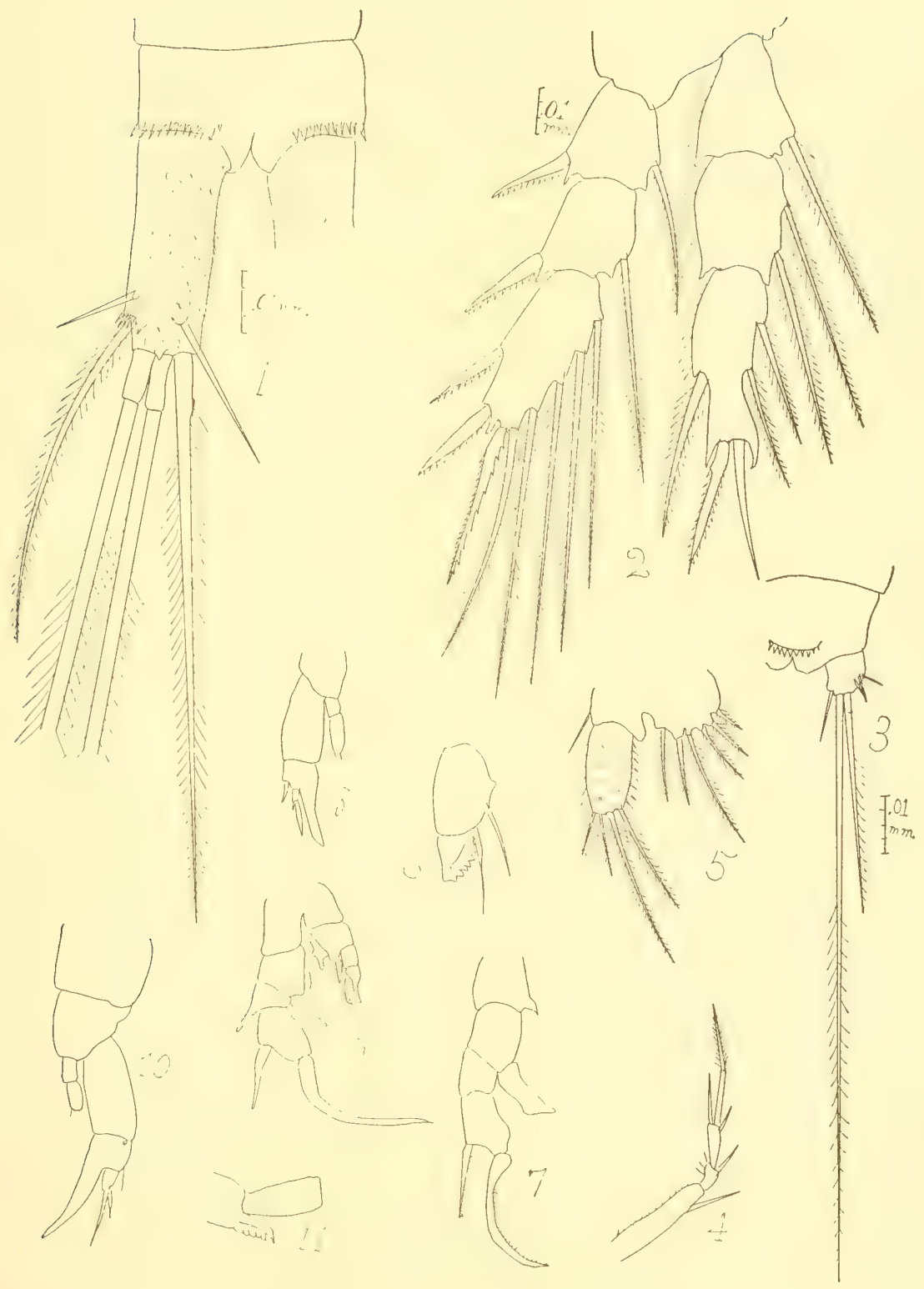



EXPLANATION OF PLATE XXXIV. 


\section{Cyclops pareus Herrick.}

Fici.

1. Camera outline of female, elongate form.

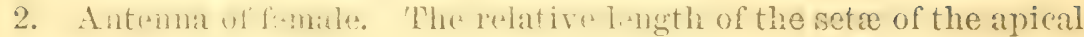
joint is not quite accurately figurea.

3. Caudal stylet of elongate form.

4. Receptaculam seminis.

5. Fifth foot.

6. Foot of first pair.

7. Foot of second pair.

8. Foot of fourth pair. 

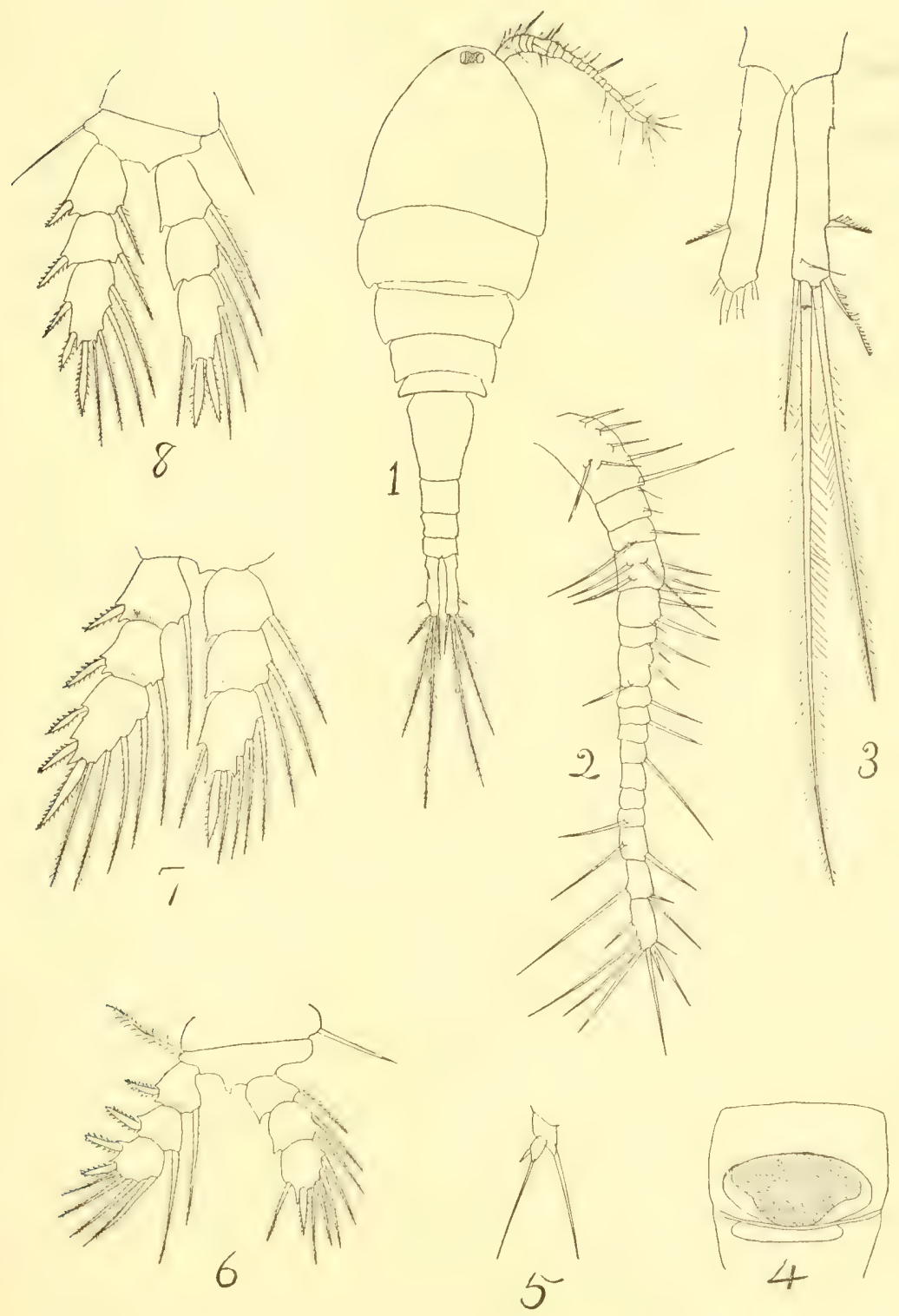

EXPLANATION OF PLATE XXXY 
14. Daphnia pulex var. nasutus.

万. 6 similis. Ontline of head and (a) beak.

(i. Tueptodora liyalina. Seen from above.

7. " h hyalina. LarFa.

$\therefore$ Iatoma setifiera. Female.

9. Limnosila frontosa. Female.

11. 6 frontosi. Anteunule of male.

11. Holopedium gibberum. Female.

12. Sida elongata. Head outline.

13. " crystallina. Head outline of young female.

14. " crystallina. Autennule of male.

15. " crystallina. Antennule of female.

16. (Diphuia hyalin: "D. gallata." Outline of had.

17. "6 "D. vitrea" Outline of head. 


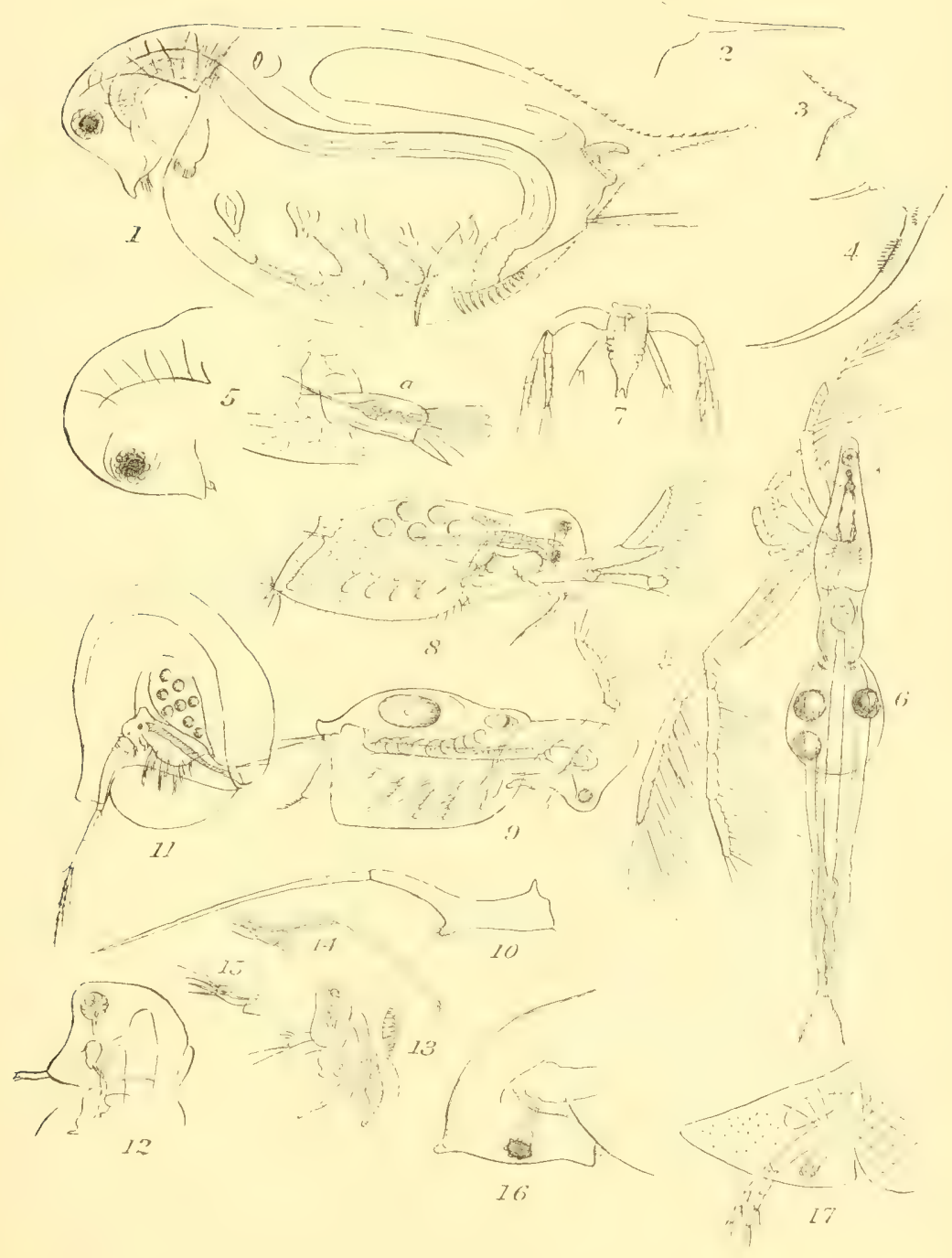



EXPLANATION OF PLATE XXXXVI. 
FIG

1. Alona sp.?

Pseudosida tridentata.

2. Female from above.

3. Antennule of female.

4. End of post-abdomen.

5. First foot.

(i. Maxilla.

Moinadaphnia alabamensis.

7. Post-abdomen.

8. Antenna.

9. Female viewed from side.

10. Antennule.

11. One of the feet of Psendosida. 


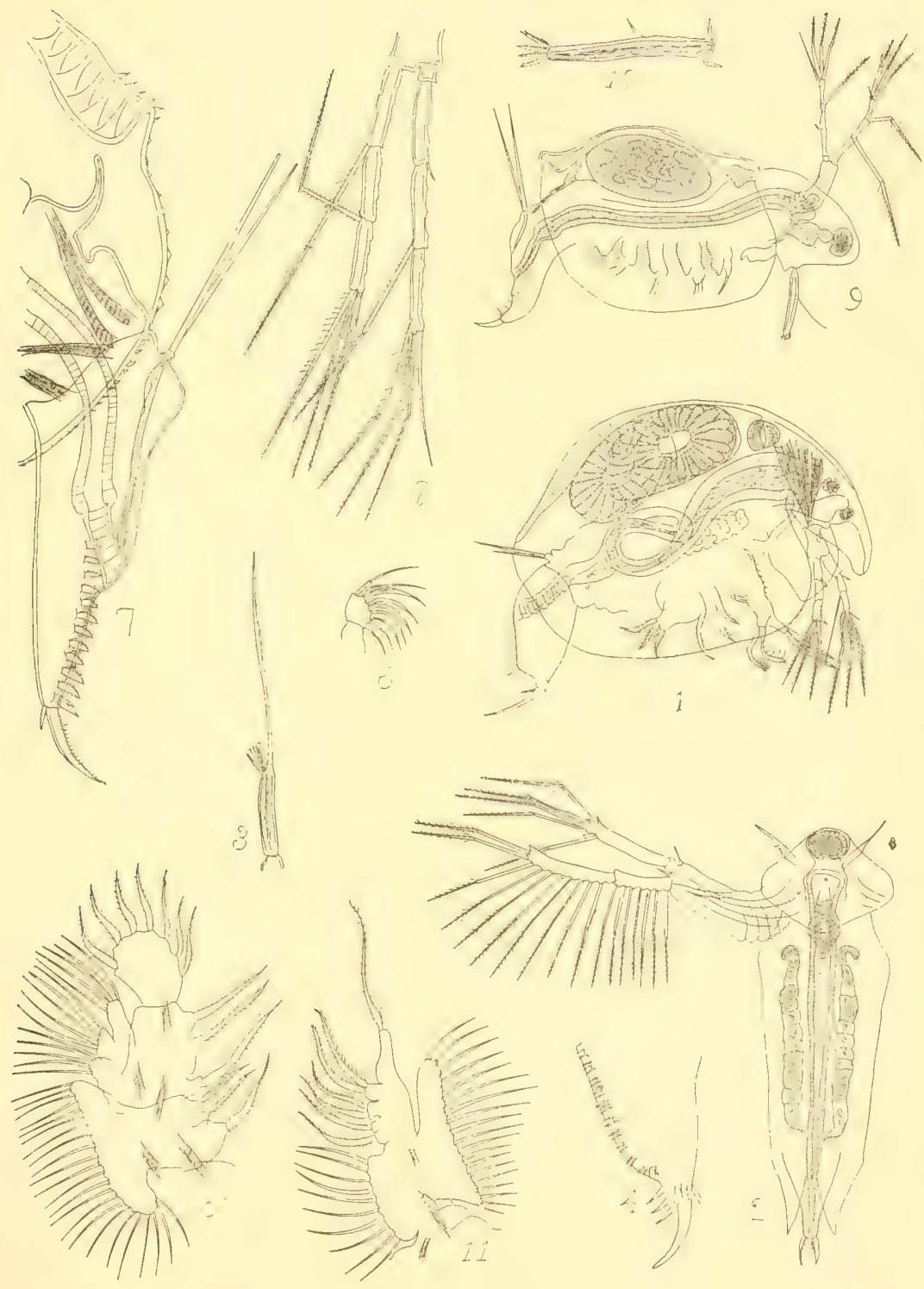



EXPLANATION OF PLATE XXXVII. 
Sida crystallina.

1. Female.

2. First foot.

\section{Daphnella brandtiana.}

3. Side view.

4. Antennule.

5. Inferior angle of shell.

6. Claw of post-abdomen. 


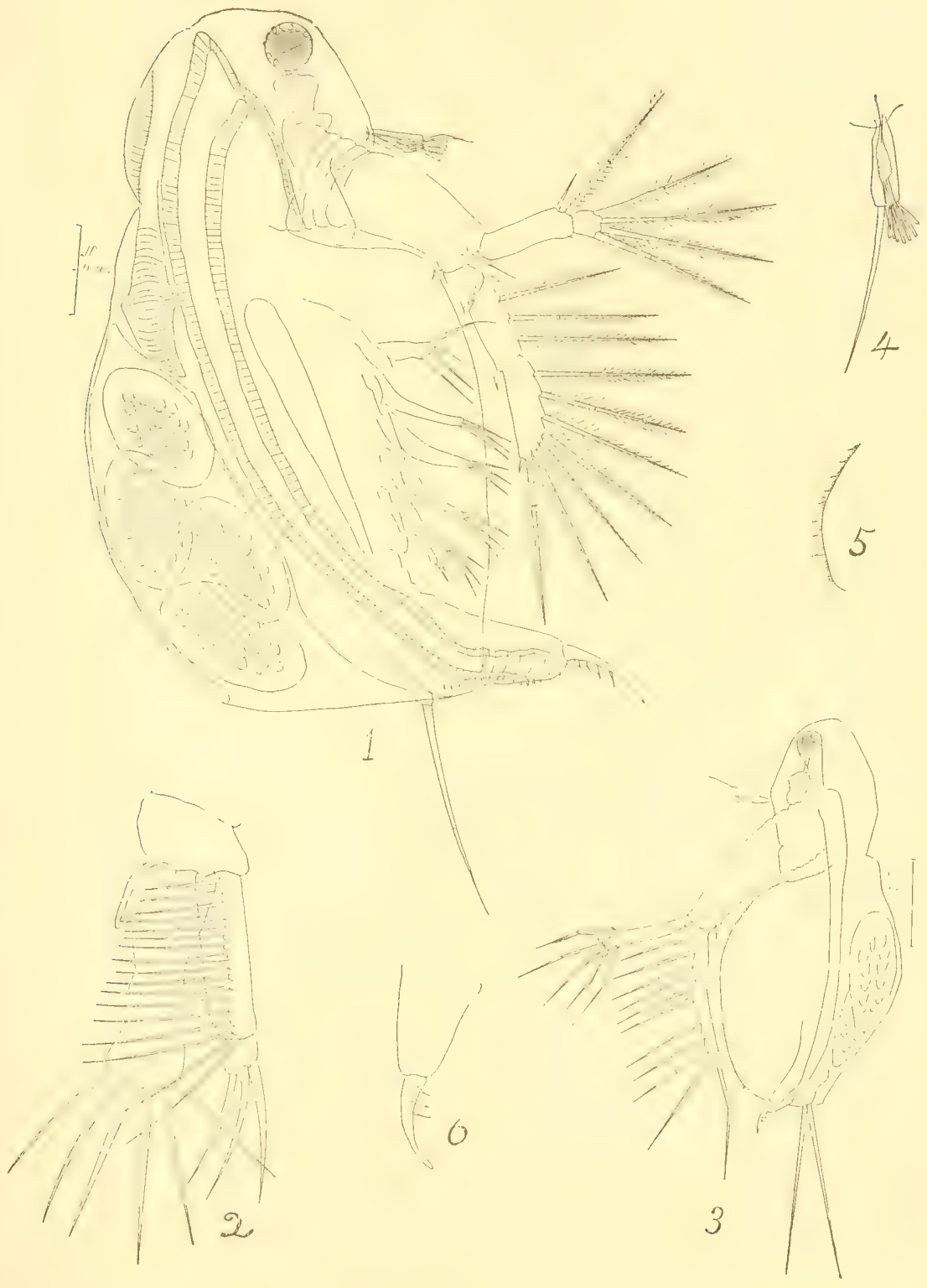



EXPLANATION OF PLATE XXXYII. 
Latonopsis occidentalis.
1. Female from above.
2. Ephippial (?) female from the side.
3. Ordinary female from the side.
4. Antennæe with usual armature.
5. Inferior angle of shell.
6. Antennule. 


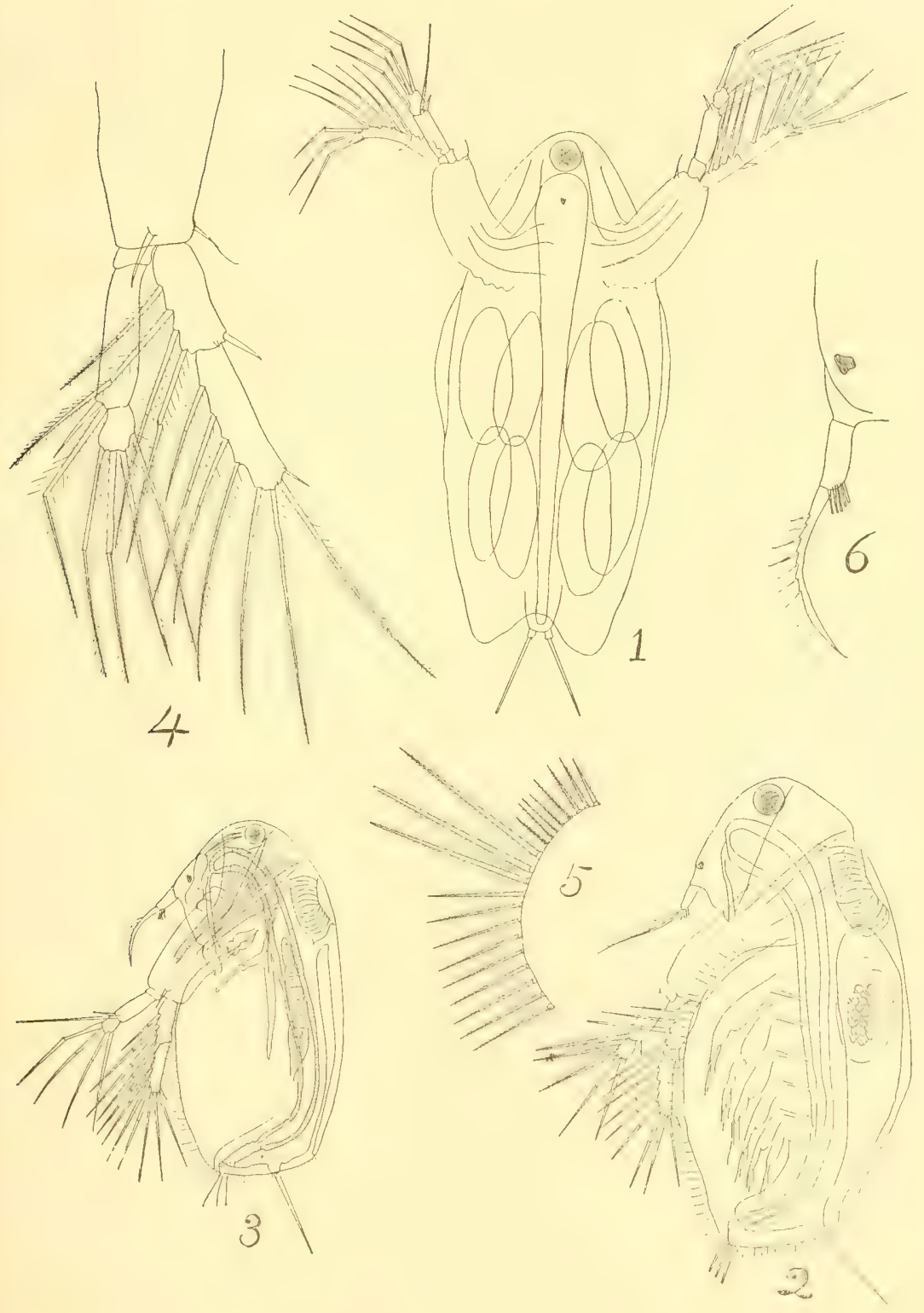



EXPLANATION OF PLATE IXXIX 
Moina rectirostris Mueller.

Iite.

1. Female with summer ova.

2 Portion of the shell near the postero-inferior angle.

:. Post-abdomen.

1. Antenuule.

Moina brachiata Jurine.

万. Female with summer ova.

i. Antenuule. The lateral flagellum is omitted.

7. Post-abdomen.

$\therefore$ First foot of female.

). Moina pandoxa Weismann. Ordinary form. 


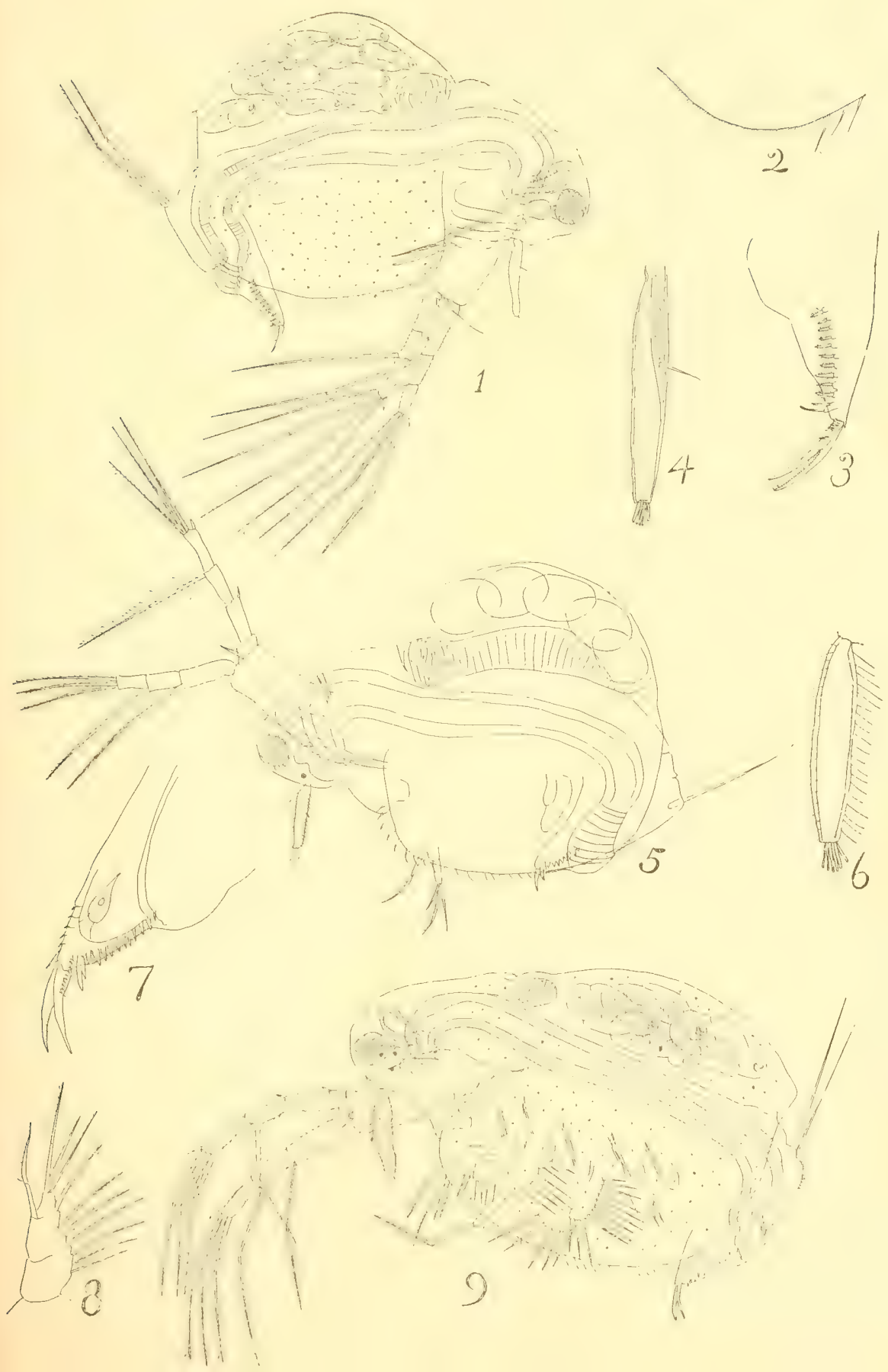



EXPLANATION OF PLATE XL. 
FIs.

Moina paradoxa Weismann.

1. Adult female with ephippium. Antenna omitted.

$\because$ Male, from the side.

$\therefore$ Adult female with summer eggs, seen from below.

1. View of the head, from the side. St, stomach; cœ, cœecum of same; $B r$, brain; anl, antennule; $f$, flagellum of same; $7 b$, labrum; $\alpha s$, osophagus; ey, eye; mb, mandible.

$\therefore$ First foot of male.

(i. Antennule of male.

7. First foot of female.

All the figures are camera drawings from New Mexican specimens. 

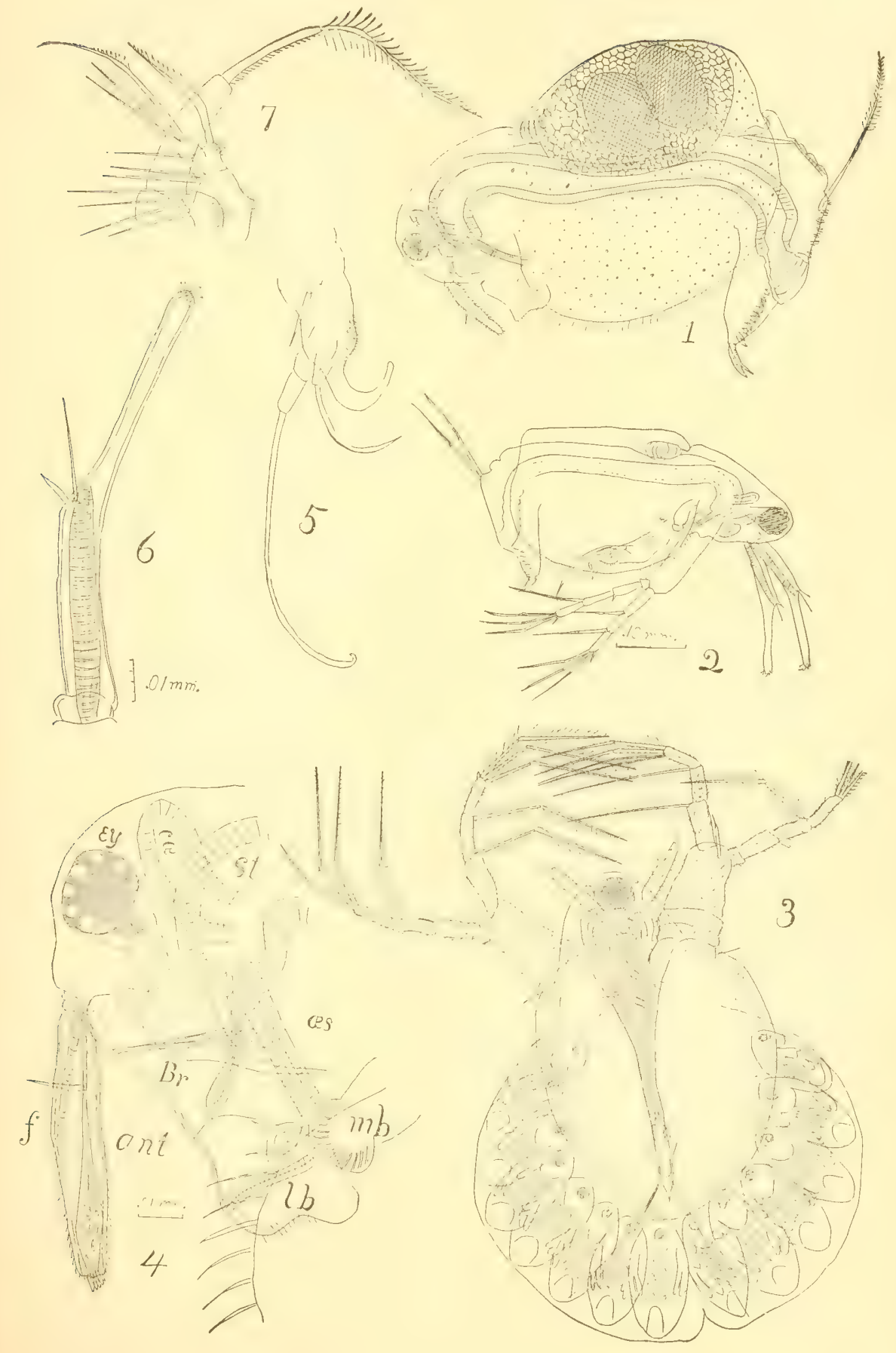

EXPLANATION OF PLATE XLT. 
1. Moina paldoloxa. Ablomen of fimale from Minnesota.

i:ı. " . $\quad$. Spine from post-abdomen.

2 .. rectirostris. Post-abdomen.

3. “ parabloxil. Head of lemale, showing: (1) eye with pigment. and lenses, (b) supra.nesophageal ganglion, antennule with $(c)$ its muscles, $(d)$ its nerve, and $(e)$ its terminal sensory filaments, $(f)$ the crecum of stomach, $(g)$ optic ganglion, (h) stomach, (i) osophagus, $(j)$ the muscles which move the eye, also part of the labrum.

1...$\quad$ paratoxa. Antennie.

5. .. rectirostris. Ephippium.

i. .. paradoxa. Ephippium.

i...$\quad$. $\quad$ Seminal cell.

ia. " $\quad$. $\quad$ A group of seminal cells less magnified.

$\therefore \quad$. rectirostris. Seminal cells.

3. .. paradoxi. First foot of male.

11) .. rectimostris. First foot of male. (From Weismann).

11. $\because$. Male. (From IVeismann).

1‥ Ceriodaphnia rotunda. Head.

13.

1.1

1.i.

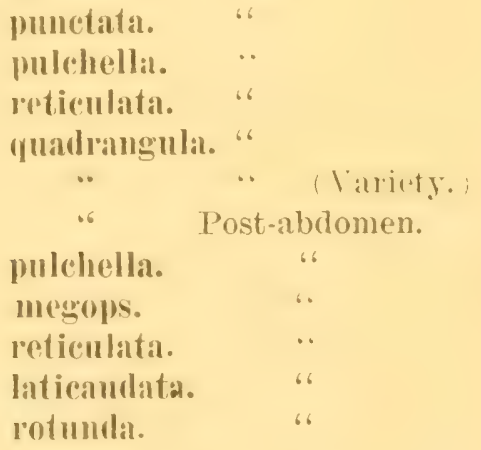

Figures $12-2: 3$ are after P. E. Mrueller.) 

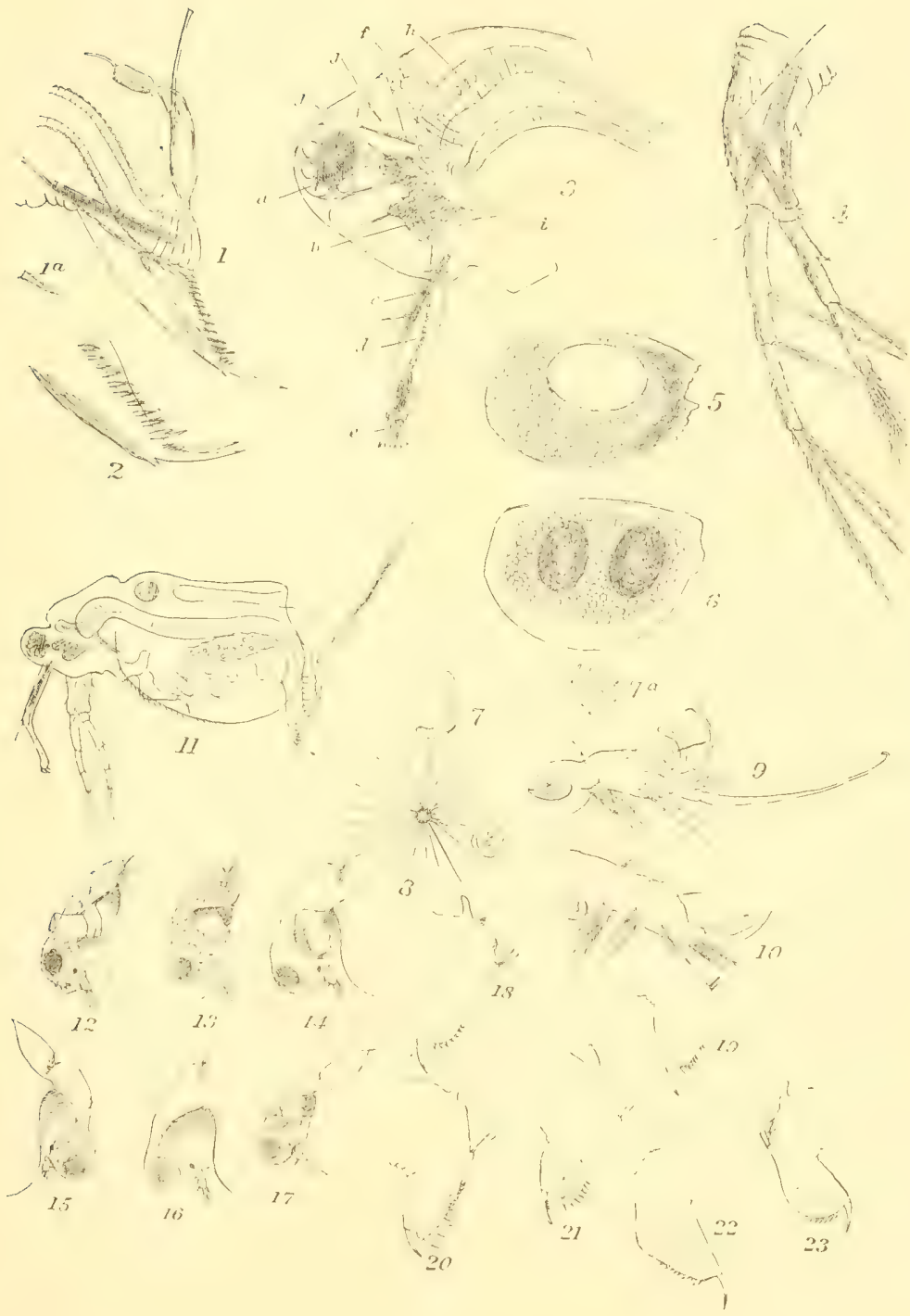

EXPLANATION OF PLATE XLII. 


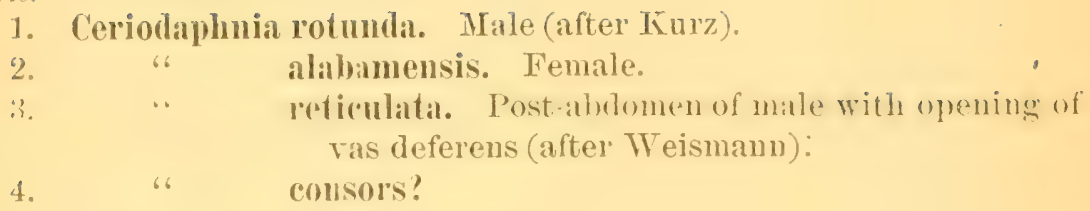

Ceriodaphuia scitula.

i. Head of female.

i. Post-abiomen.

i. Antennule of male.

8. Semen cells of male.

9. Scapholeburis angulata. Adult female.

9.

10. " armata. Adult female.

11. 66 armata. Frombelow.

Otryoxus uracilis.

12. Youner.

13. Labrum.

14. Antennule.

15. Last foot. Purple pigment in lower part. 


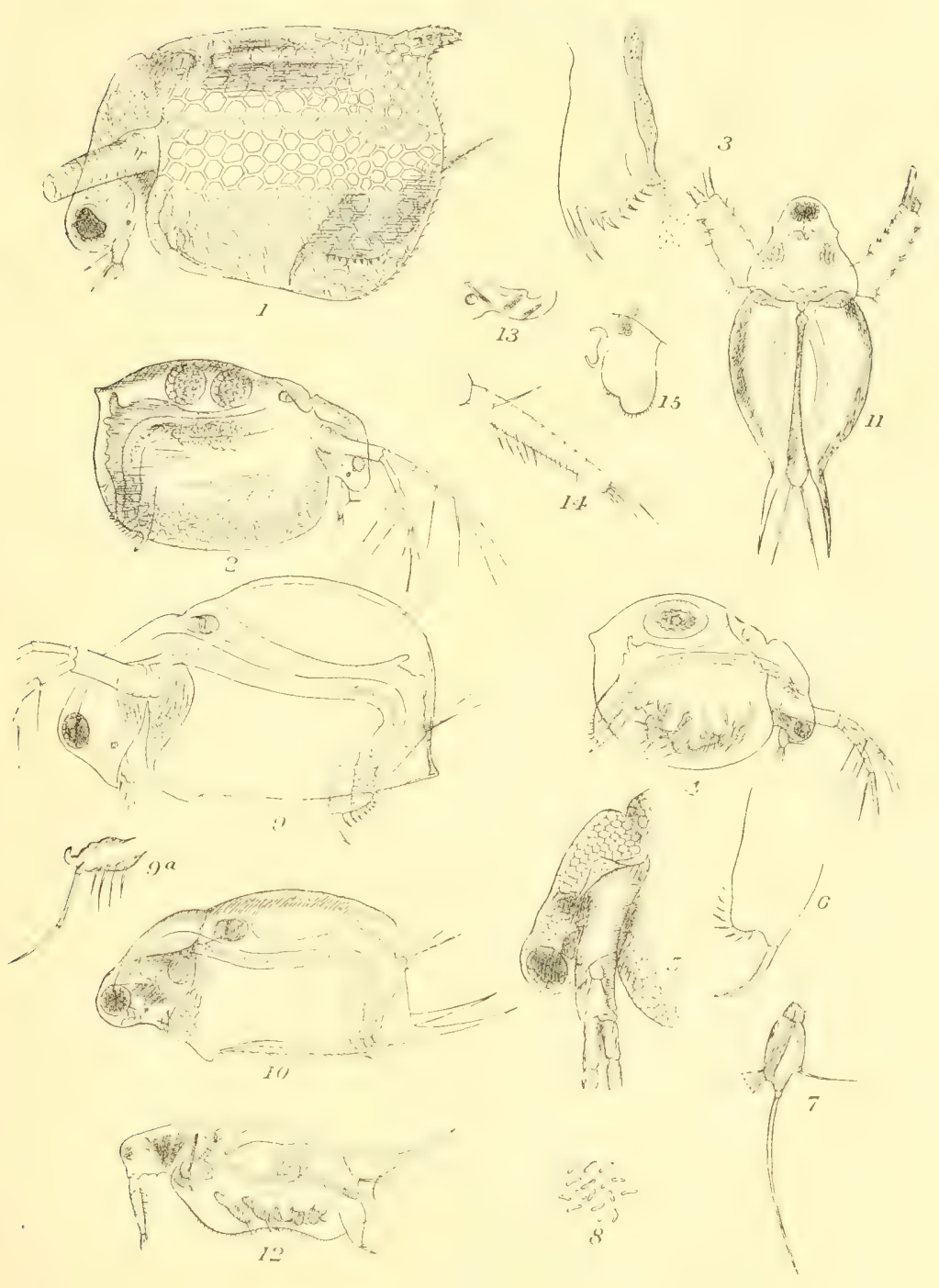



EXPLANATION OF PLATE XLIII. 


\section{Moina brachiata}

1. Leg of fifth pair, after Lund.

․ Leg of third pais.

:C Ceriodaphnia reticulata. Leg of fifth pair.

Scapholeberis mucrouata.

4. Post-abdomen.

i. Foot of second pair.

i. Foot of fourth pair.

i. Female, seen from above. 
Zool. Survey of Minn., II, I895.
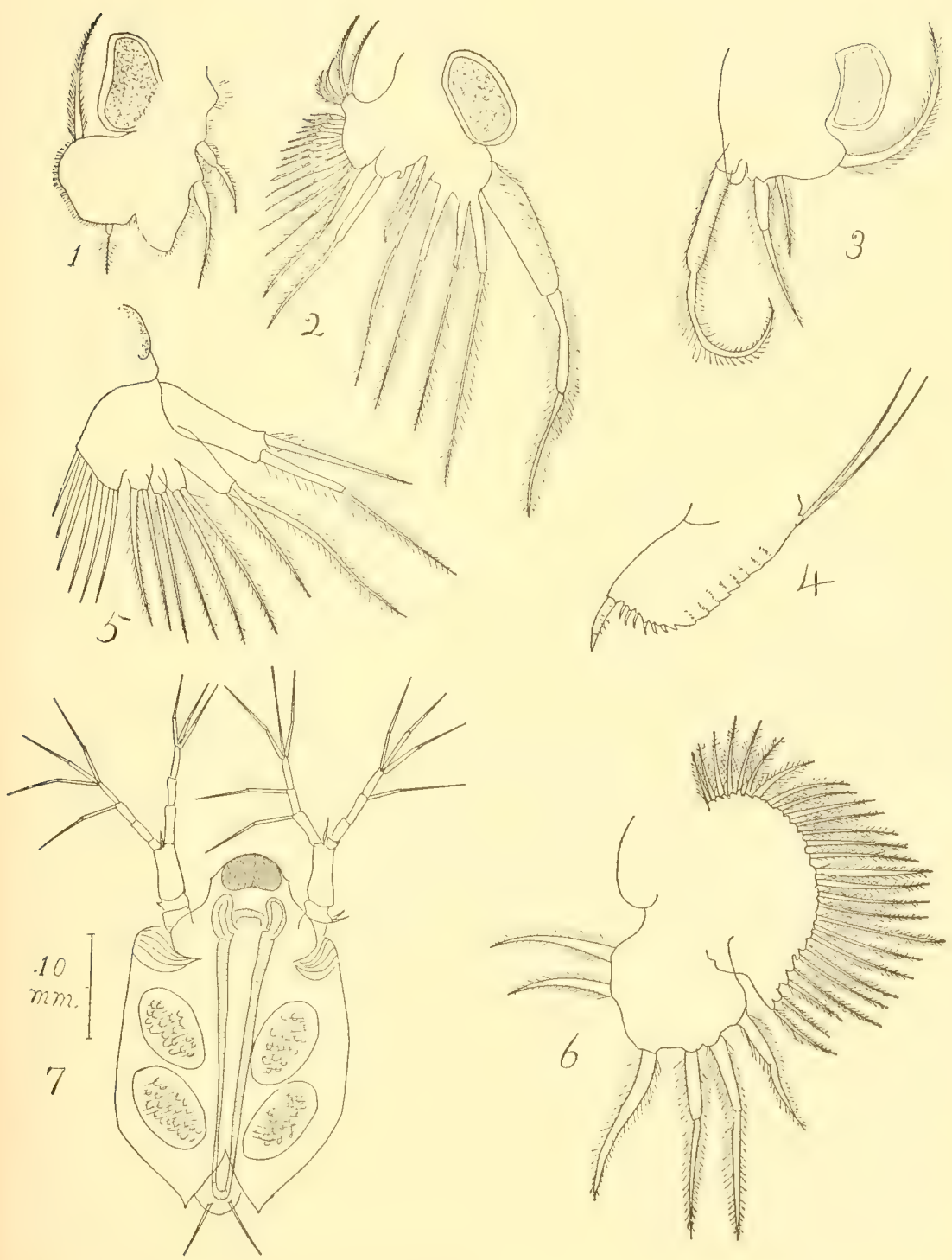

EXPLANATION OF PLATE XLIV. 
Ceriodaphuia scitula.

Fre. Head.

2. Post-abdomen.

Ceriodaphnia reticulata.

3. Post-abdomen.

4. Head.

Ceriodaphnia consors.

5. Post-abdomen.

6. Head.

7. Simocephalus vetulus. Foot of second pair. 
Zool. Survey of Minn., II, 1895.

PLATE XIV.

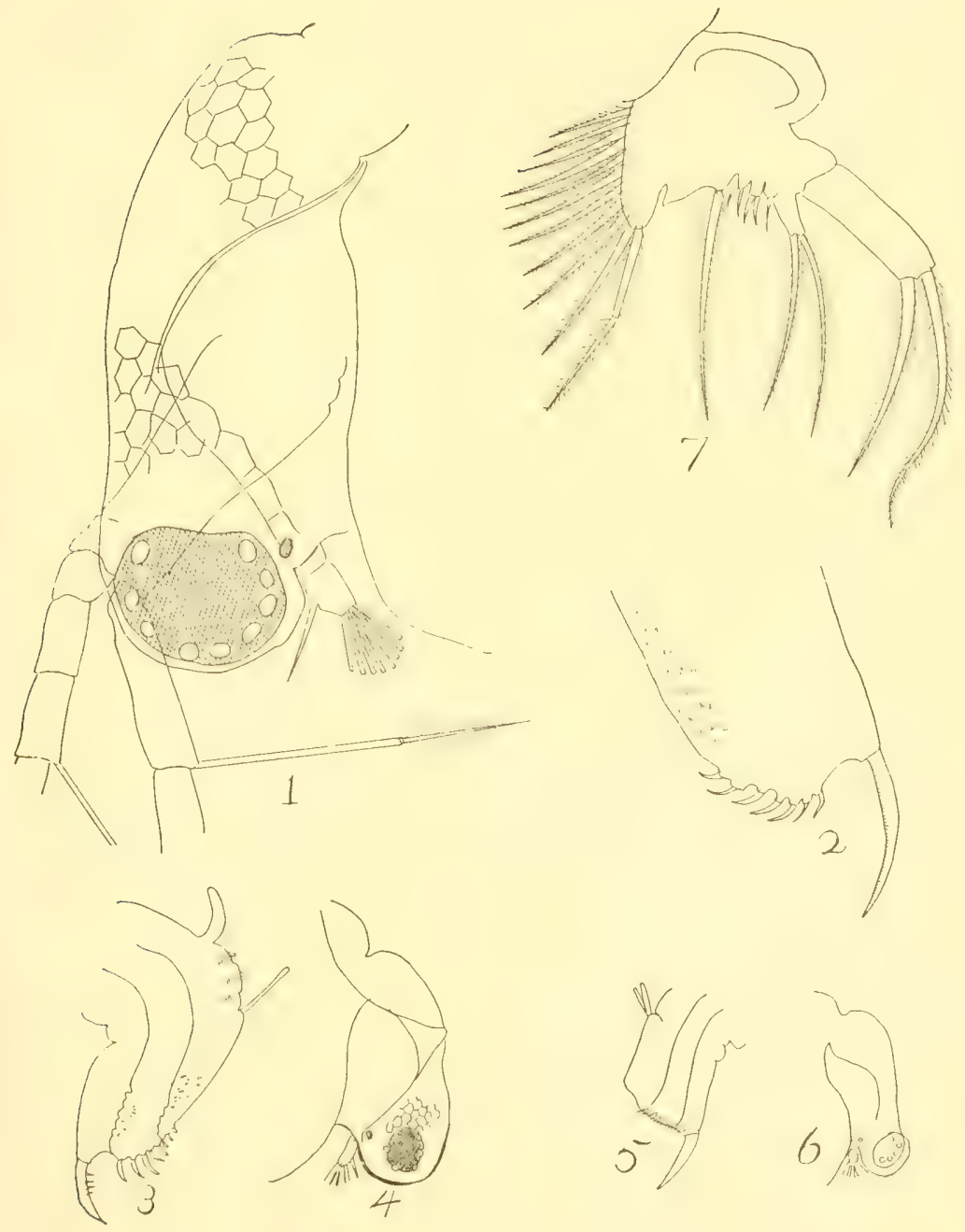



EXPLANATION OF PLATE XLV. 
Fig.

1. Coriodaphnia soitula (small variety). Ephippial female.

2. Bosmin: longirostris.

3. " " lilljeborgii. After P. E. Mneller.

4. "6 Hook on the first foot of male.

\%. Scapoleberis mucronata.

6. 6 colnuta. Head.

7. 66 angulata. Head.

7а. 66 augulata. Angle of shell.

8. Pleuroxus ilenticulatus. Male.

9. Simocephalus americanus. Head of female.

10. Rosmina. Post-abdomen of male (after Weismann). 


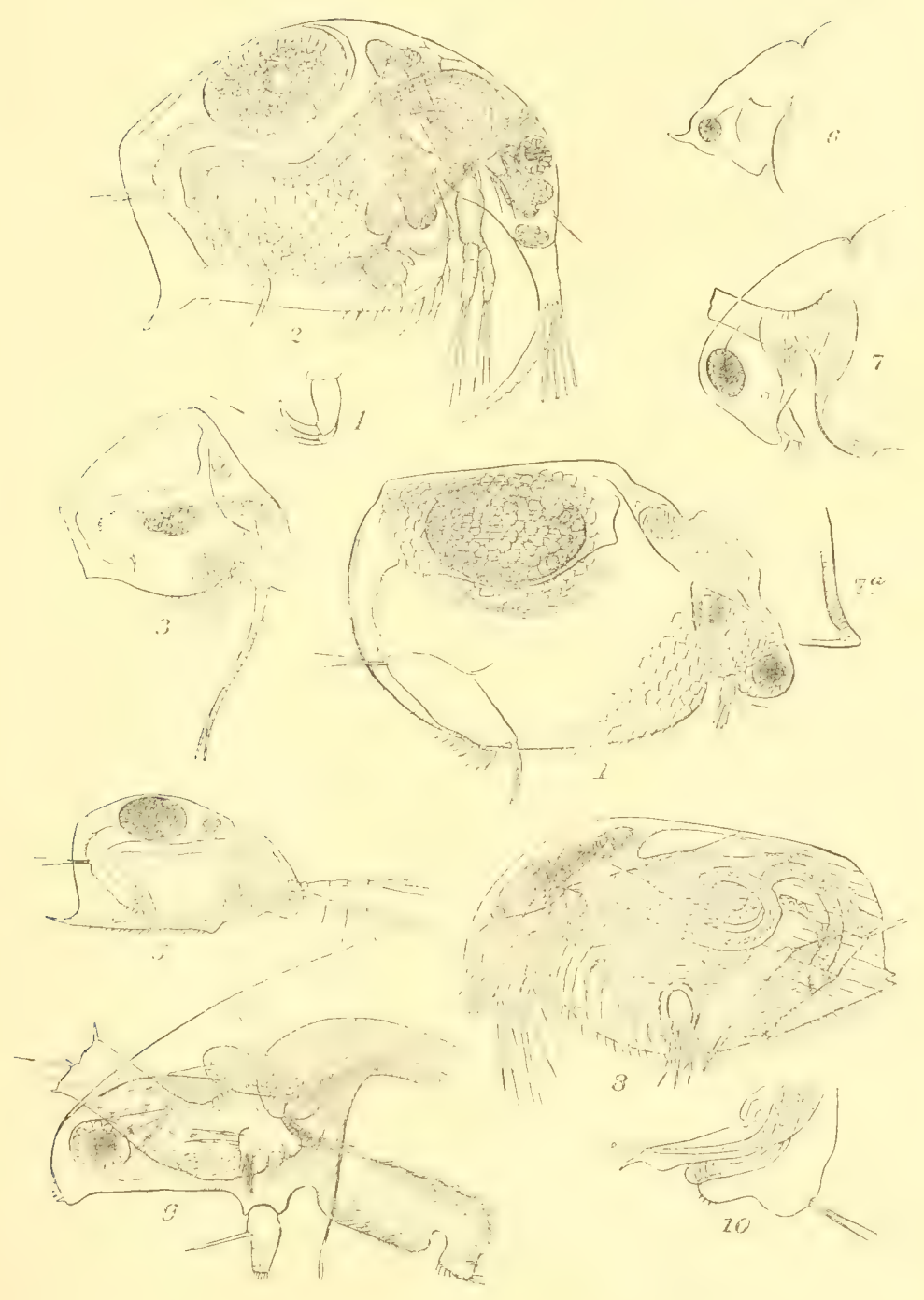



FXPLANATION OF PLATE XLVI. 


\title{
Acantholeberis curvirostris.
}

\author{
1. First foot. \\ 2. Fourth foot. \\ 3. Filth foot. \\ 4. Lateral view of female.
}

Simocephalus daphnoides.

i. Lateral view.

(i. Lower posterior angle of shell.

\section{Eurycercus lamellatus.}

7. First foot.

8. Caudal claws.

9. Drepanothrix dentata. Postabdomen of male. Alter Birge. 
Zool. Survey of Minn., II, I895.

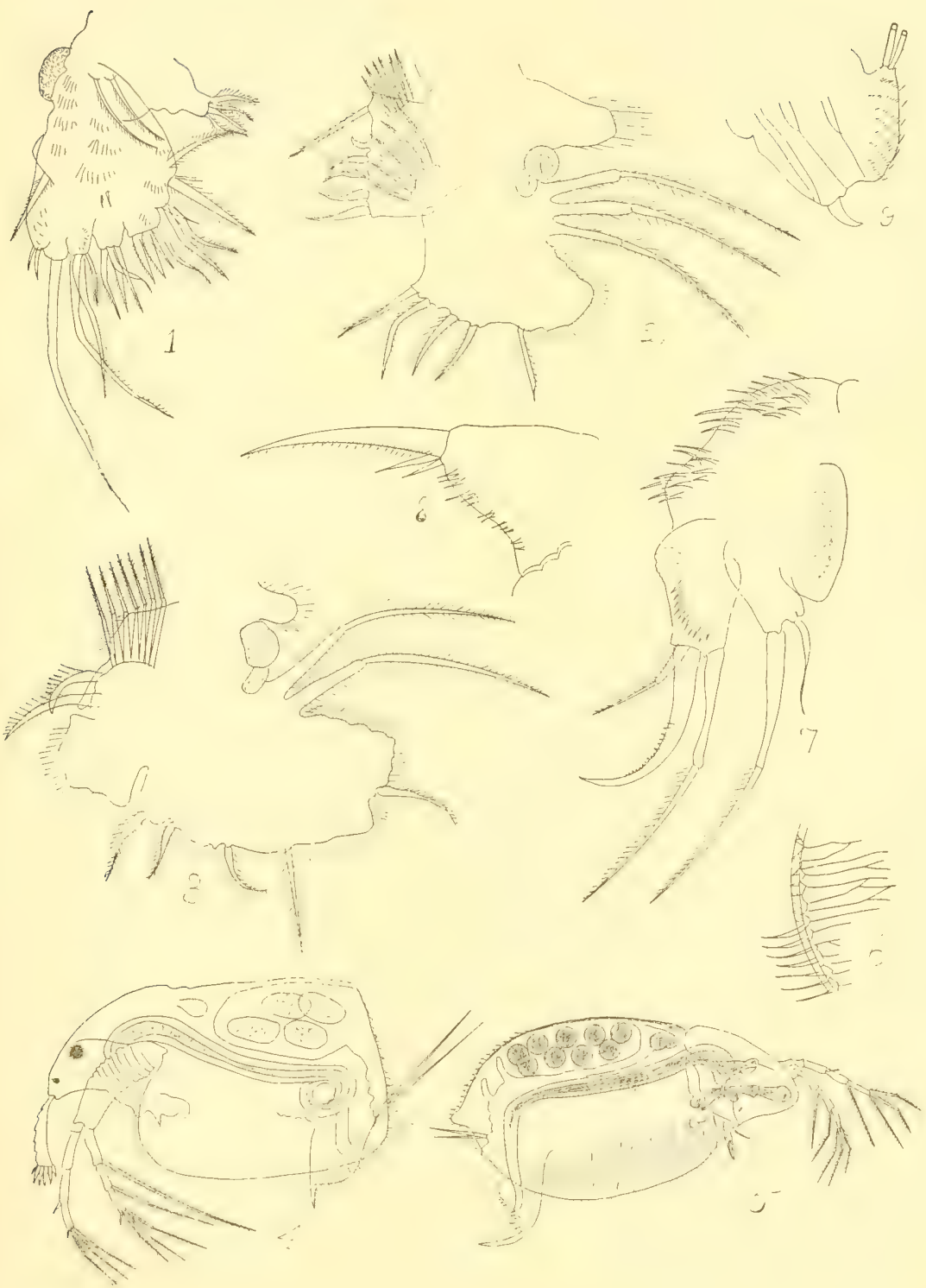



EXPLANATION OF PLATE XLVII. 


\section{Diaptonus mississippiensis Marsh.}

1. Fifth foot of male.

2. Abdomen of female.

3. Fifth foot of female.

Diaptomus birgei Marsh.

4. Fifth foot of male.

5. Fifth foot of female.

6. Terminal joints of male antenna.

\section{Canthocamptus minutus.}

7. Lateral view of male. [" "t, testis; b. cephalie ganglion; $r$, blood sinus or dorsal vessel surrounding the intestine; $d$, anus; $e$, osophagus; $f$, frontal sensory plate."']

8. Caudal stylet.

9. Antenna of male.

10. Antennule.

11. Foot of first pair.

12. Foot of second pair.

13. Foot of third pair.

14. Foot of fourth pair.

15. First maxilliped.

16. Mandible.

17. Spermatophore.

1s. Foot of third pair of male.

19. Foot of fifth pair of male.

20. Foot of fifth pair of female.

21. Maxilla. 
Zool. Survey of Minn., II, I895.

PLATE XLVII.
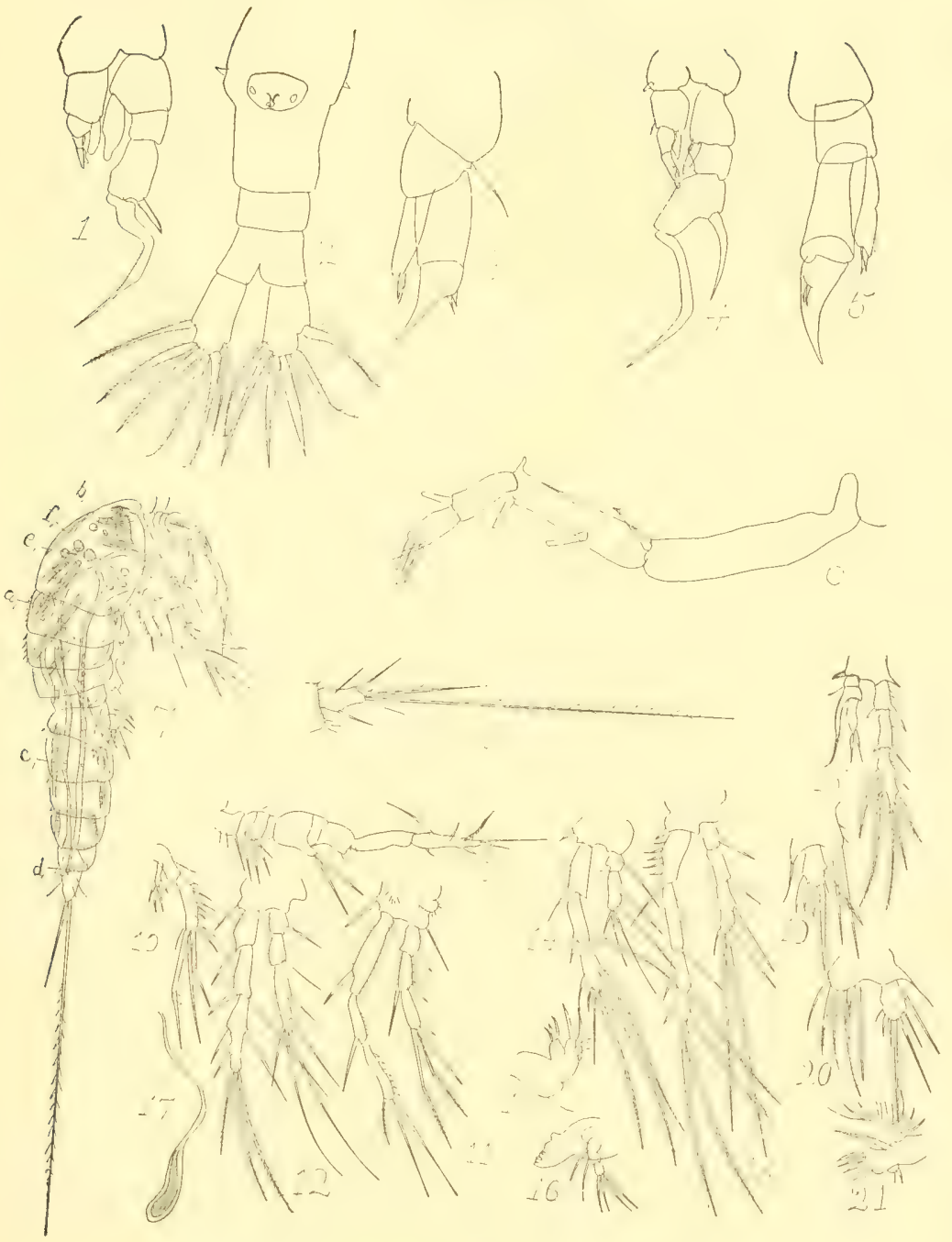

EXPLANATION OF PLATE XLVIII. 


\section{Pliyllopod Larvae.}

Fic

1. Larva of Limmetes 0.33 mm. long. $A^{1}$, first antenna; $A^{2}$, swimming antenua; Mal, mandibular palp; e, eye; $l$, lens; $L$, liver budling from anterior part of stomach; $s$, sensory filament; m, muscles of rectum.

\section{Larva of Chirocephalus.}

2. View from below.

3. Caudal stylet.

4. Head, showing organs of one side. $I$, liver.

5. Muscles of swimming antenna.

6. MLaxilla.

7. End of abdomen of an older individual.

8. Mandible and palpus $(p)$ in this stage.

9. Antenna of female.

10. Antenna of male. $p$, inner ramus; $g$, frontal organ.

11. Part of Limnetes older than Fig. 1.

12. First abdominal segment of female seen from below. This plate illustrat es the relation betweren the Phyllopola and the claducera wn one hand ( Limnetes) and the ('o)repode on the other (Chirocephatus). 
1
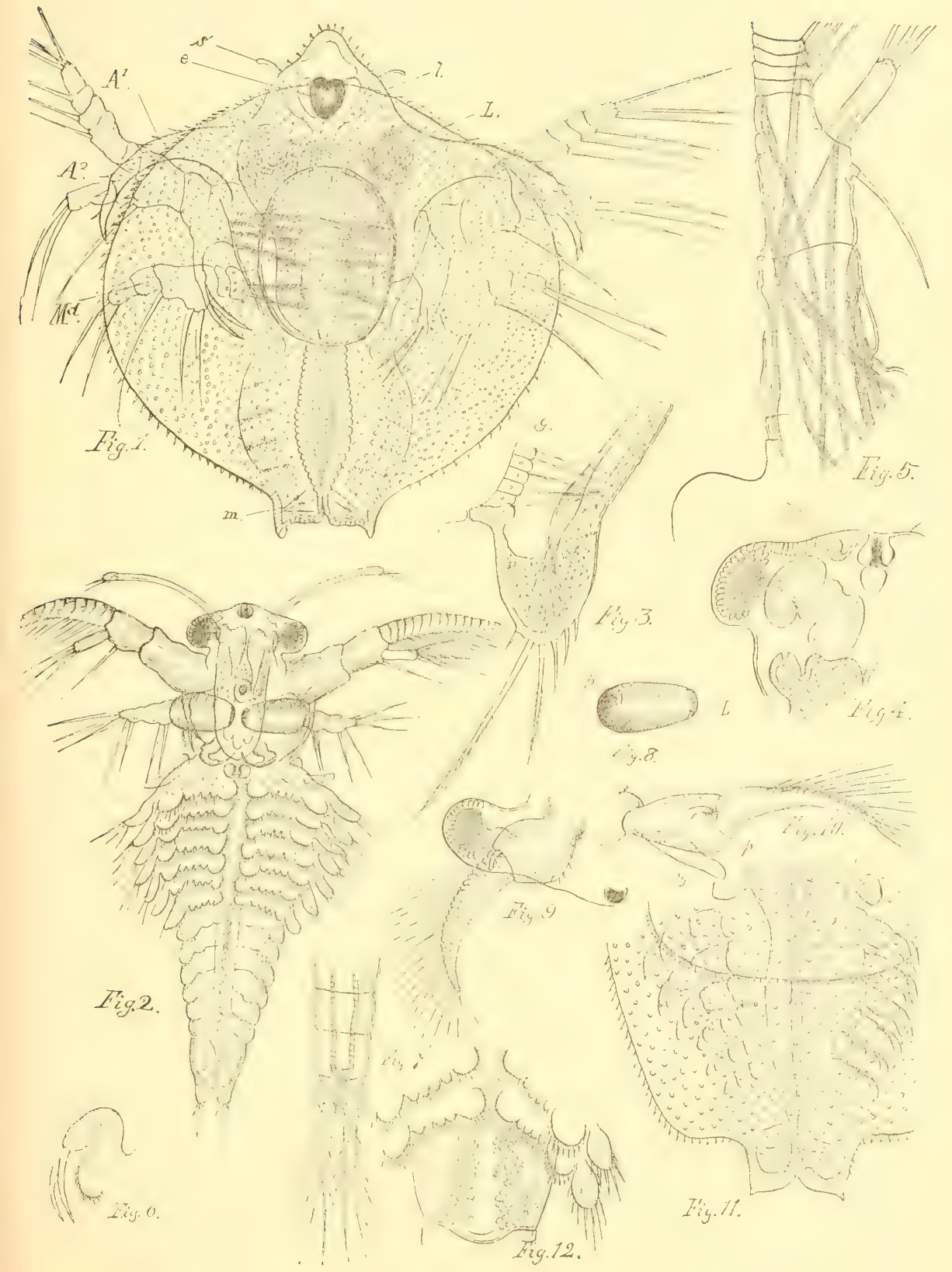

EXPLANATION OF PLATE XLIX. 
Daphnia minnehaha.

Fir.

1. Young female.

2. Head of female.

2a. Post-abdomen.

Daphnia hyalina.

3. Xoung female.

4. Young.

5. Post-imago.

Daphnia dubia.

7. Young.

S. Older female. 


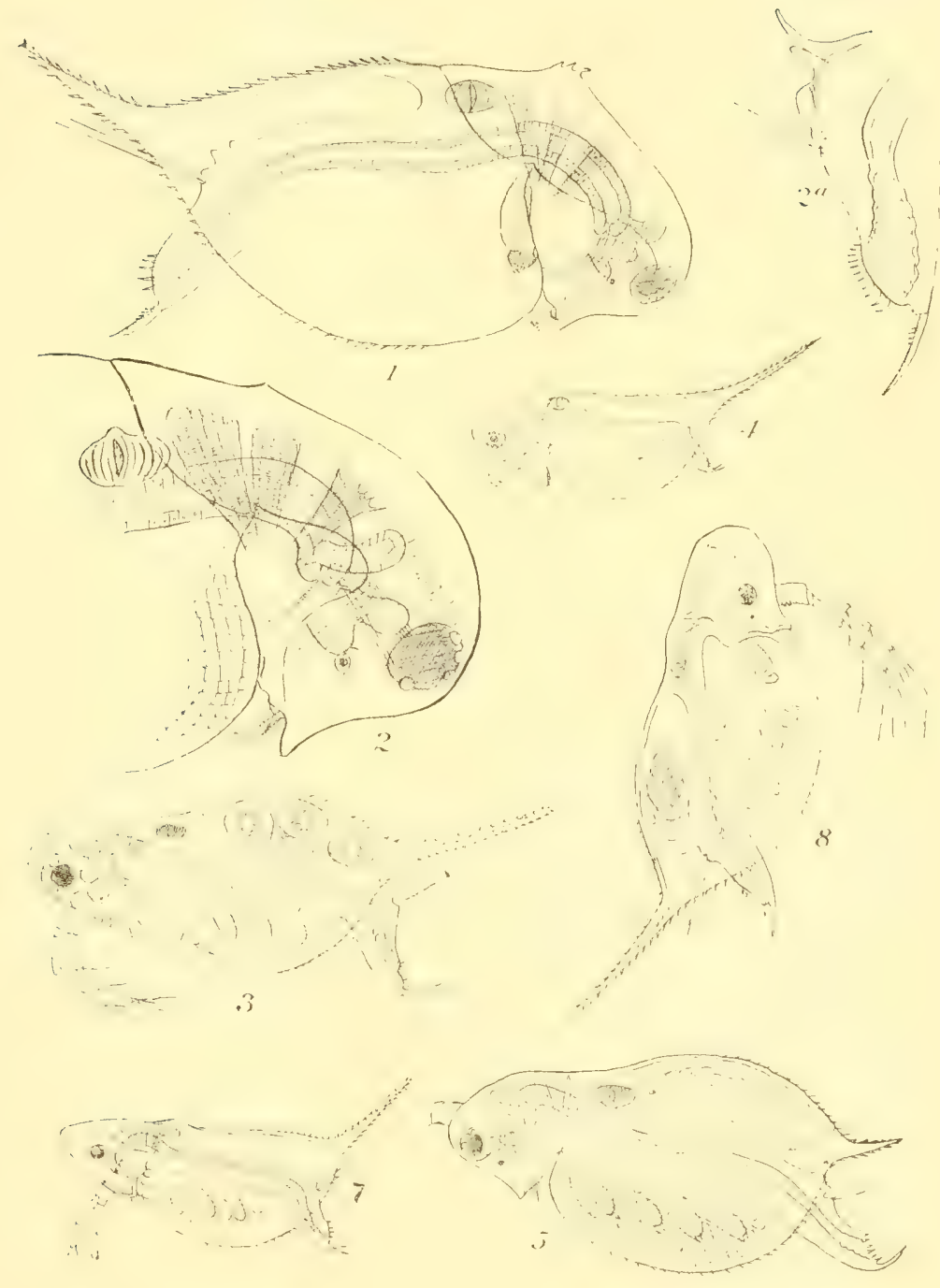



EXPLANATION OF PLATE L. 
11

1. Daphnia minnehaha. Male.

2. . . minnelahlar. Part of feet of first and second pair.

3. Canflocampras hibreniems. Antemma of female.

4. " hibernicus. Fifth foot of female.

5. " " palustris. Antenna of male.

i. ": trispinosus. Fifth foot of female.

7. " " minntus. Young.

8. " " minutus. Tauplius form.

9. Pendo-sida tridentata. Achlt female, antemules, labrum, angle of shell, and post-abdomen.

10. Daphnia minnesoteusis. Young female.

11. "6 minnesotensis. Post-imago.

12. " minnesotensis. Beak. 
Zool. Survey of Minn., II, I895.

PLATE L.

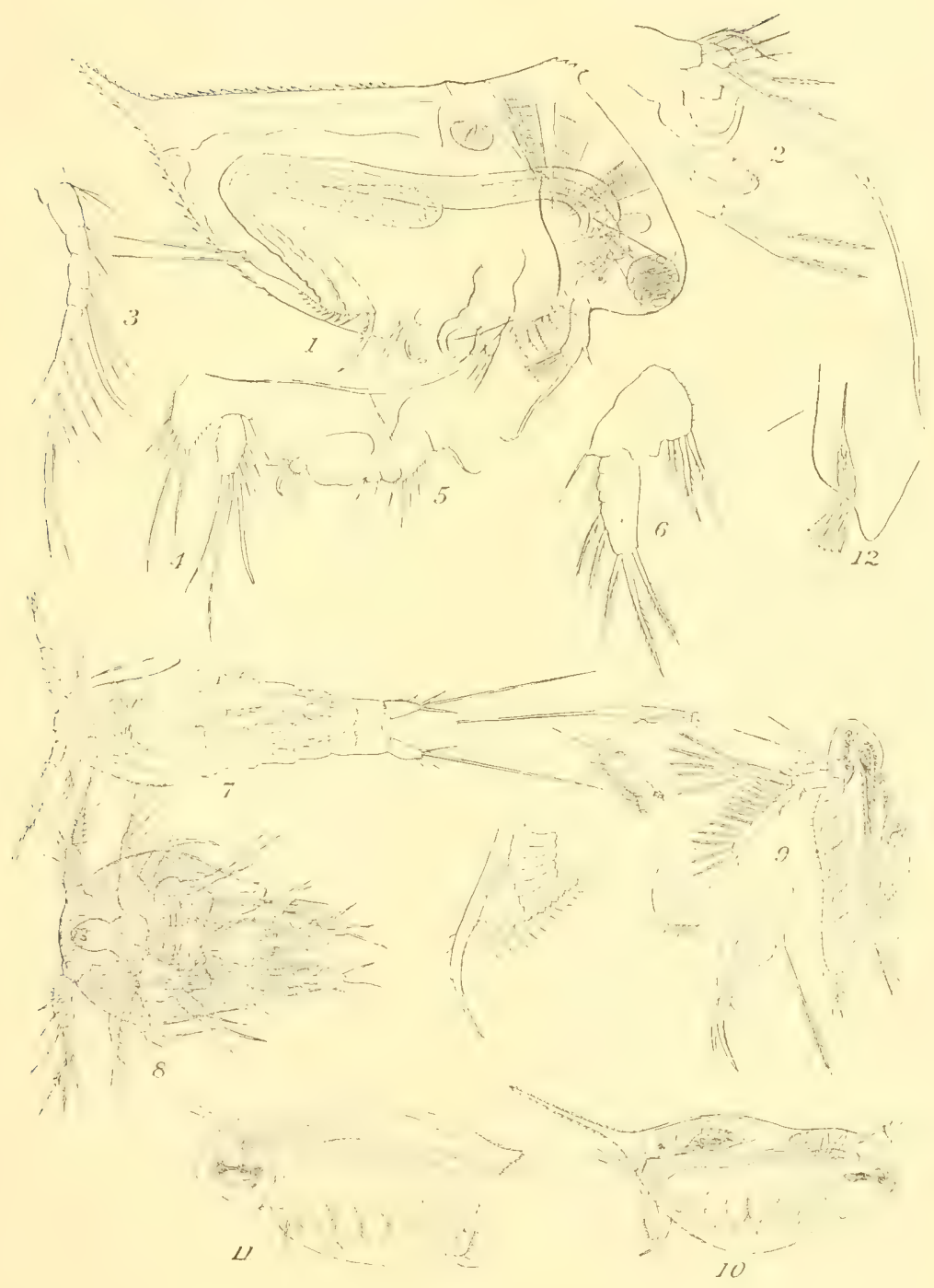



EXPLANATION OF PLATE LI. 


\section{Daphnia schafferi.}

FIG.

1. Post-abdomen of female.

2. Post-abdomen of male.

3. Male antennule.

4. Braiu and nerves. Inf. o. g.. infra-cosophageal ganglion with nerves to antenna; $\infty$.. wesophagus; $n$. f., frontal nerve; $g$. opt., optic gangliou; m. opt., muscles which move the eye; p. f., pigment fleck; n. opt., optic nerve.

5. Posterior part of embryo.

6. Eurycercus lamellatus. Heart, showing the anterior bifid portion between the lobes of which is the arterial opening and valve. The vaned arrows represent deeper currents while the unvaned indicate superficial ones. The dotted line represents the position of the pulsiting membrane separating the venous from the arterial rurrents and seen in section at (a).

7. Daphnia similis. Anterior part of the nervous system seen from below. a, optic nerve; b, optic ganglion; c. frontal nerve; d. nerve to antennules; e, commissure commecting upper and lower asophageal ganglion: f. neves to antenna and mandibles. [After Claus.] 


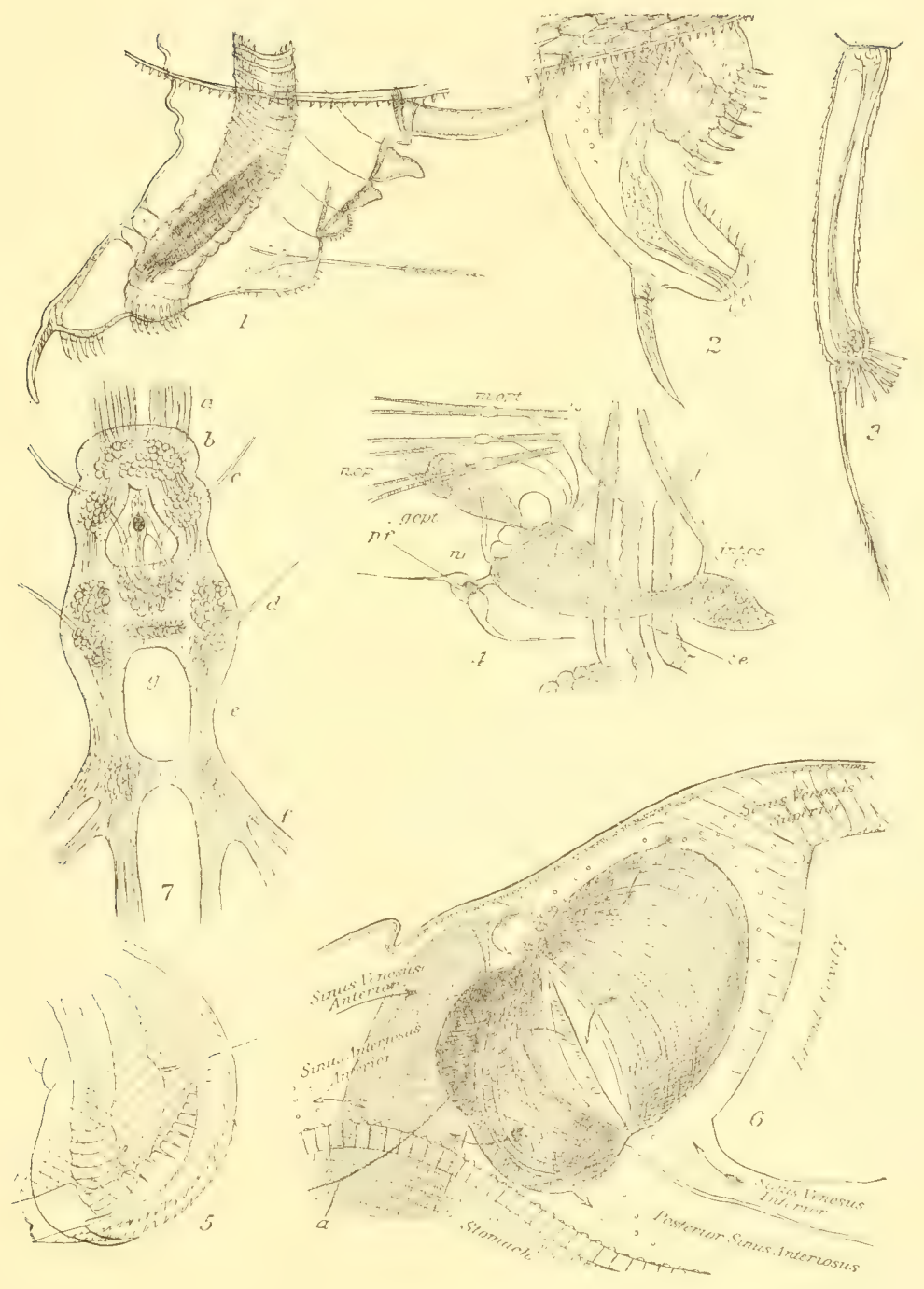



EXPLANATION OF PLATE LIT. 


\section{Daphnia minnehaha.}

Fio.

1. Ephippial female.

2. Post-abdomen.

3. Antenuule of male.

Daphnia exilis.

4. Female.

5. Post-abdomen.

Simocephalus vetulus.

6. Caudo-ventral angle of shell. The markings are on the outer lamina.

7. Margin of shell cephalad.

8. Post-abdomen.

9. Head. 


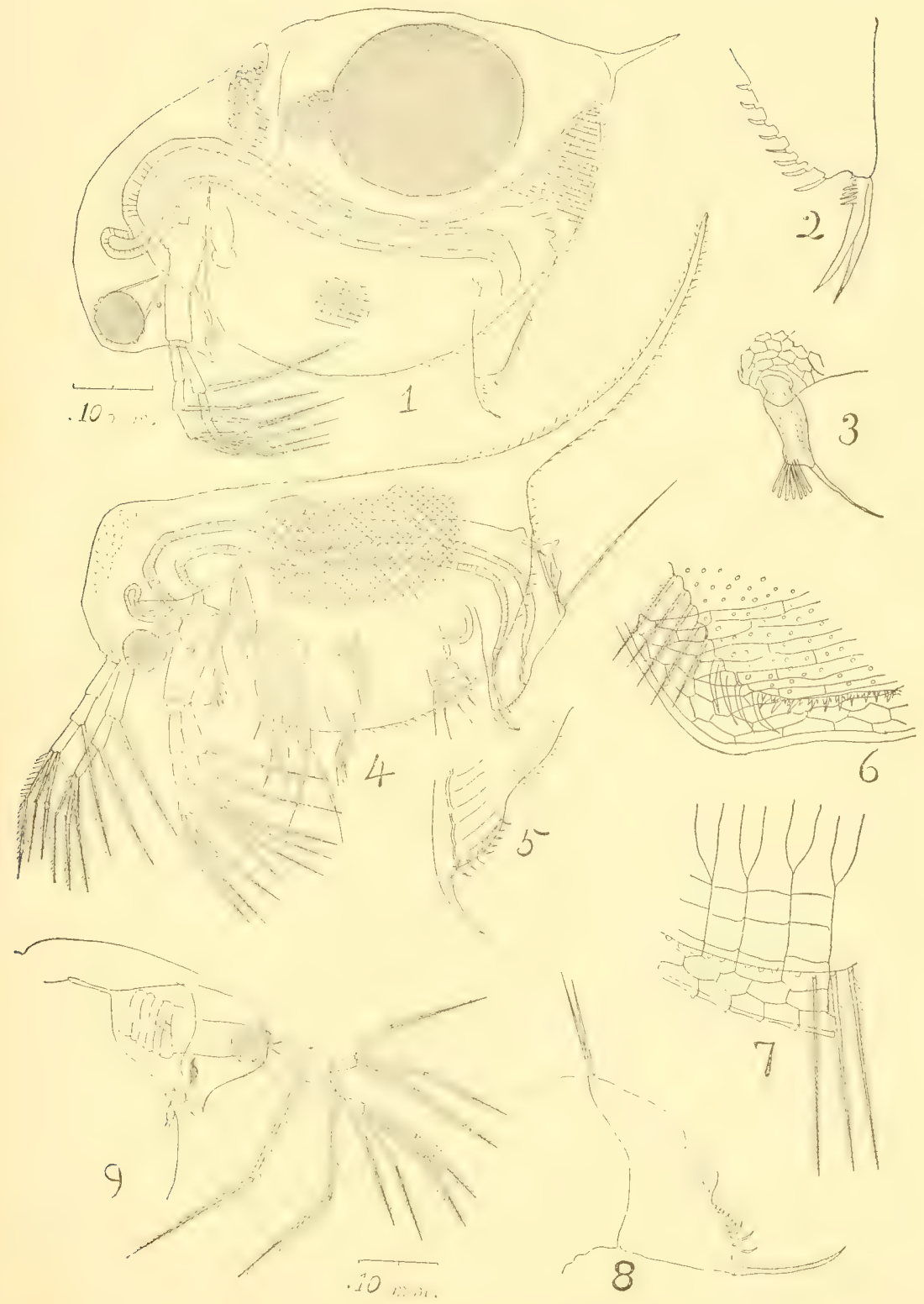





\section{EXPLANATION OF PLATE LIII.}




\section{Daphnia hyalina Leydig.}

Fir. ()utline of female from Lake Minnetonka drawn to the same scale as figure 5.

2. Head of a common form of the above species.

3. Extreme development of the crest.

4. Emingo illustratiug the (arly development of the helmet.

Daphnia kalbergensis Schoedler.

․ Typical form, from Lake Minnetonka.

i. A form of the above taken from the same gathering.

7. Post-abdomen of the above.

s. Jixtreme development of head resembling D. retrocuren Forbes, from same gathering as the above.

9. Iaplunia dentif(ral Forbes. Copy from "Aquat. Invert. II yoming." 

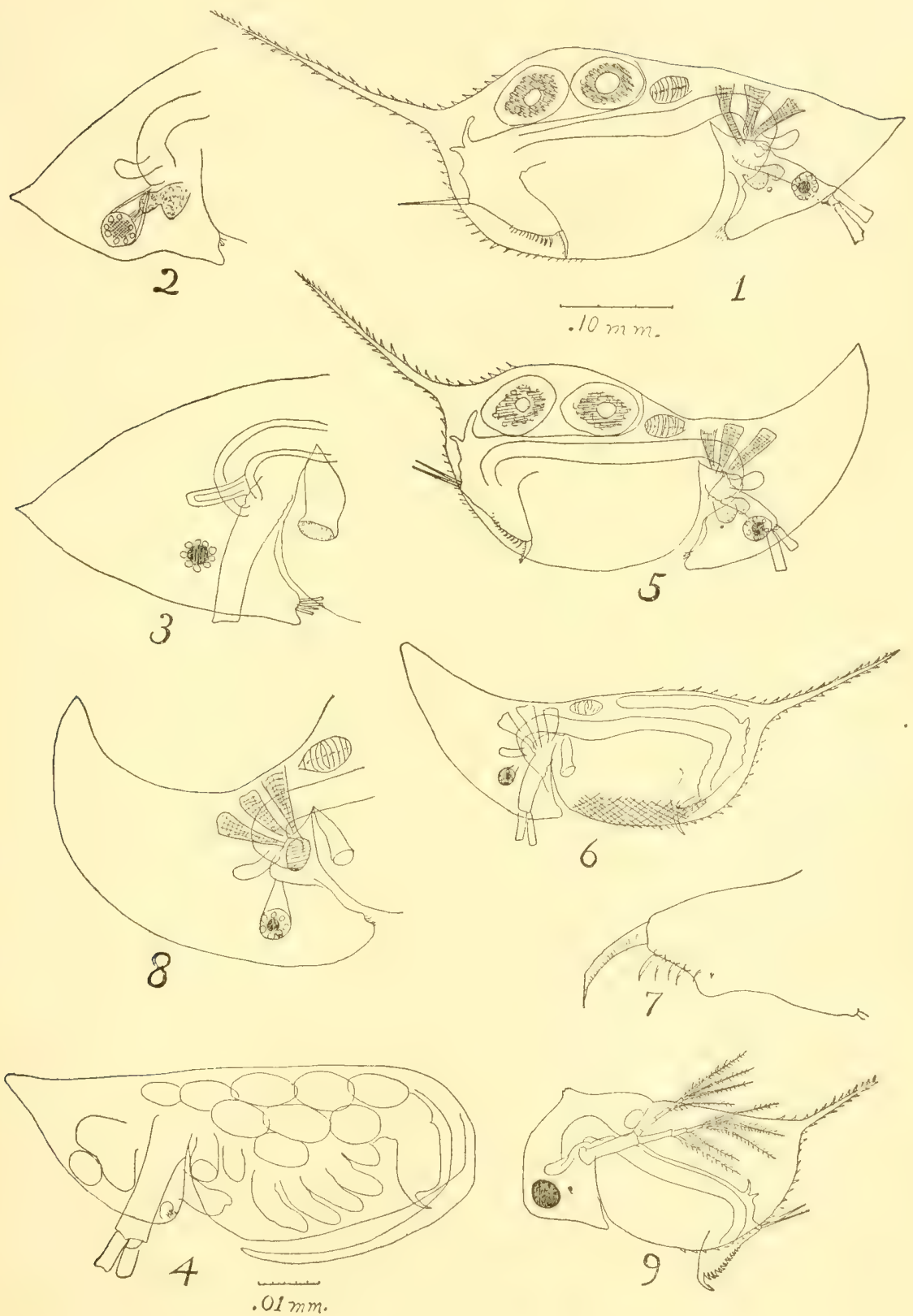

EXPLANATION OF PLATE LIV. 


\section{Macrothrix rosea.}

Fig.

1. Antennule.

2. Post-abdomen of female.

3. Post-abdomen of male.

4. Drepanothrix dentata. Post-abdomen of male.

Macrothrix tenuicornis.

5. Head.

6. Post-abdomen.

7. First foot.

8. Antennule of female.

Macrothrix laticornis.

9. Head.

10. Post-abdomen.

11. First foot.

12. Portion of dorsal ridge of shell. 
ZoOt. Surtey of Minn., II, 1895.

PLATH I.IV.

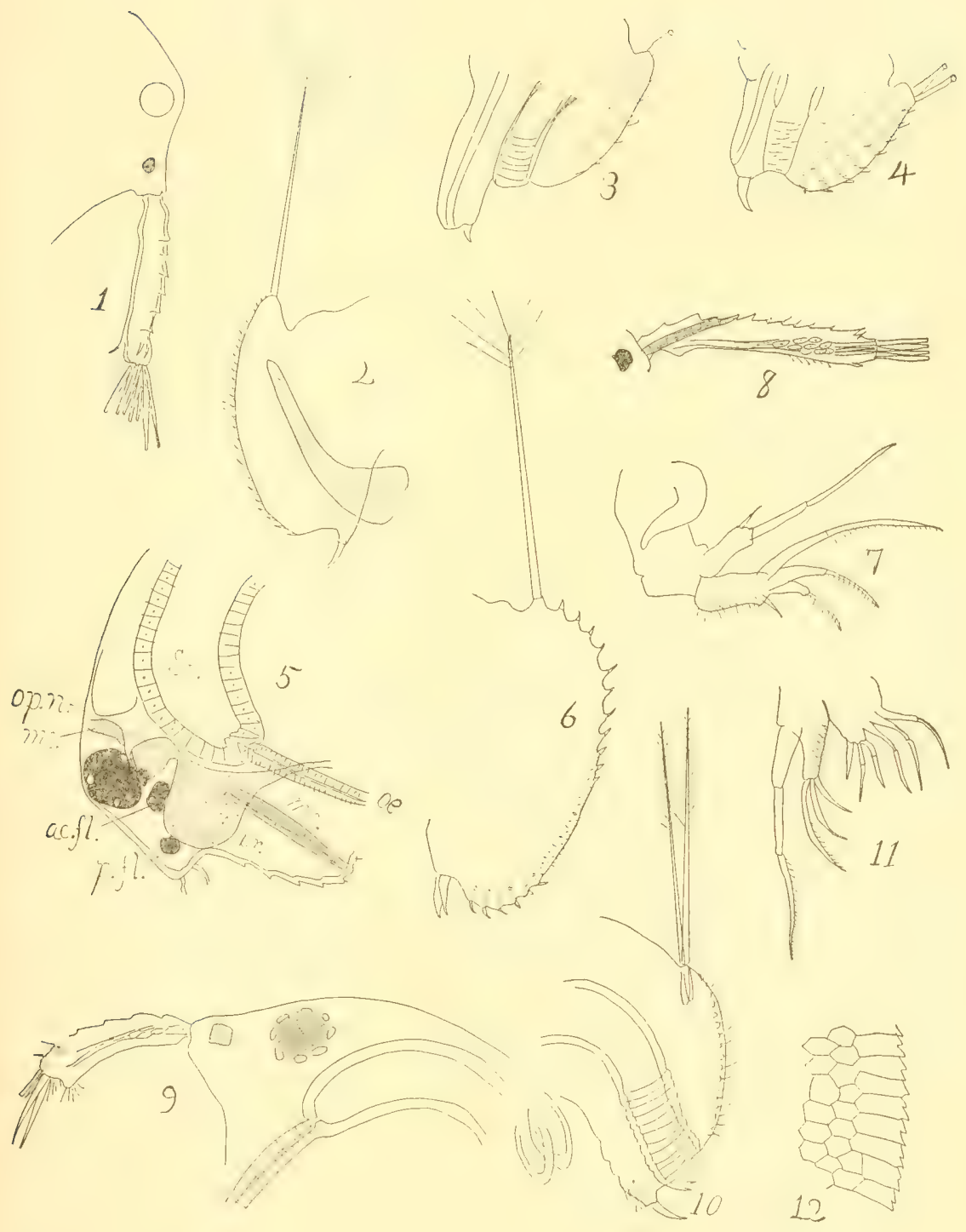



EXPLANATION OF PLATE LV. 


\section{Ilyocryptus spinifer.}

1. Lateral view.

2. Head, from below.

3. Post-abdomen.

4. Embryo.

5. Ilyocryptus longiremis.

6. 66 sordidus. Post-abdomen.

7. 6 acutifions. Post-abdomen.

8. 66 agilis. Post-abdomen.

9. 6 agilis. Head.

10. $"$ sordidus. Antennule.

11. $\therefore$ sorlidus. Spines on free margin of shell. 

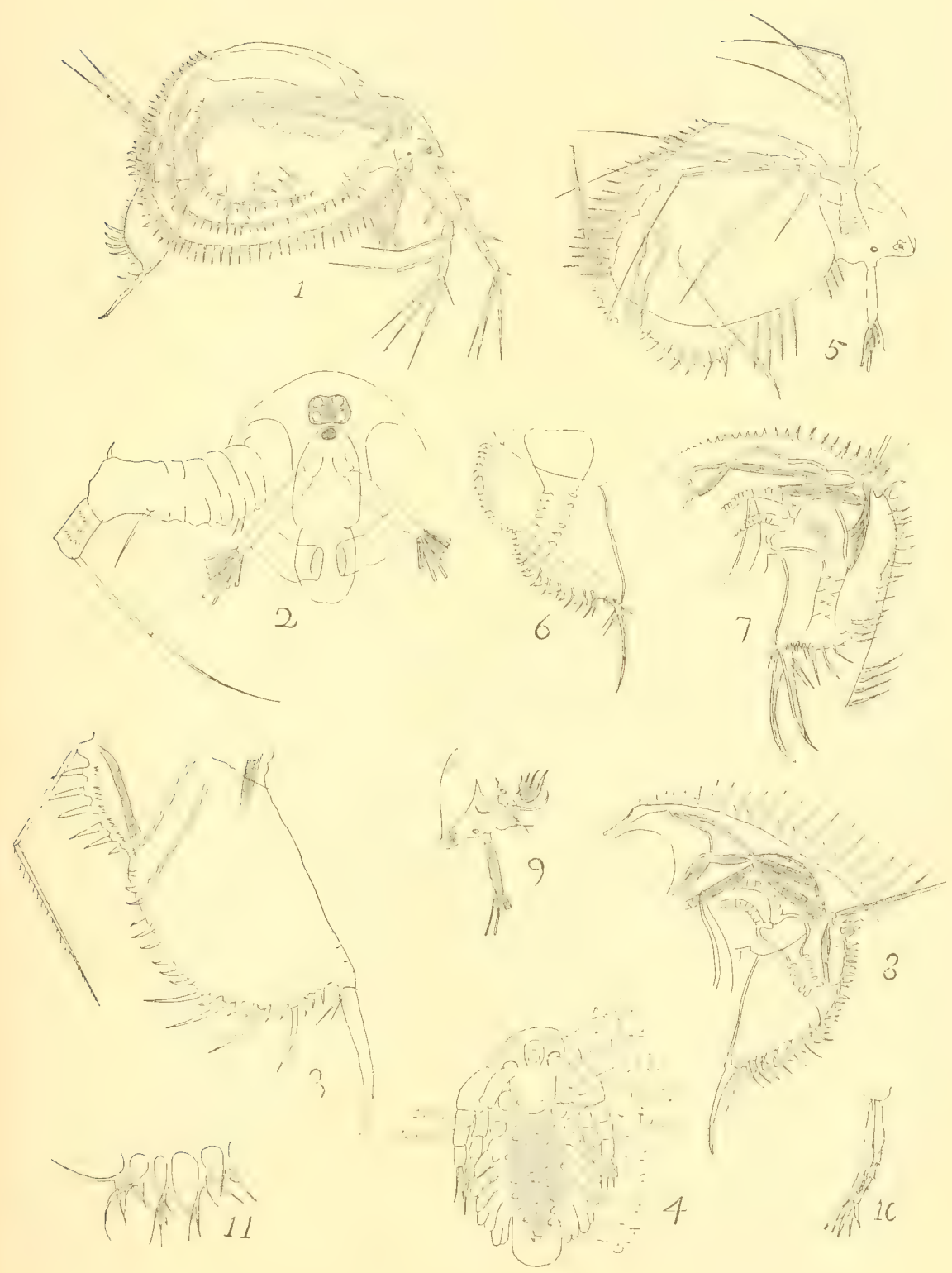

EXPLANATION OF PLATE LVI. 
Fli.

\section{Macrothrix tenuicornis.}

1. Lateral view.

1a. Labrum.

2. First foot.

3. Antennx of young.

4. Macrothrix pauper.

Macrothrix rosea.

5. Antenua of male.

6. Spines of shell margins.

7. Post-abdomen.

Macrothrix laticornis.

8. Male.

9. Semen cells.

10. Pasithea rectirostris. Male antenna.

11. Macrothrix rosea. Post-abdomen.

12. " tenuicornis. Post-abdomen.

13. " rosea. Post-abdomen of male.

14. Drepanothrix dentata. Antenna.

Ilyocryptus sordidus.

15. Marginal spines.

16. Antenna.

17. Post-abdomen.

Ilyocryptus spiuifer.

18. Lateral view.

18a. Marginal spines.

19. Antenna.

20. Macrothrix tenuicornis. Heart and accompanying vessels.

21. Ilyocryptus spinifer. Post-abdomen. 


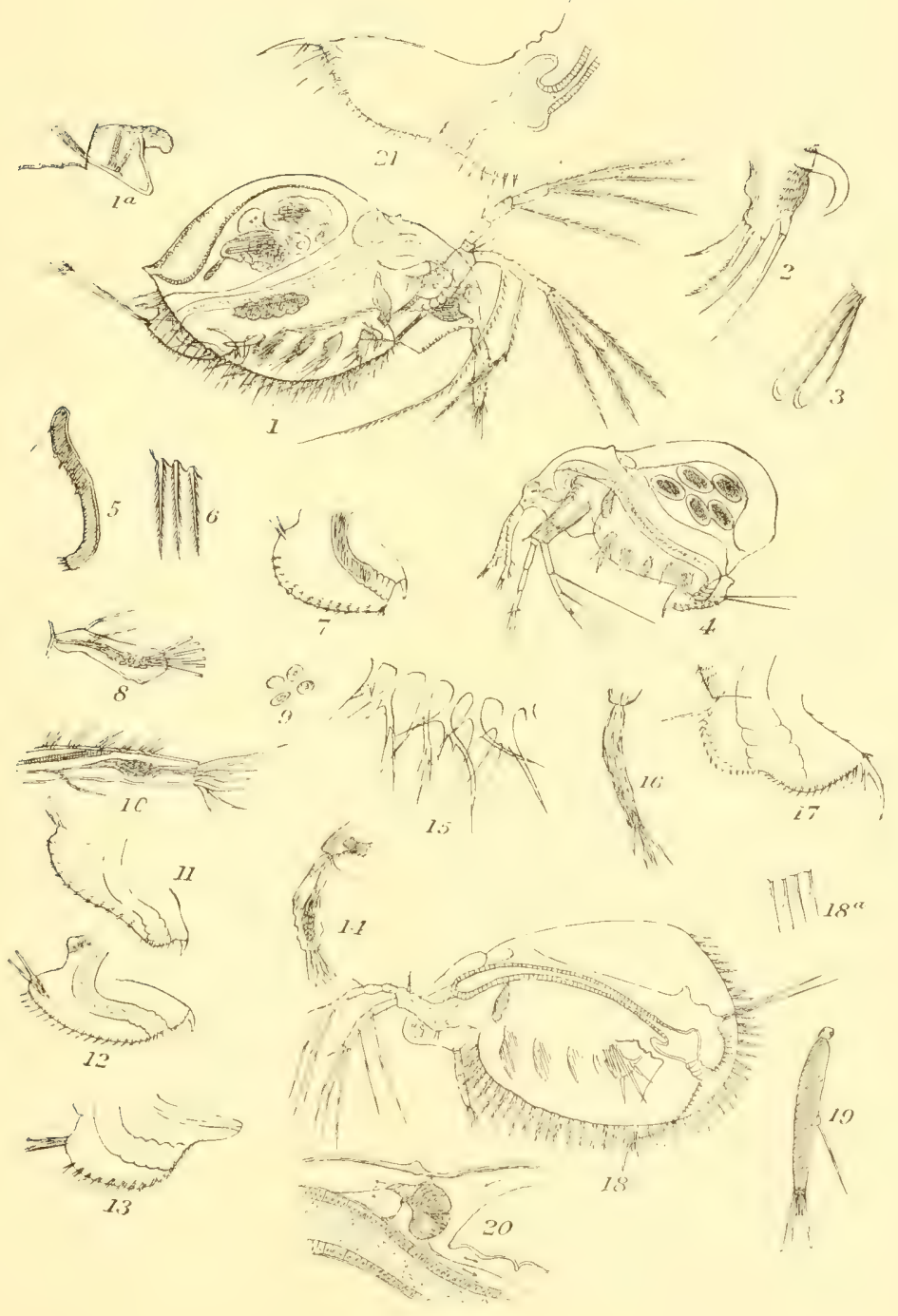



EXPLANATION OF PLATE LVIJ. 


\section{Lathonnra rectirostris.}

Fra. Fenule, flom above. a, eye; b, optic ganglion; c, muscles of eye; d, muscles of antenna; e, dorsal sucking dise; f, stomach; young in brood cavity; h, heart.

2. Female, from side.

3. Head seen from below.

4. Maxillie.

5. First foot.

6. Ovary.

7. Antennule

8. Last foot. 


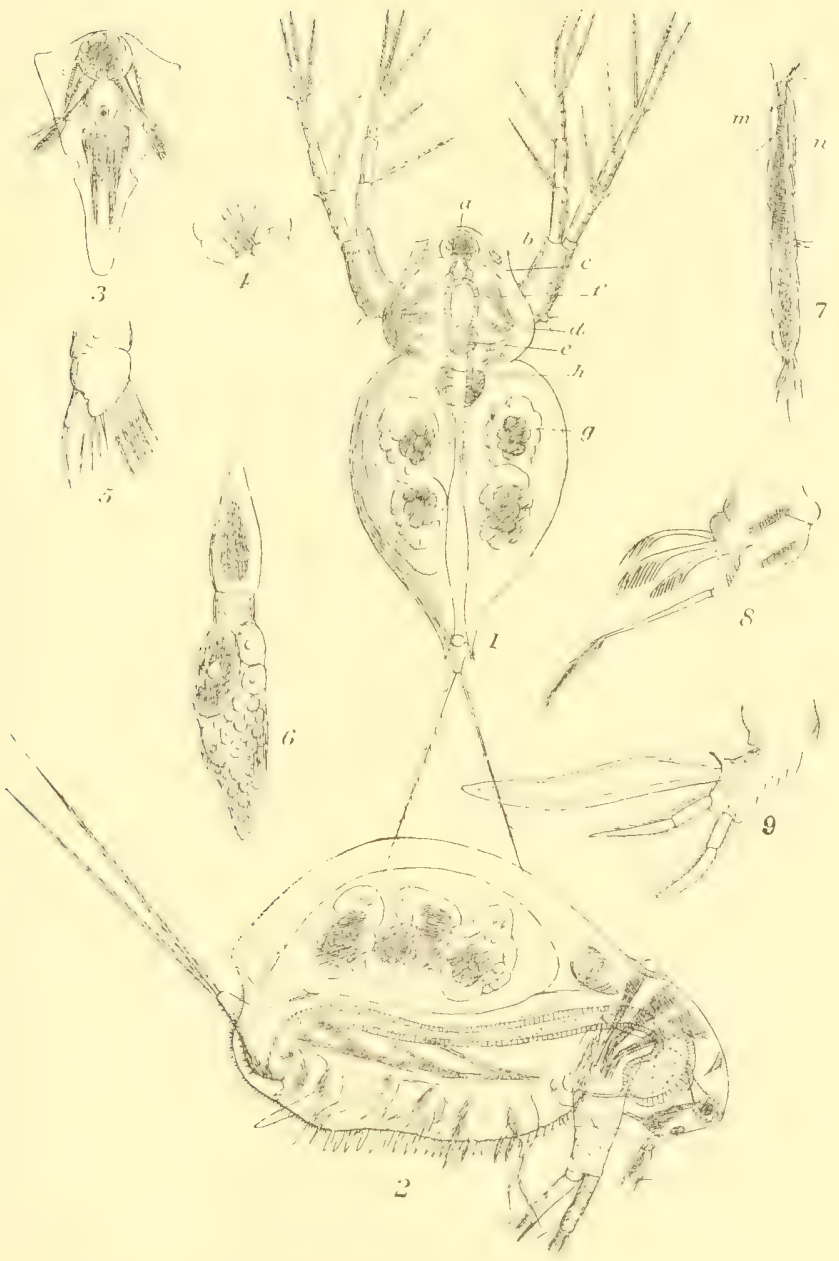



EXPLANATION OF PLATE LVIII. 


\section{Ofryoxus gracilis.}

1. Adult female, showing coiled intestine, elevated anus, long antemule, elongated seta of second antenna, anterior caca, etc.

2. Post-abdomen.

3. Antenmule.

4.6. Polyphemus pediculus. Young and adult females. 
Zool. Survey of Minn., II, I895.

PLATE LVIII.

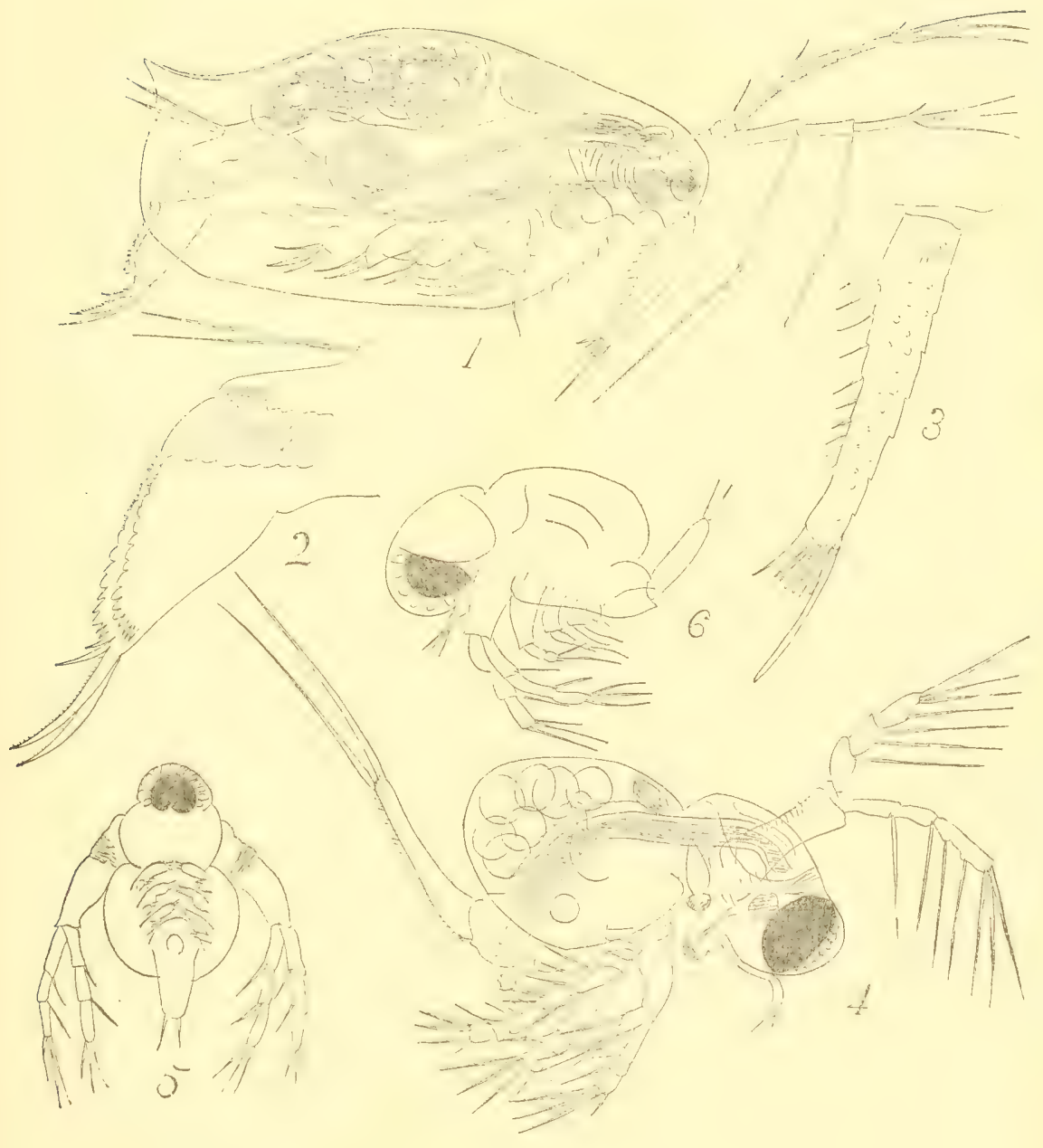



EXPLANATION OF PLATE LIX. 
1. Polyphenus pediculus. Swimming feet.

$\therefore$ Ofryoxus gracilis. First foot.

Macrothrix nova-mexicana.

3. Female.

4. End of post-abdomen.

5. Antennule.

6. Leydigia quadrangularis. First foot.

Osphranticum labronectum.

7. Antennule.

8. Fifth foot of female. 

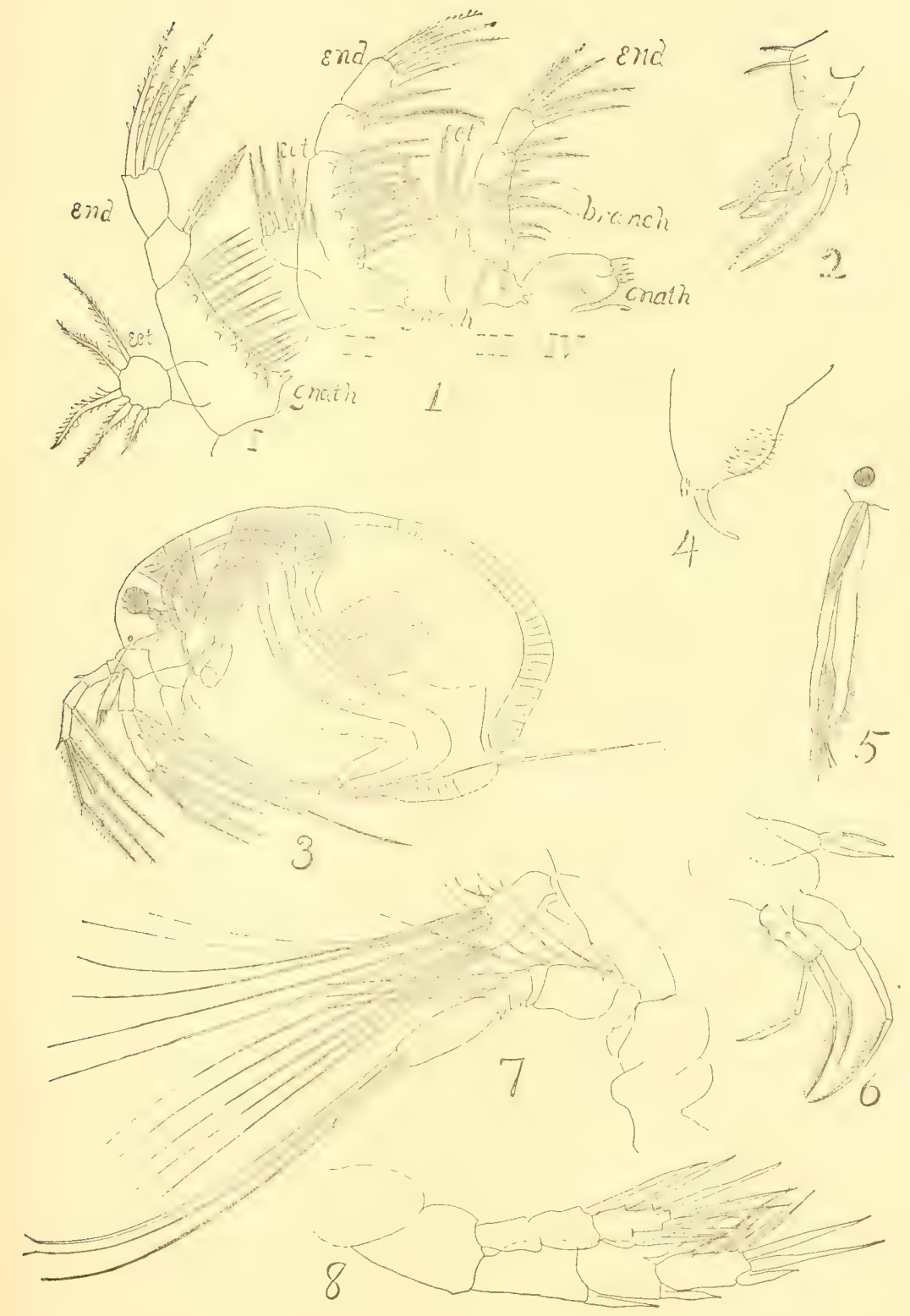

EXPLANATION OF PLATE LX. 
1. Pleuroxus hamatus. Post-abdomen and antenna.

2.6 affinis.

3. Nlona costata.

4. Leydigia quadrangularis.

Eurycereus lamellatus.

5. Male.

5. Posterior margin.

6. Antenna of female.

7. Alonella pygmaa.

Eurytemora affinis Poppe.

$\therefore$ Female.

9. Female abdomen.

10. Male.

11. Male abdomen.

12. Fifth feet of male.

13. Fifth feet of female.

14. Taw.

15. Antennule.

16. Nauplius larva of this or a related species. 

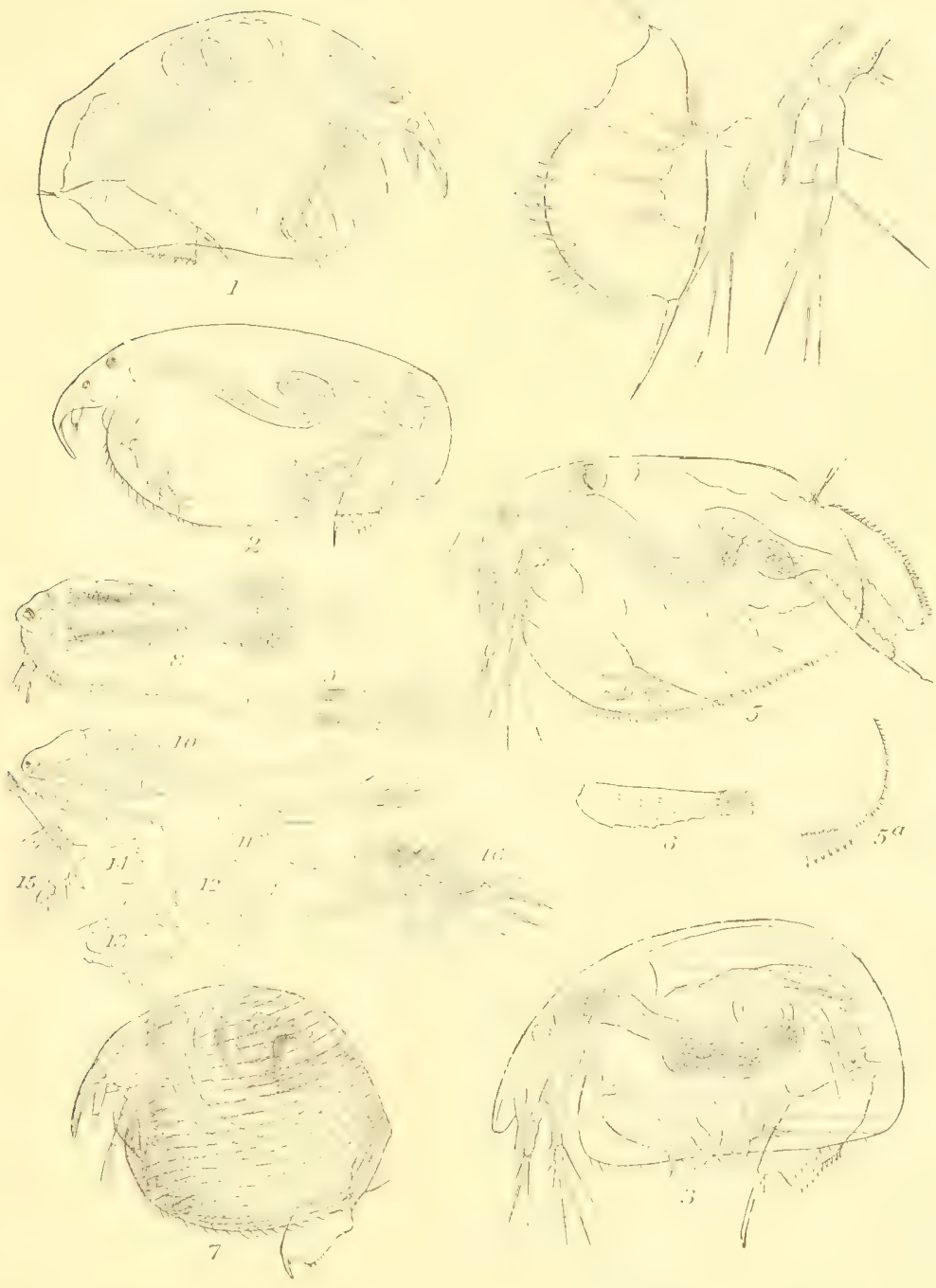

EXPLANATION OF PLATE LXI. 
Alona quadrangularis.

Fig. Femiale. A ${ }^{1}$., antennule; Idb., labrum; Mr., mandible; P-a., post abdomen; In.,anus; F. c., museulus flexor caudalis; E. c., musculus extensor caudalis; $A$. g., anal gland; n. gl., nutritive globule in embryo; t., tail of embryo; I, II, III, IV, V, five pairs of feet of embryo; mx., maxilla of embryo; at ${ }^{2}$., antennie of embryo; at ${ }^{1}$., antemules of embryo; H., heart; sh. g., shell gland; ov., ovary; MId. m., muscle of mandible; $A t^{2}$. m., muscle of antenna; E., eye; Su. g., supra-usophageal ganglion; P. f., pigment fleck.

2. Brain, eye and pigment fleck of same.

\section{Pleuroxus procurvus.}

3. Female.

4. Foot of same.

5. Acroperus leucocephalus.

Alonella excisa.

6. Female.

6a. Shell of same.

7. Antenna of same.

8. Alonopsis latissima. Female.

9.4 latissima var. media. Female.

Camptocercus macrurus.

10. Post abdomen.

10a. Lower angle of shell of same. 


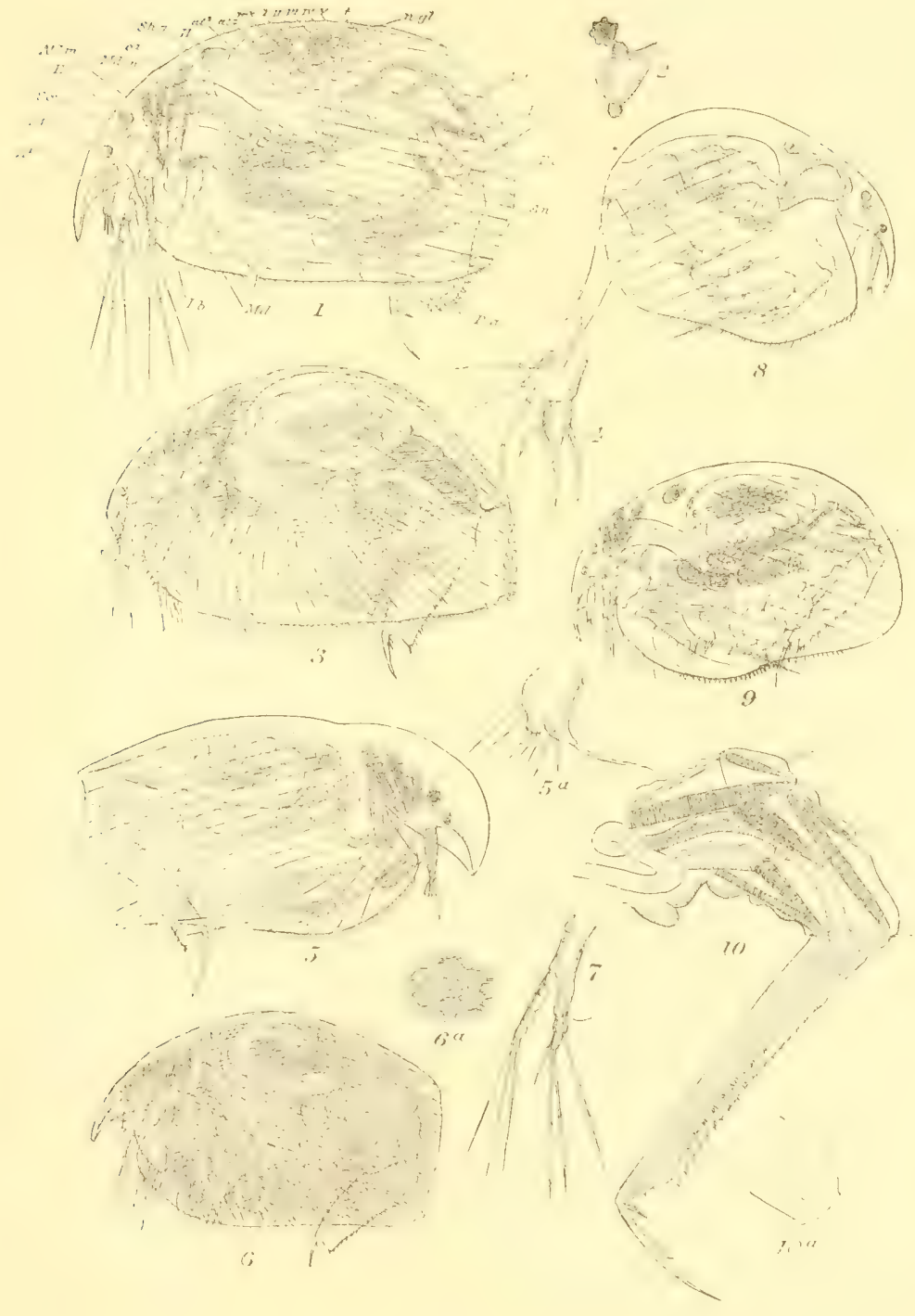



EXPLANATION OF PLATE LXII. 
IIti,

Camptocereus rectirostris.

1. Post-abdomen of female.

2. Post-abdomen of male.

3. Male.

4. Camptocercus biserratus. Head.

5. $66 \quad$ lationstris. Head of male.

6. " latirostris. Head of female.

7. 6 lilljeborgii. Head.

8. $\quad 66$ lilljeborgii. Post-abdomen of female.

9. Acroperus leucopephalus. Tost-abdomen of male.

10. 66 angustatus. Post-abdomen of male.

11. Alona temuicaudis. Post-abdomen.

12. "6 dentata. Post-abdomen.

13. 66 dentata. Female.

14. 66 elegans.

15. 6 intermedia. Post-abdomen.

16. Pleuloxus hastatus.

17. Leptorhynchus fialcatus.

18. Phrixura rectirostris. Post-abdomen.

19. Eurycercus lamellatus. First foot of female.

20. Mlona sanguinea. Shell markings.

Monospilus tenuirostris Fischer.

21. Lateral view.

21a. Head seen from in front.

Figures 19 to 21 origrinal, others firom Kurz, P. E. Mueller and Schoedler. 


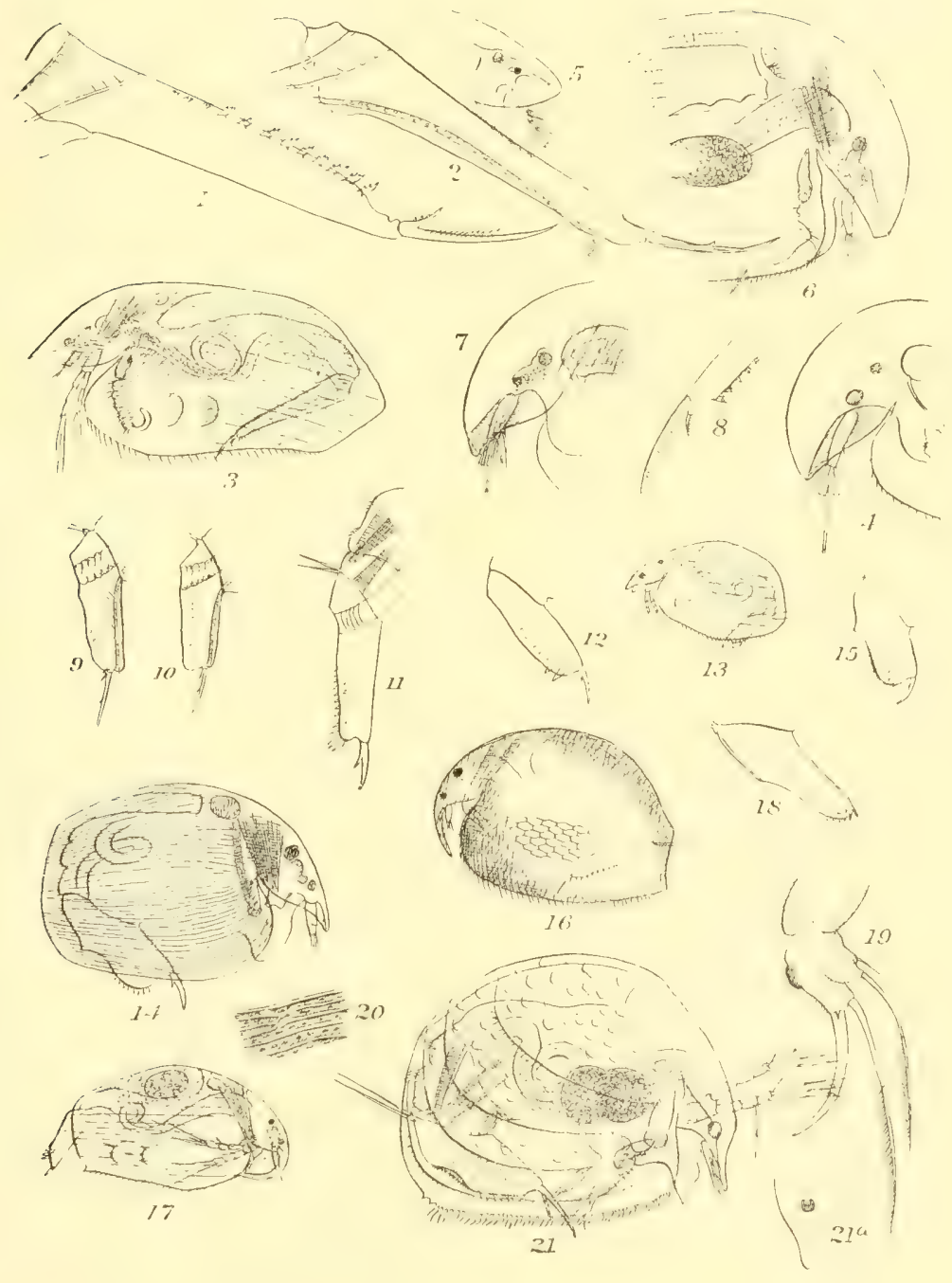



EXPLANATION OF PLATE LXIII. 


\section{FIG. \\ 1. Alonopsis latissima. Male. \\ 2. Alona glacialis? Female. \\ 3.4 glacialis? Male.}

Alona glacialis (?) var. tuberculata.

4. Lateral view.

5. Post-abdomen.

6. Labrum.

7. Antenna, setose branch.

8. Alona glacialis. Antenna.

9. Alonopsis latissima. Feet.

10,11. Alonella excisa. Details of shell sculpture.

Plenroxus denticulatus.

10a. Ontline of eqhippium.

12. Female.

13. Common variety.

14. Mlona glacialis (?) var, tuberculata. 


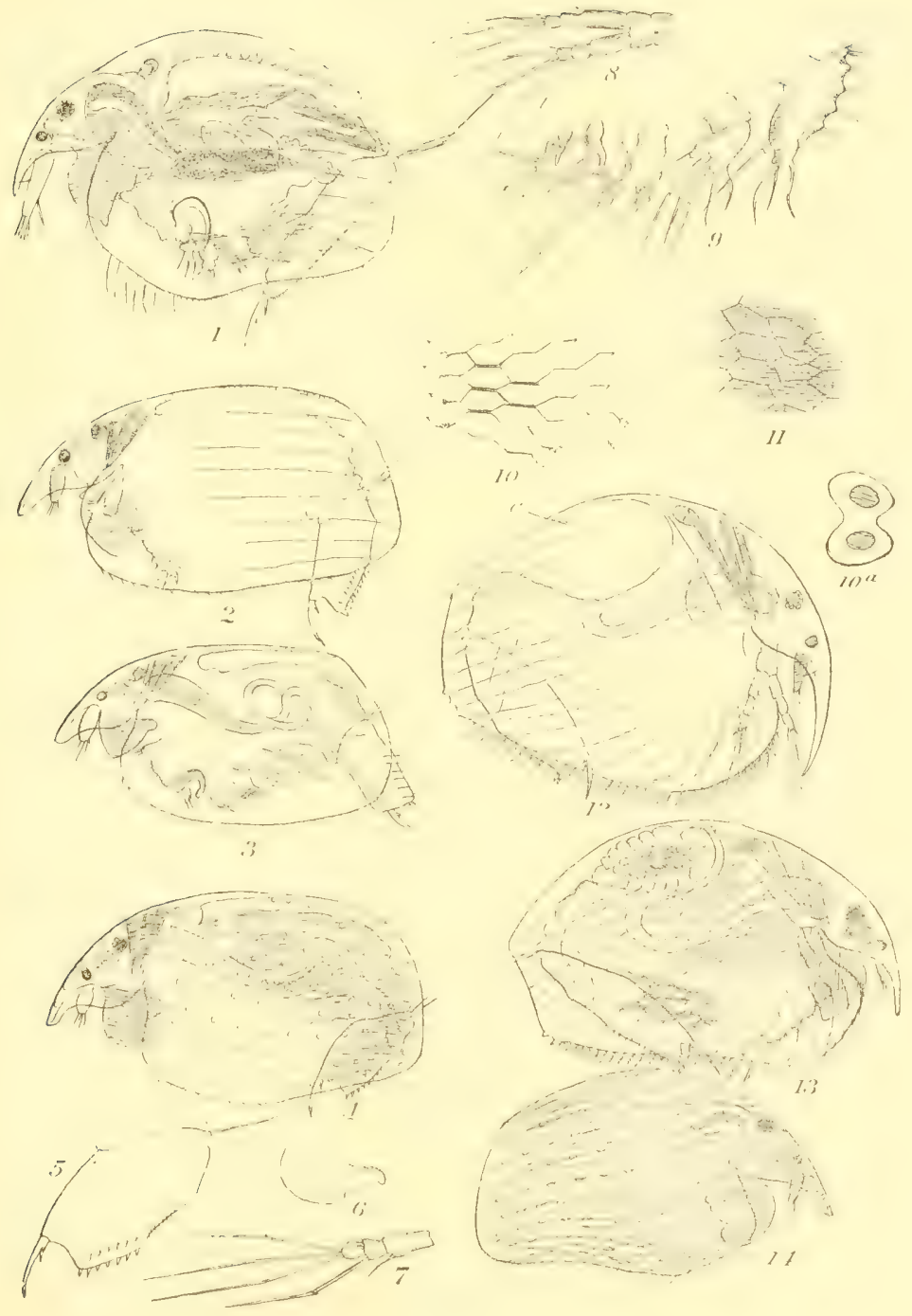



EXPLANATION OF PLATE LXIV. 


\section{Chydorus globosus.}

Fig.

1. Side view.

2. Eirst foot.

3. Fnd of post-abdomen.

4. Chydorus sphrericus. Post-abdomen of male.

5. 66 nitidus. Post-abdomen of female.

6. " 6 nitidus. Head.

7. " " spharicus. Ephippial female.

S. 6 sphrericus. Female.

$9 . \quad$ globosus. Post-abdomen of male.

10. 66 sphrevicus. From above.

11. of ovalis.

12. 6 caelatus.

13. Dunlevidia setiger.

14. Alona aflinis.

15. Plenroxus gracilis.

15a. "6 gracilis. Antenna. 


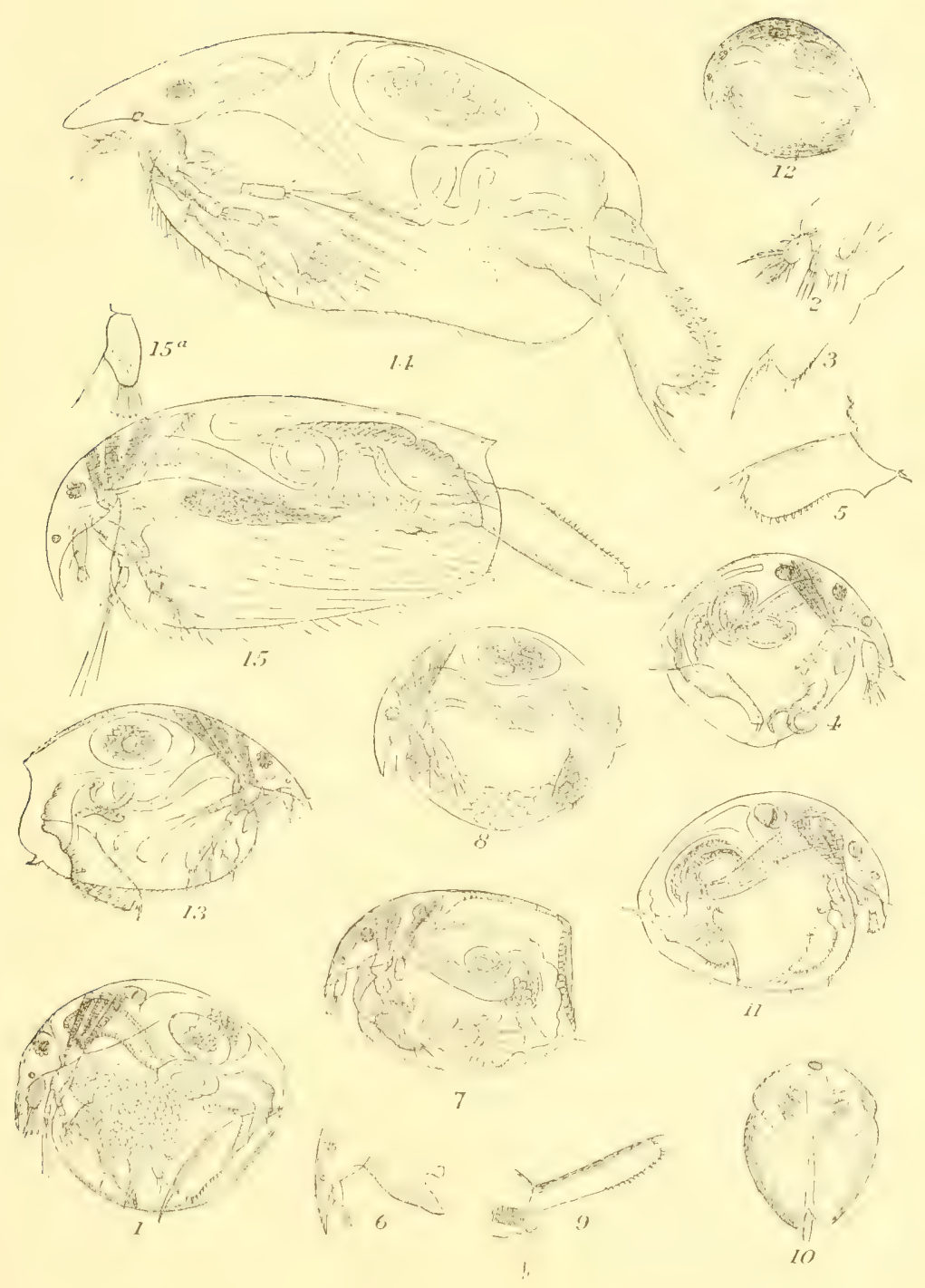



EXPLANATION OF PLATE LXV. 
1. Bosmina striata.

$2 . \quad 6$ longirostris.

3-5. " $\quad$ cornuta.

6, 7. Pleuroxus procurvus.

8. Graptoleberis testudinaria (var. inermis).

10. Acroperus sp.

11, 12. Graptoleberis testudinaria (var. inermis). 
Zool. Survey of Mini., II, 1895 .
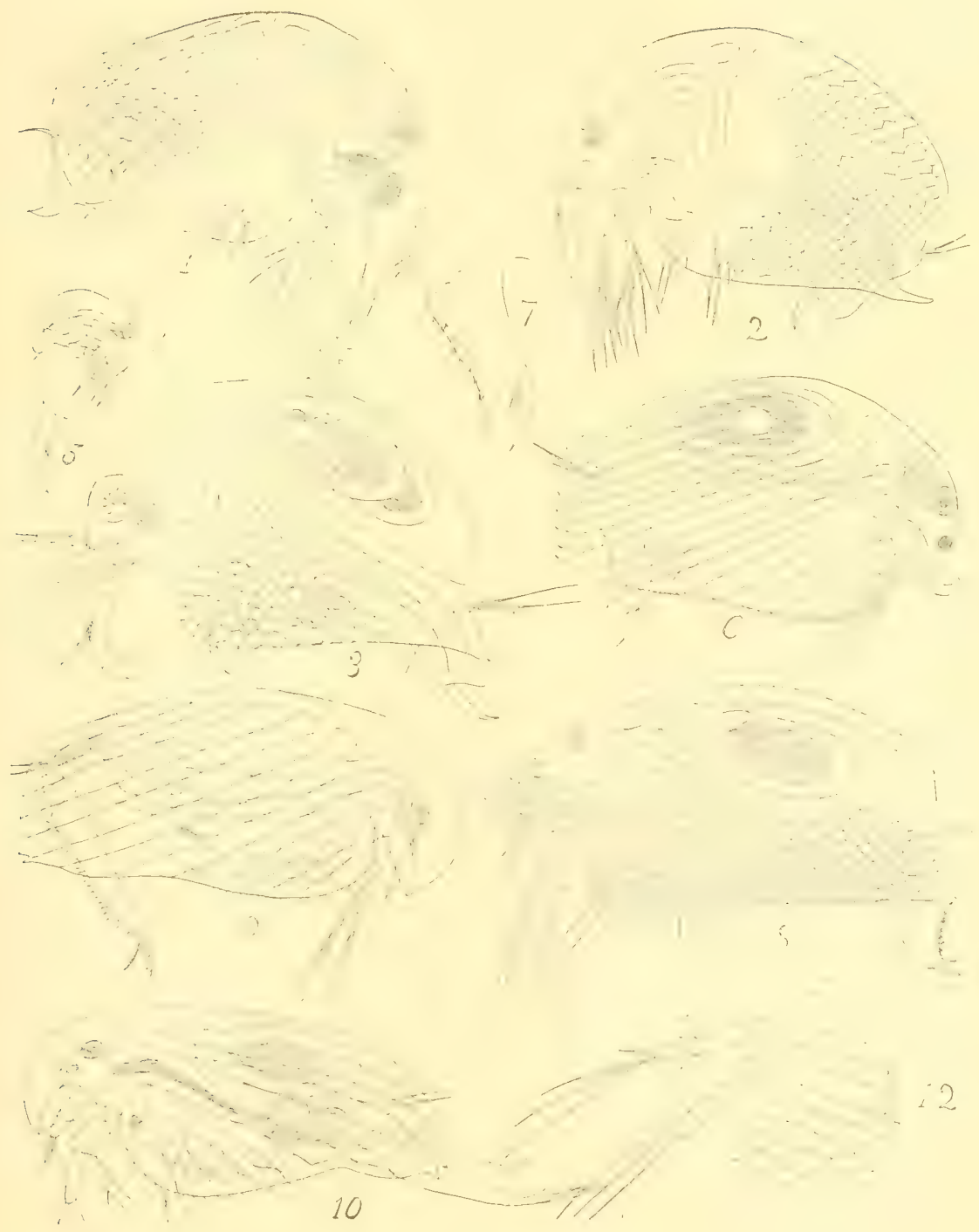

EXPLANATION OF PLATE LXVI. 


\footnotetext{
1. Streblocerus serricaudatus. Female.

2. Hacrothrix borysthenica. Antennule.

3. Plenroxus griseus. Female and post-abdomen.

4. Ceriodaphnia cornuta. Head.

5. Post-abdomen of same species.

6. Daphnia Iumholtzii. Female.

7. Leydigia australis. Post-abdomen.
} 
Zool. Survey of Minn., II, il99.

PLATE LXVI.
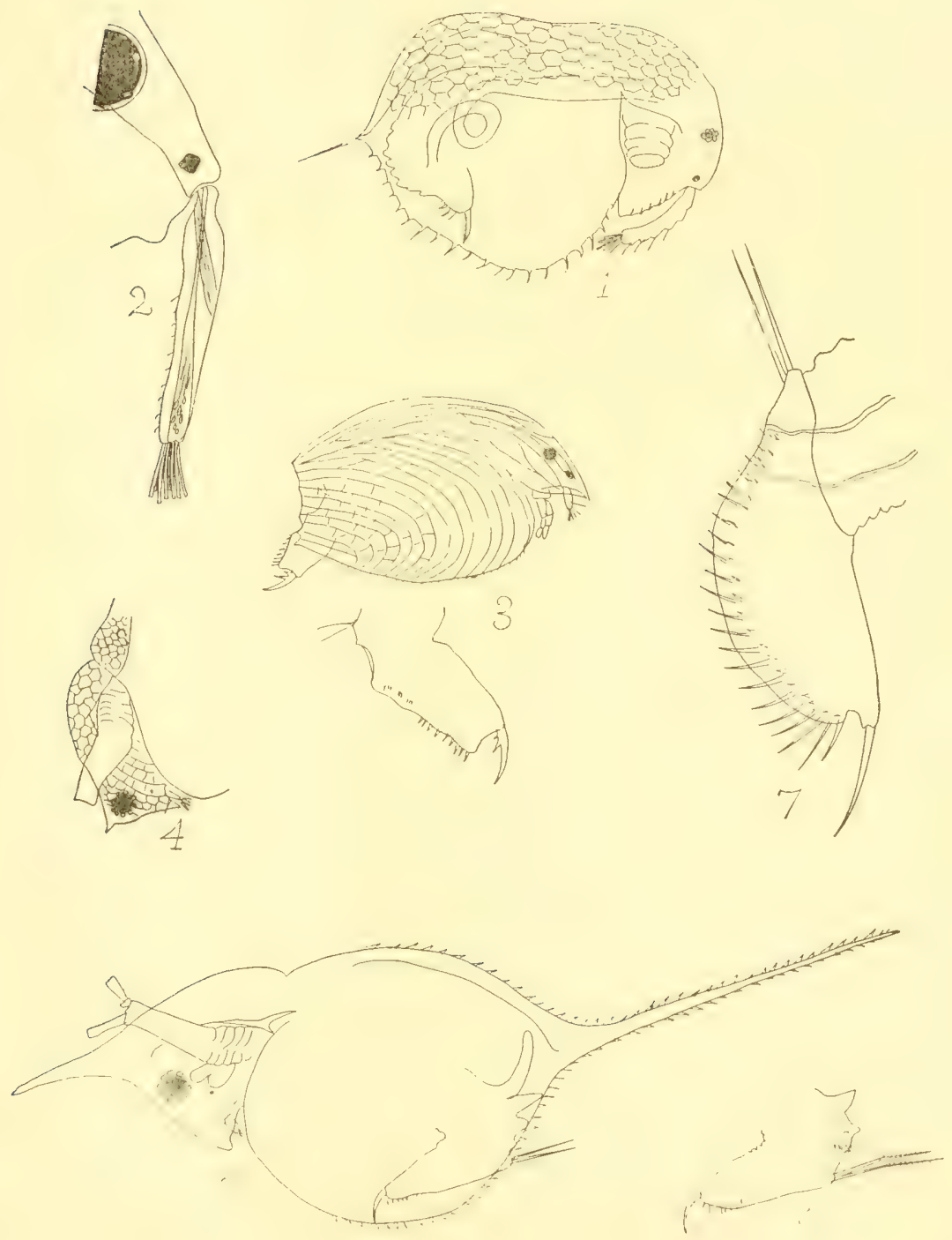

EXPLANATION OF PLATE LXVII. 
Cypris herricki.

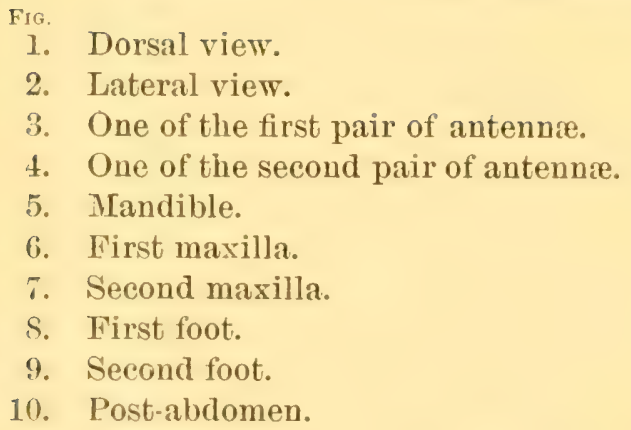

Cyprinotus crena.

11. Lateral view.

12. Mandible.

13. Feet. 

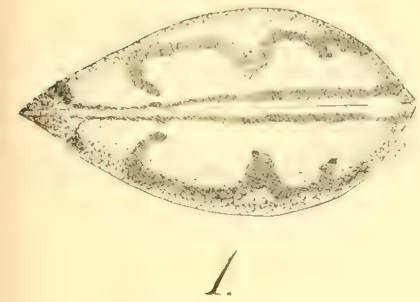

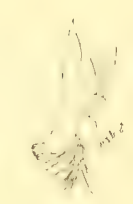

12

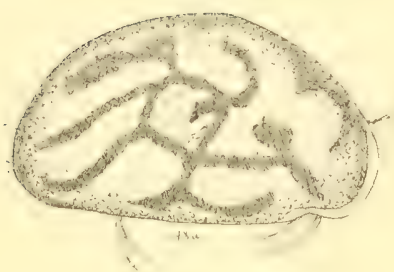

2

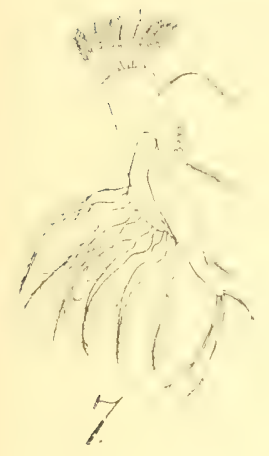

$y^{2}$

13

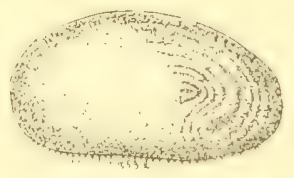

11.

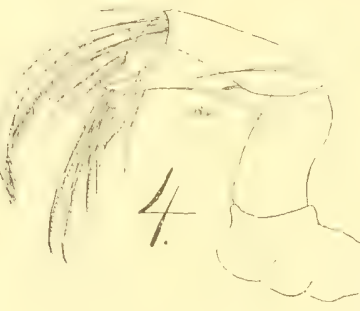

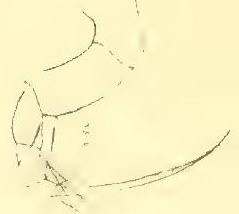

8

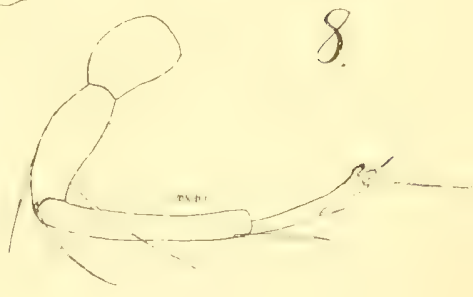

9

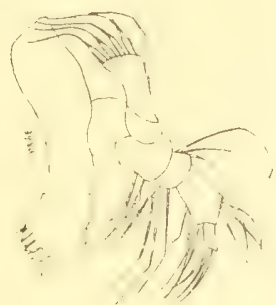

-)

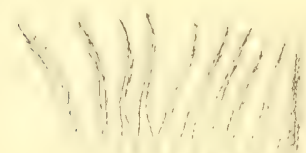

1

II

in
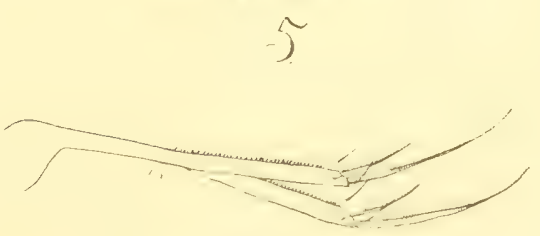

Io

3 

EXPLANATION OF PLATE LXVIII. 


\section{Cypria inequivalva.}

FIG.

1. Lateral view, female.

2. Dorsal view, female.

3. Ventral view, female.

4. Antenna, female.

5. First foot, female.

6. Second foot, female.

7. Abdominal ramus.

8. Verticillate sac.

\section{Cyprinotus incongruens.}

9. Lateral view.

10. Dorsal view, female.

11. Ventral view, female.

12. Antennule, female.

13. Antenna, female.

14. Mandible, female.

15. First maxilla, female.

16. Second maxilla, female.

Cypris herricki C. H. Turner.

40. Larval stage $\mathrm{A}$, end view.

.11. Larval stage $\mathbf{A}$, dorsal view.

42. Larval stage A, ventral view. 


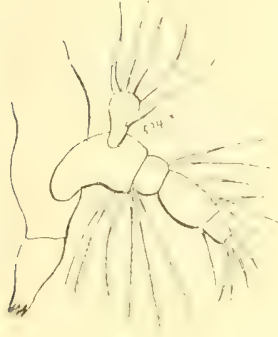

F
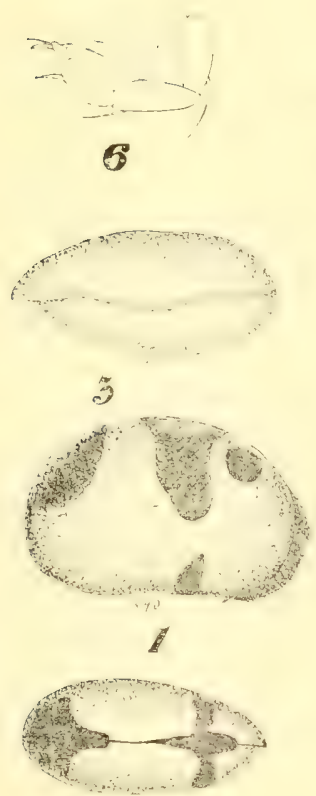

2

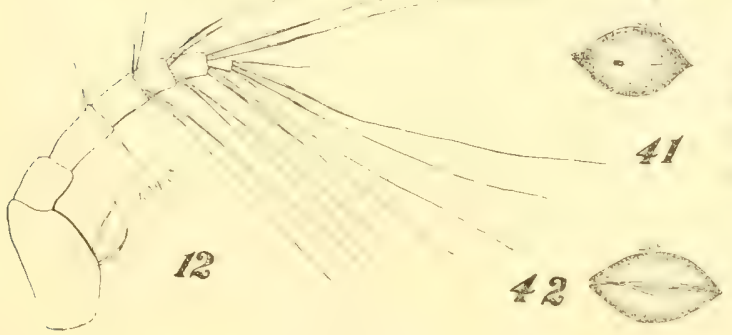

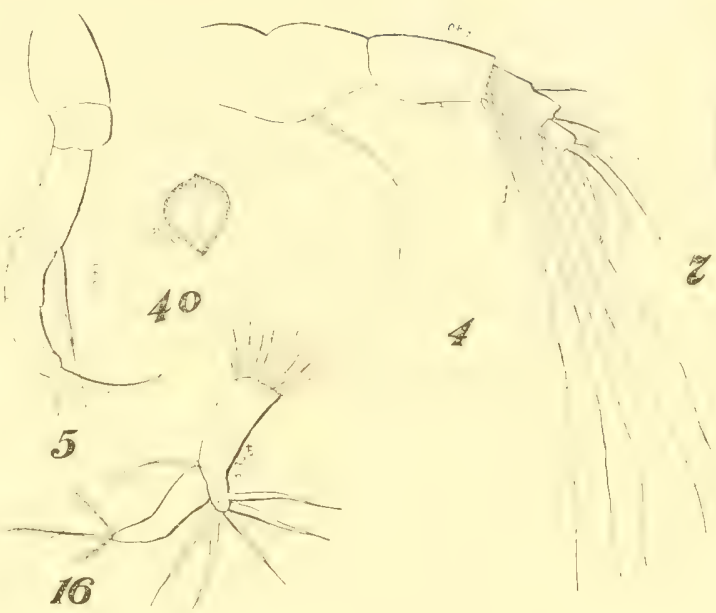

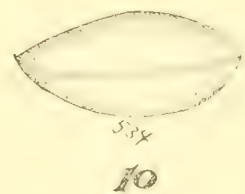

8
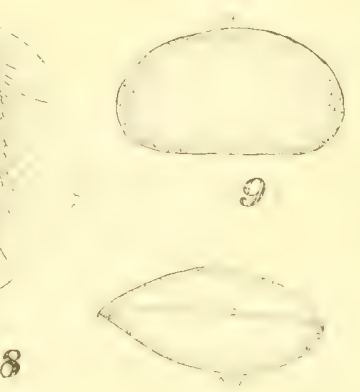

II

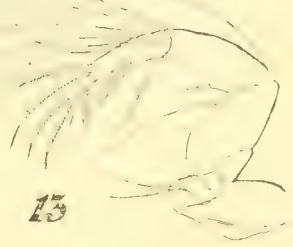



EXPLANATION OF PLATE LXIX. 
Cypris incongruens Ramdohr.

Fig. First foot, female.

18. Second foot, female.

19. Post-abdomen, female.

20. Portion of shell.

21. Lucid spots.

\section{Cyprinotus crena.}

22. Lateral view, female.

23. Dorsal view, female.

24. Ventral view, female.

24A. End view, female.

25. Antennule, male.

26. Mandible, female.

27. First foot, male.

28. Second foot, male.

29. Post-abdomen, male.

30. Verticillate sac, male.

31. Copulative organ, male.

Cypris Herricki C. H. rurner.

32. Portion of ventral margin of shell, female.

33. Stage $\mathbf{A}$, lateral view.

34. Stage A, teeth on caudal margin of shell.

35. Stage $B$, lateral view.

36. Stage B, dorsal view.

37. Stage A, post-abdomen.

38. Stage 13 , post-abdomen.

39. Stage $B$, ventral view. 

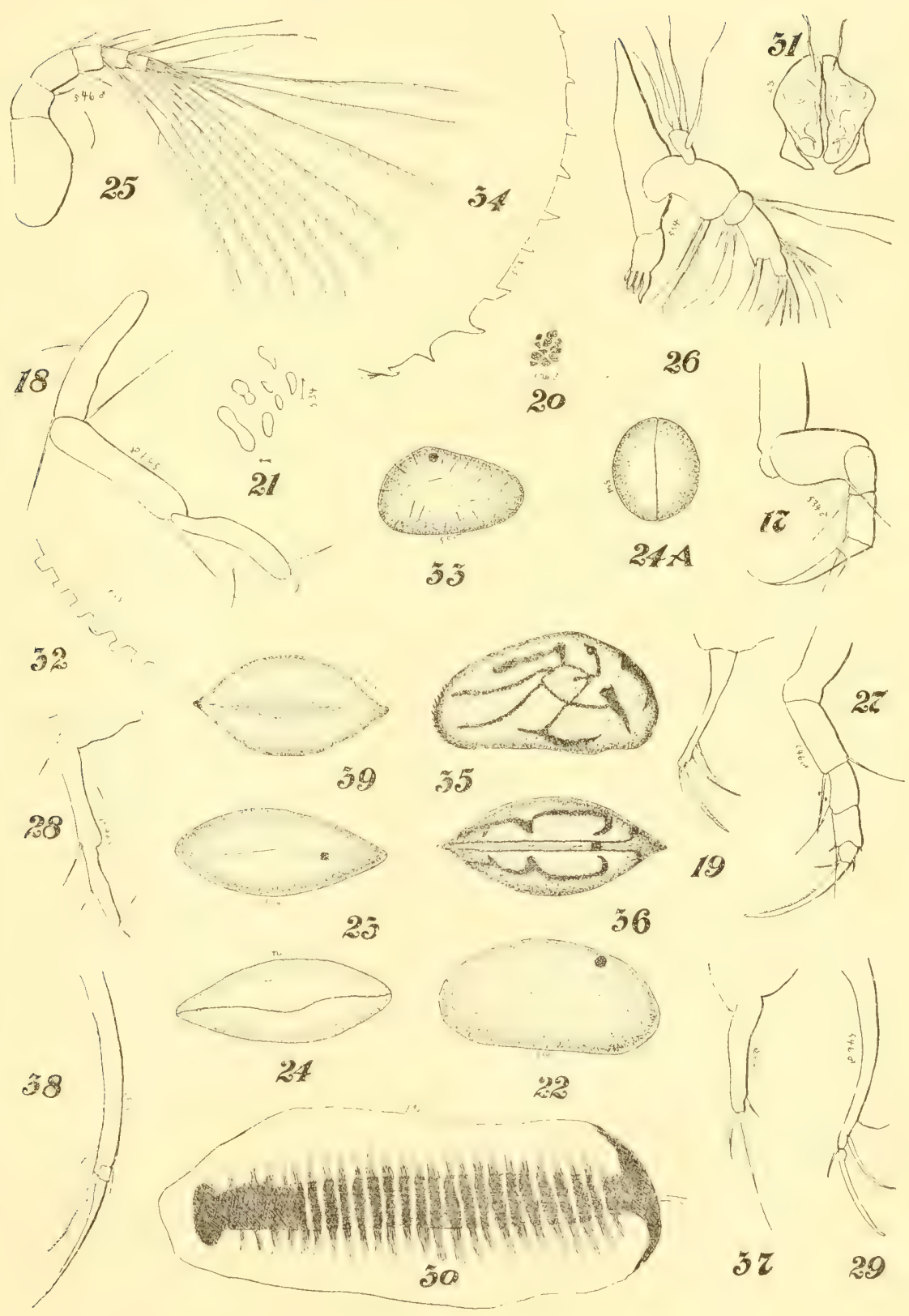

EXPLANATION OF PLATE LXX. 


\section{Cypria exculpta Fischer.}

1. Lateral view of the shell of a young specimen.

2. Second foot.

3. Lateral view.

4. First foot.

5. Shell markings.

6. Antenna.

i. Post-abdomen.

$\therefore$ Second maxilla of male.

Cyclocypris lavis Müller.

9. Antenna.

10. Post-abdomen.

11. Second foot.

Cyprinotus burlingtonensis Turner.

14. Antennule.

15. Bit of shell.

16. 'lip of first maxilla.

17. Dorsal view. (Fig. marked 692, middle of plate.)

15. Mandible.

19. Post-abdomen.

20. Antenna.

21. First foot.

2.2. Lateral view.

23. Second foot.

Figures 12 and 13 have been cut out. 


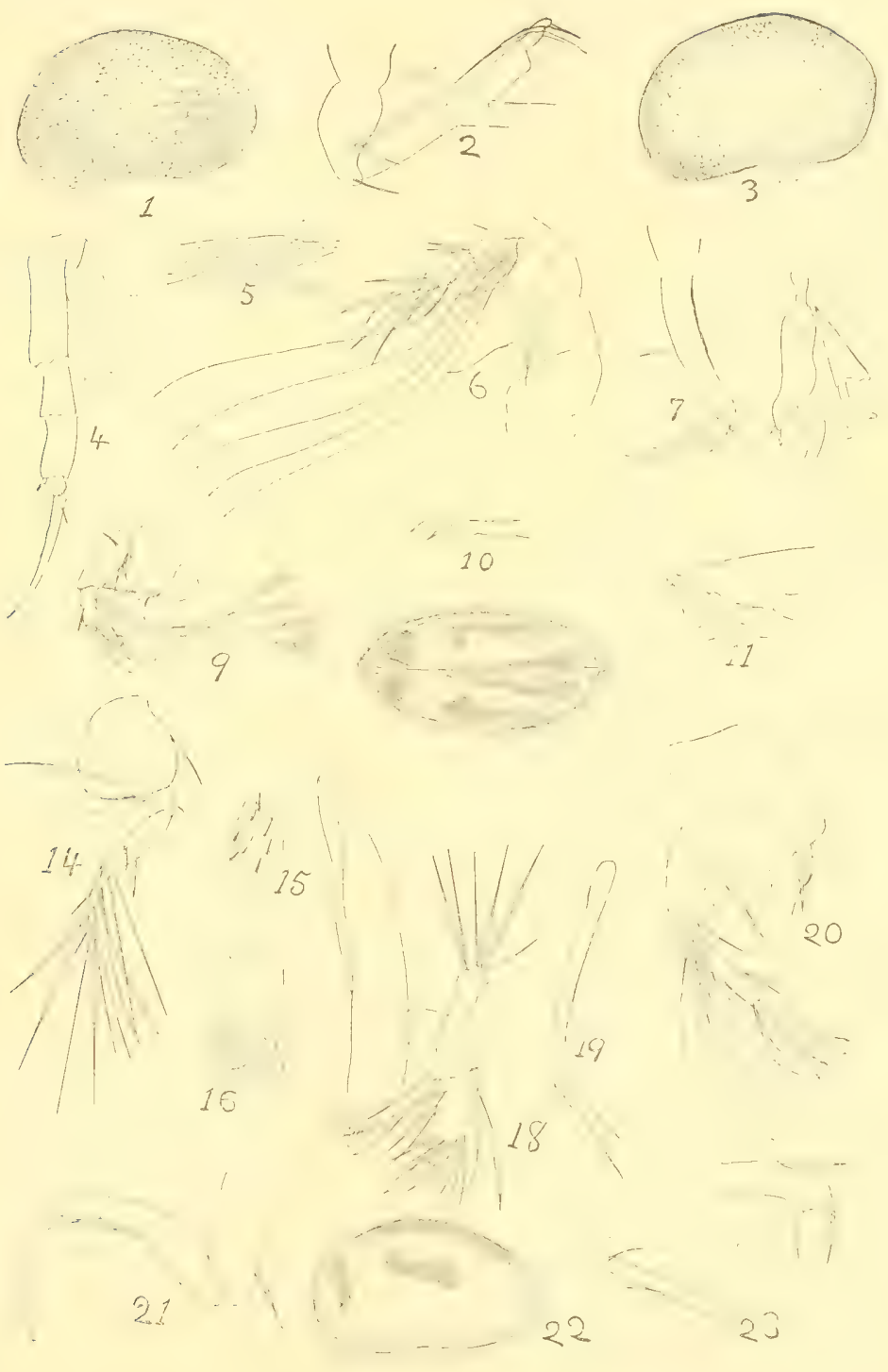



EXPLANATION OF PLATE LXXI. 
Candona crogmani Turner.

24. Mandibular teeth.

25. Antenna.

26. Sensory seta from mandibular palp.

27. Antennule.

¿s. Post-abdomen.

29. First foot.

30. Tip of second foot.

31. Mandibular palp.

32. Dorsal view.

33. Lateral view.

3. Candona acuminata Fischer. Post-abdomen.

Candona delawarensis Turner.

35. First maxilla.

3fi. Post-abdomien.

37. Dorsal view.

:38. Ventral view.

39. Lateral view.

(1). Antemna.

Cypris fuscata Jurine.

11. First maxilla.

12. Antenna.

43. Second foot.

44. Mandible.

4.). First foot.

46. Post-abdomen. 


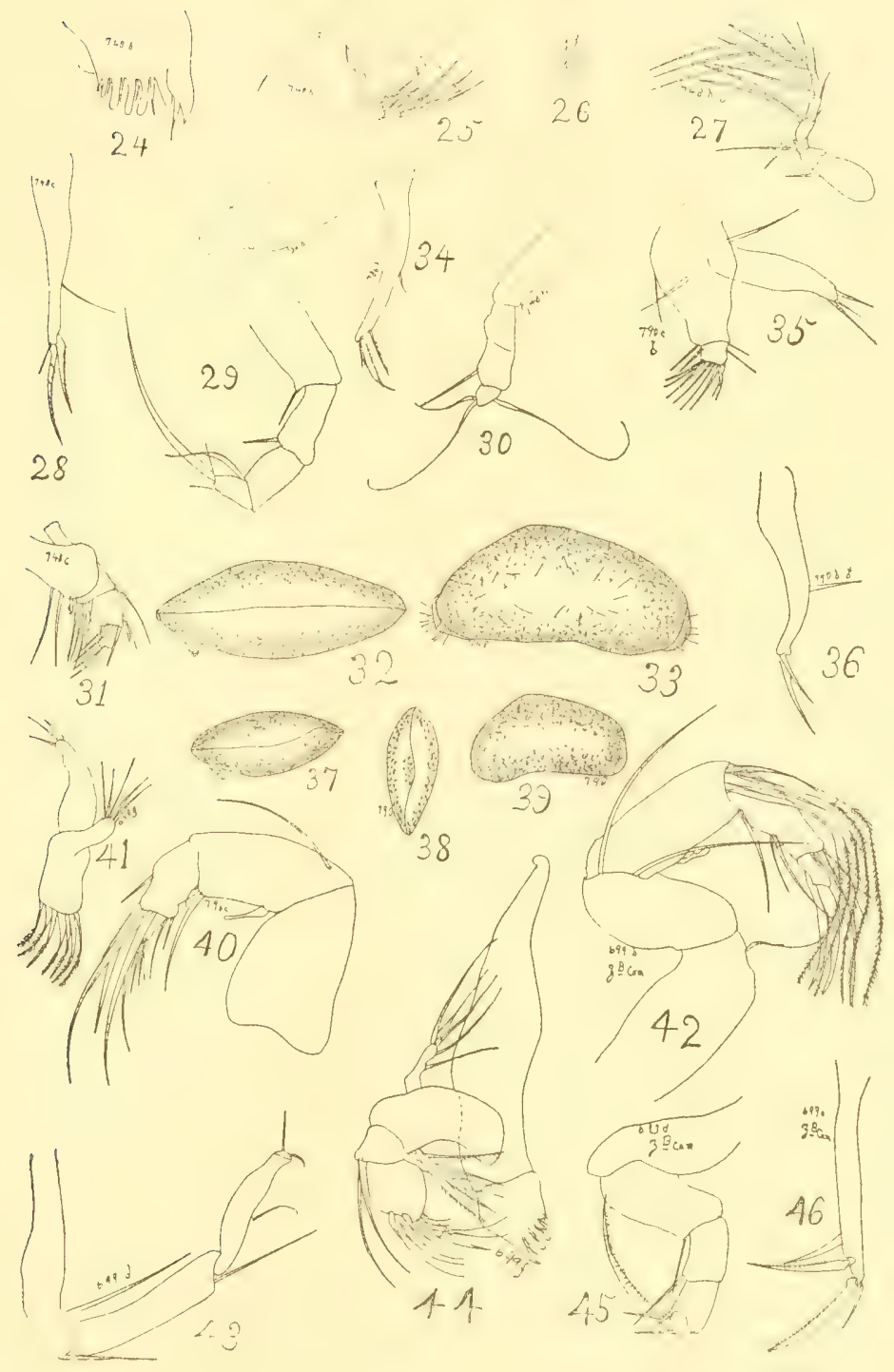



EXPLANATION OF PLATE LXXII. 


\section{Cypridopsis vidua.}

Ersi.

1. Female from above.

1:. Intenmule; 1h, antemna; 1c, first foot; 1d, second foot; 1e, mandible; $1 \mathrm{f}$, maxilla; $1 \mathrm{~g}$, labrum.

\section{Erpetocypris minnesotensis.}

2. Female from side.

2il. Intenmule: 2h, second antemua: 2e, first foot; 2d, second foot; 2e, mandible; 2b, abdominal ramus.

$\therefore$ Cypria exculpata. Lateral view.

4. Votollomats monachat. td, second foot; tf, second maxilla; 4 f. ${ }^{1}$ second maxilla; $4 \mathrm{~h}$, post-abdomen.

\section{Cyclocypris molesta.}

万. Male from side.

i). Female from side.

5a. Antumule: ih, antemua je, first foot: 5h, ablomiual ramus; ix. copulative organ.

\section{Cypridopsis newtoni.}

6. Side view of female.

$6 \%$ Anterior and posterior margins.

6at. Antemmule; fit, antrmna; fice, first foot: 6f', maxilla; 6y, lueid spots: 6 h, abdominal ramus.

\section{Cypris fuscata.}

7. Side view. Female.

$7 \because$ Dorsal view.

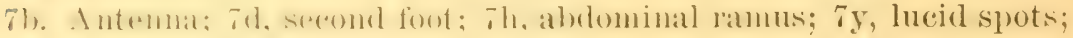
$7 \mathrm{p}$, a magnified portion of the anterior margin of the shell. Figures drawn by C. L. Herrick. Alabama Crustacea. 

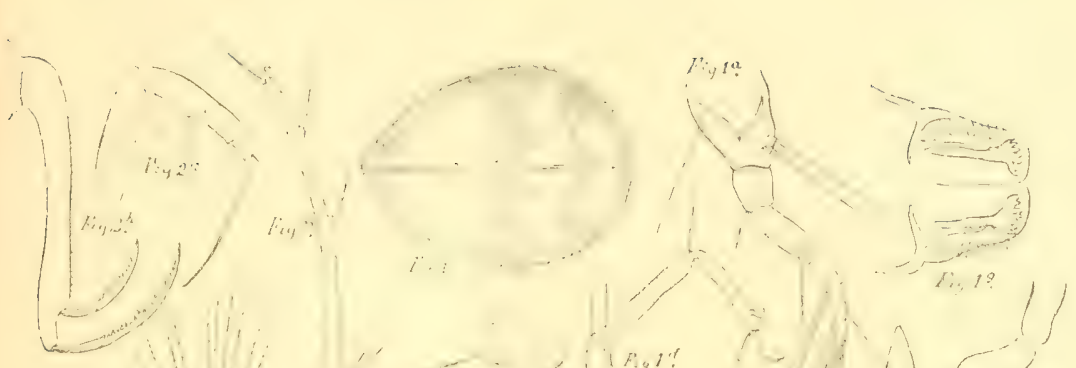

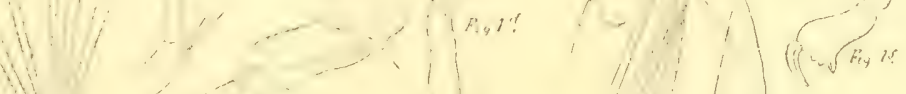
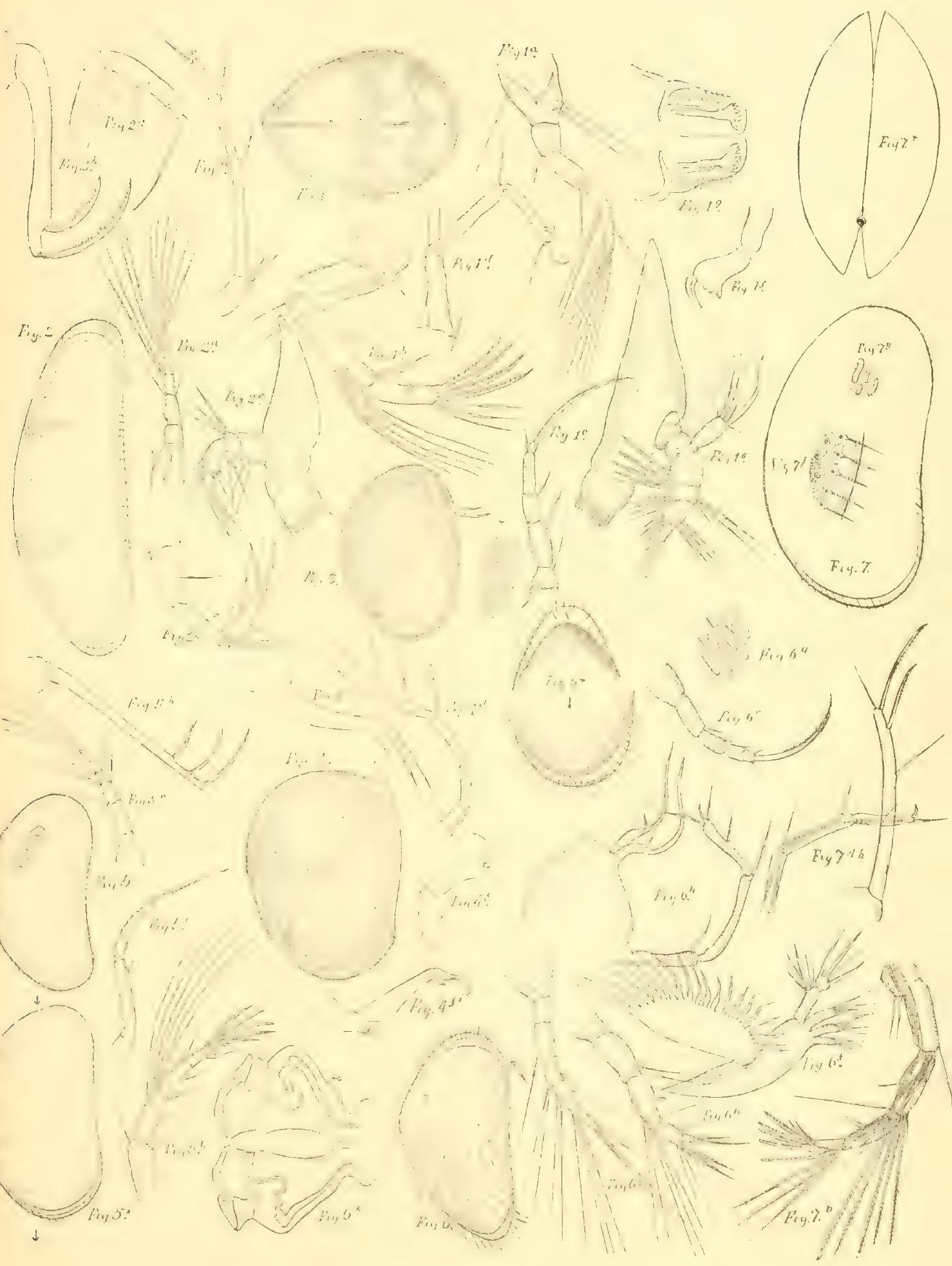

EXPLANATION OF PLATE LXXIII. 


\section{Cypris perelegans}

1. Lateral view.

2. Dorsal view.

3. Labrum.

4. Jaw.

5. Abdominal ramus.

b. Natural size. 
Zool Survey of Minn., II, i 895.
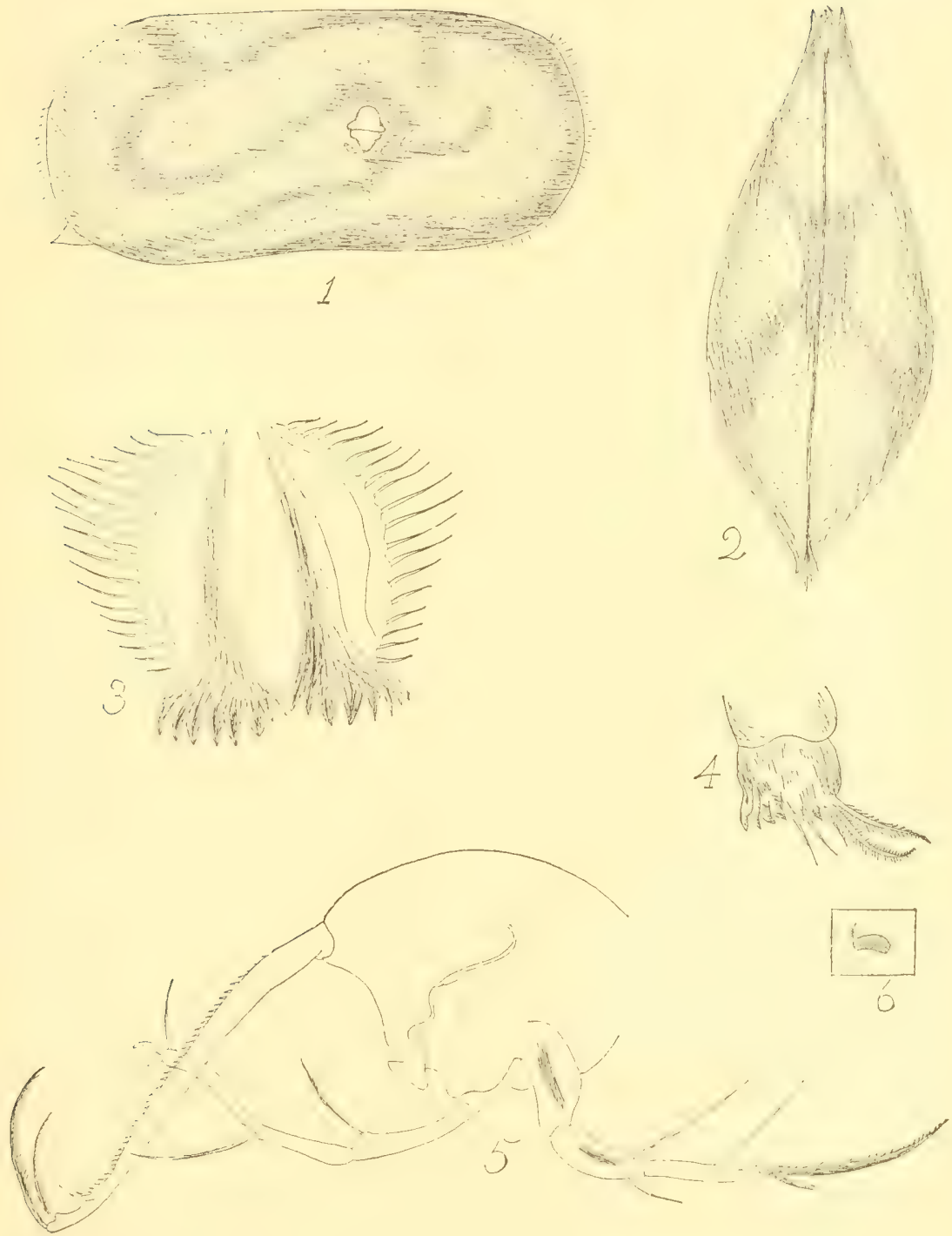

EXPLANATION OF PLATE LXXIV. 
Cypris virens (Jurine.)

FIr,

3. Labrum and both pairs of maxille.

1. Second antenna.

b. First foot.

$\because$ Second foot.

1. Jaws.

$\because \quad$ Caudal stylets.

The following figures of this plate are not noticed in the text:

1. Gammarus dubius Herrick.

2. Streptocephalus sealii Ryder.

4. Harpacticus chelifer Mueller.

5. Laponte mississippiensis Herrick.

6. Canthocamptus mobilensis Herrick. 

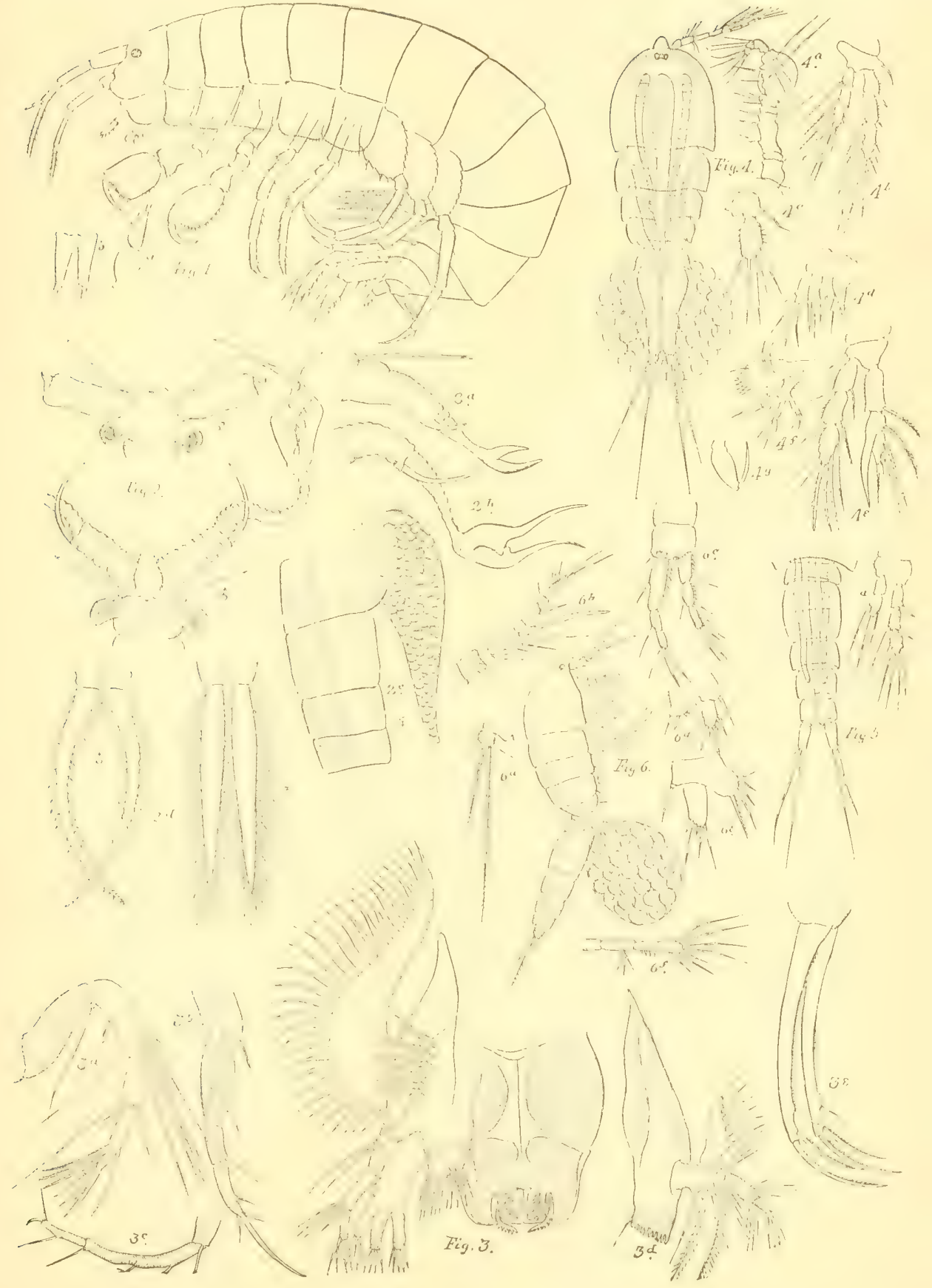

EXPLANATION OF PLATE LXXV. 
Cypria opthalmica (Jurine).

Fig.

1. Ventral view.

2. Lateral view.

3. Dorsal view.

4. Cypris. Dorsal view.

5. Cypridopsis vidua. Lateral view.

6. 66 vidua. Ventral view.

7. Cypria optloalmica. End view.

8. Crpridopsis vidua. Dorsal view.

$9 . \quad 66$ vidua. End view.

10. Candona fabroformis. Dorsal view.

11. "6 fahatormis. Lateral view. 

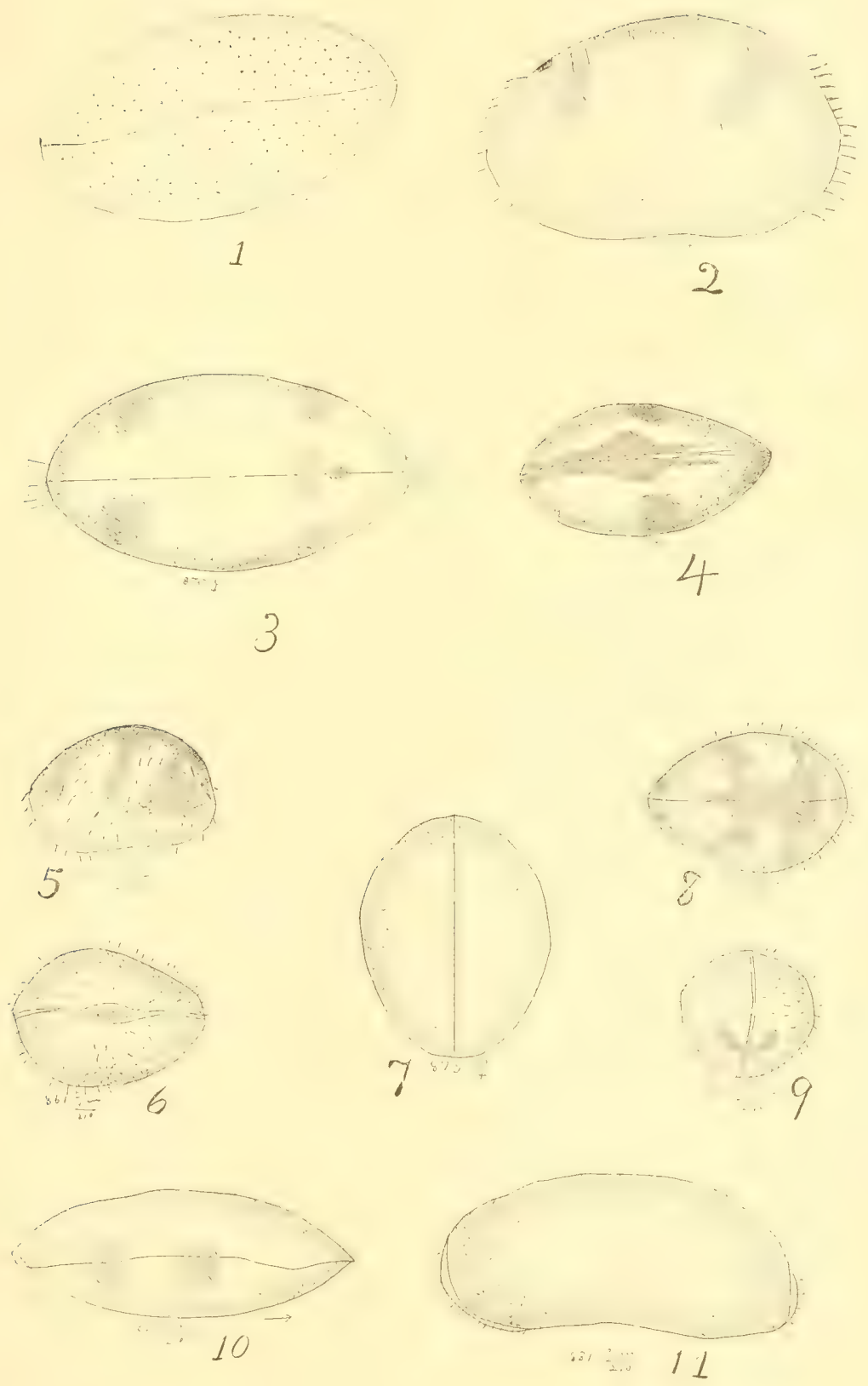

EXPLANATION OF PLATE LXXVI. 


\section{Cypria opthalmica.}

FIG,

1. Antenna.

2. Second foot.

3. Abdominal ramus.

4. Cypridopsis vidua. Abdominal ramus.

5. Cypria opthalmica. Mandible, gill missing.

6. Candona fibaformis. Antenna of female.

7. Cypridopsis vidua. Antenna.

8. Candona tabaformis. Abdominal ramus.

9. Cypris fuscata. Muscle scars. 

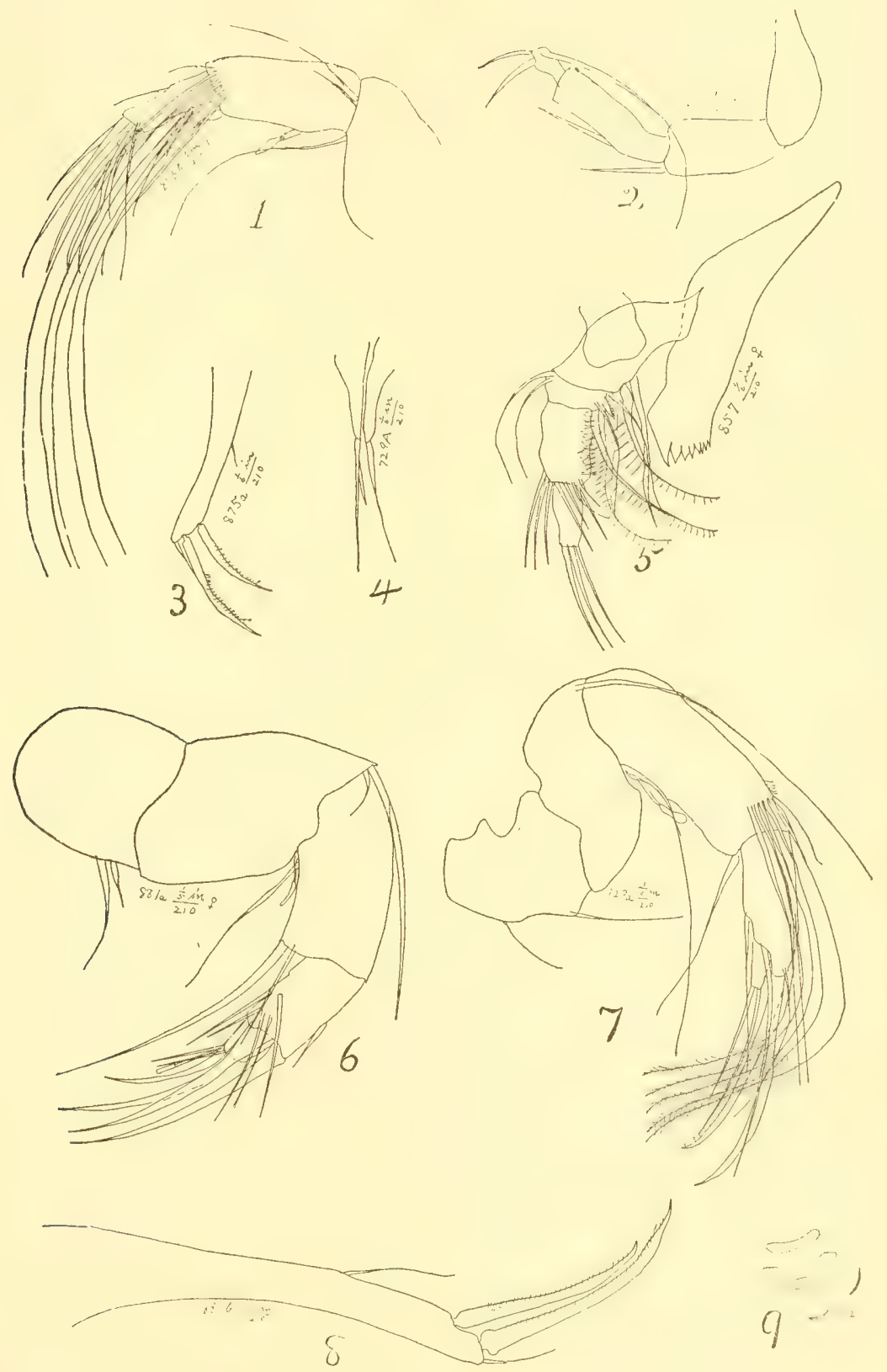

EXPLANATION OF PLATE LXXVII. 
Erpetocypris barbatus.

Fia.

1. Lateral view.

2. Antenna.

3. Caudal ramus.

'This plate is copied from S. A. Forbes. 


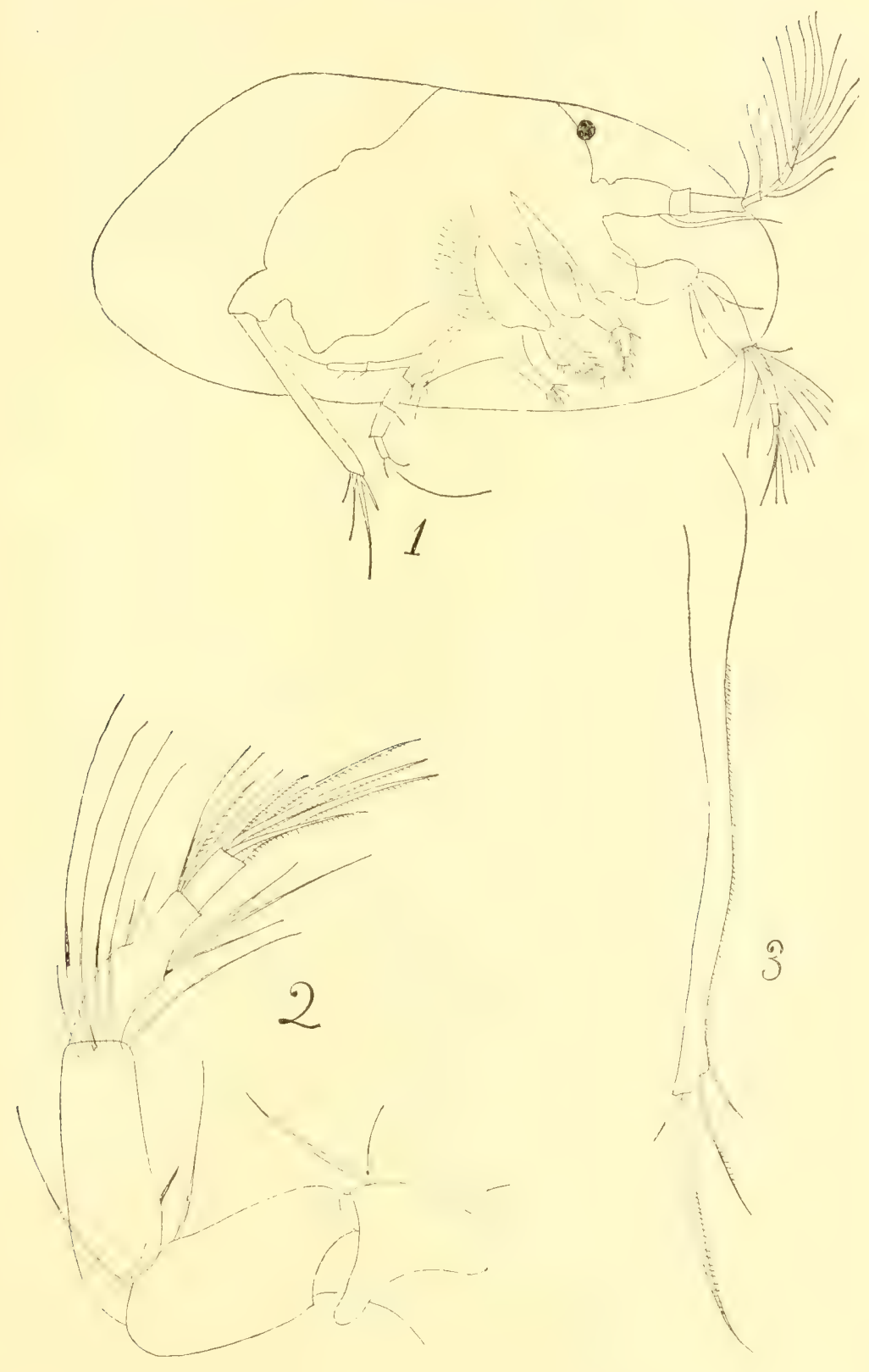



EXPLANATION OF PLATE LXYVIII. 


\section{Cypris albuquerquensis.}

FIG.

1. Lateral view.

2. Dorsal view.

3. First foot.

4. Mandible.

5. Antennule.

6. Antenna.

7. Second foot.

The figures on this plate were made by Professor C. L. Herrick. 

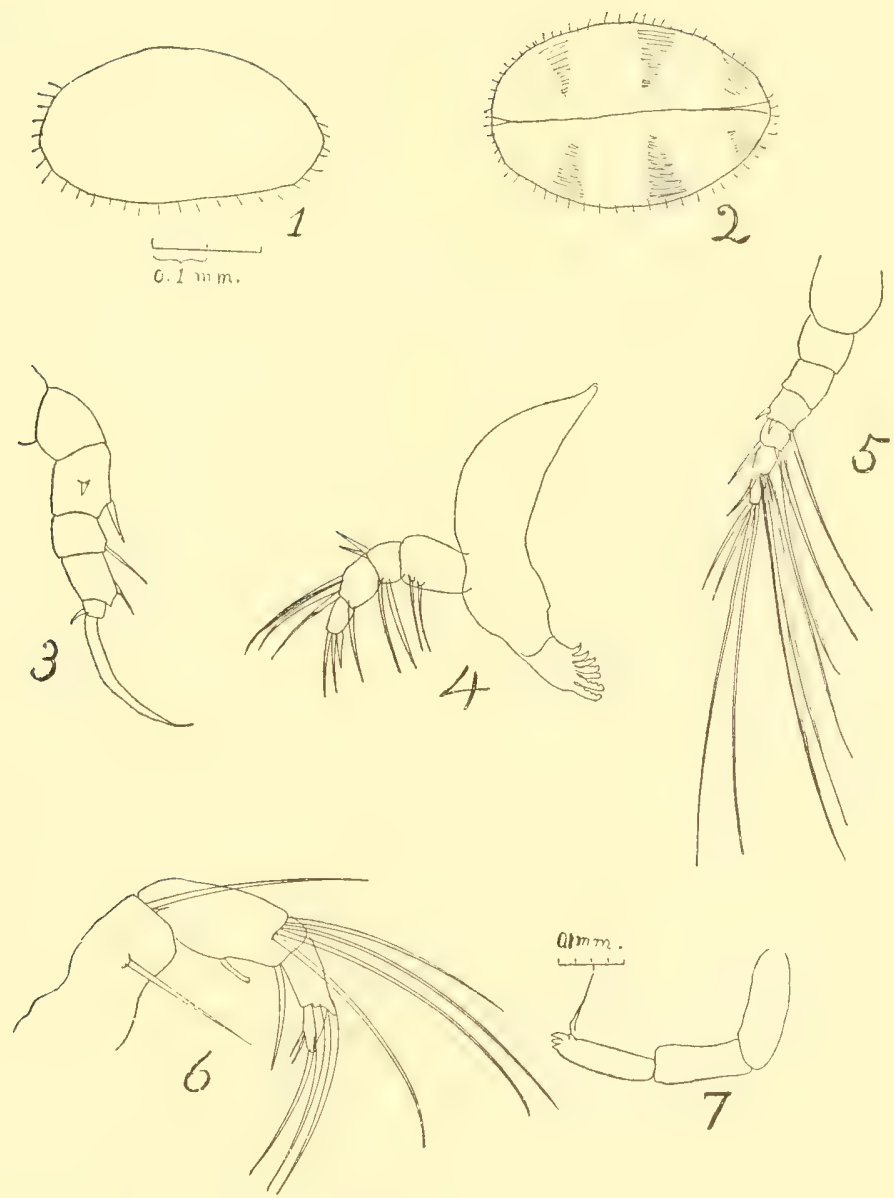

EXPLANATION OF PLATE LXXX. 


\section{Cyprinotus grandis.}

1. Dorsal view.

2. Lateral view.

3. Palp of first maxilla of male.

4. First foot.

5. Second foot.

(i. Mandible.

i. First maxilla of male.

8. Abdominal ramus.

!) Antenna.

\section{Cypris altissimus.}

10. Second foot.

11. Miscle scars.

12. Antenna.

13. Abdominal ramus. 

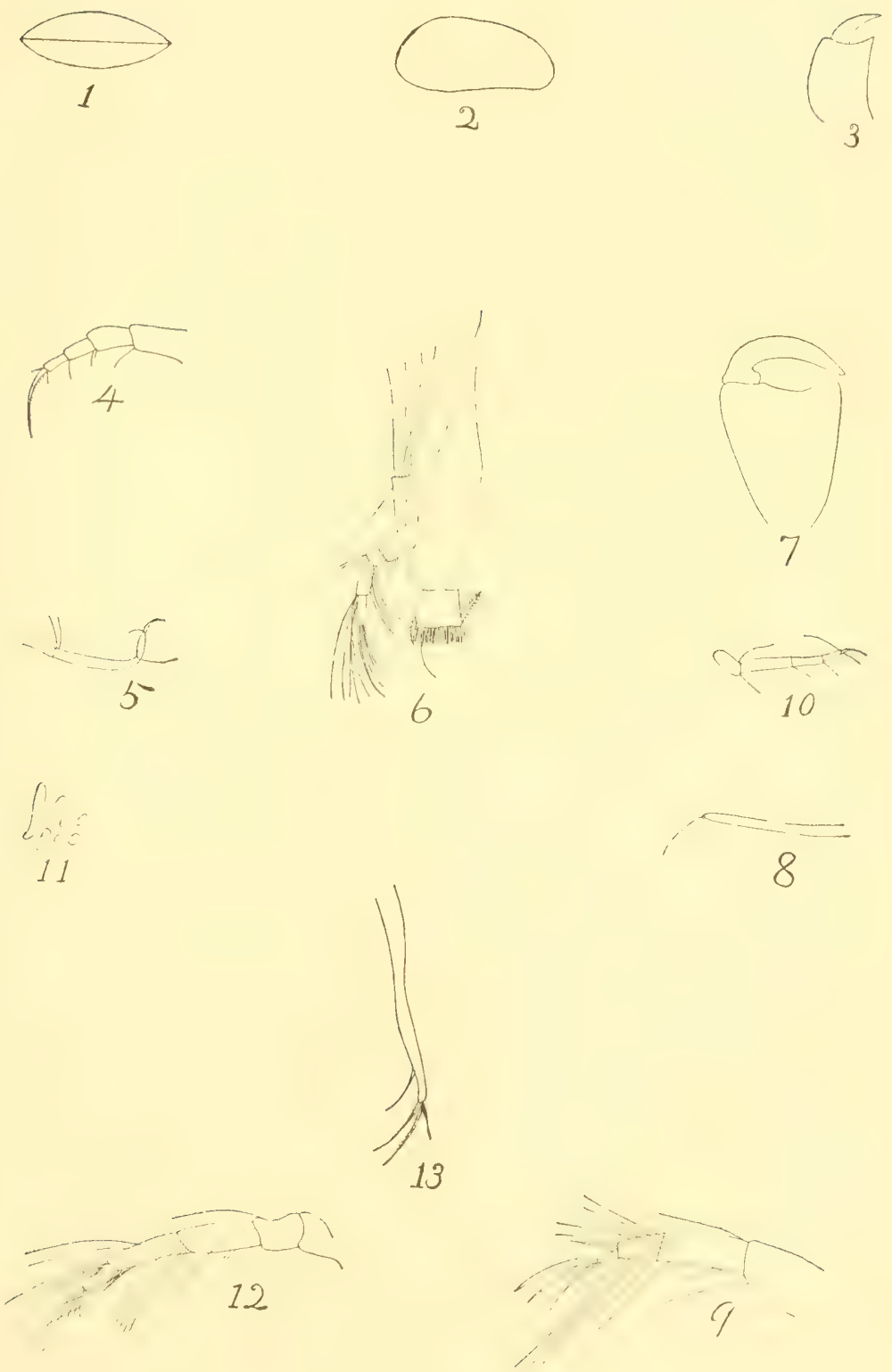

EXPLANATION OF PLATE LXXX. 
Candona peircei $\mathrm{n}$. sp.

live.

1. Antenna of female.

2. Antennule of female.

3. Antenna of male.

4. Second maxilla of male.

5. Lateral view of male.

6. Ventral view.

7. Second maxilla of male.

8. Lateral view of female.

9. Abdominal ramus of male.

10. Copulative organ of male.

11. Abdominal ramus of male. 
Zool. Surley of Minn., II, i895.
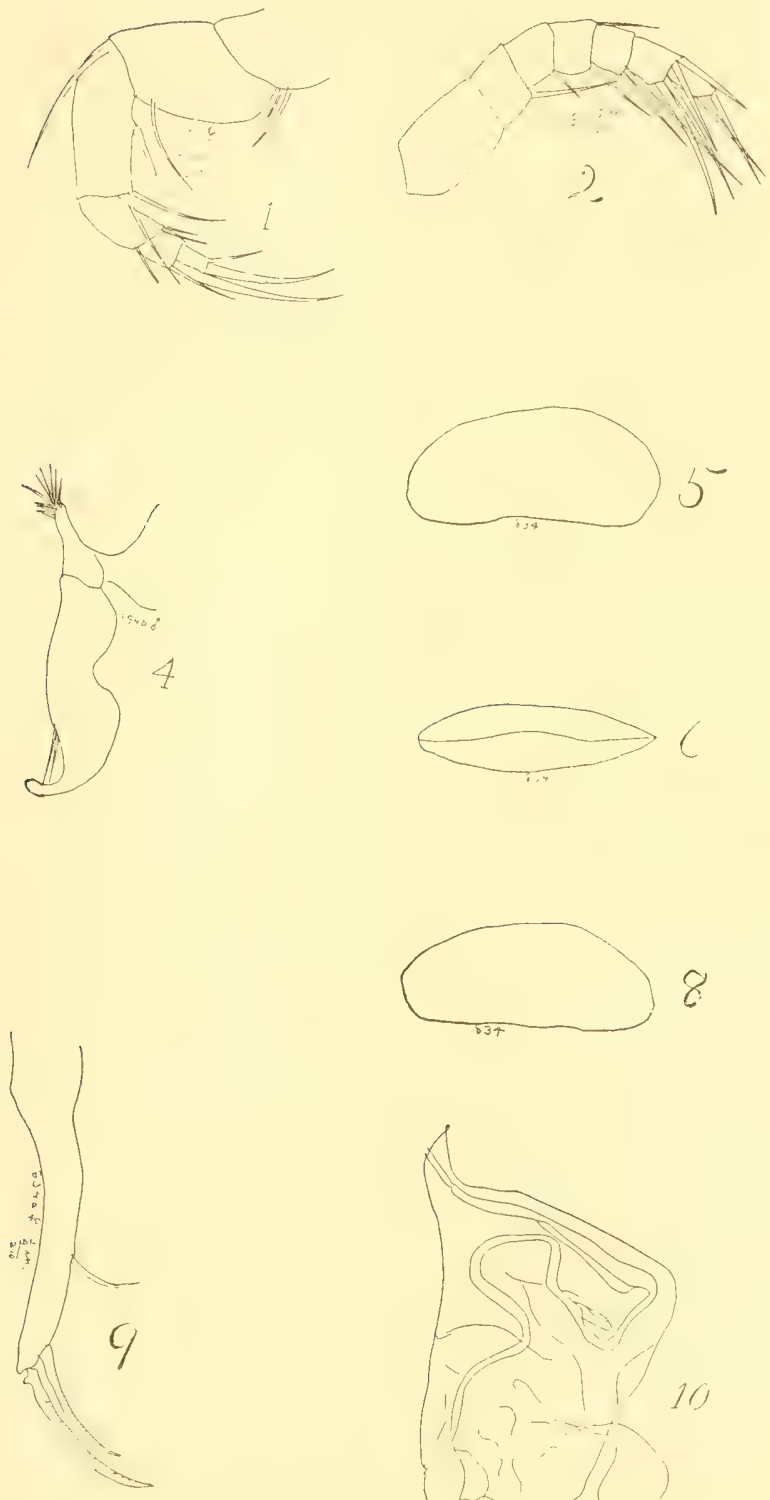

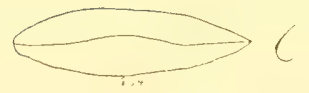

PLATE LXXX.
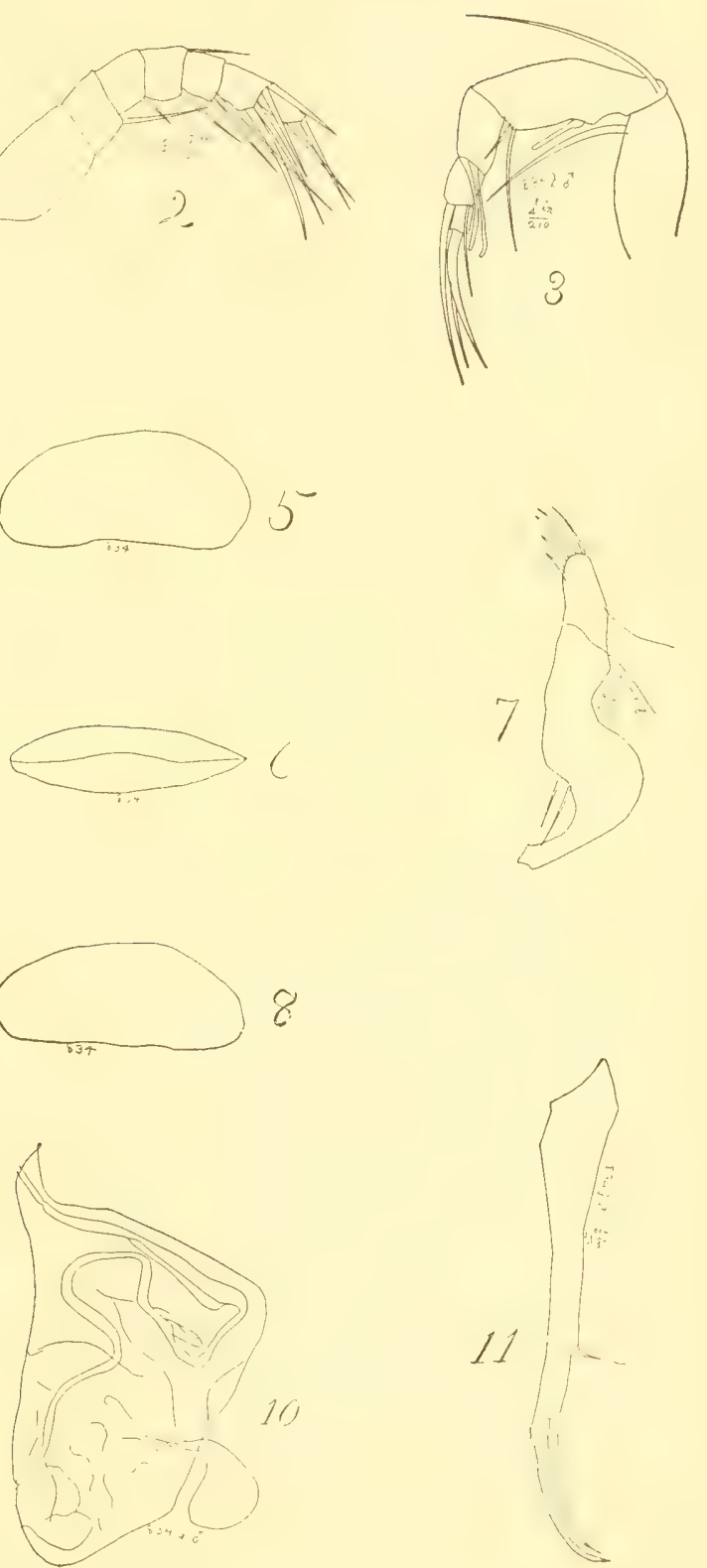

EXPLANATION OF PLATE LXXXI. 
Darwinula improvisa n. $\mathrm{sp}$.

Fra. Antennule of male.

2. Tip of second foot of male.

3. Antenna of female.

\section{Candona crogmani.}

4. Palp of second maxilla of male.

5. Palp of second maxilla of male.

Cypria mons Chambers.

6. Dorsal view.

¡. Lateral view.

8. Antenna.

?. 'Iip of first foot.

10. Lucid spots.

11. Second foot.

12. Abdominal ramus.

13. Darwinula inopina. Tip of first foot.

Figures 6 to 12 are copied from Chambers. 

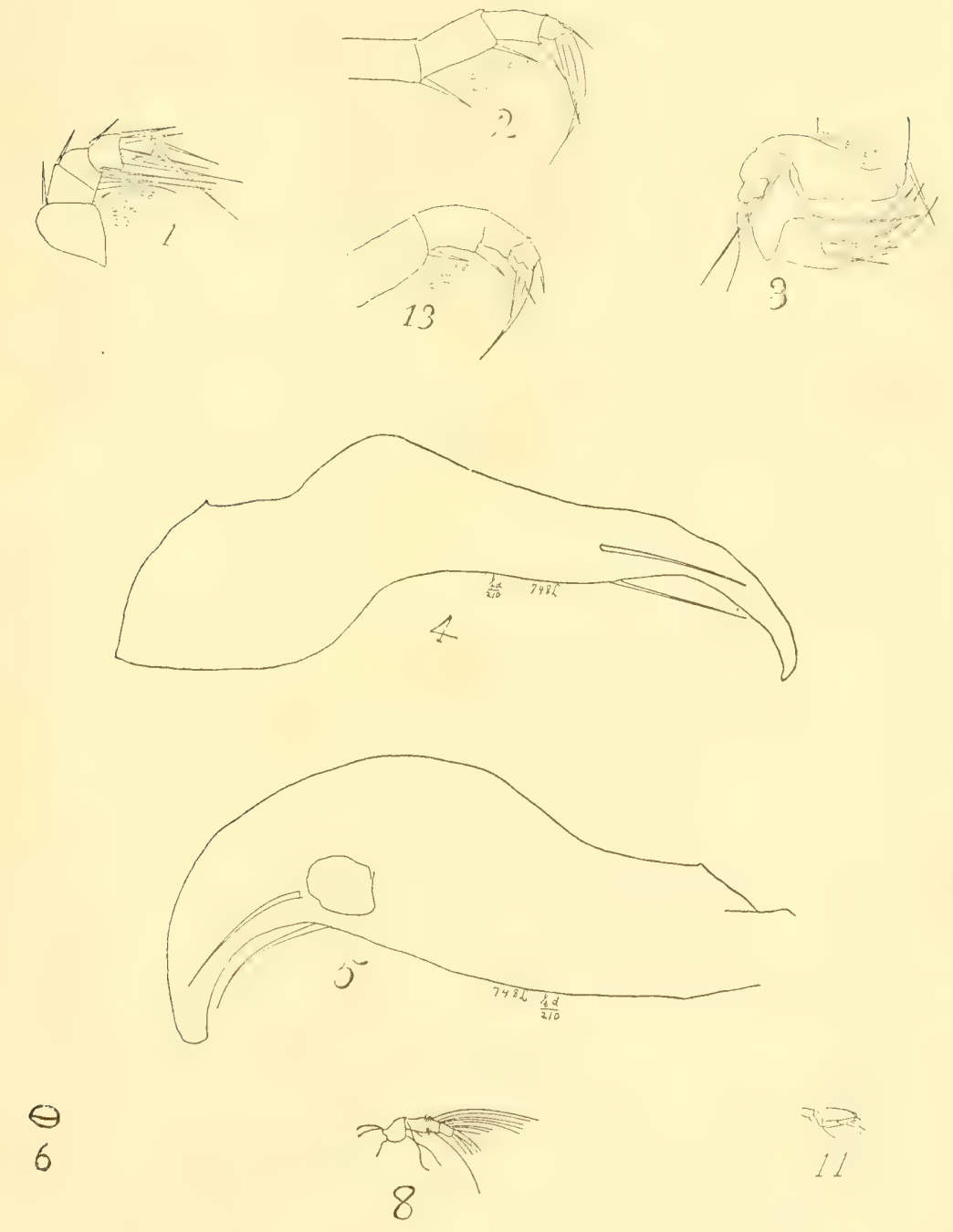

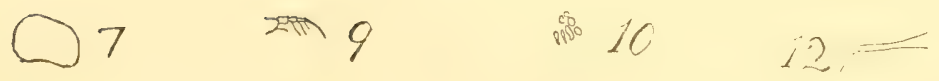





INDEX 



\section{INDEX.}

The figures in boldface refer to the page on which is found the description or "key" of the species or group.

The figures within parentheses refer to the plates.

The author's "Alphabetical Index of Species of Cyclops" (a list of synonyms) has been incorporated with the index:

The table of contents (page iii) shows the families and other groups considered in the report arranged under their respective orders.

Acanthocercus rigidus.

sordidus.

Acantholeberis

$218,143,211,273$

curvirostris $218(46), 273$

dentata .217

rigida. .218

rigidus

.218

Acroperus

alonoides 227 (sp.? 65), 226, 231, 233, 237

angustatus. 228

cavirostris $228(62)$

harpe. .228

intermedius. .227

leucocephalus. .231

striatus $227(61,62), 233$

transylvanicus

Alona . .227

acanthocercoides

228

aculeatus 238 (sp. ? 36), 143, 215, 233, 237, 249, 274 affinis 234,248

anglica... (64), 240, 275

angulata. 243,248

angusticaudata . 247

balatonica $235,24 \pi$

barroisi. 248

camptocercoides $.242,248$ coronata. $247,248,249$ costata... $245(60), 248$

dentata $244(62)$

elegans. 247 (62), 240, 242

elongata .231

elongatus. 248 esocirostris. 236,218 excisa .248 


\section{Alona}

falcata 248,260

glacialis 243 (63), 244, 248, 275

erlacialis var. levis

244

glacialis var. tuberculata...

$244(63)$

grisea .248

guttata $243,242,244,248,249$

inornata. 248

insenlpta. .248

intermedia... $244(6), 237,242,243,275$

lacustris 242

latissima. .248

lepida. 242

leydigia.... .248

leydigii ... .234

lineata.... $245,247,248$

minutia .248

modesta (13), 215, 248

moniezi 240

nanus. ..248

oblonga. $241,240,251$ ovata.

parvula. $243,242,244,249$

parvula var. tuberculata 243 porrecta 246, 275 pulchra. $215,247,249$

pygmiea .249

quadrangularis. 240 (61), 234, 237, 246, 249, 274 rectangula. .245 rectangularis. 249 reticulata 236,249

rostrata. 249,250

sanguinea $239(62)$

socors 249

spinifera 241,249 stagnalis. 246

striatia... .249

sulcata 240,249

tennicaudis 242 (62), 246, 248

testudinaria 235,249

transversit. $24 !), 253$

tuberculata. $243,244,249$

veriucosa

243,249

Alomella. $249,235-233,248,249$

excisa.... $251(22,61,63), 248-250,259$ exigua 252, 218-2j1, 253, 259, 260

grisea 252, 248 pulchella $250(13)$ pyormaea lw-tratit.... $-250,259$ striata. 
Alonopsis.

elongata.

$231,143,237,248$

latissima

231,248

latissima var. media

$232(61,63), 233,248$

Anchistropus

$232(61)$

264,257

emarginatus.

145,146

Anomopoda

Attheyella.

135,136

cryptorum

spinosa

Bairdiidx. .294

Bibliography.

Boeckella brasiliensis

triarticulata

\section{Bosmina}

atlantaensis

bohemica.

$2 C 6(\mathrm{sp} . ? 45), 143,214,215,272$
$\ldots \ldots \ldots \ldots \ldots \ldots \ldots \ldots \ldots . \ldots . \ldots . \ldots 209,273$

brevicornis

brevirostris.

coregoni....

208

cornuta.

207

curvirostris

diaphana.

..209

gibbera.

207 (65), 209, 272

lacustris.

208

.209

lilljeborgii

209

.209

londensis.

208 (45), 209

longicornis.

longirostris

207

macrorbyucha.

snaritima.

209

microps

208

nitida 208

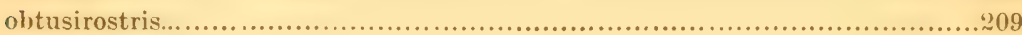

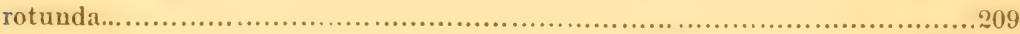

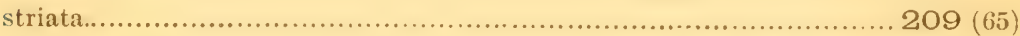

Bosminidae.................................206, 142, 146, 160, 161, 210, 272

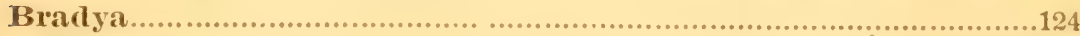

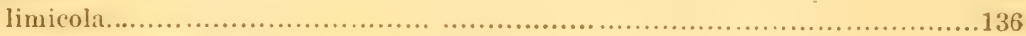

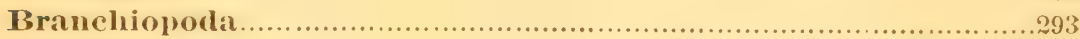

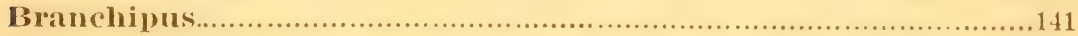

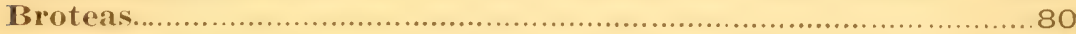

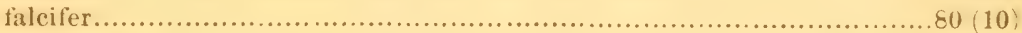

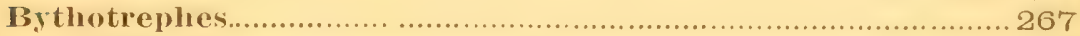

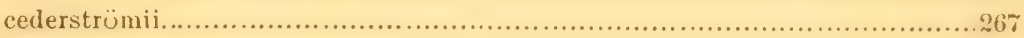

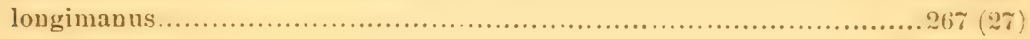

Calanidre.

Calyptomera 
Camptocereus $227,228,143,232,235,237,274$ hiserratus......................................................... 229 (62)

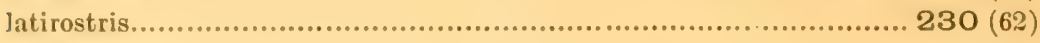

Jeticocephalus............................................................ (22)

lilljehorgii........................................................ 230 (62)

macrurus............................................... 229 (61), 230, 231, 274

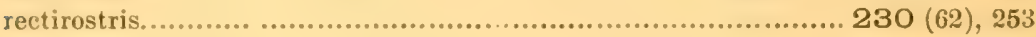

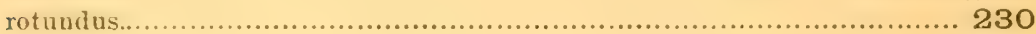

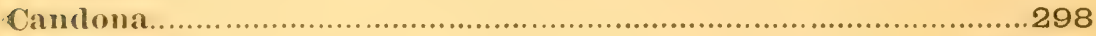

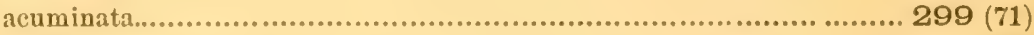

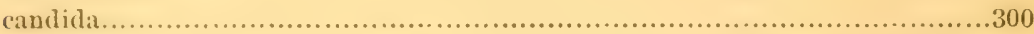

crogmani.......................................................... $300(71,81)$

crogmaniana............................................................... 300

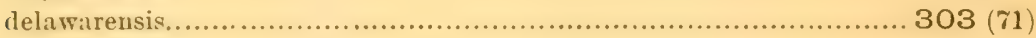

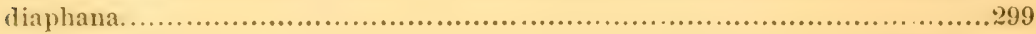

fabxformis.......................................................299 $(\mathbf{7 5}, \mathbf{7 6})$

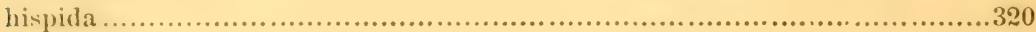

ornata................................................................. 316,319

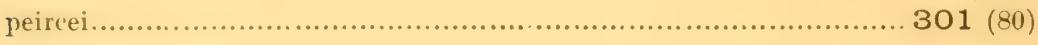

Canthocamptinae....................................................... 125

Canthocamptus.........................................125, 128, 121, 136

boreherdingii......................................................... 134

brevipes.................................................................. 130

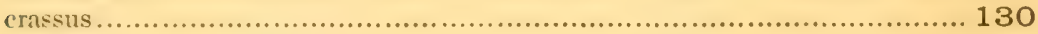

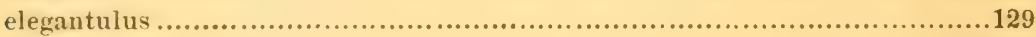

gracilis....................................................................... 129

hibernicus.............................................................. $134(50)$

horridus ..................................................................... 129

illinoisensis......................................................... 132 (29)

linearis................................................................... 129

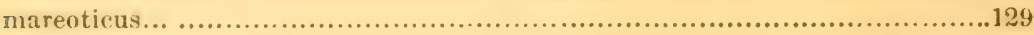

minnesotensis...................................................... 135 (22)

minutus...................................... $131(47,50), 129,130,134,135$

minutus var, occidentalis................................................. 131

northumbricus................................................... 130 (29)

northumbricus var, americanus................................... $130(29,33)$

palustris...................................................... $134(50), 128$

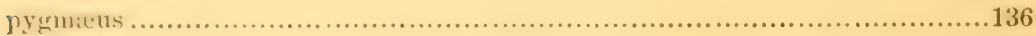

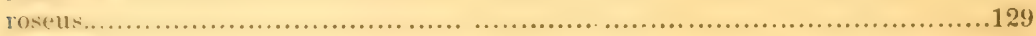

rostratus ................................................................ 129

staphynalis....................................................129, 131, 133

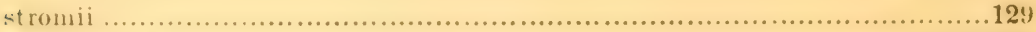

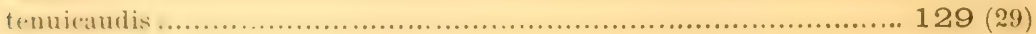

trispinosus............................................................ 130 (50)

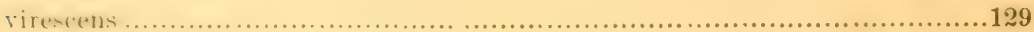

Centropages ......................................................48, 54, 86

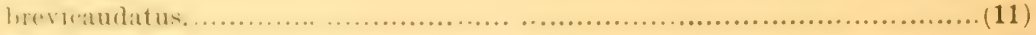

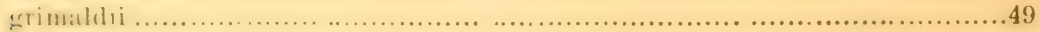

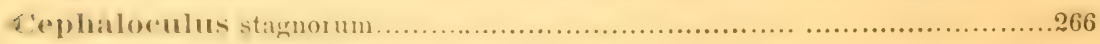


Ceriodaphnia $167,143,161,162,174,210,271$

alabamensis. $170(42)$

asperata 173

consors. $171(42,44), 271$

cornuta $174(66)$

cristata. $168,169,271$

dentata echinata. $170,169,172,173$

fisheri.. 173

laticaudata $171(41), 173$ megops. $168(41), 271$

minuta 173

nitida. 173

puichella $169(41)$ punctata quadrangula. $171(41)$ reticulata rotunda. $170(41,42,43,44), 169,171-173$

scitula. $169(41,42), 173$ setosa $172(42,44,45)$ textilis

Chirocephalus

Chydorus.

adunctus.

albicans.

alexandrowii. 263

crelatus .264

globosus $262(64)$

latifrons. $261(21,64), 262,264$

latus. 263

letourneuxi 264 muelleri. .261 nitidus. $262(64)$

ovalis.. $262(64)$

piger. punctatus sphrricus tuberculatus.

Cirripedia.

Cladocera. 263 263

Cladocopa

Copepoda

Coregonus wartmanui host of B. longimauns.

Crepidocercus. setiger...

Ctenopoda

Cyclocypris.

lævis modesta 
gracilis

Cyclops.........88 (sp) ? 21), *4. Heterogenesis in, 122. Preimago fertility of, 122 abyssorum Sars (=strenuus.) ..........................100 (23), 99, 100, 101 adolescens Herrick (= phaleratus and varicaus)........... 120 (20), 94, 11\%, 118 requoreus.

aftinis

$117(30), 118,120$

agilis Koch ( serrulatus)

alajensis Uljanin (=macrurus)

albidus Jurine (=signatus var. tenuicornis).

annulicornis Koch (=signatus var. tenuicornis).

ater $89(6,12,21)$

bicolor $118(18,21), 116,117$ bicuspidatus Sars (- bisetosus Rehberg) $99,101,107,110,111,122$ bisetosus $99(23)$

bistriatus Koch = signatus var. tenuicornis?

bodamicus Vosseler (=strenuus, pelagic form). .100 bradyi Sostaric $=$ helleri.

brevicaudatus Claus (=strenuus). $91,99,100$

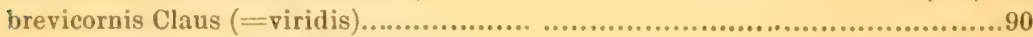
brevispinosus....................................................95 $(23,24), 94$

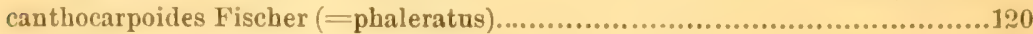
capillatus ...................................................................... 115 capilliferus............................................................. $109(6,28)$ claudiopolitanus Daday (=strenuus)......................................... 100 (lausii Lubbock ( strenuus; of Poguenpol, signatus)................99, 105, 123 claviger Müller $=$ Diaptomus.

coecus.

corvleus $M$ üller $=$ Diaptomus.

coronatus Claus (= signatus var. corouatus). 105-107

crassicaudis.

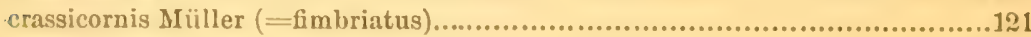

cuspidatus. ..... 89,101

dentatus Rehberg =helleri=clausii.

diaphanus $117(19), 118,120$

dylowskii. 97,99

eflax ...96

elongatus Claus (=vernalis; of Daday=strenuus?)..................8 89, 92, 100

entzii Daday (=bicuspidatus) .101

ewartii Brady=immature?

fedtschenkoi Uljanin (= $=$ strenuus). 99

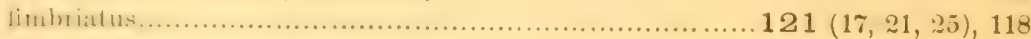
limbriatus var. poppei lehberg.

fisheri Poggenpol $=$ phaleratus.

fluviatilis.... 


\section{Cyclops}

fuscus Jurine (= signatus var, coronatus), .................................1115

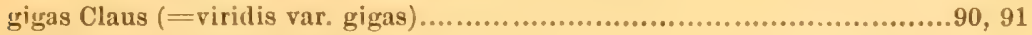

gracilicornis Lande= signatus.

grarilis

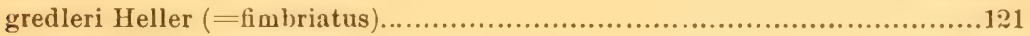

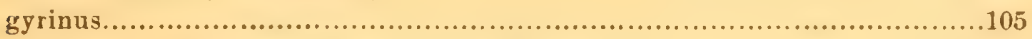

helgolandicus Rehberg (=var, of bicuspidatus) .......................101, 110

helleri Brady=immature?

hungaricus Daday (=strenuus) ........................................100

hyalinus Rehberg (=oithonoides var. hyalina; of Schmeil-dybowskii Lande) 122

ingens Herrick (=viridis var. ingens) .....................92 (25), 90, 91, 123

insectus Forbes (=bicuspidatus)......................................99 (27)

insignis........................................................... $110(22,23)$

josephi Moniez $=$ byalinus Joseph.

kaufmanni Brady, and of Uljanin=immature.

lacinulatus Müller=Eurytemora.

lacivus Poggenpol (=phaleratus) ............................................120

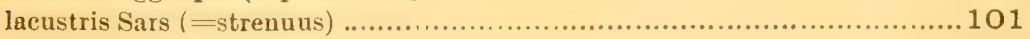

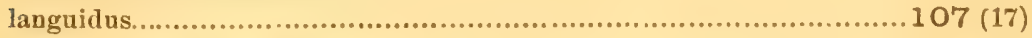

leeuwenhoekii Hoek (=leuckarti) ......................................96, 97

leuckarti................................................96 $(16,18,24), 97,98$

longicornis Vernet (= prasinus) ......................................49, 113

lubbockii................................................................110, 111

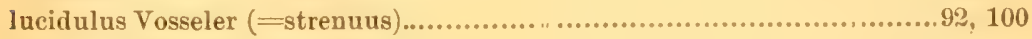

maarensis Vosseler=macrurus.

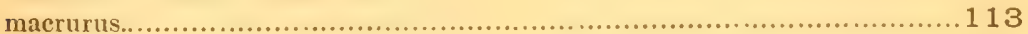

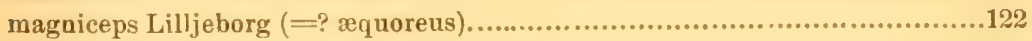

magnoctavus Cragin (=fluviatilis Herrick) ...................................114

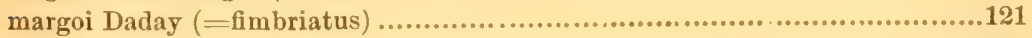

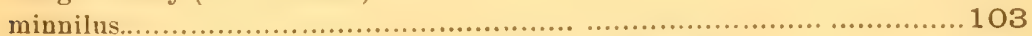

minutus Müller (=Canthocamptus; of Claus=diaphanus)......................117

modestus .............................................................. 108 (21)

navus...................................................................... 10 2

nivalis Daday =?

obesicornis Templeton=male of signatus.

obsoletus Koch $=$ ? leackarti.

odess.unus Schmankewitseh =saline var. of bicuspidatus or helgolandicus.

oithonoides ............................................................98, 97

oithonoides var. hyalina......................................................97

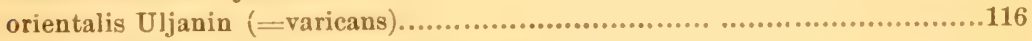

ornatus Poggenpol=?; of Rehberg=clausii.

paradyi Daday (=strenuus.) ............................................... 100

parcus...................................... $93(20,21,23,34), 90,95-97,99,118$

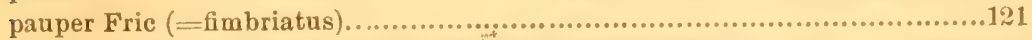

pectinatus Daday (=-leuckarti; of Herrick=bicuspidatus).................96, 101

pectinifer............................................................111, 113

pennatus Claus=signatus var. tenuicornis.

pentagonus Vosseler (= prasinus) ...................................113, 115

pentagonus var. vichyensis Richard (=prasinus)............................113 


\section{Cyclops}

perarmatus Cragin (=-phaleratus) 120

phaleratus. $120(17,18,19,21), 117,118$

poppei Rehberg (=limbriatus) 121

prasinus.

113

pulchellus Brady (=strenuus)

$101(2 ;, 28) 93,99,100,103,111$

pulchellus var. narus .................................................. 102

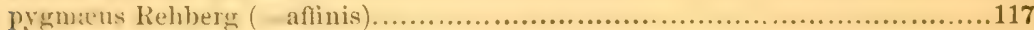

yuadricornis Koch (of' Lilljehorg, and of Müller--unidentified; of Sostaric =strenuus). .................................................... 100

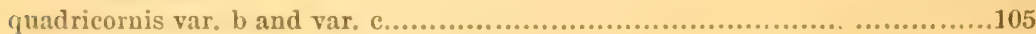

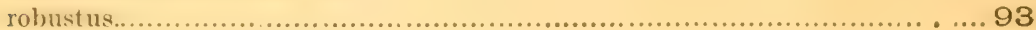

roseus Daday=bicuspidatus?

rubens Müller=Diaptomus.

scourfieldi Brady (=strenuus) ..........................................98, 96

scutifer Sars (=strenuus)..............................................99, 101

serratus Forbes $(=$ forbesi Herrick)................................... 104, 122

serrulatus........................................111 $115,19,26,29), 113,123$

serrulatus var. elegans .............................................. 112,111

serrulatus var. montanus............................................111-113

signatus Uljanin ( $=$ signatus var. coronatus)....................105 $(20,21), 124$

siguatus var. coronatus.....................................106 (15), 107, 124

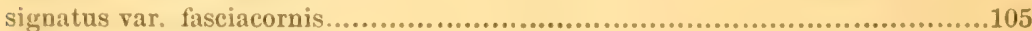

signatus var. tenuicornis........................... $106(15,20,33), 107,124$

simplex Poggenpol (=leuckarti)....................................96, 98

spinulosus Claus=macrurus?

strenuus.................................................. 99 (23), 101, 110, 111

suliterraneus......................................................... 122

tenuicornis Claus (-signatus var. tenuicornis; of Ujjanin-siguatus) $90,96,105-107$

tenuicornis var. distinctus Richard=signatus.

tenuicornis var. signatus Herrick=signatus.

tenuissimus Herrick (=leuckarti).

(24), 96-98

thomasi Forbes (=bicuspidatus) ............................ (27, 28), 101, 103

uniangrulatus............................................................. 96

varicans................................................ 116 (19, 30), 119, 120

vernalis...................................................... 92, 89, 93,94, 99

vicinus Uljanin (=strenuns)..........................................99, 100

viridis...............................................90,92-94, 115, 122, 123

viridis var. americanus............................................ 91 (14), 95

viridis var. europæus..................................................... 90,92

viridis var. grigris..........................................................

viridis var. ingens................................................... 92 (25)

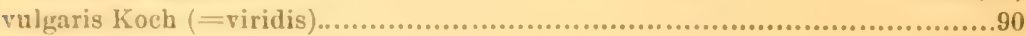

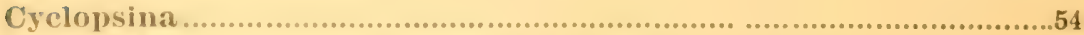

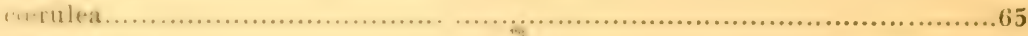

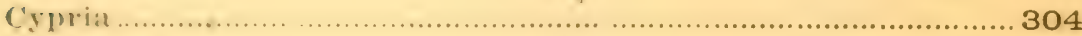

exculpta.................................................... $305(70,72), 309$

inequivalva...................................................... 307 (68), 311

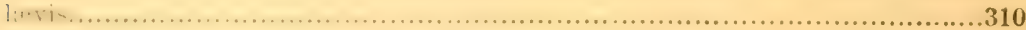

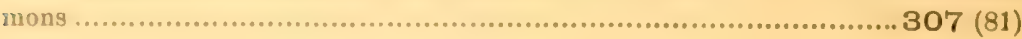




\section{Cypria}

neglecta 306

opthalmica. $306(75,76), 307,326$ punctata.

Cyprididae 294

Cypridopsis hystrix. $312,319,328,329$ newtoni. 314,328

obesa

vidua.

Cyprinotus. $312(72,75,76), 307,323$

burlingtonensis.

crena

grandis.

Cypris. 319 (sp.? 75), 293, 314-316, 328, 329, 332

acuminata 299

adusta. 320

agilis. 329

albuquerquensis.

altissimus.

aurantia

barbatus.

bimuricata... .296

brunnea . .310

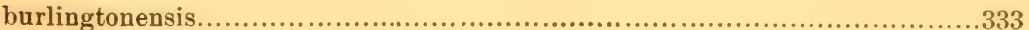

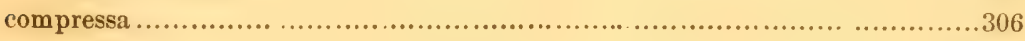

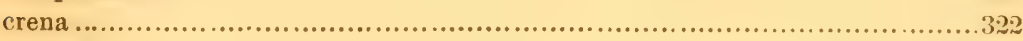

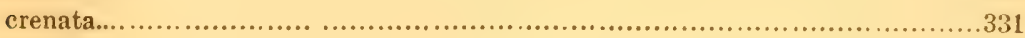

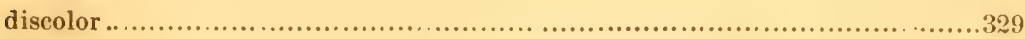

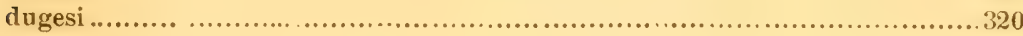

elegantula.................................................................. 306

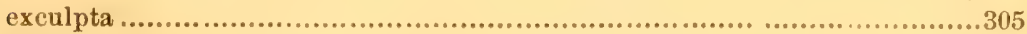

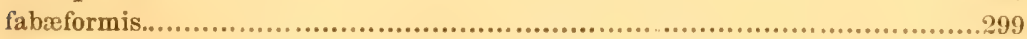

fusca............................................................................... 330

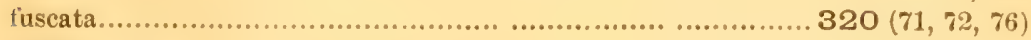

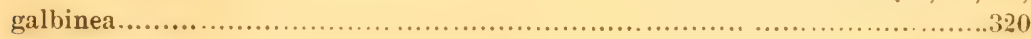

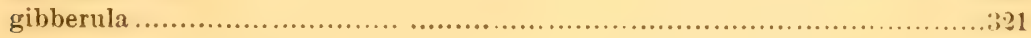

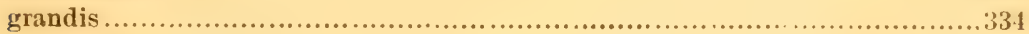

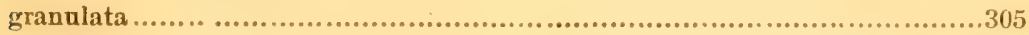

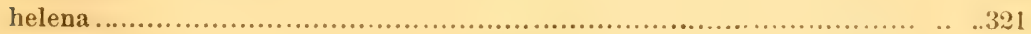

herricki.......................... $324(67,68,69)$ Late larval history of, 326

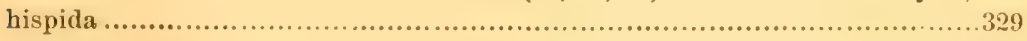

incongruens............................................................. $330(69)$

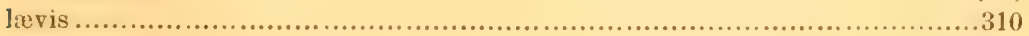

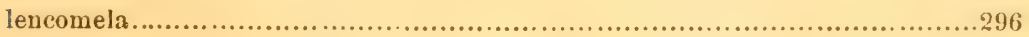

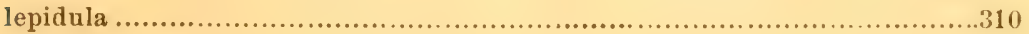

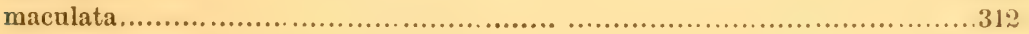

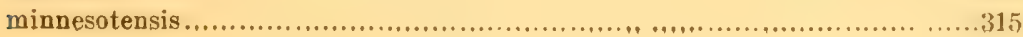




\section{Cypris}

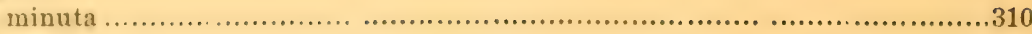

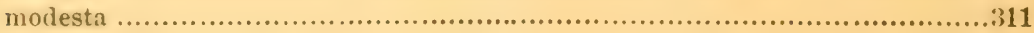

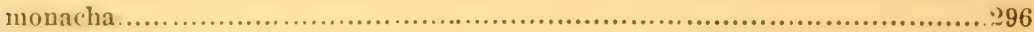

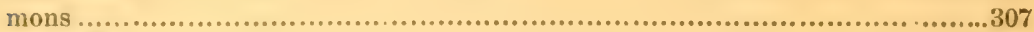

nubilosa ......................................................................296

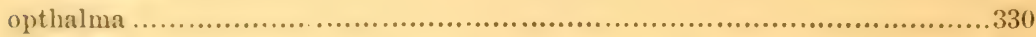

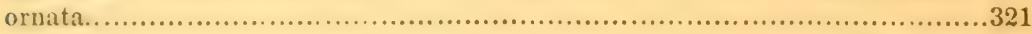

ovum...........................................................306, 310,311

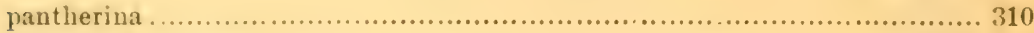

perelegans......................................................... 322 (73)

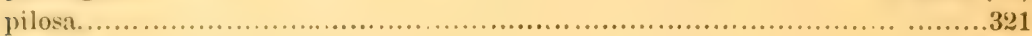

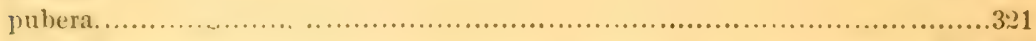

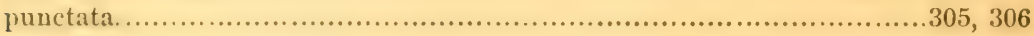

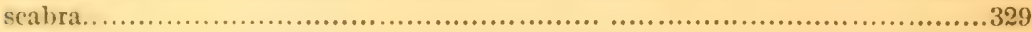

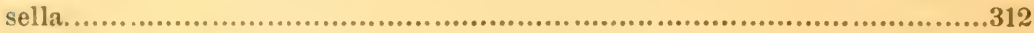

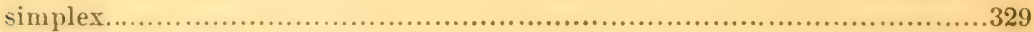

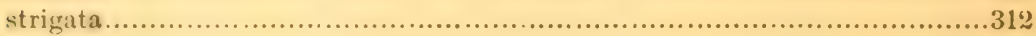

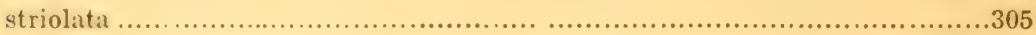

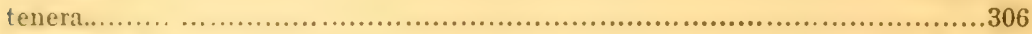

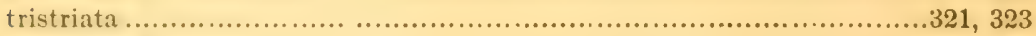

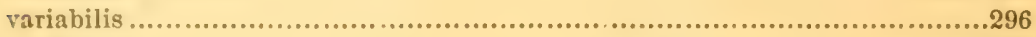

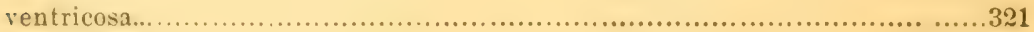

vidua................................................................312, 313

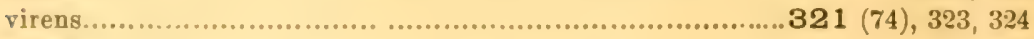

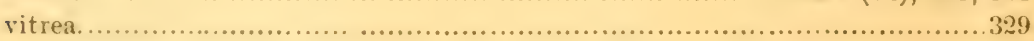

Cyprois monacha...............................................................296

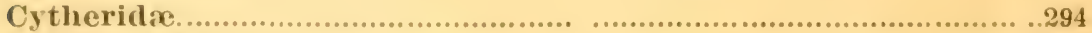

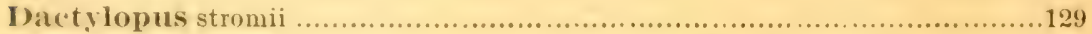

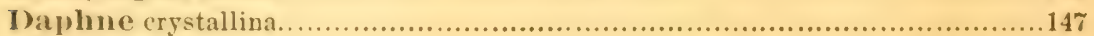

Daphnella ................................... 148, 142, 143, 149-151, 160, 161

brachyura.................................................... 148 (26), 149

brandtiana ......................................................... 149 (37), 148

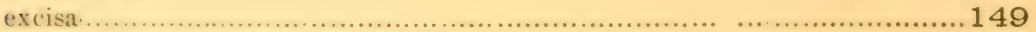

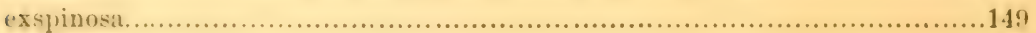

winchelli ..... ............................................................. 149

wingii................................................................... 148

Japhnia......181, 185,14 1-143,161,162,166,167,176-178, 180, 219, 260, 27.2

Development of, 182 ; Parasitic worm in..................................(22)

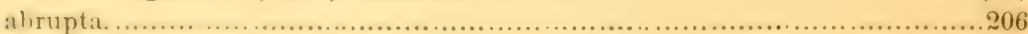

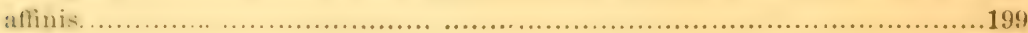

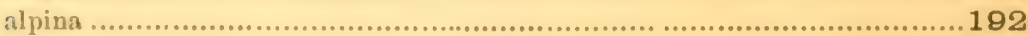

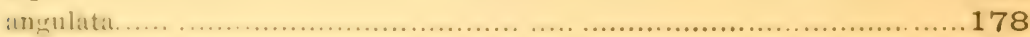

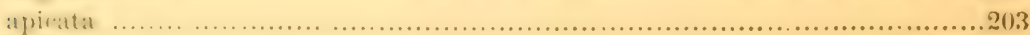

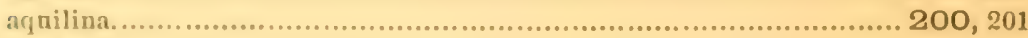

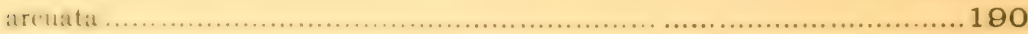

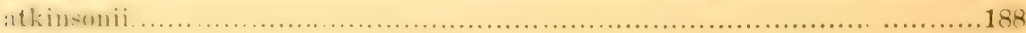

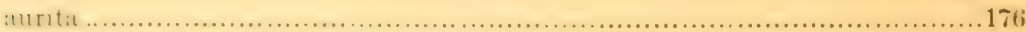

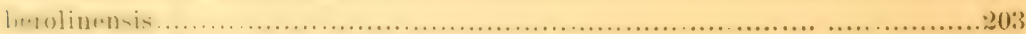

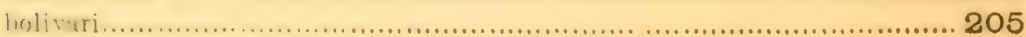




\section{Daphnia}

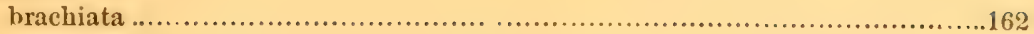

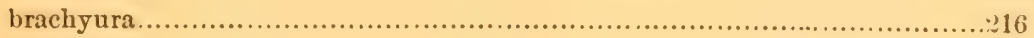

brasiliensis.................................................................. 06

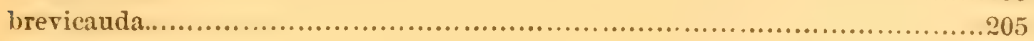

brevispina ................................................................ 193

carinata...................................................205, 189, 198, 206

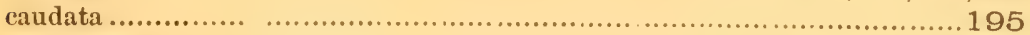

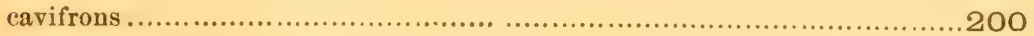

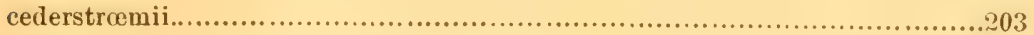

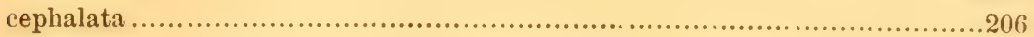

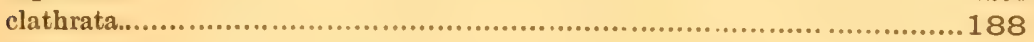

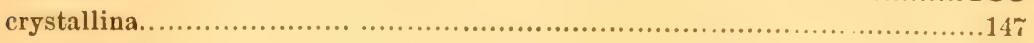

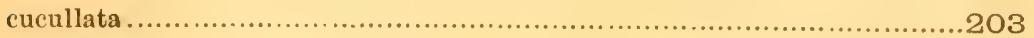

curvirostris ................................................1 194, 211, 212, 218

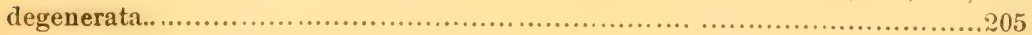

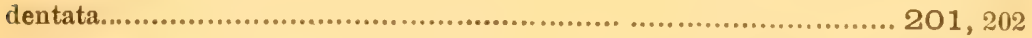

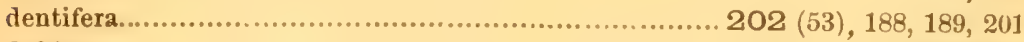

dubia.............................................................. 196 (49)

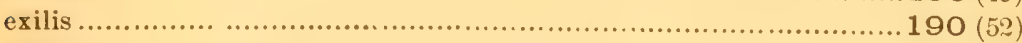

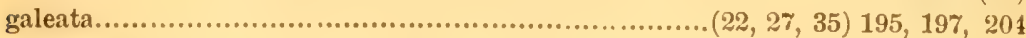

gibbosa ................................................................. 191

gracilis ........................................................................... 195

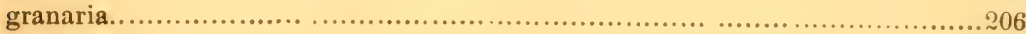

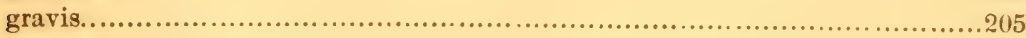

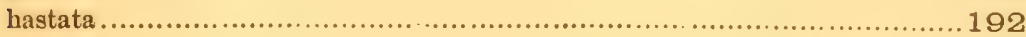

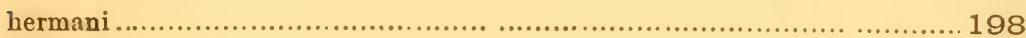

hyalina................................... $195(22,27 ; 35,49,53), 196-198,204$

kalbergensis............................................. 203 (27, 53), 195

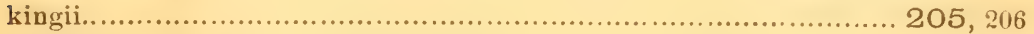

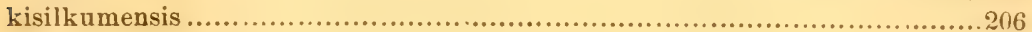

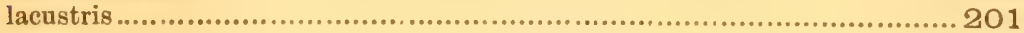

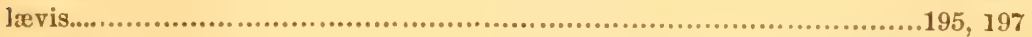

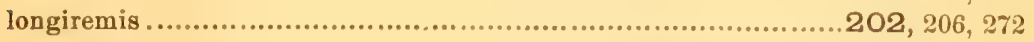

longispina..................................... 199, 189, 193, 195, 200-202, 204

lumboltzii .......................................................... 206 (66)

macrocopus ................................................................ 16

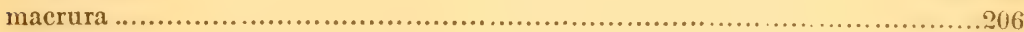

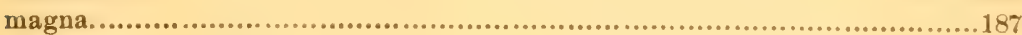

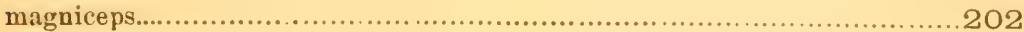

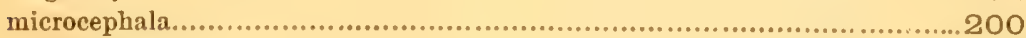

minnehaha ......................................... $189(49,50,52), 199,202$

minnesotensis ...................................................... 199 (50)

mucronata............................................................... 174

mucronata var. acute rostrata............................................. 175

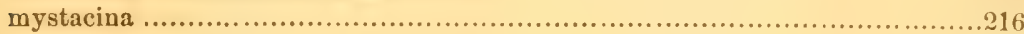

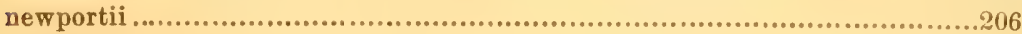

obtusa ................................................................ 191, 192

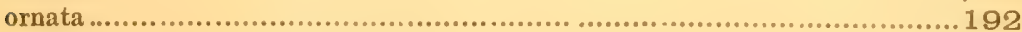

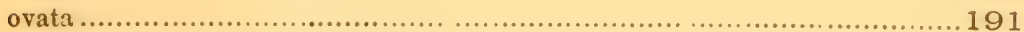

paludicola .................................................................. 198 


\section{Daphnia}

pellucida... 195,196

peunata

psittacea 187

pulex

$193,184,187,189,191,194,200,206,272$

pulex var. denticulata 194

pulex var. longispina.

pulex var. nasutus.

pulex var. pulicaria

quadrangula

rectirostris

reticulata

$170,172,206$

retrocurva...

203, 204

rosea $200,199,201,214$

rotunda . .169

rotundata.

173

rudis .205

sarsii 198

schafferi

schoedleri 187 (51), 182, 183, 191, 204-206

serrulata. 193

sima $.179,192$

similis 144,178

thorata $204(35,51), 205$

ventricosa 197

vetula 195

vitrea.

Daphnidae

(35), 196, 203, 204, 206

\section{Circulatory system of.}

$152,142,146,160,161,210,215,216,218,224,271$

Daphroidea

$152-160(51)$

Darwinula

improvisa.

336

stevensoni

$336(81)$

Darwinulidae.

337

335,294

Development of Cyclops, 122; of Cypris herricki, 326; of Daphnia...........182

Diaphanosoma brandtianum..................................................... 148

excisum.

\section{Diaptomus}

aflinis. $77(10)$

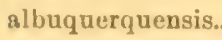

amblyodon ...... $.78(9)$

armatus.

ashlandi.

asiaticus. $56(10)$

baccillifer.

birgei

blancbardi 


\section{Diaptomus}

castor. $74(9), 56,65,66,75,76$

cœruleus. $65(9)$

denticornis. $56(10), 77$

eiseni $58(10)$

franciscanus. $58(8)$

gibber. $63(8)$

giganteus.

glacialis $.75(9)$

gracilis. $66(9), 56,69,78,80$

gracilis var. $b$ and $d$. . .61

graciloides .79

hircus. $57(33)$

incongruens. $63(8)$

laciniatus $74(8,10), 77$

lacinulatus.

laticeps

leptopus $64(2,9), 74$

lilljeborgi $76(9)$

lintoni $68(5)$

lobatus. $77(8)$

longicornis var. leptopus

lumboltzi

minnetonka...

minutus. $59(8), 60$

mirus. $75(8)$

mississippiensis. $78(47)$

montanus

novamexicanus $70(6), 67$

oregonensis.. $72(4,9)$

orientalis. $66(10)$

pallidus.... $73(4,5,13) 61$

pectinicornis. $57(10)$

piscinx. $74(5)$

richardi.

roubaui. $76(8,9)$

salinus

sancti-patricii $75(33)$

sanguineus $71(5,13), 64,72$ serricornis. shoshone. $56(8,9), 57$ sicilis $61(5), 68$ siciloides. $60(5,13), 69,70$ signicaudatus. $69(8), 61$ similis. $63(8,9)$ stagnalis $.58(13)$ tatricus. $8,62,71$

theeli.

trybomi. 


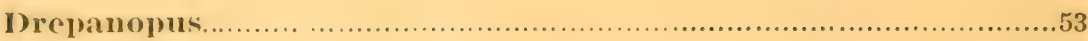

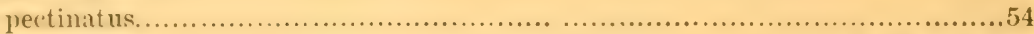

Drepanothrix............................................... 217, 143, 211

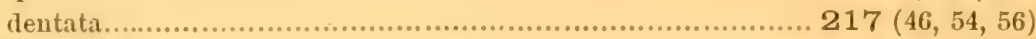

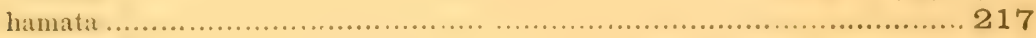

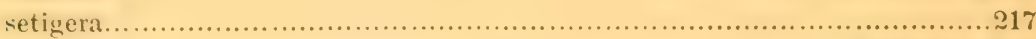

Dunhevidia................................................236, 237, 274

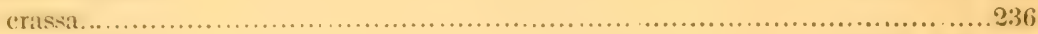

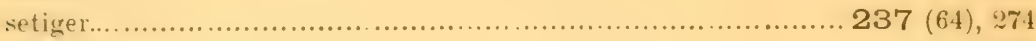

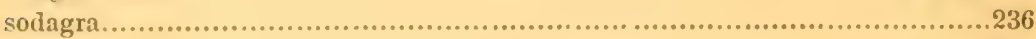

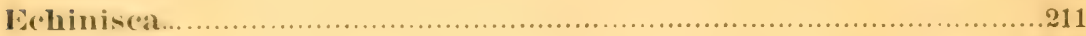

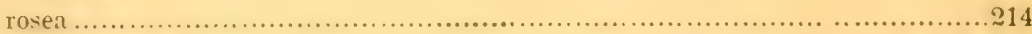

Entomostracat.....................................................293, 294

Epischura ............................................... 81, 47, 59, 63, 80

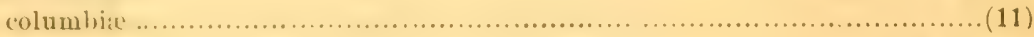

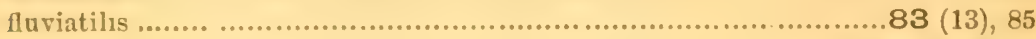

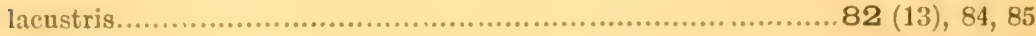

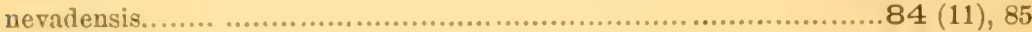

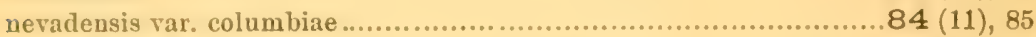

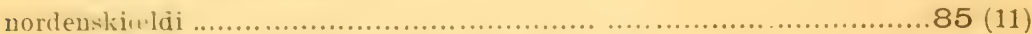

Er.atsilus depressus....................................................... (2.1)

Erpetocy pris................................................. 315, 295, 330

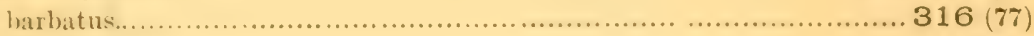

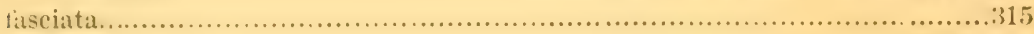

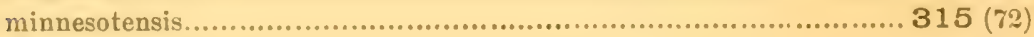

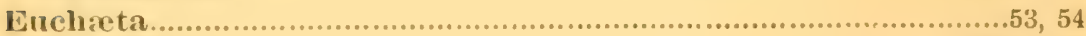

Eurycercina.................................................... 225, 274

Eurycercus .............................. 226, 143, 178, 219, 225, 258, 274

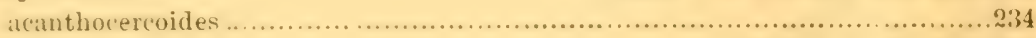

lamellatus.......................................... $226(46,51,60,62), 274$

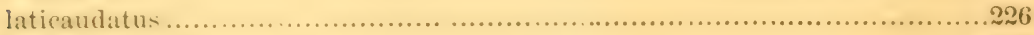

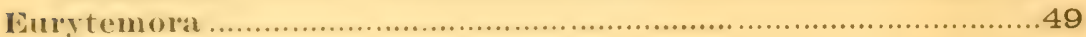

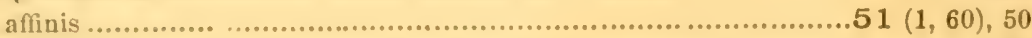

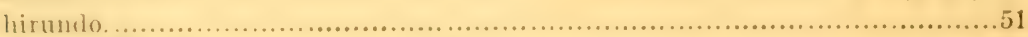

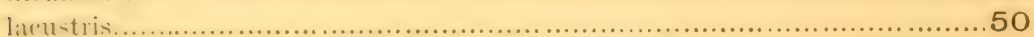

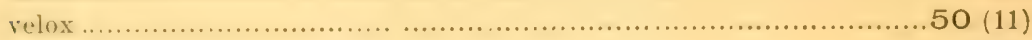

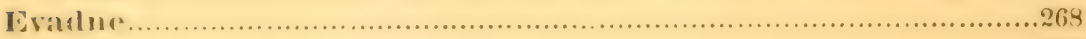

Fertility in preimago of Cyclops ................................................122

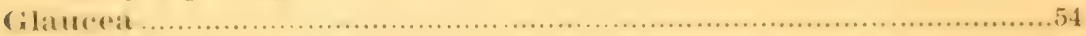

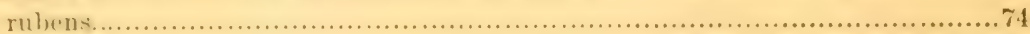

Graptoleberis..................................... 235, 143, 237, 248-251, 253

(.)

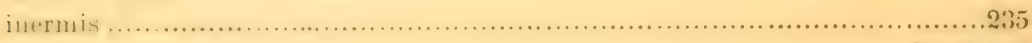

reticulata.......................................................... 236, 249

testudinaria ......................................................235 (65), 249

testudinaria var. inermis..................................................... (65)

Gymnomera .................................................145, 266, 141, 146

Harpacticidac ..........................................................46, 124

Harporhynchus......................................................237, 260

falcatus ......................................................... 244,260 
Heterocope. $80,81,47,59$

alpina

appendiculata.

borealis

romana

saliens

Heterogenesis in Cyclops

Holopedid ae

Holopedium

gibberum

Ichthyophorbia

Ilyocryptus $220,143,210,211,224,233,237,265,266,273$

acutifrons $223(55), 221,222$

agilis (55), 221, 222

longiremis

sordidus.

spinifer.

Larva of Chirocephalus, (48); of Limnetes

Larval history of Cypris herricki

Lathonura.

rectirostris $215,143,210,211,213$

spinosa

Latona.

setifera

Latonopsis

australis

occidentalis

Leptodora hyalina.

Leptodoridire

Leptorhynchus

falcatus.

Lerniroda..

Leydigia. $233,143,210,237,248,274$

acanthocercoides. 234,235 australis quadrangularis $234(59,60), 274$

Limmetes.

\section{Limnocalaurs}

macrurus.

macrurus var. anctus.

sinensis

\section{Limnosida.}

irontosa.

\section{Lophophorus.}

Lophy ropoda.

Lynceidie.

\section{Lyncein:x}

Lynceus

acanthocercoides

aculeatus 


\section{Lynceus}

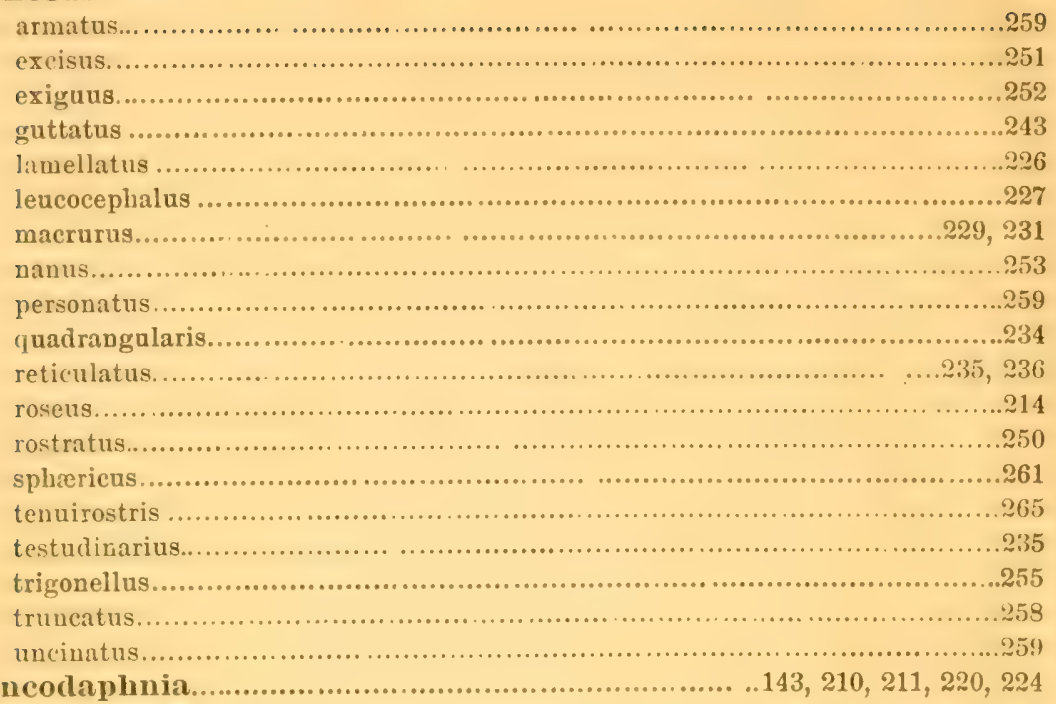

\section{Lyncodaphnia.}

Lyncodaphnidac $209,142,143,146,160,161,210,219,224,225,273$

Macrocypris minna

Macrothrix. $211,142,143,210,215,216,218,219,273$

borysthenica... $213(66)$

hirsuticornis. 213

laticornis...... $212(54,56), 211,216,217,273$ novamexicana $212(59)$ pauper.... 215 (56), 161, 210,214, 217 rosea. $214(54,56), 211-213,215$ serricaudata 214 tenuicornis.... $214(54,56), 210$

Marshia...... albuquerquensis $136(31,32), 138$ hrevicaudata.

\section{Metrida}

Misophria

Moina. $160,162,141-143,146,161,165-167,183,184,271$

azoriva

hamflyi.

brachiata...... 165,164

lisheri 166

Hizellat:i. matreayii paradoxa. propinqua. rectirostris. salina. $162(39,43), 163$ 165,164 


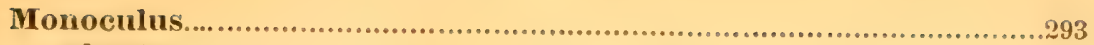

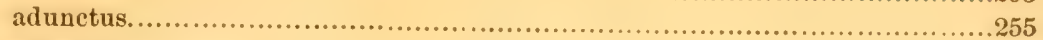

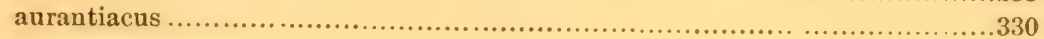

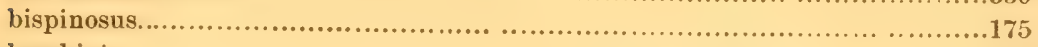

brachiatus ..................................................................... 162

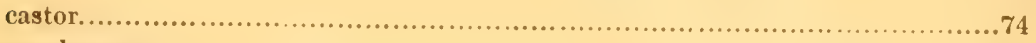

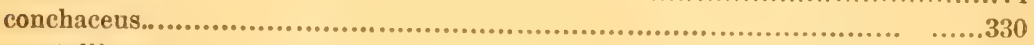

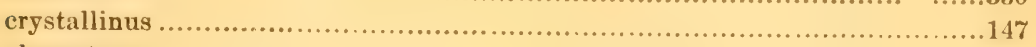

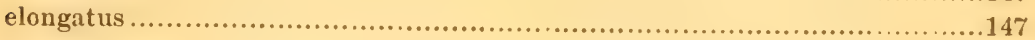

finmarchicus ..................................................................... 49

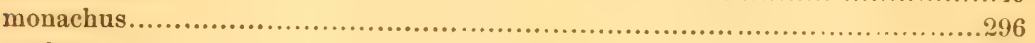

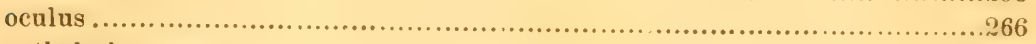

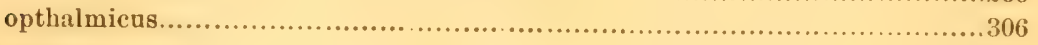

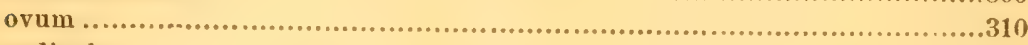

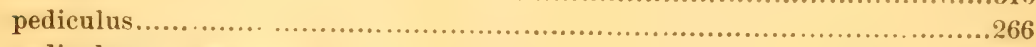

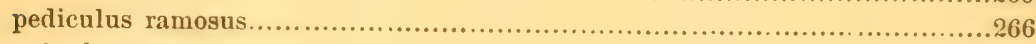

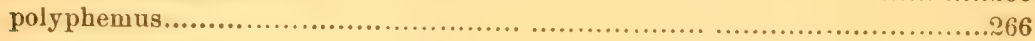

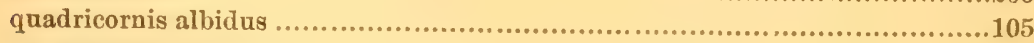

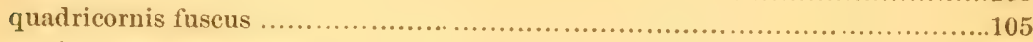

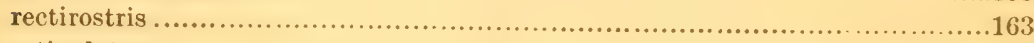

reticulatus................................................................. 170

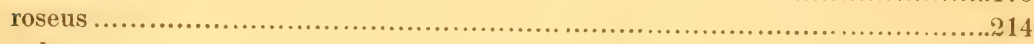

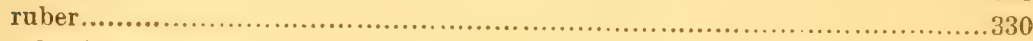

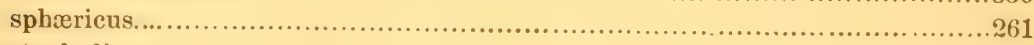

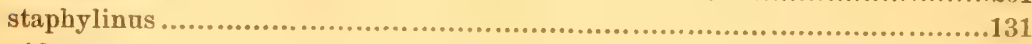

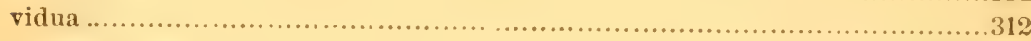

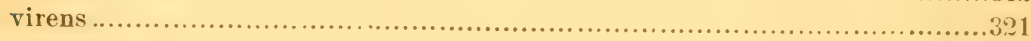

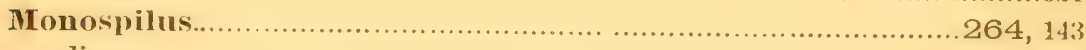

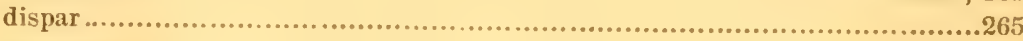

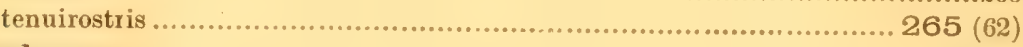

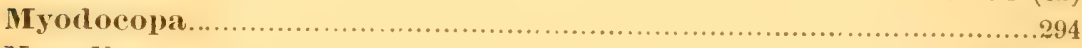

Nauplius .............................................................. (24, 60)

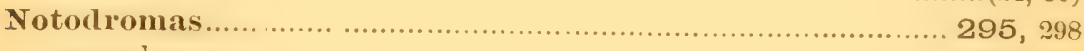

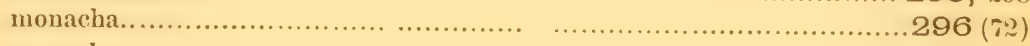

monachus ............................................................296, 335

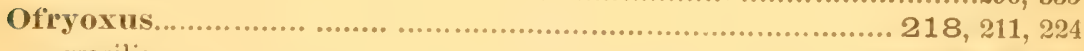

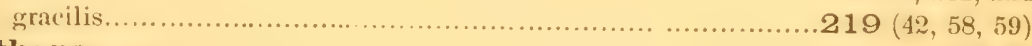

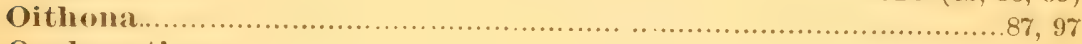

Osphranticum.................................................. 85, 47, 51

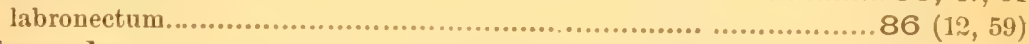

Ostracoda..........................293, 141. Bibliography, 280. Preface, 279

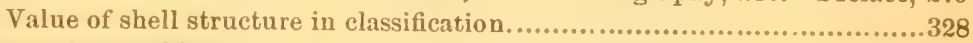

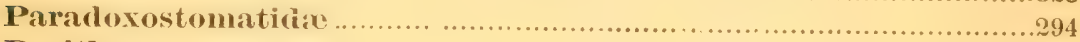

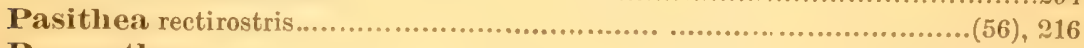

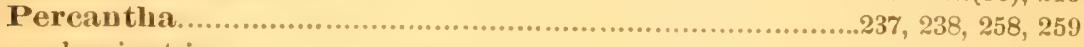

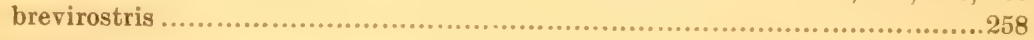

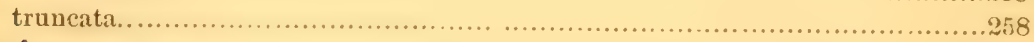

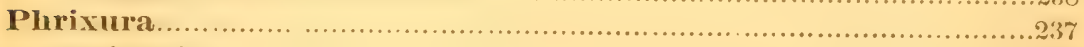

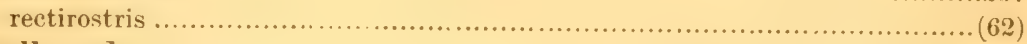

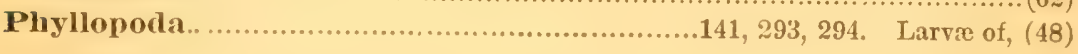


Platycopa................................................................... 294

Pleuroxus...............................253, 143, 225, 231, 236-238, 249, 260, 275

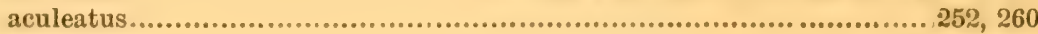

acutirostris........................................................250, 260, 275

adunctus......................................................... 255, 256, 258

affinis................................................................. (60) 250

bairdii.................................................. 256, 255, 258, 259

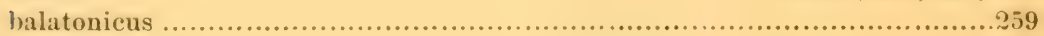

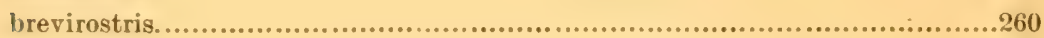

convexus...............................................................2 260

denticulatus..................................256 $(45,63), 255,257,258,275$

excisus......................................................251, 252, 259

exigua........................................................................ 251

exiguus........................................................250, 252, 259

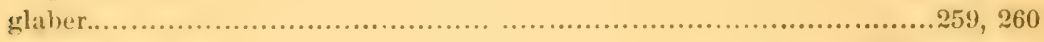

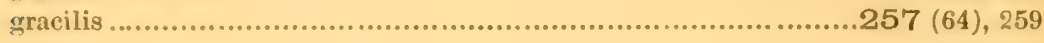

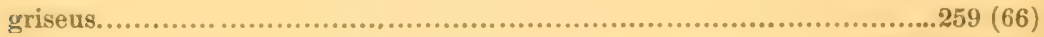

hamatus.........................................................257 (60), 275

hastatus....................................... 254 (62), 233, 255, 257, 259

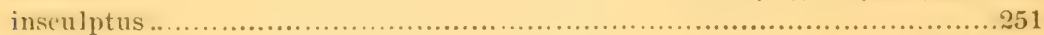

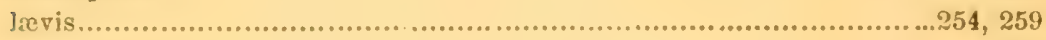

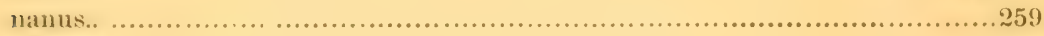

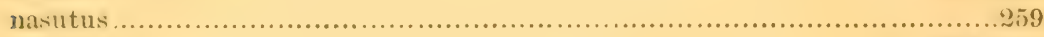

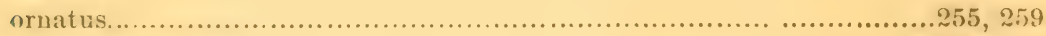

personatus........................................................... 259, 260

procurvus................................................ $258(61,65), 238,256$

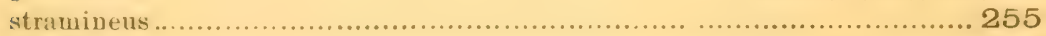

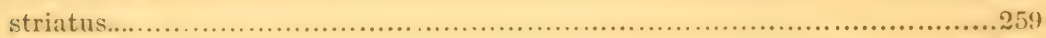

trausversus. ...........................................................253

trigonellus...............................................255, 256, 258, 259

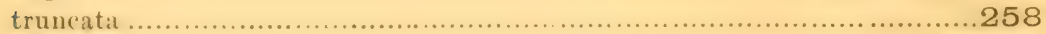

truncatus...............................................................258, 260

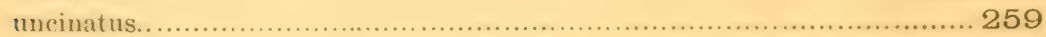

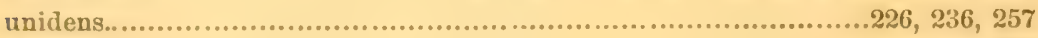

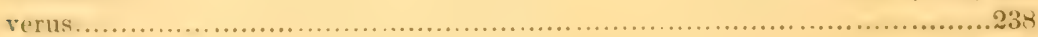

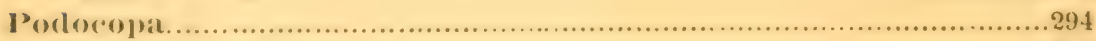

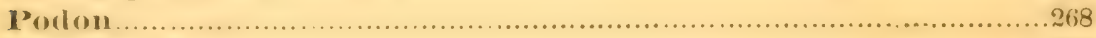

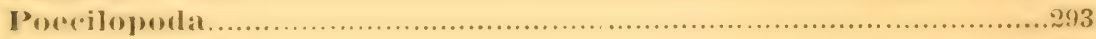

Polyphemidae...............................................266, 146, 161, 276

Polyphemus.............................................. 266, 211, 267, 276

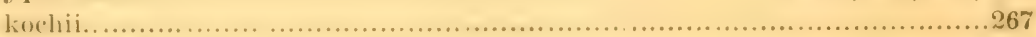

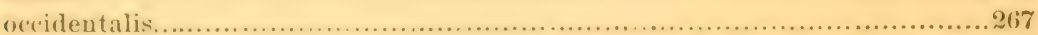

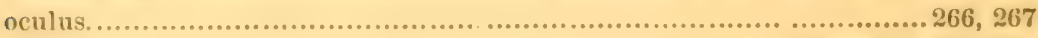

pediculus ...................................................266 $(58,59), 276$

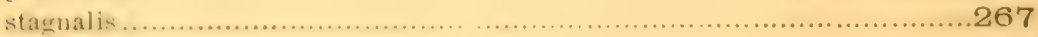

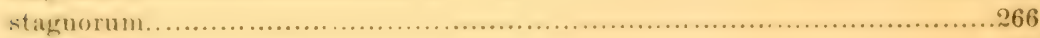

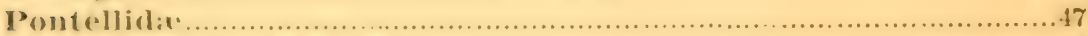

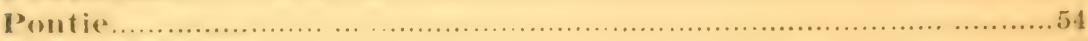

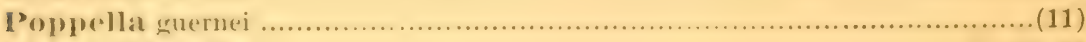

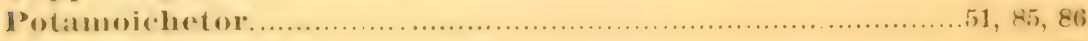

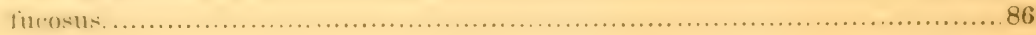


Pseudocyclops.

pelagicus

Pseudosida $147,143,161$

bidentata.

tridentata.

Rhypophilus. $175,237,238,258,259$

glaber.

personatus

Scalicerus pediculus. 266

Scapholeberis

$174,143,161,168,177,272$

angulata

$176(42,45), 161,177,181$

armata $175(42), 176$

aurita.. 176

cornuta $175(45), 177$ mucronata $174(43,45), 175,176,272$

- mueronata var. fronte cornuta. 175 nasuta

Scopiphora ragans.

Sida 81

brachyura $146,141,143,147,148,150,161,271$ crystallina 148 elongata... $147(35,37), 146,148,271$

Sididae... $146,14: 143,160,161,226,271$

Simocephalus...... 177, 143, 144, 161, 162, 167, 168, 174, 176, 181, 205, 206, 272 americanus $179(45), 178,180,219,272$ daphnoides 180 (46), 161 exspinosus 180,179

exspinosus var, congener 180

macrothroides 177

rostratus 179,219 serrulatus 179,272 vetulus $178(44,52), 177,179,180,272$

\section{Siphonostoma}

Stenlelia ima.

Stenocypris

Streblocerus

Temora $.50,49$

affinis $51(60)$

armata. 50,52

clausii.

dubia. 50,52

finmarchica

inermis 52

longicaudata velox

\section{Temorella}

affinis.

hirundo.

Thorellia 






